EASTERN EUROPEAN CULTURE,

POLITICS AND SOCIETIES 14

Jacek Leociak

\title{
Limit Experiences
}

A Study of Twentieth-Century Forms of Representation

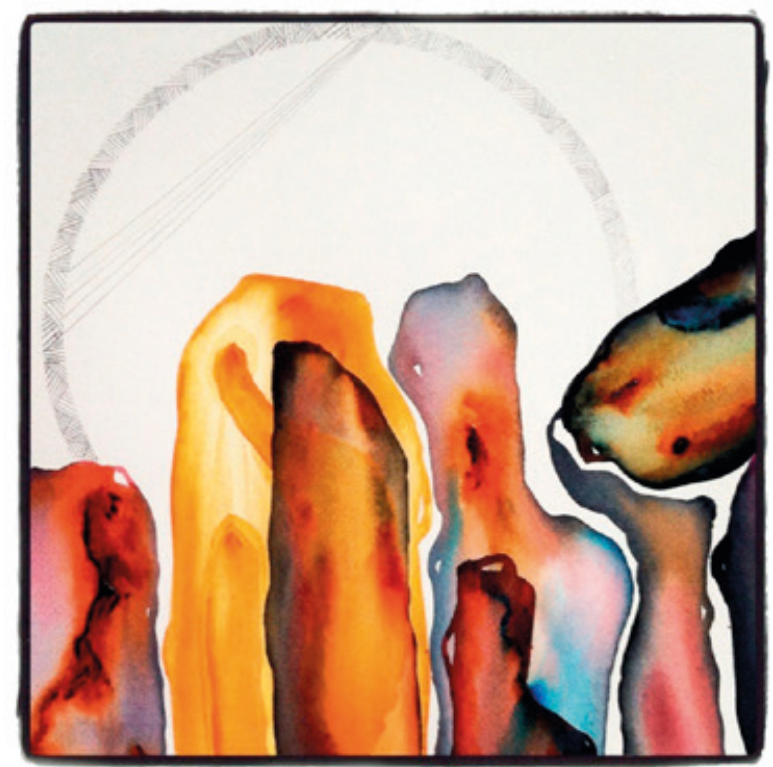


Jacek Leociak

\section{Limit Experiences}

In his work Limit Experiences, Jacek Leociak addresses questions that are fundamental to the twentieth-century experience: How can we represent such traumatic events as the Holocaust? Was Lyotard correct when he claimed that reality had succumbed to the gas chambers? How can we describe the "indescribable"? Moving seamlessly through such topics as the destruction of the Warsaw Ghetto, the carpet bombing of Dresden, and Jews left for dead in the Nazi execution pits who miraculously "exited the grave" alive, Professor Leociak succeeds in offering readers a profound representation of twentiethcentury limit experiences by embedding them in a broad array of sources and building around them a rich historical context.

\section{The Author}

Jacek Leociak is a literary historian and professor of the humanities at the Institute of Literary Research of the Polish Academy of Sciences and at Warsaw's Polish Center for Holocaust Research. Other works by Leociak include (with Barbara Engelking) The Warsaw Ghetto: A Guide to the Perished City (Yale University Press, 2009). His most recent work is Biografie ulic. O żydowskich ulicach Warszawy: od narodzin po Zagładę (Street Biographies: The Jewish Streets of Warsaw from their Birth to the Holocaust, 2018). 
Limit Experiences 


\section{EASTERN EUROPEAN CULTURE, POLITICS AND SOCIETIES}

Edited by Irena Grudzińska-Gross

and Andrzej W. Tymowski

VOL. 14 
Jacek Leociak

\section{Limit Experiences \\ A Study of Twentieth-Century Forms of Representation}

Translated by Alex Shannon

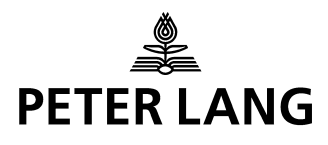




\title{
Bibliographic Information published by the Deutsche Nationalbibliothek
}

The Deutsche Nationalbibliothek lists this publication in the Deutsche Nationalbibliografie; detailed bibliographic data is available in the internet at http://dnb.d-nb.de.

\section{Library of Congress Cataloging-in-Publication Data}

A CIP catalog record for this book has been applied for at the Library of Congress.

The Publication is founded by Ministry of Science and Higher Education of the Republic of Poland as a part of the National Programme for the Development of the Humanities. This publication reflects the views only of the authors, and the Ministry cannot be held responsible for any use which may be made of the information contained therein.

\author{
(H) national programme \\ FOR THE DEVELOPMENT OF HUMANITIES \\ Cover illustration: Magdalena H. Gross \\ Printed by CPI books GmbH, Leck \\ ISSN 2192-497X \\ ISBN 978-3-631-67274-7 (Print) \\ E-ISBN 978-3-653-06856-6 (E-PDF) \\ E-ISBN 978-3-631-70996-2 (EPUB) \\ E-ISBN 978-3-631-70997-9 (MOBI) \\ DOI $10.3726 / \mathrm{b} 15362$
}

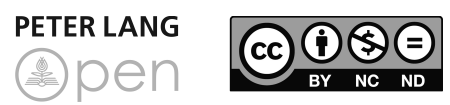

Open Access: This work is licensed under a Creative Commons Attribution Non Commercial No Derivatives 4.0 unported license. To view a copy of this license, visit https://creativecommons.org/licenses/

by-nc-nd/4.0/

(C) Jacek Leociak, 2019

Peter Lang - Berlin · Bern · Bruxelles · New York ·

Oxford $\cdot$ Warszawa $\cdot$ Wien

This publication has been peer reviewed.

www.peterlang.com 


\section{Contents}

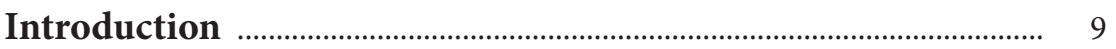

Experience as an Organizing Category ......................................................... 12

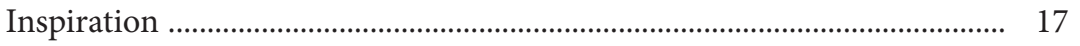

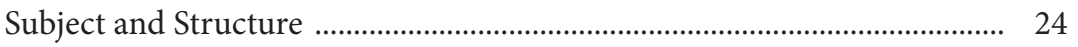

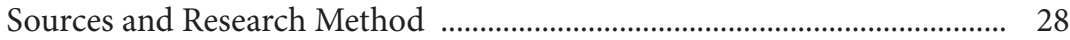

\section{Part I}

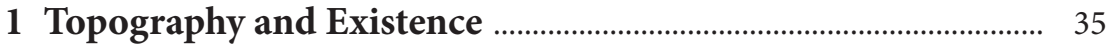

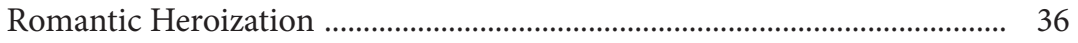

Ironic Criticism ....................................................................................... 63

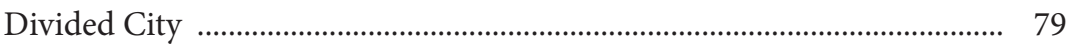

Metaphors of the Ghetto ……………………………………………………... 91

Taking an Aryan Tram through the Warsaw Ghetto ..................................... 100

2 Bombardment …………………………………………………...... 123

Bombardment and the "Morale of the Civilian Population" ...................... 125

The Target: Civilian Morale ....................................................................... 125

Bombardment in the Second World War .............................................. 129

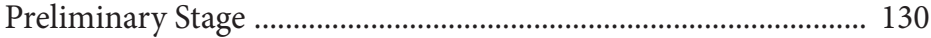

First Stage: From May 1940 to November 1941 ............................ 131

Second Stage: From February 1942 to the Middle of 1944 .......... 133

Third Stage: From the Summer of 1944 to War's End ................... 135

Bombing and Morality .............................................................................. 138

The Experience of Bombardment ................................................................. 140

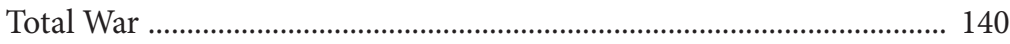

The Speed and Completeness of Destruction ......................................... 145 
The Moment of (Macabre) Transformation ............................................... 149

Ambivalence .............................................................................................. 152

The (Re-)Construction of Memory ............................................................. 157

Accounts by Victims ................................................................................... 159

Perpetrators' Accounts ................................................................................ 162

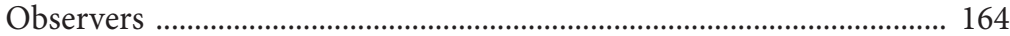

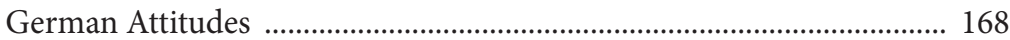

Victor Klemperer - Józef Mackiewicz - Kurt Vonnegut ......................... 170

Timothy Garton Ash and Kevin Alfred Strom ....................................... 174

Winfried Georg Sebald - Jörg Friedrich - Frederick Taylor .................. 175

\section{Part II}

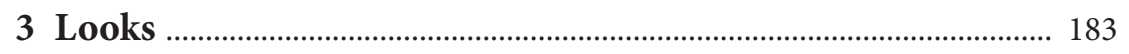

Faces in extremis ............................................................................................ 189

Before Marching off to the Front ...................................................................... 204

Damaged Photographs of (from) the Holocaust .......................................... 210

Let Us pause for a moment on the Matter of Damage ............................. 211

Types of Damaged Photographs ............................................................... 214

Kinds of Damage ……………………………………………….... 216

The Private Photograph ..................................................................................... 216

Clandestine Photographs ......................................................................... 220

Interpretive Tropes ....................................................................................... 221

Damage as a Stigma of the Holocaust .................................................... 223

Damage as a Vestige of the Holocaust ....................................................... 224

Damage as a Metonym for the Holocaust .................................................. 224

Children of the Holocaust: Obverse and Reverse ....................................... 226

The Boy from the Warsaw Ghetto ............................................................. 226

A Boy from the Łódź Ghetto .................................................................. 230

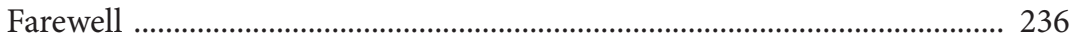


4 Encounters with a Corpse ........................................................... 245

The Postmortem Dissection ............................................................................. 247

Between the Grotesque and the Sublime ...................................................... 271

In the Arms of Eudoxie's Corpse ................................................................ 271

The Earth Discloses Its Corpses ............................................................. 277

Contemporary Antigone ............................................................................... 282

Ancient Tradition ...................................................................................... 283

The Inhumanity of the Twentieth Century ............................................... 286

"A City Engulfed by Plague" ....................................................................... 288

The Cemetery That Is Not a Cemetery ...................................................... 290

Rescuing Funeral Rituals .......................................................................... 294

Rachel-Antigone .......................................................................................... 296

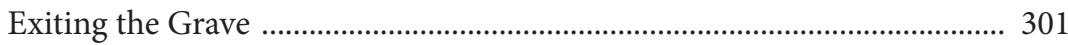

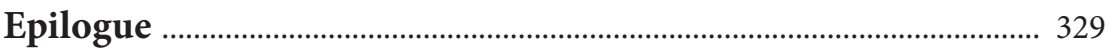

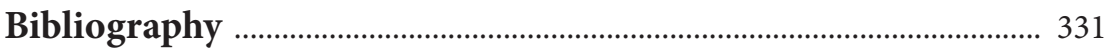

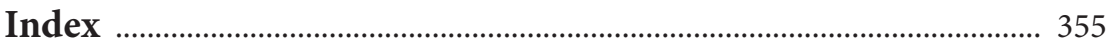





\section{Introduction}

Pain wrenches us from our everyday routine and allows us to experience the limits of our corporeal existence. It takes us to the brink, beyond which there is only the threat of death and the horror of corpses. The word turns into a cry, babble, howl. And in the end - into silence. And yet, the encounter with pain, with suffering and danger, brings recognition. Death confirms that life has meaning. Like a powerful beam of light, limit experiences provide an outline to our human shape, they draw it out from the shadows.

This book is about breaking the kind of stereotypical thinking by which the macabre is merely something horrible and repulsive; the paralyzing fear of death is simply overpowering; and what is terrible and injurious is only destruction. The pathologist does an autopsy in order the reveal the secrets of the functioning of the human organism. The anatomy of a dead body provides truth about the living body.

It is the goal of this book to show that limit experiences do not leave only a vacuum in their wake; that it is possible to represent them; that, through the examination of their various forms, we can reach the essence of human existence and man's entanglement in the world. I will keep the layers of philosophy and theoretical reflection to a minimum. I intend to remain on the level of research practice, and to concentrate on what I would call "exercises from reading."

I question the validity of the post-modern argument that limit experiences are ineffable, that their description is impossible. Talking about our inability to talk about the Holocaust (after all, the extermination of the Jews is the main subject of this discourse) seems to have become increasingly barren, because it has become increasingly predictable. The founders of this discourse left behind a full array of philosophical-poetic formulas that sound like mysterious incantations. Maurice Blanchot called the Holocaust a phenomenon in which "meaning was swallowed up," one that gave no "place to anything that can be affirmed, that can be denied," in which all thought yields to destruction and all that is left is "the mortal intensity, the fleeing silence of the countless cry." So how is it possible to "write about disaster"? In a passage from Blanchot's esoteric work, we read: "To keep still, preserving silence: that is what, all unknowing, we all want to do, writing." 2 Over this speculative notion of paralyzing language, of the power

1 M. Blanchot, The Writing of the Disaster, trans. A. Smock (Lincoln, London: New Edition, 1995), 47.

2 Ibid., 122. 
of the Holocaust to overwhelm speech and to void any meaning, a shadow is cast by Blanchot's involvement in the 1930s in the activities of the right-wing Action Française. $^{3}$

According to Jean-François Lyotard, not only had "reality" succumbed to the gas chambers of the Holocaust, but so too had the means hitherto used to talk about that reality. Great metanarratives, by which the entire world had been conceived as a meaningful whole, lay in ruins; their place was taken by micronarratives: fragmentary, temporary, provisional, unfinished. No longer was there a persistent point of support; rules of recognition were destroyed, were thrown into the middle of a conflict between various "phrase regimens," none of which can enjoy final or conclusive sanction. Lyotard called this unending struggle différend, and he made it the nucleus of his concept, which he formulated with frequent references to the Holocaust. For this French philosopher, Auschwitz was a synonym for the destruction of standard ways of naming, of making judgments, of understanding. Auschwitz also led to the destruction of the very experience of Auschwitz, since it was something so radically new in history that it canceled even the possibility to bear witness; it left us only with "the negative presentation of the indeterminate." In his work Lyotard applied the metaphor of a great earthquake that destroys all seismographic instruments and thus renders any measurement impossible. ${ }^{4}$

It is characteristic that Lyotard would refer to the names of great philosophers and theirs works from Plato and Aristotle, through Kant and Hegel, to Levinas, but he cited not a single word from such great eye-witnesses to Auschwitz as Elie Wiesel, Charlotte Delbo, Primo Levi, or Tadeusz Borowski. He made his argument somehow over their heads, as if he left in a black hole everything one could extract from there, including not just testimonies written post factum by those

3 His texts at the time did not shun anti-Semitism, they were soaked with the rhetoric of blood and violence. By the time he published his first collection of essays in 1941, the philosopher "had repudiated the political project of which antisemitism and fascism were a part," and some scholars have claimed that the fragmentary form and historical references of L'Ecriture du désastre (1980) "were marks of a movement in Blanchot's post-war writings toward disclosure of an uncertain past," and that "his remarks equivocated, as if the confessional impulse to reveal were offset by a fear concerning the risks that this revelation entailed." For more on these comments on Blanchot's prewar activities, see Postmodernism and the Holocaust, eds. Alan Milchman, Alan Rosenberg (Amsterdam, Atlanta: Rodopi, 1998), 5.

4 J.-F. Lyotard, The Differend; Phrases in Dispute, trans. G. Van Den Abbeele (Minneapolis 1996), 32-33, 56-58. 
who had survived, but also hand-written texts buried in the ashes at the crematoria in Birkenau, documents hidden there by members of the Sonderkommando in the hope that someone would discover and read them. ${ }^{5}$

I try to avoid the trap that is the aestheticization and sublimation of the limit experience. I prefer to distance myself from the tendency to create a fetish, through the use of abstract philosophical discourse, out of the "indescribable" and the "ineffable." Such a discourse carries the matter of the limit experience into the sphere of speculation; it performs a kind of deontologization and dematerialization, it separates the limit experience from empiricism.

The goal of this book is to embed experiences in the sources, to describe them in concrete historical situations, in concrete circumstances, in their "biographical" and "material" determinants. I try to resist the temptation to textualize experiences in such a way as to deprive them of their reference to factual reality. That having been said, it is important to remember that what I am examining here are representations of experiences, and not the experiences themselves.

I put forward the hypothesis that - in light of scholarly research into representations (in various forms) of limit experiences - the argument that, for example (and in particular), the Holocaust experience is ineffable can be convincingly made neither on empirical, nor on analytical grounds. There is a large body of testimony that originated from the very depth of the catastrophe, written in ghettos, in hiding, on scraps of paper in the camps. The obligation to give testimony is not just a commonly and explicitly-formulated message conveyed by those who wrote, and have written such testimony ${ }^{6}$; it also constitutes a new set of circumstances for the subject. The compelling need to bear witness that emerged in the wake of the Holocaust gave rise to a need to reflect on the notion of subjectivity and its application in the context of eye-witness accounts. ${ }^{7}$ Analysis of these accounts allows us to approach that which has been masked or obscured, to approach the meaning that the limit experience hides within itself. A meaning that, in various ways, has been disinherited and subjected to deconstruction, but a meaning that also demands that it be saved. One can attempt to

5 See Jadwiga Bezwińska, Amidst a Nightmare of Crime: Manuscripts of Prisoners in Crematorium Squads Found at Auschwitz (H. Fertig, 1973).

6 For more on the imperative to write without regard for terrifying circumstances, and on the various motivations behind texts reconstructing events hic et nunc, see the chapter "Dlaczego pisali?" (Why they wrote?) in my book Tekst wobec Zagłady. (0 relacjach $z$ getta warszawskiego) (Wrocław 1997).

7 See D. Głowacka, "Podmiotowość jako dawanie świadectwa a literatura Holokaustu," Teksty Drugie 3 (2003). 
capture this meaning only through a description of a "motion of thought" that confronts, despite barriers, the difficulty of understanding. ${ }^{8}$

\section{Experience as an Organizing Category}

It is risky to turn the word "experience" into a key conceptual category and to place it up front in the title of a book. Experience is a word that has been domesticated into our everyday language, just as it has been a conceptual category at work in European thought since Greek times and down through the present day; it has played an important role in practically every philosophical system. The popularity of this word, along with the many ways it is understood in contemporary humanities, makes it impossible - it would seem - to establish a comprehensive and coherent definition of experience. The concept of experience remains "hopelessly confused" and "is loaded down [...] with such chronic ambiguity that no single monograph, no matter how thick, can subdue" it. ${ }^{10}$ As Hans-Georg Gadamer wrote, "the concept of experience seems to me one of the most obscure we have." ${ }^{11}$ Without wading too deep into the complicated material on experience, I will introduce a few threads of thought that provide the philosophical and anthropological context for the subject of this book. ${ }^{12}$

8 I draw the metaphor of the motion of thought from K. Michalski, Heidegger i filozofia współczesna (Warszawa 1978), 9.

9 These are the words of Martin Jay, author of an important monograph on experience, Songs of Experience: Modern American and European Variations on a Universal Theme (Berkeley, Los Angeles, London: University of California Press, 2005), 3; Jay points out that he does not expect to find out "what 'experience' really is" (p. 1), but rather examines how experience, in various forms, has been part of the philosophical discourse.

10 See R. Nycz, "Literatura nowoczesna wobec doświadczenia," in Literackie reprezentacje doświadczenia, eds. W. Bolecki, E. Nawrocka (Warszawa 2007), 11-12.

11 Hans-Georg Gadamer, Truth and Method, Second, Revised Edition, trans. revised by Joel Weinsheimer, Donald G. Marshall (New York: Continuum, 1993), 346. M. Oakeshott, several decades earlier, made a similar statement, writing that " 'Experience, of all the words in the philosophic vocabulary, is the most difficult to manage [...]" Michael Oakeshott, Experience and Its Modes (Cambridge: The University Press, 1978), 9.

12 I am following in the footsteps of E. Domańska, "Rozumienie doświadczenia w filozofii i antropologii," in Domańska, Mikrohistorie. Spotkania $w$ międzyświatach, 2nd edition, expanded and updated (Poznań 2005); see also, "Doświadczenie jako kategoria badawcza i polityczna we współczesnej anglo-amerykańskiej refleksji o przeszłości," in Nowoczesność jako doświadczenie: dyscypliny - paradygmaty - dyskursy, eds. 
In the field occupied by the word doświadczenie (experience), as it has taken shape in the Polish language, we come across four semantic components. First, poddać próbie (to put somebody/something to the test), in the sense of exposing to a risk, to be threatening, dangerous, both emotionally and physically. Second, zaznać, doznać, in the sense of feeling (pain, joy). Third, dowieśc, in the sense of proving something with the use of experience, i.e. not through the expression of an opinion about a state of affairs, but through its (so to speak) sanctioning with the subjective strength of participation in that whose existence is proven. And fourth, oświadczyć, zaświadczyć, in the sense of providing testimony about (or bearing witness to) something. ${ }^{13}$

The first two semantic components of "doświadczenie/experience" play an essential role in the arguments made in this book, because they point - on the one hand - to the threat posed by that which becomes the object of experience, and - on the other hand - to the sensorial aspect of experience. In other words: I am not interested here in any kind of mystical experience, but rather in experience whose foundation is material, corporeal. The next two components dowieść and oświadczyć - are also important for my arguments, since they imply the category of evidence, testimony. Barbara Skarga has emphasized that "the word doświadczenie contains within itself testimony. Doświadczenie is thus to testify about something, and one who experiences is, quite simply, a witness." 14 I treat the entire range of source material analyzed in this book as testimony. ${ }^{15}$

Of the two terms used by Wilhelm Dilthey to define experience - Erfahrung (from the German verb fahren: to go, to travel) and Erlebnis (from the German noun Leben: life), the most important to me is Erlebnis (in Polish,

A. Zeidler-Janiszewska, R. Nycz (Warszawa 2008); R. Nycz, op. cit.; A. Radomski, “Pojęcie doświadczenia we współczesnej refleksji humanistycznej i w historiografii - jego zmiana jako rezultat przeobrazeń kulturowych w świecie współczesnym," Historyka 29 (1999).

13 The semantic field of the Polish word doświadczenie, along with its etymology, were reconstructed in R. Nycz, "0 nowoczesności jako doświadczeniu. Uwagi na wstępie," in Nowoczesność jako doświadczenie, eds. R. Nycz, A. Zeidler-Janiszewska (Kraków 2006), 12-16.

14 B. Skarga, "Doświadczenie," in Skarga, Kwintet metafizyczny (Kraków 2005), 120.

15 On the matter of testimony with reference to the Holocaust experience, see, among others, S. Felman, "The Return of the Voice: Claude Lanzmann's 'Shoah," in Testimonies: Crisis of Witnessing in Literature, Psychoanalysis, and History, eds. S. Felman, D. Laub (New York 1992); D. Głowacka, "Jak echo bez źródła”. Podmiotowość jako dawanie świadectwa a literatura Holokaustu," Teksty Drugie 6 (2003); K. Olivier, "Witnessing and Testimony," Parallax 11 (2004); D. Laub, "Zdarzenie bez świadka: prawda, świadectwo oraz ocalenie,” Teksty Drugie 5 (2007). 
przeżycie: experience, something survived), the basis of cognition and a prerequisite for understanding. Life is manifested in Erlebnis, a word that contains within itself a special semanti intensity. As Hans-Georg Gadamer wrote:

An experience is as much distinguished from other experiences - in which other things are experienced - as it is from the rest of life in which "nothing" is experienced. An experience is no longer just something that flows past quickly in the stream of conscious life; it is meant as a unity and thus attains a new mode of being one. ${ }^{16}$

For the person who is the subject of Erlebnis, that experience has a strength and persistence of its own, it constitutes the form by which that person is recognized. Gadamer suggested that the word Erlebnis "ultimately stems from its use in autobiography." ${ }^{17}$ For me this is a key assertion because the source material used in my analysis here is taken broadly from autobiographical records. For the studies referred to in this book, two specific features of Erlebnis appear to be important: first, a special directness ("everything that is experienced is experienced by oneself"). ${ }^{18}$ And second, the occurrence of a state in which one "goes beyond oneself" into a sphere that cannot be comprehended through reason.

For cultural anthropology, the problem remains: can one know the experiences of another person, and if so, in what way? From the perspective of philosophy, we can formulate the matter with the question: does experience give itself up to representation, and if so, in what way? Edward M. Bruner conceived the relationship between experience and its representation as a triangle: (1) objective reality; (2) experience in which that reality presents itself; and (3) expressions of that reality. There thus exists a fundamental difference between life experienced/ survived (reality), life experienced (experience), and life that is voiced (expression). ${ }^{19}$ Frank Ankersmit came out in favor of a three-level model of relations between historical reality and the texts on which it is based: (1) the past in and of itself (ontology); (2) the level of description (epistemology); and (3) the level of presentation/representation (aesthetics). ${ }^{20}$ In light of these distinctions, the texts

16 Gadamer, Truth and Method, 66.

17 Ibid.

18 Ibid., 67.

19 E. M. Bruner, "Experience and its Expressions," in The Anthropology of Experience, eds. V. W. Turner, E. M. Bruner (Urbana 1986).

20 See F. R. Ankersmit, "The Linguistic Turn: Literary Theory and Historical Theory," in Historical Representation (Stanford: Stanford University Press, 2001), 57. See also E. Domańska, "Miejsce Franka Ankersmita w narratywistycznej filozofii historii," which is the introduction to a collection of Ankersmit's writings: Narracja, reprezentacja, doświadczenie. Studia z teorii historiografii, ed. E. Domańska (Kraków 2004), 14. 
I analyze in this work are instances of "life that is voiced"; they are a record that demands an interpretation, placed on the level of presentation, which opens the path to experience.

I want to state emphatically that, as I write about limit experiences, what I have in mind are the various forms of their representation; what interests me is the record, the portrayal, the image, and not reality itself. In a word, what is important to me is not direct experience, but rather the mediated experience, "mimetic mediation," which, "because it makes use of [...] stylistic-compositional-representational models," produces a "scheme for the organization of experience." ${ }^{21}$

At this point we must introduce a distinction between presentation and representation. Based on historiographic theory, Frank Ankersmit applies the idea of "historical representation"; he writes about:

$[\ldots]$ the so-called substitution theory of representation. According to this theory - and in agreement with the etymology of the word 'representation' - a representation essentially is a substitute or replacement of something else that is absent. Obviously, precisely because of the latter's absence, we may be in need of the substitute's 're-representing' it."'22

Thus, to "represent" is to return something to the present, and the "represented" is that which is "not present." ${ }^{23}$ Michał Paweł Markowski points to the ambiguity of the concept of representation, which in the Polish language is manifested in the words reprezentacja and przedstawienie, which in practice are treated as synonyms, but which on the basis of philosophy cannot be treated as synonyms. Reprezentacja (representation) and przedstawienie (presentation) complement one another, but they are not the same. Reprezentacja is, on the one hand, a substitute (it appears instead of a thing) and:

$[\ldots]$ on the other hand every reprezentacja embodies [uobecnia] in some way that which it represents $[\ldots]$. Which means that every representation is divided in half, it is a "substitute and indication simultaneously," a non-depiction of that which is presented and a repeated depiction, through mediation and presentation. [...] Because reprezentacja is re-presentatio, the repeated depiction of a thing through the use of signs and symbols. In turn, as Heidegger taught us, przed-stawienie is przed-sie-stawienie (Vor-stellung), the establishment of an object by the subject through mental representation - that is, the idea that is often translated as imagination. ${ }^{24}$

21 For more on "mimetic mediation," see R. Nycz, "Tezy o mimetyczności," in Nycz, Tekstowy świat. Poststrukturalizm i wiedza o literaturze (Warszawa 1993), 247-249.

22 See F. R. Ankersmit, "In Praise of Subjectivity," in Historical Representation, 80.

23 F. Ankersmit, "Wprowadzenie do wydania polskiego," trans. E. Domańska, ibid., 31.

24 M. P. Markowski, Pragnienie obecności. Filozofie reprezentacji od Platona do Kartezjusza (Gdańsk 1999), 10-11. 
We often have the feeling that we are not able to convey to others our deepest experiences (doznanie, that which we have "gone through"), because they are so individual and inimitable that they must remain in the sphere of the unspoken. Similarly, the word "experience" has often been used to define that which is experienced (survived) but which cannot be expressed, because it is inexpressible. ${ }^{25}$ Modernity contributed to the decreased authority of experience; it turned out that experience was extremely subjective, and thus incommunicable and intransmissible. Modern experience forms and shapes reality, more than it reproduces or presents reality. Another significant feature of modern experience is its stratification: "Between that which is presented in the depiction and the object itself, inhuman reality, a gap opens up that is difficult for the intellect to bridge." ${ }^{26}$ This fundamental shift (or break), which represents a constitutive feature of the relationship between experience (doświadczenie) and presentation (przedstawienie), is revealed with particular clarity in reflections on the Holocaust and its representations. These reflections are situated in the space marked out, on the one hand, by mild theory about the crisis of representation and, on the other hand, by radical sounding formulas like "negative presentation," ${ }^{27}$ "forbidden representation," ${ }^{28}$ and the "impossibility of representation,"29 and by the promotion of concepts as the aporia of meaning, a desert, silence. ${ }^{30}$ Matters involving the representation of limit experiences and the conditions

25 This points to Jay's comment: "Although we may try to share or represent what we experience, the argument goes, only the subject really knows what he or she has experienced." See Jay, Songs of Experience, 5-6.

26 For more on the crisis in traditional experience and its consequences, see R. Nycz, "Literatura nowoczesna wobec doświadczenia," op. cit., 14-16.

27 Jean-Francois Lyotard, “Answering the Question: What Is Postmodernism?," The Postmodern Condition: A Report on Knowledge, trans. Regis Durand (Minneapolis; University of Minnesota Press, 1984), 71-82.

28 Jean-Luc Nancy, The Ground of the Image (Fordham Univ. Press, 2005).

29 A. Easthope, "Holokaust i niemożność przedstawienia," trans. M. Pietrzak-Merta, Res Publica Nowa 11 (1997).

30 For more on the issue of the (im-)possibility of representing the Holocaust, written in the broader context of philosophy, aesthetics, sociology, and history, see A. Ubertowska, "Popioły i dyskursy. Zagłada i etyczny wymiar reprezentacji (od Adorna do Lyotarda)," in her book Świadectwo - trauma - głos. Literackie reprezentacje Holokaustu (Kraków 2007). It is worth emphasizing that this author is not only thorough in his work, but also precise and clear when it comes to concepts that are often highly complicated, if not esoteric. Such an effort is particularly valuable. 
under which it is possible to present them, along with the question of what is expressible and what is not, will be one of the fundamental themes of this book.

\section{Inspiration}

The concept of the limit experience is laden with ambiguity. But I cannot find another term to define the basic subject of this book. In order to render it operational as much as possible, I will attempt to call upon those scholarly traditions that constitute the source of inspiration for my thinking about the limit experience. While some of them are close to me, I distance myself more or less from others. Below, I will sketch out the inspiration I have drawn from the ideas of Karl Jaspers, Bruno Bettelheim, Dominick LaCapra and Frank Ankersmit. They shine light on the understanding of the limit experience as proposed in this book.

Karl Jaspers drew a distinction between factual existence (Dasein) and "selfhood" (Selbstsein). Factual existence is everything that is realized in a human; it is the totality of factors contributing to human existence: biological, social, historical, cultural. "Selfhood," on the other hand, is not something given, prepared or ready-made. It is a means of existence that can be, in a sense, peeled, thanks to reflective efforts, thanks to an individual's activity as a values creating subject. ${ }^{31}$ Every person stands in the face of limit situations, which do not "happen" like a natural catastrophe or an automobile accident. They are not an affliction or ailment of existence; rather, they are its essence. "Being in a situation" is one of the most prominent dimensions of human existence.

Jaspers described limit situations as those situations that do not change, but rather are a constant companion of our presence in the world. They are: (1) entanglement in a situation of some kind; (2) battle; (3) culpability; (4) suffering; (5) death. ${ }^{32}$

The situations mentioned here take on a limit character when a people assume an existential stance when facing them - that is, when they illuminate their existence by virtue of their experience of freedom, and in the process becomes themselves (Selbstsein). "We become ourselves," as Jaspers wrote, "in that we enter limit situations with open eyes. They are perceptible as something real only through existence $[. .$.$] . To experience a limit situation and to exist are one and$ the same thing." ${ }^{33}$

31 See R. Rudziński, Jaspers (Warszawa 1978), 73-77.

32 Ibid., 106.

33 K. Jaspers, "Sytuacje graniczne," in R. Rudziński, op. cit., 189. 
Death confronts us with the pain that comes with irretrievable loss; it unveils fear about the strangeness of the world and the inevitable destruction of what exists. But it also brings awareness of a more enduring reality, one that crosses beyond the transience of life. "That which maintains value in the face of death belongs to existence; that which is destroyed belongs only to the sphere of factuality." ${ }^{34}$ Death as a limit situation appears in the form of a question about this distinction. One can overcome fear of the end of life only through an "unconditional affirmation of existence, in which we do good for the sake of good, even if we know of no larger whole to which that good might belong - an order of salvation, reason, or history."35 The experience of death as a limit experience opens up the possibility of authentic existence, the expression of which is a "heroic stance, overcoming fear and death on the path to a voluntary engagement with the world, taking responsibility for the fact that we give testimony to humanity in this place and in these circumstances." ${ }^{36}$

Bruno Bettelheim drew a clear distinction between the disasters that had previously been the causes of mass death (natural catastrophes, the plague, traditional wars) and twentieth-century cataclysms, which were prepared with premeditation by humans and brought in their wake suffering, destruction and death on what had been an unimaginable scale. The First World War had destroyed faith that civilizational progress could offer meaning to our life, solve the problems that stood in our path, and calm fears about death. Despite great scientific, technological and intellectual progress, humans became the victim of irrational forces of violence and destruction. The Second World War showed to what terrible degree humans were capable of destroying and killing. Auschwitz was the realization of a perfected system for organized cruelty. Hiroshima became the symbol of the destructive power of science. All of these experiences caused disintegration in the forms of collective human existence, and they had a devastating influence on the life of an individual, both emotionally and physically.

Human beings were, as it were, tossed into an "extreme situation," which represented for them an extreme threat, one over which they had no influence at all. What's more, they were in no position to defend themselves against it or to tame it, because old models of adaptation, strategies for survival, and defense mechanisms, were no longer applicable. They were simply inadequate. "Extreme experiences" are the key experiences of our life. They expose the destructive

34 R. Rudziński, op. cit., 108.

35 Ibid., 109.

36 Ibid. 
power of progress and lead to a disintegration of personality; to the destruction of faith in the meaning of life; to paralysis in the elaborate ways people had been able to calm fears about death; and - in the end - to questioning the extent to which humans were embedded in culture and in the world of values. ${ }^{37}$

As early as 1943, in an article entitled "Individual and Mass Behavior in Extreme Situations," Bruno Bettelheim wrote about the concept of the "extreme situation." It was a psychological study of the behavior of prisoners in concentration camps, written on the basis of his own experiences. After Germany's Anschluss with Austria, Bettelheim had been deported to Dachau, along with other Austrian Jews, and then to Buchenwald. In April 1939, he was freed and he emigrated to the United States. This article, published in the Journal of Abnormal Psychology 38 (October 1943) has been reprinted many times and brought Bettelheim fame as a keen analyst of the human condition under the extreme oppression of the concentration camp. ${ }^{38}$

Dominick LaCapra has stated that scholars who examine the twentieth century - the century of the two totalitarianisms, of two world wars, of incessant local and regional conflicts, of the Holocaust - must place at the center of their investigations the concept of trauma. In this context, he writes about the Holocaust as a "limit event," a "limit situation," and a "limit experience." This "limit" phenomenon manifests itself in such events as those listed above and, more generally, in practices that contain within themselves the potential for powerful, overwhelming and unprecedented aggression and violence, which - in effect - means aradical disruption of what had been the foundations of civilized order, the destruction of the values on which the human community depended. ${ }^{39}$ LaCapra applies the mechanisms of mourning and melancholy (drawn from Freud) to traumatic limit experiences. Sinking into melancholy represents the unending process of "working through" trauma in the present, the inability to cut oneself off from that trauma and to avoid its destructive powers. Mourning is

37 For more on the concept of "extreme situations," see B. Bettelheim, "The Ultimate Limit," in Surviving and other Essays (New York 1979).

38 Bettelheim's reflections on the concentration camps, the Holocaust, and totalitarian violence are contained in his book Surviving and Other Essays.

39 D. LaCapra, History and Memory After Auschwitz (Ithaca, New York 1998); LaCapra, Writing History, Writing Trauma (Baltimore 2001); LaCapra, "Approaching Limit Events. Siting Agamben," in Giorgio Agamben. Sovereignty and Life, eds. M. Calarco, S. DeCardi (Stanford 2007). See also S. Gigliotti, "Unspeakable Pasts as Limit Events: The Holocaust, Genocide, and the Stolen Generations," Australian Journal of Politics \& History 49 no. 2 (June 2003). 
based on the "acting out" of trauma, leaving it in the past, and returning to life, which becomes richer through a kind of new self-knowledge. ${ }^{40}$

LaCapra's comments on the forms by which limit experiences are represented is essential for my work; they point to the irreducible tension between the expressible and the inexpressible. The claim - which one can find, for example, in Lyotard's works - that traumatic limit experiences are not susceptible to representation that they carry within themselves a kind of excess that eludes any kind of representation, gives rise to two kinds of danger. First, a kind of fixation on the backdrop of non-representation can divert attention away from what actually can be represented and reconstructed and should be expressed as accurately and precisely as possible. Second, it can lead to excessive aestheticization of limit experiences, to their being positioned in the realm of the sublime, whether that be secular or (sacralized) religious. ${ }^{41}$ The sublimation or sanctification of limit experiences can be a trap; they can lead to limit experiences being obscured by abstract speculation or by the stylistics of pathos. In Representing the Holocaust, LaCapra wrote about the radical de-sublimation that came with the Holocaust, which eliminated the possibility that some kind of higher meaning could survive, because there emerges from the Holocaust no new project for metaphysical, aesthetic or theological order. The Holocaust left space only for "a negative sublime in the form of unheard-of, traumatizing transgression that is presumed to be unrepresentable and to be met only with silence." ${ }^{\prime 2}$ But LaCapra debates with Lyotard by claiming, among other things, that his concept of the sublime as a manifestation of non-representation prevents a nuanced study of various modalities and possibilities of representation. Lyotard's radical theoretical posture has also raised doubts in LaCapra's mind. Insufficient reflection on the relationship between history and theory leads to Lyotard "sacrificing" history to philosophical discourse. ${ }^{43}$

40 See D. LaCapra, "Acting-Out and Working-Through," in LaCapra, Representing the Holocaust. History, Theory, Trauma (Ithaca, London 1996). Significantly, as one of the two epigraphs for his book, LaCapra chose a passage from Freud's 1917 essay "Mourning and Melancholia."

41 See D. LaCapra, "Holocaust Testimonies: Attending to the Victim's Voice," in LaCapra, Writing History, Writing Trauma, op. cit., 92-93.

42 D. LaCapra, "The Return of the Historically Repressed," in LaCapra, Representing the Holocaust, op. cit., 172.

43 D. LaCapra, "Historicizing the Holocaust," in LaCapra, Representing the Holocaust, op. cit., 96-99. 
Frank Ankersmit has turned the categories of trauma and the sublime into one of the foundations of his concept for historical experience. The gap between the past and the present is best described by the Freudian term "uncanny." Ankersmit explained: "What most upsets us about the 'uncanny' is that which was once very close and highly familiar to us, but which is simultaneously strange and foreign. Precisely for this reason, the dead are 'uncanny"'" ${ }^{44}$ Historical experience expresses our relationship to the past and is located in a space marked both by an awareness that the past has been lost and by a desire to retrieve that past. Two opposing vectors intersect with one another, creating a tension that comes from the collision of suffering (the loss of the past) and pleasure (a desire to retrieve the past). This tension between suffering and pleasure is the source of the sublime. ${ }^{45}$ Referring to Edmund Burke's treatise A Philosophical Enquiry into the Origin of Our Ideas of the Sublime and Beautiful (1757), Ankersmit argues that "the sublime calls forth in us both pain and pleasure, joy and terror, and along with that an entire range of conflicting feelings." ${ }^{36}$ For Ankersmit, the paradigm of historical experience is the experience of trauma and the experience of the sublime. "The sublimity of historical experience originates from this paradoxical union of the feelings of loss and love, that is, of the combination of pain and pleasure in how we relate to the past." ${ }^{\prime 7}$

Traumatic experiences open us up to research into the limits of representation. Ankersmit wrote:

An exploration of these limits thus urges us to consider "testimony" and what we ordinarily associate with that word; for does not testimony give us a representation of a person's deepest and most significant experiences? And should we not agree that to the extent that the experience of the Holocaust can be represented in language, that language must take the form of testimony? ${ }^{48}$

44 F. Ankersmit, "Wprowadzenie do wydania polskiego," in Ankersmit, Narracja, reprezentacja, doświadczenie, op. cit., 45.

45 See E. Domańska, "Miejsce Franka Ankersmita w narratywistycznej filozofii historii," op. cit., 19. For a monograph on the sublime, see J. Płuciennik, Retoryka wzniosłości w dziele literackim (Kraków 2000).

46 F. Ankersmit, "Wprowadzenie do wydania polskiego," in Ankersmit, Narracja, reprezentacja, doświadczenie, op. cit., 45.

47 F. R. Ankersmit, Sublime Historical Experience (Stanford: Stanford University Press, 2005), 9

48 "The Postmodernist 'Privatization' of the Past," [chapter 5] in F. R. Ankersmit, Historical Representation (Stanford: Stanford University Press, 2001), 162-163. 
Georges Bataille is not exactly my intellectual patron, though I treat certain aspects of his writings as inspiring interpretational tropes. Bataille posed questions that are beyond the horizon of my reflections here, above all questions about experiences without an object. His questioning of the existence of a coherent experiential object led him to oppose the identification of experience with Erlebnis, which he recognized as problematic given its emphasis on experiential immediacy and the present moment. ${ }^{49}$ Erlebnis as understood and used by Dilthey and Gadamer is decidedly closer to my way of thinking. In any case, the concept of the "inner experience" alone does not work in harmony with the many studies featured in this book; at the beginning of his work, Bataille wrote: "By inner experience, I understand what one usually calls mystical experience: states of ecstasy, of ravishment, at least of mediated emotion." 50

But as the author of L'Erotisme, Bataille assists me in my thoughts on the death experience; on the fundamental ambivalence between fear and desire, attraction and repulsion; on the dialectics of limits and transgression. As one commentator on Bataille's thinking put it:

Acknowledging the finitude of others is a quintessential community-inducing limitexperience in several senses. [...] Experiencing the death of the alter, even from the "outside," compels us to experience the alterity within ourselves. ${ }^{51}$

In another place, that same commentator wrote: "Bataille knew full well that the limit of experience was met only in a death that was both impossible to incorporate into life and also its most intense, ecstatic and profound moment." ${ }^{2}$

It seems that the simplest and yet most capacious (and thus most useful for me) formula is the one put together by Jan Strzelecki. Describing limit experiences, he wrote that they mark "existence in the sphere of a human fate's final experiences, as if on the border of experiences that fall to people as members of a species." ${ }^{3}$ Following Strzelecki's thinking, one could say that we witness a limit experience at that point when a person is capable of enduring no more, but they must endure more - and they do.

49 See Jay, Songs of Experience, 375.

50 Georges Bataille, Inner Experience, trans. Stuart Kendall (Albany: State University of New York Press, 2014), 9.

51 Martin Jay, "The Limits of Limit-Experience: Bataille and Foucault," Constellations: An International Journal of Critical and Democratic Theory 2 (1995), 167.

52 Jay, Songs of Experience, 373.

53 J. Strzelecki, "Próby świadectwa," in Kontynuacje (2) (Warszawa 1974), 11. 
By way of summary, one can thus say that, in this book, I consider limit experiences to be, above all, those experiences that contain within themselves trauma, and that are connected with the macabre and horror. They accompany the great catastrophes of the twentieth century that were the Second World War and the Holocaust. When speaking of the macabre, what I have in mind are such definitions as we find in contemporary dictionaries of the Polish language: ${ }^{44}$ "coś strasznego, przerażajacego, wzbudzajacego grozę; okropność, koszmar” (something terrible, frightening; something that causes terror; horror, a nightmare). But for me it is above all about representations of death and corpses. The point of reference for the macabre, understood in this narrow sense, is of course the tradition of the danse macabre and the image of the decaying corpse - the transi. ${ }^{55}$ Death and the corpse are thus the nucleus of the macabre, which I regard as one expression of the limit experience.

I situate limit experiences both in the sphere of individual experiences (in the sense of "doznanie," e.g. macabre deformations of the faces of soldiers from the First World War caused by injuries sustained on the front, and their influence on the destruction of subjectivity) and in the sphere of collective, social experiences (e.g. the bombing of cities and their influence on inhabitants' perception of urban space). I would like to point out some common features that characterize the different types of border experiences considered in this book, including feelings of ambivalence toward the source of an experience (e.g. an encounter with a corpse: attraction and repulsion; bombardment: fascination and horror). Ambivalence toward the limit experience lends it a structural resemblance to an experience of the sacred, which Rudolf Otto called numinosum and Gerard van der Leeuw called power. ${ }^{56}$ Holiness thus conceived is experienced as menacing and fascinating at the same time.

The limit experience also contains within itself an element of illumination. Trauma is not just devastating, but also revealing. Having passed through a limit experience, we are no longer what we were before. Such a radical experience

54 For example as edited by M. Szymczak (Warszawa 1984) or S. Dubisz (Warszawa 2003).

55 For the etymology and meaning of the word macabre in the context of the human corpse, see Philippe Aries, The Hour of Our Death: The Classic History of Western Attitudes Toward Death over the Last One Thousand Years, trans. Helen Weaver (Vintage, 2008); Jean Delumeau, Sin and Fear: The Emergence of the Western Guilt Culture, 13th - 18th Centuries, trans. Eric Nicholson (Palgrave Macmillan, 1990).

56 See Rudolf Otto, The Idea of the Holy, trans. John W. Harvey (Oxford University Press, 1936); Gerardus Van der Leeuw, Religion in Essence and Manifestation, trans. Ninian Smart and John Evan Turner (Princeton University Press, 2014). 
transforms us; it gives a person bitter knowledge about the world and about ourselves (as it does about those who survive their own death, who were rescued from execution, who crawled out of a mass grave). In this sense, a limit experience is a gift, an opening, a revelation..$^{57}$

\section{Subject and Structure}

The subject of this book is the various forms by which limit experiences - which emerged in a particular way in the twentieth century - are represented.

With the First World War came the trench experience - that is, life on the front lines in a state of unending threat, under atrocious conditions, among the massacred bodies of friends and enemies, face to face with death, shoulder to shoulder with corpses. ${ }^{58}$ These war experiences depicted the full weight of the psychological trauma that marked the lives of so many people, individually and collectively, after the war. One can treat my reflections on the historical, clinical and cultural dimensions of trauma as a desire to confront the limit experience, as an attempt to understand, and elaborate on, the mechanisms for coping with life in a world of violence and chaos. ${ }^{59}$

57 See. B Skarga, op. cit., 128-129. Jay wrote: "[...] something must be altered, something new must happen, to make the term meaningful." See Jay, Songs of Experience, 7.

58 For more on the trench experience, see "The Troglodyte World" in Paul Fussell, The Great War and Modern Memory (Oxford University Press, 2000); D. Winter, "Trench Life" and "The Strain of Trench Warfare," in Winter, Death's Men. Soldiers of the Great War (London 1978); Modris Eksteins, "Rites of War," in his Rites of Spring: The Great War and the Birth of the Modern Age (Boston, New York: Houghton Mifflin, 1989). For more on the body in autobiographical accounts from the First World War, on the body subjected to the violence of war and oppression, the body wounded, dismembered and dead, see T. Trudi, Modernism, History and the First World War (Manchester, New York 1998).

59 The mental disorders appearing in soldiers who fought on the front during World War I were attributed mistakenly to brain damage and diagnosed as shell shock. Medical research carried out since the end of the nineteenth century on posttraumatic disorders, including Freud's study of the phenomenon of psychological trauma, led to the emergence of a new field of study about the effects of particularly intense and prolonged stress on the human psyche, and to the emergence in 1980 of a new disease classification tied to the name posttraumatic stress disorder (PTSD) See M. LisTurlejska, Stres traumatyczny. Występowanie, następstwa, terapia (Warszawa 2002). For more on the matter of trauma in the First World War, as analyzed from the perspective of the history of medicine, see the study "Shock, Trauma, and Psychiatry in the First World War," which is part four of the work Traumatic Pasts: History, Psychiatry, and 
The Second World War put an end to the division (already blurred during the Great War) between the war front and the home front, between soldiers and civilians. Military actions were also directed at civilian populations, and the area bombing, or carpet bombing, of cities caused "modern" destruction on a scale that had never been seen before. This war opened the way for the Holocaust: every Jew, without exception, was the target of mass extermination that was unprecedented in history. One often locates the exceptional nature of the Holocaust in the fact that the intention was to destroy the entire population of European Jews, and that it was carried out using specific methods based on bureaucratic procedures and technological solutions. ${ }^{60}$ But the question remains: was the Holocaust a modern creation, or was it - on the contrary - a manifestation of barbarism, an irrational frenzy, a matter of civilizational regression?

The concept of the Holocaust's "modernity" has many advocates, from Hannah Arendt ${ }^{61}$ to Zygmunt Bauman. ${ }^{62}$ In their view, what we are dealing with here is an "enlightened" or "gardener's" vision of the world involving the implementation of a radical plan to transform society. If one regards society as a garden, then the process of cleansing through violence, the reconstruction of the social fabric, is not the murder of people, but the pulling of weeds. It is not destruction, but creation. We are dealing with absolute power that is capable of monopolizing all means for the purpose of committing genocide. We are dealing with the planned actions of a state administrative apparatus, with the application of bureaucratized procedures for the organization of murder, with industrial methods for mass murder and the utilization of corpses. All of which leads to a functional division of labor, to the replacement of moral responsibility with administrative responsibility. Finally, we are dealing with a kind of lack of spontaneity, with a murderous routine, with the banality of evil.

Those who understand the Holocaust as a terrible error of history, an aberration, a disturbance in the normal course of history, a retreat into the abyss

Trauma in the Modern Age, 1870-1930 (Cambridge Studies in the History of Medicine), eds. M. S. Micale, P. Lerner (New York 2001). For a monograph based on analyses of testimonies from both world wars and local conflicts (Vietnam, the war in the Balkans), see W. Holden, Shell Shock (London 1998).

60 The question of exceptionality is not just a fundamental scholarly matter; it also forms one of the main aspects of the Holocaust discourse. For more on the Holocaust and exceptionality, see Alan Milchman, Alan Rosenberg, Experiments in Thinking the Holocaust (Palgrave Macmillan Limited, 2006).

61 Hannah Arendt, Eichmann in Jerusalem: A Report on the Banality of Evil (Viking, 1963).

62 Zygmunt Bauman, Modernity and the Holocaust (Cornell University Press, 1989). 
of barbarism, include the German sociologist Ralf Dahrendorf, who called the Germans a "defective nation" not prepared to hold up the standards of democracy and progress.

For Jürgen Habermas, Nazism was a consequence of the German inability to maintain a balance between universalist and particularist elements in the creation of a national identity. The particularism is an immanent feature of German nationalism, which boils down to the idea of cultural and ethnic exceptionalism. These qualities disallowed Germany from becoming a modern nation and from creating a modern state, a fact that led to Auschwitz. ${ }^{63}$

Genocide creates a pre-modern "ecstatic community" of perpetrators, who perform their transgression through participation in mass murder. Saul Friedlander described the orgiastic dimension of the experience of the perpetrators of genocide. He wrote about the world of "strangeness or uncanniness," and he introduced the term "Rausch" (ecstasy, intoxication) to describe this particular condition. ${ }^{64}$ Thus, the Holocaust was not a passionless exercise, not a coldly "modern" gardening project, but rather an act of "barbaric" frenzy. ${ }^{65}$

This book is divided into two parts. The first part examines the experience of cities and urban spaces in the face of massive attacks from the air. The second part deals above all with the experience of the body as an object of conventional military violence, and as an object of unprecedented extermination. The first emerges from an analysis of individual attitudes in order to reach the layer of social consciousness and collective memory. The second concentrates on the individual whose involvement represents a limit experience of a different kind.

Part I of the book is devoted to the phenomenon of a city subjected to oppression, violence and decomposition of many kinds, and finally to destruction. In the chapter entitled "Topography and Existence," I address, on the one hand,

63 For more on the views of Dahrendorf and Habermas, see M. Fleming, "Genocide and the Body Politic in the Time of Modernity," in The Specter of Genocide. Mass Murder in Historical Perspective, eds. R. Gellately and B. Kieman (New York 2003), 98-99.

64 See S. Friedlander, "The 'Final Solution': On the Unease in Historical Interpretation," in Friedlander, Memory, History, and the Extermination of the Jews of Europe (Bloomington 1993).

65 See D. Stone, "Genocide as Transgression," European Journal of Social Theory 1, no. 7 (2004), 48-49. For more on the tension between modernity and "barbarism" in the context of acts of mass violence, genocide and the wars of the twentieth century, see Wolfgang Sofsky, Violence: Terrorism, Genocide, War (Granta, 2003). Sofsky wrote, among other things, that "civilization, barbarism and the modern world might be interlinked in their own peculiar way" (p. 63). 
the "experience of topography" (that is, the reconstruction of the image of a city as preserved in texts) and, on the other hand, the "topography of experience" (that is, the peculiar use of the language of urban space to express experiences of war and occupation). On the basis of the defense of Warsaw in September 1939, I write about two ways of coping with extreme situations, which one might well characterize as both individual and collective catastrophes; about two strategies to reconcile the situation that are derived from different areas of tradition and that invoke different spheres of cognition, emotion and intellect. On the basis of the Warsaw Ghetto, I write about the experience of a space that was excluded, reviled and stigmatized; the ghetto itself is for me a metaphorical formula for a degraded and tormented existence. In the chapter entitled "Bombardment," I depict - from the points of view of the victims and the perpetrators - the moment of total and rapid destruction of cities as a result of mass bombing, and I present various strategies for remembering events of this kind.

Part II of the book examines the human being experiencing the destruction of his own body, suffering, fear, dying, and finally - the dead body. I contemplate various images and motifs drawn from selected writings and photography embedded in the context of twentieth-century experiences with the horrific, traumatic and macabre. These experiences are situated somewhere between the expressible and the inexpressible. In the chapter entitled "Looks"66 I analyze photographs. Based on photographs of facial injuries sustained by soldiers in the First World War, I depict ways of representing (in text and images) the deformation of the human appearance. I move from images of the tormented body to photos of people (being conscripted into the military) unaware of the approaching torment. My reflections on images tied to the Holocaust contain the motif of people unaware of the inevitable catastrophe, the obscured literalness of the macabre, and finally damaged photographs, which can be interpreted as a metonym for the Holocaust. In this chapter, a look is understood both as a topic/subject - a certain essential detail of presented reality, preserved in photos, that can be captured, isolated and described - and as a description of a certain investigatory attitude, a way of comprehending the object of reflection: an attentive gaze at the details. Following the track of looks preserved in photographs,

66 Translator's note: In the original Polish text, this chapter title is "Spojrzenia," the plural of "spojrzenie," which can be translated as "gaze," "glance," and - what I regard as most appropriate here - "look." Because the word "look" (or "looks") fits awkwardly in some English-language sentences where "spojrzenie" does not in Polish-language sentences, I will hereafter italicize look and looks. 
I attempt to capture the landscape of the limit experience: the area of transition from life to death. In the chapter entitled "Encounters with a Corpse," I move through a series of macabre subjects in an analysis of various ways of recording confrontations with the dead body: from a history of the postmortem and the cultural meanings attributed to the autopsy, through grotesque and ennobling representations of the macabre, to the image of the degraded corpse and violations of funeral ceremonies during the Holocaust. A kind of epilogue to this journey contains reflections on the experiences of those who were able to survive an execution, and those who escaped - literally - a mass grave.

\section{Sources and Research Method}

I base my work on two fundamental types of sources: written records and images (above all photographs). I treat both types as a text that is subject to interpretation. I make use of the term "text" in the broad sense of the word, one that goes beyond the scope of linguistics and crystalizes in the concept of "cultural text," in every sequence of signs and symbols in a given system, ordered according to its own rules. ${ }^{67}$ Both the word and the photographic image are, for me, a record of experience, and not just a "collection" of facts or a depository of truth. ${ }^{68}$ The distinct nature of photographic and linguistic records determines the shape of the evidence itself, as well as the possibilities for how that evidence can be "read." In my analysis of various forms of record, I have had to maneuver between two types of relations: on the one hand, the word versus the image (photograph), and on the other hand, textualization versus visualization.

Regarding written texts, I rely on source material that is personal, autobiographical in nature. The concept of a personal document was developed from within humanistic sociology, and it was Florian Znaniecki who introduced the concept to the social sciences. Znaniecki explored the autobiography as valuable sociological material in and of itself, and in so doing created the so-called "biographical documents method." The concept of the personal document was

67 This way of understanding text originated with scholars of culture and semiotics from the Tartu-Moscow School. For more, see S. Żółkiewski, Teksty kultury: studia (Warszawa 1988); T. Dobrzyńska, “Tekst jako przedmiot badań różnych dyscyplin naukowych," in Tekst. Próba syntezy (Warszawa 1993), 42.

68 "The belief that leads to the categorical distinction between sources and historical narrative and the treatment of sources as a depositary of truth, I call this a myth about historical sources." J. Topolski, Jak się pisze i rozumie historię. Tajemnice narracji historycznej (Warszawa 1996), 337. 
carried over to the study of literature by Roman Zimand, who invented "personal document literature" as a concept. This concept encompassed a wide range of written autobiographical material - personal accounts, diaries, journals, and letters - which create an internally differentiated constellation of texts that consist of an area with effaced and elusive borders. ${ }^{69}$ Such texts are an expression of a position that - simply put - can be described through a bipolar schema. On one side there would be the position of the witness, who provides his account of the world, the domain of his personal experiences; and on the other side the position of someone who offers up an intimate confession, who writes not so much about the reality around him, but rather about himself. ${ }^{70}$ The texts that I analyze are dominated by the position of the witness.

I make use of sources differently than do scholars who strongly emphasize the obligations to "describe the facts." In his work Geschichte der romanischen und germanischen Völker von 1494 bis 1514 (published in 1824) Leopold von Ranke put forward his famous postulate: to write "how it really was" (wie es eigentlich gewesen $).{ }^{71}$ According to this concept, the historian's task is to present the facts objectively, which requires that sources be examined carefully, and that they be contrasted with other sources for the sake of verification. Ranke's model includes an emphasis on "explanation" (as opposed to "understanding"). Though I respect this approach, I have set other goals for my investigation. In the sources, I am looking for not just knowledge of the facts, but rather a record of a limit experience that can be revealed and interpreted. I am far from advocating the "naïve" treatment of sources as a transparent medium, one that gives us direct access to knowledge of the experience itself or knowledge of some unmediated reality. Nonetheless, I am opposed to breaking experience from its empirical foundation, to moving within the realm of discourse entirely "detached" from reality. ${ }^{72}$ The representations of limit experiences that I analyze here are founded on source material that adheres as closely as possible to the moment of experience itself. ${ }^{73}$

69 See R. Zimand, Diarysta Stefan Ż. (Wrocław 1990).

70 See M. Czermińska, Autobiograficzny trójkqt. Świadectwo, wyznanie, wyzwanie (Kraków 2000).

71 See J. Topolski, op. cit., 23-26.

72 For more on the "displacement" of the modern experience, which is "detached" from reality, loses its cohesion and cognitive neutrality, which leads in turn to the autonomy of the representation from the presented (experience), of the medium toward the object, see R. Nycz, Literatura nowoczesna wobec doświadczenia, op. cit., 15-16.

73 For more on research methodologies applied to autobiographical source materials and the Holocaust, see my article "Literatura dokumentu osobistego jako źródło do badań nad zagładą Żydów. (Rekonesans metodologiczny)," Zagłada Żydów. Studia i materiały 
One could characterize my scholarly approach as one that involves a certain methodological eclecticism. I would count hermeneutics as an important source of inspiration (above all Gadamer's version). It gives me a kind of "tuning" (as with a piano), provides me a path to understanding, to undertake understanding. Methods used in the field of literary anthropology to cultivate reflections, along with cultural theories of literature, are also important in my approach. ${ }^{74}$ An interest in photography has led me toward those areas of the humanities that are called "visual sociology," "visual anthropology,"76 or the anthropology of the image. ${ }^{77}$

This book is the product of many years of meetings and conversations (from which I drew energy to work), suggestions, comments, commentary, and polemic impulses. I want to thank the students at the Instytut Kultury Polskiej at the University of Warsaw, with whom, during classes and seminars, I discussed many of the issues raised in this book, and I want to thank my friends from the Pracownia Poetyki Teoretycznej at the Instytut Badań Literackich (IBL) Polskiej Akademii Nauk (PAN) for their inspiring discussions and sometimes intense debates. I extend a word of heartfelt thanks to Professor Alina Brodzka-Wald for our valuable "nighttime talks." Thanks also to my friend, Professor Aleksander Nawarecki, for his thorough reading of the manuscript, his pointed comments, and valued additions. I would like to thank prof. Ewa Domańska for being ever

1 (2005). For more on my own method of reading the literature of the personal document and the Holocaust, see Tekst wobec Zagłady (chapter "Poszukiwanie formuły").

74 See R. Nycz, "Kulturowa natura. Kilka uwag o przedmiocie poznania literackiego," Teksty Drugie 5 (2001); Nycz, "0 przedmiocie studiów literackich. dziś," Teksty Drugie 1-2 (2005); see also Narracja i tozsamość: vol. 1: Narracje w kulturze: vol. 2: Antropologiczne problemy literatury, eds. W. Bolecki, R. Nycz (Warszawa 2004); Kulturowa teoria literatury, Glówne pojęcia i problemy, eds. M. P. Markowski, R. Nycz (Kraków 2006).

75 See P. Sztompka, Socjologia wizualna. Fotografia jako metoda badawcza (Warszawa 2006).

76 See S. Sikora, Fotografia. Między dokumentem a symbolem (Izabelin 2004). Sikora refers to issues of Konteksty devoted to visual anthropology (1992, no. 3-4; 1997, no. 3-4). See also Film i audiowizualność w kulturze. Zagadnienia i wybór tekstów. Część I: Audiowizualność w kulturze: wprowadzenie. Część II: Film w kulturze, ed. S. Kuśmierczyk (Warszawa 2002).

77 See K. Olechnicki, Antropologia obrazu. Fotografia jako metoda, przedmiot i medium nauk społecznych (Warszawa 2003). 
prepared to assist and for her spiritual support. And I thank my invaluable wife for her patience and understanding.

I would like to extend my special thanks to Professor Maria Hirszowicz for her friendly interest in the subject matter of this book and for her care and support during my stays in London. Without her assistance, the libraries and archives of London would have been inaccessible to me. Unfortunately, this book was published after her death. 

Part I 



\section{Topography and Existence}

There are events that break the life of an individual in a single moment. An understanding of the depth of the crisis comes with time, early for some, later for others. An awareness grows that things will never again be like they were. The participation of someone who has survived such a situation represents a kind of transition experience: the feeling that we find ourselves on the border, in between. I am not speaking here of rites of passage, which - according to the classic notion put forward by Arnold van Gennep in his book Les rites de passage (1909) - affect all areas of human life and express, in a symbolic way, the critical moments in which change emerges (births, initiations, marriage ceremonies, motherhood and fatherhood, death). ${ }^{78}$ Rather, I am talking about events that are not subject to such strict ritualization, and that strike a person more or less unexpectedly such that he has no time to prepare for the coming event. And what interests me above all are the ways that people cope with these events; how they respond to them; what levels of tradition and culture, and what spheres of emotion and intellect, people reach for in order to give expression to such events.

The city, as a creation of the human collective, is a cultural form and thus, in its own way, a significant structure. One can therefore conceive the city as a text that generates its own kind of discourse, one that can be read and interpreted. ${ }^{79}$ The object of my reflections is - so to speak - the recorded city, by which I mean the

78 Arnold van Gennep, The Rites of Passage: A Classic Study of Cultural Celebrations, trans. Monika B. Vizedon and Gabrielle L. Caffee (University of Chicago Press, 1961).

79 R. E. Park, a representative of the "Chicago school" in sociology, wrote in 1916: "The city is [...] a state of mind, a body of customs and traditions, and of the organized attitudes and sentiments that inhere in these customs and are transmitted with the tradition. The city is not, in other words, merely a physical mechanism and an artificial construction. It is involved in the vital processes of the people who compose it." See Mark Hutter, Experiencing Cities (Routledge, 2016), 90. See also M. S. Szczepański, "Z historii socjologii miasta i procesów urbanizacji. Ekologia klasyczna i konwencjonalne teorie urbanizacji," in Problemy socjologii miasta, ed. J. Wódz (Katowice 1984), 16. For more on the city as a statement or the expressions of a city in the topological semiotic context, see A. J. Greimas, "Ku semiotyce topologicznej," in E. Leach, A. J. Greimas, Rytuał i narracja, trans. M. Buchowski, A. Grzegorczyk, E. Umińska-Plisenko (Warszawa 1989); for an analysis of the semiotic city from the perspective of sociology, see B. Jałowiecki, "Proces waloryzacji przestrzeni miejskiej", in Przestrzeń $i$ społeczeństwo. Z badań ekologii społecznej, ed. Z. Pióro (Warszawa 1982); see also Pisanie miasta - czytanie miasta, ed. A. Zeidler-Janiszewska (Poznań 1997). 
various ways in which the experiences of a city have been preserved in written texts. I thus do not so much read texts of the city, but read texts about the city; indeed, not just about the city where one experiences something, about urban scenery, but rather (also) about the urban as a category of human community in the social, cultural and existential sense. About a kind of "urbanized" form of experience, about a "topographical" form of expression.

This chapter focuses on the ways of recording the various stages of the degradation and destruction of urban space, in this case Warsaw: From the September siege of 1939, through the city divided by the ghetto wall, to an attempt to describe the empty "space-after-the-ghetto."

\section{Romantic Heroization}

Diarists at the time perceived the very moment the war broke out in a kind of dual fashion. War was expected, but when it became fact, it was surprising. It seems like this reaction was almost universal. On 1 September, Halina Regulska, wife of the future Head Commandant of the Citizens' Guard during the defense of Warsaw, noted: "The news, though expected, threw us off balance." ${ }^{80}$ Ludwik Landau wrote the following about the first day of the war: "Today we had the first air raid on Warsaw, which - despite everything - was so unexpected that many people took it as an attempt to test the efficiency of the anti-aircraft defense." 11 The entry dated 1 September 1939 that begins the diary of Wacław Lipiński reads: "So, word became deed ... War! War, as I predicted months ago - unexpected, suddenly, without notice." ${ }^{2}$ Such evangelical wording emphasizes not only the significance of the event, but also the moment in which expectations were fulfilled. Something thus happened that we were waiting for, that we indeed expected, but - paradoxically - came "unexpectedly and suddenly." A collision of anticipation and surprise.

An entry in the diary of poet Jarosław Iwaszkiewicz placed the moment war broke out into the context trivial everyday existence ("Podkowa ${ }^{83}$ was bombed,

80 H. Regulska, Dziennik z oblężonej Warszawy. Wrzesień-październik-listopad 1939 r. (Warszawa, 1978), 19.

81 L. Landau, Kronika lat wojny i okupacji, eds. Z. Landau and J. Tomaszewski, vol. 1 (Warszawa 1962), 4.

82 W. Lipiński, Dziennik: wrześniowa obrona Warszawy 1939 r. (Warszawa 1989), 51.

83 Translator's note: Podkowa Leśna was (and is) an affluent suburb of Warsaw about 20 kilometers southwest of the Polish capital. 
while the girls were out picking mushrooms and we couldn't call them in") and into a metaphysical perspective:

Yesterday, after the bombing had stopped and after some idiotic talks, the Radio broadcast Debussy's "Iberia." In the chaos created by man, this clear and classical music seemed to me to be a game of pure numbers, a divine indication of the order of the totality of numbers. The possibility to think abstractly, the possibility to break from the horror of fractions through whole numbers, art, seems to me to be the possibility for salvation. And once again, even now, when all is falling apart: salvation is only in art! ${ }^{84}$

With war, ripping at the fabric of everyday life, man is faced with the ultimate danger. Iwaszkiewicz detected something more: as if in the bright light of an epiphany, the fundamental principle governing reality, both human and divine, was unfolding before him. Here we see the collision of order and chaos, of that which is constant and eternal with that which is fleeting and transient; the greatness of art set against elemental disaster. One could interpret this as testimony to an experience of something that one might call a limit event.

Let us juxtapose two visions of Warsaw during the September siege of 1939. Both were preserved as they happened, one during the bombardment, the other just after the Germans entered the city. The first one was delineated by Warsaw mayor (Poles use the term "president") Stefan Starzyński during his famous radio addresses and, by way of a climax, in his last speech on 23 September 1939, two days before the heaviest bombing and five days before capitulation, during which he uttered the famous lines: "I wanted Warsaw to be great ..." and "Warsaw, defending the honor of Poland, is today at the highest point of its greatness." 85 The second one was recorded by writer Karol Irzykowski under the date 3 October 1939, when the picture of Warsaw's destruction had become entirely clear and Adolf Hitler was about to lead a victory parade along the city's Aleje Ujazdowskie. In this diary entry, Irzykowski cited the opinion circulating through Warsaw "that Starzyński's action - his refusal to surrender the city - was 'criminal," and he added for himself that "Today W[arsaw] is the most wonderful demolished city in Europe, [...] the president could show it to tourists for money." 86

84 J. Iwaszkiewicz, Dzienniki 1911-1955, eds. Agnieszka Papieska and Robert Papieski (Warszawa 2007), 141.

85 Quote from Archiwum Prezydenta Warszawy Stefana Starzyńskiego, ed. and intro. by M. M. Drozdowski (Warszawa 2004), 294.

86 Irzykowski is quoted from his Pisma, ed. A. Lam: Dziennik, vol. 2: 1916-1944 (Kraków 1998), 363-364. 
The testimonies of Starzyński and Irzykowski are representative of the attitudes I want to describe. They grow out of distinct intellectual and cultural traditions, out of different models of patriotism; they also make use of polar opposed rhetorical styles. They display examples of different ways of coping with an event which was predictable and historically familiar (the outbreak of war), but which very quickly slipped - so to speak - out of mental and emotional control. The experience of the uneven battle between the Germans and the Poles, and of defeat, has been domesticated in Polish history. But the September siege, the scale of the destruction and the number of victims, the bitterness that came with dashed hopes, had brought Poland to an apogee. At least that is how it seemed at the time. The records analyzed here are an effect of a confrontation with these experiences. Each in a different dimension. It is difficult to find a more dramatic example of the collision of martyrological pathos and romantic frenzy (on the one hand) and bitter irony (on the other hand) undermining the heroic myth.

Stefan Starzyński, the mayor of Warsaw and a prominent representative of the Sanacja regime ${ }^{87}$ had earned himself the sympathies of Varsovians before the war, but the events of September 1939 brought him fame and glory as the leader of the nation, which allowed him entry into the pantheon of heroes and warriors for freedom. The legend of Starzyński, born during the siege of Warsaw, is alive still today. Great poets - Jan Lechoń, Antoni Słonimski - wrote verse about him, as did such lesser known poets as Ryszard Kiersnowski. ${ }^{88}$ In his account of the battle of Warsaw, written in a prison camp, Colonel Stanisław Rola-Arciszewski, deputy chief of staff of the "Warsaw" army under the command of General Juliusz Rómmel, had no doubt that Starzyński was "a man whom Warsaw owed a monument 'aere perennius"'" 99 But the two monuments erected in his name after

87 Translator's note: The Sanacja regime emerged from Józef Piłsudski's May Coup of 1926. Increasingly authoritarian and nationalistic, it governed Poland throughout the 1930s until the German occupation of Poland in 1939.

88 For more on the literary legend of Starzyński, see D. Patkaniowska, "Legenda literacka Stefana Starzyńskiego," Pamięc września, ed. A. Brodzka, Biuletyn Polonistyczny (1990), z. 3-4. For a selection of documents on this legend, see M. M. Drozdowski, Archiwum Prezydenta Warszawy Stefana Starzyńskiego (Warszawa 2004).

89 S. Rola-Arciszewski, "Wrzesień 1939," in Obrona Warszawy 1939 we wspomnieniach, eds. M. Cieplewicz, Eugeniusz Kozłowski (Warszawa 1984), 330. In his poem "Popiół i wiatr" Słonimski assured us: "Someday a monument to Starzyński will stand in Warsaw." But Ludwik Hirszfeld seemed to be more reserved, writing: "I do not know whether a monument will ever be built for President Starzyński; however, in the hearts of Warsaw's defendants he already has his monument." See Hirszfeld, The Story of One Life, trans. Marta A. Balińska (University of Rochester Press, 2010), 173. 
the war hardly fit into this category. ${ }^{90}$ The figure of the mayor battling for the city was invoked at one of the key moments in postwar Polish history by one of its greatest moral authorities. During the dedication of a memorial plate to Stefan Starzyński in St. John's Archcathedral in Warsaw, placed alongside epitaphs to Marshal of the Four-Year Sejm Stanisław Małachowski and to Polish Premier Wincenty Witos, ${ }^{91}$ the Primate of Poland Cardinal Stefan Wyszyński elevated Starzyński to the level occupied by other Polish national heroes. They all cry out:

The need for the "sword of the spirit and the action of steel" to mobilize the strength of a nation who wants to live. [...] To this chorus of the ages, which resounds with mighty organs throughout this cathedral, we add one voice - the heroic defender of the Capital, president [mayor] Stefan Starzyński. May the call go out to everyone who passes this way: "Clamate lapides de patrie - Warsaw, oh Warsaw"."2

Starzyński's place in the national pantheon was ensured by his actions during the siege: his decision to remain in Warsaw in defiance of the disorderly evacuation of the government and state administration; his self-control in avoiding panic; the perfect organization of the civil defense of Warsaw; and above all his personal courage and boundless dedication. But Starzyński's image would not have persisted in such a form down to the present day had it not been for radio. His permanent glory and fame was founded on the speeches he broadcast every day through what would seem like an impermanent medium.

Zygmunt Zaremba - one of the leaders of the Polish Socialist Party at the time, a co-organizer of the Workers' Battalions for the defense of Warsaw, a

90 Both Warsaw monuments could easily compete for the blue ribbon in the "Greatest Mistakes in Sculpture" contest. The first monument, designed by L. KraskowskaNitschowa and unveiled on 16 January 1981, is hidden in the trees of the Saxon Garden in Warsaw, and presents a kind of dwarf figure on a pedestal. The second is a complete catastrophe. Located near the Błękitny Wieżowiec tram stop at Plac Bankowy, it presents a kind of monstrous hybrid with a human head bending over something resembling a map of Warsaw. This work, by Andrzej Renes (who also did a monument to Cardinal Stefan Wyszyński in Warsaw), was unveiled on 10 November 1993.

91 Witos and Starzyński sharing the same space is particularly interesting if we remember that Witos, along with other members of the opposition, was arrested on the night of 9-10 September 1930, thrown into the Brest fortress, faced accusations at the 1931 Brest trial, and was sentenced to a year-and-a-half in prison. This entire action was carried out under orders from Marshal Piłsudski. Throughout the Brest events, Starzyński, who had taken part in the entire campaign of the 1st Brigade, was serving as Deputy Treasury Minister in the cabinet of Walery Sławek.

92 Quoted from A. K. Kunert, “Obronca honoru stolicy," Kierunki, 8 September 1985 (R. 30), no. 30. The ceremony took place on 1 March 1981. 
member of the Council for the Defense of the Capital, author of the brochure Obrona Warszawy. Lud polski w obronie stolicy (wrzesien 1939) (The Defense of Warsaw. The Polish people in defense of the capital [September 1939]), which was published anonymously by the underground press in late October or early November 1939 - pointed out the enormous role that radio had played throughout the siege. In his memoirs written after the war (a cycle of articles on "Warszawa we wrześniu 1939" were published in the London dailies Dziennik Polski and Dziennik Żotnierza in 1949), Zaremba developed this idea significantly. He was fascinated by Starzyński, his old friend from the youth organization Związek Młodzieży Postępowo-Niepodległościowej. The two men had gone on to take different ideological paths during the Second Republic (1919-1939), but the "ice was broken" by the mayor's actions in September. Zaremba's recognition of Starzyński went hand in hand with his reflections on the phenomenon of radio at the time.

The strongest stimulus, sometimes a narcotic, always the source for encouragement and a link for every unit or group within society, was Warsaw radio. Thanks to the courage and sacrifice of its staff, which had been greatly reduced by the evacuation, it functioned every day until noon, even though the Germans were concentrating their artillery fire in the area around its headquarters on Zielna Street. Every day the radio broadcast reactions from the world, saying that Warsaw's sacrifice was not in vain, that our defense was echoing in Paris, London and New York. That it was raising anger, and a will to settle the score, with the invaders trying to enslave the world through the subjugation of Poland. In those days, Warsaw radio was able to echo the experiences of the entire population of Warsaw. ${ }^{93}$

Zaremba's comments are all the more valuable because they came from a person strongly opposed to the Sanacja regime.

There are no accounts or memoirs in which the figure of the Warsaw mayor does not appear; in some cases, he appears often, and in other cases, he appears only occasionally. Who was Starzyński for these authors? What terms did they use to describe him? What attributes did they ascribe to him? What did his radio addresses mean to them? How was his behavior behind the microphone received?

Above all, Starzyński was described using the term "hero." This is not just the pure use of a conventional word or an empty linguistic gesture. For his radio listeners, the mayor's heroism contained clear cultural meaning and historical significance. It was integrated into a sphere of culture that was closest to them,

93 Z. Zaremba, Wojna i konspiracja [First edition, London 1957] (Kraków 1991), 95. 
and to him. What we are talking about here, of course, is romantic heroism. The portrait sketched by pianist and composer Władysław Szpilman encompasses both the mayor's characteristic external appearance and his moral condition. The two men met at the doors of the radio station on 23 September:

He was disheveled and unshaven, and his face wore an expression of deathly weariness. He hadn't slept for days. He was the heart and soul of the defense, the real hero of the city. The entire responsibility for the fate of Warsaw rested on his shoulders. ${ }^{94}$

Starzyński was a "national hero and the hero of Warsaw," ${ }^{35}$ he was a "hero in the war against the Germans"96 - which means his name was etched into the pages of Poland's most glorious history. He was, after all, a "hero among heroes," a Polish Vercingetorix ${ }^{97}$ - the fearless leader of the Gallic uprising against the Romans in 52-51 BCE. In this way, the heroism of the civil head of the defense of Warsaw assumed a knight-like, universal dimension.

Not just because of the actions he took as part of his official functions, but above all because of the actions he took on an everyday basis, the mayor was perceived as a defender. For writer Kazimierz Wierzyński, he was simply the "builder and defender of Warsaw," ${ }^{98}$ the father of the city in times of peace and war. But most authors attribute a deeper meaning to the term defender. Colonel Tadeusz Tomaszewski, chief of staff for the Command of the Defense of Warsaw, described Starzyński as the "dynamic flywheel of a million-person city, the soul of absolute resistance." ${ }^{\text {99 }}$ Colonel Rola-Arciszewski referred to values of the highest order: "the 'spiritual defender of Warsaw. This is what the people called him, this is what the military called him. And deservedly so. It will resound throughout Polish history with a clear chord." ${ }^{100}$ Forty-two years after the fact, in calling

94 Wladyslaw Szpilman, The Pianist: The Extraordinary True Story of One Man's Survival in Warsaw, 1939-1945, trans. Anthea Bell (Picador 2000), 38.

95 Such were the words spoken during an academic ceremony in the Teatr Polski in September 1946 by the then current mayor of Warsaw, Stanisław Tołwiński. See A. K. Kunert, op cit.

96 Fragment of a dedication to the poem "Barbakan warszawski" by Kazimierz Wierzyński.

97 These are the words of Rola-Arciszewski, op. cit., 319, 330.

98 Fragment of a dedication to the poem "Barbakan warszawski" by Kazimierz Wierzyński..

99 T. Tomaszewski, "Byłem szefem Sztabu Obrony Warszawy w 1939 roku," in Obrona Warszawy 1939 we wspomnieniach, eds. M. Cieplewicz, E. Kozłowski (Warszawa 1984), 127.

100 S. Rola-Arciszewski, op. cit., 319. 
Starzyński the "defender of the honor of the capital”"101 Primate Wyszyński made use of one of the key words that not only defined the stance taken by the mayor of Warsaw, but that also dominated the tone in which Warsaw's defense has been written.

The person of Stefan Starzyński is often associated with steadfastness, his unfaltering character, and thanks to his persistence against the German invaders, he occupies a permanent place in history. Antoni Słonimski, in his poem Popiót $i$ wiatr, published in the summer of 1940, wrote:

\begin{abstract}
Nie wiem, kogo Warszawa przeklnie czy zapomni,
Lecz w sercu długo jego zachowa jednego.

Nie giną bez pamięci tak jak on niezłomni. ${ }^{102}$

I do not know whom Warsaw will curse or forget,

But in its heart it will hold one [person] for a long time.

The steadfast like him shall not be forgotten.
\end{abstract}

On the fifth anniversary of the outbreak of war, Aleksander Kamiński, on the pages of Biuletyn Informacyjny, ${ }^{103}$ drew out the symbolic meaning of Starzyński’s actions and the current-day message for Warsaw residents, as the city burned in the Uprising:

Thus spoke President Starzyński five years ago, the man who embodied, in the eyes of the country and the world, the fact that Warsaw is fighting steadfastly, that its belief is deep, that it is faithful to the end. Today President Starzyński is no longer with us. But His words remain here in the walls of the city, to fortify us in battle, to allow us to persevere. ${ }^{104}$

In the case of Starzyński, "steadfast greatness" went hand in hand with simplicity. Many authors took note of this paradoxical quality. Colonel Rola-Arciszewski put it this way: "The soldier himself (he walked around in uniform and asked that he not be called president, but major) understood soldiers, and his steadfast greatness was felt by us in every way." ${ }^{105}$ This connection between that which was extraordinary

101 During the ceremony dedicating the plate-memorial in St. John's Archcathedral in Warsaw in January 1981. See A. K. Kunert, op. cit.

102 A. Słonimski, Poezje zebrane (Warszawa 1964), 427.

103 Translator's note: Biuletyn Informacyjny was a Polish underground weekly published in the General Government of occupied Poland during the Second World War.

104 Biuletyn Informacyjny. Wydanie codzienne, Warszawa, Friday 1 September 1944, R. VI, Nr 69 (277); quote from Biuletyn Informacyjny. Część IV. Reprint from the years 1944-1945. "Powstanie warszawskie i konspiracja," Przegląd Historyczno-wojskowy, Nr specjalny 4 (205) (Warszawa 2004), 2274.

105 S. Rola-Arciszewski, op. cit., 319. 
in the mayor's character with that which was common is shown in Jan Lechon's "Pieśń o Stefanie Starzyńskim" (Song about Stefan Starzyński), from the volume Lutnia po Bekwarku (1942). The character of Konstanty Julian Ordon - a sacred figure of Polish romantic legend who, in Adam Mickiewicz's vision, dies in the rubble of his own redoubt, fighting to the end - appears there. The question arises:

Kto jest ten mały człowiek, co w ognistym deszczu

Sród murów, co się walą, jako posąg stoi?

Who is this little man, in the fiery rain

Amidst the walls that have fallen, who stands like a statue?

Wanting to liberate himself from romantic pathos, he confirms it even more strongly:

Myślisz pewno, że to dziejów krater

Wciąż tę samą wyrzuca romantyczną lawę

I że to jeszcze jeden szalony bohater

Nieopatrzną, ułańską opętał Warszawę.

I tobie jeszcze ciągle marzy się o cudzie

I o owych nadludziach, co się biją chrobrze.

Cudów chcesz? Pomyśl tylko, że są zwykli ludzie,

Jak on, co zawsze wszystko chcą wypełnić dobrze.

You most likely think that this is the volcanic crater of history

It still throws out the same romantic lava

And that yet another crazy hero

Possessed the careless, Uhlan-like Warsaw.

And you still dream of a miracle,

Of superhumans who fight gallantly.

Miracles you want? But just think, there are ordinary people,

Like he, who always want to do things well. ${ }^{106}$

Tied to steadfastness is yet another term applied to Starzyński, namely "Książę niezłomny," or "Prince Steadfast." Wanda Kragen called him by this name in her "Kronika dni wrześniowych": "Every evening I speak with Major Starzyński, Prince Steadfast of steadfast Warsaw." 107 Don Fernand, the hero of CalderonSłowacki's masterpiece, dies in captivity because he has rejected a deal that would have freed him in exchange for handing the ancient city of Ceuta over to the

106 J. Lechoń, Poezje (Warszawa 1979), 94.

107 W. Kragen, "Kronika dni wrześniowych," published in Odrodzenie 36 (1946); quote from Antologia pamięci 1939-1945. Polski wrzesień, ed. W. Żukrowski (Warszawa 1964), 189. 
Moors. As Prince Steadfast, the Warsaw mayor attained the highest ennoblement. In the two-decade interwar era, only Marshal Piłsudski was worthy of such an appellation. ${ }^{108}$

Stefan Starzyński's role in the defense of Warsaw, along with his presence at the Polish Radio at 25 Zielna Street, is fully described in secondary literature. ${ }^{109}$ In my considerations here, I focus on the image of this character, how it was formed in the minds of eye-witnesses, and how it can be reconstructed by the records they left behind. Zygmunt Zaremba, cited above, left us a succinct description of President Starzyński's daily radio addresses, which were widely and carefully listened to, and what they meant for Varsovians and other Poles.

The speeches delivered by political leaders and military spokesmen, and above all Starzyński's daily commentary, made the people aware of the meaning of the sacrifice, stigmatized the crimes of the enemy, and gave satisfaction to built-up bitterness and hatred. By exposing to the eyes of Varsovians the wounds that the enemy of the city was inflicting, the voice of president Starzyński did not allow personal misfortune to crush

108 The appellation of resurrector of the nation, used to describe "Czterdzieści i cztery" (L. Rygier, Ślubowanie pieśni Naczelnikowi w Dniu Imienin, or A. Oppman, Oda do zwycięstwa), Konrad Wallenrod (E. Średnicka, Pierwszemu Marszałkowi Polski Józefowi Piłsudskiemu) and of course "Król-Duch" (S. Borkowska, Przed portretem Pilsudskiego or J. Dicksteinówna, $W$ spetnieniu), was also used in the case of CalderonSłowacki’s hero. In A. Prędki’s poem, Piłsudski, staring at the rising sun of freedom, calls up "Xiążąt Niezłomnych roty" and leads them into "daleki Brzask - we mgle spowity, / niszczqc zlo." See W. Wójcik, Legenda Piłsudskiego w polskiej literaturze międzywojennej (Katowice 1986). The fragment from Prędki’s poem is on p. 134. Słowacki, Calderon's congenial translator, was the architect of the Marshal's imagination, and in Piłsudski's famous speech at the spreading of the bard's ashes at Wawel castle on 28 June 1927, he was declared to be the Polish Król-Duch.

109 Two collections of documents have been published: Cywilna obrona Warszawy we wrześniu 1939 r. Dokumenty, materiaty prasowe, wspomnienia i relacje, ed. L. Dobroszycki, M. M. Drozdowski, M. Getter, A. Słomczyński (Warszawa 1964); and Archiwum Prezydenta Warszawy Stefana Starzyńskiego, ed. M. M. Drozdowski (Warszawa 2004) (from the large collection of documents from September 1939). M. J. Kwiatkowski, in the book Wrzesien 1939 w warszawskiej rozgtośni Polskiego Radia (Warszawa 1984) devoted a great deal of space to the Warsaw presydent. For more on Starzyński's role as head of the city's civil defense, see A. Aksamitowski, "Działalnosc władz cywilnych Warszawy," in Warszawa we wrześniu 1939 roku. Obrona i życie codzienne, ed. Cz. Grzelak (Warszawa 2004). For the most recent biography penned by M. M. Drozdowski, see Starzyński: legionista, polityk gospodarczy, prezydent Warszawy (Warszawa 2006), which provides a thorough description of Starzyński's activities in September and October 1939 r. 
the collective will. He fused the individual's pain with the common sense of the injuries being inflicted on the city, the nation. In front of the world and his own people, he condemned the barbarity of war on civilian populations and the brutal vandalism that was destroying the cultural heritage of centuries. He was able to reach into everyone's hearts and to extract from them the noblest tones. And above all, this voice became stirringly close when it became thoroughly hoarse from talking so often: that rough voice, now muffled and hoarse, uttered the most resonant words by which the city, in its ruins, could live. ${ }^{110}$

Starzyński revealed to his listeners the deeper meaning of the reality surrounding them. How distant we are from the informational and organizational dimension of his addresses! Of course he played an enormous role in the events playing out in the besieged city. In Dziennik z oblężonej Warszawy, Halina Regulska noted:

More than anything else, Starzyński wants to prevent panic. He says that everyone should stay where they belong. Do not take up space on the roads, which need to remain open for military traffic. Those who have left Warsaw should return to their homes and their occupations. ${ }^{111}$

But Zaremba did not write about this. He presented Starzyński more as a spiritual father explaining the "meaning of the sacrifice" endured by people affected by misfortune. Speaking through the radio, the mayor was perceived by others in much the same way. Regulska called him the "spokesman for our suffering," the one who "raises our spirits"; he "builds courage, he holds us up."112 Many others spoke of "strengthening," of "giving comfort,"

The words coming out of the radio speakers gave hope to those who had no hope, they "built trust and encouraged people to carry on in the most difficult - and increasingly difficult - conditions." 115 Which is why there was something ceremonial about people listening to the radio together. In an entry dated 17 September, Halina Regulska wrote:

Listening to Starzyński in the evenings, as he talks on the radio, takes on the significance of a celebration. We survived another day and we were happy that none of us had

110 Zaremba, Wojna i konspiracja, 95-96.

111 H. Regulska, op. cit., 46.

112 Ibid., 86, 65, 72 .

113 The account of P. Rotszyld from the Yad Vashem archive, 033/438, s. 7.

114 The account of S. Lorentz, registered in 1963, in Cywilna obrona Warszawy we wrześniu 1939 r., 267.

115 J. Krawczyńska, Zapiski dziennikarki warszawskiej 1939-1947 (Warszawa 1971), 41. 
disappeared. After a hard day of work and difficulties we gathered around the radio, staring at the speaker, waiting for the words that could give us hope. ${ }^{116}$

A community of listeners was created around the mayor and his speeches because, as Zaremba wrote: "He was able to reach into everyone's hearts." It seems that the purely practical qualities of his addresses are replaced by their clearly spiritual functions. Zaremba was on target when pointing to Starzyński's particular skills, namely his ability to embed individual misfortune in the collective awareness of "the injuries being inflicted on the city, the nation," and simultaneously to defend Varsovians against the paralyzing effects of suffering, and to prompt resistance.

In their testimonies, listeners devoted a great deal of space to how Starzyński spoke, and it was not just about the sound of his voice, but also the rhetoric that characterized his addresses, about his skills as an orator. The mayor emerges as an unequalled master of the live word, a man who perfectly guided his listeners' emotions. Authors emphasized the simplicity, clarity and accuracy of his statements. As Ferdynand Goetel wrote in his memoirs about the occupation: “The Warsaw mayor's short, commanding sentences pierced the air like lightning." 117 Warsaw journalist Jadwiga Krawczyńska described the mayor's addresses as "short, matter-of-fact [...], without cant, using the simplest words that everyone could understand." 118 Stanisław Lorentz remembered them as "lofty and powerful in their simplicity" 119 We read in other accounts about "pathos"120 and "power,"121 about "dignified and ardent speeches,"122 about the "President's manly words." 123

Starzyński spoke into the microphone and his words were heard over the sounds of artillery fire and exploding bombs, over the sounds of buildings falling and the roar of fire. Thus he was broadly received - as the one who calls out, summons, exhorts, cries out, and electrifies the listeners with his amazing hoarse voice. That hoarseness became legend, an indicator, a stigmata inextricably tied to the figure of Starzyński. There is no proper testimony in which the

116 H. Regulska, op. cit., 72.

117 F. Goetel, Czasy wojny [first edition, London 1955] (Gdańsk 1990), 11.

118 J. Krawczyńska, op. cit., 41.

119 S. Lorentz, op. cit., 267.

120 For example, L. Landau, op. cit., 17 [record dated: 30 September 1939 -17 October 1939].

121 For example H. Regulska, op. cit., 47; Z. Petersowa, Wrzesień Warszawy 1939. Reportaz (Warszawa 1946), 53.

122 Hirszfeld, The Story of One Life, 173.

123 W. Kragen, op. cit., 190. 
hoarse-voiced mayor does not appear. As the editor of Biuletyn Informacyjny, Aleksander Kamiński, recalled: "In his unbuttoned uniform, with his voice hoarse and weary, he screamed them [the words cited by Kamiński] rather than speaking them." ${ }^{24}$ And the teenage Jewish girl, Pola Rotszyld, entered the following into her diary: "Day and night he called out through the radio in his hoarse voice." ${ }^{25}$ Another Jewish diarist, Karol Rotgeber, wrote in 1943: "President Starzyński has grown so hoarse through his address on the radio and spurring [the city] to its defense."126

Starzyński had great difficulty speaking. One of the presenters at Polish Radio, Józef Małgorzewski, wrote about meeting the mayor in the radio headquarters at 25 Zielna Street on 19 September.

Starzyński pointed to his throat. - "Worse and worse," he said, hoarsely. "I don't know how it will be in a couple days." Greeting the mayor, Rudnicki said: "One needs to get enough sleep, to relax." Rudnicki suggested: "Maybe a shot of cognac?" "No thank you..." Starzyński responded. "I like it [cognac] very much, naturally, but afterwards I would be even hoarser." ${ }^{127}$

The hoarse president triggered among listeners a spontaneous reflex of assistance; the mayor was losing his voice and Varsovians tried to help in any way they could. With bombs falling, they delivered various medicines and flu remedies. Halina Regulska noted on 20 September:

Yesterday, because of a hoarse voice, he could barely speak. Today, touched as he was, he thanked the residents of Warsaw for showing so much heart. After yesterday's address, he was overwhelmed by the medicine [sent to him] for the hoarse voice. ${ }^{128}$

The phenomenon of mayor Starzyński speaking through the microphone of the Polish Radio in September 1939 had its flip side, namely Colonel Roman Umiastowski. Today, the preserved fragments of Umiastowski's radio addresses are cause for embarrassment. In fact, it is amazing that a person possessing his particular intellectual capacity and oratorical skills would be allowed to function as head of propaganda for the Polish Commander-in-Chief. Umiastowski combined the figure of a military poser with infantile argumentation, primitive manipulation, and outright lies, along with glaring incompetence in the Polish

124 Biuletyn Informacyjny. Wydanie codzienne, op. cit., 2274.

125 Ibid.

126 Pamiętnik, AŻIH zespoł "Pamiętniki," sygn. 48, 7-8.

127 J. Małgorzewski, account entitled "Polskie Radio podczas obrony Warszawy," produced in August 1963, in Cywilna obrona Warszawy we wrześniu 1939 r., 290.

128 H. Regulska, op. cit., 86. 
language. It is important to emphasize that Umiastowski's addresses were not freely improvised versions of texts prepared ahead of time, as was the case with Lieutenant Colonel Wacław Lipiński and President Stefan Starzyński. Rather, Umiastowski's speeches were carefully prepared and then laboriously read into the microphone. He made use of a mixture of poetics from barrack-room tales with phrases filled with admonition and instruction, all of which was delivered with a paternalistic tone with a pronounced speech defect (Umiastowski could not pronounce the " $r$ "). His famous radio appeal, broadcast on 6 September 1939, calling on all men capable of carrying a firearm to immediately leave the city and move eastward, where a small reserve army would be created, led to catastrophic chaos. A mass of refugees fleeing in confusion blocked the roads, hindering military traffic, which thus became easy prey for German aircraft. The panic caused by this speech had to be controlled later by Starzyński.

It turned out that this appeal was the beginning of the end for the High Command's head of propaganda. The next day he was roundly criticized by his colleagues, led by Lipiński, who submitted his resignation in protest. He was transferred to General Walerian Czuma's staff as head of propaganda for the Command of the Defense of Warsaw. But Umiastowski did not concede defeat; in the evening of that same day he was seated once again before the microphone, at which time he called on the population to begin building barricades. He also provided valuable information on how to identify airplanes, and he offered essential advice for shooting rifles: "one can shoot only after confirming [...] if an aircraft is ours or theirs. The German signs are a black cross with bent lines, the so-called swastika. Only German planes have these black signs. All others are either ours or those of our allies." ${ }^{129}$ Umiastowski's further statements were interrupted in a way that was unprecedented in the history of Polish Radio. President Starzyński called the studio and dressed down the speaker with the microphone open. Umiastowski was able to finish reading his address, but it was his last public appearance. After the personal intervention of Starzyński, the appointed civil head of the Command of the Defense of Warsaw, Umiastowski was dismissed from his position as top propagandist. He then evacuated eastward along with the High Command..

At the foundation of Starzyński's message was the calm that emanated from the recognition of his own spiritual powers, a sense of moral superiority over the invaders, and the certainty of ultimate victory in defense of what was right. On 28 August 1939 he spoke over the radio and called on Varsovians to report

129 Quote from M. J. Kwiatkowski, op. cit., 92. 
for work digging anti-aircraft trenches: "Citizens of the capital! [...] Our spirits are high, complete calm, we all know that we give of ourselves whenever needs arise."130 On the fifth day of the war, he called out: "Citizens [...] we must maintain a shared sense of calm, all possible calm and order." ${ }^{131}$ In the face of ever increasing bombing, he told his listeners: "Our hearts are gripped by remorse as we watch our homes, palaces and churches tumble every day. But do not cry, do not become desperate, do not let your spirits fall." ${ }^{132}$ On 20 September Starzyński spoke words that provide a key to his broader message:

In the afternoon hours German planes once again dropped bombs on the city [...] But the war is not finished and we calmly watch the destruction of Polish territory, we watch calmly because we are a vibrant nation, one which has shown its strength generation after generation, the strength of its soul, one which will rebuild what the barbarian invaders have destroyed. ${ }^{133}$

What was this calm that was tied Starzyński's addresses?

First of all, it was a calm (felt in defiance of the desperate situation, and in the face of obvious defeat) that flowed from the unwavering certainty that - using the words of a poet - "my victory will be beyond the grave [...]." ${ }^{34}$ The righteousness and spiritual value behind the heroic decisions regarding the defense of Warsaw, and the resulting "burying oneself under the rubble of the city," ${ }^{135}$ would triumph in the end. Such argumentation fell under a different category than the calculations of diplomats and politicians (the effectiveness and believability of allies), the purely military considerations (the balance of forces and means, battle tactics and strategies), the human and materials costs of battle. Because the real battle was being waged on another level. It was a war waged by Juliusz Słowacki's "Król-Duch" (translated variously as "King-Spirit" or "The Spirit King") and Prince Steadfast. Thus, we are "calm" because another kind of victory - not military, but spiritual - is awaiting us.

Second, we calmly watch the destruction of Polish territory, because the destruction of that which is external does not encroach upon our spiritual capability, which we will strengthen, harden, turn into something even richer and

130 Ibid., 44.

131 Ibid., 76.

132 Address dated 15 September. Quote from J. Małgorzewski, op. cit., 285.

133 Quote from Archiwum Prezydenta Warszawy Stefana Starzyńskiego, op. cit., 283-284.

134 This fragment can be found near the end of Słowacki's V Pieśń Beniowski. Quote from J. Słowacki, Utwory wybrane, vol. 1 (Warszawa 1965), 355.

135 This fragment is from an article in the underground publication Znak dated 11 May 1940. Quote from A. K. Kunert, op. cit. 
more powerful. The death of the city and its inhabitants does not weaken the spirit of the nation; quite the contrary, it makes it stronger, more capable of surviving further catastrophes and of reconstructing what has been destroyed.

Third, we are not guided by emotions ("regret," "tears," "desperation") but by something much deeper and more durable than a variable, momentary mood. Which is why we watch the destruction calmly, and why the cataclysm raging around us cannot drag us into desperation. The source of this calm is the "strength and force of our spirit." Catastrophe could not break that spirit, but would strengthen it; the persistent defense of Warsaw, in flames, was the arena for a great spiritual test. "Citizens," Starzyński called out through the radio microphone on 11 September, "the more difficult, the worse it gets, the more spiritual strength we have." ${ }^{136}$ The bombardment ruining the city was a manifestation of the barbaric fury of destruction, but it also fueled the fire in which the most precious metals are forged. Following this line of reasoning, one can say that the following stanza, used by Jerzy Andrzejewski (author of the 1948 novel Ashes and Diamonds) as a metaphorical description of the first postwar months in Polish history, takes on a particular relevance. In Warsaw, in flames in September 1939, we detect a dilemma called forth by Cyprian Norwid:

Czy popiół tylko zostanie i zamęt,

Co idzie w przepaść $\mathrm{z}$ burzą? - czy zostanie

Na dnie popiołu gwiaździsty dyjament,

Wiekuistego zwycięstwa zaranie!... ${ }^{137}$

Will only ashes and confusion remain,

What will fall into the void of the storm? - or will there remain

A star-like diamond under the ashes,

The dawn of everlasting victory!...

And in those flames, that dilemma seems to have been solved.

The more Warsaw is severely and terribly destroyed today, the more beautiful it will be rebuilt in the future. Starzyński said so more than once, including on 15 September: "After the war is won, we will build a new and more beautiful Warsaw." 138 And four days later he added: "We will rebuild the destruction and charred remains. If we don't do it, our children will." ${ }^{139}$ The day after "bloody Monday," on 26 September, the War Council met in the basement of the

136 Quote from M. J. Kwiatkowski, op. cit., 131.

137 C. Norwid, Dzieła zebrane, vol. 1: Wiersze, ed. J. W. Gomulicki (Warszawa 1966), 496.

138 Quote from J. Małgorzewski, op. cit., 285.

139 Quote from Archiwum Prezydenta Warszawy Stefana Starzyńskiego, op. cit., 275-276. 
Pocztowa Kasa Oszczędności (the Postal Savings Bank, PKO) along with representatives of the Council for the Defense of the Capital. It was there that the decision was made to capitulate. In his account of the event, Colonel Tadeusz Tomaszewski described the mayor's characteristic behavior and his words:

When someone pointed out that the fires are destroying beautiful buildings, that Warsaw has ceased to exist, Starzyński, like a powerful bison, lowered his head toward the man crying over spilt milk and said, with great strength and conviction: "We will rebuild [the city] three times more beautiful." ${ }^{140}$

Defending Warsaw, the mayor emerged as both the city's Great Builder and its Great Destroyer. Aleksander Władysław Zawadzki, who was the civil head of defense for the Warsaw district of Praga, recalled his conversation with Starzyński on the night of 27 and 28 September:

[...] he began talking about the drama he was living through, watching the devastation of Warsaw, the city he wanted to build, watching the frustrated defense of the capital, which he had begun with such faith and zeal. ${ }^{141}$

This dramatic - one is tempted to write: demiurgical - tension between creation and destruction appears particularly in poetic accounts. In one poem in her cycle Jesień niezapomniana (1946), Hanna Mortkowicz-Olczakowa adds to the topos "the more terrible it is, the more beautiful it is" a spatial metaphor that offers up a wonderful paradox: the more the city collapses into rubble, the higher its builder rises.

Gdy miasto, które budował, buchało ogniem jak krater,

Gdy praca jego i chluba waliły się w pył i w gruz,

On nam potężniał $\mathrm{w}$ tych słowach, $\mathrm{z}$ nad ruin $\mathrm{w}$ górę rósł.

When the city that he built flared up in fire like a volcanic crater, When his work and his pride broke apart into dust and rubble, He grew in strength in these words, as he rose from the ruins. ${ }^{142}$

Jan Lechon illustrates the tragedy of Starzyński, who agreed to the destruction of Warsaw - his own work - in the name of higher values. Once again we are immersed in the topos "the more terrible it is, the more beautiful it is."

I on, gdy miasto było pochodnią czerwoną,

Powiedział: "Nie ustąpię. Niech te domy płoną,

Niech dumne moje dzieła na proch się rozpękną!

140 T. Tomaszewski, op. cit., 127.

141 Account from March 1946. Quote from Cywilna obrona Warszawy we wrześniu 1939 r., 486.

142 Quote from D. Patkaniowska, op. cit., 247. 
I cóż że z marzeń moich wszystkich rośnie cmentarz?

Ale ty, co tu przyjdziesz kiedyś, zapamiętasz,

Że jest coś piękniejszego niźli murów piękno. ${ }^{143}$

And he, when the city was a red torch,

He said, "I will not give up. Let those buildings burn

Let my proud work break down into dust!

So what if my dreams turn into a cemetery?

But you who will come here remember,

That there is something more beautiful than the beauty of walls.

Antoni Słonimski captured this tragic collision most succinctly, almost in aphoristic form, writing that the mayor:

Który wiernie stolicy jak nikt inny służył,

Dumnie ją rozbudował - jeszcze dumniej zburzył. ${ }^{144}$

Who faithfully served the capital like no other,

And who proudly built it up - has even more proudly destroyed it.

Stefan Starzyński's last radio address, broadcast on 23 September, creates an image of Warsaw around the romantic topos of the hero's beautiful death. ${ }^{145}$

I wanted Warsaw to be great. I believed Warsaw would be great. Me and my staff drew up plans, made sketches of a great Warsaw of the future. And Warsaw is great. It happened more quickly than we had supposed. Not in fifty years, not in a hundred, but today I see a great Warsaw. As I speak to you now, through the window I see, enveloped by clouds of smoke, reddened by flames, a wonderful, indestructible, great, battling Warsaw in all its greatness and glory. And although there are ruins where fine orphanages should stand, even though there are barracks covered with corpses where there should be parks, even though our libraries are engulfed in flames, even though hospitals burn, then not in fifty years, nor in a hundred years, but today Warsaw, defending Poland's honor, is at the height of its greatness and glory. ${ }^{146}$

143 J. Lechoń, op. cit., 93-94.

144 A. Słonimski, op. cit., 427.

145 For more on the Greek presentation of the "beautiful death" of a young warrior dying a hero's death, and on the "beautiful corpse" of a hero resting on the battlefield, see J.-P. Vernant, "Śmierć grecka - śmierć o dwóch obliczach," in Wymiary śmierci, ed. and intro. S. Rosiek (Gdańsk 2002). Two sculptures nicely represent the aesthetic canon of the "beautiful death": the Hellenistic "Dying Gaul" in the Capitoline Museums in Rome and Michelangelo's "Dying Slave" in the Louvre. For more on the various dimensions of the topos of the hero's death, see M. Janion, Czas formy otwartej. Tematy $i$ media romantyczne (Warszawa 1984), 101-125.

146 Several apocryphal versions of this speech have survived, as jotted down by eyewitnesses and listeners. Unfortunately, among the surviving original recordings from 
The hero was the battling city, which was collapsing under the blows of the overwhelming enemy forces, but which was rescuing its honor and achieving - in defeat - true victory. The enemy's destructive fury rendered the dream of a citygarden impossible, but it did not destroy the city as a particular version of fate, as a plan for existence. On the contrary, along this path of paradoxical transformation, such fury allowed the city to reveal itself in full, or - one might say - to shine in the fire of bombardment.

Before we trace the basis of this thought construct, let us turn our attention to an important matter that not only helped create the scenery in which the mayor's speeches resounded, but also reinforced the themes of those speeches, and directs our attention directly to the source of their ideational tradition. To the point: Starzyński's addresses were accompanied by Casimir Delavigne's "Warszawianka," one of the three songs (alongside "Mazurek Dąbrowskiego" and "Boże, coś Polskę") that - as Maria Janion has written - "mark the lineage of modern Polish patriotism, shaped primarily by romanticism." ${ }^{47}$ In a fictionalized report of J. Wołowski, a radio journalist and participant in the defense of Warsaw, the sounds of "Warszawianka" could be heard, in a symbolic way, at the beginning and end of Starzyński's last address:

Starzyński entered the studio. From the speaker mounted on the wall, one could hear "Warszawianka." [...] It came to an end. He wiped the sweat from his forehead. A large group of people were standing in the doorway. Even those whose homes had been burned came out of their shelters and crowded around to listen to Starzyński. A way was made for him to squeeze between the people, who applauded. Someone ran up with a hot coffee. The sound of "Warszawianka" came again from the speaker, which had not yet been turned off. ${ }^{148}$

In this radioman's recollection, put through the filter of romantic mythology, "Warszawianka" not only provided a musical background, but also served

September 1939, there are only seven with Starzyński's voice, and there is no recording of the mayor's last speech. Quote from M. J. Kwiatkowski, op. cit., 272 (for information about recordings that survived, see ibid., 340-341). An identical text was published in Archiwum Prezydenta Warszawy Stefana Starzyńskiego, op. cit., 294. In an account written in August 1963, J. Małgorzewski cites a longer and slightly modified version (even more dramatized), but this is rather unreliable, since the author claims that Starzyński's last radio address took place on 26 September, which is impossible, simply because, after the massive bombing of "black Monday" on 25 September, Warsaw was without electricity.

147 M. Janion, Reduta. Romantyczna poezja niepodległościowa (Kraków 1979), 7.

148 "Tak bylo" was published in 1962. Quote from D. Patkaniowska, op. cit., 250. 
as ideational and rhetorical inspiration. Starzyński seemed to call out to the residents of the Polish capital with words that echo Delavigne's tune, with its extreme intransigence, its absolute dictate to defend the threatened "redoubt," its patriotic radicalism. ${ }^{149}$ In Wołowski's apocryphal version of the mayor's last address, Starzyński believes that "justice will prevail over crimes", that "liberty will come out triumphant. Withsuch faith, one can die without complaint." There would appear to be echoes of "Warszawianka" in the mayor's words about "thousands of unburied corpses," about the notion that the "entire city remains engaged in a deadly struggle" and "will soon be a flattened square covered with corpses." ${ }^{150}$ The scene ends with a description of eye-witness reactions to the mayor's final radio address. In rapture, almost in a trance, they give Starzyński a great ovation. In the midst of applause and the thunder of exploding bombs, Starzyński -along with his listeners - enters that sphere of the romantic community united in an act of patriotic sacrifice.

As many accounts of the events of September 1939 indicate, Polish Radio broadcasted the melody and lyrics of "Warszawianka" throughout the entire siege of Warsaw. This song's call, which reached the summit of patriotic radicalism ("those who survive will be free/those who die are already free", or "today is the day of your triumph or your death!"), which led a handful of Polish conspirators to battle in November 1831, was - in a certain sense - embedded in the logic of the military actions undertaken by the residents of the million-resident Polish capital and determined the fate of the soldiers defending the city and its civilian inhabitants (the difference between them, after all, being non-existent).

On 28 September 1939 (that is, the day after the capitulation document was signed and during a three-day cease-fire) an article appeared in Kurier Warszawski under the symptomatic title Odbudujemy jeszcze stolice (We will rebuild the capital). Beyond the promise that Warsaw would be rebuilt "greater

149 See M. Janion, Reduta. Romantyczna poezja niepodległościowa, 14-15, 426-427.

150 Quote from D. Patkaniowska, op. cit. What is involved here is the following passage from Delavigne’s song: "Lub zwyciężym - lub gotowi / Z trupów naszych tamę wznieść, / By krok spóznić olbrzymowi, / Co chce światu pęta nieść.” Quote from M. Janion, Reduta. Romantyczna poezja niepodległościowa, 110. An echo of this romantic frenzy can be heard in an unpublished poem of M. Ubisz from the year 1955, entitled "Song of the Presydent." The motif of barricades with corpses is packed into a poetic construction that, against the author's intentions, takes on a grotesque character. Here, Starzyński stands alone "on a hundred barricades/he arranges the bodies of his children on the ground." Quote from Archiwum Prezydenta Warszawy Stefana Starzyńskiego, op. cit., 345. 
and more splendorous" than ever before, we read about a category of evidence confirming the heroic myth of Warsaw: the fulfillment of a soldier's duty and the sacrifice made at the altar of the Motherland.

Beautiful Warsaw does not exist anymore, the historic Warsaw we all knew no longer exists, but there is the heroic Warsaw, whose history will be recorded as being among the most heroically defended cities of the world. Warsaw, which fulfilled its obligation to the motherland, like a soldier and up to the very last moment. We firmly believe that historical justice must prevail, that soon Warsaw will once again be the capital of a great and mighty Poland. We will rebuild Warsaw greater and more splendorous than it was. Our sacrifice on the altar of the Motherland was very great, but it will certainly bring great benefits. ${ }^{151}$

In an underground brochure entitled Obrona Warszawy (the defense of Warsaw), published in late October or early November 1939, Zbigniew Zaremba carried out what could be one of the first codifications of language explaining Warsaw's actions and those of the mayor.

Thus to hold out to the very last moment is a matter of honor, but it also provides testimony that Poles are prepared to make every sacrifice for their freedom. [...] [When] the organized defense of the capital was launched, one was under no illusion about a victorious end. It was about holding back the enemy and maintaining Poland's honor. Through her sacrifice [Warsaw] proved how dear the freedom of their motherland is to Poles. ${ }^{152}$

Such language conjures up imagery, preserved in romantic poetry, from the September defense of Warsaw against Field Marshal Ivan Paskevich in 1831. The references are clear. In verse written by Jan Janiczek, a soldier in the Związek Walki Zbrojnej - Armia Krajowa (Union of Armed Struggle-Home Army, ZWZ-AK) who died in 1944, Starzyński "will not give up the capital, [...]/he holds high the banner of the martyr city,/With 'Warszawianka' on our lips - until it has fallen!" 153 Colonel Rola-Arciszewski referred directly to patriotism's romantic canon when he wrote that the mayor took up the defense of Warsaw "like a soldier whom one leaves behind at a post about to be overrun." 154 According to an

151 Quote from Cywilna obrona Warszawy we wrześniu 1939 r., 123-124.

152 Obrona Warszawy. Lud polski w obronie stolicy (wrzesień, 1939 roku). Quote from the edition published in New York in 1942, pp. 45, 50, 55.

153 From the poem "Ratusz" in the cycle Warszawa wrześniowa, printed in the first underground "Antologia poezji współczesnej" with the false date of 1937 (in fact, it was the end of 1940, beginning of 1941). Janiczek was the initiator of this anthology, along with S. Miłaszewski (1886-1944). Quote from D. Patkaniowska, op. cit., 244.

154 S. Rola-Arciszewski, op. cit., 320. 
account written in March 1946 by Artur Śliwiński, head of Warsaw’s Committee for Social Assistance, during the last meeting of the Citizens Committee (of which Śliwiński was a member):

President Starzyński stood by his position that Warsaw had to be defended to the last breath and that he was the soul of the capital's defense [...]. In a fiery speech he argued that the defense of Warsaw is the sacred duty of every soldier who had a weapon in his hand, that that is where the free motherland is, and that everyone has to defend the free motherland. If we fulfill our obligations and hold out till the end, this work will not have been in vain. If it happens that everything seems lost, we will be saved by a "miracle."155

Starzyński stands on the ramparts of Warsaw like the "last gunner" from a sonnet by Stefan Garczyński. In this romantic verse, the powerful enemy is overwhelming a handful of defenders and there is no hope for victory:

Konie wszystkie poległy - żołnierze wybici -

Dowódca tylko jeden $\mathrm{z}$ dwoma pozostały,

Oszańcowany w trupy jak w zastępne wały,

All the horses have died - the soldiers have died -

Only the commander and two others remained,

Entrenched in the corpses like a makeshift rampart.

But the defense continues and the one that remained is still alive:

spiż moczy w krwi bratniej

I znowu dym i świeci kanonier ostatni. ${ }^{156}$

The cannon is soaked in fraternal blood

And again the smoke and the last cannoneer shines.

In one of Słowacki's poems, General Sowiński defends the trenches of Wola to the very end: stabbed to death by bayonets he dies, at the foot of an altar, a martyr's death. We should recall that Starzyński was called "Prince Steadfast of steadfast Warsaw." In Calderon-Słowacki’s drama, Don Fernand chooses death, though he had the opportunity to save his own life through a deal with the enemy. He dies in the act of a martyr's sacrifice. Such a death leads to immortality: "the bloody body opens up/And God liberates the soul,/And revives it for the ages."157 The Portuguese Infante prefers to die than to allow the enemy to take the city. In light of the character Prince Steadfast, the decision to defend the besieged city off

155 Quote from Archiwum Prezydenta Warszawy Stefana Starzyńskiego, op. cit., 287.

156 Sonnet XII “Ostatni kanonier." From the cycle S. Garczyński, Sonety wojenne (1832). Quote from M. Janion, Reduta. Romantyczna poezja niepodległościowa, 341.

157 J. Słowacki, Książę niezłomny ( $z$ Calderona de la Barca), in Słowacki Utwory wybrane, vol. 2 (Warszawa 1965), 580. 
Warsaw in September 1939 until the very end takes on a particular dimension, one that is more religious than military.

Romantics practiced the cult of honor, and - as Maria Janion has claimed, describing the experience of honor among Calderon's heroes - a sense of honor was one of the most important Polish national features. ${ }^{158}$ Reading Calderon's drama, Słowacki glimpsed something more than chivalric heroism. And in his congenially paraphrased version of that work, the Polish poet created a symbiosis of the knightly ethos and the Christian ethic of sacrifice. Don Fernand turns from being a knight in defense of freedom to its martyr-devotee. For Romantics, such sacrifice had the "power to make history"; indeed it was as important as (and sometimes more highly valued than) the "grandeur of military triumph." 159 Mickiewicz's Ordon and Słowacki's General Sowiński do not die. For them, death creates the prospect of life. Let us once again quote from the work of Maria Janion:

According to the religion of romantic patriotism, the one who dies for the motherland experiences ascension immediately. [...] Around the hero's death the romantic poet built, above all, a value system that turned out to be the core of national existence. ${ }^{160}$

Reading an article from the underground publication Znak (10 May 1940), we come upon romantic historiosophy and its explanation for the September 1939 defeat. I want to cite a long passage from this text since - in my view - it provides an excellent example of this type of thinking. The author wrote about mayor Starzyński:

He grew out of this terrible collapse; from the edifice of the Republic he took hold of the white-red banner [the Polish flag] and planted it on the walls of Warsaw. And when it seemed that nothing could save the honor of the Polish nation, he took upon himself the great burden and decided to defend Warsaw. With his iron will, he cut himself off from all those with whom he shared the same background but who had fled beyond the borders of Poland. He alone had a sense of responsibility. [...] All of Warsaw in flames is still defending itself. In flames and in ruins. Let us now calmly consider, from the perspective of seven months, whether the sacrifice made in Warsaw, especially in those last two days, was necessary. [...] Someone will perhaps tell me that the defense of Warsaw was extended unnecessarily to the 27th. [...] No! Great guilt is redeemed at great expense. Great work is built with great sacrifice. In rescuing the honor of the Republic, one could not simply accept the siege, one could not hesitate from making the ultimate sacrifice. We had to pay with blood. For defeat. For collapse. For the breakup of our state

158 See M. Janion, Życie pośmiertne Konrada Wallenroda (Warszawa 1990), 154-155.

159 See M. Janion, M. Żmigrodzka, Romantyzm i historia (Warszawa 1978), 190-191.

160 M. Janion, Czas formy otwartej, 116,125. 
machinery. The defense of Warsaw laid the foundation for the construction of a new and powerful Poland. [...] The defense of Warsaw transformed the defeat of Poland into an act that will be recorded in history with memorable and immortal words. [...] And that is why the defense of Warsaw was necessary. Her charred remains were necessary, as were the crosses made of sticks and planted in old street flower boxes. ${ }^{161}$

According to the schema that we know from romantic literature: defeat turns into victory, death in the battle for sacred liberty becomes an expiatory sacrifice for national guilt and the collapse of the state. Today's suffering becomes the seed for future harvests, because the martyrdom of the capital and its inhabitants ennobles and sublimates those who defend it, and those who die for it, and with it.

Such enchanting words as "honor," "sacrifice" and "altar of the motherland" impart the tone of the great bulk of political commentary and literary and memoiristic testimonies. ${ }^{162}$ The tradition out of which this language grew was obvious to everyone who, in the interwar period, was educated in the statepromoted cult of romanticism and the Polish Bards. ${ }^{163}$ Starzyński, a soldier in the 1st Brigade of the Polish Legions, always had the highest regard for Marshal Piłsudski - the Polish Król-Duch - and for the romantic patriotic tradition. He was also under the clear influence of political romanticism as practiced by the Sanacja regime. In the years 1924-1926 he tied himself to the school of Adam Skwarczyński, a post-romantic ideologue associated with the Piłsudskiites and editor of Droga, a leading theoretical organ of the Piłsudski camp. Starzyński was

161 Quote from A. K. Kunert, op. cit.

162 In his excellent study of wartime émigré poetry, W. Ligęza points out that in the poetry, prose, journalism, reportages and pamphlets of that time, an ideological and stylistic canon of writing about Warsaw as a heroic city established itself. We come upon the topos of the Warsaw of battle, one that takes on a sacral dimension, and the Warsaw of martyrdom, described in terms of martyr-oriented sacrifice. A marked contradiction emerges: "Warsaw is a city that is dead and alive, condemned to defeat and yet victorious, disgraced and yet holy." The author points to the "romantic way of interpreting the city's martyrdom" as a "necessary link between the present defeat and future victory. [...] Warsaw is called the capital of honor, persistence, and sacrifice." W. Ligęza, Jerozolima i Babilon. Miasta poetów emigracyjnych (Kraków 1998), 26-27, 31.

163 For more on romanticism's presence in the public discourse of the Second Republic, see L. Kamiński, "Romantyzm i polityka dwudziestolecia," in Problemy polskiego romantyzmu. Seria trzecia, ed. M. Żmigrodzka, (Wroclaw 1981). Translator's note: This group of bards included Mickiewicz, Słowacki, Zygmunt Kraśinski and Norwid. 
one of the leaders of a semi-legal organization called the Zakon (the "Order"), whose ideological head was Skwarczyński. ${ }^{164}$

The city of Warsaw, crumbling under bombardment and consumed by fire, was often viewed as a kind of spectacle playing out before the eyes of all Poland, but one which was intended above all - even especially - for the outside world to see. This spectacle was revelatory in nature. It was supposed to reveal the truth, expose the deeper meaning of events. It was also supposed to be a twinge of conscience for everyone who was unworthy of the great matters around which the battle was being waged; for those who were deaf to the calls for help, who had abandoned their ally and betrayed their values, in whose name Warsaw and its inhabitants were burning on a funeral pyre. One can hardly escape the impression that the defense of the capital has been the object of romantic theatricalization. Maria Janion has described November 1830 as a "clash between history and theater", and a kind of "theatricalization beyond the theater," in which "society presents itself." ${ }^{65}$ We can apply such a diagnosis to violent periods of social disruption, to transformative historical events, to situations marked by collective limit experiences, which September 1939 undoubtedly was for Poles.

We find this tone in the following apocryphal version of Starzyński's last address:

Warsaw is burning. Warsaw, bombed constantly from the air and the ground, has been turned into rubble. We have no lights, no water, no food. Seventy thousand killed, one hundred thousand wounded - this is the result of the terrible fury of the invaders. [...] Let all the radio stations, especially the French stations, that hear us repeat to the whole world: Warsaw is defending itself, Warsaw is fighting. Poland is not yet lost! ${ }^{166}$

It was important that the world knew, that it expressed its amazement, that it felt guilty. It was important to not die alone, and in silence. This ambition would be shared, not much later, by the insurgents in the Warsaw Ghetto, who feared that the carousel music on the other side of the ghetto wall would drown everything out, that "nobody in the world would notice a thing: us, the struggle, the

164 See M. M. Drozdowski, Starzyński: Legionista, 95, 104.

165 See M. Janion, Czas formy otwartej, 126-140.

166 Quote from J. Małgorzewski, op. cit., 296-297. It is important to mention that the numbers given here are hyperbole; the number of killed mentioned here is six times larger than actual estimates. Historians have calculated civilian losses in September 1939 at around 10,000 killed and between 50,000 and 60,000 injured. On the Polish side, about 2,000 Polish soldiers died and about 16,000 were injured. See ibid., p. XXVII. 
dead." 167 Let us recall here another passage from a romantic poem: "So let them see us - when we are dying!", 168 which could serve as poetic commentary on the recollections of Halina Święcka-Skoczkowa, from the Technical Department of the Warsaw Municipality. Describing a briefing of city hall staff members in the second half of September, which took place during an air attack, SwięckaSkoczkowa quoted words spoken by Starzyński: "The echo of bombs falling on our city, and the roar of buildings collapsing into rubble, resonate throughout all of Europe, [...] your burdens and your work are not going to waste." 169 Janusz Regulski, the Head Commandant of the Citizens' Guard, reported in turn on the farewell address he delivered at a gathering of Citizens' Guard functionaries on 28 September, after the capitulation had been signed, in the presence of the president:

I said that Warsaw, through its heroic stance toward the enemy, provided an example to the world about how to fulfill the most difficult duties [...]. It happened that Warsaw was surrounded by an aureole of heroism, and we owe that, in the first place, to our heroic president Starzyński. With tears in his eyes, Starzyński kissed me, and the entire hall gave a standing ovation. ${ }^{170}$

In an exceptionally condensed form, the motif of theatricalization appears in an article by Henryk Lukrec published on 22 September in Robotnik (The Worker). The author called on residents of the city to document events happening around them, so that a chronicle of the siege could be written straight away. His appeal was preceded by imagery that was full of pathos and frenzy:

The city is dripping in blood, it is burning; it glows ominously; it is trembling and collapsing under the weight of shells and bombs, but its greatness is nonetheless increasing, and by the power of its will and its dignity, it is ascending above the earth, visible to the entire intelligent and sentient world. ${ }^{171}$

167 Hanna Krall, Shielding the flame: an intimate conversation with Dr. Marek Edelman, the last surviving leader of the Warsaw Ghetto uprising, trans. Joanna Stasinska and Lawrence Weschler (Henry Holt and Co., 1986) , 7.

168 J. Słowacki, Pogrzeb kapitana Meyznera. Quote from M. Janion, Reduta. Romantyczna poezja niepodległościowa, 304.

169 Account written in 1958. Quote from Cywilna obrona Warszawy we wrześniu 1939 r., 400.

170 J. Regulski, Straż Obywatelska. Wrzesień 1939 r. Quote from Cywilna obrona Warszawy we wrześniu 1939 r., 358.

171 H. Lukrec, Piszcie kroniki w ogniu. Quote from Cywilna obrona Warszawy we wrześniu 1939 r., 115. 
The martyrdom of Warsaw was an extraordinary spectacle playing out on the global stage: toward, and for, the entire world. Everything happening in Warsaw in September 1939 (the siege, defense, bombardment, destruction, suffering, and death) had great and unquestioned value. In the context of Poland's national history, it was yet another battle for freedom carried out against the enemy's disproportionate strength. Once again, a handful of noble and steadfast Poles were standing up to the power of an aggressor that applied criminal methods in battle. What we have here is a model drawn from Mickiewicz's Reduta Ordona: brightness is flooded by great darkness ("the redoubt still in the middle, brightness from the shots, it reddens over the black"). There is, in addition, the motif of Warsaw, in battle against the enemy, confirming its eternal love of freedom over everything else and fighting to the last drop of blood. And - in the moral dimension - we once again see a demonstration of the steadfast soul, a willful determination, testimony to the highest patriotic virtues.

This is what Warsaw has to say and show to the world. The world can take note of, and hear, Warsaw only in the pathos of its martyrdom, "with streaming blood" and "collapsing under artillery shells and bombs." Warsaw speaks to the world in the language of martyrdom and destruction - only then will it be visible to the world, only then will it "ascend above the earth." The only way to exist in front of the world is to die and be buried in the rubble.

Starzyński was thus a voice, one who calls out, and one who calls forth. His addresses had three main intended audiences.

First - they represented a summons directed at Starzyński's fellow countrymen and were formulated using the language of radical romantic patriotism, in the spirit of "Warszawianka," broadcast over the radio waves during the siege. On 17 September, Halina Regulska drew up this text based on one of the mayor's addresses: "Though each day [...] brings so many victims and so much destruction, we must endure and hold out, in the name of the greatness of the Cause! Citizens! Be filled with the spirit of the offensive, because we will hold out, we will be victorious." 172 In Józef Małgorzewski’s recollection, Starzyński declared on 21 September: "We are unshaken in our belief that we will endure. It might continue to be difficult, and it might get more difficult and worse, but of one thing we can be sure: 'Victory will be ours!' "173

Second - Starzyński was addressing Poland's allies, the entire world, though this call was not formulated using the language of diplomacy. Rather,

172 Quote from H. Regulska, op. cit., 72.

173 J. Małgorzewski, op. cit., 294. 
it was an appeal to conscience and moral obligation. His words were hard and uncompromising. The question was turned into a demand. On 15 September, Starzyński said:

We remind our allies France and England of their commitments. Warsaw is fighting, Warsaw is defending itself. Every day tons of iron are falling on our open city, where over a million people live, including women and children. The enemy, our eternal enemy, sets hundreds of fires every day, our homes are being turned into rubble. They are murdering thousands of innocent victims. How long will we have to wait for the effective action of our allies and their heroic forces? You tell us that you are dropping leaflets on Berlin while the Germans drop thousands of bombs on Warsaw. [...] We demand retaliatory action. We demand the fulfillment of obligations ${ }^{174}$

Four days later he renewed this appeal, lending it an even more dramatic tone.

The lonely Polish capital - Warsaw is putting up heroic resistance to all attacks by the enemy, on land and in the air. But what are you doing, our allies, who have promised us help, who pledged to stand by us in times of hardship? I ask a second time: what are you doing to fulfill your obligations? The dead and dying ask. The women and children of tormented Poland, of tormented Warsaw, they ask ... We are waiting for your answer. We are waiting for your actions. ${ }^{175}$

Third - Starzyński directed his words at the invaders, using various poetic warnings: "And you, criminals under the contaminated cross, remember that it is historical justice that will pay for our suffering, for our tears, for our blood, for our injuries. Remember ..."176 or imprecations: "Today Germany dumped ten wagons of ammunition on Warsaw. Hell, you can dump ten times more and you still won't take Warsaw, since nothing can break the spirit of our resistance." 177

The Germans respected the strength of the Warsaw mayor's voice and the power of its influence, and in their own way they expressed their appreciation. Stefan Starzyński was arrested on 27 September 1939. The Gestapo rummaged through desks and cabinets at Warsaw's town hall in search of documents with the mayor's signature under death sentences to be meted out to traitors and saboteurs apprehended during the siege. But Gestapo agents were looking for something more, namely the texts of Starzyński's September radio addresses and press interviews.

174 Ibid., 285.

175 Ibid., 289-290.

176 Ibid.

177 Ibid., 296. 
Neither the date nor the circumstances surrounding Starzyński's death is known. One version of the story, recorded by prisoners at Dachau, where the mayor was supposed to be an inmate, contains a shocking detail.

In October 1943, SS men played recordings of Starzyński's September addresses without break day and night, transmitting them into his cell. Finally, they dragged the battered and exhausted president to the camp courtyard, ordered him to dig a grave, and read out his sentence. Then an SS unit under the command of Bockführer Lesman fired the shots that took Starzyński's life. ${ }^{178}$

Thus, the executioners decided to torment their victim with that which had been his greatest weapon and had become the focus of his fame. Starzyński died while tortured by the echo of words which he had spoken over the air waves in besieged Warsaw, but which now - diabolically - were degraded and mocked.

\section{Ironic Criticism}

Karol Irzykowski's sarcasm, which is on display in many of the entries in his diary that touch upon the September defense of Warsaw and the early days of the occupation, represented - at least in part - a way to shake off the effects of the depressing defeat: the fall of Poland, the destruction and capitulation of Warsaw, and his personal misfortune. In the final stage of the siege, the writer's apartment at 6 Sierpnia Street was completely burned down. It is generally known that, at the beginning of the occupation, the prewar Polish government - burdened as it was by responsibility for the military defeat - was the object of almost universal bitterness, indignation, condemnation, and even hostility within Polish society. Historians have written about this fact, ${ }^{179}$ and countless diarists and authors, above all, have expressed such views. We will have an opportunity to quote from some of them.

178 M. M. Drozdowski, Starzyński: Legionista, 441. Drozdowski offers six versions of Starzyński's death: he died in the Spandau prison in Berlin; he was shot in a park in Klarysew, south of Warsaw, in the winter of 1939/1940; in Dachau on 17 October 1943; in the Dora concentration camp at the beginning of 1945; in the Flossenbürg camp in the spring of 1945; in Baalberge in the spring of 1944. See ibid., 440-442.

179 See, among others, T. Szarota, who cites reports on the situation in the country at this time, saying for example: "The main characteristic of [...] moods is an inexorably hateful attitude toward the culprits of defeat. Widely regarded as such are the previous government and especially President Moscicki." (February 1940). Quote from Szarota, Okupowanej Warszawy dzień powszedni. Studium historyczne (Warszawa 1988), 478. 
But refusal to participate in the heroic myth and rejection of martyrological exaltation had significantly deeper motivations, which are connected to Irzykowski's attitude toward collective national emotions and political legends, with his defense of the sovereignty of the klerk. ${ }^{180}$ Significantly, it was with the scenery of occupied Warsaw as a backdrop that Irzykowski wrote his novel Wyspa (Island) - his testimony to klerkizm, to which he often referred in his journal. The author's use of rational and analytical methods has unescapable consequences; the reality of war is subjected to a test of critical thinking, a sober adjudication of facts and actions. "I will pound this matter out logically," ${ }^{181}$ is a comment that is preceded by Irzykowski's reflections on the recent, murderous bombardment of Warsaw. One might well treat this view as an aphoristic abbreviation that defines Irzykowski's intellectual profile. The message of patriotic radicalism, which was central to the heroic tradition, does not surrender to tests of logical reasoning. Irzykowski - klerk and anti-hagiographer - rejected the old (so-called romantic) tradition and the contemporary (so-called post-romantic, according to Sanacja regime advocates) tradition of political irrationalism, whether that involved lofty rhetoric or common lies.

Irzykowski did not sit at home during the siege of Warsaw. He moved from place to place looking (as many Varsovians were) for the best shelter from the bombing. He spent the last days of the siege in the Sejm (Polish parliament) building on Wiejska Street, which is where he survived the bombing of 25 September, which lasted all day and forced the last defenders of the city to capitulate. Called "black Monday," "bloody Monday," and even "lany poniedziałek," this day has been well documented; it is described in primary sources, in testimonies written during the siege by those who survived this traumatic experience, in countless memoirs, diaries and journals. Irzykowski returned to a discussion of this event more than once, though he concentrated not so much on descriptions or accounts as he did on evaluation and interpretation. He attempted to subject what happened to rational evaluation. He asked whether the bombardment, during which his apartment and his beloved personal library burned, could have been avoided. He reflected on the effects of the material destruction. $\mathrm{He}$

180 Translator's note: A klerk is an intellectual or artist who avoids politics and engagement in political conflict. Klerkizm is a philosophy or world view that guides an intellectual or artist in this form of (for want of a better word) "escapism." A klerk is perhaps best understood as an "ivory tower intellectual."

181 Entry dated 15 November 1939. Irzykowski is quoted from his Pisma, 434. 
examined the military, political and moral effects of the air attacks that had caused death and destruction on such a scale.

Irzykowski's entry dated 3 October 1939 begins with a shocking accusation. Granted, the writer was quoting here an opinion that he had heard, but it serves as a point of departure for his later reflections, in which we find similarly harsh words.

F. S[zyfmanówna] said that Starz[yński]'s actions - refusing to surrender the city - was a "crime," because it led inevitably to the fiery Monday that the Germans had forecast, during which our home was burned down. Rómmel wanted to give up, pointing to the lack of ammunition, but St[arzyński] wanted to be the hero in the name of the city. Who would settle this matter? [...] Undoubtedly, W[arsaw] took on an honorable wound. Today W[arsaw] is the most wonderful demolished city in Europe, a model of the modern destroyed city, maybe even Madrid will step aside for her [Warsaw], the president could show it to tourists for money with the proceeds going to the city's poor. ${ }^{182}$

The meaning of the phrase "honorable wound" is ambivalent. On the one hand, it contains a certain irony alongside such other phrases as "most wonderful demolished city," which the mayor could show "to tourists for money." On the other hand, it retains within itself something that is highly serious. At the same time, one can hear in the above passage an alien voice. The imagery of a wound inflicted on Warsaw does not fit with Irzykowski's language in that such imagery conjures up the heroic-martyrological pattern of speaking. Very early, the writer was aware of the fact that the defense of Warsaw had no real chance for success. On 12 September - that is, around a week before news arrived that the Red Army had attacked Poland from the east - Irzykowski noted: "Early in the morning I told someone: the war is over, and now I would add: there is only execution." ${ }^{183}$ Once the execution had been carried out, he returned, on 5 October, to the matter of the bombardment, stating:

Not Rómmel, but Starzyński wanted the bombardment of W[arsaw]. It would have been worth fighting, even being buried, had it had an effect on the frontline battle, had it brought some relief, but it didn't. ${ }^{184}$

Here, the mayor of Warsaw emerges not just as a hero at someone else's expense, but also as self-taught strategist.

The comparison of Warsaw in September 1939 with Madrid, besieged by the Francoists during the Spanish Civil War, appears in Irzykowski's text three times, 
and it occurred to others as well. In his radio address on the first day of the war, Colonel Umiastowski mentioned the Spanish capital:

A great city like Madrid was under fire from General Franco's units for more than two years. The city of Madrid was destroyed to such an extent that literally, in many districts, not a single building remained whole, despite the fact that, throughout the siege, inhabitants were living there, working there, and above all fighting there. And while other fronts collapsed, the huge city of Madrid held out till the end. Here we have the example of the martyrdom of the Spanish, which is not at all greater than that of the Poles. ${ }^{185}$

There is something a bit strange about the chief propagandist's statement here, given that he seems to have anticipated, at the very start of the war, the complete destruction of Warsaw. This comparison with Madrid was apparently an attempt to show that a great city could hold out against a siege for a long time. At least it was with that intention that Starzyński used it on 10 September: "Well, well. They are bombing. We know from recent history that Madrid and Barcelona were besieged and bombed for years, but they nonetheless had to maintain a normal life." 186 Characteristically, the most competent person in this subject, Wacław Lipiński (a military historian and director of the Józef Piłsudski Institute for Research in the Modern History of Poland), who often integrated into his radio addresses historical comparisons, did not refer to the example of Madrid.

Just after the war, General Tadeusz Kutrzeba, who along with the remainder of the Poznan Army broke through to Warsaw after the lost Battle of the Bzura, pointed out the erroneous nature of the Madrid comparison. What is important to me about Kutrzeba's stance is not so much his military-historical argumentation, as much as its moral dimension. Analyzing the defense of Warsaw from an operational point of view, Kutrzeba reckoned, as early as 10 September, with the possibility that Poland would have to capitulate. After the Battle of the Bzura had ended (18-20 September), no Polish army was functioning in any organized fashion, the High Command had left Polish territory, and the Soviets having crossed into Poland - were moving westward. Warsaw had become a self-contained area of operation. The German advantage in terms of weaponry, including artillery and aircraft, was obvious. Warsaw would be able to "defend" (bronić) itself for some time longer, but - Kutrzeba emphasized - it could not "save" (obronić) itself. Beyond that: the Germans were systematically destroying the city with artillery fire and from the air, practically without suffering losses

185 Quote from M. J. Kwiatkowski, op. cit., 55.

186 Ibid., 121. 
themselves. "So as Warsaw [...] was bleeding, as its defenders persisted within walls, protected against tanks, the Germans were losing no blood, only time. And they had plenty of that." 187 Such was the general's conclusion, who knew after all - what the situation on the Western Front looked like after the English and French declared war on Hitler. It was clear, that continued defense "cannot provide any operational results. It can only provide benefits that are moral in nature, which could pay off in the future." ${ }^{88}$ Thus, the issue here was whether or not to allow further death and destruction for the sake of "moral benefit."

General Rómmel, who arrived in Warsaw on 8 September with part of his broken Łódź Army, received on that day orders from the Commander-in-Chief in Brest to take over the defense of Warsaw, "as long as ammunition and food hold out." ${ }^{189}$ As commander of the newly created Warsaw Army, he issued a proclamation in which he communicated the contents of his orders and called for the continued defense of Warsaw, which was "tied to the honor of Poland." After the war, General Rómmel's chief of staff, Colonel Aleksander Pragłowski, assessed his commander in this way: "In carrying out his mission, he was rigid like an obelisk, focused on the vision of national honor that had been placed in his hands." But Pragłowski was critical of the Marshal of Poland (1936-1941) and Commander-in-Chief of Poland's armed forces, Edward Rydz-Śmigły:

Our nation has sometimes suffered defeat, but it has always fought to the end in order to preserve the soldier's honor. A commander who orders that the capital of his own country be burned to the ground should himself be a shining example of sacrificial bravery. ${ }^{190}$

On 23 September, General Rómmel rejected the arguments regarding capitulation presented by General Kutrzeba; he invoked the orders he had received from the Commander-in-Chief along with the example of Madrid, which was supposed to show that a city in ruins could be defended for months. Kutrzeba, one of the best trained of all Polish high commanders, knew perfectly well that the Madrid-Warsaw comparison was groundless. Madrid, defended by Republican

187 T. Kutrzeba, Ze wspomnień dowódcy armii "Poznań", in Obrona Warszawy 1939 we wspomnieniach, op. cit., 347.

188 Ibid.

189 See a photocopy of the letter from Marshal Rydz-Śmigły to General Rómmel on 8 September 1939 in Warszawa we wrześniu 1939 roku. Obrona i życie codzienne, ed. Cz. Grzelak (Warszawa 2004), 109.

190 A. Pragłowski, “Ze wspomnień szefa sztabu armii 'Warszawa”, in Obrona Warszawy 1939 we wspomnieniach, op. cit., 282, 279. 
forces since 1936, had never been completely encircled, and its inhabitants had thus been able to leave the city. But in the case of Warsaw, the Germans closed the ring around Warsaw on 15 September. The battle for Madrid had been carried out with varying intensity with long breaks, and the city had finally capitulated in March 1939 as a result of treason and demoralization within the Republican ranks. After the bombardment of Warsaw on 25 September, the idea of capitulation began to ripen. At a meeting called by General Rómmel for the next day, General Kutrzeba - according to the account provided by Colonel Tomaszewski - came out firmly in favor of surrendering the city: "Warsaw has carried out its ordered task fully [...], and further resistance would represent unjustified suicide, the unnecessary murder of the population, the destruction of the city." 191

Irzykowski also rejected the significance of the Madrid comparison: some people "wanted to imitate Madrid - always some kind of template, some foreign model (the Polish Bayreuth, Polish Hitlerism)." ${ }^{192}$ A few days later, he was more pointed in his disagreement, and he punctuated his statement with an iconoclastic point:

In L[auterbach]'s opinion, the comparison between W[arsaw] and M[adrid] is not very precise. The bombardment of Madrid involved only certain neighborhoods, the force strengths of the two sides were almost equal, and Madrid had a connection with Barcelona. From abroad the decision to allow the bombardment of W[arsaw] must appear not heroic, but absurd. ${ }^{193}$

We find a polar opposite estimate in the memoirs of the chief of staff for the Command of the Defense of Warsaw, Colonel Tadeusz Tomaszewski. Years after the fact, commenting on German General Johannes Blaskowitz's demand that the capitulation document contain the term "Fortress Warszawa" (a demand that Kutrzeba, who was to sign the capitulation, protested), Tomaszewski admitted:

Personally, I cannot deny that Gen. Blaskowitz was correct. Though it was a free city, Warsaw in fact became a powerful fortress thanks to its people, who remained faithful to the idea we sang in "Rota,", 194 that "for us every doorstep will be a fortress." Warsaw took this idea literally; they were not words spoken at some holiday mass or a gala affair. It was the first to understand the totality of modern warfare, and this totality was

191 T. Tomaszewski, op. cit., 129.

192 K. Irzykowski, op. cit., 372.

193 Ibid., 388.

194 Translator's note: "Rota" (Oath) is a patriotic poem written by Maria Konopnicka in 1908 and set to music in 1910. 
subordinated to action. Various Maginot Lines, Westwalls, Atlantic Walls and forts like Fort Emmanuel, have fallen like a house of cards, and free cities transformed themselves into fortresses, like Madrid and Stalingrad. Warsaw, too, was a fortress. ${ }^{195}$

Irzykowski's conclusion (not heroic, but absurd), when confronted by the above line from "Rota," reveals what is the fundamental ideational conflict here. Irzykowski turned the entire heroic-martyrological order of values on its head. One can detect this confrontation in the reinterpretation of the main motifs of the September discourse, such as calls for romantic, patriotic radicalism and the defense of honor.

In entries dated 3 October and 15 November, Irzykowski reconstructed a kind of political-moral strategy behind the decision to extend the defense of Warsaw.

$\mathrm{W}$ [arsaw] is supposed to be a twinge of conscience for West[ern] Eur[ope], a kind of bill of exchange, which it must-should pay with usury. Which means Poland's (military) honor has been saved, its reputation, its knightly tradition. ${ }^{196}$

Irzykowski confronted this position from two perspectives: its political effectiveness and its ethics. "Will Europe take note?" 197 The writer doubted that it would, and six weeks later he formulated the following accusation:

Nonetheless, those two or three days of bombing (25 September), for which Czuma, Rómmel and Starzyński are culpable, were a crime. Not in the first instance, but on appeal. Warsaw and Poland's honor was saved, supposedly, England was handed a large honorary debt, we have in our hands a bill of exchange. But in the second instance, this is blackmail, the English have been cheated, and though they see through it, they accept the bill of exchange. ${ }^{198}$

Honor is a value in and of itself, Irzykowski argued, referring to Schopenhauer, and it has nothing in common with the contrivance of a situation marked by moral blackmail. Honorable sacrifice is selfless, and in what happened in Warsaw there was something of a "desire to impress, even in poverty." To ourselves, as Poles, we are noble knights, dying under the rubble in defense of honor. But to Europe, which "acknowledges receipt and has approved," but which "has a lot of its own matters and new heroes," we reveal our "frivolity, childishness, truculence, lack of organization, of foresight. ${ }^{199}$

195 T. Tomaszewski, op. cit., 131.

196 K. Irzykowski, op. cit., 363.

197 Ibid.

198 Ibid., 433-434.

199 Ibid., 363-364. 
Irzykowski did not retreat from repudiating that which was most sacred about the Warsaw September, from discrediting the meaning of everything connected with the notion of redeemed blood and with the rubble of the defense of the capital. He struck at the solar plexus of the heroic city and its heroic mayor: "W [arsaw] was fighting for its honor? Rodomontade, at which Europe laughs." ${ }^{200}$ More than the pride that comes with rescued honor, the legacy of the September campaign is the bitter taste of disgrace and squandered military sacrifice.

It is not that $\mathrm{P}$ [oland] lost the war against $\mathrm{H}$ [itler], which is terrible, but that it lost in such a disgraceful way, shamelessly exposing our inadequacies. (Soldiers were lying in trenches under a hail of bullets and grenades, they couldn't see their own officers, let alone those in the higher ranks). ${ }^{201}$

He also metes out irony toward the meaning of the sacrifice made by the capital and its inhabitants during the siege. Such sacrifice was not fully executed because declarations of sacrifice deviated from real practice and revealed themselves once again as pretense. Since the heroic defense of the city was supposed to show the extreme determination of Poles, then:

Starzyński should have consequently buried himself with the entire city - not just metaphorically, but also personally and physically - should have let it develop to that which to the Germans later posed a threat: gas and bacteria. [...] so that Poland's stance would reach the summit of steadfastness, a historical memorial, though without the immediate practical consequences, but the horror and admiration would spread throughout all Europe [...]. I don't hold it against him, being no hero myself [...], I do not condemn others. But in the end, that Monday, on Poland's part, was also a bluff, like the entire statement on the matter of Gdańsk. ${ }^{202}$

If one took the concept of the defense of Warsaw as heroic sacrifice to its logical extreme, as Irzykowski seemed to view it, then everyone would die under the rubble and experience total destruction. Only then would they triumph spiritually in the empty landscape of annihilation..$^{203}$

200 Ibid., 372.

201 Ibid., 377.

202 Ibid., 363-364.

203 Such a vision was not just a fantastic dream; it also reflected the real state of social consciousness, as evidenced by an article from the underground publication Znak, dated May 1940, in which the author mentioned his conversations with Varsovians in September 1939: "I do not know whether I was just lucky to meet people as cut by Phidias, or by a tailor, but as God is in heaven, all those whom I was able to figure out told me they were ready to bury themselves under the rubble of the city, rather than let in the Germans." Quote from A. K. Kunert, op. cit. 
The effect of the prolonged defense of the city was its destruction. To many, that was proof of the greatest heroism, and the most valuable deposit on the future that Poland could convey to the world. But to Irzykowski, it was not just "criminal" and "absurd," but also "moral blackmail." In his "contemplative diary after defeat," written in the winter of 1939/1940, Kazimierz Wyka applied a diagnosis which was equally harsh, but which was to have incomparably greater historiosophical momentum. The "superhuman heroism" of soldiers and civilians was suspended, so to speak, in a vacuum, and beyond that - it was wasted in chaos, improvisation and mess - that "eternal Polish patchwork." But, Wyka wrote, in the heroic defense of Warsaw "there was [...] something preposterous, I dare say unnecessary," and, much like Irzykowski, he reconstructed with sarcasm the strategy by which the spectacle and moral blackmail played themselves out toward the world.

Graceful foreign words of praise, words one sends to people standing on lost battlegrounds, persisting in despair, which anyway will be broken, words, telegrams from mayors, admiration dripping from the speakers irritated rather than stimulated. Again they admire us for some sort of [Battle of] Somosierra, again with our participation condescending praise lent to the reckless and stubborn, again the final and hopeless outburst is supposed to redeem incompetence and the mistaken whole. ${ }^{204}$

With his critical judgment, Irzykowski did not accept the logic of the national sacrifice offered at the altar of the Motherland. He included the defense of Warsaw on a short list of "luminous pluses" associated with the September campaign (again there is veiled irony here, when we read, for example, about "efektowna kanonada" - that is, attractive or eye-catching cannonade ${ }^{205}$ ), but he subjected the matter to cold calculation, and he evaluated it from the pragmatic perspective of future underground activities in occupied Poland.

Starzyński should not have allowed the bombardment of W[arsaw] to happen precisely because W[arsaw], still well-off and not yet destroyed, would have been a more comfortable place for underground work than a poor city that was busy with its own vegetation. ${ }^{206}$

204 K. Wyka, Życie na niby. Pamiętnik po klęsce (Kraków 1984), 230-231. It is hardly necessary to add that Irzykowski and Wyka’s stance was isolated. W. Ligęza wrote: "In poetry abroad, the significance of the heroic defense of Warsaw in September 1939, a defense understood as an example for Europe, is very clearly emphasized." He added: "The city's martyrdom is supposed to have shocked foreign consciences, shamed politicians." See W. Ligęza, op. cit., 31.

205 K. Irzykowski, op. cit., 380.

206 Ibid., 388. 
Warsaw found itself in a situation in which its residents, along with the military, were on the very front line. Irzykowski did not deny the personal bravery and rectitude of Stefan Starzyński. He only wanted to refrain from accepting the radical message of "Warszawianka," which was that today - for everyone caught within the wall of the city - it was about "your triumph or your death." The obligation raised in the song has a dimension that is absolute and final. What was thus involved in Irzykowski's words was a refusal to accept the moral coercion that ordered every civilian to become a soldier.

This attitude was developed significantly by one of the great diarists of the Warsaw Ghetto, Chaim A. Kaplan, who described the day-to-day events of the September siege. Indeed, Kaplan manifestly disagreed with the imposed transformation of civilians into soldiers, and protested against it. On 28 September, he wrote that General Czuma had ordered every citizen to defend the city, without asking for their consent.

During a war the civilian citizens are in the category of dumb sheep. They are filled to overflowing with false patriotism, compelled to obey every word that comes out of the commanders' mouths, and the commanders regard thousands of lives as nothing when compared to a little military prestige. And here lies the root of our catastrophe. ${ }^{207}$

Military leaders changed Warsaw, which was full of unarmed civilians, into a fortress. Hitler thus treated the city like a military object and, with premeditation, ordered its destruction. These notions took on an existential dimension in the entry Kaplan registered two days later. Here, the repudiation of the universal call to battle, in the spirit of radical romantic patriotism, sounds firm and sharp, stated as it is not by an ideologue, but by a common person, full of fear and trembling in the face of death:

I never knew that the eyes of the whole world were upon me and that people marveled at my courage and wished me success. I was like a broken vessel - motivated by fear and genuine cowardice. I sat, shrunken and shriveled, in a dank cellar, overcome with fear and trembling at the terror of the bombs. Rómmel and Starzyński suddenly made a "military hero" out of me! $!^{208}$

It is entirely understandable that the tones of "Warszawianka" did not speak to a Jewish intellectual with Zionist tendencies while trying to survive the siege of the capital. But Irzykowski manifestly rejected the model of patriotism engineered by songs tied to the November Uprising. Take, for example, his attitude toward

207 Chaim Kaplan, Scroll of Agony. The Warsaw Diary of Chaim A. Kaplan, trans. A. I. Katsh (Bloomington 1999), 37-38.

208 Ibid., 39-41. 
the mass action to dig anti-aircraft trenches and build barricades in the city's streets, actions that reminded the writer of the insurrections of the previous century. This appeal, which sounded reasonable at the start, given how the military situation was developing, began to take forms that tended toward the grotesque: from anti-aircraft shelters to raising barricades and ... positioning your weapons sharp side up (as if they were war scythes).

On 24 September 1939 president Starzyński issued a proclamation to the people of Warsaw, in which we read:

It is our duty to prepare ourselves for a situation in which the state and the nation's capital are threatened. Therefore, it is imperative now to prepare a suitable number of shelters. [...] All good citizens of the capital are obliged to join this work. Most desired to report along with a shovel. ${ }^{209}$

The response was immediate and huge, and the digging itself was carried out in a fully egalitarian atmosphere. On 28 August, Goniec Warszawski wrote enthusiastically: "Workers and intellectuals, gentlemen in gloves and craftsmen," and it went on to declare that "Warsaw should have 125 kilometers of trenches capable of sheltering 300 thousand people."210 On the day war broke out the appeal was renewed, which was picked up by various social and veterans organizations, including Związek Żydów Uczestników Walk o Niepodległość Polski (Union of Jews Participating in Battles for the Independence of Poland) in the pages of Nasz Przeglad. On the night of 6/7 September, in an atmosphere of panic surrounding the evacuation of Warsaw and the government's departure from the city, around 100 thousand men got to work building barricades, fortifications and anti-aircraft trenches. ${ }^{211}$ The next day, in a special proclamation, the Commander of the Defense of Warsaw, General Czuma, called on Varsovians to defend the capital city and thanked all those residents who had reported for work digging trenches. "And you should keep going!"212 Poetic testimony to this public upsurge can be found in a verse written by Jerzy Jurandot, who not only spoke of Varsovians' mass participation and their particular work ("many men and women and boys/barricades rise from the cobblestones,/made of old furniture, baby carriages, mattresses"), but also pointed directly to the Polish uprising tradition, when it was Colonel Kiliński who, in the "days of the insurrection," led

209 Quote from Cywilna obrona Warszawy we wrześniu 1939 r., 3.

210 Ibid., 5

211 See W. Bartoszewski, 1859 dni Warszawy (Kraków 1974), 30.

212 Quote from Cywilna obrona Warszawy we wrześniu 1939 r., 23. 
the people of Warsaw "toward the Russian cannon."213 On 7 September, Colonel Umiastowski delivered his final radio address, in which he called on the people of "every settlement, village, small town and city" to rise up in battle against German tanks. The instructions were simple:

[...] one must collect material to put up barricades, which must be built with heavy items, beating piles into the ground. In front of the barricade dig a trench with steep walls, with a depth of 2 meters, a width of 6 meters. A tank that falls into such a trench will get stuck with no way to get out. [...] In front of the barricades, arrange a series, stretching hundreds of meters long, of harrows collected from the entire village, with blades pointed upward. ${ }^{214}$

On 5 October 1939, as the German military was parading in front of Hitler down Aleje Ujazdowskie, one of Warsaw's main thoroughfares, Irzykowski mocked the raising of barricades.

Czuma turned out to be a donkey, he built barricades as if it were the year 1831, or 1848 or 1871, but the G[ermans] said: We will not play this game because we have better toys. We hear nothing of Czuma anymore. We should put a harness on [the general] to repair the destroyed streets. First it was the Poles alone who destroyed W[arsaw] (600 barricades), they turned it upside down. This Polish destruction is more conspicuous to the passerby than the German destruction. ${ }^{215}$

Irzykowski was not alone in his harsh judgment of the action to build barricades, which at the time was almost universally praised and put forward as an example of Varsovians' patriotic attitude. He was preceded by the deputy commander for the defense of Warsaw, Brigadier general Julian Janowski, who recorded in his diary, written during the siege:

In response to Starzyński’s appeal, people actually got down to work and quickly raised barricades and trenches everywhere (mostly where they were not needed), causing congestion inthe streets. Movement was blocked. At the barricades people used beds, cabinets, tables, and even sheets, thrown directly out of windows. All these materials were flammable. Soldiers had to take up thankless and unfulfilling work - to dismantle not just unnecessary but burdensome barricades and clear away barriers, again to the dismay of the population, who had worked so hard for nothing, and saw how their work was being destroyed. ${ }^{216}$

213 The poem entitled "Panie pułkowniku Kiliński," original first printing: September 1943. Quote from Archiwum Prezydenta Warszawy Stefana Starzyńskiego, op. cit., 333.

214 Quote from M. J. Kwiatkowski, op. cit., 90-91.

215 K. Irzykowski, op. cit., 372.

216 J. Janowski, "Dziennik zastępcy dowodcy obrony Warszawy w 1939 roku." Quote from Obrona Warszawy 1939 we wspomnieniach, op. cit., 149-150. 
The quadrille involving the barricades (build - destroy, dig up - bury) is an example of the chaos that surrounded those September days, which was something that could be controlled, as evidenced by the actions taken by mayor Starzyński as head of the civil defense of Warsaw. What was significantly more difficult to control was the communications chaos and - to use a delicate term the information policy consciously pursued by Polish authorities, all of which was tied to misguided military decisions, and which, in the end, led to catastrophic results. Irzykowski spoke about these matters bluntly, writing that "the government cheated us utterly. You can lose a war, that's a natural disaster, like a flood. But they shouldn't incite and lie."217

Two things were involved here: an assessment of pre-September Poland and the Polish government's ongoing propaganda strategy.

Irzykowski stated bitterly that "for years in Poland, the habit of consciously using lies has taken root, under the guise of a myth - legend, the most fashionable words." ${ }^{218}$ The writer's belief that Sanacja governments had employed a program of lies in the public discourse as a way to build national identity was one that was shared by other witnesses to the September defeat as well. In his Kronika lat wojny i okupacji (Chronicle of the war and occupation years), Ludwik Landau took note of the mood of Varsovians, who on 30 September got their first glimpse of German soldiers on the streets of their ruined city:

At that moment the people understood one thing - perhaps felt is a better word than understood - how they had been constantly cheated, lied to, how little those in governing circles cared about the people's fate, those who acted with such disregard, with such self-certainty. ${ }^{219}$

In his Pamiętnik po klęsce (Diary after defeat), written in the first winter of the occupation, Kazimierz Wyka asked the question: "How could one go on, with impunity, without recognizing reality, lying to oneself, in a state of such self-admiration. ${ }^{220}$ In his essay "Dwie jesienie" (Two autumns, 1946), Wyka analyzed the September shock methodically. The military defeat, which given realities at the time could not have been avoided, became an ideational defeat in that it laid bare - so to speak - the lies that had underpinned the Sanacja regime: the strength of the army and the genius of the Commander-in-Chief turned out to

217 K. Irzykowski, op. cit., 378.

218 Ibid.

219 L. Landau, op. cit., 21.

220 K. Wyka, op. cit., 226. 
be a "common bluff." The Polish state, built on such a foundation over the course of twenty years, had fallen like a house of cards.

The camp of politicians in uniform based their very political and social existence on the uniform. So, the basis for trust in the governing camp, which had been forced upon society (indeed upon more than one society), turned out to be based on blindness, lies and recklessness. Which is why, in the September conditions, a strike at the uniform had to become, and did become, something that spread throughout the entire pre-September past.

The master of the propaganda ceremony in the first days of the September campaign, Colonel Umiastowski, intentionally hid the real situation on the front from the Polish people. It was his obsession to prevent defeatism from spreading among the citizenry; to this end, Varsovians needed to be vigilant, saboteurs needed to be tracked down, and military realities needed to be embellished. The most fantastic stories were circulating throughout Warsaw, about allied forces landing in Gdańsk, about German cities being bombed. ${ }^{221}$ Having been scolded by Colonel Tomaszewski, Czuma's chief of staff, for following a propaganda line that actually disarmed the civilian population of Warsaw, cutting them off from reliable information, Umiastowski agreed that "the truth must be told," and after a few hours he delivered his stupidest and most pernicious address, calling on Varsovians to leave the city immediately. But the excessively optimistic propaganda continued. For example, on 14 September Captain (pilot) Władisław Polesiński delivered a radio talk under the title "A German soldier as seen up close." The speaker offered listeners an encouraging portrayal of the military situation: the German Siegfried line had been broken during a daring attack by French tanks; giant benzene containers were burning in Cologne; Hitler was trembling in the face of English and French power; and the German soldiers were adolescents drunk on vodka and ether who would flee from any large attack. ${ }^{222}$

221 For example, W. Sieroszewski wrote in his diary under the date 8 September 1939 that "France has broken through the Siegfried line, a 200-kilometer front across Germany. The English are bombing Berlin, German ports and Hanover. But Poles were the first to bomb Berlin [...] From Germany there is news of disturbances in Berlin, Essen and other places." W. Sieroszewski, Dziennik (29.11.1938- 31.12.1939), prepared by A. Lam, in Sieroszewski, Dzieła, vol. XX, part 2: Varia (Kraków 1966), 108-109; L. Landau: "On the first day - I think emerging from a certain center of 'rising spirits' rumors circulated about the seizure of Gdańsk by the Polish army, about the bombing of Hamburg by the English fleet, and of Berlin by combined English, French and Polish squadrons. Quickly, however, it turned out that these rumors were completely false [...]." L. Landau, op. cit., 4.

222 See M. J. Kwiatkowski, op. cit., 181. 
Civilians as well as soldiers were deceived. General Kutrzeba recalled: "The news we were hearing during the Battle of the Bzura that Allied forces were landing in Gdańsk [...] turned out to be either propaganda or stale facts."223

The bitter taste of these lies accompanied Irzykowski until his death. The lies of his own people - for him, that was the most painful experience of the September campaign. In the fourth year of the occupation, on 16 March 1942, he noted: "September 1939. But what is most lodged in my memory is not the thunderbolts, not the ruins, but the lies of our government and the lies of the rumormongers, most likely official."224

The last entry in Irzykowski's diary is dated 7 August 1944, and was written in Ochota, a city district on fire during the Warsaw Uprising. In that entry, we find this sentence: "Before anything happens, they will burn W[arsaw] (by which I mean me - a moral pars pro toto) down to the ground."225

Injured in the leg, having been transported to a hospital in Milanówek, Irzykowski died in Żyrardów on 2 November 1944.

In answering a question that many people were asking in those days, namely who bore responsibility for the September defeat, Irzykowski searched within himself and within society. Yes, we were cheated, but should we have allowed ourselves to be so cheated? Is it not also the case that we allowed ourselves to be deluded, that we were too easily satisfied by nice-sounding words, by rose-colored appearances?

But is not the nation itself - and thus, am not I - guilty of allowing such governments to rule, that everything would break apart right away? [...] Can the nation control this? After all, military matters must be a secret [...]. But the nation is responsible for choosing the people whom we want to trust. And here is the guilt, here is the psychology and characterology. [...] So, are we not ourselves guilty? People still said: the military is untouchable, we have a top notch military, the military is our pride, the only bright spot in our national life, etc. Did they have in mind the common soldier, or the officers and above, or both? Let us stop with this talk, it is enough that the army failed. The average person, or even one who is more glamorous, in any case a civilian, is not at fault, he could not even flee [...]. He was blackmailed into thinking he had to be enthralled by faith in the military, otherwise he is not a good patriot. When the war came, this faith crumbled, suddenly, it unraveled from the inside. The wall, beyond which the citizen was not allowed to look, collapsed. ${ }^{226}$

223 T. Kutrzeba, op. cit., 345.

224 K. Irzykowski, op. cit., 539.

225 Ibid., 613.

226 Ibid., 388-390. 
Starzyński entered the pantheon of national heroes as the fearless defender of Warsaw, who refused to run from the enemy, who remained in the Germanoccupied city until the end. One-hundred-twenty-six years after the "Battle of the Nations," Starzyński repeated the grand gesture made by Prince Józef Poniatowski at Leipzig, and could well have repeated the prince's very words: "God entrusted me with the honor of the Polish people, and I shall simply return it to him." Thirty-five years after Stefan Starzyński was arrested, at a plaque placed at Warsaw's Powązki Cemetery in the mayor's memory, Father Jan Zieja said:

In some ways, his words - I will not abandon my position, I will not step down from the position entrusted in me - draw upon those words uttered in the autumn fog on the plain of Leipzig, enveloped in the smoke of gunfire. ${ }^{227}$

General Stefan Grot-Rowecki made a similar moral choice when he decided to remain in occupied Warsaw despite London's suggestions that, because he had been exposed, he make his way to England. The general's brother, Stanisław Rowecki, who - on the first anniversary of the outbreak of war had given his brother a bronze statue of Prince Józef Poniatowski, recalled a conversation they had at the end of 1942 or beginning of 1943, in which General Grot said:

I will not abandon my soldiers, who are vulnerable at every moment, as am I, to capture by the Germans, torture and death. [...] And do you know what, among other things, convinced me to not give up my position as AK [Armia Krajowa, Home Army] Commander? Your Prince Józef. ${ }^{228}$

Starzyński appeared to have found peace in defeat, which was a triumph. $\mathrm{He}$ knew that the highest and greatest values were burning in the fires of Warsaw. Irzykowski turned that way of thinking inside out. War laid bare the weakness of the Polish ship of state and the hollowness of its ideational construction. We, the defeated, experienced great disillusionment, one would like to say - we opened our eyes. The (wonderful) truth about the (wonderful) soul of the nation and its spiritual strength did not reveal itself to us. Rather, it was quite the opposite: "this faith crumbled, the "wall collapsed." For Irzykowski, it was not a diamond (as it was in Norwid's work) that burned in the fires of bombed-out Warsaw. In the end, all that was left were ashes.

227 Quote from Archiwum Prezydenta Warszawy Stefana Starzyńskiego, op. cit., 355.

228 Quote from M. Janion, Płacz generala. Eseje o wojnie (Warszawa 1998), 164. 


\section{Divided City}

Does something exist that one might call a "totalitarian city"? When talking about totalitarianism, can we imagine its urbanistic equivalent - the totalitarian organization of urban space or, to put it another way, space subjected to totalitarian pressure?

Let us draw some preliminary distinctions. It seems that there exist two polar opposite manifestations of the "totalitarian city." The architecture and "urbanism" of the totalitarian utopia (Fascist Italy, the Third Reich, Soviet social realism and its implants in satellite states) led to an at least partial implementation of urban concepts embodying utopian ideals, living spaces designed for the new collective man, the urbanistic shape that the rulers and ruled were to assume. ${ }^{229}$ I would also place in this category a kind of virtual urbanism of the totalitarian utopia, among which was the work of urbanists from Würzburg entitled "Die neue deutsche Stadt Warschau" from 1940 (known hitherto incorrectly as the Pabst Plan). Among other things, this plan called for a drastically smaller Warsaw, both in terms of area and in terms of population. Warsaw would be reduced in rank to a stopping-point city on the road to the East. The city's traditional urban arrangement would be destroyed and transformed into a pseudo-medieval "Germanic" array of narrow streets intersecting with strategic highways. Friedrich Pabst himself appeared in Warsaw only in 1942. Above all, his work involved the design of the Volkshalle, an enormous domed building that was supposed to stand in place of the Royal Castle. ${ }^{230}$ This category also includes a project to build a gigantic park on the territory of the former Warsaw Ghetto, ${ }^{231}$ along with plans (recently uncovered) made by the Berlin architecture Hans Strosberg to turn Auschwitz,

229 See R. R. Taylor, The Word in Stone. The Role of Architecture in the National Socialist Ideology (Berkeley 1974). On social-realistic architecture, see. W. Włodarczyk, Socrealizm. Sztuka polska w latach 1950-1954 (Paryz 1986); W. Baraniewski, "Ideologia w architekturze Warszawy okresu realizmu socjalistycznego," Rocznik Historii Sztuki 22 (1996).

230 For the most complete information on the urbanism of the German occupiers, see N. Gutschow and B. Klain, Zagłada i utopia. Urbanistyka Warszawy w latach 19391945 (Warszawa 1995).

231 In July 1943, after the liquidation of the ghetto, a concentration camp was established in this area, whose prisoners recovered bricks, scrap and other materials from the rubble. They also prepared the terrain for a future park. This idea originated with General Stroop. Plans and cost estimates were developed by SS-Gruppenführer, General Waffen SS, and engineer H. Kammler. See B. Kopka, Konzentrationslager Warschau. Historia i nastęstwa (Warszawa 2007). 
after military victory had been achieved, into a model Nazi city and a bastion of German culture in the East. ${ }^{232}$ All of these examples make up the - so to speak positive pole of the realization of the "totalitarian city," the pole that will not be a focus of this book.

But there is, after all, the negative pole - ways of shaping space occupied by "Untermenschen," or the existence of spaces that are specially intended for them. As seen from this perspective, the project of the "totalitarian city" would constitute a distinctively organized urban space, or rather a quasi-urban space, whose function, in its first phase, would amount to the assignation of spheres for residence and employment, and even for approved forms of entertainment, to create the appearance of normality. Over time, concentration in a designated and isolated space, along with repression and exploitation, would intensify, leading first to movement from the phase of "city" into that of "closed residential quarter" (that is, a ghetto), and then into that of the "concentration camp." The final destination would be the "extermination camp." Of course, this is not a chronological order, but rather a typological order.

No doubt, the culmination of space subjected to totalitarian pressure is the concentration camp, which - as Primo Levi wrote - "on a smaller scale but with amplified characteristics, reproduced the hierarchical structure of the totalitarian state $[\ldots] .^{233}$ The camp at Auschwitz was broken down into distinct sub-camps - "city-states of a sort, divided by borders whose crossing was prohibited. [...] The sub-camp appeared like a large city cut through with a main artery and side streets." ${ }^{234}$ The extermination camp no longer contains even the most repressively organized "living space," or rather, such living space has been marginalized and reduced to the absolute minimum; it consists of room for the Sonderkommandos. But the center of the extermination camp consists of "space for killing and utilization." The extermination camp thus loses all the appearance of a "city," and takes on the look of a "machine," an "enterprise," a "production line."

232 See D. Kortko, M. Nycz, “Spacer po bastionie Auschwitz," in "Magazyn," a weekly supplement to Gazeta Wyborcza 19 (13 May 1999), 6-10.

233 Primo Levi, The Drowned and the Saved, trans. Raymond Rosenthal (Simon \& Schuster 1986), 35. As Andrzej Werner wrote: “The concentration camp, in Tadeusz Borowski's view, is an extreme model of the totalitarian state, one taken to its final consequences. [...] totalitarianism fulfilled." See A. Werner, Zwyczajna apokalipsa. Tadeusz Borowski i jego wizja świata obozów (Warszawa 1971), 116.

234 A. Pawełczyńska, Wartości a przemoc. Zarys socjologicznej problematyki Oświęcimia (Warszawa 1995), 37, 46. 
In this section, I will more closely examine the early phase of the "totalitarian city," one that has both a peculiar and one-of-a-kind character, namely the ghetto and its predicament within the confines of an occupied city. My goal here is not so much to reconstruct an image of Warsaw at that time - in a way that Tomasz Szarota most thoroughly did - as to provide an interpretation of this image, or rather images, registered in texts, indeed personal documents, originating from the period of occupation. In a few instances, I also refer to memoirs written after the war.

In medieval Europe it was common for Jews to be concentrated in designated parts of a city, a situation marked by two tendencies: external force and internal choice. The doctrine of segregation (a prohibition on Christians and Jews living together, which took its final form after the Third Council of the Lateran in 1179) evolved toward a doctrine of isolation (special markings for Jews, concentrating them in separate districts). The wave of persecution during the Crusades, attempts to preserve religious and cultural differences, an attitude of internal solidarity among the persecuted and humiliated, practical considerations of self-defense and renewed external pressures - all of these phenomena induced Jews to live together in distinct spaces. They thus gathered in a separate part of a city and turned it into their sphere of their social, cultural and religious activity. But there are fundamental differences between a Jewish living space so defined and a ghetto. First, the former was an area of voluntary settlement; life in the group was not dictated by necessity. And second, it was an area in which final segregation and isolation had not yet take place, an area marked by continued exchange and meetings between Jews and non-Jews.

The first districts closed off by walls and designated for Jews emerged in the fifteenth century. But we should remember that they were not closed off in any absolute sense. There was pressure for Jews to live in the ghetto and to return there for the night. But the border - though fortified by a wall and guarded could be crossed.

The word "ghetto" was used for the first time in 1516 in Venice. In the Venetian dialect, Il geto or ghetto means "foundry" (from gettare - to pour, cast).

The Ghetto Vecchio and Ghetto Nuovo served as the old foundry districts of Venice, far from the ceremonial center of the city; their manufacturing functions had shifted by 1500 to the Arsenal. The Ghetto Nuovo was a rhomboid piece of land surrounded on all sides by water; buildings created a wall all around its edges with an open space in the center. Only two bridges connected it to the rest of the urban fabric. ${ }^{235}$

235 Richard Sennett, Flesh and Stone: The Body and the City in Western Civilization (New York, London: 1994), 231. 
In Venice, natural conditions themselves worked perfectly together with the ghetto's basic function: isolation and closure. At night, when the bridges were lifted and windows facing the canals were closed, the walls along the water looked like the inaccessible walls of a castle. In 1555, Pope Paul IV began construction of Rome's ghetto walls differently than in Venice in the sense that the ghetto would be located in the very heart of the city, in a place that was highly visible between two Roman market areas. The Venice and Roman ghettos provide model examples of the emerging ghetto. We find that Warsaw followed a similar schema in the creation of its ghetto: a ruler's decree ordered Jews to wear special markings; the division of the city into Jewish and non-Jewish spaces; massive resettlement and the construction of walls separating the ghetto from the rest of the city (for which the Jewish community had to pay); and a ban on Christian servants working in Jewish homes.

The Venetian ghetto, Sennett claims, was something of an "urban condom," which was to protect the city from the Jew's unclean body and his defiling touch. But the Roman ghetto was viewed as a space for missionary work; Jews were to be gathered in a single place so they could more easily be converted. In Venice the body was isolated, but in Rome the soul was "healed." Nonetheless, one can detect here a certain common denominator in the arguments made in the creation of both ghettos, which involves the use of the metaphor of disease. For Venetians, the ghetto's construction was a prophylactic action. For the Romans, it was a curative action.

The sanitary-epidemiological motivation was the argument that the Nazis most often used to justify the creation of the Warsaw Ghetto in 1940. The metaphor of disease was one of the constitutive features of the Nazi version of anti-Semitism. Susan Sontag wrote: "European Jewry was repeatedly analogized to syphilis, and to a cancer that must be excised," ${ }^{236}$ but the decisive role in the creation of the ghetto was played by typhus - as a real epidemic threat, but above all as an ideological argument. The Germans often explained the construction of the ghetto as necessary in the battle against a typhus epidemic. But the ghetto that the Nazis created, despite the partially similar language employed as motivation and its external appearance (walls, its dense population, its tight space, its filth) differed fundamentally from the historical ghetto. It could be closed off forever, its isolation could be absolute. And the real goal of concentrating Jews in an area separate from the rest of the city was to set in motion the process of indirect extermination. The Germans created the ghetto not as a prophylactic,

236 Susan Sontag, Illness as Metaphor and AIDS and its Metaphors (Picador, 2001), 82. 
not to cure, and not to convert. They created the ghetto not to carry out a policy of segregation and separation. They were interested in neither converting Jews nor sending then into exile. The ghetto was a vestibule for the Final Solution. ${ }^{237}$

Occupied Warsaw was a city divided in various ways and in different stages. The instrument in that division was use of the decree, by which a new spatial order, under new laws, was established. Before the Germans carried out the physical destruction of Warsaw, they first dismembered it through a series of such decrees, leading to something that one might call a "decreed space." It was a way of organizing space in the totalitarian city: a spatial form for a new order that was arbitrary, did not take into account existing realities, was imposed by force, and was executed under the threat of the harshest kinds of repression. Everyone who still had a right to live had to accept it.

In 1940, the Germans worked out an all-encompassing plan for the division of Warsaw into three quarters: Jewish, Polish, and German. In March, authorities established a "Seuchensperrgebiet" "“Obszar zagrożony tyfusem," Area under Typhus Threat), which indicated what would be the maximum reach of the future ghetto. On 12 September 1940, the contents of an order issued by Governor Ludwig Fischer were announced, through street megaphone, regarding the creation of three residential quarters - Jewish, Polish and German - and the definition of their borders. A wave of resettlement within the city, involving both Jews and Poles, reached its high point. The decision regarding the Jewish quarter was implemented by 15 November 1940, when the deadline for resettlement behind the ghetto walls had passed, and the ghetto was closed. Implementation of the decision to create the German quarter was delayed for the time being, though authorities referred often to this decision and issued appropriate declarations. As the war progressed, German officials no doubt were increasingly wary of concentrating too many of their countrymen in one area of the city; they could become the target of air attacks. At the same time, the Germans were feeling increasingly insecure within occupied Warsaw. In March 1942 the security police called on Germans to move to a designated part of the city, one that could be better

237 In his classic work The Destruction of the European Jews, Raul Hilberg identified "the three successive goals of anti-Jewish administrators. The missionaries of Christianity had said in effect: You have no right to live among us as Jews. The secular rulers who followed had proclaimed: You have no right to live among us. The German Nazis at last decreed: You have no right to live." See Raul Hilberg, The Destruction of the European Jews (Holmes \& Meier, 1985), 9. On the concept of "indirect extermination," see R. Sakowska, Ludzie z dzielnicy zamkniętej. Z dziejów Zydów w Warszawie w latach okupacji hitlerowskiej paździemik 1939 - marzec 1943 (Warszawa 1993). 
protected. In August and September of that year, orders were issued that defined the borders of this area precisely, but only in February 1943 did Ludwig Leist (the Nazi-appointed administrator of Warsaw) sign the decree ordering Germans to resettle there by the end of May 1943. Those who moved into the quarter set aside for Germans did so reluctantly. The drawn out process of creating the German quarter ended only in the spring of 1944 in a way that was truly paradoxical. The Germans fenced off a small section of the city that had been marked off for them with barbed wire. They closed themselves off behind barbed wired and separated themselves from the rest. ${ }^{238}$ The process of dividing the occupied city, which had started by walling off the ghetto, was finalized. The decreed space neared its completion.

We might add that, after the war, it was in Berlin were the madness of decreed space and the ideologically motivated division of the living fabric of a city was most spectacular. And it was there that we again see a kind of paradox. Berlin was divided into four sectors, and from 1961 to 1989 the western sector was closed, though it was the only free area on the territory of the German Democratic Republic. The communist rulers of East Germany ordered that West Berlin be wrapped by a wall to cut off access to it for East Berliners. But there was a second wall, one that surrounded the little town of Wandlitz, just outside of Berlin, which was set aside for party elites. The first wall was intended to keep residents of Berlin inside, as in a mouse trap. The second wall was intended to keep people out, far from the secrets held in the lair of the communist leadership. Berliners commonly called Wandlitz the "ghetto of the gods," or simply the "ghetto."239

The culmination of the division of occupied Warsaw is undoubtedly a dichotomy: ghetto - Aryan side. This dichotomy represented not only what was probably the most characteristic feature of that divided urban space, but also a kind of spatial existence marked by the words "this side" and "that side," and the axis of this space was a wall, which - so to speak - gave shape to the experience.

For ancient and medieval towns and cities, a wall was something absolutely fundamental; it was their basic quality, even their elementary definition. ${ }^{240}$ It not only defined the borders of urban space and functioned as an instrument

238 See T. Szarota, “Dzielnica niemiecka," Okupowanej Warszawy dzień powszedni, 442-446.

239 See F. Taylor, The Berlin Wall 13 August 1961 - 9 November 1989 (Bloomsbury; London 2007), 165, 243-249.

240 According to the definition cited by Fernand Braudel from Antoine Furetière's dictionary (1690), a town was the "home of a large number of people which is normally enclosed by walls." See Braudel Civilization and Capitalism, 15th-18th Century, 
of defense, but it also served as a significant symbol. One might say that the wall made the area it encircled into a city; it gave the city its identity. In antiquity, the city wall divided the world into civilized space (intra muros) and that which was wild (extra muros). The circle of walls protected that space marked by law and order, organized in an urban structure, beyond which was endless backwoods populated by wild animals, bands of robbers, and enemy soldiers. The city-wilderness juxtaposition was one of the basic elements of the medieval imagination. "The 'ring of stone' was the 'outward sign of a conscious effort for independence and freedom, which marked urban expansion in the Middle Ages."241

As a stigmata of a ghetto, at least in the early phase in which separate Jewish quarters were first taking shape, the wall still revealed a certain ambivalence in terms of its symbolic significance. We should remember - using the words of Fernand Braudel - that the sixteenth-century "ghetto may have been the prison within which the Jews were confined but it was also the citadel into which they withdrew to defend their faith and the continuity of the Talmud."242 But the wall surrounding the ghetto in German-occupied Warsaw could only be a sign of enslavement, oppression and violence, division and separation, a sign that was deeply rooted in Jewish tradition, and thus easily recognized. Ludwik Landau recorded on 17 April 1940: "[...] the Jewish population of Warsaw watches with trepidation as walls rise up around their neighborhood. [...] Varsovians are talking about these walls as if they portend a ghetto."243

To what extent were people aware that this ghetto would not be like the ones they knew from history?

What we have here is a situation in which a topographical experience is simultaneously an existential experience. Let us outline the two polar extremes of the experience thus understood. First, division and separation. And second, internalization.

vol. 1: The Structures of Everyday Life (William Collins Sons \& Company Limited, 1981), 492.

241 Ibid. For more on the practical and symbolic functions of the wall in ancient cities, and on the psychological role of the wall in the medieval city, see L. Mumford, The City in History (New York, 1961), 64-70, 304-305. On the juxtaposition of city-wilderness and the medieval urbanistic imagination, see J. Le Goff, The Medieval Imagination, trans. Arthur Goldhammer (Chicago \& London: University of Chicago Press, 1988).

242 Fernand Braudel, The Mediterranean and the Mediterranean World in the Age of Philip II, vol. 2, trans. Siân Reynolds (Berkeley: University of California Press, 1996), 810.

243 L. Landau, op. cit., 412. 
Such is the imagery conjured up in the memoirs of Adina Blady-Szwajger, who recalled a detail, a situational trifle, a fleeting moment drawn from the flood of events, but a moment that in fact takes on the significance of a universal symbol. In the sweltering heat of the day 30 July 1942, from a window of the hospital on the corner of Leszna and Żelazna Streets, the author observed a column of people being driven toward Umschlagplatz. They were walking along Żelazna, which was divided down the middle by the wall. To the east of the wall was the ghetto, to the west, the Aryan side. On Żelazna, across from the hospital window, there was a house:

On the balcony of [that] house [...] - there on the other side [of the ghetto wall] - a woman in a flowered housecoat was watering plants in window boxes. She must have seen the procession below, but she carried on watering her flowers. And, on this side, they kept going past. They kept going past and there seemed to be no end. ${ }^{244}$

The woman looking through the window and the woman watering flowers on the balcony were separated by the distance of only the width of the street and sidewalk, a distance of no more than perhaps twenty meters. And yet they found themselves on opposite poles, sealed off from one another by a wall of air, divided and separate.

This division manifested itself most dramatically during the Ghetto Uprising, a subject that has been covered in a broad array of eye-witness accounts, poetry and prose. The symbolic image that established itself in the universal consciousness is that of the carousel at Krasiński Square. From among the various testimonies, let us chose two: first, the diary of Franciszek Wyszyński; and second, the diary of Maria Dąbrowska. ${ }^{245}$ Both texts present a stance toward the Ghetto Uprising that one might call "naoczność zewnętrzna" (external observation). The two diarists are on the outside, above all in the topographical sense; they are simply on the other side of the wall. They thus find themselves in the role of onlooker, though they each play this role in different ways. Wyszyński is an active and inquisitive observer. He fills the pages of his diary with detailed notes that fit under the headings: the "Jewish front," the "battle with the Jews," the "liquidation of the ghetto." His entries from April and May 1943 are dominated by issues tied to the Uprising. The case of Dąbrowska and her diary (at least in its

244 Adina Blady Szwajger, I Remember Nothing More: the Warsaw Children's Hospital and the Jewish Resistance, trans. Tasja Darowska and Danusia Stok (Simon \& Schuster, 1992), 49.

245 Translator's note: Maria Dąbrowska (1889-1965) was a writer famous in Poland above all for her 4-volume novel Noce i dnie (1931-1934). 
print version) is something altogether different. This author is a passive observer; distant images get through to her, ambiguous news, all of which leaves behind, in her diary, a minimal imprint.

External observation also has a certain moral and existential value. Being on the outside means being situated beyond the boundaries of responsibility, but also beyond the confines of the experience of a fate that has ceased to be shared. Wyszyński's diary reads like commentary; it reports gossip and rumors that are distinct from verified information and not based on the author's own observation. The author provided different versions of news that had come to him, he made use of an expert's military terminology. For example, having heard the sounds of gunfire coming from behind the walls, he tried to identify the kinds of weapons being used. His main point of observation was an apartment in the Warsaw district of Żoliborz. From the window he could see the burning ghetto; he counted the number of fires, he calculated the size of volleys. And though he found himself at least once in the direct vicinity of events and had views of the ghetto from Bonifraterska and Leszno Streets, his entire account is marked by a cool distance and dry matter-of-factness, by the sense of having a great distance, separation from that which was on the other side. The effect of this separation, one that is deeper than just topographic, is perhaps best reflected in the passage from 10 May 1943:

Today there were more explosions, and you could see fires. Are the Jews still defending themselves? Nobody knows. They say the Germans are blowing up the tall walls of burnt buildings, which would otherwise threaten to fall; but on the one hand, blowing up the walls cannot cause new fires, and on the other hand, above all, it would be necessary to demolish the high walls of the ghetto buildings on Bonifraterska Street in order to bring back the trams there, and the Germans are not doing this. According to another version, the Germans want to burn down and demolish the entire ghetto. It would be an irreparable loss for Warsaw, which has already triggered a huge spike in prices for buildings in anticipation of a great housing shortage after the war, while the existence of vacant houses in the Jewish quarter would give Warsaw, after the war, after renovation, an enormous supply of vacant dwellings. ${ }^{246}$

One might call such externality "technocratic" when everything but cool economic calculation disappears from the field of view.

In Dąbrowska's diary, reflections on the Ghetto Uprising appear against the backdrop of the events of private life, eclipsed again and again by the diarist's everyday activities. On 22 April:

246 F. Wyszyński, Dziennik z lat 1941-1944, eds. J. Grabowski and Z. R. Grabowski (Warszawa 2007), 364. 
In the morning, I worked - then all three with Anna in the garden. Dinner with meat, joined at dinner by Jadzia, who tomorrow is going to Helena's for the holidays. In the afternoon, I worked, tea in the evening at Anna's. As we were in the garden, we saw clouds of smoke over the ghetto, where the battle apparently continues. ${ }^{247}$

Under the date 26 April, we find an entry about the weather:

On Holy Saturday there was wonderful summer weather - 20 degrees [Celsius]. Yesterday and today a little rain fell, but generally beautiful weather - sunny and springlike - and outside the window a huge cloud of smoke still hangs over the ghetto. Once again, half of Warsaw is burning .... ${ }^{248}$

The next day Dąbrowska wrote:

A cloud of smoke is still visible through the window. Frightening - disturbing - terrible thoughts take control of the brain. Mrs. Leonard was here with her son. People exhaust me terribly. I cannot tolerate anyone longer than a half hour. ${ }^{249}$

And finally, the last entry, dated 12 May:

Today Basia Wolska came over and the whole image of Stasia's death, reportedly a horrible death, came back to me with double force. In the morning we beat out some things and put them into anti-moth bags. Outside, cool but nice. The sun is ore-red from smoke. Constant explosions - as if it were a continued stage production of her death. ${ }^{250}$

In the last entry, echoes from the moribund Ghetto Uprising were associated with the memory of the death of a friend Stanisława ("Stasia") Blumenfeld, a Jewish woman murdered by the Germans in Lwów. Anonymous mass death in the burning ghetto serves as the backdrop for an experience tied to the single death of an individual. Distant explosions and clouds of smoke on the horizon call to mind the horror of the death of someone close, valued and loved. In late April and early May 1943, Warsaw was the scene of a private drama, one involving personal loss. This would thus be private externality, an externality to everyday life, a little culinary, a bit social.

The breakup of Warsaw into ghetto and Aryan sides, that division of urban space, also provoked protest, a desire for the border's removal, for the partition to be overcome. Just after the war, Kazimierz Brandys wrote (more as a declaration than an account):

247 M. Dąbrowska, Dzienniki 1933-1945, vol. 2, ed. T. Drewnowski (Warszawa 1988), 395. 248 Ibid.

249 Ibid., 396.

250 Ibid., 397. 
The high gates of the ghetto closed behind the people of Leszno and Bonifraterska Streets. Let us not turn our backs on them, these walls should not separate our consciousnesses from them [...] Snow falls on Gęsia Street just as it does on Krucza, Żurawia and Topiel Streets. ${ }^{251}$

How drastic the breakup of the space of occupied Warsaw must have been, since the author - in order to question that breakup - drew upon a commonsense argument based on the universal laws of nature! Clearly, such an obvious fact was not universally accepted as obvious. During the Uprising, Brandys was moving through the streets outside the ghetto, separated, but with a sense of guilt:

I wanted to be close to them in those days, when I was overwhelmed with shame that I was not with them. [...] The walls always blocked my path. [...] I felt guilty because of the crowds gathered around a cinema or taking a walk on the [Ujazdów] Avenue, where boys were flirting with the girls. ${ }^{252}$

Writer and dramatist Zofia Nałkowska was also on the outside; she also viewed the Uprising from a distance with its flames, clouds of smoke, and explosions. But here, observation of the external symptoms of the Uprising did not end with the recording of superficial phenomena. It also led to internal reflection: on ways of experiencing brutal reality; on the paradox of proximity and distance in the face of tragedy; and - in a veiled way - on the fatal (in the sense of fate and doom) coincidence of two acts of genocide - the liquidation of the ghetto and the Katyń massacre, which had just been discovered.

Reality is tolerable because we are not given everything in the experience, not everything is visible. It comes to us in fractions of events, in shreds of the relationship, in the echoes of gunshots, terrible and untouchable - in the clouds of smoke, in fires, about which history says that they will be "reduced to rubble," although no one understands these words. This reality, distant and happening behind the wall, is tolerable. But you cannot stand the thought. These are the graves that have undermined the old system of relations. We are stretched - we here - tightly along the axis of this symmetry. The fate of those people far away, the fate of these people near. They have died, they have died. Grave and serious marches of the resigned, leaping into flames, leaping into the abyss. ${ }^{253}$

Thought is organized around spatial images, which give shape to reflections offered in an Aesopian (as it were, encoded) language. In the above entry, spatial categories turn out to be categories of fate, torn between "here" and "there";

251 K. Brandys, Miasto niepokonane (first edition, 1946). Quote from edition IX (Warszawa 1962), 114.

252 Ibid., 202.

253 Z. Nałkowska, Dzienniki. V. 1939-1945, ed. H. Kirchner (Warszawa 1996), 445-446. 
between "near" and "far," "behind the wall"; between the metaphorical abyss that divides the ghetto from the Aryan side; by the real distance that divides Katyń from Warsaw.

A record of the crumbs of information reaching Nałkowska about events playing out behind the wall becomes a dramatic record of the author's own existential experience.

I live next to it, I can live! But in the end I feel unwell, I am changing into someone else. How is it that I can be forced into it, in order to be in it, in order to only live - stop! It is still a disgrace, not just a torment. This is terrible shame, not just compassion. Any effort to hold out, to not fall into madness, to maintain oneself in this horror, feels like guilt. ${ }^{254}$

Nałkowska was aware of the fact that something was happening here that - in a very deep sense - was also touching her, something that touched a person faced with the terrible "ordinariness" of the world:

Why am I so distressed, why am I ashamed to live, why can I not hold on? Is the world horrific? What is happening is in accordance with the rest of nature, it is animalistic - as goes the non-human world, so goes the world. [...] Is the world horrific? The world is ordinary, one must suppose that. That is how the world is. The world is ordinary. The only strange thing about it is my own horror and the horror of others like me. ${ }^{255}$

Alicja Iwańska and Jan Gralewski - a married couple militarily active in occupied Warsaw - wrote short "letters/non-letters" to one another almost daily. In a note dated 12 May 1943, we have a description of the situation marked by separation:

The ghetto is burning $[\ldots]$ constant explosions. And people are walking quietly along the streets full of sun and violets. Hearing the shots and explosions, no one even averts one's eyes. ${ }^{256}$

The next note was written in the night of 12-13 May, just after a huge Soviet air raid on Warsaw:

Fires ... Right now I do not believe in the existence of anything, beyond Warsaw, which is burning ... I [Iwańska] went out on the balcony. A warm blast comes from the flames. One hears the crack and crash of walls, I feel it all in my chest: huge buildings collapsing. I am just a scaffold, but this scaffold is reinforced ... I am calm now. ${ }^{257}$

But later, the calm disappears, and sleeplessness appears. The entry dated 29 May:

254 Ibid., 446.

255 Ibid., 448.

256 A. Iwańska, J Gralewski, Wojenne odcinki (Warszawa 1940-1943) (Warszawa 1990), 184.

257 Ibid. 
I [Iwańska] have not been able to sleep the last couple days. I am filled with severe terror. I have within myself the entire net that has been thrown over the city. Tonight there were shots fired, and then some kind of explosion, then more shots. ${ }^{258}$

In Iwańska's epistolary notes from the period of the Ghetto Uprising we find not just a desire to overcome distance, but also a longing to unite the divided and separated spaces. Iwańska appears to think in holistic categories. For her (but not for others, as she pointed out in the entry dated 12 May, cited above), Warsaw was indivisible. The ghetto was burning from fires set by the Germans, and buildings were burning from Soviet bombs. And the entire terror was inside her. She thus carried out a peculiar act of incorporation, one involving divided space, a kind of internalization.

\section{Metaphors of the Ghetto}

The Nazi ghetto turned out to be something quite different than the historical ghetto, though the process by which people recognized this distinction was long (just as the process by which people grasped the horrible reality of the Holocaust was long). At the beginning, Warsaw Jews associated the ghetto above all with the painful history of persecution, and in this sense the ghetto - though it was the cause of great fear and anxiety - invoked a well-known version of the Jewish fate. Naomi Szac-Wajnkranc wrote about the clock having been turned back; she viewed the ghetto through the prism of what she had read about the Venetian ghetto: "dark, dirty alleys, dilapidated buildings, sad people with a yellow patch on their backs." ${ }^{259}$ Emanuel Ringelblum saw differences, though only those that were quantitative: "The Ghetto is much more painful now than it was in the Middle Ages, because we that were so high and mighty have now fallen so low." ${ }^{260}$ The Germans avoided such historical comparisons. Henryk Bryskier wrote: "By decree of the German authorities, the ghetto was disguised under the name "Jewish residential quarter." ${ }^{261}$ Chaim Kaplan referred many times to this

258 Ibid., 188.

259 N. Szac-Wajnkranc, Przeminęlo z ogniem. Pamiętnik (Warszawa 1947); quote from second edition (Warszawa, ca. 1988), 12.

260 Emanuel Ringelblum, Notes from the Warsaw Ghetto: The Journal of Emanuel Ringelblum, ed. and trans. Jacob Sloan (McGraw-Hill, 1958), 85.

261 H. Bryskier, Żydzi pod swastyka, czyli getto w Warszawie w XX wieku (Warszawa 2006), 7. The author wrote his diary in the years 1943-1944 while in hiding on the Aryan side of Warsaw. 
onomastic manipulation. As he saw it, the Germans wanted to avoid negative associations:

In their radio programs the conquerors are very careful never to call the Jewish quarter by its correct name - ghetto; it is not comfortable for one who wishes to create a 'new Europe' to return to the customs of the Middle Ages. ${ }^{262}$

The Germans wanted to present the entire operation as part of the normal administrative division of the city into three districts.

But neither historical analogy nor bureaucratic euphemism fully reflects the phenomenon that was the Warsaw Ghetto. It not only exceeded the sum of all previous imagery, but it also eclipsed the well-worn ways of metaphorically grasping and understanding a closed space. The discourse on the ghetto has its own dynamic; it changes as the form of the ghetto itself evolves through its various stages. It departs from the formulaic ways of depiction, away from the object most deeply embedded in tradition. The archetype and synthesis of any closed space is the prison. ${ }^{263}$ Let us then consider a way of using the metaphor of the prison with reference to the Warsaw Ghetto. But we should point out that this metaphor appeared, in its classical sense, even before the walls were raised and the ghetto was built. In the second month of the occupation, Wacław Sieroszewski wrote: "We all feel that we are sealed off from the world by a thick, impenetrable wall. A huge prison, around which, somewhere out there, life goes on."264

Walls raised in the middle of the city degraded its urbanistic structure; they tore through natural transportation routes, increased topographic absurdities, and caused growing problems in the everyday functioning of the urban organism. They reminded Poles of a labyrinth. Stanisław Srokowski noted in April 1940: "With their various walls the Germans have circumscribed Warsaw's Jewish neighborhood such that they have created in places a veritable labyrinth, from which it is difficult to escape." ${ }^{265}$ It is characteristic that those writing down

262 Kaplan, Scroll of Agony, 224.

263 See M. Głowiński, "Labirynt, przestrzeń obcości," in Mity przebrane. Dionizos. Narcyz. Prometeusz. Marcholt. Labirynt (Kraków 1990), 175. In these multi-layered and highly inspirational reflections on the labyrinth and prison as spatial metaphors for enclosure, the author does not take into account the situation of the ghetto.

264 W. Sieroszewski, op. cit., 144. Translator's note: Wacław Sieroszewski (1858-1945) was a Polish independence activist, ethnographer, novelist and politician.

265 S. Srokowski, Zapiski - dziennik 1 IX 1939 - 29 VIII 1944, Archiwum PAN, sygn. III, 22, p. 70. 
their thoughts on the other side of the wall did not entertain the image of a labyrinth as Srokowski did. After all, for Jews the walls were above all the source of the traumatic experience of being closed in, imprisoned. Two weeks before the ghetto was closed, Ringelblum wrote: "The walls have been built higher than had already been built on Rymarska Street. They give the impression of prison walls. They want to wall us in alive - that is what the Jews are thinking." And a few days later he added: "The long wall at Wielopole Street looks like a prison wall."266

The walls thus created a gigantic prison in the middle of the city, an area disconnected, separated, hermetically closed. The ghetto prisoners, like all prisoners, rearrange their dreams for freedom into a yearning for open spaces, without borders and walls that divide streets, for an open path ahead. One of the paradoxes of this prison was its great size and yet its lack of space. The walls encompassed a good chunk of the city; it was a relatively large space. But it was still crowded and foul-smelling like a tight prison cell. Ludwig Hirszfeld described his impressions after having moved into the ghetto: "The gate was shut behind us. It was as if we had moved from a cold room into a crowded, stinking prison [...]."267 Another paradox was the existence in this prison-like space of enclaves of relative freedom, or at least privacy, for example apartments, houses, backyards. Green areas were an unusually rare enclave - indeed they were practically non-existent in the ghetto - which is why every one of its meager manifestations were taken as signs of refusal to take part in the prison-like order. On 24 June 1942 Adam Czerniaków paid a visit to playgrounds being built in spaces where rubble from buildings destroyed in the siege had been cleared away. We can sense the above-mentioned paradox in his laconic diary entry: "I visited the playgrounds being built on the corner of Franciszkańska and Nalewki Streets and on Nowolipki Street, a playground in a prison."268

But the metaphor of a prison does not fully reflect the peculiar nature of the ghetto. Indeed, there is no simple analogy, though Henryk Makower apparently thought so:

The realization that one could not wander from one street to another, that one could not take a walk along the Vistula, or visit "Aryan" friends [...] was difficult to bear. The only

266 E. Ringelblum, Kronika getta warszawskiego: wrzesień 1939 - styczeń 1943, intro. and ed. A. Eisenbach, trans. from the Yiddish A. Rutkowski (Warszawa 1983), 185-186; for the last fragment quoted, see Ringelblum, Notes from the Warsaw Ghetto, 83.

267 Hirszfeld, The Story of One Life, 189.

268 Adama Czerniakowa dziennik getta warszawskiego 6 IX 1939 - 23 VII 1942, ed. M. Fuks (Warszawa 1983), 291-292. 
people who are able to comprehend this are those who are in prison or in some other closed camp. ${ }^{269}$

Władysław Szpilman viewed it differently; he drew a distinction between a prison cell and the ghetto, and what emerges from his comments is a precise description of the torture associated with a closed life in that peculiar, incomparable space that was the Warsaw Ghetto.

I think it would have been psychologically easier to bear if we had been more obviously imprisoned - locked in a cell, for instance. That kind of imprisonment clearly, indubitably, defines a human being's relationship to reality. There is no mistaking your situation: the cell is a world in itself, containing your own imprisonment, never interlocking with the distant world of freedom. [...] The reality of the ghetto was all the worse just because it had the appearance of freedom. You could walk out into the street and maintain the illusion of being in a perfectly normal city. [...] However, the streets of the ghetto - and those streets alone - ended in walls. I very often went out walking at random, following my nose, and unexpectedly came up against one of those walls. They barred my way when I wanted to walk on and there was no logical reason to stop me. ${ }^{270}$

Thus, city space decreed to be a closed ghetto coexisted with space decreed to be open, though occupied. And herein lay the essence of torture. The possibility of maintaining eye contact with the "other side," its palpable closeness, created the impression of an irresistible spatial continuum. But it was just a pernicious illusion. One's presence in the ghetto was greater torture than being locked up in a normal prison, because the ghetto was a constant "allusion to freedom lost," a constant expression of the radical nature and irreversibility of being closed in, and a reminder - simultaneously - of its irreality. A wall laced with shards of glass could not completely blind itself to the "other side" as can cell walls surrounding a prisoner. Unable in a literal sense to isolate and separate the two worlds from one another, the ghetto wall intensified its symbolic functions to an exceptional degree. It was a kind of sign demarcating space subjected to the criminal dictates of clerks. The power of their decisions became the boundary between life and death, freedom and captivity, hope and desperation, hell and normality.

Those who managed to get to the Aryan side usually formulated their impressions in radically different categories. As if they had been able to bridge the gulf between various forms of existence, or various states of existence. In

269 H. Makower, Pamiętnik z getta warszawskiego. Październik 1940 - styczeń 1943, ed. N. Makowerowa (Wrocław 1987).

270 Szpilman, The Pianist, 62-63. 
this case, the shift to the other side not only has a colloquial meaning; it also takes on a deeper metaphysical meaning. There are many descriptions of such experiences. Let us point to three fundamental attributes of the experience of shifting to the Aryan side.

First - a spatial paradox. The world behind the walls was close by, within arm's reach. But the physical proximity of two worlds stood in stark contrast to the gulf that separated them. It was forbidden, under the threat of death, to cover the distance of a couple steps between the two sides of a street divided by a wall. How one normally experienced space thus had to be re-evaluated. Some witnesses conceived the passage across the border of the closed quarter in absolute categories: the passage from one world to another world, from death to life. Władka Meed left the ghetto in December 1942.

One Sunday I was strolling along a Warsaw street in the 'Aryan sector,' not too far from the ghetto wall. There was a playground on Krasinski Square opposite the wall, and that Sunday it was crowded with youngsters and adults engaged in sports, dancing and games. The small cafes were bursting with young men eating, drinking and having a good time. I paused at some distance and took in the scene, then turned left and caught sight of the ghetto wall only a stone's throw away. Two different worlds on the same street. $^{271}$

Having gone over to the Aryan side, Noemi Szac-Wajnkranc saw "people calm and quiet, trams and cars, stores, commerce, life. We are divided only by the wall, just a few dozen steps, here is life, there is death." ${ }^{272}$ Hirszfeld stated simply: "The streets beyond the walls seemed to belong to another world."273

Second - shocking normality. The category of "normality" appears very often in descriptions of the passage to the other side. Authors reported a striking change: from monstrosity to ordinariness, from terror to calm. They had left behind a horrifying world, one that had gone awry, and crossed into a reality that regained is true proportions. In these testimonies, the moment of crossing resembles waking up from a nightmare. Still half-awake from a bad dream, one is greeted by common household items, a window from which one can see a normal world. Having crossed from the ghetto (after the Grossaktion Warsaw of the summer of 1942) over to the Aryan side, Leokadia Schmidt could not believe her own eyes: "normal street activity, trams, open stores. After the hell of

271 Feigele Peltel Miedzyrzecki [Meed], On Both Sides of the Wall: Memoirs from the Warsaw Ghetto (Holocaust Library, Jan. 1, 1979), 87.

272 N. Szac-Wajnkranc, op. cit., 48.

273 Hirszfeld, The Story of One Life, 173. 
the ghetto, where all movement and life has died out, you have the impression of something unreal." ${ }^{274}$ Ruth Cyprys escaped the ghetto through the Law Court building on Leszno:

For the first time in many long months I had left our street to venture onto the Gentile side. [...] I felt happy to be in a normal street and to see the town. [...] shops, people, cars, cabs, trams, everything seemed so strange, so unusual. [...] Like a child, I enjoyed my freedom, going from shop to shop, buying unnecessary things for the sheer pleasure of buying, and behaving like a normal human being. Aimlessly I got on trams, alighting at the following stop. But what a pleasure this was! I scanned the faces of passers-by. I wanted to read people's eyes to find out whether they thought me a normal person; I was constantly sure that my face bore a stigma. ${ }^{275}$

The normality of the Aryan streets stunned Helena Merenholc.

I walked through the streets and it was normal. Such was my first impression: normality. Bewilderment. It seemed to me that I was a free person. When, from the ghetto, I looked through the window at people on the Aryan side, it seemed to me that they were happy. The feelings of prisoners. [...] After all, I knew full well what kind of tragedy was playing out in Warsaw, in all of enslaved Poland. But the shadow of the ghetto followed me hunger, typhus; the shadow of the irreversible Extermination. ${ }^{276}$

Third - the incomprehensible contrast. The experience of fracture was often formulated in sacral language, using biblical metaphors. In Franciszka Grünberg's account, the ghetto gate took on the character of the gates of hell, at which the guard played the role of the angel of death. Everything underwent radical change. The crowds of poor people, the clamor and dirt of the ghetto turned into the emptiness of clean Aryan streets. This contrast was unbearable. The brightness was blinding.

The gendarme calmly opened the gate. I felt as if the angel of death were releasing me from the depths of hell. One moment later, instead of throngs of miserable poor beggars with swollen yellow faces, instead of the desperate clamor, the terrified mob, instead of dirty streets full of trash, I saw clean, empty streets with an occasional figure passing by. I felt hypnotized: completely disoriented by the new sights, and by a new kind of fear; everything seemed strange and unfamiliar. I was in a thick fog and couldn't see a thing ahead of me. I was like someone who's been sitting in the dark for a long time and

274 L. Schmidt, Cudem przeżyliśmy czas zagłady (Kraków 1983), 153.

275 Ruth Altbeker Cyprys, A Jump for Life: A Survivor's Journal from Nazi-Occupied Poland (New York: Continuum, 1997), 81-85.

276 Quote from B. Engelking, Na łqce popiołów. Ocaleni z Holocaustu (Warszawa 1993), 205. 
who then goes outside to discover that he can't see: The sunlight makes him squint; the blinding brightness hurts. I felt blinded as well. ${ }^{277}$

The prison as a spatial metaphor for the ghetto turns out to be too pale, a bit too indistinct, to describe reality behind the ghetto wall. What seems necessary is either an additional, reinforcing attribute - as reflected in this entry by Abraham Lewin dated 18 May 1942 ("We are rotting in a prison, the like of which has never been seen before, for the ghetto the Germans have set up for us has no model or precursor in human history."278) - or perhaps another choice of words, for example the metaphor of a cage (Noemi Szac-Wajnkranc, on her impressions during the ghetto's early phase: "We are locked in a cage." ${ }^{279}$ ). We read in Leokadia Schmidt's diary about a lockdown in the workshop (szop) during the Grossaktion Warsaw: "The trap slammed shut. Everyone is in the cage. There is no way out."280 But Abraham Lewin wrote, after the mass deportation was done: "The walls around the ghetto, that is, around the few streets still occupied by us, are nearing completion. The new ghetto - even more than the old - is like a small cage."281 One associates a cage with a significantly more cramped space than a prison, but above all it is an inhuman enclosure. Animals are kept there, or some kind of mutated freaks who do not deserve to be called humans - that is "subhumans," to use the language of the clerk overseeing the decreed space of occupied Warsaw.

Yet another phrase is "closed city," an expression used many times by Rachel Auerbach, which functioned in her diary as a synonym for the ghetto. The closed city invokes a different conceptual tradition than does a prison, for example a city under siege, or one that is overcome with the plague, or one that is seized by death. ${ }^{282}$ "[...] I was about to write about death. About death walking in broad daylight through the streets of a closed city."283 The phrase closed city, as conceived in a broad anthropological context, reshapes the ghetto into a gigantic scene in which the final spectacle plays itself out. That drama of fate, of the mystery of life

277 Michał Grynberg, ed., Words to Outlive Us: Eyewitness Accounts from the Warsaw Ghetto, trans. Philip Boehm (Picador, 2002), 313-314.

278 Abraham Lewin, A Cup of Tears: A Diary of the Warsaw Ghetto (Fontana, 1988), 77.

279 N. Szac-Wajnkranc, op. cit., 10.

280 L. Schmidt, op. cit., 59.

281 Abraham Lewin, A Cup of Tears, 192.

282 For more on the comparison between the ghetto and a city affected by the plague, see B. Engelking “Czas przestał dla mnie istniec...”. Analiza doświadczenia czasu sytuacji ostatecznej (Warszawa 1996), 160-177, and J. Leociak, Tekst wobec Zagłady, 217-226.

283 R. Auerbach, Pamiętnik z getta (zapisy: 4 VIII 1941 - 13 II 1942), Archiwum ŻIH, Ring I, 654, p. 14. 
and death, is expressed in the language of modernity, in the categories of mass culture, in the registry - so to speak - of reduced means of expression. Thus, not an ancient tragedy, but some kind of street tragifarce - a "corpse fair,"284 "spontaneous theater," or a "self-winding sound film." 285 On 6 March 1942, Rachel Auerbach wrote:

Life, especially the kind of life as ripe for death as ours in this closed city, sometimes offers up bizarrely vivid symbolic abstracts, like melodramatic ideas for a banal film. ${ }^{286}$

The ghetto before and after the Grossaktion Warsaw, deserted and broken up into isolated enclaves of workshops, consisted of two completely different scenes. From the many visions of the vestigial ghetto, let us choose two examples. Abraham Lewin was aware that death, walking in the streets of the closed city, had transformed those streets into a "dead city." We find precisely such wording in his entry under the date 16 October 1942:

The Jewish streets of Warsaw are deserted, their residents have disappeared. I get the chills as I make my way to work in the morning, and particularly in the evening, when I cross the deserted streets. A "dead city" - in the full sense of the word. ${ }^{287}$

Rachel Auerbach highlighted the horrible condition of a city in which there is no longer a single living soul; humans being gone, things were now dying in the streets and courtyards.

Oh, the "still lifes" of the Ghetto plunged into agony! [...] It is enough - in order to understand what has happened - to look at the trash piles created in the Jewish yards. ${ }^{288}$

The ghetto was thus transformed into a refuse dump, a disorderly pile of junk, the image of chaos, degradation and debasement. But it would seem that, in Rachel Auerbach's description, the trash dump is something more - some kind of extreme form of degraded and tormented existence. The dead city stripped, defiled, desecrated - died once again in the most hideous scenery of biological decay.

Things solidly made and from even more solid materials defend themselves a bit more fiercely against decay. However, they follow the same determined path. Dumped on a

284 Ibid., 39.

285 Ibid., 10.

286 R. Auerbach, Dziennik getta (zapisy: 6 III 1942 - 6 VI 1942), Archiwum ŻIH, Ring I / 641, p. 1.

287 Quote from fragments of the Polish translation of Lewin’s diary, Biuletyn ŻIH 23 (1957), 72.

288 R. Auerbach, "Lament rzeczy martwych," Przełom 2 (1946), 6. 
pile, like a corpse in the summer, swelling terribly day by day, smudged everywhere with shit, brewed and rotting at once from the heat and humidity, fetid, and befouled, they are waiting only for the fire, which would put an end to the monstrosity of their decomposition. ${ }^{289}$

The metaphor of the prison thus changes, metonymically, into a rubbish heap. Based on a similar principle, pars pro toto, one can view the Jewish cemetery along Warsaw's Okopowa Street as a metonym for the ghetto, ${ }^{290}$ because the cemetery is a form of exclusion. Jean Baudrillard wrote about how the dead are cast out into the cemetery-ghetto:

There is an irreversible evolution from savage societies to our own: little by little, the dead cease to exist. [...] They are no longer beings with a full role to play, worthy partners in exchange, and we make this obvious by exiling them further and further away from the group of the living. In the domestic intimacy of the cemetery, the first grouping remains in the heart of the village or town, becoming the first ghetto, prefiguring every future ghetto $[\ldots]]^{291}$

Zygmunt Bauman took up Baudrillard's thought, writing: "Cemeteries, Baudrillard suggests, were the first ghettos; the archetypal ghettos, the pattern for all ghettos to come. However they differ in ritual, all funerals are acts of exclusion."292

All of the tropes discussed so far have been spatial in nature. But we have another metaphorical arrangement available to us that serves to describe the ghetto, the sources for which we can find in the tradition of the metaphor of sickness and disease. Not to take this theme too far, let us point to the most expressive example. The wooden footbridge over Chłodna Street at Żelazna Street, one of the ghetto's most characteristic spatial stigmas, was what Henryk Makower called an "urbanistic wound on the countenance of Warsaw." ${ }^{293}$ In one of Wojdysławski's diary entries, the entire ghetto was a wound. A description of a person dying of hunger on the street becomes a description of the city and the world:

289 Ibid., 7.

290 For more on the Jewish cemetery in the ghetto, see the below section, in part II of this book, entitled "Contemporary Antigone."

291 Jean Baudrillard, Symbolic Exchange and Death, trans. Iain Hamilton Grant (Sage, 1993), 126.

292 Zygmunt Bauman, Mortality, Immortality and Other Life Strategies (Stanford: Stanford University Press), 24.

293 H. Makower, op. cit., 176. 
Fatal hunger. And the legs get thicker. They are not legs, but rather massive chunks of meat torn up by the swelling of the hunger. [...] And all this enormous space of meat is one suppurative, swollen wound. [...] The eyes of a man not used to such a sight turn away. But that cannot be done. The head remains still, the muscles are tight, the eyelids are too short to cover the eye. The wound remains. The whole street is a wound. The ghetto is a stinking, festering wound. The sun is a wound. ${ }^{294}$

We have presented here a review of the chain of metaphors that could capture the phenomenon that was the ghetto. But the ghetto itself was a metaphorical formula: for the topography of the absurd, of strangeness and enslavement; for divided, lacerated, wounded space; for a stigmatized, degraded, imprisoned and tormented existence.

\section{Taking an Aryan Tram through the Warsaw Ghetto}

As of 1 January 1939, eight tram lines ran through that part of Warsaw that would soon make up the territory of the ghetto. The greatest number of these trams traveled along Chłodna Street: the "11," "16," "21," and "15," which also ran along Bonifraterska, along which the "17" also ran. The " 9 " ran along Tłomackie and Leszno Streets. Tram cars identified by letters served the so-called circular lines. For example the "O" tram covered Gęsia - Dworzec Glówny (the main railway station) - Miodowa - Franciszkańska - Gęsia; and the "T" tram ended its route at Plac Teatralny by way of Towarowa, Twarda, and Trębacka.

The war broke up this thick net of tram connections. Severed overhead lines, tracks pulled up from their foundations, tracks strewn with rubble, destroyed tram cars, burned out power stations. The damage was huge, and yet the first tram moved out of Wilson Square station, headed for Krasiński Square, on 18 October 1939. At the end of October, trams along the next line began to move: from Młynarska Street in the Wola district to Żelazna Brama Square. Partly rebuilt tracks guided trams to the same places as before the war, and the renovated tram cars were the same ones that had run in the prewar era, but nothing was the same as it had been, because the Warsaw trams had returned to life in an occupied city. They traversed the area that the occupier had taken and now ruled. Signs of conquest and captivity were not just the painful evidence of material damage and the increasing repression. Decrees issued by the occupation authorities had broken the previous urban order, they had imposed on the

294 [?] Wojdysławski, Refleksje z okresu okupacji (1939-1942), Archiwum ŻIH, Ring. $\mathrm{I} / 489,28$. 
city a new spatial system - foreign and oppressive, based on segregation, division and isolation.

In the autumn of 1939, the two first tram lines still ran freely through the area that would soon be closed, that would soon be separated from the rest and encircled by a wall. For now these trams were unobstructed, but they were already partially isolated and specially marked. They passed barbed wire fences and signs reading "Area under Typhus Threat." They entered Chłodna Street (which was the topographical axis of the future ghetto, and which - as of June 1940 - would be called Eisgrubenstrasse), passed Plac Mirowski (which would soon be called An der Markthalle), continued along Graniczna Street (Grentzstrasse), and ended at Żelazna Brama Square (Torplatz). In March 1940, line number 16 began to run along Leszno (as of August of that year Gerichtsstrasse), as later would line 22. In April a new line started, number 1, which ran through Dzika and Zamenhofa (soon to be combined as Wildstrasse), Gęsia (Gänsestrasse), Franciszkańska, and Bonifraterska (Klosterstrasse) Streets. As of September, line 28 ran along Żelazna (that is, Eisenstrasse), Nowolipki, Smocza, Gęsia and Nalewki Streets.

The path and names of streets through which these trams ran changed, as did the street scenery. From the beginning of the occupation, certain spaces were reserved "Nur für Deutsche," and after a certain time it was firmly established that these spaces were the front of platforms, and the front of tram cars. At the end of September 1940, a tram entered the streets of Warsaw that was to be used only by Jews. It was painted yellow and marked on all sides with a Star of David. Placards read "Nur für Juden." Ringelblum pointed out that "the 'pure Jewish' streetcar - i.e. a single streetcar for Jews - has a yellow placard; when there are two cars in a train, one of the cars is for Jews, the other for Christians (the Jewish one in the rear), and the placard is half-yellow."295 That tram continued to run in undivided space. What was divided was the tram itself, with one wagon designated as Christian, and one as Jewish. On 26 November 1940 (that is, just after the ghetto was closed), three tram lines were activated that were designated for Jews only; they ran within the range of the closed space. Signs bearing the numbers 15, 28 and 29 were painted yellow. In February 1941, the three special Jewish lines were shut down, replaced by a tram marked by a blue-white Star of David. At the beginning, it ran from Muranów Square through Muranowska, Zamenhofa, Dzielna, Karmelicka, Leszno, and Żelazna Streets, to the crossing with Chłodna Street. On December 1941, after the ghetto's borders were changed, the path of the Jewish tram changed; it started at the Leszno-Żelazna intersection, and ran

295 Ringelblum, Notes from the Warsaw Ghetto, 65. 
along Żelazna, Nowolipki, Smocza, Gęsia, Zamenhofa, Muranowska Streets, Muranów Square, and Nalewki Street, and then again on Gęsia and Zamenhofa, Dzielna, Karmelicka Sreets, and then back along Leszno to Żelazna Street.

This was a new tram line, built exclusively for the ghetto's needs. But the tram car itself, though changed since the occupation, remained a traditional Warsaw tram. At the same time, peculiar horse-drawn ghetto trams appeared on the streets of the closed quarter, which belonged to the "Towarzystwo Komunikacji Omnibusowej" of Kohn and Heller, which had received a license from the Germans. As Henryk Bryskier wrote, they were a strange hybrid of a traditional omnibus, mobile circus shed, and gypsy wagon. They were set up:

$[\ldots]$ on a high, heavy platform, a main body with windows and painted yellow and blue, stairs up the back with handrails, and benches inside both left and right. The conductor with a light violet armband and Maciejówka cap on his head with a violet bandsold tickets, and instead of a motorman, a coachman, urging the horses forward with a whip. ${ }^{296}$

These trams debuted in July 1941 and, at the beginning, served the Small Ghetto. As of February 1942 they were at work on two lines - one in the Large Ghetto and one in the Small Ghetto - which were completely separated by Chłodna Street, which was now Aryan and could not be crossed.

The rise of the closed ghetto in the middle of the urban organism posed a major challenge for the prewar company "Tramwaje i Autobusy," which was transformed in July 1941 into the Miejskie Zakłady Komunikacyjne (Städtische Verkehrsbetriebe Warschau) and was headed up by the German Hipolit Alertz. The fact that such a large tract of land in the northern part of Warsaw had been cut off from the rest of the city was unacceptable. It would block the east-west thoroughfare (Leszno and Chłodna Streets) and the south-north thoroughfare that is, the shortest path leading from the Warsaw Center to the northern district of Żoliborz. Thus, compromise solutions were implemented - which were practical in transportation terms, but which represented a breach of the principle of complete isolation - involving the policy of "transit" through the ghetto, by which the idea of the ghetto as a closed area, one which was disconnected, separated and - so to speak - impenetrable, would be violated.

On 23 October 1940, the Jewish wagons attached to line number 1 trams were eliminated. From that date on, line 1 trams, which ran from Powązki to Teatralny Square via Dzika and Muranowska Streets, Muranów Square, Nalewki and Bielańska Streets, could thus carry only Aryan travelers. Which means that,

296 H. Bryskier, op. cit., 80. 
three weeks before the ghetto was closed, a tram appeared that played a "transit" role, though it was only a half-measure because, though Jews could not get on the number 1 tram, it was for Aryan passengers still a normal line, and line 1 trams stopped at every tram stop. This situation changed after 16 November, when Aryan trams, during their transit through the now closed ghetto, were escorted by the Blue Police; they travelled at maximum speed and did not stop at the ghetto tram stops. At first, the transit routes were Chłodna, Gęsia, Muranowska, Nalewki, Franciszkańska, Bonifraterska and Leszno Streets. As the area of the closed quarter was reduced, as ghetto gates were eliminated, and as the battle against smuggling heated up, the number of transit streets went down. As of the middle of March 1941, trams on lines 16, 22, and 23B no longer went through Leszno, but rather through Chłodna Street. A month later transit through Muranów Squarw, Franciszkańska, Nalewki, and Sierakowska Streets was closed, and the shortened line 4 route led only through Bonifraterska Street.

The practical benefit of this abnormal situation, marked by transit through the extraterritorial area of the city, was smuggling. Bags of food, bread, and packages were thrown from trams moving along the ghetto streets without stopping, things which immediately disappeared behind the gates of neighboring buildings. Mojżesz Passenstein, author of a monograph on smuggling written on the Aryan side in 1943, wrote:

Tram cars moved through the ghetto along Chłodna (from Wrona to Mirowska), Zamenhofa (from the opening of Dzika), Gęsia, Muranowska, Nalewki, Franciszkańska, Bonifraterska (there was even a terminal tram stop there), and Leszno Streets. These were used by smugglers very effectively. Polish smugglers, usually young, would stand near the tram's steps, and as the tram wagon was moving through the ghetto, would quickly toss out bags of food, mostly potatoes, onto the cobblestones. Their Jewish partners waiting on the sidewalks would grab the bags and run toward the gates. ${ }^{297}$

The archive of the Jewish Historical Institute in Warsaw contains an account written in 1963 by Tadeusz Buze, who worked during the occupation as a conductor in trams running in transit through the ghetto. He described the entire smuggling procedure in detail: cramming the bags under the benches, throwing them through the window or from the tram steps, paying off the Blue Police. He also talked about mishaps. One of the conductors, "during such work, was taken from the tram in the ghetto and sent to Auschwitz, where he died."298

297 “Szmugiel w getcie warszawskim," Biuletyn ŻIH 26 (1958), 54.

298 AŻIH 301/6001. In Bogdan Wojdowski's novel Bread for the Departed, we read about the trolley car driver who "always had a loaf of bread in plain view behind the windshield [...] and when he drove through the Ghetto he would slow down, ring his bell 
Jerzy Fudakowski, an engineer by profession, described an interesting aspect of this history. ${ }^{299}$ During the occupation, he worked for the Miejskie Zakłady Komunikacyjne. In order to solve the smuggling problem, the German supervisors of the MZK introduced what they called "pilots" - that is, ticket inspectors from the MZK Traffic Department who were supposed to keep an eye on activities in tram wagons as they rolled through the ghetto, and to requisition all smuggled goods and hand them over to German authorities. But the "pilots" most often simply took the smuggled goods for themselves, which was a serious crime in the eyes of the occupiers. One man - a certain Bolesław Macioszczyk, director of the Division of Personnel and Supervision in the Traffic Department, and one of Hipolit Alertz's trusted associates - distinguished himself with his level of private requisition. He had supposedly hung a portrait of Hitler on his apartment wall, but neither the Führer on the wall nor his German connections could save him from being sent to Auschwitz when, in the spring of 1941, the Germans discovered that he had been hoarding in his apartment goods "requisitioned" from trams traveling in transit through the ghetto.

The policy of transit thus opened up new opportunities for smuggling, which was strictly banned and harshly punished. But it seems that no one was able to oppose another one of the transit policy's benefits, namely that it provided an opportunity for a particular cognitive experience, a one-of-a-kind spatial experience: travel through the ghetto on an Aryan tram. Such passage, though formally legal, was in fact a violation of the principles on which the Jewish residential quarter was based. And yet the borders of the ghetto, the crossing of which could mean the death penalty, stood wide open for a common Warsaw tram.

The uniqueness of transit through the ghetto was not based on the fact that a tram with passengers moved through forbidden terrain without proper authorization. Such would be a trivial situation, not worthy of our interest. The transit area had not only a different administrative-legal status but above all a different so to speak - ontological status. This was truly a different world, in which walls, barbed wire and guarded gates took on the character of a border between life and death. It was a closed space, separated and disconnected from the spatial continuum designed, first of all, to effectuate its degradation, and second, to cut

for the beggars, and throw the bread into the street for them." One day "they pulled him out of the trolley and shot him." See Bogdan Wojdowski, Bread for the Departed, trans. Madeline G. Levine (Northwestern University Press, 1997), viii.

299 Work entitled Dzieje Miejskich Zakładów Komunikacyjnych podczas wojny i okupacji w latach 1939-1945, Archiwum Państwowe m. st. Warszawy, Zbior Rękopisów, sygn. 76. 
it off from normal existence, to cause it to be eclipsed, covered over. To wall it off (in the deepest sense of these words) from the rest. One of the most perceptive diarists of the Warsaw Ghetto, Chaim Kaplan, wrote about the two kinds of wall enclosing the ghetto: "We are imprisoned within double walls: a wall of brick for our bodies, and a wall of silence for our spirits." ${ }^{300}$ One needed to turn one's eyes away from the ghetto, to not look (just as we today sometimes do not look at drastic photos from those times), to distance oneself from it, to make it into something foreign, existing somewhere beyond the sphere of our moral responsibility. The sealed-off ghetto was thus a prologue to the Holocaust not just in the sense of indirect extermination, through hunger, illness and repression. It was one element in a strategy for the mental extermination of the world behind the walls, of that which was vanishing from the consciousness of people on the other side.

So, a tram entered that other world. One could not get off, but one could look. No one had expressly forbidden that. Aryan passengers could thus look at the ghetto, though it was forbidden for Jews to look out the windows of their homes around Pawiak prison; those windows had to be covered with dark paper and plywood. Ringelblum noted: "For every crack, for every little hole" in those windows, "there was the threat of a death sentence." 301 In the tram, a policeman or a "pilot" was there to make sure food was not smuggled. But the smuggling of images picked up by the retina was allowed.

What then could they see, those who wanted to look through the window, those who decided to look? First, the "Area under Typhus Threat" - ever more crowded, more ashen and gray, more distinct and separated from the rest of the city. The ghetto, collapsing further into itself, further and more foreign, even as it was moving past just outside the window. It was precisely this paradox of proximity and distance, the sense of the strangeness of a well-known city, that imposed itself as the first impression in testimonies describing travel on an Aryan tram through the Warsaw Ghetto. Testimonies written at the time, during the occupation. Let us present them in chronological order.

The earliest account known to me about passage by Aryan tram through the ghetto comes from the diary of Stanisław Rembek. He was a writer known before the war for two novels about the war with the Bolsheviks in 1920: W polu and Nagan. Throughout the war he lived in Grodzisk Mazowiecki, a town just outside of Warsaw, where he traveled to take care of various matters. In the entry dated

300 Kaplan, Scroll of Agony, 359-360.

301 E. Ringelblum, Kronika getta warszawskiego: wrzesień 1939 - styczeń 1943, 377. 
25 November, Monday - 27 November, Wednesday, Warsaw [1940], Rembek noted that he traveled by tram number 27 to Żoliborz:

I had to pass through the ghetto twice on the day before it was closed. There were such crowds on the sidewalks and in the streets, as if an incessant demonstration were taking place. Crossing the street all the Jews were baring their heads. Twice the tram was searched by the gendarmes in search of food items. Apparently a couple of Christian hawkers had been shot. Bread and butter were placed on one of them in order to deter the others. Those who refused to carry out humiliating tasks were killed. Because the Germans ordered the hawkers to kiss Jews on their bare buttocks. One woman was ordered to kiss a Jew whose buttocks had been smeared with cream. ${ }^{302}$

The writer did not know that he was passing through a ghetto that had already been closed. As of 16 November 1940, twenty-two gates were guarded by German gendarmes, Polish Blue Police, and Jewish police. But Poles were able to freely cross the ghetto border until 26 November. It was probably on this very day that Rembek was traveling by tram. The entry under the dates 25-27 November continues, but its content involves events of the next day, 27 November:

Today I set off for Inflancka Street via the Kierbedź Bridge. The tram drove through the ghetto without being searched, it even stopped at the stops. To be sure, Polish police stood at the front of the platform, obviously to make sure that no one would get on or get off. There is a great deal of traffic in the ghetto. I submitted my application with no great difficulty. Then I walked along Freta Street to Lilka's, and from there I went to 3 Maja Avenue, where I caught the tram number 24. ${ }^{303}$

Stanisław Srokowski, a professor of geography at the University of Warsaw, lived in Bukowiec at Legionowo. He thus traveled to Warsaw from the north, to Warszawa Gdańska train station, and from there to the city center by tram. On 29 November 1940 Srokowski traveled through the ghetto. Not quite two weeks after its gates had been closed:

I was in Warsaw today (29.XI). One can reach the city from the Gdańska train station by tram (lines 17, 14, or 4) or by going around on Konwiktorska, Zakroczymska, Freta and Długa Streets. The gates to the apartment houses on the ghetto border are walled up and plastered. Probably, over time, the windows will be walled up, too. Jewish guards with armbands stand everywhere along the border of the Ghetto, not allowing people to enter. In addition, German soldiers in helmets with rifles. The ghetto is a peculiar sight, with its whirling crowd of Jews. I took line 4 through Nalewki and Muranów. Prices are supposed to be high there. Apparently bread goes for as much as $10 \mathrm{zl}$. per kilo, butter for $50 \mathrm{zł}$., bacon for $30 \mathrm{zł}$., etc. The Germans have broken up many so-called mixed

302 S. Rembek, Dziennik okupacyjny (Warszawa 2000), 133.

303 Ibid., 134 
marriages. The wife in the ghetto, the husband on the Aryan side, or the reverse. The children stay on the Aryan side. Soon the Jews will have their telephones cut off. Even today there is no way to get into the Jewish quarter because they are not issuing passes. ${ }^{304}$

The next trip through the ghetto - chronologically, in terms of when it was written - came on 8 January 1941. The passenger this time was Zofia Nałkowska. She had gone to this area before to pick up goods for her store from the Państwowy Monopol Tytoniowy (the State Tobacco Monopoly) on Pawia Street. In January 1941 the ghetto was already closed and inaccessible, but one could still get a look at it:

The tram crosses through the exotic Jewish quarter with its dreadful streets, overcrowded despite the cold, its boarded-up shops, its burnt-out buildings. In fact only Jews and all Jews live there now, guards stand at the entrances and exits, and throughout the entire trip the tram does not stop even once. It is extremely strange - as an image, as an idea. ${ }^{305}$

The following entry in Jarosław Iwaszkiewicz's diary is dated 23 February 1941:

For the first time I take a tram through the ghetto. It stops on this side of the wall, then goes the entire length of Leszno, and stops only on the other side of that wall there. We stand with the conductor at the front platform of the tram and, with a heavy heart, I observe. What strikes me above all are the congestion on the streets and the crowded people in black. That crowd looks exotic, incomparable even to what we used to see on Nalewki. Many stores, a lot of trade traffic. I notice that beggars are lying on the streets, on the sidewalks, with terribly white faces. Some are covered by newspapers: corpses. I see a rickshaw-hearse driver. He is pushing a large black box, I do not know if it is with a corpse, or if it is empty. There are a couple beautiful cafés on Leszno. The tram operator has a couple of packages, slowing down at the turns, he throws them out, looking only for people he knows. The package are carried away by practiced and greedy hands, they disappear into the black crowd. I shiver at the thought that my friends live here, the parents of friends. Now and then I get news from them, but they are written as if from the beyond. ${ }^{306}$

Stanisław Rembek went through the ghetto once again on 6 March 1941:

In the ghetto I saw a great crush of people. There is apparently more food there than in the Aryan part, and the gendarmes and policemen are said to take in thousands in bribes every day. ${ }^{307}$

304 S. Srokowski, op. cit., 121.

305 Z. Nałkowska, op. cit., 249-250.

306 J. Iwaszkiewicz, op. cit., 175.

307 S. Rembek, op. cit., 173. 
Zygmunt Klukowski, a doctor from Zamojszczyzna, traveled to occupied Warsaw for vacation. He was a careful observer of the city, and he wrote down his observations in his diary. As a passenger on an Aryan tram in the ghetto, Klukowski found himself in a situation marked by a two-fold distance, because his presence in Warsaw itself was as a person from the outside; one might say, it was a crossing. On 3 September 1941, he wrote:

I went through the ghetto by tram several times. It is something so strange that it is truly difficult to understand how something like this could have been thought up and done. Barriers with Polish and German policemen, high walls, sometimes a wooden bridge thrown up from one sidewalk to another. All of this closes off the entire quarter as if it were plague-stricken, separating the Jewish population from the Aryan. The tumult and clamor is frightening. What strikes the eye is the exceptionally small number of Jews in traditional garb. Movement everywhere is highly animated, stores are full of goods, at least it seems that way looking from a tram moving through the entire Jewish quarter without stopping. Apparently the death rate here is huge, of course among the poorest, who live in the most terrible conditions. ${ }^{308}$

Maria Dąbrowska traveled through the ghetto on Sunday, 2 November 1941:

Warsaw woke up today under drifts of snow and $3^{\circ} \mathrm{R}$ frost. In the morning, tidying up and darning. At 2 pm we left for Żoliborz to visit the Moszyński's for dinner. Dinner was good, with hors doeuvres and vodka. We returned at $5 \mathrm{pm}$. We went through the ghetto, where there is no longer gas or electricity. Jadzia came over in the evening. ${ }^{309}$

Barykada Wolności (Barricade of Liberty) was an underground publication of the leftist organization Polish Socialists. In its no. 75 dated 30 November 1941, we find an article entitled "Solidarność ofiar - to także braterstwo broni" (Solidarity of the victims - that, too, is brotherhood in arms) with the following passage:

Several dozen thousand onlookers travel every day through the closed Warsaw Ghetto. They look at the crowded streets, at idle groups of emaciated and bedraggled children drifting around, sometimes at corpses lying on the sidewalk. How little do they reflect on what is going on in this collective prison? A tenth of the residents have died there over the course of a year. And of that number, a significant part - from hunger. ${ }^{310}$

The next two entries in Rembek's diary involve the year 1942. Under the date 11 April, the diarist recalls his stay in Warsaw three days before. He emphasized that frost was giving way to warm weather, the earth was thawing. Spring was on the way. His wife was waiting for him at a friend's house. "I went from Saska Kępa [a

308 Z. Klukowski, Zamojszczyzna, vol. 1: 1918-1943 (Warszawa 2007), 247.

309 M. Dąbrowska, op. cit., 366.

310 Polacy - Żydzi 1939-1945. Wybór źrodel, ed. A. K. Kunert (Warszawa 2001), 199. 
Warsaw neighborhood on the right bank of the Vistula river] and then through the ghetto. What struck me was the emptiness there." This last comment, which is rather strange in light of other observations - emptiness in the ghetto (?) - can perhaps be explained by the fact that the date 8 April was the final day of Passover, which lasted seven days (eight in the diaspora) beginning with the Seder meal, which in 1942 fell on Wednesday, 1 April. The writer got a view of the ghetto in the spring of that year, ten days before the deadly night when the Gestapo murdered, according to a prepared list, 52 people pulled from their homes and into the streets. This was the first organized act of terror, methodically carried out, and it was a development that many took as a sign of the coming catastrophe. We should recall that Operation Reinhard, designed to exterminate the Jews in the Generalgouvernement, was already underway, and that concentration camps at Bełżec and Sobibór were up and running in March and April 1942, respectively. The next time that Rembek saw the ghetto was after the Grossaktion Warsaw had begun, but he did not make it inside. In his entry dated 31 July we read, among other things:

[...] since somewhere around the 20th of this month, the Germans have begun liquidating the Warsaw Ghetto. [...] Riding alongside the ghetto, I saw a unit of Ukrainians under the command of a Gestapo officer, guards posted along the wall, and I heard shots. Apparently they are transporting around 600 Jews daily from the Gdańska train station in sealed train cars. But no one knows where they are going. ${ }^{311}$

The chronologically final trace of a transit passage through the ghetto is the entry in Zofia Nałkowska's diary dated 31 August 1942. The Grossaktion Warsaw had been underway for forty-one days. Close to 210,000 Jews had already been transported to Treblinka. ${ }^{312}$ Franciszek Wyszyński, who was careful to record the weather in his diary every day, wrote under the date 31 August: "in the morning cloudy; in the afternoon rain, in the evening cool, a wintery night." ${ }^{13}$ On this day, Nałkowska visited her mother's grave at Powązki Cemetery. She returned from the cemetery by tram. "Passage through a deserted city, a city of terror and torment. Every window and balcony, which used to be full of people, today empty." ${ }^{14}$

311 S. Rembek, op. cit., 301.

312 See statistics compiled on the victims of this action in "Raport zjednoczonych organizacji podziemnych getta," in Archiwum Ringelbluma. Getto warszawskie lipiec 1942 - styczen 1943, ed. R. Sakowska (Warszawa 1980), 286, 290.

313 F. Wyszyński, op. cit., 202.

314 Z. Nałkowska, op. cit., 411. 
It is difficult to recreate a concrete topography based on Nałkowska, Klukowski, and Dąbrowska's diary entries. We can only state that when Nałkowska traveled through the ghetto in January 1941, she did so before the tram routes were changed and the movement of Aryan trams within the ghetto walls was restricted. She could thus take a longer route than Klukowski, who traveled through the ghetto in September 1941 (that is, after the above changes had been made), but who made the trip "several times." The route she took on 31 August 1942 is even more problematic. If she really did travel through the ghetto during the Grossaktion Warsaw, then she might have taken the number 1 tram, which ran from the Military Cemetery at Powązki to Teatralny Square by way of Powązkowska, Dzika, Muranowska Streets, Muranów Square, Nalewki and Bielańska Streets. Nałkowska could thus have entered the ghetto near Umschlagplatz (at the corner of Dzika and Stawki Streets), turned onto Muranowska Street, continued to Muranów Square, then turn onto Bonifraterska Street. But was that still possible at the time? Probably it was also possible that she took a tram that ran along Okopowa Street and the ghetto wall. We know from Dąbrowska's entry that in November 1941 she returned from Żoliborz to her apartment on Polna Street, which means she traversed the ghetto from north to south. Thus, she must have traveled along Bonifraterska Street because, since April 1941, the transit route nymber 4 had been shortened and afterwards ran only along Bonifraterska Street. But Srokowski, also on his way from Żoliborz to the city center, could still go through Muranów Square and along Nalewki Street (which he himself highlighted), since he took line 4 at the end of November 1940 - that is, in the first weeks after the ghetto was closed off. Beyond the names of streets and squares, we have no other topographical details that would allow us to locate this trip in concrete space. In November 1940, Rembek traveled to Inflancka Street, which means he must have gone by tram along Bonifraterska Street, which until December 1941 was inside the ghetto between Świętojerska and Sapieżyńska Streets. Later the area east of Bonifraterska Street was separated from the ghetto and this part of it became a border street. We know that Iwaszkiewicz traveled along Leszno between Żelazna and Tłomacka Streets, but we do not know in what direction: from the Wola district toward Teatralny Square, or vice versa. On 19 March 1941, because the entrance gate at Tłomacka Street (which led to Bielańska Street) was closed, the routes taken by trams number 16, 11, and 22B were changed. Iwaszkiewicz, traveling three weeks earlier, must have taken one of them. After these routes were changed, the path to Teatralny Sqare via Bielańska Street was blocked; transit trams could no longer run along Leszno Street. Their course thus took them along Wolska Street; they entered the ghetto through the gate at Wronia Street, continued along Chłodna Street until Mirowska Street, 
crossed the ghetto border, and continued to Teatralny Sqare via Żelaznej Bramy and Bankowy Squares and Senatorska Street. Iwaszkiewicz thus still had the opportunity to view the ghetto's main street along its entire main stretch. As Jan Mawult wrote: "Leszno - it is Marszałkowska Street with its traffic, trade, and commotion." 315

Srokowski's attention is drawn to the external characteristics of the recently closed Jewish quarter, above all the resulting transportation difficulties; the walled up gates and windows of apartment houses; "Jewish guards with armbands" and "German soldiers in helmets with rifles" standing watch everywhere along the ghetto borders; and - in this walled-up world - the whirling crowd of Jews. Descriptions of scenery written from the perspective of an observant witness cross over into informational discourse. This diarist did not write just about what he had seen, but about what he knew or had heard about from circulating rumors. His comments on prices are characteristic; indeed, this motif runs throughout the entire diary, almost obsessively. Srokowski constantly reported on fluctuating prices and tried to comment on them, most often putting blame for high prices on the Jews. Rembek's entry is also two-layered: observation becomes a canvas for adducing rumors and gossip. The observational level is, after all, rather thin "crowds on the sidewalks," "a great deal of traffic," the "great crush" of people - as if the diarist was paying more attention to what people were saying about the ghetto than what was visible through the window. The key needed to open this perspective is the single word "apparently," such that: the Germans had "apparently" treated some Christian hawkers on the ghetto streets brutally; a couple were shot, others humiliated; "apparently" there was more food in the ghetto than on the Aryan side; "apparently" the Germans were transporting Jews somewhere in sealed train cars.

The Aryan tram passenger entered the ghetto with a certain amount of knowledge gained previously, with a certain set of images of the world to be found there. One can only assume how the confrontation between these images and reality looked. A reality - we might add - that was perceived in parts, fragmentarily; that appeared in a peculiar (if we might risk the use of such a term) theatrical situation. It seems that one of the most conventionalized (even at that time) images of the ghetto was that of the crowd in the streets. It is a motif that dominates descriptions and accounts. Those "dreadful streets, overcrowded despite the cold" (Nałkowska), and that "whirling crowd of Jews" (Srokowski), seem to blind the viewer to anything else. People crowding on the sidewalks lend

315 J. Mawult, "Wszyscy równi...," Biuletyn ŻIH, 62 (1967), 107. 
the streets of the ghetto an exotic appearance, an adjective used by Nałkowska, who wrote about the "exotic Jewish quarter," and by Iwaszkiewicz, for whom the "crowd" itself looked "exotic, incomparable even to what we used to see on Nalewki [Street]."

That which was exotic and strange was thus the most significant feature of the ghetto that displayed itself through the tram window. Nałkowska wrote: "It is extremely strange," Srokowski called the ghetto a "peculiar sight," and Klukowski began the commentary on his trip through the ghetto with the sentence: "It is something so strange that it is truly difficult to understand how something like this could have been thought up and done." In Iwaszkiewicz's account, the radical otherness of the ghetto reality takes on an eschatological quality: What we are looking at is not of this world.

But what did passengers on those trams really see? What was Jarosław Iwaszkiewicz able to see while moving along Leszno Street? He passed, for example, the Carmelite Church of the Nativity of the Blessed Virgin Mary, which was the focus of the ghetto's Catholic community. He also passed the apartment house at Leszno 18, where Emanuel Ringelblum lived, and the building across the street at Leszno 13, the headquarters of the Office to Combat Usury and Profiteering, also called Group 13, which was in fact collaborating with the Gestapo and was led by Abraham Gancwajch. He certainly could not see the fotoplastikon at work from April through July 1941 on the ground floor of the eighteenth-century Jacobson townhouse at Leszno 27. At the time, this venture was widely promoted. Rabbi Szymon Huberband reported that posters were put up every week promising a new program; boys walked the streets lifting boards attached to long sticks advertising the event; and a clown with a red nose and pink cheeks stood at the gate at Leszno 27 encouraging passers-by to come in. But maybe, from the window of his passing tram, Iwaszkiewicz managed to get a glimpse of that colorful clown amidst "the congestion on the streets and the crowded people in black."

In addition to the crowd, Klukowski saw Polish and German policemen, walls, a wooden bridge thrown up over the street, "stores [...] full of goods, at least it seems that way looking from a tram." Nałkowska saw guards at the exits, boarded-up stores, burnt-out buildings. Iwaszkiewicz saw beggars, corpses covered with newspapers, a man pushing a hearse with a black box, but also "beautiful cafés." Only Maria Dąbrowska’s entry lacks any element pointing to the topography or appearance of the ghetto. It includes a single sentence in which the diarist, beyond stating simply that she had ridden through the ghetto, mentioned that there was no gas or electricity in the closed quarter (which was inaccurate, since ghetto residents had gas and electricity, though only at defined 
hours). Dąbrowska's entry lacks the kind of observations that characterize the other diaries; the chance to get a glimpse, through a tram window, of that closed world - to which one normally did not have access and which one was, in principle, not allowed to see - did not call forth in this writer a need to take note of the imagery. She confined herself to what amounted to common knowledge.

Dąbrowska's record is provocative. One might treat it as an expression of a certain indifference when - between mention of a visit to the Moszyński’s (dinner with "hors doeuvres and vodka") and an evening visit by Jadzia - we read a laconic indication that she had travelled through the ghetto. Here there are no expressive statements, no adjectives like "frightening," no emotions invoked like those we read in Iwaszkiewicz's entry: "with a heavy heart" and "I shiver at the thought [...]." Dąbrowska eschewed use of the convention of observation, the stylistics of expressing horror, furor, or shock. She eschewed description itself, confining herself to the statement: "We went through the ghetto." But maybe that is enough. Maybe that is more powerful than any attempt at a description.

The passage cited from the article printed in Barykada Wolności has a special place. It was the end of November 1941. The second and most severe wave of the typhus epidemic had reached its zenith, ${ }^{316}$ the death rate was reaching its peak, ${ }^{317}$ and hunger was increasing at a frighteningrate. ${ }^{318}$ In this article, the individual and private point of view disappears. The perspective widens. The camera's narrative lens shows the tram passengers on front stage, while that which they are seeing is in the background. The vision that we know from other testimonies extends out from the window: crowded streets, emaciated children, corpses on the sidewalks. But that is not what is most important in this entry. What is essential is the appraisal. Those who are traveling on this tram are not "passengers,"

316 The largest number of cases of disease came in October $1941(3,438)$, but that is just official data; it was common practice to hide disease. Estimates are that, during the second epidemic wave, between 100,000 and 110,000 people fell ill. See B. Engelking, J. Leociak, Getto warszawskie. Przewodnik po nieistniejącym mieście (Warszawa 2001), 281.

317 According to a Judenrat report in November 1941, a total of 4,801 died. The greatest number of officially registered deaths in the ghetto until the start of the Grossaktion (that is, until 22 July 1942) came in August 1941 (5,560). See T. Bernstein, A. Rutkowski, "Liczba ludności żydowskiej i obszar przez nią zamieszkiwany w Warszawie w latach okupacji hitlerowskiej," Biuletyn ŻIH, 26 (1958), 84.

318 Because the Germans were reducing allocations, soup kitchens were forced to drastically limit the number of soups handed out, from 128,000 in September to 87,000 in November 1941. See B. Engelking, J. Leociak, op. cit., 305. In August of that year, Leyb Goldin wrote his moving essay on hunger. 
but "onlookers," a term that contains within itself an assessment of the attitudes taken by those looking through the tram window. One would like to say: they are not so much looking, as thoughtlessly gawking. The author accused "several dozen thousand onlookers," crossing through the ghetto every day, of lacking reflection.

Accounts written post factum have an entirely different status. Their contents had been passed through the filter of memory, in which what was most poignant, but what was also most stereotypical and schematic, have become embedded and belong to the sphere of collective imagination. Postwar testimonies are dominated not by description, but by evaluation. Let me refer to two examples of memoirs, whose authors represent two extremely different political orientations. First, Ferdynand Goetel: a widely-read interwar writer; an associate of the nationalist-rightist Prosto $z$ Mostu; a speaker at meetings of Bolesław Piasecki's ONR-Falanga (National Radical Camp - Phalanx) and a sympathizer of Italian fascism; during the occupation, head of the Rada Główna Opiekuńcza (Central Welfare Council); with the approval of authorities in the Polskie Państwo Podziemne (Polish Underground State), a member of the delegation of observers invited by the Germans to assist in the exhumation of the victims of the Katyn massacre. Pursued by the communists, Goetel spent all of 1945 in hiding in a Kraków monastery, after which he fled to the West, first to Italy then to London. And second, Zygmunt Zaremba: one of the most prominent leaders of the Polish Socialist Party; in September 1939, co-organizer of the Workers' Battalions for the defense of Warsaw; during the occupation, co-creator of the underground party of Freedom, Equality, Independence; throughout the entire period of the Warsaw Uprising, editor of Robotnik; pursued by the Urząd Bezpieczeństwa (Secret Police, UB), he fled to France in 1946.

In his work Czas wojny (Time of War, 1955), Goetel wrote:

The enclosure of the Jews in the Warsaw Ghetto was a long and drawn-out process, one which led to their absolute separation - on the eve of the destruction of the ghetto from the Polish city. The longest lasting gap was part of Muranów, through which a tram line ran to Żoliborz. I went there almost every day. The tram did not stop in the ghetto, but it did not progress through the area unrestricted, since those streets at the time were packed with people driven into the ghetto, with crippled children and feeble old people wandering into the tram's path. I paid careful attention to the image of this quarter. Muranów definitely belonged to the poorest part of the ghetto. Deeper, in the middle of Nalewki, the image was apparently less terrifying. Around Zielna Street there was said to have been, for some time, a kind of plutocratic neighborhood with elegant stores and cafés. Paupers showed up there as street beggars and died at the steps of the night cafés. But in Muranów, poverty was right at home. Over time I had to witness the most terrible things, but I had never seen a dying city and I probably never will again. The ghetto 
buildings looked like they had been hit by the plague. Stores peered at the street with blind window displays. One in five lanterns lit up at dusk. Uncollected trash was piling up on the sidewalks. Broken window panes were repaired with newspaper and rags. And the people? In juxtaposition to theirs, our faces, the faces of the tram passenger, our clothes, washed hands and shave faces, seemed somehow shameful. More than once in these times, a person had to ask the question if he had the right to live in a human way, to care about maintaining those aspects of human dignity that had been left to him. Later, in the rubble of all of Warsaw, the question would arise whether it was not shameful to be alive at all, whether life was not a matter worthy of contempt. ${ }^{319}$

In Goetel's words, we see a clear indication of a narrative situation: observation of the ghetto through a tram window. The images over which the observer swept his eyes are highly valorized, as evidenced by the chosen vocabulary and metaphors. One thing that deserves particular attention is the metaphor of dying (the ghetto as a dying city) and the metaphor of disease (ghetto buildings hit by the plague). But what is perhaps most telling is the author's juxtaposition of the faces of passengers (Poles) with the faces of those on the street (Jews).

In Zygmunt Zaremba's Wojna i konspiracja (War and Conspiracy), we read:

Only with a look could one express compassion and swear an oath in one's heart that such mistreatment of people would not go unpunished. There was a corridor through the ghetto where a tram ran. Through the tram car window it was possible to get a glimpse into the place where the last torment of Polish Jewry was happening. I travelled through this corridor and I still have in my mind's eye the image of an SS-man standing arrogantly, legs apart, and a group of children staring from a distance at the passing tram. The German's pink mug and the gray little faces with large, sunken eyes looking for mercy. This image was for me a glaring illustration of the increasingly horrifying stories emerging from behind the wall. ${ }^{320}$

This recollection begins by conjuring up a look into the ghetto, one that defines the witness's condition. But it is not a neutral look, and it is not a thoughtless look. Zaremba is not merely gawking through the tram car window; rather, he is looking in a particular way. This recollection of a tram ride through the ghetto is embedded in an evaluative discourse, which serves above all as an expression of moral judgment of reality. Here, the factual-graphical report gives way to metamorphosed images (the look takes us "into the place where the last torment of Polish Jewry was happening"), or to an axiologically motivated juxtaposition of the appearance of perpetrators and victims (the German with his pink mug and the children's gray little faces). Viewing the ghetto through the window of an

319 Goetel, Czasy wojny, 84-85.

320 Zaremba, Wojna i konspiracja, 200. 
Aryan tram was the only way one could "express compassion" for the Jews, but also led to accepting the obligation to make sure the perpetrators did not escape punishment. In this sense, looking crosses over into the domain of empathy and moral duty.

Let us now switch to the other end of the perspective gained from the tram moving along the street. How was the Aryan tram remembered not by the passenger, who was sitting inside the tram, but by the pedestrian; not by the observer, but by the observed? Pola Rotszyld put it in unusually harsh terms:

But soon the "other side" became a kind of legend, a land of fairy tales. When trams came through, people from the other side looked at us like monkeys in a zoo cage. They were pleased. Because they too had always wished everything bad for the Jews, though they did not expect such luck. ${ }^{321}$

What is striking is the dissonance between the accounts provided by Zaremba and Pola Rotszyld. But the impression of painful contrast is less deep when we remember other entries described above, which were dominated by feelings of distance, foreignness, the exotic.

In the passages cited above, accounts of travel through the ghetto are not so much about what passengers saw through the window, as about how they looked (that is, how they did the looking). But they are also about the question if, and to what extent, we (as we try ourselves to look at the ghetto) are similar to them. What we are thus dealing with here is an attempt to get at the essence of the Holocaust experience, to grasp the conditions under which it is possible to approach the Holocaust, to reveal one of the formulas of this experience.

If we turn the topography of the so-called Jewish residential quarter into an object of research, then we are faced with the cognitive challenge posed by the experience of the ghetto as a space, or rather by the experience of the space-afterthe-ghetto. We are faced with a kind of hermeneutics of an empty space.

We sometimes come upon comparisons between the destroyed Warsaw Ghetto and Pompeii. Nothing could be more mistaken. Let me first point out something that is obvious and no one questions, namely that the events that wiped Pompeii and the ghetto from the face of the earth were radically different; the two spaces were met by entirely different kinds of annihilation. Second, any similarity between what "remained" of Pompeii - covered in ash and discovered much later by archeologists - and what "remained" of the ghetto is only a matter of appearance. Pompeii exists in its ruins; material evidence has remained in the wake of the city's destruction; there is a physical record of the drama that

321 Archiwum Yad Vashem, relacja E/438E/19-2-4, p. 37. 
has been preserved for centuries. A record which, when we touch the stones of Pompeii, is accessible and legible, and which - through its material existence manifests a kind of continuity over time, a bond between the past and the present. The Warsaw Ghetto no longer exists; rather, it is something that one might call space-after-the-ghetto. In no way did this space congeal, it did not "stop in time." Nothing - at least almost nothing - was preserved. It is not fixed in material that was imprinted by that event. Indeed, it was purged of that event and filled with something else.

One thus cannot view this space-after-the-ghetto as falling under the Pompeii model. Pompeii is fossilized testimony to its ancient catastrophe, which we are able to read from its remains, its remnants. But the space-after-the-ghetto is a non-existence, an absence. It is a particular experience "of the space itself, and yet of a completely other space," an experience of true absence, only ostensibly filled in.

The destruction of the ghetto was not the destruction of space. That space has remained, but it is empty (though it has been built over with apartment buildings and business complexes), it is stripped bare and dead (though it is buzzing with life). The space survived, though it is somehow hollow, bereft of "content," of an "interior." The ghetto that was here succumbed to annihilation, but that "here" remained; it was just eclipsed by another presence. The frames stayed behind, which now contain another reality; a topographical point remained, a cartographic abstraction.

Broadly speaking, the hermeneutic project of the empty space-after-theghetto involves three things. First, the hermeneutics of the space itself, and not the written text, testimonies, accounts, and personal documents. Second - the experience of topography as text. In the hermeneutic process, one can look for support in the texts of testimonies, but the space of perception and understanding takes up an area that is much larger. Third and finally - the spatial experience marked (or affected) by the Holocaust; ways of grasping this experience, the possibilities to relate, represent and understand this experience. The next steps in the hermeneutic process can be presented in the following way:

Superimposition and co-presence. This is a kind of expanded vision: I see what is, and simultaneously what is not. In other words: I go by tram down today's Solidarność Avenue (the old Leszno Street), and while so doing I try to imagine what passengers on the Aryan tram saw as they rode through the ghetto along Leszno Street. This situation starts a thought process. We begin to research the nature of superimposed images - real and reconstructed (imagined) images which themselves enter into manifold relations with one another, whose character needs to be captured, revealed, represented. 
An act of filling in. When we venture into the hermeneutics of an empty space, we must above all carry out an act of filling in. The process of understanding assumes the existence of an object to be understood. In our case, it is not so much about its existence, as about its intelligibility - about whether it can be conceived, fathomed. In other words: we are faced with a fundamental question about whether that emptiness (in the wake of the ghetto) can be filled in at all, whether it can be encompassed by understanding, permeated by meaning. Here, we are touching upon the enormous issue of whether it is possible at all to understand the Holocaust. Not wanting to mull this over too much, I will invoke two contexts of thought that correspond to the concept of the empty space as an object of understanding. The first context is the negative hermeneutics of the ghetto as practiced by Piotr Matywiecki, ${ }^{322}$ who entwines the elusiveness of the ghetto with a network of incongruities and antitheses. He places himself in a kind of crevice of existence, between the ghetto (to which he does not have access) and the after-the-ghetto reality (from which he feels disinherited). $\mathrm{He}$ wants to be there, but he cannot be there; he does not want to be here, but he must be here. The second context involves a conception of the Holocaust as an aporia of meaning, an absence of meaning. Cynthia Ozick gave this approach powerful expression ${ }^{323}$ when she spoke of a common desire to make redemptive sense of the monstrosity that was the Holocaust, since one simply cannot endure the idea that the suffering and death of so many innocent people could lack such sense. But, according to Ozick, the experience of the Holocaust is precisely a confrontation with senselessness, with the absence of meaning. The Holocaust has no message for us, except one - that it could happen again.

To unveil, to reveal - the classic hermeneutic activity. The space-after-theghetto is empty because the reality that had made up the ghetto was annihilated, leaving no trace behind. What little remained of buildings and small fragments of cobblestone were just the exceptions that proved the rule, which was - absence. But that empty space-after-the-ghetto has been filled in, or - to put it another way - it is an obscured after-the-ghetto reality. In a sense, it has been appropriated by everything that grew out of the after-the-ghetto. Thus, by applying a layer of memory and imagination onto the empty space-after-the-ghetto, we

322 See P. Matywiecki, Kamień graniczny (Warszawa 1994).

$323 \mathrm{I}$ am thinking here about her statement during a discussion in which, in addition to Ozick, R. Hilberg, A. Appelfeld and S. Friedländer took part. See Writing and the Holocaust, ed. B. Lang (New York 1988), 277-284. 
contribute to the process of unveiling its hidden presence, and revealing its concealed meaning.

The experience of the space-after-the-ghetto is paradoxical in nature. It involves giving expression to the emptiness, extracting traces and remains from non-existence, from underneath the heaps of ignorance, indifference, and oblivion. This experience is accompanied by a particular kind of separation of vision, an expansion of vision, a dual perspective. Thus I begin to see what I do not see (an imagined reconstruction of the ghetto); but I no longer see what I see (reality perceived here and now). So, on the one hand, we have a situation marked by the suspension of reality. The topography of contemporary Muranów is enclosed in brackets; it becomes a kind of transparent curtain that covers the true object of our experience. On the other hand, the not-present is made present; that which exists only in the order of memory, or imagination, is made real.

Let us return to the trip through the ghetto by Aryan tram. Passengers move through a kind of aerial corridor. Space twists and turns. They find themselves in the ghetto, and yet they are separate from it. There are in some sort of space between, neither here nor there. Their participation was - to the extent that it could be - an experience of being in the middle (of the ghetto) and simultaneously on the outside, alongside; being here and, at the same time, somewhere else. This situation seems to nicely reflect the paradoxical nature of the hermeneutics of the empty space-after-the-ghetto. We can thus treat it as a metaphor for our scholarly investigation, our attempts to get at the reality of the Holocaust, to understand the Holocaust.

What connects us with the passengers of that Aryan tram, it would seem, is the experience of separation, of the existence of a kind of curtain - or rather a clear pane of glass - along which our gaze slides. We are apparently very close, but we are in fact terribly far away. Everything seems remote, strange, indeed exotic; it cannot be grasped by thought, it cannot be touched with sight. Everything escapes somewhere, like that Carmelite church in Leszno Street. Iwaszkiewicz saw it in 1941, and we see it today. But that remnant is not in its place, but off to one side! In December 1962, in connection with the expansion of the old Leszno Street (which, as General Karol Świerczewski Avenue, became part of Warsaw's new "Trasa W-Z"), the church, which had been lifted from its foundations and put on wheels, was moved 21 meters to the north. Thus it is not where it was, it is where it was not. As such, the church on Leszno Street becomes a link in the chain of paradoxes of the empty space-after-the-ghetto.

In the end, let us cite two more records describing tram trips through this same part of Warsaw, but before the war. Zofia Kirkor-Kiedroniowa remembered the day before the Miracle on the Vistula, Józef Piłsudski’s famous maneuver 
to outflank the Bolsheviks, carried out on 16 August 1920 at the Wieprz River, which forced the Red Army to retreat from Warsaw.

On this beautiful holiday day (Assumption of Mary) I went to Ochota [district of Warsaw] to visit my sister-in-law. As I returned to the tram stop, I saw something so frightening that it froze me in my tracks: along Grójecka Street they were moving heavy cannon and crates of ammunition out of Warsaw. What could this mean? Were they intending to give up Warsaw? I walked further with difficulty. Riding on the tram through the Jewish quarter, I witnessed with horror and anger crowds of Jews talking with great excitement and not in the least hiding their joy. ${ }^{324}$

The country's fate was hanging in the balance. A country that had just regained its independence after years of bondage. The Bolsheviks were approaching the gates of Warsaw. The threat that Poland would once again be wiped from the map of Europe was written into the Catholic liturgical calendar (The Assumption of Mary, Święto Matki Boskiej Zielnej). Three years later that day for remembering the Battle of Warsaw would become "Święto Żołnierza" (effectively, like America’s Memorial Day). At the same time, "crowds of Jews" in the Jewish quarter were not hiding their joy. Quite clearly, they were waiting for the Bolsheviks. It was difficult to imagine a more ostentatious manifestation of foreignness and hostility. Zofia Kirkor-Kiedroniowa did not have, and could not have, anything in common with the world that she saw through the tram window.

In one of his reports from the late 1930s, Franciszek Lewicki wrote:

For 20 groszy, a crowded number 16 takes me into an unknown, prehistoric world. Beyond Mirowski Square, beyond Chłodna Street, we start to plunge slowly into a wave of time; the restless surface of the twentieth century closes above our heads; and through the tram window, as if from a deep sea ship, I see, amazed, deeper and deeper layers of time. Here, life descends to earth. Warsaw, elevated in the center, begins to fall away, to shrink, to decline. Wolska Street continues to extend along the border, but there are more gaps and passages in it, and every turn opens up a wider, unobstructed horizon. $^{325}$

Lewicki brought to the surface that which, in texts written during the occupation, was most often merely suggested. The description of his tram ride has an explicit metaphorical dimension. The tram car assumes the character of a deep sea ship dropping its passengers down into another world. What we have here is

324 Z. Kirkor-Kiedroniowa, Wspomnienia, vol. III (Kraków 1989). Quote from KARTA 45 (2005), 27.

325 F. Lewicki, "Różne bywają dachy nad głową," in Niepiękne dzielnice. Reportaże o międzywojennej Warszawie, ed. J. Dąbrowski, J. Koskowski (Warszawa 1964), 54-55. 
a clear situation of separation, of foreignness. And - in a way that is truly prophetic - the above passage from the interwar report anticipated the tram trips that Aryan passengers would later take in transit through the wartime ghetto, though it anticipated not what they would see, but how they would look (that is, how they would do the looking). 



\section{Bombardment}

George Grosz (1893-1959) was born in Berlin, a city that Allied bombardment during World War II turned largely into a pile of rubble. Before the First World War, Grosz studied at the Royal Academy of Arts in Dresden, which was completely destroyed during the famous British-American air raid on 13-14 February 1945. He himself had experienced the terror of artillery shelling in the trenches of the Great War. He had enlisted into the military in November 1914, but war broke him psychologically. After six months, doctors determined he was unfit for service, as a result of shell shock, ${ }^{326}$ and he was demobilized. While recovering, Grosz completed a lithograph entitled "Das Attentat," in which he depicted his traumatic experiences on the front in an urban landscape. The work illustrates the effects of a bomb, dropped from the air, exploding with great violence in the middle of a city; building structures are destroyed, all existing forms are torn apart. After the explosion, the city indeed, the entire world - is plunged into chaos. Grosz's lithograph captures the abruptness, the immediacy, the totality of destruction caused by a bomb thrown from an airplane, dropped straight from the sky like lightening - that is, something irreversible and final, against which there is no way to defend oneself.

After recovering, Grosz returned to his unit in January 1917. But shortly thereafter, his depression having returned, he was placed in a hospital for the psychologically ill, where he experienced repeated emotional breakdowns, he was tormented by nightmares and hallucinations. In this period he painted "Die Explosion," imagery that testifies to the creator's psychological destruction, but one that also serves as an allegory for global destruction. It is significant that Grosz, in order to express such content, returned once again to the experience of bombardment and he located that experience in an urban space. He showed a city that had been broken into pieces by an explosion and was falling to the surface of the earth. In Grosz's painting, the bomb not only destroys a city, it annihilates the world, whose forms are thrust into the chaos

326 The term "shell shock" was used for the first time by Professor Charles Myers in 1915 in the periodical The Lancet. Myers - editor of The British Journal of Psychology - was assigned to the Royal Army Medical Corps at the rank of captain, where his focus was traumatized soldiers from the trenches. See W. Holden, Shell Shock (London 1998), 17. 
of war. The bomb draws a thick line directly through the order of things as previously known; nothing will be like it used to be, before the war, before the bomb.

During the Spanish Civil War, on 26 April 1937, a special Luftwaffe unit handed over to General Franco by Hermann Göring bombed the Basque town of Guernica. With these events in mind, Picasso painted his famous work "Guernica," which was exhibited that same year at the Pavilion of the Republic at the Paris International Exposition. Picasso's "Guernica" is not a painting that chronicles a historical event; it does not present the bombing, but rather penetrates into its essence. The bombardment of a city becomes a universal symbol; a criminal air raid leads to new and hitherto unknown experiences with the sudden, violent and almost complete destruction of a local community and the urban space that that community had cultivated for centuries. The Cubist dismemberment in the painting captures the effect of the city's fabric having been pulled apart, the bodies of its residents rent to pieces as a result of the explosion. As presented in the painting, reality is distorted. The attack on the city happened on a sunny afternoon, but the painting is dominated by darkness, and the sun has been changed into an electric bulb. That which is cold and callous serves as a symbol for an indifferent world. The painting contains no crowd consumed by the panic that contemporaneous reports described. There are only the figures of four women immobilized in an ecstatic scream, one of them with a dead baby in her arms; a knight's monument is knocked down; there is a bull, a bird, and a horse head with an open mouth that dominates the entire group. Characteristically, there is no image of the perpetrator. Those who are sowing destruction remain invisible, they are beyond the world subject to destruction, in a literal sense above it, which allowed the artist to avoid political actualization or ideological instrumentalization. What remains is a work that is a universal icon of human tragedy. ${ }^{327}$

Grosz and Picasso's imagery depicts the basic components of bombardment as a limit experience: the all-powerful strength of destruction, its speed and violence, its complete and irreversible character, the defenselessness. Bombardment gives rise to the horror of changed reality. Nothing is, and nothing can ever be, like it used to be. The key quality of that experience is ambivalence, the collision of "horror and beauty," the experience of the mysterium tremendum.

327 See R. Arnheim, The Genesis of a Painting. Picasso's Guernica (Berkeley 1973). 


\section{Bombardment and the "Morale of the Civilian Population"}

\section{The Target: Civilian Morale}

The first known case of the use of air power for bombardment came during the Italo-Turkish War of 1911-1912. The Italians carried out several dozen air attacks on Tripoli and Arab villages in Libya in connection with a campaign to annex the Turkish provinces of Northern Africa. The first bomb exploded on 1 November at an oasis near Tripoli. An air force communique stated that the bombs had had "a wonderful effect on the morale of the Arabs." British newspapers wrote about the shameless and merciless slaughter of civilians: women, children, and old people. ${ }^{328}$

In 1912 a certain German naval officer designed the first plan for the bombardment of England. Massive air attacks were to damage not only the enemy's material potential, but also its civilian morale. Two basic goals of future air offenses emerge from this project: to cause widespread material losses and to sow terror within the civilian population, which would weaken morale and undermine the will to resist. These goals for bombardment have remained a part of strategic thinking until today, the only variable being which is given greater emphasis, material loss or civilian morale. ${ }^{329}$

During the First World War, aerial bombardment became an integral part of military strategy. In January 1915, the Germans began using zeppelins to carry night bombardments of industrial targets in England. Bombs were sometimes dropped outside of the target area. Though these were not intended in principle to be mass bombardments - that is, bombardments intended to strike military, industrial and civilian targets indiscriminately - civilians in residential areas nonetheless fell victim to the falling bombs. Actual practice showed that such attacks had a ruinous influence on the morale of civilian populations: people panic and chaos ensues. From the middle of 1917 the Germans carried out daily attacks, using Gotha biplane bombers, on southern England and London, where they claimed their greatest number of victims.

On 30 June 1917, Frankfurter Zeitung published a report from one of those who had participated in the first day of the bombing of London. We find in this

328 Sven Lindqvist, A History of Bombing, trans. Linda Haverty Rugg (The New Press, 2001), 33 (\$ 78); S. A. Garrett, Ethics and Airpower in World War II. The British Bombing of German Cities (New York 1997), 1-2.

329 See M. Middlebrook, The Battle of Hamburg. Allied Bomber Forces against a German City in 1943 (London 1984), 15. 
report no description of the kind of sea of flames that would characterize stories provided by bomber pilots during the Second World War, but the author of this report expressed clear satisfaction with the results of having dropped bombs in the very heart of England.

There, below us, a sea of London homes was surprisingly visible. Now, calmly and deliberately, we move forward, away from the suburbs, we must strike at the center. Focus on nothing but the target. Here is the Tower Bridge, The Tower, Liverpool Station, the Bank of England, Admiralty House, dazzling ships on the Thames - everything below us. I wave my hand to the commander, and I take the viewing mechanism in my hand streets and buildings move slowly through the circle. The time has come. I press the lever with brief intervals, releasing the bombs, and in suspense I track the course of the projectile! There is an entire swarm of them. One after the other heavy bombs detonate in the heart of England ... the group turns, a last look at the city. Goodbye! $!^{330}$

Using zeppelins, the English carried out a series of attacks on military targets in Germany, and the French bombed German cities as revenge for the German bombardment of Paris and other French cities. But it was the Germans who played the leading role in aerial bombing in the First World War. That having been said, one should keep in mind that the total number of those killed as the result of German bombardment of England during the First World War was 1,400, which was a small fraction of those killed every day on the Western Front. ${ }^{331}$

German bombardment was met with almost universal condemnation as an "act of barbarism." Only Lord Montagu dared to make the claim that industrial London, where arms factories were located, was a justified target for air attacks. ${ }^{332}$ But it was not about weapons factories, but about the population's morale. Winston Churchill, who had recently been named Minister of Munitions, stated in October 1917, after a German air attack that killed 33 Londoners: "It is improbable that any terrorization of the civil population which could be achieved by air attack would compel the government of a great nation to surrender." 333 It is worth remembering these words, because during the Second World War the British Bomber Command, in carrying out the strategic bombardment of Germany, would act contrary to the above-stated belief.

Just after the Great War ended, some demanded that the German pilots who had bombed London be brought before a court on charges of war crimes. At the

330 See J. Piekałkiewicz, Kalendarium wydarzeń II wojny swiatowej, trans. P. Seydak et al., 2nd edition (Janki k. Warszawy 1999), 522.

331 Lindqvist, A History of Bombing, 41-42 (\$100).

332 See Middlebrook, The Battle of Hamburg, 16.

333 Garrett, Ethics and Airpower in World War II, 46. 
time, the British Air Ministry secretly opposed this idea, arguing that such a trial would be tantamount to placing a noose around the necks of British airmen in any future war. Interestingly, along with this argument, British officials indicated the goal that air attacks on German towns would have had, namely "to weaken the morale of the civilian inhabitants (and thereby their 'will to win') by persistent bomb attacks which would both destroy life (civilian and otherwise) and should, if possible, originate a conflagration which should reduce to ashes the whole town." 334 Such was the secret view expressed by the heads of the British air force at the end of 1918. Publicly, however, they were saying something quite different. In light of accusations about the "barbarity" of German air attacks on civilian populations, they emphasized the need to legally limit aerial bombardment to military targets, conveniently avoiding the fact that, given the technology of the day, it was practically impossible to conduct an air war and still respect such limitations.

The Hague Convention of 1907 prohibited the bombardment of "undefended ports, towns, and villages." The Treaty of Washington (1922) prohibited bombing as a way of terrorizing civilian populations. That prohibition was not added to the Geneva Convention, but the international community universally accepted the principle that bombardment, as an act of terror directed against civilian populations, was unacceptable. In 1924 a commission on international law in The Hague worked out two positions. While the British wanted to limit bombardment to "military installations," the Americans wanted to limit it to the area around the battle. The final compromise was based on the British proposal: wherever a military installation is located such that it cannot be bombed without simultaneously bombing the civilian population, then it cannot be bombed at all. ${ }^{335}$

Limitations placed on aerial bombardment during the First World War managed to reveal the fundamental issues involved here, issues that would characterize bombardment during the Second World War: unavoidable losses sustained by civilian populations in attacks directed against industrial targets; the destructive influence of air attacks on the morale of civilian populations; and the associated conclusion that, under sufficient pressure, a people can succumb. ${ }^{336}$ Bombardment during the First World War had only a slight influence on the results of the war, but it was precisely at that time that the dream was born

334 Lindqvist, A History of Bombing, 40 (\$96).

335 See Middlebrook, The Battle of Hamburg, 19.

336 Ibid., 17-18. 
of a powerful and modern air force and large and strategic bombing attacks that would quickly decide the course of a future war.

The foundation for this dream was set in the interwar period by two people: Giulio Douhet - the Italian general who led the first bombardments of Libya in 1911, commander of the first Italian air squadrons in 1912-1915 - and the English general Sir Hugh Trenchard - commander of the Royal Flying Corp in France during the First World War, which under his leadership became the Royal Air Force, or RAF. For both of these men, the central focus of attention was "civilian morale."337

Douhet was the first theoretician of strategic bombing. In 1921 he published a book under the title The Command of the Air, in which Douhet analyzed how bombing could play a significant role in the process of disorganizing and degrading the enemy's military potential. In Douhet's view, mass bombing of population centers could break citizens' morale and could, in effect, lead a tormented and terrorized nation - deprived of shelter and lacking food and effective assistance - to turn against its government and force that government to end the war. Douhet wrote:

Take the centre of a large city and imagine what would happen among the civilian population during a single attack by a single bombing unit. I have no doubt that its impact on the people would be terrible. [...] What civil or military authority could keep order, public services functioning, and production going under such a threat? [...] A complete breakdown of the social structure cannot but take place in a country subjected to this kind of merciless pounding from the air. The time would soon come when, to put an end to horror and suffering, the people themselves, driven by the instinct of self-preservation, would rise up and demand an end to the war. ${ }^{338}$

His theories were later adopted and applied in practice by the world's military powers, above all by the Bomber Command led by Artur Harris, who would become Air Chief Marshal and, as of February 1942, Commander-in-Chief of Bomber Command and creator of the strategy to carpet bomb Germany. Douhet is the spiritual father of the huge bombardments of the Second World War that destroyed Hamburg, Dresden, and Tokyo.

337 For more on Douhet and Trenchard's theories, see ibid., 18-19; R. Neillands, The Bomber War. The Allied Air Offensive against Nazi Germany (New York, 2005), 13-25; J. Friedrich, The Fire. The Bombing of Germany 1940-1945, trans. A. Brown (New York, 2008), 54-57. A. C. Grayling, Among the Dead Cities. The History and Moral Legacy of the WWII Bombing of Civilians in Germany and Japan (New York 2006), 129-135.

338 See Grayling, Among the Dead Cities, 130-131. 
According to Trenchard, who had an enormous influence on the shaping of doctrines that guided the British air force, aerial bombing could be used most effectively to attack the enemy's morale, which meant in practice striking at civilian populations, which is why he pushed so hard for the expansion of offensive air power and the reduction of defensive forces. He harbored the belief that a future war could be won by "causing such a moral effect among the enemy's civilian population that its government will be forced to start peace talks." At the heart of this theory was the belief that it would be easier to destroy the will to resist on the part of industrial workers in munitions factories than it would be to destroy the material foundation of a nation's defense. Trenchard claimed that the "moral effect" of bombing was twenty times more effective in weakening the enemy than material losses; it was incomparably more powerful than destruction itself. A country could win a war without having to deploy a huge army and could thus keep its own losses to a minimum.

The term "civilian morale," which bombing was supposed to "weaken," "erode," "undermine," or absolutely "destroy," has had great longevity. Indeed, one might say that it became - on an equal footing with arms factories and transport hubs a target of planned air raids. While specialists in international law discussed the need to draw a clear distinction between soldiers and civilians, between military and civilian facilities, the hard voice of strategists - for whom civilian morale was simply another military target - grew more resonant.

\section{Bombardment in the Second World War}

In the period between the First and Second World Wars, bombers were used in local conflicts. For example in 1919, during the Third Afghan War, British bomber divisions under the command of Arthur Harris bombed Jalalabad and Kabul. In 1925, during the Rif War between Spain (and France) and Morocco, the town of Sheshuan in the picturesque mountain region of Rif was bombed by Spanish and French air forces in an act of vengeance for the horrible treatment of prisoners. One can see in the bombardment of Sheshuan a prototype for later terroristic air attacks on civilian populations. ${ }^{339}$ In 1936, the Italians bombed

339 See ibid., 51 ( $\$ 122)$. A book that appeared two years after this event accused a squadron of volunteer American pilots and the French Air Corps of the criminal massacre of defenseless citizens (at the time of the bombing, there were no soldiers or military facilities in the town). See W. B. Harris, France, Spain and the Rif (London 1927), 300. 
Addis Abeba several times during the war in Ethiopia, and in 1937 the German Condor Legion carried out the devastating air raid on Guernica.

The art of bombing - perfected over the years and supported by improved bombers and an ever deadlier arsenal of bombs - fully demonstrated its destructive potential in the Second World War. The airplane, that symbol of modern times lifting toward heaven the Christ-airman of Apollinaire's "Zone"340 and returning him to earth as the "new Christ" - Lindbergh ${ }^{341}$ - manifests itself as a machine bringing mass death and destruction. Tossing bombs from airplanes had turned Sheshuan and Guernica into rubble, creating at the same time a new kind of urban landscape. Soon Warsaw, Rotterdam, Coventry, London, Cologne, Hamburg, Berlin, Dresden, Tokyo, Hiroshima and Nagasaki would themselves experience bombardment and the horrifying vision of ruins.

\section{Preliminary Stage}

Bombardment during the Second World War developed in several stages. ${ }^{342}$ The period between September 1939 and May 1940 was the preliminary stage. The air war started against Poland. The first city bombed in this war was Wieluń. On 1 September, at 4:40 a.m., planes from the Luftwaffe's Immelmann Sturzkampfgeschwader (dive bomber-wing) 76, under the command of Walter Siegel, appeared in the skies over Wielun. The first target of this air attack was the Wielun hospital. The bombardment demolished about $75 \%$ of the city, and

$340 \mathrm{~J}$. Kwiatkowski points out that the vision in the above-mentioned "Zone" of the Ascension and the Christ-airman, to which the twentieth century was compared, was inspired by, among other things, "paintings by German primitivists in a museum in Cologne. These paintings present Christ on a cross suspended in the air by wings." G. Apollinaire, Wybór poezji, ed. J. Kwiatkowski (Wrocław 1975), footnote on pp. 39-40.

341 The moment that Lindbergh landed in Paris on 21 May 1927 was described like this: "a small white hawk of a plane swoops hawk-like down and across the field - C'es lui, Lindbergh, LINDBERGH! and there is pandemonium wild animals let loose and a stampede towards the plane [...] running people ahead running people all around us running [...] and it seems as if all the hands in the world are touching or trying to touch the new Christ and that the new Cross is the Plane [...]." See Eksteins, Rites of Spring, 243.

342 The secondary literature on this topic is deep. The works that I have used, those mainly of English and German historians, are cited in the footnotes below. The latest synthesis on a Polish foundation is an article by M. Andrzejewski, "Bombardowanie niemieckich miast w latach II wojny swiatowej przez brytyjskie i amerykanskie lotnictwo. Zarys problematyki," Dzieje Najnowsze 4 (2007). 
about 1,200 residents lost their lives. Wieluńs historic city center saw the greatest destruction. This was the war's first terroristic air attack against a civilian population; at the time of the bombing, there were no Polish Army units stationed in or around the city. ${ }^{343}$ On 25 September the Germans carried out a massive all-day ground and air attack on Warsaw - an air raid on the city that, at the time, was the largest in history. ${ }^{344}$ Burning Warsaw had to capitulate. The initial stage ended on 14 May 1940 with the bombing of Rotterdam. The city center was destroyed, and streams of burning oil flowed from a damaged margarine factory. After the September air raids on Warsaw, the British treated the bombardment of Rotterdam as a new example of the brutality of German air power, while the British air force was rather cautious in its approach, limiting itself to dropping propaganda leaflets on German territory. Sir Arthur Harris later joked that the only thing that was achieved at the time was to increase the supply of toilet paper on the continent. ${ }^{345}$

\section{First Stage: From May 1940 to November 1941}

The first stage of bombing lasted from May 1940 to November 1941. In this stage the British bombed military targets along with selected cities. Special instructions from the War Cabinet in June 1940 expressed "a distinct concern"

343 See J. Trenkner, “Wieluń, czwarta czterdzieści,” Tygodnik Powszechny, 29 August 2008; Wieluń 1 IX 1939, eds. J. Żelazko, A. Ossowski (Łódź 2009).

344 On "black Monday," 25 September 1939, the Germans dropped 560 tons of explosive bombs and 72 tons of incendiary bombs on Warsaw. For the first time they used 1,000 kilogram bombs. A total of 1,455 tons of bombs were dropped on Cologne during the air raid of 30-31 May 1942; the size of the explosive bombs ranged from 1,800 kilogram explosive bombs and not quite 2 kilogram incendiary bombs. During "Operation Gomorrah," nearly 9,000 tons of bombs were dropped on Hamburg - that is, more than 14 times more than on Warsaw on "black Monday." During the famous air raid on Dresden on 13-14 February 1945, the English and Americans dropped around 4,500 tons of explosive bombs (weighing between 1,800 and 3,500 kilograms) and incendiary bombs. T. Szarota, "Naloty na Warszawę podczas II wojny światowej," Kronika Warszawy 3/4 (1993), 18; J. Piekałkiewicz, op. cit., 662-663, 1034-1035; R. H. Bailey and the editorial team of Time-Life Books, Wojna nad Europa, trans. S. Kędzierski (Warszawa 2000), 60-61; Frederick Taylor, Dresden: Tuesday 13 February 1945 (Harper Perennial, 2005), 124. In his monograph (The Battle of Hamburg, 322), Middlebrook claims that 8,344 tons of bombs were dropped on Hamburg (4,243 tons of explosive bombs, and 4,101 of incendiary bombs).

345 See S. A. Garrett, Ethics and Airpower in World War II, 9. 
that, in conducting air attacks, "any unnecessary harm to enemy civilians" had to be avoided. ${ }^{346}$

In July 1940 the Luftwaffe launched the "Battle of Britain" and German bombs began to kill English civilians. London fell victim to air raids many times (the largest bombardment came on the night of 10-11 May 1941), but the most famous bombardment of this period, one which achieved the rank of a symbol, was the air attack on Coventry on the night of 14-15 November 1940 that the Germans code-named "Moonlight Sonata." Compared with later air raids, the number of victims is not very impressive: 568 killed (that is, victims counted in the morgue and whose bodies were identified) and 1,256 injured. The Coventry Cathedral sustained massive damage, and the overall losses were so spectacular that Goebbels coined the term to "Coventry-ize," or to completely ruin.

On a certain evening in 1940 at the height of the air battle over England, Hitler painted an apocalyptic picture of London to his guests assembled for an evening meal. In his memoirs, Albert Speer described the dictator's frenetic speech. It was then that Hitler prophesied London's fate, which would be Dresden's fate five years later: a gigantic firestorm consuming the entire city.

Have you ever looked at a map of London? It is so closely built up that one source of fire alone would suffice to destroy the whole city, as happened once before, two hundred years ago [the Great Fire of London, which destroyed as much as $80 \%$ of the city, broke out in 1666 - J. L.]. Göring wants to use innumerable incendiary bombs of an altogether new type to create sources of fire in all parts of London. Fires everywhere. Thousands of them. Then they'll unite in one gigantic area conflagration. Göring has the right idea. Explosive bombs don't work, but it can be done with incendiary bombs. What use will their fire department be once that really starts! $!^{347}$

For the British, the air raids on Coventry were not only a shock; they also marked a turning point in the social mood. From that point on, the RAF intensified its attacks on German cities. The British air force's obligation to follow a prohibition on the intentional attack of civilian targets and instructions to avoid unnecessary harm to enemy populations would soon be undermined by Churchill himself. The logic of retaliatory action would begin to take over: an air raid on Berlin in retaliation for the bombing of London; an air raid on Mannheim in retaliation for the bombing of Coventry. ${ }^{348}$ The escalation of bombardment thus found its

346 Ibid., 10.

347 Taylor, Dresden, 124.

348 See T. Lewis, Moonlight Sonata. The Coventry Blitz, 14/15 November 1940 (Coventry 1990). 
justification: it was the Nazis who first bombed civilians in Warsaw, Rotterdam, London and other English cities, and we have a right to respond in kind.

In July 1941, Churchill said:

If tonight the people of London were asked to cast their votes whether a convention should be entered into to stop the bombing of all cities, the overwhelming majority would cry, "No, we will mete out to the Germans the measure, and more than the measure, that they have meted out to us."349

The Prime Minister's words were welcomed by Londoners. Recalling the German air raids on London in his memoirs published two years after the war, Arthur Harris admitted that he had felt a desire for revenge. Turning his gaze from the fires, he said to the chief of the Air Staff accompanying him: "Well, they are sowing the wind." To which the chief responded: "[...] the enemy would get the same and more of it."

But the air battle over England showed that bombing did not cause the panic and disorder that might have been expected. On the contrary, the air raid over London on the night of 10-11 May 1941, which according to some sources took 3,000 lives and according to others 1,500 lives, ${ }^{351}$ indicated that residents of the capital city, along with the rescue services, were well prepared, and courageous. A surprising aspect of the Blitz experience was thus the discovery that, after the first shock, a well-organized civilian population was able to adapt to mass bombardment, and could maintain high morale even under very difficult conditions and in the face of tragic losses. ${ }^{352}$

\section{Second Stage: From February 1942 to the Middle of 1944}

The second stage ran from February 1942 to the middle of 1944. British strategy was at an important threshold. The turning point was directive no. 22 issued by the War Cabinet on 14 February 1942. Air raids were to serve as a substitute for a second front in support of Russia in the war against Germany. The directive also elaborated on the goals and effects of aerial attacks:

A review has been made ... and it has been decided that the primary object of your operations should now be focused on the morale of the enemy civilian population and, in particular, of the industrial workers. ${ }^{353}$

349 J. Glover, Humanity. A Moral History of the Twentieth Century (London 2001), 82.

350 Taylor, Dresden, 125.

351 See also J. Piekałkiewicz, op. cit., 472, and J. Mack and S. Humphries, London at War. The Making of Modern London 1939-1945 (London 1985), 96-97.

352 See Middlebrook, The Battle of Hamburg, 22.

353 Ibid., 24. 
In order to realize these goals, a new method for bombing was developed, so-called area bombing. Air Marshal Arthur Harris became head of Bomber Command.

Churchill agreed to mass bombing raids on German cities, and on the night of 28-29 March 1942 an air attack was carried out on Lübeck in which a new kind of incendiary bomb was used for the first time, which meant that the firestorm phase of the war had been entered, marked by the intentional terrorization of civilian populations. The night bombing of Cologne on 30-31 May 1942 involved the first application of a new method: a "raid by a thousand bombers" using a combination of explosive and incendiary bombs.

In August 1942 Churchill traveled to Moscow where, in a conversation with Stalin, he explained that the western allies were not yet able to open a second front in Europe, but that Great Britain would carry out intensive bombardment of Germany. Stalin praised this idea and emphasized that both German buildings and factories should be destroyed. The British Prime Minister agreed completely, stating that "civil morale was a military objective, but the bombing of working men's houses came as a by-product of near-misses on factories." 354

An increasing number of German cities came under Allied bomb attacks (as of June 1942, the Americans participated in air operations over Germany). Without a doubt, the culmination of events in this stage was "Operation Gomorrah" that is, the British and American carpet bombing of Hamburg between 24 July and 2 August 1943 (The RAF bombed at night, the U.S. Air Force during the day). This series of bombardments exemplified the new phenomenon of the so-called firestorm. Roofs were destroyed by explosive bombs, which prepared the ground for incendiary bombs. Dropped in huge numbers, these bombs ignite fires throughout a city that cannot be battled. The fires spread quickly and turn into a single sea of flames. Extremely high temperatures draw in colder air from all levels of the atmosphere, which creates a kind of tornado - winds of great force rage through the burning city, carrying with them people, trees and rubble, igniting new fires. The number of victims in the Hamburg bombardment has been estimated at around 45,000. ${ }^{355}$ After Hamburg, it was Berlin's turn. The "Battle of Berlin" began with systematic carpet bombing on 22 November 1943.

354 Glover, Humanity. A Moral History of the Twentieth Century, 72. Glover cites a report by Averell Harriman, President Roosevelt's emissary for talks with Stalin.

355 For comparison, it is important to remember that all of the German air raids on Great Britain during the Second World War killed 51,509 civilians (Middlebrook, The Battle of Hamburg, 328). 
At the beginning of November 1943, a report from the RAF Air Intelligence Department suggested that the Germans had been broken by the massive air raids on cities:

The full effects of air attack since the devastation of Hamburg have become known in all parts of the country $[\ldots]$ the general attitude is approaching one of peace at any price and the avoidance of wholesale destruction of further cities in Germany. ${ }^{356}$

But as it would turn out, and as is often the case with intelligence reports, the contents of this report deviated far from reality.

\section{Third Stage: From the Summer of 1944 to War's End}

The third stage of bombardment lasted from the summer of 1944 through the end of the war. The Allies had gained complete control over the skies, and after the invasion of Normandy they could make use of air bases in France, which made daily precision bombing possible. At this time, two concepts collide with one another: on the one hand, the concentration of air raids on industrial targets and the transport system and, on the other hand, the plan pushed by Air Marshal Harris to continue the carpet bombing of German cities. The following argumentation was used to support the second concept: first - it would save the lives of Allied soldiers by emphasizing air operations and reducing the deployment of land troops (an argument like "a life for a life"); second - it would bring about the final destruction of German industry; and third and finally - it would break the morale of the civilian population..$^{357}$

In this stage of the air war, the Germans were making use of their "miracle weapon," the V-2 rocket. By the end of March 1945, 1,115 V-2 rockets had fallen on England (517 of them on London), killing 2,724. The effect was tiny compared to the air raid over Dresden carried out in a combined effort by the RAF and the U.S. Air Force on 13-14 February 1945. Smaller attacks continued over the course of the next ten days, and the Americans launched the last raid on 2 March, but the first strike had already turned the city into rubble. According to the most recent estimates, the immense firestorm claimed between 35,000 and 40,000 victims and destroyed about $85 \%$ of the city. ${ }^{358}$

356 Robin Neillands, The Bomber War: The Allied Air Offensive Against Nazi Germany (Penguin, 2001), 281.

357 See Glover, Humanity. A Moral History of the Twentieth Century, 73-75.

358 See Sebastian Cox, “The Dresden Raids: Why and How," in Paul Addison, Jeremy A. Crang, eds., Firestorm: The Bombing of Dresden, 1945 (Ivan R. Dee, 2006), 51, 57. 
Dresden had become a bargaining chip in great power politics, part of Churchill's preparation for his trip to the Crimea. During the Yalta Conference, the Prime Minister intended to offer Stalin military support for the Soviet offensive launched in January 1945. He thus pressured the RAF to make a spectacular move in support of actions on the Eastern Front. In his analysis of priority bombing targets - fuel installations, submarine bases, and weapons factories Sir Charles Portal, the Chief of the Air Staff, called for the massive bombardment of Berlin, Dresden, Leipzig, and Chemnitz, stating that "a severe blitz will not only cause confusion in the evacuation from the East but will also hamper the movement of troops from the West." ${ }^{359}$ In the evening of 25 January, Churchill had a telephone conversation with his Secretary of State for Air, Sir Archibald Sinclair. He demanded information about what plans the Bomber Command "might have for basting the Germans in their retreat from Breslau." ${ }^{360}$ One could interpret this as "tanning the Germans' hide (to 'give them a bruising, or to 'punch them') during their retreat from Breslau." But the verb "to baste," of course, has three meanings: 1) to sew temporarily; 2) to moisten meat while cooking, with its own drippings, as in "to roast in its own drippings"; and 3) to beat with a stick, to thrash, as with a cudgel. In light of what was about to happen in Dresden, use of the culinary definition indicating roasted meat would be both amusing and terrifying.

The Yalta Conference began on 4 February 1945. Though the general idea to support the Soviet offensive on the Eastern Front through intensive bombardment had been worked out in London, it was the Russians who pushed for the bombing of Dresden, which was regarded as a key transport hub. One member of the British delegation, who worked as a translator between the Prime Minister and the Russians, stated that Stalin wanted to paralyze German transport and hinder the organization of an effective defense. From that moment, the fate of the "Florence on the Elbe" was a political matter of the greatest importance, given that it lay in the sphere of interests of the three great powers. Some historians have speculated that the destruction of Dresden was but a show of strength by the western Allies. Negotiating with Stalin, Churchill wanted to make sure he had the dictator's respect. Did he already realize that the Soviets understood only the argument of power? One way or the other, the decision was made at the highest level. Now, they only needed favorable weather - a bright moon, a cloudless sky. The Yalta Conference ended on Sunday, 11 February. The first wave

359 Addison, Firestorm: The Bombing of Dresden, 25.

360 Taylor, Dresden, 210. 
of bombing started on Tuesday, 13 February, at 10:03 pm and lasted until 10:25 $\mathrm{pm}$, and the second wave started at 01:45 a.m. the next day. In the morning of 14 February, American bombers appeared over the city to carry out the third attack. Dresden was burning. It was Ash Wednesday, the first day of Lent. ${ }^{361}$

By the end of 1944, it had become clear, beyond any reasonable doubt, that the results of the air offensive against German cities was paradoxical. Carried out in order to "undermine and break civilian morale," the air raids had not fulfilled expectations. Reports that residents of German cities, inundated by bombs, had been broken in spirit and were ready to deny the Führer their obedience turned out to be - to put it delicately - overly optimistic. The main press organ of the Office of Information and Propaganda of the Home Army (Armia Krajowa AK) High Command, Biuletyn Informacyjny, reported on 4 May 1944:

The Germans are starting to feel as if they allowed themselves to be drawn into a blind alley by their "genius" leader, into a situation from which there is no escape! [...] Falling spirits among the Germans. According to a great deal of reliable information, the current German mood can be thus described: 1) armies battling on the Eastern Front are increasingly discouraged and doubting in victory, 2) just behind the front the mood is entirely bad, both in the army and within German society, 3) in the Reich under the influence of catastrophic bombardment, and given serious food shortages and other shortages of many kinds, along with war exhaustion, the mood among the German people is very low, clearly close to collapse and panic. After the last huge air attack on Berlin, 400 people were shot for "defeatism." The "Heil Hitler" greeting in the Reich is no longer used, at least they are using only "Heil." ${ }^{362}$

In his diary, Victor Klemperer described the mood among German civilians entirely differently. On Monday, 1 May 1944, three days before the above-cited article appeared in the Biuletyn Informacyjny, the diarist recorded the story of a young girl who had arrived in Dresden from Berlin:

What she reported from Berlin shook me, because it confirmed what Goebbels repeatedly emphasizes. The Berliners are quite used to the raids [...]. Serious destruction on every street, loss of life everywhere, but in general the people's mood is good, humorous, prepared to see it through. Special rations and fear help things along, there's grumbling here and there, but on the whole people carry on with self-confident Berlin wit and cockiness. No one is expecting imminent defeat; some say the war will last another two

361 On the origins of the bombardment of Dresden, see F. Taylor, "Thunderclap and Yalta," in Taylor, Dresden, 179-192; S. Cox, op. cit., 18-61; D. Irving, “Thunderclap” in Apocalypse 1945: The Destruction of Dresden (Focal Point Publications, 2007), 90-108.

362 “'Biuletyn Informacyjny.' Część III. Przedruk rocznika 1944. Konspiracja,” Przegląd Historyczno-Wojskowy, rok IV (LV), nr specjalny 3 (200) (Warszawa 2003), 1985. 
years, others, that the decisive German "retribution" is at hand. [...] The girl works in some Berlin factory, so hears this and that. Therefore the regime has no need to fear internal collapse or revolt. And on this point Goebbels is undoubtedly correct: As a means of bringing pressure to bear on morale the air offensive is a failure. ${ }^{363}$

\section{Bombing and Morality}

The Germans, tormented by bombardment, did not fall into despair, and did not collapse into chaos. They also showed no great sign of rebellion against authority. Indeed, what they showed was a certain "fighting spirit" and a sense of humor. The vast destruction and personal misery did not lead them to revolutionary action, but rather pushed them into apathy. Shocked by the loss of relatives, homeless, bereft of their possessions built up over a lifetime, the Germans sought what was most elemental, what secured basic needs. The tragedy of bombardment forced them into even closer cooperation with the regime. Able to rely only on the state for help, they became absolutely dependent on it.

In addition, air raids over the city caused no great damage to the German armaments industry. The true catastrophe for Germans came as result of the precision bombing raids on selected fuel facilities and transportation lines. But such raids were not carried out with sufficient intensity and consistency. Albert Speer, Hitler's Minister of Armaments and War Production, admitted in his memoirs:

Actually, as I had earlier recognized, the war could largely have been decided in 1943 if instead of vast but pointless area bombing, the planes had concentrated on the centers of armaments production. ${ }^{364}$

Any attempt to evaluate Churchill's stance toward the bombing offensive against German cities has to confront the ambiguities, even contradictions, contained in his own statements on the subject. One can lay out a series of statements energetically supporting the air raids and expressing faith in their effectiveness, but one can also cite statements indicating skepticism and outright criticism.

No doubt, Churchill's views evolved. In 1935 he expressed outrage that "it is only in the twentieth century that this hateful condition of inducing nations to surrender by massacring women and children has gained acceptance."365

363 Victor Klemperer, I Will Bear Witness 1942-1945: A Diary of the Nazi Years, trans. Martin Chalmers (Modern Library, 2001), 311.

364 Albert Speer, Inside the Third Reich: Memoirs, trans. Richard and Clara Winston (Simon \& Schuster, 1970), 280.

365 This quote of Churchill, along with the others below, can all be found in Garrett, Ethics and Airpower in World War II, 20, 44-47. 
However, in July 1940, as Prime Minister of His Majesty's Government at the start of the Battle of Britain, Churchill stated that bombing was not subject to moral judgment, but rather could be evaluated only in terms of its effectiveness.

[...] when I look around to see how we can win the war I see that there is only one sure path. We have no Continental Army which can defeat the German military power. The blockade is broken [...]. But there is one thing that will bring him back and bring him down, and that is an absolutely devastating, exterminating attack by very heavy bombers from this country upon the Nazi homeland. We must be able to overwhelm him by this means, without which I do not see a way through.

When Conservative MP Robert Cary called on the Prime Minister to order the approval of a full-scale bombing operation against German cities in retaliation for German bombardment, Churchill's response was ambiguous. In a conversation on 17 October 1940, he at first categorically rejected the suggestion:

My dear sir, this is a military and not a civilian war. You and others may desire to kill women and children. We desire (and have succeeded in our desire) to destroy German military objectives.

But then, as if to contradict himself, he added: "I quite appreciate your point. But my motto is 'Business before Pleasure."

From February 1942 to the spring of 1945 - that is, in the period in which the air offensive reached its peak - Churchill's statements contained not the slightest allusion to the moral implications of the air raids. In response to the words of one of his closest advisors, namely that "[...] as time went on, and the accumulated horrors of the war hardened all our hearts, he [Churchill] grew indifferent to the sufferings of the German cities," Churchill stated:

[...] it is absurd to consider morality on this topic .... In the last war the bombing of open cities was regarded as forbidden. Now everybody does it as a matter of course. It is simply a question of fashion changing as she does between long and short skirts for women.

After the attack on Dresden, in a letter to the Chief of the Air Staff, Churchill changed his stance and expressly criticized air bombardment.

It seems to me that the moment has come when the question of bombing of German cities simply for the sake of increasing terror, though under other pretexts, should be reviewed. Otherwise we shall come into control of an utterly ruined land. [...] The destruction of Dresden remains a serious query against the conduct of Allied bombing. I am of the opinion that military objectives must henceforward be more strictly studied in our own interests rather than that of the enemy. 
But just after the war he reportedly said the following to one of the Bomber Command officers: "We should never allow ourselves to apologize for what we did to Germany."

According to the logic of modern total warfare, which blurs the boundaries between the battlefield and the home front, the bombardment of cities was aimed at that which - it would seem - was beyond the reach of the direct conflict, and which was not vulnerable during conventional battles waged between opposing armies. Bombardment annulled the concept of a front line; it redefined the concept of battlefield; and it thus struck at common people and their very existence, at their bodies and spirits - at their morale.

But morale was not so easily weakened, broken, or destroyed, as proven by the civilian populations of Warsaw, London, and other cities demolished by German bombs. Did the Allied air offensive against German cities bring the predicted results? To be sure, many people were killed and an enormous number of structures of great historical and cultural value were destroyed. But there is reason to doubt that bombing contributed to an early end to the war. Were German civilians, tormented and down on their knees, in a position to have any influence over the matter?

\section{The Experience of Bombardment}

\section{Total War}

Bombardment is the climactic moment of total war. Here, I evoke the concept of totality in three contexts: 1 . the history of military action; 2 . the concept of total war as enunciated by Erich Ludendorff in his work Der Totaler Krieg (1935) and as proclaimed by Joseph Goebbels in his famous speech at Berlin's Sportpalast on 18 February 1943; and 3. a definition of the nature of experiences triggered by bombing and thus involving the psychology of war.

The Third Punic War led to the three-year siege of Carthage. The Roman army under Scipio Aemilianus took the city in 146 BCE. As a result of the battle, hunger and disease, $90 \%$ of Carthaginians were killed and the rest were sold into slavery. Carthage was completely destroyed, ploughed over, and sown with salt, which was supposed to complete the work of destruction and render the land on which the city had been built barren and empty for ages. The destruction of the Phoenician city is an excellent example of a total war waged between civilized nations before the era of modern means of mass destruction. Gwynne Dyer was correct in claiming that, had an atomic bomb been dropped on Carthage, the agony of the Carthaginians would have been 
shorter but the result would have been little different than what the Romans achieved. ${ }^{366}$

Captain Peter Strasser, head of the German navy's airship division, who during the First World War directed the air bombing campaign on English cities (and on Paris and Antwerp), had no doubt about the nature of modern warfare. In a letter to his mother, he wrote:

We who strike the enemy where his heart beats have been slandered as 'baby-killers' and 'murderers of women.' [...] What we do is repugnant to us too, but necessary. Very necessary. Nowadays there is no such animal as a non-combatant; modern warfare is total warfare. A soldier cannot function at the front without the factory worker, the farmer and all the other providers behind him. ${ }^{367}$

Strasser was one of those who promoted total war in its modern understanding: war calculated to destroy not just the enemy's armed forces, but also its material assets and home front support; war carried out through the use of all available means, contrary to legal and moral limitations. But the German airship commander did not have a chance to experience for himself the effects of total war at its peak. He did not see Warsaw ruined by German bombs, nor Hamburg and Dresden burned to the ground in firestorms ignited by Allied carpet bombing. On 6 August 1918, during a night raid, Strasser's airship was shot down over England and crashed on the Norfolk coast.

Carpet bombing cities is considered to be the final stage of aggression to which the brutal logic of total war inevitably leads. We can identify three of its key elements: harnessing the entire population of a belligerent country with the war effort; access to the resources that such a universal mobilization makes possible; and finally, access to military technology capable of mass destruction. ${ }^{368}$

In 1935, General Ludendorff wrote that a future war would take on the character of total war. What he had in mind was the need for absolute and universal mobilization, for a country's military needs, of its entire social, industrial and political potential, which means that everyone - soldiers and civilians, adults and children, women and men - have to be, one way or another, engaged in military activity. The consequences of total war thus conceived for civilian populations are obvious - they become a target of the enemy's armed attacks. In any conventional war, there is no way to avoid civilian victims, but total war assumes a fundamental re-orientation: the immunity of the civilian population is put into

366 See Gwynne Dyer, War: The Lethal Custom (Basic Book, 2006), 188.

367 Ibid., 262-263.

368 Ibid., 188. 
question - whether de jure or de facto - and the borders between battlefield and home front are obliterated. That having been said, total war, as Ludendorff conceived it, is not the same as genocide. The killing of civilians remains a means to an end, not the end itself. ${ }^{369}$

Goebbels' speech on 18 February 1943 was delivered at a turning point in the war. Hitler's Propaganda Ministry had declared total war just after the final capitulation of Field Marshal Friedrich Paulus and his 6th Army at Stalingrad. Around 364,000 German soldiers died in battle or as the result of hunger or disease, and around 100,000 soldiers were captured, almost none of whom survived. After the defeat at El Alamein in November 1942, the Afrika Korps under General Erwin Rommel - the legendary "Desert Fox" - was in full retreat, and Rommel himself was evacuated from Tunisia in March 1943. According to some historians, these two battles contributed most to the final defeat of Nazi Germany. From that point forward, it could only get worse. At the Casablanca Conference in January 1943 the Allies made the decision to invade Italy, and in July they landed on Sicily, which led to Mussolini's fall and arrest. At Casablanca, Roosevelt and Churchill also demanded the unconditional surrender of the Axis Powers, which fed perfectly into Hitler's paranoid mentality: he could either achieve absolute victory and rule the world, or he could suffer absolute defeat and take the world down with him. There was no third option; compromise was not possible. At this time - Ian Kershaw has argued - only a few of the Führer's closest associates were still able to believe in victory. Decisions made at Casablanca confirmed Hitler's belief that his uncompromising stance was justified. In February 1943, in conversations with Nazi Party leaders, Hitler pointed to the demand for "unconditional surrender" as proof that any effort to negotiate peace was pointless, and that he himself no longer felt any obligation to negotiate. Kershaw concluded: "The road to destruction was opening up ever more plainly. For Hitler, closing off escape routes had distinct advantages. Fear of destruction was a strong motivator." ${ }^{370}$

Goebbels' speech portrayed the Hitler regime, plagued by defeat and weakening day by day, as a great power burdened with the sacred obligation to hold back and defeat the Bolshevik onslaught threatening the foundations of Western civilization. Europe was in terrible danger and could be saved only through the greatest mobilization of all forces at the disposal of the Thousand-Year Reich.

369 For more on Ludendorff's concept and its consequences, see Hew Strachan, "Strategic Bombing and the Question of Civilian Casualties up to 1945," in Firestorm, op. cit.

370 Ian Kershaw, Hitler: 1936-1945 (Norton \& Company, 2001), 577. 
The German people's trust in the Führer - Goebbels claimed - was unlimited, and it was Hitler who would lead them to "final total victory." What was required at that moment was total war. Germans had to freely give up what theretofore had been their standard of living in order to support the Reich's war effort as quickly and conspicuously as possible. Goebbels continued:

The total war effort has become a matter of the entire German people. No one has any excuse for ignoring its demands. A storm of applause greeted my call on 30 January for total war. I can therefore assure you that the leadership's measures are in full agreement with the desires of the German people at home and at the front. The people are willing to bear any burden, even the heaviest, to make any sacrifice, if it leads to the great goal of victory. ${ }^{371}$

The Propaganda Minister rose to the heights of oratorical artistry. Over the course of two hours, he brought the auditorium of 14,000 carefully selected spectators to a white heat. They jumped from their seats, interrupting the speaker more than 20 times with applause and cheers. The hysteria reached a peak near the end of Goebbels' speech when he shouted from the podium 10 rhetorical questions. "The English maintain that the German people has lost faith in victory. I ask you: Do you believe with the Führer and us in the final total victory of the German people?" The audience responded with thunderous confirmation. "The English maintain that the German people are resisting the government's total war measures. It does not want total war, but capitulation!" The hall resounded with the cry: "Never! Never! Never!" The speaker now asked: "Do you want total war? If necessary, do you want a war more total and radical than anything that we can even imagine today?" The spectacle ended with the singing of the national anthem "Deutschland, Deutschland über alles" and the Nazi Party anthem the "Horst-Wessel-Lied," and with the chant: "The great German Führer Adolf Hitler, Sieg Heil, Sieg Heil!"

Without extraordinary measures, Germany was in no position to carry on with the war, which meant the need to open the "internal front" and throw civilians into the wheels of the war machine. Goebbels was seeking approval for a total war that Germany could no longer win. And he gained this approval from his fanatical party comrades, who with a thunderous "yes" expressed their agreement to self-destruction. This incredible policy, supported by draconian measures of repression against the German people themselves, delayed the fall

371 For the full text of Goebbels' speech in English, including the quote above and those below, see: http://research.calvin.edu/german-propaganda-archive/goeb36.htm (accessed 7 January 2018) 
of the Nazi regime by two years and would lead to the senseless prolongation of battles that the Germans had not the slightest chance of winning, battles carried out on Hitler's orders to fight "to the last drop of blood." 372

The idea of total war, called forth during Goebbels' frenetic speech at the Sportpalast in Berlin, hung a death sentence over the heads of hundreds of thousands of "common Germans," one that would be carried out with ruthless effectiveness by British and American bombers. Historians have calculated that, as a result of the Allied bombing offensive against German cities during the Second World War, between 305,000 (American estimates) and 593,000 (according to the Federal Bureau of Statistics in Wiesbaden) civilians died. ${ }^{373}$

Bombardment understood as a total and all-encompassing experience involves, without exception, perpetrators and victims, people and things, body and soul. The materiality of bombardment is compelling, it attacks the senses: the agonizing roar of explosions; buildings crumbling under the falling bombs; fires consuming entire neighborhoods and cities; stacks of corpses growing in the streets, squares, and basements; victims torn to pieces, burned to ashes, choked by carbon monoxide. The city trembles, rattled by explosions. People also tremble, wracked with fear, which cannot be controlled. Intolerable levels of stress can either cause apathy or lead to feverish activity. But a mortal fear of death is not the exclusive domain of those on whom bombs fall. It also grips the pilots who drop those bombs. Alongside accounts provided by residents of bombed cities, we find pilots' accounts and military medical reports describing the psychological disorders, caused by combat stress, which inflicted members of bomber crews. The totality of bombardment is reflected in all such accounts. ${ }^{374}$ Terror grips everyone: perpetrators and victims.

372 Kershaw, Hitler: 1936-1945, 558-562.

373 See Glover, Humanity. A Moral History of the Twentieth Century, 77. Most often, the number of victims of Allied bombing is estimated to have been around a half million, and seriously injured around a million (Middlebrook, The Battle of Hamburg, 22; Garrett, Ethics and Airpower in World War II, 46). A. C. Grayling has estimated the number of civilians killed at between 305,000 and 500,000, and the number of injured around 780,000 (see Grayling, Among the Dead Cities, 104).

374 Two American psychiatrists, R. R. Grinker, who served in the army as a colonel, and J. P. Spiegel, who served as a major, conducted research among airmen in the U.S. Air Force fighting in North Africa. They published their medical report in 1945 under the title Men Under Stress. Upon its publication, the prestigious Science (8 June 1945) welcomed the book as transformative. Even today, the work is considered a great achievement in psychology and the study of air war, and it is often cited in psychological works on military activities and on posttraumatic stress caused by air war experiences (e.g. 
Every participant in such an event plays his role and takes his own proper place. Bombardment is carried out in three areas, which can be presented in vertical order, along the flight of a falling bomb, from top to bottom. On the first level, in the air high "above earth," there are the bomber pilots, who look from above at the bombed city. Below is the "earth," where civilians are moving about amidst troops manning anti-aircraft guns and members of fire brigades and other emergency services. The city is burning and collapsing around them. Their behavior indicates movement: panic, disorderly escape, desperate rescue attempts. And then there is the third level: "underground" - that is, the antiaircraft shelters and bunkers, tunnels and canals, and finally common cellars. People hidden there experience bombardment as if from the inside, from the depths. The feverish movement typical of existence on the surface of the earth changes into immobility, apathy, people waiting for a bomb that will bury them alive under the rubble, or will ignite a fire that changes their shelter into a furnace filled with poisonous gases.

\section{The Speed and Completeness of Destruction}

The complete annihilation of a city is by no means an invention of twentiethcentury warfare. On the contrary. The city destroyed by invaders such that no stone is left on top of another, or crushed by the kind of natural disaster or divine anger that sweeps it from the face of the earth, is in fact an archetypical image in culture. The ruins of Homeric Troy, plundered and destroyed by the Greeks, were found centuries later by Heinrich Schliemann. Babylon was destroyed many times. It seems that the Assyrian King Sennacherib drew a line through that city's existence finally in 689 BCE. But in 612 BCE the Medes and the Babylonians devastated the capital of the Assyrian Empire, Nineveh, and the great builder Nebuchadnezzar II lifted the city back up from the depths, making it the largest city in the ancient world. In 587 (or 586) BCE, that same ruler demolished Jerusalem and took those who had survived the slaughter into

J. Bourke, An Intimate History of Killing. Face-to-Face Killing in Twentieth-Century Warfare [London 2000], 29, 142-145). RAF pilots were haunted by depression and fear and could be deemed by their commanders to be "LMF" (Lacking in Moral Fibre) - in other words, cowards. Losses within the Bomber Command under Sir A. Harris were huge, reaching $50 \%$. At a certain point in the war, the chances of survival in the first tour of raids, which consisted of a standard 30 operations, was only $17 \%$, and those chances dropped drastically to $2.5 \%$ in the second tour. Among the 125,000 pilots who served in the Bomber Command, at least 6,250 had confirmed signs of combat depression. See W. Holden, op. cit., 104-113. 
captivity in Babylon. This event became the model for lamentation over an annihilated city, which Jeremiah compared to a broken clay pot. ${ }^{375}$ In 146 BCE the above-mentioned Scipio Aemilianus razed Carthage to the ground. Vesuvius buried Pompeii and Herculaneum in lava and ash in AD 79, though it is difficult to know when fire and brimstone consumed biblical Sodom and Gomorrah.

And he looked toward Sodom and Gomorrah, and toward all the land of the plain, and beheld, and, lo, the smoke of the country went up as the smoke of a furnace" (Genesis 19:28).

No doubt these archetypes set the framework for the experience of bombardment in the twentieth century. How else are we to interpret the fact that the bombing campaign over Hamburg was called "Operation Gomorrah?"

The modern element that bombardment brought to destruction rests in technology, which involves both the tools themselves and the effectiveness of their use. An airplane is able to master space and lift itself toward the skies, freely crossing previously impassable borders. The bombs it drops pierce through the ceilings of multi-storied apartment buildings, turning whole neighborhoods into rubble, leaving behind only fire and death.

Bombardment destroys a city in a modern way - that is, methodically, planned, and quickly. Very quickly. Five hours of mass bombing over Hamburg was enough to ignite a firestorm that completely altered the city's appearance and represented a turning point in its multi-century history. Ernst Heinrich, Prince of Saxony, watched the bombing of Dresden from a nearby hill, mourning the loss, in one night, of his family's possessions:

The entire city was a sea of flame. This was the end! Glorious Dresden was burning, our Florence on the Elbe, in which my family had resided for almost four hundred years. The art and tradition and beauty of centuries had been destroyed in a single night! I stood as if turned to stone."376

The unbearable speed of destruction caused by bombing could serve as a pretext for reflection on the insignificance of one's own existence compared to the fathomless beauty of nature, which gives true solace. In 1943, during the Allied bombing of Budapest, Sándor Márai wrote:

375 "And shalt say unto them, Thus saith the LORD of hosts; Even so will I break this people and this city, as one breaketh a potter's vessel, that cannot be made whole again" (Jeremiah 19:11).

376 Frederick Taylor, Dresden, 361. 
At the end of the fourth year of war, when over the course of twenty-four hours the city in which I live could be destroyed, and many things could be lost to which I am attached, and during which I myself could die, I feel a peace that I have rarely felt in life. I am calm and almost content; I am working and I do only what I want; I want nothing from the world, I am jealous of no one ... I am pleased by the beautiful weather, a bowl of raspberries, a meaningful sentence in a book. ${ }^{377}$

Márai's contemplative mood could not have been shared by those who found themselves in the eye of the hurricane - on the streets of Budapest as it was being bombed. Built up through the centuries from wood, stone and brick; growing roots in the depths of culture; and bound in an inseparable way, it would seem, with the lives of generations of its residents - the city in a moment fell like a house of cards. Significantly, a certain baker used just such a metaphor to describe Guernica, which became the prototype of a city destroyed in modern fashion:

A row of bombs fell along the street. One after another, in a line, like a pack of cards, the houses began to collapse. I saw them sway and fall with a roar that I could hear even above the sound of the planes. [...] All the explosions fused together. ${ }^{378}$

Terrible confusion reigned in a bombed city. Everything - people, houses, streets - spun like mad in an infernal vortex. Everything was in movement: residents trying to save themselves in a chaotic escape; rubble and glass flying through the air; bombs, with their screeching whistle, fell from the sky. Maria Rosenberg found herself in Dresden as it was being bombed. At the last moment she escaped from a collapsing building and fell in the street, engulfed by flames. She felt like she had been tossed into a "witches' cauldron":

Burning curtain material was flying towards us and glowing pieces of wood came flying down on us from above; also bits of windowpanes. One had the feeling everywhere of walking only on broken glass. It was as if fire was poured from the sky. [...] As my sister knew the city, she managed to find ways out of this "witches' cauldron".379

The violence, speed, and completeness of the destruction took on an apocalyptic dimension. A nurse from a military hospital in Dresden was sucked into the monstrous confusion of the dying city:

377 Sándor Márai, Dziennik (fragmenty), trans. T. Wornowska (Warszawa 2004), 16.

378 See A. Arazamagni's account in Gordon Thomas, Max Morgan-Witts, The Day Guernica Died (London: Hodder and Stoughton, 1975), 259.

379 See Rosenberg's account in Alexander McKee, Dresden 1945: The Devil's Tinderbox (London: Souvenir Press), 169. 
There was crashing and thundering, whistling and howling. The walls trembled, swayed by the impact of the bombs. This is the end, we thought. How long it lasted, don't ask me. Minutes? It appeared to be hours. ${ }^{380}$

And here is how Sabina Dłużniewska, a nurse at a hospital on the grounds of the University of Warsaw, described the bombing on Monday, 25 September 1939:

I saw the bombers approaching high above Warsaw. It was incredible. A swarm, a herd of airplanes. Hundreds. The sky was darkened. What is this? An earthquake? Only one thought: It's all over. (...) Without end, eleven hours, every second the whir, whistle, rumble, and roar. Thick dust, the earth shakes, the walls shook. (...) among the incredible flashes of light, against the background of a whirl of sparks, branches, leaves and clouds of ashes, I saw a person running toward us (...). Who it was who jumped first from the hall into this terrible confusion, I do not know. The earth rocked under our feet. People stumbled through the whirling debris, or they simply ran. ${ }^{381}$

The scene of Warsaw being bombed resembled the end of the world. Ludwik Hirszfeld described his experiences during "bloody Monday" by writing: "This is probably what the world's end will look like." 382 Ferdynand Goetel recalled the bombing of Warsaw in a similar way:

Hundreds of explosive bombs and tens of thousands of incendiary bombs fell on Warsaw. A dry gale ripped through the night and threw flames across the entire neighborhood. It was the first vision of the end of the world that Warsaw would experience. ${ }^{383}$

\section{And Zygmunt Zaremba:}

Entire blocks of houses and neighborhoods succumbed to the firestorm. The city was overtaken by a cloud of smoke and ash, blocking out the sun. The subdued light contributed to the eerie ambience of the end of the world. ${ }^{384}$

In search of the best form of expression for the entire "magnitude of destruction," Chaim Kaplan evoked the pathos of biblical language: "Beautiful Warsaw - city of royal glory, queen of cities - has been destroyed like Sodom and Gomorrah."385

380 See Annemarie Waehmann's account in ibid., 150.

381 S. Dłużniewska, Pamiętnik warszawski (Warszawa 1965), 77-79.

382 L. Hirszfeld, Historia jednego życia (Warszawa 1989), 222.

383 F. Goetel, op. cit., 13.

384 Zaremba, Wojna i konspiracja, 110.

385 Kaplan, Scroll of Agony, 38 (entry dated 29 September 1939). J. Święch indicates that, particularly in the poetry of T. Gajcy ("Trójgłos," "Rapsod o Warszawie," "Widma"), we see the vision of a city on the verge of apocalypse. In the opening poem Widma, one can discern in the apocalyptic scenery of urbs devastata references to the siege of Warsaw, bombardment and the image of a destroyed city after capitulation. See 


\section{The Moment of (Macabre) Transformation}

The macabre transformation under discussion here has two aspects: dynamic (which manifests itself during the act of bombardment itself) and static (which characterizes the effects or product of bombardment - that is, ruins and charred remains). In the first case, we observe the violent metamorphosis while it is happening; forms yield to radical change before our very eyes. That which was permanent and durable, falls apart; that which had an established shape, succumbs to decomposition. The second case involves changes that have already taken place, frozen in forms that are terribly altered, strange, foreign, somehow mutated. What will be of interest to me below is only the dynamic aspect of this macabre transformation.

A city collapses and loses its previous form not at all as a result of some kind of impulsive destructive action, but rather as a scrupulously developed method of action. The strength of a powerful explosive bomb brings down walls, smashes roofs and windows, and prepares the way for a rain of smaller incendiary bombs, which fall on the thus exposed city, igniting fires. Bombs that shatter buildings and fires that consume the city - these are the two fundamental factors in the macabre transformation. In the work of destruction, two powers participate: explosion and fire.

Juan Silliaco, a fireman in Guernica, witnessed an event in 1937 that contained within itself the threat of something extraordinary, unprecedented: a bomb had struck an apartment building, burying people under rubble who had no chance to survive. The shell did not even need to explode in order to alter the building into a shapeless heap of debris. The tragedy was that Guernica was one of the first cities to be caught up in a terrible metamorphosis for which it was in no way - militarily or mentally - prepared. Soon, residents of other cities would experience a similar shock, over and over again, and accounts of buildings collapsing under falling bombs would become, in a sense, routine in bombing narratives. But let us remain in Guernica and quote a passage from a prototype account:

There were many buildings $[\ldots]$ which as a result of a direct hit had totally collapsed in a heap of rubble. [...] It had once been a rooming house, four floors high, filled with refugees. A bomb had penetrated the roof and plunged through to the ground floor. It had failed to explode, but the sheer force of its passage through the poorly built building

"Stolica” in Piesń niepodległa. Model poezji konspiracyjnej 1939-1945 (Warszawa 1982), $120-122$. 
had collapsed the inner supports. The upper floors had caved in, sending ceilings down on floors, floors down on ceilings. The building had been reduced to half its normal height. ${ }^{386}$

An explosion effectively changes the outline of a city; in a sense, it redraws the city. Particular buildings and, indeed, the entire urban landscape are altered beyond recognition. Stating the nature of this terrible transformation (beyond a realization of the scale of the death and material destruction) is an essential component of the experience of bombardment. King George VI, who visited Coventry immediately after the bombing as the city was still smoldering, wrote in his diary under the date 16 November 1940: "I walked amidst the destruction. People on the street could not grasp where they were, nothing was recognizable." 387

In a city that has been bombed and is engulfed in a firestorm, everything burns. Hermann Kröger, a fireman in the Hamburg rescue brigade, wrote: "Suddenly, there came a rain of fire from heaven [...]. The air was actually filled with fire."388 Fires merge into one gigantic sea of flame: "There was a fire-storm out there," Kurt Vonnegut wrote. "Dresden was one big flame. The one flame ate everything organic, everything that would burn." 389 In Józef Mackiewicz's work on the bombing of Dresden, we also read of a sea of flames. ${ }^{390}$

The fury of the attack and the scale of the destruction caused by bombardment demanded particular expression, one that would often search for references in imagery from hell. There are many examples, though most of them do not reach beyond worn-out stylistic formulas. ${ }^{391}$ But there are accounts that expose the infernal terror. Warsaw, Hamburg, Dresden, Tokyo, and finally Hiroshima - it is there where true hell was unleashed.

386 See Thomas, The Day Guernica Died, 252-253.

387 T. Lewis, Moonlight Sonata, 165.

388 See Middlebrook, The Battle of Hamburg, 257-258.

389 Kurt Vonnegut, Slaughterhouse-Five: A Novel (Dial Press Trade Paperback; Reissue edition, 1999), 224.

390 "Streets are burning. Fire has consumed everything. The entire city has drowned in a sea of fire." J. Mackiewicz, Sprawa pułkownika Miasojedowa (London 1989), 651.

391 In one particular volume, Cywilna obrona Warszawy we wrześniu 1939 r. Dokumenty, materiały prasowe, wspomnienia i relacje (eds. L. Dobroszycki, M. Drozdowski, M. Getter, A. Słomczyński (Warszawa 1964), we find such phrases as "true hell" (p. 144); "unleashed hell" (p. 296, p. 334); "a raging day of hell" (p. 336); "hell on earth" (p. 338); all referring to a single day of the siege, about which one of the authors wrote: "For Warsaw, 25 September was a thoroughly hellish day." (p. 320). 
Ludwik Landau, describing Czacki Street burning during the air raid over Warsaw on "black Monday," drew a comparison with a fiery furnace from which there is no escape:

During a fire, it was improbable that one could have escaped this street, with its several dozen buildings and closed in between two other streets; fire, raging on both sides of the street, opened a vault of flames, under which people ran, consumed by fear [...]. People felt sentenced to imminent death; people reportedly fell to their knees and began to pray. ${ }^{392}$

Sabina Dłużniewska, who during that bombing found herself on the campus of the University of Warsaw, described a gloomy cellar at the Law Department, filled with people moaning in delirium alongside people dying from their wounds, as hellish.

It was dusk, but we could see the courtyard from the light of the fires. [...] It was no longer possible to work in the operating room. Ola Wróbelewska said: "Come look at hell," and she led me to the Law Department building. There in the basement were the injured, laying on the bare floor, closely, one after the other. The air was horrible. Tropical heat. The huge basement was poorly lit by a couple candles. Hundreds of people muttering in delirium. The foul smell made it difficult to breath. [...] No one had removed the corpses away from the living. ${ }^{393}$

In an account written during his time in German captivity, Colonel Stanisław Rola-Arciszewski presented the day of 25 September as "hell unleashed."

There began an exceptional bombardment, unprecedented in history. As if hell had tossed up all its devils from the abyss. [...] On the streets, smoke like impenetrable fog. And German planes diving from above this fog, into this bubbling cauldron of dust, smoke and flames [...]. Warsaw is surrounded by horror. ${ }^{394}$

Let us quote from a testimony describing an air raid over Düsseldorf carried out by British bombers on 10 September 1942. Marii Schmitz, who survived the bombardment, wrote:

Fires raged for many hours, in the burning heat the winds grew to the strength of a hurricane. It seemed like the gates of hell had been opened. With the characteristic, monotone and almost pathetic rumble, all along the street, staircases, curtains, furniture turned into ashes and cinders. [...] Glowing ash rained down, sparks struck us in the face. The all-consuming fire boiled, hammered and crackled. The heat surrounded us with a power that was difficult to endure. ${ }^{395}$

392 Landau, op. cit., 16

393 S. Dłużniewska, Pamiętnik warszawski, wyd. 2 (Warszawa 1965), 79-80.

394 S. Rola-Arciszewski, op. cit., 326.

395 Quote from J. Piekałkiewicz, op. cit., 67. 
Fire is a force of violent, unrestrained and all-encompassing transformation. We say that fire "consumes," that it is insatiable, that it devours everything within its grasp, that it transforms everything into something unrecognizable. This transformation is destructive. Forests and steppes, cities and people are defenseless against it. Elias Canetti, to whose views I refer below, highlighted fire's power of attraction, the magical influence that fires have on people. ${ }^{396} \mathrm{In}$ his The Psychoanalysis of Fire, Gaston Bachelard began with a statement about its ambivalence:

If all that changes slowly may be explained by life, all that changes quickly is explained by fire. [...] Among all phenomena, it is really the only one to which there can be so definitely attributed the opposing values of good and evil. It shines in Paradise. It burns in Hell. It is gentleness and torture. It is cookery and it is apocalypse. ${ }^{397}$

\section{Ambivalence}

So far, in the analysis of the experience of bombardment, such terms and phrases as "scenery," "sight," and "played out in front of one's eyes" have appeared. And this is no coincidence, because bombardment contains within itself something of a spectacle, a gigantic para-theatrical spectacle, played out in natural locations. The difference between modern displays of "light and sound" and the spectacle of bombardment is - so to speak - ontological: reality vs. pretend; reality vs. fiction. That having been said, the phenomenon of bombardment is based on the effacement (at least to a certain degree) of the boundary between literality and that which is made-up or unreal, and on the commingling of two roles, two perspectives: viewer and (simultaneously) participant. Bomber pilots, and the city residents on whom the bombs fall, each fulfill the role that is assigned to them (one attacks, and the other defends himself from the attack); both the one and the other watch what plays out below or around them. Viewing, observing, watching the spectacle of bombardment - this is the state, the condition, that connects victim and perpetrator.

What we thus have here is a peculiar situation involving a "spectator in a theater." I write peculiar because the paralyzing awareness of the genuineness of the observed event does not completely negate the feeling of its unrealism, its theatricality. Genuineness and unrealism even seem to coexist with one another, they complement one another - a fact that deepens the uncommon and inexpressible

396 Elias Canetti, Crowds and Power (Farrar, Straus and Giroux, 1984), 77-78.

397 Gaston Bachelard, The Psychoanalysis of Fire, trans. Alan C. M. Ross (Beacon Press, 1987), 7. 
nature of the entire experience. Paraphrasing such feelings, one could say that "what I am seeing is inconceivable," or "what I am looking at cannot be true"and yet it is true, it is really happening. To put it yet another way: the sight of the bombardment of a city is a spectacle, but the viewer knows - as in Cyprian Norwid's Marionetki - that this theater is “życiem płacony" (paid for with life).

What do viewers - those who were the object of air raids, who came close to death, but who (by some miracle) escaped with their life - have to tell us? The following accounts were arranged chronologically, in the order of changing city-scenes.

Warsaw in September 1939. An employee in the Jewish Community observed an air raid, which was so awful, so amazing, so captivating:

The entire horizon was shrouded by columns of smoke and fire. Everything together had become one great and terrible glow. I stood for several moments as if bewitched by this terrible destructive power, it was so awful, so amazing that I ran back from this burning hell, stepping over corpses and rubble. ${ }^{398}$

Canterbury, 1 June 1942. Jack Waller, a 35-year-old bus driver, observed the city being consumed in flames - terrible and beautiful at the same time - as he contended with the feeling of impropriety:

I was standing between two small brick buildings. And so I was standing there looking at the flames. Fire gradually enveloped St. George's Street, engulfing shop after shop. [...] As I was standing there, I thought, look at all the great clothing that is burning, all the cakes and shoes. That's what I was thinking. The church spire at St. Gregory's looked like a huge torch. It was wonderful, I mean it would have been a great view, if not for these tragic circumstances. It was really a beautiful view, the whole spire consumed in flames, everything was burning, and I'm one of the few who is witnessing it. Because no one was around, not another living soul. ${ }^{399}$

Ruth Taylor was 24-years-old when the bombs fell on Canterbury. She admitted that the view was "absolutely fantastic."

Canterbury looked like a huge mass of flames, but it was absolutely fantastic what was happening at St. George's Terrace, with the old tenement houses. It was one wall of fire, rising, as it seemed, straight to heaven. I'd never seen anything like it in my life. ${ }^{400}$

398 [author unknown], “Z notatek pracownika Gminy Żydowskiej w Warszawie," Biuletyn ŻIH, 93 (1976), 100.

399 Memories of the Blitz. The People's Story of the Bombing of Canterbury, 1st June 1942, compiled by A Pope (Canterbury 1992), 10.

400 Ibid., 20. 
Hamburg, 24 July-2 August 1943. A German soldier named Albert Hartung, at his post in an anti-aircraft battery and apparently embarrassed and helpless in the face of his contradictory feelings, described his impressions:

We were up on a hill at Neu-Wulmstorf, south of the city, and we had a panoramic view of the bombing. I know it sounds a bit silly now but it was a lovely view. We couldn't hear the bombs falling because there was a Flak battery firing nearby. We didn't see the effects of the bombs, only this marvelous fireworks display. I changed my mind when I saw the destruction a few days later. ${ }^{401}$

The Warsaw Uprising. Leopold Buczkowski was battling in the district of Żoliborz, and during the battle he made entries into his diary. His entry dated 2 August 1944, about the bombardment and fires, turns into a Marian invocation, unusual in this context:

The German air force is above us several dozen times every day - they bomb without opposition, fires are raging! - Ave Maria! Today St. John's Cathedral collapsed! And other churches. Non licet! Ave! ${ }^{402}$

Leszek Prorok on the Soviet air raid on the Warsaw district of Praga on 10 September 1944 - a view worthy of a paint brush:

A Soviet air raid over Praga. The right bank of the Vistula is illuminated by lanterns on parachutes. Powerful detonations and air battles can be heard. The entire city is sitting on roofs and taking in this wonderful view, one that is worthy of the best paint brush. ${ }^{403}$

A hospital orderly named Wiesława Kamper from the Old City, the night before her evacuation through the sewers to Warsaw Sródmieście (Center), sat in the Market Square among the burning buildings, "strangely calm, numb. And I suddenly thought to myself that I am sitting like Nero before burning Rome and that I am watching the fire with pleasure." ${ }^{304} \mathrm{~A}$ moment later, she adds, with concern: "I was overcome with a mood that was inappropriate to the situation." This feeling of something "inappropriate" is testimony to the ambivalence of the experienced event.

401 See Middlebrook, The Battle of Hamburg, 154.

402 L. Buczkowski, "Powstanie na Żoliborzu” [dziennik powstańczy], Regiony 3/4 (1992), 3-4.

403 L. Prorok, "Notatnik powstańczy," in Prorok, Kepi wojska francuskiego (Warszawa 1973), 147.

404 Account by W. Kamper ("Sławka”). Quote from Pelnić służbę... Z pamiętników i wspomnień harcerek Warszawy 1939-1945, eds. A. Zawadzka, Z. Zawadzka (Warszawa 1983), 274. 
Dresden, 13-14 February 1945. In her diary written just after the war, GiselaAlexandra Moeltgen confessed that the monstrosity of Dresden was also impressive:

Out through the narrow cellar windows we went, flames whipping down the staircase, the whole building alight. It was a gruesome and at the same time impressive picture as one stepped out into the street. Flames, flames wherever one looked. ${ }^{405}$

Tokyo, 9 March 1945. Around midnight, American Superfortress bombers began dropping incendiary bombs on the city in such a way as to create a vast circle of fire. The night sky was lit by markers falling on parachutes which, at a predetermined altitude, exploded - like fireworks - throwing out a fountain of light illuminating the target. Robert Guillain, a French war correspondent, was in Tokyo at the time and also perceived the bombing as an impressive display:

All the Japanese in the gardens near mine were outdoors or peering up out of their holes, uttering cries of admiration - this was typically Japanese - at this grandiose, almost theatrical spectacle. ${ }^{406}$

Accounts provided by the pilots, the direct perpetrators of this infernal spectacle, resemble the victims' accounts. British bomber pilots, observing the sea of flames expanding below, wrote about "fantastic views" and a "wonderful, amazing spectacle," about terror and fascination. When a group of Lancasters flew over Dresden to drop their entire load of bombs, huge expanses of the city were already in flames. One of the navigators remembered:

[...] my skipper called me on this particular occasion to come and have a look. The sight was indeed fantastic. From some twenty thousand feet, Dresden was a city with every street etched in fire. ${ }^{407}$

From his plane, Flight Lieutenant A. Forsdike from the RAF 78 Bomber Squadron, looked down upon burning Hamburg. What is significant in his account is the mixture of horror and delight:

The burning of Hamburg that night was remarkable in that I saw not many fires, but one. Set in the darkness was a turbulent dome of bright red fire, lighted and ignited like the glowing heart of a vast brazier. I saw no streets, no outlines of buildings, only brighter fires which flared like yellow torches against a background of bright red ash. Above the city was a misty red haze. I looked down, fascinated but aghast, satisfied yet horrified. ${ }^{408}$

405 McKee, Dresden 1945, 153.

406 F. Guillain, I Saw Tokyo Burning. An Eyewitness Narrative from Pearl Harbor to Hiroshima (Garden City 1981), 182.

407 D. Irving, op cit., 241.

408 Middlebrook, The Battle of Hamburg, 244. 
Another pilot flying over Hamburg, Sergeant W. G. Lamb of the 460 Squadron, described his impressions in an almost identical way: "I was fascinated by the awesome and amazing spectacle. As far as I could see was one mass of fire." ${ }^{409}$

The sight of a burning city, collapsing under the burden of exploding bombs has a particular virtue, namely ambivalence: the intertwined features of terror and beauty, horror and fascination. What was written above about the dual nature of fire and its magical powers of attraction is highly useful here. Through its ambivalence, the experience of bombardment can be inscribed into the structure of the experience of the sacred - that is, what Rudolf Otto called numinosum, and Gerard van der Leeuw called power. ${ }^{410}$ So conceived, one experiences the sacred simultaneously as dangerous and fascinating. Making use of Rudolf Otto's terminology, we would say that numinosum is contained within experience as a mystery that is both repulsive and appealing, as mysterium tremendum et fascinosum. ${ }^{411}$

Finally, let us turn to one more bombardment. Hiroshima, 6 August 1945, 08:45 in the morning. Instead of thousands of bombs falling on a city, only one bomb was dropped. Today we know that this was the beginning of a new era. But

409 Ibid.

410 See Rudolf Otto, The Idea of the Holy; Gerardus Van der Leeuw, Religion in Essence and Manifestation.

411 “The qualitative content of the numinous experience, to which 'the mysterious' stands as form, is in one of its aspects the element of daunting 'awfulness' and 'majesty', which has already been dealt with in detail; but it is clear that it has at the same time another aspect, in which it shows itself as something uniquely attractive and fascinating. These two qualities, the daunting and the fascinating, now combine in a strange harmony of contrasts." A few lines later, Otto writes that "the 'mystery' is for him not merely something to be wondered at but something that entrances him [...]." In explaining the difficulty involved in grasping the meaning of the Greek term deinos (that which is astounding, terrible), Otto indicates that "if we ask whence this difficulty arises, the answer is plain; it is because $\delta \varepsilon$ เvó is simply numinous (mostly of course at a lower level, in an arrested form, attenuated by rhetorical or poetic usage). Consequently, $\delta \varepsilon \imath v$ ó $\varsigma$ is the equivalent of 'dirus' and 'tremendus'. It may be evil or imposing, potent and strange, queer and marvelous, horrifying and fascinating, divine and daemonic, and a source of 'energy."' (Rudolf Otto, The Idea of the Holy, 31, 39-40). Z. Benedyktowicz applied the concept apparatus of phenomenology to the basis of ethnology. In his study of that which is "other" in folk culture, he states that, in many respects, the relationship to others resembles the relationship to the sacred, and he points to similarities with many elements of the numinous experience, whose structure Otto examined. See Z. Benedyktowicz, Portrety "obcego". Od stereotypu do symbolu (Kraków, 2000). 
on that August morning, could residents of Hiroshima possibly have been aware of this fact? They remembered the fiery destruction of Tokyo and other "conventional" bombardments, which were, for the people of Hiroshima, the closest comparative context. At the time, Michihiko Hachiya, director of a hospital located about 1,500 meters from the explosion's epicenter, was maintaining a diary. $\mathrm{He}$ described his own observations and the experiences of others, including one Mr. Hashimoto:

It was an awful experience [...] I saw a huge cloud rise angrily over Hiroshima, and on both sides of the main cloud beautiful smaller clouds spread out like a golden screen. I have never seen anything so magnificent in my life! [...] That beautiful cloud! It was neither red nor yellow. Its beauty defies description. ${ }^{412}$

Compared to accounts cited above on the bombardments in Europe, this anecdote is something absolutely extraordinary. In the mass imagination, Hiroshima - wiped from the face of the earth by the explosion of the first atom bomb - remains the embodiment of all that is monstrous about modern destruction. In his account, Mr. Hashimoto, who saw with his own eyes the mushroom cloud rise above the city, revealed the extraordinary nature of the experience of bombardment's "holy terror" - the mysterium tremendum et fascinosum.

\section{The (Re-)Construction of Memory}

In 1945, Elias Canetti wrote:

Germany, destroyed earlier in the year as no land has ever been destroyed. And if it is possible to destroy one land in this way - how can Germany remain the only one? [...] The cities die, men hole up deeper. ${ }^{413}$

What is happening today with memory extracted from the depths, with the past buried in rubble? What kind of future does that memory project? What role does it assign to the new generation? How does it shape the present in which we all live?

Of greatest interest to me are: the ways in which the experience of bombardment has been fixed in the memories of victims and perpetrators; the ways in which this experience appears in public discourse; how memory of the air raids has undergone metamorphosis; and the nature of the relationship between memory of the events and their present-day evocations. More succinctly: can

412 Michihiko Hachiya, Hiroshima Diary: The Journal of a Japanese Physician (The University of North Carolina Press, 1995), 161-162.

413 Elias Canetti, The Human Province (Seabury Press, 1978), 60. 
we point to a certain strategy for remembering, to an attempt to instrumentalize memory?

Let us describe the basic stages in which Germans have reckoned with their past, attempted to create a new self-identify, over the course of the last decade of the twentieth century and the first years of the current century. ${ }^{414}$

The first stage involved a "sudden return to reflections on guilt," and is characterized by conflicts over the "Wehrmacht Crimes" exhibition (1995-2000), over Daniel Goldhagen's book Hitler's Willing Executioners (1996-1998), and over the Holocaust Memorial in Berlin (1998-2000). A turning point came with the heated debate surrounding Martin Walser's acceptance speech for the 1998 Peace Prize of the German Book Trade. Many people received that speech as a manifesto for historical "normalization," which - in a simplified version - can be thus paraphrased: enough of the instrumentalization of National Socialist history, particularly the Holocaust; enough of the masochistic remembrance of German crimes. Among other things, Walser said:

[...] when I am reproached every day in the media for this past, I notice that something inside me reacts against the permanent presentation of our disgrace. Instead of being thankful for this continuous presentation of our disgrace, I start to look away. ${ }^{415}$

The second stage involved the "return to reflections on German victims." In 1997, two American political scientists published a book under the title Das deutsche Dilemma, in which they claimed that Germans had stopped perceiving themselves only as perpetrators and increasingly viewed themselves as victims of the war. The Germans' historical memory (including memory of the Holocaust),

414 I make use of the following works: W. Pięciak, Niemiecka pamięć. Wspótczesne spory w Niemczech o miejsce III Rzeszy w historii, polityce i tożsamości (1989-2001) (Kraków 2002); Pięciak, "Naród ofiar," Rzeczpospolita, 2 August 2003; Pięciak, "Drezno, akt oskarżenia," Rzeczpospolita, 22-23 lutego 2003; Pięciak, "Requiem dla miasta Drezna," in Pięciak, Jak obalano mur. Niemcy 1988-96 (Kraków 1996). Spór o niemiecka pamięć. Debata Walser - Bubis, intro. K. Woycicki, ed. P. Buras (Wrocław 1999).

415 Translator's note: The above text is my translation from the original German: "[...] wenn mir aber jeden Tag in den Medien diese Vergangenheit vorgehalten wird, merke ich, daß sich in mir etwas gegen diese Dauerpräsentation unserer Schande wehrt. Anstatt dankbar zu sein für die unaufhörliche Präsentation unserer Schande, fange ich an wegzuschauen." Quoted in Rolf-Peter Janz, "Zum Tabu des Antisemitismus: Die Kontroversen um Martin Walser und Günther Grass," Zeitschrift für interkulturelle Germanistik: 7. Jahrgang, 2016, Issue 1, p. 49. See also M. Walser, "Przemyślenia przy pisaniu mowy na niedzielę," in Spór o niemiecką pamięc, 43. 
which helped define the political culture of the Federal Republic of Germany before 1989, was disappearing because:

[...] the mechanisms of political legitimacy and collective identity will, in the future, assume different forms than in the "old" Federal Republic. To an ever greater degree, "historicized" crimes from the past take on new meanings; in particular guilt, shame, and a sense of responsibility, and thus emotional reactions, will gradually be replaced by purely intellectualized forms of reckoning with the past." ${ }^{\prime 16}$

Wojciech Pięciak has summarized the thesis of Das deutsche Dilemma in this way: the two authors show that "political normalization" leads to "normalization of the past"; that the Germans have stopped viewing themselves as perpetrators alone, and increasingly regard themselves as victims of the war; that after the "historicization of Auschwitz," the condition of victimhood becomes an equal element of German collective memory. ${ }^{417}$ In March 1999, during the Kosovo War and the associated refugee crisis, German public opinion supported the case of the victims of ethnic cleansing and expressed empathy for those who had been "expelled." A year earlier, discussion began over the creation in Berlin of a Center Against Expulsions (Zentrum gegen Vertreibungen). Public debate on this subject drew strength from Günther Grass's Crabwalk (2002, English version 2002), which describes the tragedy experienced by German refugees and injured fleeing Prussia on board the Gustloff, which was torpedoed and sunk by a Soviet submarine in January 1945. In the Gustloff tragedy, 9,343 people died.

One distinct aspect of this second stage of debates over German memory involves the Allied bombing of German cities.

\section{Accounts by Victims}

Accounts by victims who survived the bombardment are striking. It is clear that their authors have grappled with descriptions of an experience that was without precedent. That having been said, many of them are not in a position to liberate themselves from worn-out conventions ("sea of flames," "fiery rain"); from obsessive use of infernal imagery ("Dresden had been turned into hell"418); from biblical comparisons or concepts that border on kitsch ("it was like "The Last

416 Quote from W. Pięciak, op. cit. 363.

417 Ibid.

418 See the account of G. Kühnemund, who at the time of the bombing was a fifteen-yearold member of the Hitlerjugend, in A. McKee, op. cit., 153. 
Days of Pompeii' "'419). For them, bombardment was not just something terrible and frightening, it was also surprising; hence, alongside terror, victims express feelings of a kind of amazement, disbelief.

Another typical feature of these accounts is the fragmentation of experience. We are often confronted with severe and brutal images, isolated from one another, and with stray scraps of observed situations. Hamburg: A completely naked woman in an advanced stage of pregnancy runs from the street, engulfed by flames, to the gate of a burning (but still standing) building. She falls to the sidewalk and bears her child. ${ }^{420}$ Dresden: A woman with a small child in her arms runs in panic through the firestorm, she trips and falls, losing her grip on the child. The bundle with the child flies straight into the fire, the mother frozen stiff on the sidewalk. ${ }^{421}$ Dortmund: the Italian priest Giuseppe Barbero wrote about the devastation caused by the bombs among the prisoners of Stalag VI-D:

Our air was cut off and at the same moment our lungs were smothered and we were buried in dust. A shelter of the French and Serbs was utterly demolished. All that remained was a pile of flesh where you could make out only arms, legs, and ripped off heads. The Russians again suffered the greatest number of deaths, about two hundred. ${ }^{422}$

From among the macabre scenes, one can detect a series of repeating motifs; the motif that appears most often, and is offered up in a most literal way, is that of the path through the fire. Trute Koch, who was a fifteen-year-old girl at the time, wrote about her experience in Hamburg:

Mother wrapped me in wet sheets, kissed me, and said 'Run!' I hesitated at the door. In front of me I could see only fire - everything red, like the door to a furnace. An intense heat struck me. A burning beam fell in front of my feet. I shied back but, then, when I was ready to jump over it, it was whirled away by a ghostly hand. I ran out to the street. The sheets around me acted as sails and I had the feeling that I was being carried away by the storm. ${ }^{423}$

The Wehrmacht soldier Wilhelm Riecker wrote about the burning streets of Pforzheim, in which - during the bombardment through the night of 23-24 February 1925 - a third of the city's 65,000 residents perished:

419 See the account of Frau Canzler, wife of a doctor at a Dresden hospital. Quoted from ibid., 233.

420 See G. Musgrove, op. cit., 83.

421 See McKee, op. cit., 191.

422 Friedrich, The Fire, 137.

423 See Middlebrook, The Battle of Hamburg, 264. 
They dunked blankets and towels in the bucket, wrapped them around themselves, and ran through the flames to the Enz River, where they doused themselves again with water, since the heat and flying sparks were incredible. Sedan Square converged the flames from all the streets leading into it and then let the scorching force escape toward the bridge. The flames shot over it into the city center and there the mushroom rose up steeply, drawing all the fire into its shaft. During this hour the radiant heat was so intense that people were jumping into the wintry cold river. ${ }^{424}$

The desperate escape from the flames into a river, reservoir, or canal often represented the only path to safety for residents of Hamburg and Dresden. But it was precisely in the freezing waters where many of them found their deaths: splitting their heads on the concrete walls of the reservoirs, drowning, or suffocating on smoke.

Another motif that repeatedly appears in accounts written by those who survived bombardment is the almost surreal annihilation of the Dresden zoo. The death of animals, mad with terror amidst the fiery streets, seems to turn Salvador Dali's vision of a burning giraffe into a nightmarish reality:

In the middle of the square was the round circus building; I believe there had been a special Carnival night performance. The building was burning fiercely, and was collapsing even as we watched. In a nearby street I saw a terrified group of dappled circus horses with brightly coloured trappings standing in a circle close to each other. ${ }^{425}$

The macabre image of a corpse welded into the heated-up asphalt also appears repeatedly in accounts. A certain woman from the Reich Labor Service, which was deployed to remove the corpses after the air raids in Dresden, remembered:

One shape I shall never forget was the remains of what had apparently been a mother and child. They had shriveled and charred into one piece, and had stuck rigidly to the asphalt. They had just been prised off it. The child must have been beneath its mother, because you could clearly see its outline, with its mother's arms clasped around it. [...] All across the city we could see the victims lying face down, literally glued to the asphalt, which had softened and melted in the enormous heat. ${ }^{426}$

Though they do not minimize the drastic nature of their experiences, survivors recalling an air raid after many years attempt to tame the chaos of those experiences; they try to narrate them "in order." Narrative organization is achieved here by imposing a pre-arranged strategy for recalling events onto traumatized memory.

424 Friedrich, The Fire, 91-93.

425 Irving, Apocalypse 1945, 182.

426 Ibid., 211-212. 
Alexander McKee quoted widely from Margaret Frezer's account written three years after the air raid on Dresden. ${ }^{427}$ She lived in the city's Old Town, and was not a Nazi enthusiast. In 1943, the Gestapo interrogated her for an entire day for having told a joke in a theater cloakroom. On the night of 13-14 February 1945 she found herself right in the middle of the firestorm that would devastate Dresden. She survived that infernal "witches' cauldron," as she called the burning city. Her account is the voice of one of thousands of residents whom Allied airmen could not reach from above. This moving testimony provides a record of an individual experience with bombardment in which the author never forswears that which is private in favor of the broader view of events. She represents only herself. She displays a limited and increasingly narrow field of vision; she describes the chaos of the world around her, which - in its unconstrained horror - defies description. Margaret Frezer is mercilessly matter-of-fact; she does not allow emotions to obscure the materiality of her imagery. She does not use shocking adjectives, and she does not obscure factual accounts with evaluative reflections. She tries to keep language as close as possible to things, in order to be able to lift and carry the burden of memory. Here, matter-of-factness (sometimes treated dispassionately, as if by a reporter, and sometimes revealing in its macabre literality) becomes an idiom for bombardment.

\section{Perpetrators' Accounts}

What dominates accounts by the perpetrators - that is, British pilots dropping bombs on Dresden - are various strategies to justify the air raids and explain their pangs of conscience. These strategies are supported by three pillars, which can be called by three names: orders - war - and revenge.

If any of them expressed sympathy for the victims, it was clouded by a sense of higher necessity to which the pilot had to submit. "It was terrible," one pilot said in a film documentary on the 50th anniversary of the bombing. "I looked down on that sea of flames and thought, how can people do this to other people. But we had to." Another pilot added: "Sometimes you have to fight evil with evil. It is difficult, but it has to be this way." 228

A Lancaster bomb-aimer, recalling the first wave of bombing and the streets of Dresden below, wrote: "It was the only time I ever felt sorry for the Germans. But my sorrow lasted only for a few seconds; the job was to hit the enemy and to hit him very hard." 429

427 See McKee, op. cit., s. 189-195.

428 Quote from W. Pięciak, Requiem dla miasta Drezna, op. cit., 301-302.

429 Irving, Apocalypse 1945, 240. 
The classic argument involves war, and one might add: total war, which justifies inflicting death on civilians, since one way or another they are tied to the enemy's military machine. One of the pilots bombing Dresden said:

I do not have a bad conscience [...]. I dropped bombs on civilians, but it was war: I was flying an airplane that was built by civilians, and those civilians down below could be the ones who put together the anti-aircraft gun that shot down my friends. ${ }^{430}$

Peter de Wesselow, squadron leader during the second wave of attacks, put together a many-layered system of argumentation. First - it was better to "preventively" kill German civilians, who are not "so completely innocent," than to allow them to kill "completely innocent" (read: our) civilians. Second - though the fate of German civilians was tragic, they lived around transportation, industrial and military centers, which must be destroyed, since the war was ongoing. Third - as an argument ex post, the question of capitulation: the bombing of Dresden was a response to the fact that Germany had not capitulated, even in the face of obvious defeat. If Dresden's fate was worse than Hiroshima's, then why did the Germans not immediately capitulate like the Japanese? ${ }^{431}$

Finally, the question of revenge for German crimes as a fundamental motivation for pilots' actions, and simultaneously as a kind of absolution. From this perspective, bombardment was a justified act, a kind of "payback." Józef Zubrzycki, a Polish pilot in Division 300 taking part in the air raid over Dresden, put the matter this way:

You cannot pose such questions to airmen. About suffering and death. Because during flight one thinks in other categories. Down below is the enemy. That enemy attacked you, murdered your countrymen. Left your homeland in cinders. He is an occupier. Now you are fighting them. You look to see if the target is burning well. And you are happy when you see fire. One has to learn to think like a machine. And one can think only about two things: I am flying to carry out a task, and I have to return alive. You cannot think about anything else. Nerves and emotions can kill. ${ }^{432}$

One of the British pilots appearing in the 1995 anniversary documentary admitted:

If our boys up there had known then what we know today, about the Holocaust and other German crimes, they would have destroyed without hesitation not one Dresden, but a dozen. ${ }^{433}$

430 Quote from W. Pięciak, Requiem dla miasta Drezna, op. cit., 301.

431 See McKee, op. cit., s. 182.

432 Quote from M. Nocuj, W. Pięciak, "Musiałem myśleć jak maszyna," Tygodnik Powszechny, 13 lutego 2005.

433 Quote from W. Pięciak, Requiem dla miasta Drezna, op. cit., 302. 
Relatively rarely do we read about a pilot who spoke of the horror that came with sympathy for the victims, who wanted to look for no justification; or who even admitted to pangs of conscience or openly condemned the air raids. One member of a British bomber crew, as his plane was flying over the burning city, admitted:

The fantastic glow from two hundred miles away grew ever brighter as we moved in to the target. At twenty thousand feet we could see details in the unearthly blaze that had never been visible before. For the first time in many operations I felt sorry for the population below. ${ }^{434}$

Dresden was too peaceful for us. It would have been fair if we'd been fired at. To just fly over it without opposition felt like murder. I felt it was a cowardly war, that there were people down there who were defenseless. I always felt the same way about Dresden and I've never gone back on it. I can remember that raid, visually, as if it was yesterday. That wasn't so with other raids. I've forgotten them, they've all become blurred in my memory, so similar were they to each other - Hamburg, Cologne, Berlin. But I feel guilty about Dresden. You could have flown low over Dresden, which you couldn't do elsewhere. It struck me at the time, the thought of women and children down there. [...] I found myself making comments to the crew: "Oh God, those poor people." It was completely uncalled for. ${ }^{435}$

\section{Observers}

Air raids over German cities were treated like expected revenge. This payback militated against the Germans: they destroyed more and caused more harm. One author commented in an article for Biuletyn Informacyjny dated 15 July 1943:

The Germans, incensed by damage inflicted on the Cologne cathedral, have so far destroyed 800 churches in England alone, and two historic cathedrals in Canterbury and Exeter. And how many churches in other countries have the Germans destroyed?! And in Poland?! Hypocrites ${ }^{136}$

Among people in German-occupied countries, bombardments triggered a basic sense of satisfaction and joy. In the context of the growing terror against Poles, Ludwik Landau - in his Kronika lat wojny i okupacji - wrote about what a "consolation" it was for dejected Varsovians to hear the news of the bombing of Berlin. This news was the "greatest, most anticipated 'attraction' for Warsaw."

434 Irving, Apocalypse 1945, 150.

435 McKee, op. cit., s. 222.

436 Quote from “'Biuletyn Informacyjny.' Część III. Przedruk rocznika 1944. Konspiracja," Przeglad Historyczno-Wojskowy, rok IV (LV), nr specjalny 3 (200) (Warszawa 2003), 1665. 
Commenting on the first powerful wave of air raids that initiated the "air battle for Berlin," Landau noted on 24 November 1943:

There was huge destruction and huge fires. The waterworks were destroyed and telephone connections with other cities were broken off. The radio station was damaged, etc. [A day later, Landau added:] And again one thing for consolation is the air raid over Berlin - or rather, air raids, because they come one after the other until people lose count. Berliners are not losing count. [...] It seems that the English are now doing to Berlin what they did to Hamburg. Are the Germans going to wait for the destruction of all of their great cities? ?37 $^{2}$

From distant Palestine, Władysław Broniewski sent a poetic blessing to airmen bombing German cities:

Bomby na Hamm, na Essen, na Berlin, na Kolonię! Za każdą bombą lecę sercem na spadochronie i błogosławię dymom, i błogoslawię zgliszczom. i aniołom-olbrzymom: niechaj lecą i niszczą! ... ${ }^{\text {a }}$
Bombs on Hamm, on Essen, on Berlin, on Cologne! I'm flying behind every bomb With my heart on a parachute and I bless the smoke, and I bless the ruins. and angels-giants: let them fly and destroy! ...

a Fragment of the poem "War Pictorial News," from Drzewo rozpaczajqce (1945). Quote from W. Broniewski, Wiersze i poematy (Warszawa 1970), 123.

The mood on the streets of Warsaw was reflected in a carol from December 1943, printed in Biuletyn Informacyjny. It brings "cheerful news" about the fact that:

Tysiąc bombowców

Leci do Berlina!

Berlin się pali, w gruzy się wali! [...]

Ludzie się radują, Bimbrem się częstują, Końca wojny oczekują! ...
A thousand bombers are flying to Berlin! Berlin is burning, collapsing into rubble! [... and in response to all that] People rejoice, They pass around moonshine, Waiting for the war to end! ...

437 L. Landau, Kronika lat wojny i okupacji, vol. 1, lipiec 1943 - luty 1944 (Warszawa 1963), 426-427, 430. 
The author who anonymously submitted this text for print attached a characteristic commentary. The carol was sung everywhere: in the alleyways, at churches, at tram stops. It was the voice of the people, "proud, rugged and tenacious, as proud, rugged and tenacious as Polish honor!" The laughter that this carol caused was "laughter through tears", since the tormented people of Warsaw knew that "the bloody German beast's end [is] near." In an interesting way the pathetic rhetoric of suffering is embedded in a boisterous and picaresque tone. The Warsaw streets on which this carol was born were:

[...] soaked in the blood of insurgents and the blood of warriors. [...] Fluffy white snow falls onto the rubble of German-bombed Warsaw, onto the burned out streets, onto the apartment blocks blown to bits, and mixes with the martyred blood of [the city's] hostages. ${ }^{438}$

In this way, the tragic fate of Warsaw, abused by its occupiers, provided the moral legitimacy for the logic of revenge.

But the "cheerful news" about bombardment was tainted by the bitter awareness that the joy and satisfaction offered by revenge was a blemish on the conscience and testimony to the moral corruption - for which (we might add) the enemy was to blame. We find such an attitude in the writings of Andrzej Bobkowski:

18.10.1942. The English are currently bombing Germany with two-ton bombs, but we also hear about four-ton bombs. The Germans call them "Bezirksbomben" because one of them can bring down an entire city district. One is happy like a child when one hears of such miracles. They brought such rubble upon us. And we are repaying them with their own "culture." 439

It was not just "carols about the bombing of Berlin" that circulated through occupied Warsaw, but also a poem by Leonia Jabłonkówna under the title Modlitwa. The author referred to the Christian command to love your enemy and to the warning to avoid the destructive power of hatred. Without forgetting the litany of disasters that had befallen the Polish people, she rejected the temptation for revenge and directed her plea toward God:

Zbaw, Panie, kobiety i dzieci Lord, save the women and children

Z płonących pożarów Hamburga. ${ }^{a} \quad$ From the burning fires of Hamburg.

a L. Jabłonkówna, Modlitwa, "Prawda," periodical of the Front Odrodzenia

Polski, ed. Z. Kossak, issue for October-November 1943, quote from

W. Bartoszewski, 1859 dni Warszawy (Kraków 1974), 470-471.

438 Biuletyn Informacyjny, 23 December 1943, quote from Biuletyn Informacyjny, część III, op. cit., 1728-1729.

439 A. Bobkowski, Szkice piórkiem (Warszawa 1995), 33. 
When the hail of bombs began to fall on German cities, staunch opponents of the air raids protested vehemently. They condemned bombing regardless of its strategic goals and in spite of the extraordinary military situation, and they treated them as operations that could not be justified, that were clearly evil, unprincipled, and barbaric. Georges Bell, the Anglican Bishop of Chichester, stated that the entire German nation could not be blamed for crimes committed by the Nazi leadership and could not be punished for them. He particularly opposed the air raids carried out over German cities, writing that:

[...] to bomb cities as cities, deliberately to attack civilians, quite irrespective of whether or not they are actively contributing to the war effort, is a wrong deed, whether done by the Nazi or by ourselves." 440

The author of what was probably the most prominent antiwar pamphlet at the time was Vera Brittain, whose Seed of Chaos, published in London in 1944, was a powerful condemnation of Allied bombing. George Orwell was one person who aggressively criticized the work, but such critics did not yet know what would happen to Dresden on the night of 13-14 February $1945 .{ }^{441}$

Traveling through Allied-occupied Germany in the autumn of 1945, Jerzy Stempowski wrote that German cities had been "razed," and that the ruins of this new urban topography "looked like the remains of an ancient city." In his Dziennik podróży do Austrii i Niemiec, he wrote that the indirect goal of bombardment was to threaten to strike at the heart of Germanic civilization, which could rise again after the war in a Rhenish, Bavarian, Hanseatic or Saxon version to replace the militarily defeated Prussian version. What would be necessary for such a renaissance was the will of the nation to root their thought in buildings and monuments. What would happen if that foundation were destroyed? Hence, the Allied threat:

[...] if you don't capitulate immediately, we will deprive you of your past, we will dump rubble in the path of your traditions and hopes. Today we know that neither the threat, nor the carrying out of that threat, brought the desired results, above all because Hitlerite Germany had no intention of protecting the past and tradition. Like Soviet

440 See Middlebrook, The Battle of Hamburg, 346.

441 On the moral attitudes of the British toward the bombardment of German cities, and on Vera Brittain and her work, see Grayling, Among the Dead Cities, 179-208 (chapter entitled "Voices of Conscience"). 
communism, National Socialism emerged from ahistorical currents and looked a thousand years into the future, without looking back. ${ }^{442}$

A half-year after the war ended, Stempowski was asking key questions about the influence of bombardment on Germany's future, on its internal development, and on the place it would take in Europe. He feared that the traumatic experiences associated with the air raids would push Germany "toward a new anti-historicism and a new variant of national communism. ${ }^{443}$

\section{German Attitudes}

Victor Klemperer noted that, in the face of Allied air raids, the Germans were finally beginning to be afraid, and he cited the reaction of Jews from Dresden to the sight of people fleeing Hamburg: "Now the Aryans know what we feel like when we are driven out in just such a state of nakedness!" 444 A year before the destruction of Dresden, Klemperer added an entry to his journal stating that German fear of bombardment was in part the result of a bad conscience and feelings of guilt just then coming to the surface.

Today Frau Stühler for the first time heard someone say out loud in a queue of women that the Jews really had been treated too badly, they were "human beings, too" after all, and the attacks on Berlin and the destruction of Leipzig were retribution. ${ }^{445}$

But Klemperer was under no illusion: Goebbels' propaganda was effective, and the air raids - contrary to Allied expectations - were not weakening civilian morale, but strengthening it.

But the next and increasingly powerful bomb strikes left behind not just chaos and destruction, but also desperation and fear. An 18-year-old Günther Jäckel, who in 1944 had exchanged his Hitlerjugend uniform for a Luftwaffe uniform, was injured during the raid over Dresden and found himself in the crowd of refugees fleeing the city's smoldering ruins. He described the panicky flight: "Desperate people, ruthless people, women with baggage and children $[\ldots]$ loud and noisy and ruthless [...] there was already a feeling of collapse." 446

442 J. Stempowski, Od Berdyczowa do Lafitów, ed. and intro. A. S. Kowalczyk (Wołowiec 2001), 117.

443 Ibid., 118.

444 Klemperer, I Will Bear Witness 1942-1945, 254.

445 Ibid., 294.

446 Taylor, Dresden, 419. 
Latent feelings of guilt and a desire for the war to end as quickly as possible yielded to loud expressions of condemnation of Allied barbarity and a lust for revenge.

It was only after the British bombing of Dresden that the injured Waffen-SS officer Claus von Fehrentheil, who lay in a military hospital in the city, became aware of the Geneva Convention, which - according the Fehrentheil - was respected by all countries, but which the English had turned into a farce. Some compared the attack on Dresden with English cruelty during the Boer War. ${ }^{47}$ Traveling in the summer of 1943 "through the burned out cities of western Germany, which formed a dark chain one after the other," Ernst Jünger overheard:

[...] conversations among fellow passengers that strengthened this impression, conversations in which the sight of this world of rubble aroused the desire to produce even greater rubble; they hoped to see London soon in the same condition and muttered things about immense artillery batteries that were supposed to have been set up on the English Channel to shell that city. ${ }^{48}$

For Nazi elites, bombardment, particularly in its last stage, represented an extreme humiliation. Over and over again, Allied bombing compromised Göring and his bellicose declarations that he would never allow German cities to share the fate of Warsaw, Rotterdam, or London. Hitler took the destruction of Dresden hard. His personal doctor, Teodor Gilbert Morell, described the Führer's emotional condition: "His morale is low; he seems to have lost faith, evidently on account of the Eastern Front situation and the air-raids on Dresden." But Hitler's melancholy, the uncontrolled trembling in both of his hands, his generally weakened condition, did not prevent him from roaring at the Gauleiters who had assembled at the Reichschancellery on 24 February - 10 days after the catastrophic bombardment: "Even if my whole left side were paralyzed I would still call on the German people again and again not to capitulate but to hold out to the very end." ${ }^{449}$ After being informed of the Dresden bombing, Goebbels went crazy. His adjutant, Rudolf Semmler, described the Propaganda Minister's reaction:

The tears came into his eyes with grief and rage and shock. Twenty minutes later I saw him again. He was still crying and looked a broken man. But then there came a passionate outburst of rage; his veins swelled and he became red as a lobster. ${ }^{450}$

447 See McKee, op. cit., s. 160.

448 Ernst Jünger, Sämtliche Werke - Band 3: Tagebücher III: Strahlungen II (Klett-Cotta 1978), 82. Translator's note: The above text is my translation from the original German.

449 David Irving, The Secret Diaries of Hitler's Doctor (Focal Point, 2009), 211.

450 Roger Manvell, Heinrich Fraenkel, Doctor Goebbels: His Life and Death (Skyhorse Publishing, 2010), 268. 
Joseph Goebbels and Robert Ley, head of the German Labor Front, managed to get Hitler to agree to a drastic revenge operation. They proposed that Germany break with the Geneva Convention and execute tens of thousands of Allied prisoners of war, one for each German citizen killed in the air raids. Hitler liked this proposal and - as General Guderian recalled after the war - began to dwell on the Convention's effects on the German soldier's fighting spirit:

The soldiers on the Eastern Front fight far better. The reason they give in so easily in the west is simply the fault of that stupid Geneva Convention, which promises them good treatment as prisoners. We must scrap this idiotic convention. ${ }^{451}$

But the Führer's advisors talked him out of taking this step, and the plan to take bloody revenge was not implemented.

\section{Victor Klemperer - Józef Mackiewicz - Kurt Vonnegut}

By bombing Dresden, destroying the city's historic substance, and killing its residents, the Allies contributed to the fact that Victor Klemperer managed to survive the Thousand-Year Reich. On Friday 16 February, the tenants of the "Jewish home" in which the Klemperers lived were to be definitely evicted. On Tuesday evening, 13 February, the first bombs fell on the city. In the wave of refugees fleeing from the east, Victor and Eva Klemperer made their way to the Bavarian countryside, where they were liberated by the Americans on 28 April 1945. The writer, along with his wife, began the strenuous march eastward and finally returned to the scorched remains of Dresden in June 1945. He remained in the Soviet zone of occupied Germany until his death in 1960. He died in Dresden. His analysis of Nazi code (LTI - Lingua Tertii Imperii: A Philologist's Notebook), a pioneering work that has become a foundation of the study of totalitarian language, was first published in 1947, east of the Elbe, and then again in East Berlin two years later, at the very moment when the Soviet occupation zone was being transformed into the German Democratic Republic (GDR). As one reviewer of the Polish translation of LTI wrote, Klemperer would soon become an important consultant on the GDR's project to create a new political code. ${ }^{452}$ This would not be surprising, when we read, for example, one of the most amazing parts of LTI - Klemperer's comparative analysis of two metaphors, namely the famous verb gleichschalten and the less famous phrase Ingenieur der Seele. By way of conclusion, the author wrote: "Gleichschalten and Ingenieur

451 Ian Kershaw, Hitler: 1936-1945, 779.

452 See B. Bakuła, Pamiętnik Literacki 4 (1985), 428. 
der Seele [engineer of the soul] - both are technical expressions, but whilst the German metaphor points to slavery, the Russian one points to freedom." ${ }^{453}$

The ingenious philological ear that allowed Klemperer to unmask Nazi language clearly failed the author of LTI when it came to the language of communist propaganda. But it is worth asking how this seasoned expert in the French Enlightenment, not to mention experienced diarist, handled the description of the bombing of Dresden, which he miraculously survived.

The entry involving the air raid is dated 22-24 February 1945 and was written in the village of Piskowitz, ${ }^{454}$ about 25 kilometers northwest of Dresden. The Klemperers found themselves there, with other refugees, illegally, having registered themselves as Protestants. That distance traveled of 25 kilometers was, for the Klemperers, like leaping over a deep and deadly abyss; it marked the beginning of a new period in their lives. And it is in part for this reason that Klemperer viewed the air raid from two conflicting perspectives: as an extreme experience with a deadly threat, and at the same time as an incredible opportunity to be rescued.

Klemperer's portrayal of the bombardment is orderly; he carefully marks off the events, situations, experiences in which he and his wife took part. It is the story of a private experience, but the diarist's perspective covers a broader area. We thus have a panoramic view of the Dresden Old City in flames, as viewed from the other side of the Elbe; we see crowds of people seeking protection at Brühl's Terrace along the river. But in his desire to give expression to the unprecedented experience of bombardment, Klemperer tried to maintain a cohesive narrative, and he was unable to liberate himself from conventional stylistics. "Fires were blazing"; "in the distance there was fire everywhere"; buildings "standing out like a torch" - all of this was a scenario in which one could liberate oneself from the Jewish stigma, which was just as lethal as Allied bombs. Klemperer scrupulously noted particular links in his rescue operation. He left home as a Jew wearing the Star of David, obediently asked the sentry if the alarm had been announced. He stepped down into a Jewish cellar, having been allowed entry into no other shelter. Later, he ran through the burning streets. "I had wrapped the woolen blanket [...] around head and shoulders, it also covered the star." Along with other Dresdeners he sought shelter along the banks of the Elbe, making his way to Brühl's Terrace where, he wrote, Jews were not allowed to enter. The next

453 Victor Klemperer, Language of the Third Reich: LTI: Lingua Tertii Imperii (Bloomsbury Academic, 2006), 147.

454 All of the below quotes come from Klemperer, I Will Bear Witness, pp. 406-413. 
morning he encountered an acquaintance, Herr Eisenmann, who was crying, but who "then $[\ldots]$ pulled himself together. We would have to try to find our own people, I would have to remove my star, just as he had already taken off his. Eva thereupon ripped the star from my coat with a pocketknife." In this context Klemperer's words - "our lives were saved and we were together" - take on a double meaning.

Józef Mackiewicz's novel Sprawa pułkownika Miasojedowa (1962) ends with imagery of the bombing of Dresden. That event is but a single episode in the large work, though - it would seem - one hears in that episode not just the roar of bombs, but also the grim voice of historical irony. One of the main characters, the Pole Marian Szatkowski, has been exiled to Siberia during the First World War. There he marries Klara, the former wife of Colonel Miasojedow, who was falsely accused of spying for the Germans and executed. Together, they return to independent Poland, but in 1939 they have to flee from Soviet occupation. After numerous adventures and signing the Volksliste, they manage in 1945 to make their way to Dresden, where they make plans to cross over to Switzerland. Klara leaves for Vienna to obtain papers, while Szatkowski stays in the city and dies in the bombardment. The leisurely narrative, the classic formula of the Mackiewiczean epic, suddenly picks up pace in the Dresden episode, though the work maintains its internal discipline. Images proliferate that - as the author wrote - "one can compare with the specter of hell predicted by the prophets," but what we have here is still realistic prose with such conventional phrases as: "The entire city was drowning in a sea of flames." 455

And yet the horror of the reality described in this novel cannot be expressed using traditional language. A longer passage from the work gives us an idea of what Mackiewicz's style is driving at:

Having arrived with the crowds of those in flight, during the second air raid, toward the "Großer Garten," he [Szatkowski] stood for a brief moment among the people under the trees. Soon a "carpet" of explosive bombs fell on them. His jacket was torn from his body, his shirt and tie flew away into the darkness and were hanging on a bush. His left hand was mashed into the bark of the plane tree. Part of his torso and his legs were in the next alley, mixed up with the flesh of strangers. But his head flew upward, so unfortunately that it was stuck between the branches of that plane tree, above the overhanging intestines of other people. - Unfortunately, because it later stunk terribly when the wind came from that side.

Almost all the crowns of the trees that were left in the park were hung with shreds of clothes, pieces of flesh and intestines, which were later removed partly with poles and

455 J. Mackiewicz, Sprawa putkownika Miasojedowa, 652, 651. 
ladders. But Szatkowski's head could not be reached. It was a disgusting sight. After two weeks, it was decided to cut down the old plane tree with a mechanical saw. But it turned out that no saw could take down a tree that has been so packed with steel shards. The saw's teeth dulled and then broke. It took a long time for the roots to be cut through and the tree toppled. Only then did one of the workers state that the head had been stuck so firmly because it had been driven into a sharp knot, like a skewer.

"What a stubbbborn head," the worker drawled, as he removed the stinking head in disgust. ${ }^{456}$

Two motifs in this passage function as a metonym for the experience of bombardment. One: the motif of body dismemberment that often emerges in victims' accounts. Bombs tear people into pieces, and witnesses see, with their own eyes, either the moment of such a death or its effects. The curate of the Würzburg cathedral observed, as prisoners were cleaning up the rubble after the air raid of 16 March 1945 and loading corpses into a truck: "It was a chaotic pile of human limbs, torsos, and heads." 457 Second: the motif of explosions. Explosion is the essence of bombardment. The explosion of a bomb - hundreds and thousands of bombs - puts a definitive end to previously existing forms of reality. This is the violent decomposition of the world that Grosz and Picasso, mentioned at the beginning of this chapter, portrayed in their works. The description of bombardment in Sprawa pułkownika Miasojedowa has a particular dramaturgy. In its finale, the work moves from a wide and panoramic view to a close-up, to macabre detail. The narrative, which is not without pathos and stylistic clichés, accelerates violently and changes its tone. At its culmination, there emerges an aesthetic dissonance: horror is detracted by triviality, the nightmare is lined with unexpected comedy. Here, the removal of the mass of corpses lying in ruins - terrible work, which was often done by prisoners of war - is turned into a story filled with black humor about how further adversity is overcome. Mackiewicz resorted to descriptions of the grotesque macabre, which - in his novel - becomes an idiom for bombardment.

The legend of the Dresden bombing was consolidated by Kurt Vonnegut's famous novel and antiwar manifesto, Slaughterhouse-Five (1969). The work has not only come out in many editions, but it was also adapted for the big screen. The film, based on a screenplay by Stephen Geller and directed by George Roy Hill, came out in 1972. In 1996, presumably on the wave of commemorations surrounding the fiftieth anniversary of the bombing of Dresden, the novel was brought to the stage in a play directed by Eric Simonson, which premiered at

456 Ibid., 657-658.

457 Friedrich, The Fire, 273. 
the Steppenwolf Theater Company in Chicago. In the same year, an opera was produced based on Slaughterhouse-Five, the libretto and music for which were written by Hans-Jürgen von Bose. Its premiere opened the annual Opera Festiwal in Munich.

Vonnegut, as an American prisoner of war, survived the destruction of Dresden, and in Slaughterhouse-Five he attempted to give expression to his incommunicable experience. At the novel's center was not so much the presented world, but the possibility of its presentation. Not the phenomenon of the city's annihilation, but rather the phenomenon of describing annihilation. This "famous novel about Dresden," which in the end there was no way to write, is:

[...] so short and jumbled and jangled, Sam, because there is nothing to say about a massacre. Everybody is supposed to be dead, to never say anything or want anything ever again. Everything is supposed to be very quiet after a massacre, and it always is, except for the birds [...]. And what do the birds say? All there is to say about a massacre, things like "Poo-tee-weet?" 458

For Vonnegut, the idiom of the air raid is thus babble, the destruction of a hero "unstuck in time," the destruction of narrative logic, the destruction of novelistic space and time.

\section{Timothy Garton Ash and Kevin Alfred Strom}

In 1980 Timothy Garton Ash (born 1955), the English historian and publicist, made a trip to the GDR He was in Dresden for the thirty-fifth anniversary of the air raids. In his work entitled Niemieckość NRD (The Germanness of the GDR, published in Poland by the underground "Krąg" press), Ash pointed to a kind of fracture in the German memory about Dresden - two anniversary ceremonies: one official, one unofficial. But what is most important are his personal reflections. Ash situated himself beyond (or above) the bookkeeping by which grievances and payback are counted; beyond conventional arguments about the need to carry out orders, about the pressing war situation; beyond explanations for the infliction of a concrete evil through the use of abstract formulas about the insanity of twentieth-century totalitarianisms, about the perversions of fascism or imperialism, or about the innate human tendency to destroy. It was also not enough for him to rest on the fact that he had the good fortune of being born later. For Ash, Dresden is a matter of personal responsibility. "If I identify with my nation," he writes, "then I identify also with its entire past, good and bad." 459

458 Vonnegut, Slaughterhouse-Five, 24.

459 Quote from W. Pięciak, Requiem dla miasta Drezna, op. cit., 302. 
On the fiftieth anniversary of the bombing of Dresden, Kevin Alfred Strom delivered a radio address entitled "Dresden: a Real Holocaust." In 1982, Strom joined the National Alliance, a neo-Nazi organization active in the United States (so-called "white nationalists"). In April 2005, he set up his own organization called the National Vanguard. Let us extract from Strom's address the basic principles on which the memory of Dresden is molded, one of which is no doubt the "principle of hyperbole." The day of 13 February is the most somber anniversary in all of Western civilization. The principle of hyperbole is subordinate to the topos of the "huge number of victims" (though the matter of the victim count has its own separate history, one that is worth telling). Strom tosses around the highest possible number - 300,000 - according to the "more is better" rule. The principle of "innocent and defenseless" builds a black-and-white divide between the immaculate victims and the bestial executioners. The phrase "delicate Chinese porcelain" is a kind of metonym for Dresden - a defenseless city from which anti-aircraft weaponry had been withdrawn; a city of old people, women, children, refugees and the injured; a city of hospitals, museums, theaters and artworks; an innocent city that had no military targets and was in no way connected to Germany's war machine; a city whose factories produced only tooth paste and baby powder, and not mustard gas. Strom also applied the principle of linguistic substitution. When talking about German suffering and German victims, he uses the language commonly used in relation to the victims of German atrocities and crimes, above all the language used to describe the Holocaust. In this, Strom has many imitators. Finally, Strom rises to the summit of historiosophic reflection by reaching for the principle of the conspiracy theory of history, through which the true reasons behind the annihilation of Dresden emerge. Thus, the destruction of the "Florence on the Elbe" was the result of a conspiracy against the white race and Western civilization led by such traitors as Churchill, Roosevelt and their communist allies. ${ }^{460}$

\section{Winfried Georg Sebald - Jörg Friedrich - Frederick Taylor}

Winfried Georg Sebald, the famous German writer who died in 2001, could have remembered neither the war nor the bombardment. He was 10 months old when Dresden and its inhabitants were incinerated in the firestorm. But it was Sebald who brought about the return to German consciousness of the memory (still unreconciled at the end of the twentieth century) of the bombings and their German victims.

460 See http://www.christusrex.org/www1/war/dresden4.htm (accessed 25 May 2008). 
In the autumn of 1997 Sebald delivered a series of lectures in Zürich, which were published in Munich two years later under the title Luftkrieg und Literatur. ${ }^{461}$ His starting point was the claim that the Allied carpet bombing of German cities, even though it was a horrible experience for millions of Germans and left scars that are visible still today, was obscured and repressed; it became a taboo subject. The postwar period was marked by individual and collective amnesia, and social rebirth in the postwar era meant driving certain events into oblivion. Bombardment - that enormous collective limit experience (as Sebald called it) was absent in the public discourse, in historiography, in family memory. Sebald dedicated most of his lectures to a discussion of the "literature of bombardment," which existed somewhere on the margins, and which - with a few exceptions (such as Heinrich Böll's novel Der Engel schwieg, or The Silent Angel, which was written in the late 1940s and early 1950s, but was published only in 1992) - is of meager value.

Sebald's book marked the beginning of an entire process by which past experiences were liberated from a psychological blockade and political correctness, which led to the reconstruction of national memory. But the author himself had doubts that memories of bombardment should in fact be used to create a new identity for the Federal Republic. While admitting that Germany had to remember these events, Sebald raised the fundamental question: was this memory to be about the horrors of the catastrophic Third Reich, or about the nostalgic recollection of wrongs committed by the world on Germany? At the end, Sebald remembered the fates of Guernica, Warsaw, and Rotterdam, and he placed great emphasis on the fact that it had been Germany that provoked the catastrophe on German cities. Sebald not only raised great interest in the subject of the air raids, he also showed how the scarred German memory could grapple with the experience of bombardment. Reaction to his lectures left no doubt that there was a growing need to recognize the victims of the Second World War in Germany.

In 2002, Jörg Friedrich's Der Brand. Deutschland im Bombenkrieg 1940-1945 was published. ${ }^{462}$ This book has been extraordinarily important in the German debate on the shape that memory of the bombings has taken. The name and surname that appear on the cover of Der Brand is the pseudonym for Friedrich

461 For the English-language version, see W. G. Sebald, On the Natural History of Destruction, trans. A. Bell (New York 2003).

462 For the English-language version, see J. Friedrich, The Fire. The Bombing of Germany, 1940-1945, trans. A. Brown (New York 2006). 
Krabbe, who - like Sebald - was born just shortly before the destruction of Dresden. His sister, Hanna Krabbe, a terrorist in the left-wing Rote Armee Fraktion (RAF), was sentenced to life in prison for her participation in an attack on the West German embassy in Stockholm in the spring of 1975 (she was released conditionally in 1996). In his youth, Krabbe was a Trotskyite actively involved in the revolt of 1968. He also participated in anti-Vietnam War protests. Later he wrote about the Nuremberg trials and the careers of former Nazis in West Germany. Known for his antiwar and anti-Nazi attitudes, he tends today to treat the de-nazification process as a political purge that violated Germany's sovereignty and had no basis in international law. ${ }^{463}$ Currently he is widely considered a "historian-revisionist," a label he gladly accepts. He would most like to be viewed as a person who breaks taboos, a knight fighting for the truth, a conqueror of myths, an iconoclast, ${ }^{464}$ though in one interview he called himself an independent scholar and emphasized that Der Brand is "pure description [...]. There's nothing about war crimes. I'm a historian, not a judge." ${ }^{665}$

This epic tale of the bombardment of German cities plays itself out in seven scenes. One after the other, the author describes the weapons that the Allies used; the strategies they employed in the air raids; the cities and their rich historical heritage that were the object of those raids; methods of defense used against the bombs; collective experiences; individual experiences; and finally, the ruins that is, stones that speak. Der Brand is not a book written sine ira et studio, and its emotional temperature, its suspenseful narrative, and its emphasis on concrete individual experiences resembles the style of Goldhagen's more famous book, Hitler's Willing Executioners. But if Goldhagen excessively and ahistorically accused "ordinary Germans" of eliminationist antisemitism, then Jörg Friedrich, in an equally excessive and ahistorical way, accused Churchill and Roosevelt of carrying out genocide on the German nation. In any case, Friedrich brought about a spectacular reorientation of the historical discourse on bombardment, his declared goal being to "describe the forms of suffering" inflicted by Allied air raids on German civilians, in both cities and the countryside.

The language that Friedrich used in Der Brand is significant; in the book, he performed a creative stunt that resembles the one mentioned earlier in our brief analysis of the neo-Nazi Kevin Alfred Strom's address and involves the principle of linguistic substitution. Friedrich transferred words and phrases used to describe

463 See L. Harding, “Germany's Forgotten Victims," The Guardian, 22 October 2003.

464 See I. Buruma, [review of Der Brand], The Guardian, 22 November 2002.

465 See conversation with R. Bernstein, New York Times, 15 March 2003. 
the reality of the Holocaust, words and phrases associated with the Holocaust in the social consciousness, to the reality of bombardment. For example, he wrote that cellars in burning Pforzheim "worked like crematoria"; that in Hamburg, "after a while, the cellars started absorbing the external heat and functioned like crematoria," having filled up with combustion gases; and in Dresden, "the tightness of space, heat accumulation, combustion gases, lack of oxygen, and the draft in the cellars all contributed to making the closest escape route into a crematorium." ${ }^{366}$ The heat from the burning buildings and the resulting poisonous gases "turned the shelters into execution sites" 467 and it was British and American pilots who carried out these executions from the air. The logic of carpet bombing "was geared toward inescapable mass extermination."468 The RAF's No. 5 Bomber Group was described as the "RAF elite" named the "Mass Destruction Group"469 In the German language, such a label sounds more than synonymous with Einsatzgruppe, a term which every person with a basic knowledge of the history of the Second World War cannot help but associate with the motorized SS units that followed the Wehrmacht into Russia in the summer of 1941, where they committed mass murder on "Jews and communists." The Einsatzgruppen were "responsible for more than 2 million deaths, one of the greatest orgies of mass killing in the history of mankind." 470

On the fiftieth anniversary of the Dresden air raids Jörg Friedrich published an article in Die Welt (10 February 2005) under the title "Mongolensturm des Abendlandes," in which he treated the destruction of Dresden and Hiroshima as the beginning of the "cold war." A few days before the bombardment of Dresden, at the Yalta Conference, Stalin, Churchill and Roosevelt had divided up postwar Europe. The Big Three peace conference at Potsdam (with Truman replacing Roosevelt, who had died several months earlier) came to a close exactly four days before an atomic bomb was dropped on Hiroshima. The bombardment of those two cities, which brought in their wake such apocalyptic consequences, was Friedrich claimed - a demonstration of British and American power against Russia, which would soon change from an ally into an opponent. Friedrich called what happened to Dresden and Hiroshima "a theater of slaughter, in which there was no way to distinguish between enemy and ally."

466 Friedrich, The Fire, 93, 166, 340.

467 Ibid., 313.

468 Ibid., 314.

469 Ibid., 306.

470 Michael Robert Marrus, The Holocaust in History (University Press of New England, 1987), 39. 
One of the most recent monographs on the bombing of Dresden is Frederick Taylor's Dresden. Tuesday, 13 February 1945 (2004). ${ }^{471}$ Taylor not only made use of a wide variety of sources, and not only carefully arranged the facts and contexts of that event, he also deconstructed the legend of Dresden that had been fixed in historiography and in collective memory. Let me refer to just two examples.

Taylor confronted the myth of the "massacre on the Elbe meadows." In David Irving's The Destruction of Dresden (1963) we find, for example, drastic descriptions and accounts from eye-witnesses, who talk about American planes diving close to the ground and strafing defenseless civilians fleeing Dresden in flames. But there was no premeditated mass attack on those who had survived the bombardment; such an attack cannot be confirmed by the historical evidence. That having been said, the Americans carried out a third wave of bombing and it is not impossible that, after the attack on the city, individual fighter planes reduced their altitude and, flying low over the city, perhaps fired their onboard weapons. In any case, before midday on 14 February, Dresdeners died from bombs, not bullets. ${ }^{472}$

Taylor devoted an entire appendix to "counting the dead." From the very beginning, the number of victims was a matter of macabre statistical manipulation. The astronomical number of 350,000-400,000 fabricated by Goebbels' propaganda machine can be found in a book published in West Germany in 1955, Axel Rodenberger's Der Tod von Dresden. The very same unrealistic estimate was repeated uncritically in Mackiewicz's Sprawa putkownika Miasojedowa. In his work published in East Berlin, Die unbesiegbare Stadt (1955), the communist politician Max Seydewitz wrote about 35,000 victims. David Irving, in his book The Destruction of Dresden, stated that the most probable number was 135,000 . Taylor pointed out that recent scholarship accepts that the most reliable estimates run from a minimum of 25,000 to a maximum of 40,000 killed. ${ }^{473}$

471 In 2006 Pimlico published a collection of essays under the title Firestorm. The Bombing of Dresden 1945, edited by P. Addison and J. Crang. Ten authors discuss, one by one, the history of strategic bombing until 1945, the political and military genesis of the bombing of Dresden, the air raids themselves, the testimony of Victor Klemperer, military reactions to the air raids and the postwar debate about the bombing, reflections on the reconstruction of the historic city, the bombardment of Dresden from the point of view of ethics and war, and war crimes. The classic work on the subject remains Götz Bergander's Dresden im Luftkrieg: Vorgeschichte, Zerstörung, Folgen, 2nd updated edition (Weimar 1994) (1st edition, 1977).

472 See F. Taylor, Dresden, op. cit., 429-442.

473 Ibid., 443-448. 
During the Second World War, the city in which the greatest number of inhabitants died as the result of a conventional air attack was Tokyo, bombed by the Americans on the night of 9-10 March 1945. The number of victims is currently estimated at around $100,000 .{ }^{474}$ But in the collective imagination, the symbol of the total annihilation of a city in modern times were the American atomic bomb explosions on 6 August 1945 over Hiroshima and three days later over Nagasaki.

474 R. Guillain reports that after the war, Japanese sources counted 197,000 dead. See R. Guillain, op. cit., 187. On the sixtieth anniversary of the air raid on Tokyo the commonly accepted number of victims was around 100,000. See M. Fujimoto, "The Great Tokyo Raid: 'Scorched and Boiled and Baked to Death"' The Japan Times, 13 March 2005. 
Part II 



\section{Looks}

In this chapter, I turn our attention to photography which, for me, is one form in which limit experiences are recorded; it provides testimony of a particular type, a kind that demands close reading and interpretation. But photography speaks in a way that reverberates on entirely different levels than verbal text. The distinction between the photographic and textual record determines both the shape of the testimony itself and the possibility to closely "read" that testimony.

The sphere of my reflections here contains not only the relationships that occur between the photograph and the photographed object, but also - and perhaps above all - the relationship between the preserved photographic image and those who view that image. These issues, so defined, are tied to fundamental questions in the theory and aesthetics of photography.

The eye is a kind of pinhole camera. Even in ancient times, the phenomenon by which an image is thus created was known by the term camera obscura. The oldest illustration from a camera obscura, created by the Dutch physicist and mathematician Gemma Frisius (1508-1555), shows a view of a solar eclipse: we see a room with a small opening in a wall, through which light falls, which is projecting onto the opposite wall a miniaturized and reversed image. Clearly visible here is the fact that the continuity between the observed object and its image is maintained, despite the change in proportion and situation. It is still the same light ray, though captured and restrained, and yielding a "touch" of the real world. The novelty of photography, the powers of its invention, are thus not based on the ability to capture a light ray and use it to create an image of reality; the ancient Greeks, the Chinese, and Renaissance artists knew how to do that. Rather, photography was born out of chemistry, which made it possible to preserve an image, and from technology, which allowed for an image's reproduction.

We commonly regard a photograph as a faithful reflection of reality, its objective copy, one that possesses a kind of authenticity and genuineness unattainable in any other way. We consider it to be irrefutable testimony to the fact that something really happened, that someone really existed and looked one way (and not another way); it plays the role of "material proof," of a document, a sui generis historical source. ${ }^{475}$ It is not the place here to talk about the documentary function

475 On photography as material evidence and its application in trials and investigations, see Susan Sontag, On Photography (Picador, 2001), 5. On photography as testimony to the Holocaust, see B. Zelizer, Remembering to Forget: Holocaust Memory 
of photography, about the tradition and contemporaneity of "documentary photography," or about the relationship between the document, expression and art in photography. ${ }^{476}$ Nor is it the place to enter into a discussion of the complicated matter of the ontology of the photographic image. Nonetheless, it is important to state that the theory put forward in radical form by André Bazin in 1945 about photography's realism (while the photographic image is identical to its object, a painting is only similar to its object $)^{477}$ is unsustainable. One can gain a better grasp of photography's particular status through an understanding of the semiotic theory of Charles Sanders Pierce, who identified three kinds of signs: icons (which refer to their object through similarity); symbols (through the power of convention); and indices (through a factual connection, for example smoke as an indexical sign for fire). From the perspective of Pierce's semiotics, there are three ways to understand a photograph. First - as a "reflection of reality" based on its iconic "similarity" to that which is presented. Second - as a "transformation of reality" in accordance with the mechanisms of symbolic interpretation of that which is real. Third and finally - as a "trace of reality." 478

The notion of a photograph as a trace, which we find in the works of Susan Sontag ${ }^{479}$ and Roland Barthes, ${ }^{480}$ is precisely what highlights its indexical character. A photograph would be a kind of index, one that manifests continuity between reality and the photographic image. The photograph is a trace of light ray that was, then and there, reflected off the object, passed through a lens, and then detained, preserved, and expressed in a photograph. Susan Sontag pointed to the photograph's peculiar character as depiction. It usurps a position that is owing to reality, since the photograph is not just an image (a recreation of reality) but also a trace (reality's imprint), which is precisely the basis for a photograph's

Through the Camera's Eyes (Chicago, 1998); Janina Struk, Photographing the Holocaust: Interpretations of the Evidence (I. B. Tauris, 2004).

476 See S. Sikora, Fotografia. Między dokumentem a symbolem (Izabelin 2004); A. Rouillé, Fotografia. Między dokumentem a sztuka współczesną, trans. O. Hedemann (Kraków 2007).

477 André Bazin, “The Ontology of the Photographic Image," trans. Hugh Gray, Film Quarterly 13, no.4 (Summer 1960), 4-9.

478 On the semiotic approach to photography, see François Soulages, Estetyka fotografii. Strata $i$ zysk, trans. B. Mytych-Forajter, W. Forajter (Kraków 2007), 98-102. For the original French version, see Soulages, Esthétique de la photographie (Nathan Université, 1999).

479 See Sontag, On Photography.

480 Roland Barthes, Camera Lucida: Reflections on Photography, trans. Richard Howard (Hill \& Wang, 1980). 
aura, its magic. As Roland Barthes wrote, a photograph is "an emanation of past reality," and not its copy. ${ }^{481}$ We do not construe, in some naïve way, the photograph to be a real version of that which it presents (after all, we cannot confuse a photo of the Eiffel Tower with the tower itself). Rather, the photograph offers us the possibility to see in a new way. A story or painting places between us and the world a filter of language, the distance of narrative strategy or of an artistic form. With a photograph, there is a kind of bridge between the subject and the perceived object. In a peculiar way, the photograph is transparent, a transparent medium, one that mediates between us and the world; it does not break contact with reality. ${ }^{482}$ However, one must keep in mind that, with a photograph, the path from thing to image is never direct. The photograph is an "imprint" of the thing, but there is a physical separation between the thing and its photographed image. A photograph is also a "record" of a thing - that is, the effect of the next stages of the chemical process, which lead from the thing to its preserved image. ${ }^{483}$

Walking in the footsteps of the structuralists, who described not so much particular literary works as their characteristics, their "literariness," we can ask: what is a photograph's "photograph-ness" based on? The stuff of photography (the camera, photosensitive material, chemical solutions, light, photographic paper), without which photography would not be possible, does not help us define photography's special nature. Because - as Francis Soulages stated ${ }^{484}$ we find "photograph-ness" at the juncture of the irreversible and the uncompleted. Photography is at once humanistic and materialistic. It is a person who photographs, but through the act of taking a photograph that person is inevitably confronted with materiality. The press of the shutter button sets in motion physical and chemical processes that lead in effect to the achievement of a negative, which is a process that is both irreversible and a one-off event. One can subject photosensitive material to exposure one more time, but it will produce a different photo. One cannot retrieve a negative, once exposed (an irreversible process), and turn it into an unspoilt negative that can be exposed once again. But a photographer's work on an exposed negative is something altogether different.

481 Ibid., 88; on the philosophical-semiotic way of defining the documentary nature of photography, see Sikora, op. cit., 21-40.

482 K. L. Walton, “Transparent Pictures: On the Nature of Photographic Realism,” Critical Inquiry 11, no. 2 (1984).

483 On record and imprint in the context of the truth of photography, see A. Rouillé, op. cit., 81-86.

484 In this paragraph, I follow the views of F. Soulages, op. cit. (particularly the chapter "Przedmiot fotograficzny: fotograficzność," 137-171). 
Such work is open and unlimited in character, and in this sense it is repeatable and potentially unending. As an effect of the act of taking a photograph, the negative is a single (and no other) moment, an object, shot, or constellation of worldly elements, one that is preserved "forever." But the photographs derived from that negative can be infinite in number, one way or another regenerated and reprocessed by the photographer. Soulages wrote: "One of the characteristic features of photograph-ness is infinity. That is, that the photographer enjoys unlimited possibilities. Photography is thus the art of possibilities in the full sense of these words." 485

Tracking the characteristics of photography, Soulages identified three distinctive spheres: the conditions for existence, production, and reception. If, in relation to the negative, the photographer is both creator and receiver, and work on the negative "is merely the first link of an infinitely long chain of readings", 486 what role does the viewer play in the multi-layered process of reception? In the case of the photographs that will be the object of my analysis here, the viewer's interpretative activity involves the relationship between the photographic image (as a "trace" or "impression" of that which is real) and one's knowledge of the photographed reality and his emotional stance toward it. The viewer always possesses a "surplus of knowledge," he always knows more than the photographed figures. The secret of the photographic record rests in the fact that time futurepast is captured in the photo: this will be and this already has been. Looking at Alexander Gardner's famous 1865 photo of assassin Lewis Payne in his death cell, we are aware that the young man will soon die, but also that he has already died. ${ }^{487}$ In the case of the photographs discussed in this chapter, this paradox involving future-past time and the viewer's inexorable knowledge about the end is particularly dominant.

The countless illustrations of the appearance and functions of the human eye (organum vivus) scattered throughout anatomy atlases, encyclopedias and school textbooks are helpless in the face of the mystery of vision. A diagram of the eyeball (bulbus oculi), marked with a network of arrows and numbers, is perhaps a faithful rendition of a reconstruction of that part of our body, but it conveys a surrealistic image, far removed from the truth of our everyday experience. Above all, it reveals that which is supposed to remain hidden - the insides of our corporal world. This laying bare, this breakdown of the natural border

485 See ibid., 143; see also ibid., 154-155.

486 Ibid., 158.

487 For more on Payne, see Barthes, Camera Lucida, 96. 
between that which is inside (us) and outside (us) can be read in the categories of the rational discourse of science as a cognitive value: we know more because we see more; our vision is more penetrating, it digs deeper. The spectacle of the autopsy, along with anatomical drawings, illustrations, and models mapping out the vast territory hidden under the surface of the skin, have long been the work of artists and scholars discovering the perfect order of a creation to which their powers of reason had access. The old and widely available anatomical tables do not make the same macabre impression on us as do naturalistic wax models, such as the one created by Clemente Susini in 1803 presenting the "organ of sight," made up of a wax head (the back is "cut away" to reveal the interior) and a quarter of a face designed to highlight a profile of one eye socket, next to which lie a set of eyeballs (whole eyeballs, and others cut in half). ${ }^{488}$

The human eye works much like a camera. Light rays enter and they are captured. By way of chemical procedures, the latent image is "conjured up" and recorded. The pupil, located at the center of the iris, serves as an aperture, regulating the amount of light that passes through to the lens. The cornea, the chamber of transparent liquid behind it, the lens, and the so-called vitreous body together make up the eye's optical system. It refracts the light rays and directs them toward the photosensitive surface of the retina, where an actual, miniaturized and inverted image of the viewed object emerges. Photochemical reactions stimulate nerve impulses, which reach the visual cortex in the occipital lobe of the cerebral cortex. Thus we have the encyclopedic description.

Diagrams, models and graphs fail to capture the mystery of vision - the phenomenon of embracing and absorbing unconcealed space; the seclusion within the small eyeball of the enormous surrounding reality; the miraculous mediation between the outer world and the inner world. The eye serves as the border between what is outside and inside of us. In the eye, light refracts and inverts, arriving there like a messenger with news about what is happening around us. But the elementary experience of vision is based on the conviction that, in a sense, we (by looking) step out into the external world, that we cross the border of our own body and move toward all that extends beyond us. The eye is thus a field of exchange and reciprocity, a secret aperture through which the world, in its visible form, relates with us, and we - by casting our glance toward it - relate with the world.

488 See the illustrations in Spectacular Bodies. The Art and Science of the Human Body from Leonardo to Now, eds. Martin Kemp, Marina Wallace (London 2000). Susini's model is preserved at the University of Cagliari. 
What interests me is the look that is preserved in a photograph, I could even say "written into" a photograph, given that photography, from the Greek, is "drawing with light." If one would present the history of photography, as Roland Barthes proposed, as the "history of looking," 489 then photographs showing a person in a limit situation would occupy a special place in that history. One chapter could describe "looks" locked, as it were, within the confines of the photo's world, detained within the framework of experienced suffering, cruelty, and fear; the look in the eyes of those photographed; the look of a terror not yet experienced but already a foregone conclusion, or of a terror already overwhelming but not yet annihilative. And finally, the looks that one can find in the faces of the dead, murdered, and tormented coming from the other side of the border between life and death. The network of these looks - those of the executioner (if he is visible), the victim, and gathered onlookers (if there were any) - is recorded on photosensitive paper. Their vectors cross, or they lead away from each other. The victims can be by themselves, or left to themselves. They might not yet know that they will be victims. We alone have such knowledge, as we look at the photo. Based on these looks, one can reconstruct the larger story and thus negate the commonly held belief that the photograph is, by nature, non-narrative. A separate chapter could contain an analysis of the relationship between reality, its photographic reproduction, and the viewer. The photo's creator, along with the one who views the photo and anyone who finds himself in the photo, play out with one another a silent drama of looks. The photographer's gaze is directed at the chosen object; it takes note of that object, isolates it in space, and locates it in the frame. That look through the lens is hardly "objective," since it is a manifestation of an individual point of view, of a personal perspective, a concrete take on the matter. The look in the lens suits the photographer - conquering time and space, breaking away from the order of life and death, looking directly at us, the viewers. In the end, we accept this vision of those who were photographed, and whether we like it or not - we look at them through the eyes of the photographer.

A photograph is a record of the experience of the person who created it; it is an expression of their experience, their mindset, their attitude. It is also a challenge to the viewers; it appeals to their emotions and sensitivities; it conveys images that transmit some kind of "objective" knowledge of the world, but more importantly indicate a way of perceiving the world. As such, we can include the photograph as evidence in those kinds of investigations that serve to not just document reality, but to understand reality.

489 Barthes, Camera Lucida, 12. 
Photography is one of those manifestations of human activity that both derive meaning from the world and give it meaning. Taking a photo and looking at a photo can be placed under the category of communication: as ways of conveying and reading a certain message. Thus understood, photography is an element of culture, a medium between the human being and the rest of the world, among participants in the human community. Photography - as a cultural medium of a particular kind that enjoys a particular ontological status - has a deep anthropological dimension. Roland Barthes called photography "an anthropologically new object" that "must escape, it seems to me, usual discussions of the image." ${ }^{990}$ Viewed from this perspective, the issue of photography belongs to the developing field in the humanities that is tied to visual anthropology $y^{491}$ or the anthropology of images. ${ }^{492}$

The look is not just the subject of these current reflections, but rather something more - it is a path along which our thoughts will run. In other words: it is a way of conceiving that to which our thoughts are turned, around which they circle. I will attempt to follow the trope of looks given in the context of the experiences of people in limit situations. When considering the forms by which experiences are recorded, experiences that are situated at the border of possible expression (indeed, that belong to the sphere of the inexpressible and seem to be beyond discourse), I am confronted with the look.

\section{Faces in Extremis}

Eugéne Delacroix, who like other great painters made use of photos as a kind of optical note, pointed to photography's imperfections when it came to capturing nature, even though photography relies on its ability to achieve the greatest possible resemblance to the external object. The fact that photographic technology allows for the most faithful image of reality can stand in the way of understanding and perception. The best photographs come about as a result of flaws or inadequacies in the reproduction process. Delacroix wrote:

490 Barthes, Camera Lucida, 88.

491 See S. Sikora, op. cit. Sikora referred to issues of Konteksty devoted to visual anthropology (1992, no. 3-4; 1997, no. 3-4); see also Film i audiowizualność w kulturze. Zagadnienia i wybór tekstów. Częsc I: Audiowizualność w kulturze: wprowadzenie. Częsc ll: Film w kulturze, ed. S. Kuśmierczyk (Warszawa 2002).

492 See K. Olechnicki, Antropologia obrazu. Fotografia jako metoda, przedmiot i medium nauk społecznych (Warszawa 2003). 
The photographs which strike you most are those in which the very imperfection of the process as a matter of absolute rendering leaves certain gaps, a certain repose for the eye $[\ldots]$. If the eye had the perfection of a magnifying glass, photography would be unbearable. $^{493}$

The imperfection of photography thus rests in its ability to produce a perfect replica of the photographed object showing only that which is on the outside. It cannot reach things and phenomena that are under the surface, to reflect their essence; it cannot synthesize; there is no room for the work of the imagination. In his journal, Delacroix wrote that "cold perfection is not art." ${ }^{494}$ In another place, he cautioned:

One should not lose sight of the fact that the daguerreotype must be considered only a translator whose purpose is to further initiate us to the secrets of nature; for despite its astonishing reality in certain parts, it is only a reflection, a copy of the real that is false, in a way, because it is so exact. The monstrosities it presents are justifiably shocking, even though they are, literally, those of nature itself. ${ }^{495}$

These comments by the painter of "The Massacre at Chios" about the photography of monstrosities and the impressions they provoke in the eyes of those viewing such photographs, to which one could also attribute the particular virtue of "literalness" and "exactitude," are leading us in medias res. The reflections in this book involve the matter of how we consort with the image of frightening and macabre things. I emphasize: with the image of the macabre, and not with the macabre itself; with reality's likeness, not with reality itself in which we encounter something macabre. In a word, it is about mimesis of the macabre, about ways of presenting, about forms of representation. What is of interest to me in this section is, above all, certain photos from the First World War showing heavily injured soldiers - more specifically, their faces.

What photographs showing monstrosities could Delacroix have had in mind? Did he have access to Alexander Gardner's famous photos from the American Civil War (1861-1865), which showed for the first time, on such a scale, the macabre of the battlefield? For example at Antietam, where on 17 September 1861 26,000 soldiers fell. Gardner took a series of photographs of fields strewn with corpses. Another famous photo by Gardner that had an enormous influence

493 Eugène Delacroix, The Journal of Eugène Delacroix, trans. Walter Pach (New York: Crown Publishers, 1948), 645.

494 E. Delacroix, Dziennik, część pierwsza (1822-1853) (Wrocław 1968), 243.

495 Quote from M. H. Huet, Monstrous Imagination (Cambridge, Mass; London 1993), 188. 
on the American consciousness, and that became for Americans a synonym for the brutal truth of war, was "Home of the Rebel Sharpshooter, Gettysburg" (1863), which shows a soldier's body in a trench. After Delacroix's death in 1863, America was shaken by photos of Yankee prisoners held in Confederate camps in the South, including the most infamous camp at Andersonville, where 100 prisoners had died every day. The camp was built in the spring of 1864 . What is most striking about these photos is the connection between the conventions of a medical study, exhibiting with laboratorial exactitude emaciated bodies of starved humans - images of the "living skeletons" we know so well from our own times - with the conventions of a portrait. Each photo presents one naked (or almost naked) figure, holding himself in the sitting position with great effort, posed against a dark background, like an anatomical specimen. These photos became an object of Congressional proceedings; a special investigating committee attached them to its report; drawings based on these photos were distributed widely in the press; and they were used as evidence in the trial of Captain Henry Wirz, the camp commander at Andersonville, who was sentenced to death and hanged. ${ }^{496}$

During the Civil War, but much more so during the First World War, photographs of injuries sustained by soldiers were taken for medical documentation. But these photos were meant for internal use only and not for publication. Terrible stories circulating among Union soldiers about the situation of prisoners of war at Andersonville, along with growing public pressure regarding this matter, led to the photos being publicized. They thus became a key propaganda argument in mobilizing public opinion. The shock that these photos caused was tied to their medical aspect, which had - I would argue - a fundamental influence on how they were received. It was thus not just the subject matter itself (that is, the emaciated human body) that made the photographs - to once again refer to Delacroix's term - "unbearable," but above all the way that the body was presented - with cold exactitude, medical dispassion, reducing the human to an anatomical specimen.

496 On Gardner's photographs from the Civil War and photographs of prisoners of war, see V. Goldberg, The Power of Photography. How Photographs Changed Our Lives (New York 1991), 20-28 (reproductions of some photos). It is worth adding that the picture of the corpse in the trench had been arranged by Gardner. The photographer moved the soldier's body and his rifle to a place that was more suitable for a photograph, and he used the same body for two differently arranged photographs. See. J. Ruby, Secure the Shadow. Death and Photography in America (London 1995), 13 (a photo reproduction). 
The anatomical dimension of the presentation of the human body has a long tradition in European art; we need only mention the sketches of Leonardo da Vinci, the illustrations of Andreas Vesalius in his monumental De humani corporis fabrica (1543), or the full series of "anatomy lessons" of Rembrandt, Adriaen Backer, Albert van Neck, and Cornelis Troost. From the Renaissance to the middle of the nineteenth century, anatomical imagination emanated from works of art, and the creators of anatomical illustrations were artists guided by the Greek maxim "know thyself." They harbored the conviction that visible nature, through which the divine order manifested itself, was accessible to reason. In their artwork, they thus tried to explore the internal mechanisms of the human organism - muscle functions and skeletal movement, but also internal signs of character, types of emotional expression. After all, they argued, the body was home to the spirit, to the external manifestation of that which was internal. And the human face, according to physiognomists, was the area that most perfectly revealed a person's soul, his essence, his identity. Hence, physiognomic studies of the face in extremis - portraits (for example, Rembrandt's "Self-portrait with Open Mouth" and Gustave Courbet's "The Desperate Man"), illustrations (for example, Le Brun's "Despair") and sculptures (for example, Gian Lorenzo Bernini's marble bust "Damned Soul") - represent an attempt to fathom the deepest secrets of humanity, to find an artistic form of expression for human limit experiences. In the final decades of the nineteenth century, the situation changed radically: standardization of anatomical illustrations, the use of photography for medical reasons, and finally the use of x-rays (let us recall the characters of The Magic Mountain and their fascination with their own internal portraits), led to increasing accuracy in the mapping of the human body, at the expense of a devaluation of the human's spiritual dimension. That process of mapping was transformed from a great artistic endeavor into an object of technical reproduction. ${ }^{497}$

The photos of the Andersonville prisoners contain within themselves something that is artistic, which turns photographs into a kind of hybrid: photographic exactitude combined with a painter's sense of composition, with ways of positioning the object in front of the lens. The photos included in Sir Harold D. Gillies' powerful book (bound in red leather) entitled Plastic Surgery of the Face. Based on selected cases of war injures of the face, including burns, with original illustrations (London 1920) are essentially only medical documentation of particular cases described in this thick volume. Sir Gillies (1882-1960) was the

497 See Kemp \& Wallace, op. cit., 11-19, 94-107. 
founder of modern plastic surgery in England, and his work turned plastic surgery into a recognized branch of medicine. He practiced on injured soldiers from the First World War who had been transported from the Western Front to the Cambridge Military Hospital, where he developed his own methods for treating extensive wounds and facial burns by replacing missing tissue and transplanting natural skin from undamaged places on the head or other parts of the body. The photos, or rather entire sequences of photos, illustrate the various stages of treatment, beginning with the patient's condition just after being wounded, through subsequent phases, to the final result. Cases are ordered according to the area of operation, and we thus see chapters on methods for treating wounded cheeks, upper and lower lips, chins, noses, eye regions, foreheads - that is, so to speak, a full survey of the most essential areas covered in Johann Kaspar Lavater's physiognomy, the most important physiognomic signs. ${ }^{498}$ But these signs are terribly deformed, they have succumbed to far-reaching destruction, some of them hardly recognizable.

Plastic Surgery of the Face is Sir Gillies' great album of images of people stigmatized by war, though it is one that cannot be read according to the physiognomic tradition by which the texts of human faces were read. At the heart of Lavater's approach was the belief that there are a finite number of features of appearance that reflect a finite combination of features of character. The goal was to unveil and describe a certain code; hence, physiognomy was situated - as it were - in the field of semiotics, and it posed questions tied to reading and interpretation. The face became a kind to text, a statement, formulated in a readable language. But the faces of Sir Gillies' patients were written in the modern script of war; they had been torn apart by shell fragments, blown through by bullets, burned by fire and gas. They do not suit the traditional physiognomic approach. Their appearance had undergone a fundamental disturbance. Their features, recognized theretofore in conventional terms and consisting of a recognizable system of physiognomic signs, succumbed to decomposition, deformation, even complete destruction. The semiotics of the face had been annihilated.

498 "The eye, eyesight, the mouth, the forehead, cheeks, in a word: the human face [...] is that which science calls physiognomy" - we read in Zasady fizyognomiki i frenologii. Wykład popularny o poznawaniu charakteru z rysów twarzy i ksztaltu głowy. Przez A. Ysabeau, profesor nauk przyrodniczych, trans. W. Noskowski (Warszawa 1883), 13. For more on Lavater's basic physiognomic signs, see J. Bachórz, "Karta z dziejów zdrowego rozsądku, czyli o fizjonomice w literaturze," Teksty 2 (1976), 90-91. See also comments on eyes, ears, and the forehead as basic elements of facial expression, see A. Kępiński, “Twarz i ręka,” Teksty 2 (1977), 11-28. 
The texts used to describe the individuals presented in Gillies' photos were, for obvious reasons, reduced to the kinds of wounds they had sustained and the operations they had endured. The images themselves are limited to various shots of massacred faces, and they are accompanied by rudimentary information about the person appearing in the photo, boiling down (though not always) to name, rank, branch of service, date of injury, date on which aid was first provided, and date on which surgical therapy started. There are occasional onesentence instances when a soldier's suffering, his courage, or his strength of spirit are mentioned, but even such instances are subordinate to the medical discourse. A certain private (no name given, case 139), during the Battle of the Somme, on 4 July 1916, had taken a gunshot to the face which tore apart his jaw, chin, and part of his cheeks.

It is an interesting point to note that this gallant fellow walked several miles to the dressing station on July 4th, 1916, during the battle of the Somme, and this very feat of endurance, maintaining, as it did, the upright position, may have prevented an emergency tracheotomy or even a worse fate..$^{499}$

This description of case 139 is accompanied by six photos. In "Early condition" we see a person whose lower face around the mouth had been turned into a mass of tissue. The upper part of the face is untouched - the nose, eyes, forehead and the hair is neatly combed. "Healed condition" - shows the effects of several months of healing: reduction in the cheeks and jaw area, shapeless lips, but a face without chin. "After first plastic" - condition dramatically better than after the "Second plastic," in part because skin from the top of the head had been brought down to fill the cavity caused by the gunshot and now covered the area around the patient's lower lip, cheeks, and chin. The two final photos document the surgical treatment's next stages. In each of them the face is different, though equally frightening and equally unlike the human face.

The requirement to document the different stages of therapy comes with a kind of narrative element. We are witnesses to a story, illustrated by photos, about horrifying transformations of the face. And though the intention behind repeating, with brutal monotony, these sequences of photos was to show the amazing achievements of plastic surgery, the inescapable impression on "nonprofessional" viewers of these photos is that they are participating in a spectacle, a theater of horrors. Above all these are stories of transformation. In a sense, such extensive and destructive injuries set the face in motion. The changes in

499 Sir Harold D. Gillies, Plastic Surgery of the Face, based on selected cases of war injures of the face, including burns, with original illustrations (London 1920), 168. 
appearance are so deep that they blur not just individual similarities (subjects stop resembling themselves), but also broader similarities (it is unclear if that is still a face, or something else). The face thus stops being a face, it turns into ruins, in which it is difficult to spot that which was. Becoming something else, something strange, and yet remaining the same (the terribly distorted face of a concrete person), the face defies description; it does not submit to categorization; it crosses borders. It turns into a monster; it radiates a threat that is unpronounceable and unspeakable. ${ }^{500}$

In Sir Gillies' book we see photos of things we do not want to look at, from which we would prefer to shy away. The horribly transformed faces of injured soldiers, subjected to plastic surgery, are not faces. They are monsters that resemble nothing. And at the same time, they are concrete people who suffered greatly, about whom we know nothing beyond what we read about the treatment process, which is delivered in an expert's cold language. The striking contrast between the person's anonymity and the surgical precision with which his monstrous appearance is shown is one of the sources of shock that we feel when looking through Plastic Surgery. What is most shocking is the collision of various disproportionalities: the expressiveness of the presentation, purged of any situational context, unceremoniously reveals what should be hidden; a reality that cannot be grasped, because it is amorphous and thus incredible, is recreated with laboratory-like exactitude; and finally, the soulless analytic nature of the image, the fact that it is broken down into its elemental parts, into more or less broken parts of some mechanism, collides - in the viewer's consciousness - with the symbol of the face (deeply rooted in culture) as a reflection of the soul, a sign of a person's unique identity.

It seems that it is not so much the brutal nature of these images as their medical coldness and passionless expressiveness that lend them their quality of peculiar eeriness. We are reminded of Delacroix's comments on the shock that can be caused by photos containing repugnant content. Photographic perfection has rarely been more intolerable than it is in this case. We see the detailed anatomy of injuries and nothing more. The owner of that which was once a face is now the specimen of an anatomical monster. Anatomical, because it is bereft

500 The Aristotelian definition of monstrosity is related not so much to the deformation of appearance, but to a lack of tangible relationships between the parent and descendant. Monstrosity is deceptive, its bizarre appearance disturbs the natural relations of resemblance (it is not known what exactly it is similar to), it violates the boundaries between categories and breaks Nature's order. See Huet, Monstrous Imagination, 4 . The monstrous is thus "between"; it is something yet not something. Hence, the horror. 
of metaphysics, of mystery, of unsettling ambiguity. In a sense, the photos of soldiers treated by Sir Gillies injured them once again. Shrapnel and bullets had savaged their faces, robbing them of their natural appearance. In order to restore them, at least partly, their faces are taken away once again, by turning them into an object in the documentation of surgical proceedings. In this sense, the photos in Plastic Surgery are empty and flat, one-dimensional - which is precisely what is intolerable about them. They strip down the wounded soldier, depriving him of the terrible mystery of his wounds. We are told to look at flesh; we are thus blocked from the possibility of finding sense in what we see. With their mechanistic exactness - as Delacroix would put it - they falsify reality. Skin, tissue, flesh and bone reduce the experience of having lost a face, the destruction of that physiognomic text that serves as a record of identity, the morbid transformation of the face into a non-face, a monstrous mask, into photographic documentation, into an inventory of broken and repaired facial material. These photos also do away with one of the great phantasms of culture involving the effacement of the border between mask and face, the desire to gaze "at the inside" of the face, in order to check if something exists "between," if something exists that is simultaneously under the mask and in front of the face. ${ }^{501}$ The response we receive is a shapeless mixture of tissue and bone.

The main character in Erich Maria Remarque's All Quiet on the Western Front goes directly from the trenches on a short leave of absence at home. His mother asks him about nothing. His father is constantly demanding that he talk about the war. "I realize he does not know that a man cannot talk of such things." 502 "Dear mother, how shall I ever speak of the unspeakable things I have had to see?" ${ }^{03}$ Egon Erwin Kisch, an experienced journalist who served in the Austrian army and who maintained a journal during the Serbia campaign, wrote desperately at the beginning of the war: “[...] but now I don't know what to write. Where should I begin, if I want to speak of this unprecedented horror?"504 Invocations of the topos of inexpressibility are usually followed by descriptions

501 See the anthropological commentary of S. Rosiek on the relationship between the mask and face in the fourth part of the series "Transgresje" under the title Maski, ed. M. Janion and S. Rosiek (Gdańsk 1986), vol. II, 157-188.

502 Erich Maria Remarque, All Quiet on the Western Front, trans. A W. Wheen (Ballantine Books 1987), 165.

503 Quote from John Laffin, ed., Letters from the Front 1914 -1918 (London 1973), 25.

504 Egon Erwin Kisch, "Schreib das auf, Kisch!": Das Tagebuch von Egon Erwin Kisch (Berlin: Erich Reiss Verlag, 1930), 96. Translator's note: The texts above and below drawn from Kisch are my translation from the original German. 
of that which cannot be described. The reader is prepared for the use of exceptional language: a special assortment of words, metaphors, and stylistic tones; a suitable manner of speech, all in an effort to build the textual equivalent of "this unprecedented horror," which does not submit to textualization. None of the authors quoted here shied away from descriptions of drastic scenes, but this letter, written by a young French soldier, would seem to be particularly shocking, in large part because of the collision between the letter's macabre content and the fact that the letter was addressed to the soldier's mother: "For five days my shoes have been slippery with human brains. I have walked among lungs, among entrails. The men eat, what little they have to eat, at the side of the dead." 505

The above passage from the letter from son to mother is photographic in its literality. Photographic in that its account is cold, bereft of adjectives, objective, as if the author was trying to convey reality through a camera's lens. The macabre appears in this text as if unshielded, as if not passed through the filter of linguistic expression. Neutral images of the macabre are set alongside various forms of the macabre's verbal occlusion, making it more tolerable and ingestible. As if in a report, Kisch writes: "Countless injured were carried by us, [...] Bandaged or unbandaged, people whose cheeks or nose had been ripped off." ${ }^{506}$ Remarque reports dispassionately: "We see men living with their skulls blown open; [...] we see men without mouths, without jaws, without faces." ${ }^{507}$ In this context, a story told by Robert Graves can serve as an example of how an author can distance himself from the macabre, how to obscure the macabre through the use of sarcasm, through the brutalization of language:

[poor bastard] Sergeant Gallagher [...] thought he saw a Fritz in No Man's Land near our wire, so the silly booger takes one of them new issue percussion bombs and shoots it at 'im. Silly booger aims too low, it hits the top of the parapet and bursts back. Deoul! man, it breaks off his silly f-ing jaw and blows a great lump from his silly f-ing face, whatever. Poor silly booger. Not worth sweating to get him back! He's put paid to, whatever."508

The facial injuries described here remind us of Sir Gillies' patients. While in those photographs we see everything with excessive exactness, here the visualization is much more complicated, determined by the meaning of words and sentences. Sometimes an author avoids descriptions of injuries altogether, by

505 Laffin, Letters from the Front 1914 -1918, 25

506 Kisch, “Schreib das auf, Kisch!”, 47.

507 Erich Maria Remarque, All Quiet on the Western Front, 134.

508 Robert Graves, Good-Bye to All That: An Autobiography (Vintage, 1958), 98. 
invoking the topos of inexpressibility, or by approaching the subject situationally, as Stefan Żeromski did in his portrayal of the injured character Śnica: "The head was wrapped in bandages, with only the eyes and mouth exposed. The eyes were unconscious, full of hellish fire." ${ }^{509}$ The injured face wrapped in bandages, a kind of merciful disguise in front of seeing eyes, also has a quality of photographic documentation. ${ }^{510}$ The dressing hides what we are afraid to look at, but the hidden monstrosity will soon be laid bare during the surgical operation, and then preserved on film.

In autobiographical records from the First World War, faces of corpses appear significantly more often than faces of the living. In many descriptions we read of people being in constant touch with death, unable in the trenches to avoid the companionship of corpses; of close contact with bodies lying for weeks or months in "no man's land" or buried in earth constructions fortified by decaying corpses. Even if one got used to the macabre, its vision remained difficult to tolerate and ways were sought to - literally - cover it up. Ernst Jünger took note of a typical scene:

Arms and legs and heads stuck out of the slopes; in front of our holes were severed limbs and bodies, some of which had had coats or tarpaulins thrown over them, to save us the sight of the disfigured faces. ${ }^{511}$

It thus turned out that it was the monstrous deformation of the face that particularly needed to be covered. Whether it was the face of a living person torn to pieces by a bullet or the decaying countenance of a corpse, looking avoided the sight of macabre transformation. It is so difficult to look at the medicinal photographic documentation showing the subsequent stages of metamorphosis undergone by the faces of Sir Gillies' patients because what is most horrifying about such a face is that, though it has retained some of the outlines of its old shape, it is no longer something that resembles itself, or something that resembles anything. In his journal, a British general on the Western Front, Frank Percy Crozier, used precisely this term - "something":

509 S. Żeromski, Charitas (Warszawa 1974), 254.

510 Among many such photos, one that is particularly characteristic and serves practically as an illustration of the quote from Żeromski, is Lievin, 18 July 1917 - two injured Canadians are sitting in a military ambulance, both of whose heads are completely wrapped in bandages, which create a kind of white mask with holes for the eyes and mouth. In the Photograph Archive, Imperial War Museum, London, sygn. C. 0.1636.

511 Ernst Jünger, Storm of Steel, trans. Michael Hofmann (Penguin, 2004), 98. 
In the main communication trench we passed a man carrying a sandbag full of something. Thefts of rations and minor stores from the line are increasing. I therefore asked, "what have you in the bag?" "Rifleman Grundy, sir," came the unexpected reply. ${ }^{512}$

In Kazimierz Wierzyński's verse, poetic frenzy serves to depict the battlefield: "No, those shapeless lumps, torn apart corpses / Lie sticking, bloated and unrecognizable." ${ }_{13}^{13}$ But in Henri Barbusse we read: "It is befouled faces and tattered flesh, it is the corpses that are no longer like corpses even, floating on the ravenous earth." 514

The laws of human perception, the elementary mechanism of understanding, dictate that we relate that which is new, different or inconceivable to that which is known and understood. Which is why, in order to express that aphoristic "something," that which remains after a person, we reach for various comparisons for assistance. If corpses are no longer even like corpses, to what can we compare them? Maybe they were like "washing" hung on the barbed wire in "no man's land," like "scarecrows who scared no crows since they were edible," as a result of which "the bodies had the consistency of Camembert cheese." 15 What does the skyward face of a dead soldier in a flooded trench resemble? "The eyes are two white holes; the mouth is a black hole. The mask's yellow and puffed-up skin appears soft and creased, like dough gone cold." ${ }^{\prime 16}$ With what does one associate the massacred heads of dead soldiers?

I remember two of our fellows in a shell hole. They were crouching unnaturally. One had evidently been saying to the other, 'Keep your head down.' Now in both men's heads there was a dent, the sort of dent that appears in the side of a rubber ball when not fully expanded by air. ${ }^{517}$

In the photographs in Plastic Surgery we observe - if I may put it this way - the face in movement. The dynamics of this transformation did not lead, clearly, to the complete reconstruction of the face; it did not bring about a return of its original appearance. The patient and doctors could be satisfied with the sculptural effect of the operation; after all, given the horrible nature of the inflicted wounds,

512 Denis Winter, Death's Men: Soldiers of the Great War (Penguin, 2014), 205.

513 The poem "Popkowice” in "Rozkwitały pąki białych róż...” Wiersze i pieśni z lat 19081918 o Polsce, o wojnie i o żolnierzach, ed. and intro. A. Romanowski (Warszawa 1990), 379 [author's emphasis - J. L.].

514 Henri Barbusse, Under Fire: The Story of a Squad (BBBZ Books, 2010), 209.

515 These words are taken from an account by S. Cloete. See Winter, Death's Men, 208.

516 Henri Barbusse, Under Fire, 206.

517 The recollection of S. Graham. See Winter, Death's Men, 207. 
the victim - after the surgical procedure - seemed to have recovered a human countenance. But from an anthropological perspective, the "repaired" face was not the same face. It was an artificial construction, a mask built with different pieces of the body joined together. In this case, can one still talk about a face as a "spiritual mirror," as a sign of a person's unique identity? Such a surgically fabricated face is rather a deceptive monster - pretending to be what it is not. Some descriptions of corpses' faces, drawn from literature from the First World War, contain another kind of duality. The dynamics of change are characterized by an intense process of transmogrification that begins right after death: decay, bloating, decomposition, and mummification - the corpse's "life after life," so to speak.

In a novel by Zofia Nałkowska, we read:

He was changing, although it was really completely superfluous, in a certain way he was still alive. He was swelling up. He was changing color. It was almost like he was moving. He was shifting around in his own clothing. ${ }^{518}$

Robert Graves described a scene in which the dead were being collected from "no man's land":

After the first day or two the corpses swelled and stank. [...] Those we could not get in from the German wire continued to swell until the wall of the stomach collapsed, either naturally or when punctured by a bullet. [...] The colour of the dead faces changed from white to yellow-grey, to red, to purple, to green, to black, to slimy. ${ }^{519}$ Ernst Jünger, struggling alone through a wood churned up by shelling, heard:

[...] a quiet hissing and burbling sound. I stepped closer and encountered two bodies, which the heat had awakened to a ghostly type of life. The night was silent and humid; I stopped a long time before the eerie scene. ${ }^{520}$

This moment is characteristic, when one's gaze - as noted by Jünger - is caught by the sight of something that, even in a front-line situation that is saturated with brutality, represents an "eerie scene," one that mesmerizes the viewer. In his description, the author of Storm of Steel avoids describing how the corpses looked in full detail; he points only to the sounds that attracted his attention. What he saw and called a "quiet hissing and burbling sound" was not named directly. The contents of the "eerie scene" are indicated metaphorically. The visualization of that "awakening to a ghostly type of life" is a task left for the reader. What we thus have from Jünger is a metaphor that mediates between (a macabre) reality

518 Z. Nałkowska, Hrabia Emil (Warszawa 1977), 229.

519 Graves, Good-Bye to All That, 163.

520 Jünger, Storm of Steel, 152. 
and its representation. It is a kind of mimesis, one that conveys the macabre, not along the path of a veristic description, but by setting in motion the imagination. We also have an attitude that allows us to contemplate the macabre vision. The author frames - so to speak - a part of reality and extracts it from the background, and though his look - directed and intentional - he composes from that reality an image.

Language is capable in many ways of circling around that which is inexpressible. The indefinite pronoun "something" used by General Crozier when he was speaking of a bag filled with human remains, along with Jünger's use of metaphor, stimulate the work of the imagination. But the photographic image cannot evade literality. "Something" must be filled with a concrete thing. Exactitude and absolute clarity seem to close off the field of imagination. The question remains, in the case of photos presenting the macabre: do initial shock and rejection always precede later indifference and dulled sensitivities? In other words: is it possible to have hermeneutic contact with such images?

In the Museum of the History of Photography in Florence one can view two juxtaposed photos creating a dual portrait of a soldier named Brunier. Both photos look like a standard identification photo. In one, we see a young person in his buttoned-up uniform. The shape of the head, close cut hair, a thin mustache under his nose, the outlines of the eyes and ears lightly retouched. In the other, the same person in an unbuttoned uniform, head on a pillow, his entire face, forehead and neck burned and covered in incrustation, in which the crevices of the eyes and ears are barely visible. In the bottom right corner we see the name: "Brunier" and the date: "21-6-16." But in the upper left corner, the date: "23-6-16." Does the first date indicate the day he was burned, and the second date the day he was admitted to hospital? Was Brunier the victim of a flamethrower, or was his burned face - and this seems more likely - the effect of a gas attack? After chlorine and phosgene gasses, mustard gas was the third generation of poison gases used in combat on the fronts during the First World War. Perversely, it was called the "most humanitarian" gas because it killed only 2 percent of its victims. It terribly maimed the rest. Sister Millard, who worked at a dressing station, remembered: "Gas cases are terrible. [...] Some have their eyes and faces entirely eaten away by gas and their bodies covered with first-degree burns." 521

This dual portrait of Brunier shares the kind of exactitude and literality that we see in the photos in Plastic Surgery, and yet it does not give the same repulsive 
impression of laboratory-like sterility as does the photographic documentation of Sir Gillies' work. The photos of Brunier show the macabre metamorphosis of his appearance, but they do not undermine the integrity of the individual, they do not try to dig deeper, under the mask of incrustation into which his face had changed. They present only two images to the viewer: one "before" and another "after." The history of this terrible transformation is something we have to figure out for ourselves.

In addition to the photos, Sir Gillies' books included pastel drawings by Henry Tonks (1862-1937), an English physician and painter who gave up medicine for art. In 1916 he joined the military and served as a lieutenant in the Royal Army Medical Corps. He was transferred to the Cambridge Military Hospital, where he did a wide range of sketches, diagrams and portraits of injured patients. Sir Gillies valued the painter's work, particularly for its documentary value. Tonks himself saw something more in his work. In a letter to a friend he wrote: "I am doing a number of heads of wounded soldiers who had their faces knocked about. [...] It is a chamber of horrors, but I am quite confident to draw them, as it is excellent practice." 522 But Tonks, one of the closest friends of the great American painter John Singer Sargent (one of whose famous paintings was Gassed, which takes up Bruegel's theme of the blind leading the blind), was not indifferent to the horrors of war and did not treat it as just an opportunity to carry out a technical exercise. Just after the war, in France, he painted his most famous work, An Advanced Dressing Station - a panoramic scene from the front containing a crowd of injured and medical personnel in a feverish commotion. His Studies of Facial Wounds (these pastel drawings, done at hospital bedsides, go well beyond the framework of surgical documentation) hang in Tate Britain and the Imperial War Museum in London.

Tonks' pastel drawings faithfully depict facial deformation and do nothing to hide their monstrous appearance. And yet their exactitude is not the exactitude of a photograph, because it is not - to use Delacroix's word - "cold." Far from standard examples of realism, they contrast sharply with the battle-scarred faces of the living and dead that emerge from a portfolio of fifty etchings by the outstanding German painter and graphic artist Otto Dix (1891-1969). Published in 1924 under the title Der Krieg, the collection became Dix's most famous work. With expressionistic lines, full of passion and unrestrained violence, these etchings exhibit Dix's own front line experiences (he took part in the Battle of the Somme, served briefly on the Russian Front, and then fought at Verdun and 
Ypres). Between the macabre reality of the trenches and that reality's image there is a screen of forms. The observed world persists in the artist's memory, it is processed through his consciousness; the images are created by his hand, having been filtered through his individual sensitivities, his heart, and his mind. They are not mechanistic replicas of reality, but rather its interpretation.

One of Dix's etchings shows the heads of two corpses in an advanced stage of decay $^{523}$ - a sight that often accompanied soldiers on the front, and one that often made its way into journals and memoirs. In Barbusse's work, we find a passage that would provide an excellent caption for Dix's etching:

This plain $[\ldots]$ is an amazing charnel-house. It swarms with corpses, and might be a cemetery of which the top has been taken away. Groups of men are moving about it, identifying the dead [...], turning the remains over, recognizing them by some detail in spite of their faces. [...] It is some months now since death hollowed their eyes and consumed their cheeks [...]. By the side of heads black and waxen as Egyptian mummies, clotted with grubs and the wreckage of insects, where white teeth still gleam in some cavities, by the side of poor darkening stumps that abound like a field of old roots laid bare, one discovers naked yellow skulls wearing the red cloth fez, whose gray cover has crumbled like paper. ${ }^{524}$

In Dix's work, the two heads disgorge themselves from their former shapes, afflicted as they are by this macabre metamorphosis; they still resemble a human face, with the bared teeth and eye sockets, but they are already leaning out toward strange, monstrous forms. In the front, between the two heads, there is a soldier's "dog tag." One can even read the soldier's name and his date of birth: Miller, 3 $\mathrm{V}$ [18]94. Between the appearance (as suggested by the presence of the dog tags and as evoked in our imagination) of the twenty-year-old private Miller and that which remained of him, there is a story about this terrible transformation. The image of the living Miller, not revealed directly but existing as subtext, connects this etching with the tradition of the danse macabre, processed expressionistically. That meeting between the living and the dead also speaks to a transformation, which depicts contact between a living face and the decaying countenance of a transi. The contrast that Dix achieved by matching the immutable piece of metal (as an indicator of a soldier's identity) up against human heads falling into

523 I am referring here to the last of the fifty etchings, entitled Tote vor der Stellung bei Tahure. See Disasters of War: Callot, Goya, Dix, published on the occasion of "Disaster of War: Callot, Goya, Dix, a National Touring Exhibition" organized by the Hayward Gallery (London 1998). Almost half of the items in Der Krieg were reproduced in this catalog, which also includes an essay on Dix's etchings written by J. Willett.

524 Barbusse, Under Fire, 169-170. 
decay, builds a type of expression that - capturing the horror of the macabre does not confine itself to "cold literality," but obscures it with form.

The experience of the macabre has an ambivalent character. It repels and attracts at the same time; it frightens and, in a sense, fascinates. It is also a mixture of metaphysical horror and trivial materiality. The collision of these two orders triggers the shock we feel when we have this type of experience. When strangeness (which cannot be reconciled or expressed, which defies description and depiction, which arouses horror) is confronted with the literality of the photographic record (without the distance of form, without a screen, without metaphor), the shock intensifies. We see a flat image, in which everything is exactly what it is: a corpse, decaying flesh, torn tissue, festering wounds, a tangle of boiling material. If such a photo faithfully represents reality, does it faithfully represent experience?

Delacroix cautioned against photography's exactitude and literality. The literality of the photos in Plastic Surgery is anatomical. There is no depth. It offers no opportunity to take a hermeneutic stance. It is to serve other purposes. To give expression to limit experiences (one kind of which, no doubt, is the macabre), a language must be developed and consciously shaped by which we can attempt to conquer this literality, master the horror, overcome the shock, and come closer to understanding.

\section{Before Marching off to the Front}

After the Archduke Franz Ferdinand, heir to the Austro-Hungarian throne, was killed in Sarajevo, war fever struck politicians, military leaders and people on the streets of Europe. While German diplomats pressed for war, German intellectual and artistic elites were exuberant; in war, they saw Faustian forces destroying old forms, radically changing and renewing the world, a unique opportunity for spiritual liberation and rebirth. British, French and American opinion-makers treated war as an order to protect legacy, that which was inherited from the past, to preserve the highest values developed over the course of generations, to defend Honor, Motherland, Family. War caused excitement among everyone, even antiwar pacifists and reluctant socialists. The British contrasted the Germans' apocalyptic fantasy of "a new heaven and a new earth" with their own kind of social-political millennialism, expressed in the famous slogans: "The war to end all wars" and "the war to make the world safe for democracy." 525 However it 
might sound today - after the experiences of the twentieth-century wars - news that war had broken out was welcomed with joyous elation by certain poets and writers on both sides of the conflict, since - as it seemed to them - it offered cleansing, purification. The English poet Rupert Chawner Brooke, an officer in the British Navy, fatally wounded during an expedition in the Dardanelles in 1915, wrote in his poem 1914:

\section{Now, God be thanked Who has matched us with His hour, [...] \\ To turn, as swimmers into cleanness leaping, \\ Glad from a world grown old and cold and weary, [...] \\ Honour has come back, as a king, to earth, [...].}

And for Thomas Mann, future Nobel Prize in Literature laureate, war was to be:

[...] a purification, a liberation, an enormous hope. [...] The German soul is opposed to the pacifist ideal of civilization for is not peace an element of civil corruption?"526

News about the war was welcomed with spectacular explosions of joy. Scenes of cheering crowds were immortalized in a wide range of photos which, though they were taken in various European capitals on opposing sides of the front, are amazingly similar to one another. On 28 July 1914, the day Austro-Hungary declared war on Serbia, enthusiastic Viennese carried portraits of Franz Joseph through the streets, lifting their hands, waving their hats in the air, smiling and screaming. In the back, above the heads of the crowd, we see black umbrellas opened to protect people from the sun. The hats quavering in the air stand in contrast to the calm and static umbrellas. ${ }^{527}$ The Germans declared war on Russia on 1 August. A crowd of many thousands of people poured into the street, and in front of the royal palace enthusiastic Berliners greeted the Kaiser. And when the mobilization proclamation was posted on the palace gates, the gathering sang the national anthem, "And now let us all thank the Lord." ${ }^{28}$ On 4 August, after German troops crossed into neutral Belgium, Great Britain declared war on Germany. From the balcony of Buckingham Palace King George V, surrounded by the royal family, greeted the crowd, which sang in joyous excitement "God Save the King." Again a forest of raised hands waving hats. It was night, and the bright lamps highlighted the palace façade against the dark backdrop and

526 For both quotes (Brooke and Mann), see Barbara W. Tuchman, The Guns of August (Presidio Press, 1962), 369.

527 See photo in I. Westwell, World War I Day by Day (Osceola 2001), 11.

528 See photo in Eksteins, Rites of Spring, no. 6, 208. 
reflected off the raised white hats. ${ }^{529}$ At the same time, people in Trafalgar Square were singing, screaming, rejoicing, and waving their hats in the air. ${ }^{530}$

In a photo showing a patriotic demonstration on 2 August 1914 in front of the Feldherrnhalle at Odeonsplatz in Munich, hats are mostly sitting on their owners' heads, only few are lifted into the air. ${ }^{531}$ The signs of joy are raised hands with clenched fists, smiles on faces. In the crowd packed into the square in front of this monumental Field Marshals' Hall there was a certain young man, without a hat, gazing out toward some point in space. Many years later, looking at this photo, Adolf Hitler remembered that he was in this heaving crowd at Odeonsplatz, hoarse from singing "Die Wacht am Rhein" and "Deutschland, Deutschland über alles." Heinrich Hoffmann, the man who had taken the photo and who would later become Hitler's court photographer, enlarged the photo several times and, as Ian Kershaw wrote:

[...] discovered the face of the twenty-five-year-old Hitler in the centre of the photograph, gripped and enraptured by the war hysteria. The subsequent mass reproduction of the photograph helped contribute to the establishment of the Führer myth - and to Hoffman's immense profits. ${ }^{532}$

War fever was felt especially by young people. On the wave of patriotic enthusiasm, they followed their hearts; they wanted to participate in a knight's battle over the noblest ideals, though they also wanted to experience a true and manly adventure. Rallies and demonstrations, celebrating the coming war in the huge theater of open urban spaces, led to other scenes of public spectacle, namely mobilization campaigns, which were also widely photographed. The same actors appear in new roles, though they remain in the same costumes. The emotionfilled crowd, the vibrating mass of people, transform themselves into a group of volunteers, crowded tightly, motionless, staring at the camera lens, and waiting in civilian clothes in front of the recruiting center. Hats and caps are no longer waving in the air; they had long come down and, without exception, are resting nicely on the heads of those who had decided to join the army. In response to the appeal by Sir Horatio Herbert Kitchener, the British War Secretary, who on 8 August 1914 requested 100,000 volunteers, 175,000 came forward within a week. By 5 September, that number had climbed to 250,000. On that day, for the first time, the famous poster appeared with a huge image of Kitchener

529 See photographs in J. Terraine, The Great War (London 1999), 10.

530 See photo in Eksteins, Rites of Spring, no. 9, 208.

531 Ian Kershaw, Hitler: 1889-1936 Hubris (W. W. Norton \& Company, 2000), after p. 162.

532 Ibid., 89. 
pointing toward the viewer with the words: Lord Kitchener "wants YOU." Thus were the origins of the British Expeditionary Force, an army made up of mostly volunteers, about which Ian Hay, several months later, would write the following in a popular hymn dedicated to the so-called Kitchener's Army:

Within their hearts be writ

This single-line memorial: -

He did his duty - and his bit. ${ }^{533}$

I am looking at a photo taken in August 1914 at the Central London Recruiting Depot. ${ }^{534}$ Volunteers are crowded in front of the gate. Visible behind them is a brick wall with grim, probably barred windows. The men are standing in a strikingly ordered way. The photo, taken from slightly above, gives the impression of people arranged in an amphitheater. In the foreground, a few characters are fully visible, but behind them, the middle of the photo is filled with heads. Almost parallel layers build themselves one upon the other, and their linearity is highlighted by the sharp lines of the cap and hat brims. Horizontal lines are dominant: the arrangement of the heads, faces, eyes, the clear outline of the wall bricks, the window grilles. The iron gate's horizontal beam makes up an upper border of the composition, above which the lines of the radiant grating flow up and outward, toward a space beyond the frame's limits. Everyone is looking at the camera, and a counterpoint for these centered looks consists of two figures at the photo's foreground: a man standing with arms akimbo, his back to the photographer, looking at the group of volunteers; and a police officer - the only person in uniform - who is also facing the men gathered in the courtyard.

One would like to say that all of the above indicated some kind of military order, as if the volunteers waiting to be called into the army had already unconsciously fallen into formation. The dynamic movement of crowds of people, joyous over the knowledge that war was coming, had changed into some kind of wait-and-see motionless. The smiles visible on some of the volunteers' faces seem to be more restrained, and the expression on other faces is a mixture of gravity, interest, excitement, fear; all eyes are set in one direction - that is, at the photographer, and thus toward us, as we look at the photograph. But we look at these men from a distance of 100 years; between the time this photo was taken and time we give our looks, there was not just the history of the Great War, in which these volunteers were about to participate, but the entire twentieth century.

533 Eksteins, Rites of Spring, 178.

534 See photo in Fussell, The Great War and Modern Memory, 20. 
The photograph of volunteers standing in front of the recruiting depot tells a story about waiting for something that would transform everything, which no one at the time was able to comprehend. The Great Change - sensed, longed for eludes the view from August 1914. Anticipating that change, the volunteers look us in the eye, joyous and boisterous, excited while they wait for their adventure to begin, intoxicated by their patriotic mission. They do not know yet, because they cannot know, what will happen to them, what will befall Europe and the entire world. They have no idea what the object of their anticipation will turn out to be. War had not yet managed to reveal to them its monstrous face. Still healthy and whole, they stand before us as the Great Change approaches: civilian caps will be exchanged for helmets; they will take off their civilian clothes and put on uniforms; bodies vibrating with life are changing into bodies that are exhausted, tormented, injured, torn apart by bullets, dead and decaying; youthful enthusiasm transforms itself into disappointment, horror, shock, and torpor.

Then and there - in front of the Central London Recruiting Depot in August 1914 - nothing had happened yet. Like those faces looking into the camera lens, preserved in time, the entire photo leans toward the future, as if, together with the London volunteers, it had caught sight of what was about to happen. The narrative potential of this photograph is contained in our knowledge of what was about to happen, and of what they did not know at the time. This surplus of knowledge transforms itself into a story drawn (or rather extrapolated) from the photo. It would be a story about how their faces were frozen in a mask of horror, about how they had been massacred or choked by gas, about how - with noses ripped off, jaws crushed, and cheeks torn open - they found themselves lying in a field hospital. It could also be a story about crippled men without legs or arms populating postwar Europe; about those who had drowned in mud in the trenches or had been buried under the ruins of destroyed shelters or in artillery shell craters; about unburied corpses decaying for months in "no man's land"; or about soldiers suffering from shell shock and hidden from the world in psychiatric hospitals. All of them, dead or alive, could have had the faces of the volunteers in the photo.

Our look puts them today in a situation marked by tragic irony; it reveals the gap between the perception shaped by the first salvoes in August 1914 and the war reality that was waiting for the volunteers behind the gate of the Central London Recruiting Depot. They are about to set off on a trip whose end only we know. We know that what the volunteers wanted and what they were doing would not stop the catastrophe toward which they were all inevitably headed. We look at them as an audience looks at Oedipus, the noble king of Thebes, on whom the knowledge that he had killed his father and married his mother 
would, in the end, fall. Would knowledge gained in the trenches also take from them those eyes (as in the case of Oedipus) that were now looking with excitement toward future events, focused on a photographer who was eternalizing the moment when they had started down the path toward war, eyes that were directed toward us?

Nineteen-year-old Roland Leighton enlisted in the army as a volunteer in August 1914, but he was accepted only in October, in Norwich. He thus could not have been one of the London volunteers, and was certainly not one of the volunteers in that photo. He fought first in the 4 Norwich Regiment and then the 7 Worcestershire Regiment. He died on 22 December 1915, two days before his holiday furlough, shot to death at night in "no man's land" while repairing barbed wire fencing. On 11 September 1915, he had written to a friend, Vera Brittain, from the trenches of France:

The dug-outs have been nearly all blown in, the wire entanglements are a wreck, and in among this chaos of twisted iron and splintered timber and shapeless earth are the fleshless, blackened bones of simple men who poured out their red sweet wine of youth unknowing, for nothing more tangible than Honour or their Country's Glory or another's Lust [for] Power. Let him who thinks that War is a glorious thing, who loves to roll forth stirring words of exhortation, invoking Honour and Praise and Valour and Love of Country with as thoughtless and fervid a faith as inspired the priests of Baal to call on their own slumbering deity, let him but look at a little pile of sodden grey rags that cover half a skull and a shin bone and what might have been its ribs, or at this skeleton lying on its side, resting half crouching as it fell, supported by one arm, perfect but that it is headless and with the tattered clothing still draped around it; and let him realise how grand \& glorious a thing it is to have distilled all Youth and Joy and Life into a foetid heap of hideous putrescence. Who is there who has known \& seen who can say that Victory is worth the death of even one of these? ${ }^{535}$

This same kind of rapacious, ironic disillusionment was employed by the English poet Wilfred Own, who enlisted and was sworn into the military almost exactly a year after Roland Leighton - on 21 September 1915 - and who died on 4 November 1918 under artillery fire during the crossing of the Sambre-Oise Canal. In his poem "Dulce et Decorum Est," Owen described a gas attack and the death of a soldier who had not managed to put his mask on:

If in some smothering dreams you too could pace

Behind the wagon that we flung him in,

535 Letters from a Lost Generation. First World War Letters of Vera Brittain and Four Friends: Roland Leighton, Edward Brittain, Victor Richardson, Geoffrey Thurlow, eds. A. Bishop, M. Bostridge (Abacus 1999), 165. 
And watch the white eyes writhing in his face,

His hanging face, like a devil's sick of sin;

If you could hear, at every jolt, the blood

Come gargling from the froth-corrupted lungs,

Obscene as cancer, bitter as the cud

Of vile, incurable sores on innocent tongues,-

My friend, you would not tell with such high zest

To children ardent for some desperate glory,

The old Lie: Dulce et decorum est

Pro patria mori. ${ }^{536}$

\section{Damaged Photographs of (from) the Holocaust}

I will now focus on those instances in which the transparency of the photographic medium is disrupted, and when what Barthes called "reference worship" is questioned or seriously restricted. ${ }^{537}$

In this context I would like to consider the situation in which external circumstances - independent of the subject, the material, and the very mechanisms by which a photographic image is produced - interfere with the photograph's materiality. What interests me here is the photograph that was "destroyed" by events or circumstances beyond the knowledge, will and intentions of the photographer handling the negative or photographic print, and to what extent such destruction enriches photography as the "art of the possible."

The photographs I have chosen to examine here have a particularly significant feature: they are, in various ways, damaged, and they thus lose the virtue of transparency for the viewer; they cannot be reduced to the reference itself; they unveil the materiality of the photographic medium, its texture. Such damage exposes the photograph's "fiction of transparency" 538 and the principle of the

536 Wilfred Owen, The Collected Poems of Wilfred Owen, ed. C. Day Lewis (New Directions Book, 1965), 55.

537 For more on the "reference worship" in Barthes' reflections on photography (what we have here are "photographs without an image," because - as Barthes stated - it is not the photo we see, but "that-which-was"), see A. Rouillé, op. cit., 74-79. It is worth noting that Soulages is invoked here, and that Rouillé also questions the transparency of a photograph.

538 On the fiction of the photographic image's transparency, see A. Rouillé, op. cit., s. $71-73$. 
"invisibility of the negative," ${ }^{339}$ which reveals in turn the paradoxical nature of the relationship between the object and its photographic image. Damage impedes perception, establishing distance between the object and its image, highlighting discontinuity between the object seen in the photos and the object itself. A damaged negative or defective photographic emulsion become visible on the print, "screening" the photograph's object. And yet, damage would appear to lend (at least in certain receptive situations) the photographed object an exceptional aura, one that - in a sense - brings the viewer closer to the reality preserved in the photo. I would like to reflect on this paradoxical phenomenon.

\section{Let Us Pause for a Moment on the Matter of Damage}

In one way or another, all of us have seen works of ancient art (in museums, in published reproductions, or in their original locations). A fundamental quality of these works is their "being in ruins," and they include surviving fragments of temples, columns broken into pieces, statues without heads, without hands, without faces. Our relationship with a work of art that is damaged, defective, or destroyed - despite the fact that it is in this condition, or perhaps precisely because of this fact - has for us a particular aesthetic value. After all, we could not imagine "repaired" Greek statues. Reconstructed arms on the Venus de Milo or a head on the Nike of Samothrace would no doubt be treated not as a supplement to its aesthetic value; on the contrary, it would represent impoverishment, deformation, destruction. In the colloquial view of Greek statues, their white stone, washed out by thousands of years of water and wind, have a natural severity, but we in fact are not aware of their original appearance. In Greek art, Acrolith are statues made with various materials: the head of the sculpture was of marble, the feet and hands of stone, and the body of wood. These figures were clothed in the kind of ornate fabric robes that one can see today in Catholic churches. What followed from this was chryselephantine works made of ivory and gold; the body was sculpted from ivory, the robes were made from sheets of gold leaf, all of which was built around a wooden frame. ${ }^{540}$

From antiquity we have inherited not only broken columns and headless statues, but also pieces of papyrus. At the beginning of the twentieth century, during an excavation at ancient Oxyrhynchus, 160 kilometers southwest of

539 "The negative in itself is invisible, because I only look at it through the already-created photo, inasmuch as looking at a negative is seeing in it a picture [...]." F. Soulages, op. cit., 156.

540 See K. Estreicher, Historia sztuki w zarysie (Warszawa; Kraków 1977), 132-133. 
Cairo, the English archeologists Hunt and Grenfell found on an ancient trash heap papyrus scraps with the poetry of Sappho (as well as fragments of Pindar, Sophocles, and Euripides). How are we to reconstruct them today? We stand before an impassable barrier: the element of destruction is invincible, destruction is omnipresent, only scattered phrases and single words have been preserved on scraps of papyrus. But when one reads these remnants of Sappho's poetry, do they not sound - precisely because of their fragmentary nature - like excellent modern poetry which requires nothing more, which is already whole, despite or because of -defects.

For Cyprian Norwid, ruins themselves were a work of art - that is, not only something left over from past beauty, an evocative thought of time inevitably gone by, but a lasting and current source of aesthetic experience. In Rzecz o wolności stowa, the poet drew an image of the ruins of Palmyra in Syria:

Patrzyłem i wydziwić się nie mogłem onej Całości rzeczy w całość ruiny zmienionej, Pięknej ogółem, który powstał ze zniszczenia, Z potrącenia, zdeptania i zlekce ważenia,

[...]

chciałem kamień drobny

Podjąć, lecz nie jak fragment wydał się osobny

Palcom moim; zadrząłem i ramię cofnąłem,

Czując, że za część jedną rzeczy pełnej wziąłem,

I natychmiast szepnęła do mnie mysł ostrożna:

"Patrz!... oto i Ruinę nawet popsuć mozna!"

A jam jej odpowiedzial:

“...Zaprawdę: Ruina

Jest całoscią!...

... I nową twórczość odpoczyna

I looked and could not stop wondering

Things in their entirety changed into complete ruin,

A beautiful whole that arose from destruction,

from being knocked down, trampled and disregarded,

[...]

I wanted to pick up a small stone

But to my fingers it did not seem like

a separate fragment; I shivered and withdrew my arm,

Feeling that I took a part of a larger whole,

And at once a cautious thought whispered to me:

"Look! ... here one can even ruin Ruins!"

And I responded to that thought: 
“... Verily: Ruins

They are a whole! ...

... A new creative work. ${ }^{541}$

Polish poet Zbigniew Herbert was more skeptical:

We have learned to look at works of Greek art as fragments and scraps. We believed too easily that they owe their perfection and beauty to being fragments and scraps. We cannot, nor do we even want to imagine the Venus of Milo or any Greek temple as they really were. We derive a strange aesthetic satisfaction (which has probably never been fully analyzed) from the fact that the capital of a column holds up nothing, that the marble cheek of a goddess suddenly loses its fleshly smoothness and turns into raw uneven stone. This constant neighboring of art and nature, the clear border between what was carved by the artist's chisel and nature's chisel, does not prompt the imagination to fill out the whole but on the contrary, silences it. ${ }^{542}$

It has happened to all of us, or it could happen - a photograph gets dirty or becomes bent or torn. "Tattered" private photographs are a part of any "domestic history," of a family's story, of everyday private life. John Berger drew a distinction between "private" and "public" photography. Private photography demonstrates a sense of continuity; such a photograph is surrounded by meaning and received within the context of private life, guaranteeing continuity with regard to the life from which it is severed. Public photography demonstrates a lack of continuity between the viewer and the event presented in the photograph (and its original meaning). Information is severed from all lived experience; it preserves the memory of a stranger. ${ }^{543}$ The kinds of damage of interest to me here are not "innocent"; they have come about not as a result of inattention or neglect. These instances of damage are not trivial, the kind that mark the everyday life of objects and are inevitably tied to them. They are an effect of such an event as the Holocaust, and they are thus manifestly "not-everyday." They are exceptional.

This initial treatment of the matters at hand leads us to the following assertions:

First - the subject of these considerations will be the damage that marks the object of our looking (in the broadest possible sense, it involves an artifact, but more strictly speaking: in the text below, we are talking about a photograph). Second - this damage is the result of the interaction of a wide variety of factors, which certainly were not part of the creator's intentions; they were separate

541 C. Norwid, Pisma wszystkie, ed. J. W. Gomulicki, vol. III, 616-617.

542 Zbigniew Herbert, "Labyrinth on the Sea/Acropolis," in The Collected Prose, 19481998, ed. and intro. Alissa Valles, preface Charles Simic (Ecco, 2010), 478.

543 John Berger, About Looking (Vintage, 1992), 55-56, 60-61. 
and independent of the creative process; they are not part of the world of art, but of nature and/or history.

Third - we will treat the damaged Venus de Milo statue, the damaged poems by Sappho, or a damaged photo as an aesthetic object. Aesthetic objects can be created intentionally (like all works of art) or not. What is decisive in determining whether something achieves the rank of an aesthetic object is the adoption of an aesthetic stance by the viewer. It is the viewer who causes something to potentially become an aesthetic object. For me, phenomenological aesthetics is only an inspiration, a point of reference, one that carries no obligation to follow philosophical orthodoxy. Roman Ingarden's concept of the aesthetic object - which has an intentional character and is the concretization of the work-scheme based on the supplementing or complementing of "indeterminable places" - seems to me to be closest to what I want to achieve in these reflections; it best reflects the features of my view of damaged photographs, which is why I refer to this concept at this point.

\section{Types of Damaged Photographs}

Photographic documentation of the Holocaust is dominated by photographs that were taken by the perpetrators. The Holocaust was photographed both by common soldiers ("amateurs") who would fill up hundreds of albums with thousands of prints, ${ }^{544}$ and by professionals from specialized propaganda units in the Wehrmacht or the Waffen-SS, within which distinct propaganda companies were active. ${ }^{545}$ I want to emphasize most strongly that all of the damaged photos analyzed below were taken by victims.

We have at our disposal both scattered, individual photos and collections of photos taken by Jews themselves. Two albums of photos taken by the FotoForbert portrait studio emerged from occupied Warsaw: one was put together in April 1940 for Joint (the American Jewish Joint Distribution Committee) and exhibited the activities of various self-help institutions, and another one was put together in the autumn of 1941 illustrating work done in the szopy (German-run

544 See J. Levin and D. Uziel, “Ordinary Men, Extraordinary Photos,” Yad Vashem Studies XXVI (1998); J. Struk, Photographing the Holocaust (see chapter "Armed with a Camera" and part of the chapter "Cameras in the Ghettos")

545 See D. Uziel, "Wehrmacht Propaganda Troops and the Jews," Yad Vashem Studies XXIX (2001). 
workshops in the ghetto). ${ }^{546}$ The photograph archive of the Jewish Historical Institute in Warsaw contains many private Jewish photos along with those that survived together with other materials in the Underground Archive of the Warsaw Ghetto (the Emanuel Ringelblum Archive). But this clandestine photographic documentation is rather meager - 76 photos showing life in the ghetto and its officials in 1941 and 1942 and documenting smuggling operations (passing bags of food over and through the ghetto walls). Also saved from the Holocaust was a book manuscript under the title Choroba głodowa. Badania kliniczne nad głodem wykonane $w$ getcie warszawskim $z$ roku 1942 along with ten photographs. This work was published by Joint in Warsaw in 1946. Two Jewish photographers were active in the Łódź Ghetto: Mendel Grossman ${ }^{547}$ and Henryk Ross, ${ }^{548}$ who were able, under the conditions of occupation, to assemble extensive photographic documentation of various aspects of life in the closed quarter of Łódź. Under the auspices of the Łódź Council of Elders, official albums appeared that had a certain propaganda quality (they contain photos taken by Grossman and Ross). Arie Ben-Menachem (who, after the war, went by the name Artur Printz) compiled his own album made up of montages of photographs both clandestine and official, and attached with new captions that changed their meaning. ${ }^{549}$ The ghetto in Kaunas was photographed by Zvi Kadushin (later George Kadish), who secretly took more than a thousand photographs of everyday life. He managed to escape the ghetto and, after the war, to return and retrieve the hidden negatives. He died in the United States in 1997. ${ }^{550}$ Photos taken by Naftali Zaleszczyc (Naftali Saleschutz) of the ghetto in Kolbuszowa also survived. ${ }^{51}$

546 Both albums are preserved in the photograph archive of Yad Vashem. For more, see http://www1.yadvashem.org.il/search/index_search.html (accessed 25 May 2008) and http://www1.yadvashem.org.il/search/index_search.html (accessed 25 May 2008). See also Struk, Photographing the Holocaust, 120-122.

547 Grossman, With the Camera in the Ghetto, ed. Z. Szner and A. Sened (New York 1977); Grossman, My Secret Camera. Life in the Lodz Ghetto. Photographs by Mendel Grossman (San Diego 2000).

548 Ross, Łódź Ghetto Album. Photographs by Henryk Ross [London] 2004.

549 Struk, Photographing the Holocaust, 89-92.

550 See the United States Holocaust Memorial Museum online photo archive, go to https:// www.ushmm.org/search/results/?q = Zvi+Kadushin (USHMM search results for "Zvi Kadushin”). M. Gilbert, Holocaust. Ludzie-dokumenty-pamięc, trans. Z. Dalewski (Warszawa 2002), 96, 99, 174.

551 See https://www.ushmm.org/wlc/en/idcard.php?ModuleId = 10006202 (USHMM search results for "Naftali Saleschutz"). 


\section{Kinds of Damage}

Damage - involving both paper prints and negatives - can be divided into two basic types: chemical damage and mechanical damage. ${ }^{552}$

Chemical damage is caused above all by the effects of the photographic fixer sodium thiosulfate. The chemical treatment process must take place in suitable conditions (temperature, humidity) which, in the ghetto and particularly in the creation of clandestine photos, were difficult to ensure. Sodium thiosulfate should be very carefully rinsed, otherwise it reacts with the silver present in the photographic material, thus creating silver sulfide. The effect of this reaction on a poorly rinsed print is discoloration: brown stains and rusty shades turning into sepia tones (old photos, over time, take on such tones); and on poorly rinsed negatives, a yellow-brown coat is visible (mainly at the perforations).

Beyond scratches on the negative or paper, external smudging, and tears of various kinds - mechanical damage involves above all the effect of humidity and water. Henryk Ross's negatives, having been recovered from their hiding place under ground, carry traces of both chemical and mechanical damage, though the greatest destructive role was played by mechanical factors, namely the conditions under which the negatives had been stored - that is, buried in a damp space under the ground. Humidity softens the emulsion; moisture sometimes washes out large areas of the negative surface. Black deposits visible on Ross's photographic prints are empty spaces on the negative, spaces lacking exposure but corroded by dampness of the photographic emulsion.

\section{The Private Photograph}

Here, private photographs (as Berger understood it) would seem to be a typical attribute of "normal times." They provide documentation of the life of family and friends, family celebrations, trips, excursions, fun, everyday activity. They are photographs taken as if ignoring the war and the Holocaust; they are taken, as it were, despite the Holocaust, or on the margins of the Holocaust, in at least a dual sense. First - thematically, they are "alongside"; they show not what we know about those times: individual and collective portraits, family groups, faces, common amusement, meetings, and smiles. Second - they are the effect of purely private activities, which manifestly ignore public obligations and

552 I want to thank Agata Pietroń, a graduate of the University of Warsaw's Europejska Akademia of Fotografii and Instytut Kultury Polskiej, for her advice on photography's technical matters. 
the moral duty to bear witness to the fate of the exterminated collective. They seem not at all to document the times of the Holocaust, but rather to focus on recording expressions of privacy which were not touched by the Holocaust, from which the Holocaust was distilled. The Holocaust creeps into these photos only through the context of their reception, because of our knowledge of when, and in what circumstances, these photos were taken.

In front of us is an identification photo taken in Vilnius between the time when the ghetto was established in September 1941 and its liquidation in September 1943. Blended into the dark background, the face of a woman - dressed in a dark jacket and with hair pulled back - is the only bright spot against the gloomy backdrop. The face has black eyes with clear rings around them. The official nature of the identification photo is, in a sense, broken from the inside a usable photo, which satisfies the standard and customary visual schema, is transformed into a psychological portrait. The facial features, the lighting, the shadows under the eyes, the background, the look - all of this carries within itself an individual truth. What's more, it seems to not speak directly about the situation in which the photo was taken. The photo contains a note of sadness, of hidden suffering. But the photograph is also marked "from the outside." A single distinct scratch runs across the entire photo, marking the woman's right cheek and dividing her nose from her upper lip, and two other scratches, less visible, cut through the photo vertically and horizontally, crossing at the forehead. The woman's name is Henrietta Zeldowicz, the mother of Emilia, born in 1922, who married Aleksander Sedlis in the Vilnius ghetto. Both Emilia and Aleksander were doctors working in the ghetto hospital. Aleksander's parents, Elian and Anna Sedlis, were also doctors at the ghetto hospital. Anna died. Elian survived. Aleksander and Emilia also survived, and they are the ones who saved the family photos, among which is the identification photo of Henrietta Zeldowicz - the only vestige of her existence. Henrietta died during the liquidation of the Vilnius ghetto. ${ }^{553}$

Another photo, carefully cropped and lightly sepia-toned, is creased. These creases bypass the figure of a smiling girl in the foreground and just barely touch her feet. From behind the girl, a boy leans forward with his hands in his suit coat

553 See https://www.ushmm.org/search/results/?q = Henrietta+Zeldowicz (USHMM search results for "Henrietta Zeldowicz"). To go directly to the photo described above, see https://collections.ushmm.org/search/catalog/pa1156977. There are three other photos of the Zeldowicz family in the USHMM photo archive showing Henrietta, daughter, husband, and relatives. 
pocket, looking toward the photographer, interested and amused. The eyes of both the girl and the boy are aimed directly at the camera lens. They are giving a look of curiosity and good cheer. In the background, a tree and a brick wall. In the photograph is Dorka Lewin. The scene takes place in Kłodawa. In December 1940 Dorka sent this photo to a friend, Gina Tabaczyńska, who was living in the Warsaw Ghetto. Dorka died in the Chełmno extermination camp. Gina went into hiding in a bunker during the ghetto uprising, after which she crossed over to the Aryan side. She was then sent to Germany to work as a Pole. After the war, she returned to Poland, and in 1947 she left for the United States through France. ${ }^{554}$

The brother-sister photo of Jadzia and Szlamek Mącznik is almost completely undamaged. Only the bottom left corner is torn off, and at the top and middle we see a small scratch. Such portraits of children have adorned the windows of hundreds of photo studios. The one we are looking at here was taken in one of those studios in 1942, in this case in the Sosnowiec ghetto. This conventional shot features the heads close together of brother and sister, dressed up for the photo. They are looking at the camera lens with a serious expression on their faces, well aware of the role that has been handed to them - to pose for a family portrait in a photo studio. From their look one cannot read what is about to happen to them. Between May and August 1942, in three successive waves, the Jews of Sosnowiec were deported to Auschwitz. One of these waves carried away Jadzia and Szlamek along with their parents. Their brother Berl and sister Dorka survived. In 1948, Berl left Europe for Israel. He was the one who gave the photo of Jadzia and Szlamek to the Holocaust Museum archive in Washington, a photo taken just before their annihilation. ${ }^{555}$

Two other portrait photos originated from studios: one of Berek Putersznyt, a cobbler from Dąbrowa Górnicza, and another of his wife, Natalia Netka Puterszynt. These photos are significantly damaged: creased, with a thick network of cracks, rust-colored stains covering the sepia-tone surface like chickenpox spots. As parents, Berek and Natalia took these photos themselves in 1942 and sent them from the ghetto in Dąbrowa Górnicza to their daughter, Zosia, who had been transported to the concentration camp at Oberlstadt. Miraculously, Zosia was able to hide the portraits in a shoe. In May 1945 the nineteen-year-old

554 See https://collections.ushmm.org/search/catalog/pa1087278 (USHMM photo archive).

555 For biographical information, see Photo Archives online USHMM http://www. ushmm.org/uia-cgi/uia_doc/query/2?uf = uia_zFlcPn (accessed 25 May 2008). 
Zosia was liberated by the Red Army. Her parents died in Auschwitz in August 1943. The photos, hidden in her shoe, survived. ${ }^{556}$

Let us now move on to private photos taken by Henryk Ross in the Lódź Ghetto, among which there are many damaged photos, though the damage in these items is different than what we see in the ones discussed above. Those above were mostly scratched, creased or torn. Ross's photos exhibit black and white stains creeping across significant portions of the surface, discoloration that takes on strange shapes, washing away, in a sense, the photographic image. The world presented in the photos is thus eclipsed. What's more, it enters into a relationship with another visual order, with an abstract form that not so much disrupts the image as originally recorded as it, in a sense, broadens the present perspective. This collision of orders was not a product of the photographer's intentions, but was rather imposed from the outside as an effect of material disturbances of the image's original whole.

From this rich collection I have chosen three photos, in one of which the photographer's wife, Stefania, is lying on the grass with her hands up behind her head. The scene is idyllic. Stefania, dressed in a summer dress with short sleeves, is illuminated by warm sunlight. Her eyes are shut. She is resting, napping, dreaming. From the top of the frame, two black stains flow toward her face, in the shape of tongues, with bright white edges. The larger one touches her forehead, the smaller one is approaching her chin. Stefania is calm, unconcerned, as if she did not see the threat. The damage gave Ross's photo an unexpected and new dimension, one which can be perceived and interpreted only from the other side of the Holocaust. Stefania survived. In another photo a child is laughing, standing probably in a crib set up in a room. It is no more than a year old. The face is quite visible, its polka-dot outfit, but the rest has been devoured - like a translucent ameba - by a stain running from the bottom, top and side. Ross took this photo in 1940. We do not know what happened to the child. In the third photo, a mother, kissing a child (perhaps the same child) that she is holding in her arms, is photographed in front of a house. Some fencing is visible, behind which there are plants. The edges of the photo are marked by black serrated stains, from below - like black smoke - a stain climbing upward and eclipsing the figure of the mother. The child, dressed in a sleeveless overshirt covering a checkered short-sleeve shirt, is fully visible. The mother is able to save only her face and neck from the black, her dark and wavy hair blends with the tumbling

556 For biographical information, see Photo Archives online USHMM http://www. ushmm.org/uia-cgi/uia_doc/query/3?uf = uia_npTeMa (accessed 25 May 2008). 
texture of the stain. There is no way to say what happened to the characters in this photo.

\section{Clandestine Photographs}

Clandestine photographs document conditions in the ghetto, deportations, terror and crimes. They constitute material evidence, often prepared within the framework of a wider secret campaign to depict the Holocaust and its processes.

Three examples come from the Henryk Ross collection. First, Execution on Łódźs Bałucki Rynek. At the center is a gallows. A person hangs from a rope. It is a gray winter day. Snow has fallen on the cobblestones and roofs. The public execution had been carried out earlier. The crowd on the square has dispersed. Visible next to the gallows are the dark silhouettes of a few passers-by. The photo is unclear, unfocused, because it is poorly lighted. A mistake that is difficult to avoid when one is photographing in secret. But it is not that technical mistake that dominates the photo. From the top and bottom edges of the photo, two black stains flow toward one another, hemmed in by white bands, like the outlines of non-existent continents. They tend toward the gallows, but they do not cover it. Next photo. One of the deportations to the extermination camp in Chełmno. In the forefront, two Jewish policemen are escorting the deportees as they walk toward the Radogoszcz train station, which is where these deportees will board the train. Right now they are walking, carrying their belongings in bags, bundles thrown over their shoulders, milk cans. More or less a quarter of the photo is consumed by blackness, over which eerie white ripples are visible. Another scene. During the September 1942 "szpera" (from the German word "Gehsperre" referring to a total blockade of movement in the ghetto), the sick locked up in the hospital on Łagiewnicka Street are attempting to escape through a window. The Jewish police have caught them. The left side of the photo is reduced in size by a margin a few centimeters wide with ragged edges. And it is toward this blackness that an old women, bent almost to the ground, is apparently fleeing, trying to avoid the grasp of one of the policemen.

Several photographs taken in the autumn of 1944 by members of the Sonderkommando at Auschwitz-Birkenau are absolutely exceptional. They emerged from a situation marked by extreme threat, from strict clandestine conditions. They show the macabre "everyday events" of a crew at Crematorium $\mathrm{V}$ : the burning of bodies that do not fit in the crematorium furnaces, naked women moving toward the gas chamber. The frame is extremely tilted, the silhouettes of the women disappear into the background, among the trees. In another photo the field of vision is, to a large extent, obscured by the door 
frame of the gas chamber, from which the photographer snaps the photo. These photos show no visible traces of damage. They are blurred and shaky. They are marked by the very act of photographing: time and place. They carry the image of what was the Holocaust's culmination - the technological process of mass murder. They were smuggled out of the camp to Kraków, accompanied by a note dated 4 September 1944 and signed with the pseudonym "Stakło" (Stanisław Kłodziński). ${ }^{557}$

\section{Interpretive Tropes}

Photographic damage directs the viewer toward the medium of the photographic image; it forces the viewer to shift attention from the "represented world" to the material substrate, that which determines the appearance of that world in front the viewer's eyes. Damage reveals what is usually hidden, overlooked, unnoticed: the material surface of the photographic paper that is susceptible to mechanical influences, the chemical metamorphoses of the negative.

The layer of a photograph's damage appears as a result of external actions with respect to the act of photographing, external with respect to the object (subject) of the photograph, and independent of that act. Damage is the effect of a tangle of incidental circumstances (in the sense that they are planned by no one, that they are random) and the influences of mechanical factors and chemical processes. But this external affliction is an integral part of photography and makes up - so to speak - one of its aesthetic dimensions. Chance turns out to be an essential part of presentation; happenstance seems to cross over into the sphere of intentions in meaning-creation; the destruction of forms of representation endows the photo with additional meaning.

In photography there is an artistic phenomenon known as the aesthetics of error. The work of Jerzy Lewczyński falls into this category, by virtue of his use of the so-called "found negatives." One work - presented at the exhibition entitled "Archeologia fotografii" (the archeology of photography), from the cycle Znalezione fotografie (1985) - presents the highly creased identification photos of a young woman, which are remarkably like the portraits of Berek Putersznyt and his wife taken in 1942 in Dąbrowa Górnicza. Critics call Lewczyński’s method an aesthetics of error "in light of the generally destructive nature of the author's use of negatives, which - through their scratches and damage - further strengthen

557 Georges Didi-Huberman, Images in Spite of All: Four Photographs from Auschwitz, trans. Shane B. Lillis (University of Chicago Press, 2012). 
the medium with regard to the passage of time." ${ }^{358}$ But it is the photographic work of Wojciech Prażmowski that would seem to be closest to the photos discussed above, even though Prażmowski never made the Holocaust a focus of his work. A breakthrough in his approach to photography was the "Pierwsza światowa wystawa zdjęć zepsutych" (The first world exhibition of defective photos, at the Mała Galeria ZPAF-CSW, Warsaw 1989). Prażmowski intentionally applied all kinds of defects to negatives and double exposed them to reflect the qualities that come with the passage of time. His Album rodzinny (family album) is one his most interesting works, in which he imposed two images of reality upon one another: one - a reproduction of a historical photograph, and another - a contemporary photograph, often stylized as an old photo. ${ }^{559}$

But there is a fundamental difference between the above-mentioned works and the damaged photos that I am analyzing here. Lewczyński and Prażmowski's photographs came about as the effect of conscious artistic actions; they are the product of concrete creative methods applied by their authors. But the damaged photos from the time of the Holocaust become an aesthetic object during the process of reception, when they are viewed; they are perceived as an object; they are a correlate of an intentional act - an aesthetic experience. It is not the creator who lends his work a patina of agedness by arranging its features, by producing damage, cuts, scratches or stains. This damage is caused by the "chisel of history," and as such becomes (or can become), when viewed, an integral part of the photographic image. In addition, in photos taken by artists practicing the aesthetics of error, their scratches, tears and discolorations are supposed (according to interpreters) to mimic the effect of the passage of time, of time gone by, giving them an aura of melancholy. It seems, in the case of the damaged photos from the Holocaust, the situation is the complete opposite. Thanks to the layer of damage, which "disturbs" a photograph's reception, the image is - in a sense - updated; the patina of agedness, the aura of time gone by is put into question. The viewer is moved from the safe "here and now" to the disturbing "there and then." The disturbed reception is a confirmation of the

558 Z. Tomaszczuk, Świadomość kadru. Szkice z estetyki fotografii (Września 2003), $126-127$.

559 Ibid., 132-133 and http://www.galeriaff.infocentrum.com/2000/prazmo/prazmo_p. html (accessed 16 February 2018). See also Christian Boltanski, Gymnasium chases (1991), which makes use of photos of Jewish school children in a Vienna gymnasium in 1931. Magnification, grain, images deformed, blurring, "collapsing" of the image, etc. - all suggest the terror of the Holocaust. 
authenticity and the up-to-date nature of the medium. The "calm" and "normality" presented in private photos are a matter of appearances; their defective form confirms our knowledge about what would happen later, our knowledge of the end. The terror presented in the clandestine photos breaks up form, it decomposes form.

Let me propose three interpretative tropes:

\section{Damage as a Stigma of the Holocaust}

Involved here are photographs originating from that place and that time - that is, photos from the Holocaust and photos of the Holocaust. Material damage visible in the photographs under discussion here emerged from that time and that place. The Holocaust mutilated them.

A damaged photographic image was - so to speak - "stripped of its skin," revealing its internal tissue, which became the photo's additional texture, a mark on the image, its stigma.

I am aware how risky it is, when talking about the Holocaust, to refer to Christian tradition, but it is precisely from this tradition that I want to borrow a certain interpretive formula. In Christianity, a stigma is not a flaw, not a defect, but a mark of a specific bond with the sacred. If we treat damaged photos of (from) the Holocaust as "stigmatized," then we must ask: what meaning does this stigma reveal?

Is this not "negative stigmatization"? Damage and destruction is the stigma of the fate of the victim: hounded - pursued - tormented - killed, but also hiding in various places and in various ways. Photos share the fate of the people whom they are presenting, whom they make present, whom they "hold" in an infinite moment of eternal duration. They burn along with them, or - if destined for survival - carry within themselves uneffaced trauma. Because we remember that stigmata are wounds that are tied to suffering, and a stigma is the language of trauma.

Damaged photographs from the ghetto - they lay bare the trauma of the material, and through that, the trauma of memory. ${ }^{560}$

560 Texts on (from) the Holocaust are similarly damaged: texts are wounded, they bleed. For more on this understanding of damaged texts (deteriorated, soiled, distorted) see my chapter "Losy tekstów" in Tekst wobec zagłady; see also P. Rodak, "Wojna i zapis (o dziennikach wojennych)," Teksty Drugie 6 (2005), 33-45; Rodak, "Dziennik osobisty: praktyka, materialność, tekst," Przeglqd Kulturoznawczy 1 (2006). 


\section{Damage as a Vestige of the Holocaust}

A photograph is not just an image, a representation. A photograph is also a vestige, an attestation of presence. A vestige - that is, something directly reflected in the world, like a footprint on the sand or a death mask. In this sense, photographs of (from) the Holocaust are a vestige.

On the basis of these vestiges, we are able to reconstruct the fate of a photograph itself as an object, as a thing; to reconstruct the history of its materiality (its preservation, the fact that it was hidden, the influence of the conditions in which it was hidden).

Damaged photographs of (from) the Holocaust join with an entire legion of other things left behind by Jews; they fit nicely into the history of those things, snatched up by looters or rotting in trash heaps.

In hiding on Warsaw's Aryan side, Rachel Auerbach wrote:

There are tears of things - sunt lacrimae rerum. And there is a cry of things. [...] The death, extermination, demolition of the individual, and then there is the extermination and demolition of things. In the image of the annihilation of the Jews, the annihilation of things occupies a prominent position. The tragedy and mistreatment of things is equal to the tragedy and mistreatment of people. [...] And then there is this: the trash heap of the ghetto in August 1942. [...] Photographs. A terrible number of photographs. $[\ldots]$ photographs in trash heaps were not put on display, and none of them had captions attached. They demonstrated themselves what they had to say. It was the dot over the "i" in the fantastic phraseology of the trash heap in the wake of the Jews. [...] Oh, those wedding photos, family portraits. Vacation photos in happy times against the backdrop of nightmarish reality. ${ }^{561}$

\section{Damage as a Metonym for the Holocaust}

Let us refer to an article by Frank Ankersmit, "Remembering the Holocaust: Mourning and Melancholia." ${ }^{562}$ The fundamental question is: what kind of discourse is proper for research into the Holocaust? The answer can be found within the tension between "historical discourse," whose "goal is to describe and explain the past," and a "memory discourse." While a "historical discourse" makes use of metaphors, a "memory discourse" is metonymic, and not metaphorical ${ }^{563}$ - that is, its element is closeness, contiguity, a desire and search for contact. In a sense,

561 R. Auerbach, “Lament rzeczy martwych,” Przełom 2 (1946).

562 F. R. Ankersmit, "Remembering the Holocaust: Mourning and Melancholia," in Historical Representation, 176-194.

563 Ankersmit uses the opposing concepts of metaphor and metonymy within the understanding originated by R. Jakobson, which has become most common in modern 
metaphor is the intellectual appropriation of, taking possession of, the object of knowledge. Metonymy is different. Memory, governed by the rules of metonymy, first tends toward something, much like looking, which we direct in front of ourselves in order to be able to see something at all. As we look, we - so to speak "touch" with our look that which we come across in our line of sight, which appears within our field of vision. We "touch" but we do not "appropriate." In this sense, the "memory discourse" does not destroy the aura of ineffability, and it respects that unnamable reality that we usually associate with the Holocaust. Ankersmit put it this way:

Metonymy favors mere contiguity, respects all the unpredictable contingencies of our memories, and is, as such, the very opposite of the proud metaphorical appropriation of reality. Metaphor has the pretension to go right to the heart of the matter, metonymy makes us simply move on to what happens to lie next to it - and so on, ad infinitum. Metonymy ties together a web of associations depending upon our personal experiences and a host of contingent factors, instead of forcing (past) reality within the matrices of a metaphorical appropriation of reality. ${ }^{564}$

Damaged photographs of (from) the Holocaust set forth a metonymic reading: they invite the viewer into intimate contact with the material of an image, which talks with a voice that is muted, faded, and tormented, one that is often difficult to hear and recognize; which talks in a way that is intermittent and fragmented, but which talks entirely through itself; it forces us to look at the whole (precisely - paradoxically - because it presents itself as a whole that is broken, maimed). Because we look, the image achieves integrity of a different order. It not only represents that reality (over there), it not only conveys its image; that reality being broken and deformed, it manifests the impossibility of its representation (within the classic framework of mimesis).

Nothing resembles that which was then and there. Thus, deformation turns out to be the only possible form of representation. Deformation which breaks apart and damages (impossible) mimesis. Deformation which, by its own self, reveals the affliction of that reality, over there.

humanities. It is a concept based on the "fundamental distinctiveness of metaphor and metonymy, understood broadly as two cooperating but opposing ways of developing and composing every lingual expression: the metonymic way is based on relationships of contiguity, the metaphorical - on relationships of similarity [author's emphasis - J. L.]. See M. Głowiński, T. Kostkiewiczowa, A. Okopień-Sławińska, J. Sławiński, Słownik terminów literackich, ed. J. Sławiński (Wrocław 1998), entry “Metonimia," 308.

564 Ankersmit, "Remembering the Holocaust," in Historical Representation, 178. 


\section{Children of the Holocaust: Obverse and Reverse}

\section{The Boy from the Warsaw Ghetto}

He is standing with his hands up. His palms are visible held up to the level of his head, on which he is wearing a flat hat. His carefully buttoned overcoat comes to an end around the bottom of his short pants, revealing his thin bare legs in socks that are pulled up almost to the knees. On his feet, leather shoes covering his ankles. All of which, in the ghetto, represented exceptional luxury. His clothing shows not the slightest sign of ghetto poverty. His face - delicate, sensitive, subtle - is not marked by the torture of horror, is not branded by the stigma of hunger or suffering. He is expressing no violent emotion, but rather restrained amazement mixed with fear. He is looking out in front of himself under dark eyelashes. Behind him, a group of Jews with hands up - men, women and children - are emerging through a building gate. Standing a few steps behind the boy, on the gray cobblestone sidewalk on other side of the street gutter, is an SS-man aiming the barrel of his machine gun toward the boy's back.

This is one of the most famous photographs from the Holocaust. It has been reproduced countless times in albums, on book covers, and on posters, and it has been enlarged into gigantic dimensions for museums in Warsaw, Jerusalem, Washington and London. It has been published for television reports, as an illustration in anniversary press articles, as an emblem invoked almost automatically. This image of the "ghetto boy" has assumed a permanent place in the inventory of mass imagery; it has become an icon of mass culture preying on the Holocaust.

The anonymous boy from the ghetto, with his hands up, is looking out toward the inevitable final solution. We look at this photo of him with greater knowledge of what is about to happen than that which is just beginning to flicker in his eyes. We see him just before the finale. His hands still raised, his eyes still looking forward, his legs still carrying a boy's body and still filled with warm blood. But the boy, thrown into the cogs of mass imagination, cannot hang in suspension; his story, fulfilled and pushed shut, built into the universal project to reconcile the Holocaust, must emerge from the photo. Ultimately, from the core of darkness, he exerts a ray of hope; among those who survived the Holocaust, there were children who, though they have a terrible story to tell, fill our hearts with calm. They are an archetypal figure of the infernal Odyssey, a trek through the land of horror, suffering and torture toward the home port. Great narratives in the global village cannot remain open, cannot be fragmentary, and cannot burn up in ashes. We know how the story continues, but we want to listen to it once again. What's more, we want the nightmarish story, in the case of the boy in the photo, 
to represent an exception. We want the Holocaust to release him from its claws, at least him, the one who stands before us, so innocent and fragile, so very definite and tangible. We want this story to proceed differently, so that (as in Steven Spielberg's Schindler's List) life-giving water flows from the showers in Auschwitz and not deadly gas. In a word, we want the boy to survive, to be saved.

The photograph of the boy from the ghetto is overgrown with stories. Let us attempt to separate fact from fiction. The photo belongs to a so-called "Bildbericht," which contains 59 carefully cropped photos attached with handwritten Gothic script captions. These photos are an integral part of the Report put together for Reichsführer SS Heinrich Himmler by the man who led the suppression of the Warsaw Ghetto Uprising, Jürgen Stroop. The report carries a title that has itself become one of the textual icons of the Holocaust: Es gibt keinen jüdischen Wohnbezirk in Warschau mehr! The thick volume, elegantly bound in leather, lay on a bookshelf in Stroop's Bavarian villa until the American Seventh Army took control of the area. The Report was added to evidence presented at the Nuremberg Trials and Stroop's trial in Warsaw. ${ }^{565}$ The photo under discussion here carries the title "Mit Gewalt aus Bunkern hervorgeholt." The scene recorded in this photo thus took place during the suppression of the Warsaw Ghetto Uprising, between 19 April and 16 May 1943. These are irrefutable facts.

We know when and under what circumstances the photo was taken. But the question remains: who are the people in the photo? Recently, Edward Kossoy carried out what is probably the only attempt in the Polish secondary literature to deconstruct the legend surrounding the photo of the "ghetto boy." ${ }^{566} \mathrm{He}$ pointed out that the first stage of identifying the people in the photo came during Stroop's trial (he was sentenced to death and hanged in Warsaw on 8 September 1951), when research into the matter was led by Professor Paweł Horoszowski, director of the Laboratorium Kryminologiczne in Warsaw. At this time, only one person could be identified: The German aiming his machine gun at the boy. He turned out to be SS-Rottenführer Josef Blösche, who was tracked down in 1967, put on trial in Erfurt and sentenced to death in 1969. Investigators at the time were able to discover the names of none of the Jews seen in the photograph. But indirect testimony began to emerge. Two women claimed, independently of one another,

565 See B. Mark, Introduction to Stroop, The Report of Jürgen Stroop Concerning the Uprising in the Ghetto of Warsaw and the Liquidation of the Jewish Residential Area (Warsaw 1958).

566 E. Kossoy, “Chybiona parada. Dzieje pewnej fotografii,” Zeszyty Historyczne, no. 149. I want to thank J. Petelewicz for pointing this article out to me. 
that the boy with his hands up had the last name Siemiontek and was a child of affluent parents from Łowicz. His family had been deported to the Warsaw Ghetto in the summer of 1941. But the women's testimony was not enough to officially identify the boy, and he remained an anonymous child of the ghetto. Thus ended the first stage of identification.

In the Photo Archives of the United States Holocaust Memorial Museum in Washington there is information about people who can be recognized in the photograph. In addition to the above-mentioned Blösche, four of the people in the group of Jews have been identified: the little girl on the left edge of the photo looking directly at the camera lens is Hanka Lamet. She is positioned right next to her mother, Matylda Lamet Goldfinger (second from the left), who has her hands stretched above her head and is also looking toward the camera lens. Deeper in the photo, not far from the gate, the boy with a white bag over his shoulder is Leo Kartuziński. The woman at the forefront with the bag hanging from her elbow, her head turned toward the central figure of the boy, is Chana Zeilinwarger. The identity of the photograph's main character is still an open question. The archivists cite five hypotheses, none of which - they emphasize can be sufficiently confirmed. The boy's name could be Siemiontek, Artur Domb, Izrael Rondel, Levi Zeilinwarger (the son of the woman positioned next to him and looking at him), or Tsvi Nussbaum. ${ }^{567}$

The careful hypotheses put forward by archivists do not satisfy our need for a great narrative. The second stage of identification begins, one that is mythcreating. As Kossoy stated, in 1978 the Jewish Chronicle found the "ghetto boy." Of course he was alive, and of course he was a successful man, a wealthy fortythree-year-old entrepreneur living in London. But the newspaper had to quickly retract its story because that story had a brutal confrontation with the facts. The alleged "ghetto boy," who spent the war in Turkestan, and not the Warsaw Ghetto, dated the photograph as having been taken in 1941. The fiasco of this story led to another, when a New York doctor (again, a successful man!) Tsvi Nussbaum came forward claiming that he was most likely the boy in the photograph. Even though Nussbaum's claim was not categorical, he nonetheless became a media sensation. He put together a tableau: a framed portrait of the ghetto boy and a photo of himself at the age of ten, which was supposed to show a striking resemblance between the two faces. He allowed himself to be photographed with this tableau

567 See https://collections.ushmm.org/search/catalog/pa1088110 (USHMM photo archive). 
and his commentary: "An event from my past, which haunts me until today" 568 In 1982, the New York Times promoted the Nussbaum revelations, and in 1990 a French-Finnish team produced a 50-minute film entitled Tsvi Nussbaum. A Boy from Warsaw. Finally, and sadly, the idea that Nussbaum was the ghetto boy was further propagated by the authors of an excellent, pioneering handbook on the Holocaust published for the Polish market. ${ }^{569}$

In light of his own story, the doctor from New York cannot be the ghetto boy. And in order to confirm this fact, no especially deep knowledge is required. It is thus no real wonder at the irritation felt by Edward Kossoy, who called Nussbaum's story "rubbish," "fantasy," and "obvious nonsense." 570 The alleged boy in the photo claimed that it had been taken on 13 July 1943 as a group of Jews was being removed from the Hotel Polski at 29 Długa Street. ${ }^{571}$ Advocates of the New York doctor story do not want to notice the obvious problem here, since July is not May, and since the Hotel Polski was not within the moribund Warsaw Ghetto, and Długa Street - though it was not far from the ghetto - was always outside its boundaries.

The need for myth is stronger than humility in the face of facts. Rooted in historical experience, in concrete events, and individual fates, this need moves beyond the facts and soars toward the universal horizon, which is what a great Holocaust narrative requires, one that reconciles the story about a child's hecatomb. The boy captured by the Nazi photographer is marked off from the group of other Jews. In the photograph's compositional structure, he is positioned at the photo's focal point, at the intersection of the lines of the golden ratio. $\mathrm{He}$ stands next to those exiting the gate, next to the group of Germans, as the only autonomous, separate, individual figure in the photograph. His face, eyes, and

568 See "Child of the Ghetto," in M.-M. Robin, 100 Historic Photos of the 20th Century (Köln, 1999), no. 24. Robin identifies the boy in the photo as Tsvi Nussbaum, though she also cites the expert opinion of Professor Izrael Gutman of Yad Vashem, who claims that though several dozen people have aspired to be the ghetto boy, the boy's identity is in fact not important, given that his image has become a "symbol of victory."

569 See R. Szuchta, P. Trojański, Holocaust, Zrozumieć dlaczego (Warszawa 2003), 219.

570 E. Kossoy, op. cit., 87-88.

571 Jews still hiding in Warsaw who could afford to purchase, from Jewish agents of the Gestapo, South American citizenship or Palestine certificates gathered at the Hotel Polski. From there, they were to participate in an exchange for German citizens. Some of them were in fact interned and exchanged, but most were shipped off to Bergen-Belsen or Auschwitz, or were shot in the ghetto rubble. For more on the Hotel Polski, see A. Haska, "Jestem Żydem, chcę wejść". Hotel Polski w Warszawie, 1943 (Warszawa 2006). 
silhouette immediately catch the viewer's attention, and are etched in memory. They embody everything tied to the fate of a child of the Holocaust: a defenseless and innocent victim of unimaginable violence. The sight of these victims, symbolized by the boy in the photo, pierces our hearts, but it also releases in us a more or less conventional reaction. This type of victim, a child victim, is - so to speak - culturally reconciled and emotionally accepted. It is easier to identify with a victim whose appearance is like our own than it is to identify with a child's body that is monstrously deformed by hunger. In a word - it is easier to open oneself up to such a victim, because it is immaculate, clean; the sight of such a victim is easier to internalize, and it is easier to identify with the victim himself, because he is heroic.

The story about the photograph from the Stroop Report, tied to a great narrative about the Holocaust, not only establishes the axiom of the rescued child, but also engineers a legion of hero-storytellers. Here we have the triumph of hope over hopelessness, the triumph of insatiable life over the Nazi death sentence. The ghetto boy living a good life across the ocean or along the Thames complies with our thirst for justice, perhaps even a "happy ending."

\section{A Boy from the Lódź Ghetto}

A boy with a chubby face is turning his head toward the camera and giving a delightful smile. The sunlight is shining on his full cheeks. The brim of his police cap with a flat top, modeled on the French kepi, casts a shadow over his right eye, while the left eye is looking - through the camera lens - directly at us. The cap is a policeman's cap, because the boy is wearing a play uniform of a Jewish policeman - that is a member of the Ghetto Police (Ordnungsdienst). At various times in the Łódź Ghetto, between 850 and 1,200 Jewish police officers were mobilized to maintain order and cooperate with the Germans in the deportations. ${ }^{572}$

572 The structure of the Jewish police in the Łódź Ghetto was extremely complicated. The Ghetto Police (Ordnungsdienst, OD) had one headquarters and 5 stations. A separate section of the OD was called the Überfallkommando, used for the suppression of demonstrations and strikes. The OD Reserve Section guarded ghetto institutions, the OD Isolation Service organized the quarantine of flats and buildings during epidemics. The Hilfsordnungsdienst - that is, the Auxiliary Order Service - guarded wooden objects, protecting them from being dismantled for firewood by ghetto residents. There was also the so-called Policja Gospodarcza (Economic Police), Policja Żeńska (Women's Police), which dealt with minors, and Policja Obyczajowa (Morality Police). Within the OD, there was also the so-called Sonderkommando, renamed over time to Sonderabteilung, or the Special Branch, which tracked illegal trade in goods and 
The boy is dressed in a uniform coat. On his sleeve there is a regulation police armband, and on his head a regulation cap. He holds in his left hand a police baton, or rather a toy baton suitable for a child's small hand. The little policeman is not alone. He is standing behind another boy, who is a bit taller and thinner, dressed in a gray jacket and wearing a flat hat. The little policeman is holding the other boy tightly by the collar with his right hand, and - with the baton in his left hand - he is striking the other boy on the arm. No doubt we are witnessing children playing. The boys are playing a version of the old game of cops and robbers. The chubby one is the policeman and he has just caught the thief, which gives him the genuine satisfaction that we see painted on his happy face.

The photograph I have just described is not an icon of the Holocaust. Until 2004 , only a few people knew about the photo. It was put into public circulation through the publication of a collection of photographs taken in the Łódź Ghetto by Henryk Ross. ${ }^{573}$ Does it have a chance of becoming as famous as the image of the boy with raised hands in the Warsaw Ghetto?

Henryk Ross (1910-1991) was born in Warsaw. Until the Second World War he worked in Łódź as a photo reporter for one of the Warsaw newspapers. Drafted into the army, he fought in the September campaign against the invading Germans. After the defeat, he returned to Łódź. In January 1940, along with the other Jews of Łódź, he moved into the area of the future ghetto. In the ghetto, together with his friend Mendel Grossman, he worked for the Judenrat Department of Statistics as one its two official photographers. His job was to take propaganda photos and personal identity photos. Like Grossman, he had access to photographic equipment and a darkroom, and like Grossman, alongside his official duties, he took clandestine photos of the ghetto and its inhabitants. These items make up an exceptional archive of photographs documenting life in the Łódź Ghetto: back-breaking work, hunger, and deportations, but also family life, celebrations, and wedding ceremonies. What attracts our attention in particular are photographs that draw a collective portrait of privileged ghetto residents, namely the family members of the Judenrat and Jewish police. As the Germans were liquidating the ghetto, Ross managed to hide three thousand negatives, which he retrieved after the war. He lived with his wife, Stefania, in Łódź until 1950, when he left for Israel. Ross's photos were used as evidence in the trial of Adolf Eichmann, during which Ross himself gave testimony. The conditions

valuables among the ghetto inhabitants. See D. Dąbrowska, "Struktura i funkcje administracji żydowskiej w getcie łódzkim," Biuletyn ŻIH 51 (1966): 46-50.

573 See Ross, Łódź Ghetto Album. 
(under ground) in which the photos had been preserved caused damage to parts of the negatives, but they did not efface the poignant images that those negatives contained. ${ }^{574}$

According to experts at the Ghetto Fighters' House in Galilee, the photo showing the children playing cops and robbers was taken on 22 October $1943,{ }^{575}$ which means around a year after the notorious "szpera" in September 1942, when around 20,000 children (10 years old or under) and old people (65 years old or older) were deported from the ghetto to the Chełmno death camp. It was at this time that Chaim Rumkowski called on desperate parents to gather at Łódź’s Bałucki Rynek:

They [the Germans] demand what is most dear to it [the ghetto] - children and old people. [...] I never imagined that my own hands would be forced to make this sacrifice on the altar. In my old age I am forced to stretch out my hands and to beg: 'Brothers and sisters, give them to me! - Fathers and mothers, give me your children...." ${ }^{\prime 576}$

In another one of Ross's photos the same chubby boy in a police uniform is chasing a bunch of fleeing children. One of the children has stopped to look around, and - as if stepping out of the game - he looks with interest at the person taking the photo. ${ }^{577}$ Yes, all of this is pretend; the children at play are posing for a photograph. No one is really fleeing, and no one is really chasing anyone. But this game, like probably every children's game, is an imitation of the adult world, and in the world of the Łódź Ghetto the scene played out by the children was not something rare. Perhaps the father of the boy playing the policeman took part in such scenes, with an adult policeman's cap on his head and a police baton with proper dimensions. Let us remember that the scene with the playing children was set in the ghetto after it had been emptied of children. During the September action "Jewish police had to pull children away from their Jewish mothers, take Jewish children from their parents," wrote Oskar Singer, one of the main creators of the Chronicle of the Łódź Ghetto, who was murdered in August 1944 in the gas chambers of Auschwitz-Birkenau. Singer added: "The Chairman [Prezes] demoralized the Jewish police. He assured the safety of their children so that they

574 See ibid., 11-12.

575 See ibid., 117.

576 For the text of this famous speech by Rumkowski on 4 September 1942, see Documents on the Holocaust. Selected Sources on the Destruction of the Jews of Germany and Austria, Poland, and the Soviet Union, ed. Y. Arad, I. Gutman, A. Margolit (London; Jerusalem 1999), 283-284.

577 See H. Ross, op. cit., 118-119. 
would, with full strength, wrestle other children from their mothers' grasp." 578 On the subject of the fate of children of the Eódź Ghetto, a certain Goldman testified in December 1945:

The head of the ghetto Mordechai Chaim Rumkowski did everything to indulge the ghetto inhabitants. He assured everyone that he loved little children above life. Until the point when the Gestapo demanded that he deport children from the ghetto and he immediately signed over all of them from 1 to 10 years old. But did he hand over all of them? No. It was clear whose children were taken away. Not the children of the Rajnholces, Sienickis, Fuchses, Farbers, Praszkers and other directors of departments and businesses. Rather, the children of workers were taken, the children of the mass of people who worked hard and starved so that directors could wallow in all possible goods. It always worked this way, with every liquidation action that ever took place in the ghetto. ${ }^{579}$

The boys at play were children of the ghetto's prominent people, who had evaded being gassed at Chełmno. We get to know their parents through Ross's photographs. We can easily see the joyous and proud faces of the mother and father of the boy in the police uniform, who is a character in a series of at least 41 photos: portraits of their dear only child, photos of the boy playing, at a birthday party. One of the photos shows a group of children at a long table filled with food. At the end of the table, next to the mother dressed in white, stands the party boy in a white short-sleeve blouse. Everyone - children and several adults - is holding glasses in their hands: they are offering a toast, after which they will sit down to eat. ${ }^{580}$ This scene reminds me of the birthday of a certain child from the Warsaw Ghetto celebrated in the spring of 1942, around four months before the start of the Grossaktion. We can quote from the journal of Rachel Auerbach, for whom the fundamental stylistic and conceptual figure is the grotesque. To give a full sense of the strength of this entry, an extended quote is necessary:

Life, especially the kind of life as ripe for death as ours in this closed city, sometimes offers up bizarrely vivid symbolic abstracts, like melodramatic ideas for a banal film. Once I saw with my own eyes, near the gate to a building containing a soup kitchen and Jewish police station, at the entrance to a candy store, a child's corpse covered with a "Month of the Child" poster with the text: "Save the children! Our children must live!" But two facts which I heard about this week are very original in their thinking. One of them involves a police report that a policeman I know told me about. As the corpse of a

578 O. Singer, Przemierzajqc szybkim krokiem getto... Reportaze i eseje z getta łódzkiego, trans. K. Radziszewska (Łódź 2002), 72.

579 Archiwum ŻIH, Relacje 301/1419, k. 1.

580 See H. Ross, op. cit., 121. 
child was being collected from an apartment on Krochmalna Street it was noted that the corpse was missing a piece of its haunch. An investigation indicated that that part of its "flesh" had been sliced off by a family member - I don't know if it was his mother - to make a meal... tenderloin. But the second fact I heard about involves maternal affection. The young son of the "director of directors" of the "szop" working for the Germans was celebrating his birthday. A "fajf” [afternoon party] was planned for the child. His most recent passion was little pigs. He is raising a few piglets at home, apparently given to the family by the Germans. Not only was a piglet killed for the birthday feast, whose head probably garnished the serving platter - the mother, infatuated with her son, also made a decorative motif out of a piglet's head under whose sign all the birthday celebrations were held. A painter called in especially for the party painted a trail of piglet heads on the wall of the child's room, and a tinsmith prepared a special mold to create a cream pig's head placed on top of the cake. But the greatest feat of the maternal heart was the fact that this woman "ran through the entire ghetto" to achieve a truly amazing miracle. She managed to find a mask in the form of a pig's head and, having put on the mask, she personally served the children at the fajf... The pig illusion was thus complete. Imagine this [little scene]: "Once upon a time there were three little pigs ..." As would have been written back when columns in newspapers could be devoted to facts like this: "Further comment not necessary." 581

There were various children's games behind the walls. Little Michał played chess or spent hours looking through an "enormous German atlas. [...] I would spread it out on the floor," he remembered, "and look at the world."582 Ernest:

[...] puffs his cheeks, carefully blows and lets soap bubbles float through the street. [...] The rainbow bubble grows, flies, floats freely in the air. It floats carelessly over the beautiful and terrible, impossible world $[\ldots] .{ }^{583}$

Three boys are playing horse on the street. Next to them on the sidewalk is:

[...] a youngster either alive or already dead. [Their] ropes (reins) get tangled up. They discuss it, they try several things, and they grow impatient - with their feet they poke at the youngster lying on the sidewalk. Finally one of them says: - let's move aside, he's just in our way. They move a couple steps away, and they continue to struggle with the reins. ${ }^{584}$

Ringelblum noted in May 1941: "The children are no longer afraid of death. In one courtyard, the children played a game of tickling a corpse." 585

581 R. Auerbach, Dziennik z getta, Archiwum ŻIH, Ring I, 641, k. 2.

582 Michal Glowinski, The Black Seasons, trans. Marci Shore (Northwestern University Press, 2005), 162.

583 B. Wojdowski, Chleb rzucony umarłym (Warszawa 1981), 95.

584 J. Korczak, Pamiętnik, in Pisma wybrane, vol. 4, [wybór A. Lewin, oprac. i przepisy M. Falkowska, M. Kopczyńska-Ciesielska, I. Olecka] (Warszawa 1986), 355-356.

585 Ringelblum, Notes from the Warsaw Ghetto, 174. 
Playing soldier and playing with toy soldiers have always been popular among children. Wooden sabers, pistols, rifles are natural props for boyhood games. Children dressed in a police uniform or playing cop was nothing exceptional, either in the Łódź Ghetto or the Warsaw Ghetto. The powerful pressure of reality was in operation here - the ludic rule of mimesis. In March 1941, Ringelblum wrote: "Children's badges reading 'Law and Order Service' are being sold on the street - in a word, the police are now in fashion." ${ }^{886}$ Krystyna Żywulska provided a particularly striking example of this "mimetic" kind of playing. Szymuś and Anulka are playing in the staircase of an apartment building in the Warsaw Ghetto. Szymuś is building a forest out of blocks, and Anulka "knocks the blocks down, saying that there aren't any trees at all in the world." Szymuś complains that Anulka:

$[\ldots]$ only wants to play wall and gendarme. She always wants to build a wall. Then she screams at me: "stop smuggling!" or "I am the gendarme and now I'm going to shoot you." And I don't want to play that game. ${ }^{587}$

The boy in the police uniform in Henryk Ross's photograph and the boy with his hands up in the photograph from Jürgen Stroop's Report. Two images of children of the Holocaust. Two figures representing the child-victims of the Holocaust. Obverse and Reverse. The "ghetto boy," famous throughout the world, with whom so many people want to identify, and the chubby boy with the police baton in his hand, who is known to no one.

Can we measure the level of suffering inflicted on children condemned to the Holocaust by Hitler's Germany? The boy from Warsaw and the boy from Łódź were deeply wounded before death. And after all - I have no reason to doubt - they both died. We are already used to the suffering that emanates from German photography. Looking at the photograph taken by Henryk Ross makes us feel the kind of pain that is caused by a thorn that we cannot remove. Indeed, Ross's photograph conveys one of the most terrible images of the Holocaust that I have ever seen. Not a pile of corpses, and not walking skeletons with glowing eyes, but a smiling boy who, in play, unconsciously exchanges the role of victim for the role of perpetrator. This is th "gray zone," about which Primo Levi wrote ${ }^{588}$; the blurred line between executioner and victim; the insertion of victims into the executioners' trade as an act of the greatest depravity. Games played by these children from prominent

586 Ibid., 140.

587 K. Żywulska, Pusta Woda (Warszawa 1963), 9-10.

588 See P. Levi, “The Gray Zone," in Levi, The Drowned and the Saved (New York 1986), 36-39. 
families in the Łódź Ghetto exhibit precisely such an inversion, a reversal; their participants thus represent the kind of victim that does not fit nicely into the category of the heroic-martyrological.

Who would want to identify with that Łódź boy in the Ordnungsdienst cap? Who will come forward with a story of miraculous survival? Who will put their childhood photo alongside that ghetto photo and state: "Look how I resemble that boy? That's me."?

\section{Farewell}

The Łódź Ghetto. Closed off on 30 April 1940. In many ways exceptional, and despite a basic similarity shared by all ghettos (they were all an intermediate step on the path to absolute extermination) - distinct and dissimilar to other ghettos. It was the only ghetto that found itself on territory that had been joined with the Third Reich. Two-hundred-thousand of its residents were hermetically isolated from the rest of the world. They found themselves behind a heavily guarded border made of barbed wire and in German surroundings, unlike the Warsaw Ghetto. The Łódź Ghetto became a German state institution, managed by the Gettoverwaltung, whose head was Hans Biebow. It was a huge production enterprise in support of the German war economy. Indeed, it was one of the most profitable enterprises in the Reich, and it was tied to the fates and interests of hundreds of German officials, party members, and SS officers. The Łódź Ghetto was the longest lasting of all the ghettos; the final transport to Auschwitz departed on 30 August 1944, with the Warsaw Uprising already a month old and the Red Army waiting at the Vistula River. On 19 January 1945 the Soviet army entered Łódź, where around 800 Jews remained.

In 1987 around 400 color slides turned up in a Vienna bookstore. To everyone's surprise, they showed images of the Łódź Ghetto! Noone had had any idea of their existence. They had been in a state of latency, to finally see the light of day after 42 years. A former nurse and probably the lover of the slides' author - Walter Genewein, the head accountant of the Łódź Gettoverwaltung, who had died 13 years before the slides surfaced - tried to sell them quietly and anonymously. The plan failed. The matter became public. The Jewish Museum in Frankfurt bought the slides, which represent some of the very earliest color exposures. IG Farbenindustrie (today's AGFA) first put color photo technology on the market in 1936. The ghetto in color - it runs against our expectations; it challenges our imagination; it shocks us. Images of the Holocaust had come to us only in macabre black-and-white. As Michał Głowiński wrote in The Black Seasons: The only color in the ghetto was black, or various shades of gray. 
We are able to view the Łódź Ghetto through the lens of Walter Genewein thanks in part to an excellent film by Dariusz Jabłoński entitled Fotoamator (released internationally as Photographer). Genewein, one of the main ghetto overseers, is not an executioner, at least not in the traditional understanding of the word. He is an official. His ghetto is seen through the eyes of an Austrian bookkeeper, a bureaucrat climbing tirelessly up the career ladder, proud of his achievements. Genewein also reveals his private ambitions. He is an amateur photographer, someone who loves taking photos; he is passionate about this activity, is delighted by the new possibilities offered by color photography, though he expresses concern about technical deficiencies and problems caused by the poor quality of photosensitive materials. He takes photos not just out of professional obligation, but also out of an entirely private passion.

Jabłoński conducted a kind of hermeneutics of the image, preserved in photos. His camera carefully tracks every detail of particular photographs; with reverence, he scrutinizes fragments, as if he is searching for something that is not visible on the surface of the color slides. As if he wanted to reach into the depths, to touch the people Genewein had caught on film. The looks of the people photographed by Genewein seem to say more than what is in the photograph, more than the camera lens is able to capture, more than the photographer would like. As a rule, those being photographed are looking at the lens: momentarily interrupted from their work in the ghetto workshop, stopped in the street, waiting in line, selling their old things spread out on the sidewalk - they lift their heads and look. Their looks follow us the entire time; they look into Genewein's camera lens - as an obligation, as a punishment; maybe they fear being accused of insubordination; maybe they want to please; maybe they think it is expected of them, or that it is simply something interesting. In any case, they always look at us, at us watching them not in the "then and there," but in the "here and now." Here, a barber at work - he stands next to a colleague cutting a client's hair, standing unnaturally straight, his back to a mirror, and - with an amazing look on his face, a look from beyond the grave - he stares straight into our eyes. Here, in a cobbler's workshop, a boy - sitting at the end of a table and holding a hammer in his hand - lifts his gaze from the sole of a shoe. Here, the looks of women in a weaver's workshop, foggy and unreal with their faces obscured by the looms. Here, in the background, an apartment building with an open window, and in the open window is a blurry silhouette looking out. And here, the face of a boy peeking out from behind ties hanging on a fence, ties being inspected by Biebow.

The reality captured in a photographic negative can overwhelm its "objectivity," can escape the photographer's grasp, can evade his intentions. And, in the end, it is precisely on this strength that the extraordinary and amazing nature 
of Genewein's photographs rests. Ghetto residents managed to escape the cool eye of the head accountant. Genewein was unable to capture their looks in any statistics, he was unable to rule over them. Looking into the lens of his camera, they were - in a certain sense - liberated, though they were still in captivity, still full of fear, trembling. With one click of the camera shutter, they were freed, as free as their last look, as it escaped the tormented body and crossed the border between life and death. And now, conquering time and space, that look reaches us, since they are looking right at us, directly into our eyes, and there is no way to avoid their gaze.

The Austrian bookkeeper was not the only photographer in the Łódź Ghetto. Mendel Grossman and his friend, Henryk Ross - great photographers who are absent in Dariusz Jabłoński’s film - took thousands of clandestine photos, putting their lives at risk every day. Some of Genewein's color slides (for example, of boys standing in line for soup) have practically identical duplicates in blackand-white photos taken a moment before (or after) Genewein - the boys have their heads turned away, they are looking in another direction. This is evidence that a clandestine photographer often moved along with Genewein, step by step, photographing the same objects. But were they really the same?

Mendel Grossman was born either in 1917 or, as other sources indicate, 1913. His family was Hasidic, but he decided to pursue the study of the fine arts: literature, theater, painting, sculpture, and photography. He recognized photography as an art, and that the camera was a magnificent tool in the hands of an artist, one that opened up new possibilities for artistic expression. He photographed flowers, still lifes, landscapes, and portraits, and at the same time he painted, with a focus on the same objects that he preserved in photographs. Before the war, when the theater group Habima from Tel Aviv visited Łódź, Grossman photographed the actors on stage in rehearsal, and from that point on - fascinated by the possibility of capturing action and movement on film - the focus of his work was the human being in movement. He started to photograph street traffic, pedestrians, suburbs, children playing. Still a young man, he earned himself a high position in Łódź circles as an artist-photographer, one expression of which was the fact that, at the beginning of 1939, Grossman got an offer from the Jewish Towarzystwo Ochrony Zdrowia (the Health Protection Society) to create an album of photos depicting hJewish children, in particular poor children and street children. He finished this work in the summer of 1939, but the album was never published. Grossman's photographs and the children he had photographed vanished during the war.

After moving into the ghetto, Grossman began working at the photo lab of the Wydział Statystyczny (Statistics Department) of the Judenrat (which in Łódź 
was called the Ältestenrat, led by Chaim Rumkowski as Head of the Council of Elders). It was this department's task to collect and process data documenting the activities of workshops in the ghetto and the products produced there; such documentation included photographs. Work permit photos were also taken at the department's lab, where there was a large supply of film and photographic paper. Work at this lab provided the perfect cover for Grossman's work as a clandestine ghetto documentarist. He no longer photographed flowers, clouds and still lifes. The main object of his photographs were humans in movement, though it was movement of a specific kind - movement toward death. Grossman was able to look at the reality around him; he was able to penetrate the depths of that which was happening around him; but above all he was able to see into people, to see their suffering, the pain emanating from their eyes, the battles and defeats, the struggles with hunger, illness, and fear, with the death that would overwhelm them. He set aside his artistic ambitions; his mission was now clear: to provide the world - if that world was to survive - tangible evidence of the crime, preserved in a universally understandable language, in photographs.

Grossman was inseparable from his camera, which he hid under his clothes. He took photographs in secret, pulling back his coat flap. He spent most of his time on the streets, in the alleyways, in soup kitchens, in bread lines, in flats, at the cemetery. He photographed workers in the workshops, children at work, families pulling carts of faeces, bread being delivered, rationed soup being eaten. $\mathrm{He}$ climbed poles in order to photograph deportees walking to the train. $\mathrm{He}$ took photos from roofs, he walked up church towers, in order to photograph the changing of guards at the barbed wire. From a great distance, he photographed the first public execution. He was not satisfied with the quality of the photo. For the next execution, he moved closer. In the silence that fell over the square, the sound of his shutter was so loud that it almost gave him away. He photographed the unburied corpses of the murdered, attached numbers to them, and later with these numbers - marked the mass graves into which they were thrown so that families - recognizing their relatives in the photos - could later find where they had been buried. He did a photo report from the liquidated gypsy camp in the Łódź Ghetto. He also photographed the activities of youth organizations. At the end of the day, he returned to the lab and developed pictures until late in the night. In the morning, he handed out prints to friends and acquaintances, keeping the negatives for himself, which he hid in metal containers. His collection of negatives grew day by day, until it numbered more than ten thousand.

Just before the final deportation in August 1944, Grossman hid the negatives in a window-sill in his apartment. He later found himself in a labor camp in Germany, at Königs Wusterhausen, where he continued to take photos in secret, 
but he was no longer able to develop the pictures. He died during the evacuation of the camp, a few days before Germany capitulated, having suffered a heart attack at the age of thirty-two. His photographer friend, Henryk Ross, survived. Ross moved to Tel Aviv and died in 1991. Just after the war, Grossman's sister retrieved the negatives that Mendel had hidden. She immediately left for Palestine, where she handed them over to the kibbutz Nitzanim in the Negev desert. During the 1948 Arab-Israeli War, the kibbutz fell into the hands of the Egyptians and everything was destroyed, including Grossman's ten thousand negatives from the Łódź Ghetto. Only those prints that the photographer had handed out to friends, and that they managed to hide, survived. ${ }^{589}$

Between 5 and 12 September 1942, during the so-called "szpera," the Germans cleansed the Łódź Ghetto of children 10 years old or younger and old people 65 years old or older, all of whom were deported to the Chełmno death camp. In his famous speech, Chaim Rumkowski stated that the Germans had demanded a "resettlement," and he turned to ghetto residents with his appeal: "give me your children." Jewish police delivered these young and old Jews to collection points, where they waited to be transported further. Grossman went to these collection points. Some of the photos he took at the time survived. Their leitmotif is the wire fencing dividing families: on one side, adults and youngsters, and on the other side, the younger children. Within the closed ghetto, one more enclosure had emerged that contained the very youngest. Those who were more than ten years old are standing on the outside. Both groups are very close to the fencing, both are touching it, bringing their faces close to it, entwining their fingers in it, piercing it with their looks.

In one of these photos, a boy in shorts is sitting cross-legged on the ground, with his back to the camera lens. ${ }^{590}$ On the back of his jacket, near his right shoulder, a sewn-on Star of David. On his head, a flat cap. Right in front of him is the wire fencing, which covers almost the entire surface of the photograph. Just behind the fence, on some kind of blanket or bags, a group of people: a woman of middle age, a girl, a boy, another girl - all of them gathered in front of the boy sitting on the other side, bent in his direction. No doubt this is family mother and brothers and sisters. They have come to say goodbye to the boy. In

589 One can view these photos in Grossman's With a Camera in the Ghetto (New York 1977); in Grossman, My Secret Camera: Life in the Lodz Ghetto (London 2000); in an anthology published by Adelson and Lapides entitled Lodz Ghetto. Inside a Community under Siege (1989); and in the updated version of Dawid Sierakowiak's diary, translated into English and published by Oxford University Press in 1996.

590 For this photo, see My Secret Camera. Life in the Lodz Ghetto (no pagination). 
the background there is a woman in a white blouse, clearly separate from the rest, sitting with her back toward the camera and looking off to one side. We do not know who this woman in the white blouse is. Is she a member of the boy's family, is she a stranger? What is she doing there, seeing off one of her own relatives? Unlike many other photographs, no one is looking into the camera lens. And they are not looking at each other, as if they are avoiding each other's gaze, as if they cannot look each other in the eye.

We see only the eyes of the older brother of the boy designated for deportation. On his head he is wearing the very same flat cap, and - instead of a jacket he is wearing an overcoat (we should recall that it is early September). He has protruding ears, half-open mouth. He is looking over his brother's head, somewhere into the distance. Perhaps he is observing other children closed off in the collection point, perhaps he has noticed some younger friends. But it seems that his gaze is reaching significantly farther, beyond the limits of space and time. So what does he see? Maybe he is looking without seeing anything in particular, and maybe his look extends beyond the visible shapes and objects on the other side. Or perhaps it was precisely about this older brother - this boy from the Łódź Ghetto immortalized in Grossman's photo - that Roland Barthes wrote: "In fact, he is looking at nothing; he retains within himself his love and his fear: that is the Look." 591

The mother is on her knees, leaning toward her son, closed behind the fence. She is saying something to him, but her gaze is directed downward. What is most important are her hands; they are folded, one on top of the other, resting near the ground in front of the fence. With the fingers of her right hand she is gripping the fence from the bottom (it does not quite reach the ground) and from the side occupied by the closed-in boy. Four of the mother's fingers have crossed the border of the enclosure, but they are not reaching toward her son, they do not try to touch him. They remain on the border, resigned, hopeless; in a sense, they are holding up the fence, confirming - in a way - the state of separation. The mother's hand under the fence is the only distinct gesture recorded by the photograph. A gesture - so to speak - forsaken.

The figure of the boy with his back turned to us is the focus of the drama contained in this photographic tale. We see the shaved nape of his neck, his ears sticking out, his bare legs, on which he has propped his elbows. We even see the belt he is wearing, pulled through a loop, and a small piece of his shirt through a gap between his shorts and the belt. We see from behind a slightly opened suit

591 Barthes, Camera Lucida, 113. 
pocket, a patterned cap - delicate white stripes. We do not see his face. We do not know how he looks, or whether he is saying anything. The position of his head suggests that he is not looking at his family on the other side of the fence, but rather down toward the ground or at something he is holding in his hands. We do not know that, and we will never know that. We never look him in the face, just as - at the moment when this photo was taken - the family members around him were not looking at him. I know of no photograph that depicts, in a more poignant way, the pain of terrible loneliness and abandonment, of resignation and hopelessness.

The people captured in Grossman and Genewein's photographs already knew (not completely, unclearly, approximately, though this is the only way we know it here on earth) what a ghetto is. In this sense they were already on the other side; they were experienced, as opposed to the World War I volunteers, who had no idea what was awaiting them. This time, those in the photo had greater knowledge than we, the viewers, have. In the case of the volunteers, it was the opposite: only we know their fate. Residents of the Łódź Ghetto experienced what has not been given to us to experience. Relative to us (the viewers), they find themselves "inside" in multiple senses: inside the photograph and inside the ghetto, and inside an experience that is inaccessible to us. Which is why their look also runs from the inside - through the camera lens - outward, toward us. We cannot share their experience, but their gaze rests upon us.

Every photograph has a connection with death. It revitalizes that which died long ago; it preserves that which fell into ashes. It talks about a death that happened in the past. Every photo is a "return of the dead." ${ }^{92}$ But Grossman and Genewein's photographs are marked by death in a particular way. They show living corpses. Dawid Sierakowiak, closed off in the Łódź Ghetto, noted on Wednesday, 20 August 1941: "The cadavers walking along our streets have given the entire ghetto a pale, musty, tubercular look." Less than a year later, on Friday 10 July 1942, he wrote: "Most people are just cadavers, walking shadows of their former selves." ${ }^{593}$ We know that the people visible in these photographs would soon be exterminated, they would no longer exist. We know all of that and we see that they are still looking at us. It is not essential that, at the moment the photo was taken, they are still alive; knowledge about death has been provided

592 Ibid., 9.

593 Dawid Sierakowiak, The Diary of Dawid Sierakowiak: Five Notebooks from the Lodz Ghetto, ed. Alan Adelson, trans. Kamil Turowski (Oxford University Press; Reprint edition, 1998), 121, 195. 
them, and they are being taken over by their own death. They are doomed, and they are starting to realize this very fact. A limit situation of being in between was captured on film: simultaneously "here" - on the streets of the ghetto, in the hectic bustle of life - and "there" - toward the horizon, on the narrowing railway tracks, in the hectic bustle of death.

I have referred to several photographs in which we can detect traces of events that the twentieth century inflicted on us. With only one exception, they are not photos that show, in any drastic way, anything particularly brutal or macabre. On the contrary, one could say that what is most important in these photos is what was eclipsed in them, and perhaps it is precisely for this reason that they attract our gaze. Their meaning reveals itself only when I turn toward the look that was detained then and there in the camera frame. The hermeneutics of a look are based on tracing what appears between us. I look at them (captured in the photo) and they (from the photo) look at me. In looking, we lean out beyond our own selves, we exceed ourselves, we move toward something else, we seek something in the world that is external to us in order to invite it to us, to comprehend it.

In some of the photographs discussed here we see the deformed faces of injured soldiers, crowds welcoming the outbreak of the First World War, English volunteers in August 1914 standing in front of the London Recruiting Depot, Jews in damaged family photographs from the Holocaust, boys from the Łódź and Warsaw Ghettos. I follow the looks that come toward me from these photographs, and I try to capture what they reveal to me: the landscape of the limit experience, that area where we cross from life to death. 



\section{Encounters with a Corpse}

The point of departure for these considerations is the many different events that can be defined, in abbreviated form, as an "encounter with a corpse," which has a special place in the broader space of a person's encounter with death. I want to focus my attention not on the various dimensions of the experience with death, but on corpses, because what interests me here is not so much the process of dying as the effect of dying - that is, the corpse. By "encounter with a corpse" I mean the ways - embedded in cultural patterns and subject to social regulation - in which human corpses are treated, the attitudes and images that are associated with them, and the language that is used to talk about them. The number of forms these encounters take is huge, though it seems that, at the foundation of all of them, is a fundamental, indeed primal, experience with taboo and an ambivalence that stems from that experience. The corpse is unclean, disgusting, subject to hideous decomposition. At the same time, it is fascinating, alluring, and attractive. Repulsion seems healthy and normal, culturally embedded in welllighted areas. Attraction is concealed, stifled, pushed down into areas marked by perversion and darkness. ${ }^{594}$

One of the oldest and most expressive descriptions of an ambivalent encounter with a corpse is the story that we find in book IV of Plato's Republic:

Leontius, the son of Aglaion, was going up from the Piraeus along the outside of the North Wall when he saw some corpses lying at the executioner's feet. He had an appetite

594 George Bataille has written about the taboos involving the dead and death that originate in prehistoric times: "The essential difference is that between a man's dead body and other objects such as stones. [...] We perceive the transition from the living state to the corpse, that is, to the tormenting object that the corpse of one man is for another. For each man who regards it with awe, the corpse is the image of his own destiny. It bears witness to a violence which destroys not one man alone but all men in the end. The taboo which lays hold on the others at the sight of a corpse is the distance they put between themselves and violence, by which they cut themselves off from violence." See Georges Bataille, Erotism: Death \& Sensuality, trans. Mary Dalwood (San Francisco: City Lights Books, 1986), 44. Louis-Vincent Thomas stated that, "in the face of the hideous, our phantasms [associated with the corpse - J. L.] are organized according to a dynamic that juxtaposes the clean with the dirty, the beautiful with the ugly, the unblemished with the blemished, the hard and indestructible with the soft, which is easily destroyed [...]." See Trup. Od biologii do antropologii, trans. K. Kocjan (Łódź 1980), 78. 
to look at them but at the same time he was disgusted and turned away. For a time, he struggled with himself and covered his face, but, finally, overpowered by the appetite, he pushed his eyes wide open and rushed towards the corpses, saying "Look for yourselves, you evil wretches, take your fill of the beautiful sight!"595

In the biological order, every one of us is moving inevitably toward such an encounter.

Without fail, it happens when we stand at the border between life and death, and when - subject to that great transformation - we leave our body behind and enter into the new reality of a corpse. In the cultural order, since ancient times, we deal with the encounter with the corpse with a variety of death rituals and funeral ceremonies. The object of my reflections here is not the experience itself, but its description, its various representations. Through this description - verbal or iconic - I attempt to access the content that lies behind representations (subject to analysis) of the experience of interest to me here. It is thus about mimesis of the encounter, about its suitably organized (textual or pictorial) equivalent.

From among the many forms of description of the encounter with a corpse we can distinguish two polar types: first, the encounter that is accidental, unpredicted, sudden and violent, shocking, one that disrupts the normal course of life; and second, the encounter that is prepared, organized, reconciled and included in the culturally defined system of behavior. The first type includes both "unwanted" encounters, which only later might turn into intentional participation (this is precisely what happened to Leontius, and we see such a description in Baudelaire's "The Carcass"), and "wanted" encounters, when onlookers move toward the location of a catastrophe in order to get a glimpse of the victims. In the 1940s and 1950s, Mell Kilpatrick photographed car crashes in the American countryside, and one of the motifs of his photos involved people gathered around the bodies pulled from the wreck. ${ }^{596}$ The second type is made up of various kinds of funeral rituals and behaviors toward the corpse as preserved in culture. ${ }^{597}$ Included in these culturally reconciled encounters are, no doubt, the danse macabre, contemplation of the threatening and rotting corpse - the transi, and the prototype of the experience under discussion here, namely that of "The

595 Plato, Republic, ed. C. D. C. Reeve, trans. G. M. A. Grube (Hackett Publishing Company, Inc.; 2nd edition, 1992), 115.

596 See M. Kilpatrick, Car Crashes and Other Sad Stories (Taschen 2000).

597 For a monographic outline of the matter of the funeral and mourning based on testimony from various cultures, see Alfonso Maria Di Nola, La morte trionfata: Antropologia del lutto (Newton Compton 1995). For the Polish version, see Tryumf śmierci. Antropologia żałoby, ed. M. Woźniak, trans. J. Korecka et al. (Kraków 2006). 
Three Dead Kings" (or "The Three Living and the Three Dead"), in which three riders come upon three open coffins and the decaying corpses inside. ${ }^{598}$

From the multitude of possibilities, I have chosen the following situations and their associated discourses: the postmortem dissection; encounters with corpses in the trenches of World War I in Flanders and in the camps of the Gulag Archipelago in Kolyma; and violations of the funeral ceremony in the reality of the Warsaw Ghetto.

\section{The Postmortem Dissection}

Descartes devoted more than half of part V of his Discourse on Method to reflections on anatomy. The object of his meticulous commentary is the functioning of the heart and the circulatory system, the extensive network of veins and arteries, the directions of blood circulation, and above all - the mystery behind the mechanism that sets this whole complex system in motion. In the introduction, he wrote that he wanted "to place here the explanation of the movement of the heart and of the arteries," and he advised his readers:

I would like those who are not at all versed in anatomy to take the trouble, before reading this, to have the heart of some large animal that has lungs dissected in their presence (for such a heart is in all respects sufficiently similar to that of a man) $[\ldots] .{ }^{599}$

A natural source for gaining an understanding of the laws governing the workings of the human organism was, for the French philosopher, the postmortem. There is nothing extraordinary about this. Methods for opening up corpses already had, in Descartes' day, a long tradition; we need only recall the animal dissections performed by Galen (120-200) and the medical works of Avicenna (980-1037). The postmortem, performed sporadically in the Middle Ages, became highly popular in the Renaissance; it represented one of the ways to cultivate the revitalized study of the human being. Contrary to common belief today, the postmortem in medieval and Renaissance Europe was not associated with something dark, was not associated with the breaking of taboo, and was not seen as violating the integrity of the corpse. In those days, opening the body of a dead person in an odor of sanctity - with the goal of conserving the body or, in the case of deceased members of high-ranking families, quickly removing perishable

598 On the origins of various versions and meanings of this tale, see Jean Delumeau, Sin and Fear.

599 René Descartes, Discourse on Method and Meditations on First Philosophy, trans. Donald A. Cress, Fourth Edition (Hackett Publishing, 1998), 26. 
internal organs when it was necessary to transport them a long distance - was accepted. ${ }^{600} \mathrm{~A}$ taboo surrounding the postmortem emerged only in the nineteenth century. In the eighteenth century, autopsies could be performed freely. Foucault wrote: "So there was no shortage of corpses in the eighteenth century, no need to rob graves or to perform anatomical black masses; one was already in the full light of dissection." ${ }^{601}$ Dissections took place in large auditoriums filled with viewers, as in a Vienna clinic in 1754 or in the classicistic amphitheater at l'École de Chirurgie, built in 1769-1775 and crowned with an enormous cupola.

Dissections were performed in public. The first such demonstration is presumed to have taken place at the University of Bologna under Professor Mondino de Luzzi (1276-1326), who did his work on the body of a convict, a common practice at the time. The Florentine physician Antonio Benivieni (ca. 1443-1502) performed twenty dissections that he described in a treatise published after his death entitled De abditis nonnullis ac mirandis morborum et sanationum causis. ${ }^{602}$ A particularly spectacular dissection was performed in 1540 in Bologna, in the presence of as many as two hundred students, by Andreas Vesalius (1514-1564), one of the fathers of modern anatomy and author of the monumental set of books entitled De humani corporis fabrica libri septum (1543). This work was illustrated with superb woodcuts that are now a part of art history. Such great artists as Michelangelo participated in dissections, as did Leonardo da Vinci, the genius creator of famous anatomical drawings who himself "performed dissections on more than thirty male and female corpses of almost every age." 603

In his Historia Corporis Humani sive Anatomice, Alessandro Benedetti (1450-1512) included a description of the principles behind how an anatomical

600 See A. Wieczorkiewicz, Muzeum ludzkich ciał. Anatomia spojrzenia (Gdańsk 2000), 71-73.

601 Michel Foucault, The Birth of the Clinic: An Archaeology of Medical Perception (Vintage, 1994), 125.

602 See A. Wieczorkiewicz, op. cit., 73-76. Benivieni described, among other things, the case of one A. Bruno, who was not able to take food and died of hunger. It was for the public good - as Benivieni emphasized - that the body was opened. The dissection showed that the entrance to the dead person's stomach was closed, which made it impossible for food to enter the gastrointestinal tract. It was worth considering the diagnostic and educational value of the postmortem. For more on Benivieni's treatise, see I. Carr, http://www.umanitoba.ca/faculties/medicine/units/history/lesion/lesion3. html (accessed 25 May 2008).

603 Such was how Don Antonio de Beatis, secretary to the Cardinal of Aragon, wrote about Leonardo. Quote from F. Lebrun, "Jak dawniej leczono," in A. Wieczorkiewicz, op. cit., 134. 
spectacle should proceed; indeed, he provided a kind of scenario. As a civilized person, Benedetti did not recommend opening the bodies of living people, which is what barbarians would do. For people taught to explore nature's secrets, corpses were enough. The body should be carefully chosen, middle-aged, with a solid frame - so that it could serve as good dissection material and could be easily visible to participants in the spectacle. Which is why Benedetti recommended that a well-lighted table be placed in the center of the room. Viewers were to be seated according to their positions in society, their social status, and in a way that protected the "masters of the scalpel" from being crowded by interested observers. The author did not forget matters tied to the maintenance of order: "it is necessary to set up guards in order to prevent feverish crowds from pushing into the center," and to organize someone who would collect money to fund the spectacle's essential needs. The dissection would best take place in winter, Benedetti argued, since the cold would prevent the corpse from succumbing to rapid decomposition. Another practical suggestion was based on similar motives, namely that the length of the demonstration be set so that it could be completed "before the dissection material succumbed to decay." 604

By 1637, when the Discourse on Method was published, Descartes had lived in Holland for eight years, including in Leiden, whose university was founded in 1572 through funds provided by William I, Prince of Orange in recognition of the perseverance of the city's residents during the year-long Spanish siege. Leiden was also famous for its theatrum anatomicum. I am aware of three illustrations of the anatomical theater, which Descartes no doubt visited. One of these illustrations is entitled "Anatomical Lecture in Leiden at the time of Doctor Pauw" and dated 1609. It shows a crowd of viewers packed into amphitheater benches forming concentric circles around the dissection table. The anatomist with his assistant stands before the open corpse with one hand held over a book lying on the table next to him, and with the other hand holding an organ extracted from the body. In the tool cabinet situated above the head of the man performing the dissection, an open compass is visible, and among the viewers there are skeletons holding banners with Latin inscriptions. A view of Leiden stretches across the top of the illustration, along with the university's seal. A year later, another illustration presents the same theater, except this time there are practically no people. There is a dissected body on the table, alongside which stand two men who look like anatomists. One of them is lifting the sheet that

604 For passages from the English translation of Benedetti's treatise, see http://researchnurses.go.cc (accessed 25 May 2008). 
covers the corpse. They are being watched by human and animal skeletons. The few visitors in the theater, apparently there to view a museum exhibition, do not seem especially interested in the anatomical demonstration. A third and anonymous illustration comes from the year 1700 showing the anatomical theater with an empty dissection table and with skeletons and human anatomical models arranged throughout the benches, all of which is being viewed by a handful of visitors. It looks as if, sometime over the course of the seventeenth century, the anatomical theater in Leiden was abandoned.

But public dissections did not at all come to an end. They simply evolved. The act of opening up a dead body slowly lost its character as a half-medical, half-religious ritual, one that called forth shivers of unhealthy fascination and took place within the conventions of an amphitheater, attracting scholars and students, but also onlookers of all kinds (including women). Increasingly, the anatomist leading the dissection, as the master of ceremonies revealing the secrets of the human body (that perfect piece of art created by the Divine architect), was transformed into an anatomopathologist. More than ever, dissections in the nineteenth century were marked by professionalism and medicalization. With the increased use of photography for medical purposes and standardization in anatomical illustrations, images of the human interior were relatively easy to create and distribute. The circle of those viewing an autopsy was made up of select medical practitioners, and the demonstration itself was more often a closed event taking place not in an amphitheater with organized seating, but in dedicated spaces in medical clinics and academies, which resembled laboratories equipped with several dissection tables and sophisticated equipment. That having been said, some modern dissection rooms have maintained the specific architecture of the old anatomical theaters. ${ }^{605}$

The Leiden illustrations of the theatrum anatomicum illustrate several significant features of old postmortems. Let me point them out and systematize their most important qualities.

Above all, there is the spectacular nature of the event, its grandeur, the presence of the public made up of professionals, amateurs and simple onlookers.

605 On the increasing professionalization of the postmortem performed by emotionally distant and proficient technicians, and the transfer of the operation itself from open spaces for the public to specialized, closed spaces, see Kemp and Wallace, Spectacular Bodies, 17-19, 31. See photos of an American morgue where postmortems take place equipped with modern research tools in B. Innes, Granice śmierci, trans. M. Bernacki, E. Krzak-Ćwiertnia (Warszawa 1999), 51. The anatomical theater at the University of Padua exhibits the old architecture; see photos in A. Wieczorkiewicz, op. cit., 86-87. 
In such places as Leiden the act of dissection became a public spectacle. The many gathered viewers took part in a moving anatomy lecture, which took on the character of a ritual act, which - by its very nature - revealed the deep secrets of the human body. The theatricalization is significant, the event's thought-out arrangement of the space in which the dissection played out, which appears to have reshaped an anatomical demonstration into a carnival-like spectacle, in the full anthropological sense of that concept. ${ }^{606}$ In this spectacle, two orders came into contact: the scientific (activities that were cognitive and educational in the context of anatomy) and the ceremonial (movement toward the border of cultural and religious taboo, occupying the space of divine competence with regard to final matters, including the secrets of life and death). Scalpel in hand, the anatomist is not just a common physician, but a medical priest who reveals the divine architecture of the human being. He makes explicit what was hidden. Like a guide in the middle of a dark forest, he leads others through the intricate labyrinths of the human interior. In this context, anatomy becomes part art, part "natural theology" of a kind. At least since the Renaissance and until the nineteenth century, the dominant belief was that the goal of a public dissection and the preparation of anatomical images of the human body involved not just

606 On the theatricalization and carnival-like nature of anatomical demonstrations, A. Wieczorkiewicz wrote: "Just like when a stage play was being considered, people took care to correctly reproduce a spectacle, to appropriately divide the event into separate phases, and the final form of the spectacle was to be subordinated to the norms of decorum. In some [anatomy] theaters, the spectacles were accompanied by music. Viewers had to follow certain rules regarding appropriate behavior. Sometimes they had to pay for admission. The famous Parisian professor of anatomy, Ch. Estienne, who - in a textbook on the theory and practice of anatomy - devoted one chapter to a description of the ideal place for anatomical demonstrations to take place, repeatedly using theatrical terminology, sometimes directly referring to ancient theater (for example when he said that the anatomy table should be placed at the front of the theater, in a place where the ancients set the scene). [...] The spectacle reached its peak in the eighteenth century. The anatomical theater was decorated with damask and thoroughly illuminated. [...] There was one more spectacular feature of this ceremony. Anatomy was presented in Bologna (and in some other cities) during the carnival. Winter favored the conservation of the corpse. [...] It was considered correct [...] to attend anatomy lessons during the carnival - while the people of Bologna, their faces hidden behind masks and with music playing in the theater, could watch anatomy at work, not always understanding the Latin explanations. The anatomy lesson here took on a new dimension. The lecture was simultaneously a show - and the show was a carnival-like spectacle." See Wieczorkiewicz, op. cit., 84-85, 88-89. 
medical knowledge strictly defined, but also the art of understanding the beauty and perfection of creation. Visible nature, which can be subjected to analysis on the dissection table and whose structure can be presented to the public, contains within itself a reflection of the divine order of things, an order that is accessible to human reason. ${ }^{607}$

The iconography of the anatomical theater at Leiden is embedded with a particular set of symbols (including an open book, the images of Adam and Eve in the form of skeletons, an open compass), which lead us toward the deeper meanings behind the dissection spectacle. The highly powerful symbolism of the open book points to the authority of science, but also the "book of the living" or the "book of life," about which the psalmists wrote (Psalms 69:29), as did the prophets Isaiah (Isaiah 4:3) and Daniel (Daniel 12:1), and St. John in Revelation (Revelation 3:5). In this Book, before we even existed, our entire life was written, and on the last day it will be opened so that everyone can be "judged out of those things which were written in the books, according to their works" (Revelation 20:12). The "Book of life" is not the same as Book of the Seven Seals maintained by the Apocalyptic Lamb (Revelation 5:1). The Book on the dissection table contains a kind of dual symbolism: of the highest conceptual values, a depositary of truth accessible to reason, and of that which is most sacred, the revelation of divine mysteries, and it was in this dual aura that dissections took place. The figures of Adam and Eve evoke the biblical history of human beings - from sin to salvation. The open compass is one of the symbolic elements of cabalism and freemasonry, a shape resembling the letter " $\mathrm{A}$ " signifies the beginning of all things. It appears in allegories involving geometry, architecture, and justice; it is an emblematic presentation of the act of creation and a symbol of the divine architect - the creator of man. The anatomist at Leiden is positioned directly under the open compass, which one can interpret as the highest consent and sanction for the penetration of the human interior. The open compass creates the form of a triangle, which also serves as a symbol of the triune God. The triangle as a Manichaeistic symbol of the Holy Trinity was at first rejected by the Church, but it was later assimilated; since the Middle Ages, the triangle symbolizing the Holy Trinity has appeared in connection with other symbols (the hand of god, the Eye of Providence, doves). ${ }^{608}$

607 0n the philosophical foundations of anatomy spectacles and images, and on the rituals surrounding dissections, see Kemp and Wallace, Spectacular Bodies, 11-16, 23-25.

608 See J. E. Cirlot, Słownik symboli, trans. I. Kania (Kraków 2000), 100, 210; E. R. Curtius, "Książka jako symbol," in Literatura europejska i łacińskie średniowiecze, trans. A. Borowski (Kraków 1997), 309-357. D. Forstner, Świat symboliki chrześcijańskiej, trans. 
Another feature of the dissection that needs to be emphasized is the act, of opening a dead human body, itself. We can omit a discussion of the history of funeral rituals (and other ceremonies associated with death) in which the practice of opening a corpse for embalmment has long played a role, because what is central here is the motif of opening a body as a drastic violation of the border between that which is inside a person and that which is outside - the surface of the body as the display for internal emotions, thoughts, and the condition of the soul. From the perspective of cultural anthropology, one can view the dissection as a crossing (or, more bluntly, a breaking through) of the threshold of that which serves as the soul's house.

Ancient Orphic wise men treated the body as the soul's prison; they even called it the soul's coffin, which was repeated in almost identical form by one of the Church Fathers, Clement of Alexandria (ca. 150-ca. 215). St. Augustine softened this antagonism, writing about the beauty and harmony of the body, designated as the soul's dwelling place. Modern times have been dominated by Cartesian dualism. According to Descartes, the human being is made up of two irreducible substances: thinking substance without extension (that is, souls) and extended substance lacking consciousness. They are opposed to one another, and one has no influence on the other. The soul only resides in the human body - specifically, in a small gland located in the brain called the pineal gland (conarium). ${ }^{609}$ The body is just an unconscious mechanism; one might say, a "soulless machine." The Catholic Church teaches that in death, which is the separation of the soul from the body, the human body is destroyed and the soul passes on to an encounter with God. But at the moment of Resurrection, God grants incorruptible life to our bodies, reuniting them with their souls (Catechism of the Catholic Church, $\$ 997)$. Only in light of this perspective does the full meaning of the topos of the body as the soul's dwelling place become apparent, ${ }^{610}$ and the postmortem dissection takes on the quality of a transgressive experience.

No one can see or touch his own heart. Similarly, no one can see the heart of another person without violating his bodily covering. The body's border, whether marked out by nature or defined by the Creator, is guarded by many

W. Zarzewska et al. (Warszawa 1990), 59-60; Słownik teologii biblijnej, ed. X. LeonDufour, trans. K. Romaniuk (Poznań; Warszawa 1985), 412-414; A. Wieczorkiewicz, op.cit, 90-91.

609 See D. Leszczyński, “Foucault, Kartezjusz, szaleństwo," Nowa Krytyka 14 (2004).

610 See the entry "Ciało ludzkie" in Encyklopedia katolicka (Lublin 1985), vol. 3, k. 440447. On the anthropological significance of transgressing the border of the body and of opening the body, see A. Wieczorkiewicz, op. cit., 70-75. 
cultural and religious norms. Marsyas, flayed by Apollo, is transfixed by the form of his suffering, which arouses both horror and disgust. Which is perhaps why many artistic representations of this subject avoid literality. For example, Titian's painting (1570-1576) shows the preparations for the execution, and in José de Ribera's painting, Apollo is holding the prostrate Marsyas by the legs as he begins to remove his skin. The face of this master of the aulos is contorted by a monstrous scream. In his poem, Zbigniew Herbert revealed for us the internal landscape of the screaming Marsyas, who relates:

nieprzebrane bogactwo

swego ciała

łyse góry wątroby

pokarmów białe wąwozy

szumiące lasy płuc

słodkie pagórki mięśni

stawy żółć krew i dreszcze

zimowy wiatr kości

nad solą pamięci. the inexhaustible wealth

of his body

bald mountains of his liver

white ravines of aliment

rustling forests of his lungs

sweet hillocks of his muscles

joints bile blood and shudders

the wintry wind of his bones

over the salt of memory ${ }^{\mathrm{a}}$

a Zbigniew Herbert, "Apollo and Marsyas," trans. Czesław Miłosz and Peter Dale Scott, Selected Poems (Ecco 1986), 82-83.

But the anatomist is able to remove the heart from a body and show it to the viewers. Their gaze falls upon areas that are closed to the human eye; it follows a complicated and multi-stage process by which the body's barrier is crossed: pulling the skin from the torso, removing the tissue, splitting the sternum and twelve pairs of ribs, opening the chest cavity and preparation of subsequent layers of the pleura, mediastinum, pericardium, to finally get at the heart. Participation is such a spectacle caused shudders of horror and excitement; it was accompanied by an awareness that the fundamental taboo that surrounds death and the corpse had been broken. During the autopsy, we all but literally enter the insides of a dead body while remaining on the outside. We extend our control over the corpse, which arouses a primal reaction of horror and repulsion. We look into the face of death in order to extract from death the secrets of life. The corpse is tamed; it is subordinated and harnessed in the service of science. Under the scalpel, having unveiled its internal landscape, the corpse ends the scandal of useless decay by moving from a place marked by the dark anarchy of decomposition and into the light of knowledge, serving life. Silent forever, the corpse on the dissection table is forced to speak. 
In the illustrations of the anatomical theater at Leiden, and in Rembrandt's painting depicting The Anatomy Lesson of Dr Nicolaes Tulp (see I; the Roman numerals indicate the number attached to the reproductions found at the end of this book), we see an open book by the dissection table. But in fact it was the corpse that was an open book, from which the master of the anatomical ceremony publicly read the divine symmetry of the human body. St. Augustine, describing the beauty and harmony of the human body, wrote about the anatomist, who - through his practices - could unveil this harmony. Though the dissection itself, according to St. Augustine, involved the "cruel zeal for science," and even if it was true that the human's "inward parts" would seem to "have no beauty," those parts nonetheless contained within themselves an enticing beauty, because they are a visible sign of the perfection of God's design. ${ }^{611}$ In an illustration adorning the title page of his De humani corporis fabrica and presenting a dissection performed on a woman by the master himself, Andreas Vesalius is presented as a great lecturer on anatomy and teacher reading the scriptures of the exposed viscera. One can interpret many other representations of the postmortem in terms of a kind of semiotics of the body, including an entire series of paintings depicting the anatomy lecture by such Dutch painters as Aert Pietersz (1601-1603), Jakob Adriaensz Backer (1670) (see III), Jan Van Neck (1683) with his dissection of a child (see IV), Cornelis Troost (1728), and Rembrandt with his famous Anatomy Lesson of Dr Nicolaes Tulp (1632). The dignified men gathered around the corpse demonstrate great seriousness, but also supremacy, like someone who has a way to steal long-hidden secrets and is now experiencing a moment of deserved triumph. Or someone who has found the key to deciphering a secret code. Or someone who has finally found his true teacher and leader on the path to understanding. The activities of the anatomists,

611 Zbigniew Herbert, "Apollo and Marsyas," trans. Czesław Miłosz and Peter Dale Scott, Selected Poems (Ecco 1986), 82-83.

the dead, and sometimes even of sick persons who died under their knives, and have inhumanly pried into the secrets of the human body to learn the nature of the disease and its exact seat, and how it might be cured, yet those relations of which I speak, and which form the concord, or, as the Greeks call it, 'harmony', of the whole body outside and in, as of some instrument, no one has been able to discover, because no one has been audacious enough to seek for them. But if these could be known, then even the inward parts, which seem to have no beauty, would so delight us with their exquisite fitness, as to afford a profounder satisfaction to the mind-and the eyes are but its ministers - than the obvious beauty which gratifies the eye," Saint Augustine of Hippo, The City of God, trans. Marcus Dods (Hendrickson Pub., 2009), 769. 
and the artists depicting their burdens, were guided by the maxim visible above the entrance to the Temple of Apollo at Delphi: nosce te ipsum - know theyself. The source for knowledge of human nature is the corpse. The English anatomist Helkiah Crooke (1576-1648), an authority on medicine in the first half of the seventeenth century and author of the work Mikrokosmographia, a Description of the Body of Man (London, 1616), wrote that "anatomy is as it were a most certaine and sure guide to the admirable and most excellent knowledge of our selves, that is of our owne proper nature." ${ }^{612}$

The discovery of pathological anatomy was the harbinger of a new spirit in medicine. Dissection produced an image of death - to put it paradoxically - in statu nascendi. This new medical view of things, as Foucault claimed, made possible a perception of death that sheds light on the miracle of creation and allows us to understand life. Anatomy leads from the symptomatic surface to the depths of the unseen. It thus gradually crosses over to "the other side" of the body and reveals the mysteries of health and sickness.

With Bichat, knowledge of life finds its origin in the destruction of life and in its extreme opposite; it is at death that disease and life speak their truth: a specific, irreducible truth, protected from all assimilations to the inorganic by the circle of death that designates them for what they are. [Foucault then quotes Bichat] "Open up a few corpses: you will dissipate at once the darkness that observation alone could not dissipate." The living night is dissipated in the brightness of death. ${ }^{613}$

Rembrandt's less famous The Anatomy Lesson of Dr Deijman (1656) (see II) depicts a rather rare motif of the open skull of a dead man and a brain being opened. The body is laid out flat, with the feet in the forefront, and the torso, already opened, is partially covered by a white sheet. The position of the body and painting's perspective is remarkably like what we see in Andrea Mantegna's ingenious Lamentation of Christ (1490) (see V). Of course, the resemblance is not an accident. The dead person resting on the dissection table experiences, in this way, a kind of sanctification; he becomes a sacrifice on the altar of science.

The symbolic sacralization of a corpse subjected to dissection indicates a peculiar quality of the anatomical spectacle, namely its ambivalence. At least until the middle of the nineteenth century, the "dissection material" - as Alessandro Benedetti and later generations of pathologists put it - consisted of the bodies of

612 Quote from C. Collier, The Body as Teacher: From Source of Knowledge to Object of Knowledge, http://www.bu.edu/wcp/Papers/Anth/AnthColl.htm (accessed 23 March 2018).

613 Foucault, The Birth of the Clinic, 145-146. 
executed convicts, people on the margins of society, the poor, the homeless. The source for corpses was thus the executioner's dungeon, hospital, and poorhouse, such places that could provide bodies which no one cared to remember. In his treatise, Benedetti wrote plainly about these sources, which are confirmed by the statutes of universities where anatomical demonstrations were performed, and by the special privileges granted to particular faculties by officials who could thereby dispose of bodies and, through the majesty of the law, present them to anatomists. ${ }^{614}$ The dead convict, stretched out on the dissection table, cut open by the scalpel and showing it insides - took on a dual role: the criminal serving his just sentence, and the sinner paying for his sins in an unbelievable act of sacrifice, a sacrificial offering made of himself. Thus, in terms of iconographic design, the body laid out on the table was tied to the symbolism of the Last Supper, and the dead criminal resembled Adam (the skeletons of Adam and Eve were present in depictions of the anatomical theater) - condemned and redeemed. ${ }^{615}$ The dissection thus takes on the hallmarks of a great parable about the fall and exaltation of man. The open body - twice stigmatized (first as a corpse in general, and then as the corpse of a criminal expelled to the social margins) - played a key role in the drama of understanding life and death. In this way, it moved inexorably into the sphere of ambivalence.

Let us imagine the scenery surrounding a postmortem transformed into a paratheatrical spectacle. The body of a hanged murderer is delivered to the anatomical department. In life he had caused fear, but now one can see him dead. Fear mixes with interest. Nervous movement in the gallery, murmurs of excited voices in the crowd, a table is put in the center of the room and a motionless body

614 See A. Wieczorkiewicz, op. cit., 96-97. The author refers, for example, to the Statutes of the University of Bologna from 1442, according to which municipal authorities had to provide annually two bodies originating from a territory at least thirty miles away from Bologna, in order to avoid a situation in which anatomists and students would find themselves performing postmortems on relatives or close friends. Genoa, Perugia, Pizza, Florence and Padua had similar statutes. In the middle of the sixteenth century in London, King Henry VIII extended a privilege to the College of Barbers and Surgeons (later known as The Regal College of Surgeons) according to which professors and students had the right to receive four corpses of hanged criminals each year. This privilege, including the implementation of the testament records marking the body for medical purposes, became for the College the only legal source of acquiring corpses until the nineteenth century. See V. Walter, From Body Snatching to Bequeathing, http://www.quotesandsayings.com/findquoteframes.htm (accessed 25 May 2008).

615 See A. Wieczorkiewicz, op. cit., 98. 
is placed on it. The blade of a scalpel sinks into the cold body of waxy pallor. In the anatomist's hand the muscle of a human heart - pulled from an open chest, covered with a network of veins, with a massive aortic arch and severed arterial endings. The heart of a criminal - the heart of a person, visible for all to see. In the crowded and stifling room, the smell of sweat and formalin, and that delicate sweet scent of the beginnings of decomposition (we recall the recommendations that dissections be carried out in winter and that they be limited in duration; of course, in those days there were no cooling systems).

The awe of the corpse was mixed here with the notoriety of the convict, and with suspicions of the moral and religious ambiguity that accompanied the practice, of cutting open a body, itself. In Christian Europe, the admissibility of the postmortem was limited or doubtful, given the Christian faith in the resurrection of the body. The fear was that dismemberment of the body would hinder that resurrection. From this perspective, the dissection was regarded even as profanation of the corpse, which would make a normal funeral impossible, and was more disgraceful than an execution. The devotional imagination offered people gruesome and grotesque scenes of a corpse, cut into pieces, roaming around at the moment of resurrection in search of lost body parts. ${ }^{616}$

This is no way to remain indifferent to a corpse. Georges Bataille has written:

Violence, and death signifying violence, have a double meaning. On the one hand the horror of death drives us off, for we prefer life; on the other an element at once solemn and terrifying fascinates us and disturbs us profoundly. [...] Death was a sign of violence brought into a world which it could destroy. Although motionless, the dead man had a part in the violence which had struck him down; anything which came too near was threatened by the destruction which had brought him low. [...] Death is a danger for those left behind. If they have to bury a corpse it is less in order to keep it safe than to keep themselves safe from its contagion. ${ }^{617}$

The corpse delivers us into the sphere of taboo and transgression. Once again, Bataille:

616 See V. Walter, op. cit. In 1300, Pope Boniface VIII issued a bull which did not prohibit the performance of postmortems, but forbade dismembering the body. From the theological perspective, autopsies could thus be considered a matter of unsettled law. However, we know of acts that legalized the practice of dissections, such as the edict issued by Emperor Frederick II in 1240 authorizing the medical school in Salerno to perform a postmortem once every five years. See A. Wieczorkiewicz, op. cit., 74-75.

617 Bataille, Erotism, 45-46. 
Men are swayed by two simultaneous emotions: they are driven away by terror and drawn by an awed fascination. Taboo and transgression reflect these two contradictory urges. The taboo would forbid the transgression, but the fascination compels it. ${ }^{618}$

A series of poetic texts addressing the subject of the postmortem fall somewhere on the spectrum between contemplative, empathetic observation and horror; between sympathy and disgust; between purity and innocence and ignominity. On one end of the spectrum we have the highly valued area of beauty, and on the other end that area of experience that Julia Kresteva has called "abjection." 119

The poem by Stanisław Grochowiak entitled "Lekcja anatomii (Rembrandta)" exudes the beauty of the old masters' canvases, their serenity and grandeur. Both the dissection procedure itself and the corpse, as the object of anatomical analysis, are subject to aestheticization. The opening of a body resembles the pealing of a piece of fruit, which under the knife reveals its resplendent flesh. Between the anatomist, the viewers watching his work, and the dead person, there is full harmony and understanding. No violence is involved here, no brutal incursion into the interior of a dead person. On the contrary - the corpse cooperates with the anatomist with the greatest dedication. His skin and insides lose their repellent physiological qualities and become a kind of book, on whose pages are recorded the hallmarks of a past life: the imprint of emotions, the signs of suffering. Meanwhile, the activities surrounding the dissection resemble simple, everyday household tasks: dressing, washing up, winding wool. In Grochowiak’s

618 Ibid., 68.

619 Julia Kristeva, Powers of Horror: An Essay on Abjection, trans. Leon Roudiez (Columbia University Press, 1982). One commentator on Kristeva's thinking wrote the following: "The abject - that is, what has already been rejected - is neither a subject nor an object, but is situated between them, which is precisely what makes it insidious and dangerous. [...] The abject must therefore be abandoned by the subject, concealed [...] removed from the field of perception [...] for its own good, meaning a stable identity [...]. Kristeva emphasizes, however, that the desecrated cannot be completely destroyed or safely disconnected from itself. It is always only pushed away into an abyss from which the subject turns in a constant struggle. The subject always stands above the chasm between birth and death, beginning and end, salvation and condemnation, while the abject connects it with all that the ratio does not understand and what is avoided, i.e. with decay, fortuity and death; the abject thus blurs lines between right and the wrong, clean and scarred. [...] While religion pushes aside, indeed practically forbids contact with the abject, literature, poetry and art sublimate the abject, make it acceptable - that is, they reconcile it and allow it to be alongside." $\mathrm{M}$. Bakke, Ciało otwarte. Filozoficzne reinterpretacje kulturowych wizji cielesności (Poznań 2000), 25-27. 
verse entitled "Rozbieranie do snu," imagery of dying and decay is tied to the act of undressing for bed. The poet reaches a higher degree of aestheticization in his "Portretowanie umarkej" (Portrait of a dead woman).

A series of poems on the postmortem by Gottfried Benn leads us toward a place which is disgusting and shocking, but which is also - in a dangerous way ambiguous, which steps beyond the boundary between what is clean and unclean, proper and improper. We see in these poems something that fits perfectly with the expressionistic aesthetics of colliding extremes, a mixture of perversely attractive beauty and abhorrence of the abominable. The body of a white woman, prepared for dissection, is illuminated by the sun, bringing out the alluring shape of her thighs and breasts, which have not yet been deformed by "vice or birth." She looks like a drowsy fiancée, anticipating happiness. But this beautiful body is overwhelmed by the corpse of a black man, bringing disgrace upon the innocence of the feminine corpse. The illusion of beauty, harmony, and purity fades when the scalpel is put into the woman's throat ("Negerbraut"). Another example. In the teeth of a drowned man there is a "lavender aster," placed there by someone as a joke. As the larynx and palate are being cut open with a "long knife," the flower falls from the corpse's mouth and slides down into a container with the brain. The contrast between the corpse, subjected to anatomy's full literality, and the delicate (living) flower does not end there. In the final section, it finds its new place, its "vase" - that is, its place for life, in the empty chest of the drowned man stuffed with "excelsior" ("Little Aster"). For Benn's "dissection" poems the penetration of the territories of life and death is significant. What is probably most shocking is the example of "Beautiful Youth," whose focus is the dissection of a young girl "who had lain for long in the rushes." Indeed, for such a long time that little rats had nested among her insides ("under the diaphragm"). The decaying cadaver of a beautiful drowned woman is the cradle of life. But not for long. During the dissection, the animals are pulled out of their cozy home and thrown into the water. ${ }^{620}$

Let us take a closer look at the central organ of the human body - the heart. If the postmortem dissection is supposed to reveal the mysteries of life, there is no doubt that the heart (as the ancient symbol of the source of life, the habitat of feelings, but also of reason, will, and memory - that is, a person's entire interior

620 Gottfried Benn, "Negerbraut," Gedichte (Reclam, 1988), 11 (Translator's note: In English, the poem's title would be "Nigger Bride"); Benn, "Little Aster," trans. Michael Hofmann, Poetry (March 2011); Benn, "Beautiful Youth," trans. Michael Hofmann, Poetry (March 2011). 
along with his conscience, or in a word: the human soul) should be the focus of the anatomist's interest. But in graphics and paintings representing dissections, the heart is in the background, or disappears altogether. In Rembrandt's works, we have a dissected arm and a trepanation of the skull with the brain exposed, and in the work of van Neck we see the corpse of a baby with an open abdomen. The arm - more specifically the elbow - and the knee are organs of movement, and the mysteries of movement, its mechanisms, fascinated not only anatomists in those days. In the era of Descartes and Isaac Newton the rhythm of philosophical discourse marked out rationalistic schemes of knowledge and mechanical concepts to describe a broad variety of phenomena. None of the illustrations portraying a dissection (that I know of) shows a heart. What is most often presented is an opened abdomen or the very moment when a scalpel is applied to the body. In one famous drawing, Andreas Vesalius shows the internal organs of a female's abdominal cavity. Only in a certain medieval image of a dissection do we see an anatomist holding an organ in his hand, which had been taken out of the corpse lying right next to him. The image contains other organs, among which we can certainly identify a lung and intestines. But is that thing in the anatomist's hand really a heart?

In the above-cited Discourse on Method, Descartes devoted much of his anatomical reflections to the heart, which sets in motion the entire circulation system. He was fascinated with the constant beat of the heart and the continual circulation of blood, by which life in the organism is maintained. He knew that people were able to build "many different automata or moving machines," but he entirely approved of the view put forward by those who understood the body "as a machine which, having been made by the hands of God, is incomparably better ordered and has within itself movements far more wondrous than any of those that can be invented by men." ${ }^{221}$ In Descartes' eyes, the heart is thus a miraculous device, the center of the divine machine that is the human being. ${ }^{622}$

Poets describing anatomists and their activities, in contrast with painters, are particularly interested in the heart - one of the most poetically privileged parts

621 Descartes, Discourse on Method, 31.

622 This mechanistic and materialistic vision of the human being was taken to its extreme by La Mettrie in his work Machine Man (1747). Paul Hazard summed up ironically the fate of the Leiden-trained physician and philosopher: "There was more matter in him than in the general run of men. He was enormously fat, bloated and pot-bellied, and a chronic glutton. On the 11 November 1758, his machine broke down. Indigestion was the trouble." See Hazard, European Thought in the Eighteenth Century: From Montesquieu to Lessing (Peter Smith, 1973), 124. 
of the body. A corpse is opened simply to get at the heart. Such is the case with Jarosław Marek Rymkiewicz:

[...] o piękne ciała tonące: i te zwłoki białe,

Nagie zwłoki, na kamiennej posadzce, obmywane

Przez wiatr znad rzeki, włosy zlepione krwią: i płacz i czemuś

To się w lotne pióra nie przyodział: i lancet przecina

Skórę, i sięga serca: [...]. ${ }^{623}$

[...] oh, beautiful drowning bodies: and these white corpses,

Naked corpses, on a stone floor, washed

By the wind along the river, hair matted with blood: and weep, and why

Did you not dress yourself with floating feathers: the lancet cuts

Through the skin, and reaches the heart: $[\ldots]$.

In the work of Konstantin Biebl, a representative of modernist Czech poetry, we find a poem entitled "Postmortem," in which the heart is the protagonist. Pulling organs into the light of day, previously hidden from view, becomes an act of disillusionment, exposing the deceptive games of appearances. The poet seems to ask: what is the human being really? What becomes of it? Or, to put it another way: what is it truly made of? The heart has a particular occupation - as an icon of humanity. Removed from the body and weighed in the hand, it no longer means anything. It disappears:

Bierzesz je nagle do ręki

i jest jakby pusta

Gdzie te góry boleści?

Już nie myśl o nich

wszystko to się pomieści

w ludzkiej dłoni ${ }^{\mathrm{a}}$
You take it in your hand suddenly and it is kind of empty

Where are these mountains of grief?

Do not think about them anymore

all of that will fit

in the human hand

a K. Biebl, “Sekja zwłok," trans. R. Stiller in Strofy z derszczykiem, ed. R. Stiller (Warszawa 1986), 368.

In the discourse of modern anatomic pathology, the heart is the subject of lingual deconstruction. One the one hand, Shearer's classic handbook ${ }^{624}$ for

623 Wiersze z wygnania. I. "Topielec" from the volume Animula (1964). Quote from J. M. Rymkiewicz, Wybór wierszy (Warszawa 1976), 119.

624 See John Weber, Shearer's Manual of Human Dissection, 8th Edition (McGraw-Hill Education/Medical, 1999). The description of the anatomy of the heart can be found in the chapter entitled "Thorax" on pp. 109-117. 
prosectorial activities, which has been used by several generations of students and updated many times since 1937, leads the hand of a young pathologists by helping them find particular organs in the body. On the other hand, it seems to cover them, page after page, with aggressive and expanding terminology. Of course, I am bypassing the merits-related legitimacy and conceptual functions of such a discourse, because my focus here is the paradoxical absence, in the dissection, of a description of the heart, which ceases to exist as an integral organ; it falls apart into an incomprehensible multitude of parts, surfaces, and elements. Activities aimed at dissecting the heart have a kind dramaturgy after all, each cut of the scalpel moves closer to finale. But their descriptions are extremely nominalized. Such terms are dominant: "the interior surface of the heart" (faciem interior cordis), "coronary groove" (sulcus coronarius), "right ventricle" (ventriculus cordis dexter), "left ventricle" (ventriculus cordis sinister), "interventricular septum" (septum interventricularis) etc., etc. For the initiated, the very succession of these names has a narrative character. One can read these prosectorial indicators like a travel report. We walked along a difficult path, made our way over great heights and through great depths, and in the end we reached our destination. But in the meantime, our destination - the heart - remained elusive, though we familiarized ourselves with its internal workings. The heart falls apart into a thousand pieces like the glass heart in Snow White.

The heart appears very differently in the dissection protocol included in a treatise by Dr Józef Stein under the title "Anatomia patologiczna choroby głodowej," which along with other studies written by doctors in the Warsaw Ghetto was included in the one-of-a-kind book: Choroba głodowa. Badania kliniczne nad głodem wykonane w getcie warszawskim z roku 1942 (Starvation Disease: Clinical Research on Famine Performed in the Warsaw Ghetto in 1942). As the title suggests, this book was the product of research conducted in the Warsaw Ghetto on the effects of extreme hunger. At the end of 1941 a team of researchers emerged under the direction of Dr Izrael Milejkowski, head of the Health Department of the Rada Żydowska. Separate rooms dedicated to those suffering from starvation were organized in hospitals, and workshops were equipped with laboratory instruments purchased using funds collected for this purpose. Research began in February 1942. The analyses, measurements, dissections and results of this research were discussed at scientific meetings. Members of the research team were eventually deported from the ghetto and murdered. In a note written in January 1943, we read: 
We have begun preparing the typescript of the discussed works. We did not know if we would see them printed. But in any case, we wanted to leave behind a sample of our efforts - non omnis moriar. ${ }^{625}$

Józef Stein, who was also director of the Zakład Anatomii Patologicznej Żydowskiego Szpitala na Czystem (Department of Anatomic Pathology of the Jewish Hospital in Czyste), included in his contribution to Choroba głodowa six dissection protocols illustrating six concrete examples of death through starvation. One of them involves the case of a sixteen-year-old girl, whose dissection was performed eighteen hours after her death:

Growth below average. Nutrition, very poor, build fragile, normal. Hair - brown. Skin - sheer, dark, not very elastic, peeling off at the stomach and breasts. The brain weighs 1300 gm., very soft, swollen. [...] In the abdominal cavity about 2 liters of transparent yellowish fluid. [...] Heart - smaller than the deceased's fist, weight 150 gm. ${ }^{626}$

The unprofessional reader - who is not familiar with the rules of the poetry of dissection protocols and the peculiar wording used in them - is no doubt struck by the fragment: "Heart - smaller than the deceased's fist." This sounds like a quote from a poem, with its semantic dynamics, roused both by the situational and stylistic context and by the construction of the expression itself. The appearance and condition of the dead girl's heart muscle is defined through a comparison with a blurred indicator, a comparison that remains on the borders of the dead girl's corporeality, but in a sense also steps over those borders. It seems that the dry description of internal organs is suddenly illuminated by a discourse of a different order - a discourse that humanizes the corpse opened on the dissection table. We imagine a young, emaciated girl with dark hair. Her frail body, dark hair, tiny hands balled into fists. The "deceased's fist" is a metaphor for the heart, thanks to which the heart, in this anatomical description, survives.

And yet one cannot help but regard this interpretative trope as somehow off the mark, given that the comparison of the heart with a fist is a standard expression, commonly used in anatomic pathology. From the six cases cited by Stein, the size of the heart is defined four times through a comparison with the dead person's fist. In this context (the horror of the ghetto and death by hunger), it would seem to be nothing unusual; it turns out to be a linguistic cliché. From the perspective of anatomic pathology, the heart is a muscle subjected to an

625 Choroba głodowa. Badania kliniczne nad głodem wykonane w getcie warszawskim $z$ roku 1942 (Warszawa 1946), 18.

626 Ibid., 48-49. 
unstoppable element of analysis which is performed both with a lancet and the anatomist's pen.

The epilogue to my reflections on the postmortem involves the times from which Dr Józef Stein's dissection protocols originate. The Third Reich harnessed anatomic pathology, which had long been used to learn the secrets of life, in the service of Nazi medicine and racist anthropology.

Under Hitler's regime, Professor August Hirt, director of the Anatomy Institute at the Reich University in Strasbourg, decided to create a collection of "Jewish-Bolshevik" skulls which, according to Hirt, would be of enormous scientific and didactic value. Hirt wrote:

There is a rich collection of sculls of almost every race and people. But science has at its disposal such a small number of Jewish sculls that research into them has produced no certain results. The war in the East has provided us with a way of correcting this problem. Securing the skulls of the Jewish-Bolshevik commissars, in which the disgusting but characteristic of the Untermensch is embodied, would provide us with the opportunity to obtain compelling scientific evidence. ${ }^{627}$

A specially chosen staff member, Hirt continued, would choose from Jews captured "in the East," make some anthropological measurements, take a series of photographs, record all of the data, and then:

$[\ldots]$ after causing sudden death $[\ldots]$ separate the head from the trunk. Having been soaked in a specially-designed and tightly closed tin container with a preservation fluid, the head will be sent to a given address. ${ }^{628}$

Hirt's project was of great personal interest to Himmler himself, who in the spring of 1942 offered the professor all possible support and resources., It was decided, in agreement with Eichmann, that the material for the collection would be sent to Strasbourg from Auschwitz. Seventy-nine Jewish men, twenty Jewish women, two Poles and four Asians were selected and transported to the Natzweiler concentration camp near Strasbourg, where they were murdered in a gas chamber. The corpses were transported to Professor Hirt's Anatomy Institute, where they were placed in special tanks filled with an alcohol solution. But the project was never completed. With the Allied offensive in the autumn of 1944, Hirt fled the city, having ordered the corpses to be destroyed. Institute employees managed to cut up and burn only some of the bodies; the rest fell into the hands of the

627 See J. Mikulski, Medycyna hitlerowska w stuzbie III Rzeszy (Warszawa 1981), 86. All information about Hirt's collection is derived from this source.

628 Ibid., 87. 
Americans (who took Strasbourg on 22-23 November 1944). The Strasbourg Professor had combined a passion for science with the flair of a collector. Not only had he encouraged the killing of human beings in order to turn them into anatomical exhibits, but he also collected the gold teeth that had been extracted from the corpses' mouths. The professor's ultimate fate is not known; no doubt, he lived somewhere to a ripe old age.

SS-Obersturmführer Johann Paul Kremer - a doctor of philosophy and medicine who habilitated in anatomy at the University of Münster, a camp physician at Auschwitz from 30 August to 18 November 1942 - was a specialist in heredity. He was also interested in changes in the human organism caused by starvation; he was able to pursue this interest fully during his time at the camp, where he was told that, for his research, he would be able to select "completely fresh material for my research from those prisoners who were killed by phenol injections." ${ }^{\prime 29}$ Kremer observed extremely emaciated prisoners; he chose those whom he regarded as suitable experimental material, and - as he himself stated - he "reserved" them for his work. Each chosen individual was sent to a special room in block 28 and:

[...] was put upon the dissecting table while he was still alive. I [Kremer] then approached the table and put several questions to the man as to such details which pertained to my research. [...] When I had collected my information the orderly approached the patient and killed him with an injection in the vicinity of the heart. ${ }^{630}$

In the journal he had systematically maintained since 1899, Kremer noted his activities as an anatomic pathologist at Auschwitz four times.

Today I preserved fresh material from the human liver, spleen and pancreas (3 October 1942); fresh material from liver, spleen and pancreas taken and preserved (10 October 1942); have taken fresh liver, spleen and pancreas material (17 October 1942); Living-fresh material (liver, spleen and pancreas) from a Jewish prisoner of 18, extremely atrophic, who had been photographed before (13 November 1942). ${ }^{631}$

629 Kremer made these statements during an interrogation on 30 July 1947 in Kraków. Rudolf Höss, Pery Broad, Johann Paul Kremer, KL Auschwitz Seen by the SS (Interpress Publishers, 1972), 167 (footnote 71). In the 1947 Kraków trial of Auschwitz perpetrators, Kremer was sentenced to death by the Supreme National Tribunal, a sentence that was reduced to life in prison. In 1958 he was freed, in 1960 he was tried in Münster and sentenced to 10 years. The German court credited him with the years already spent in prison and released him. He died in 1965 in Cologne.

630 Ibid.

631 Ibid., $167-169$. 
SS-Hauptsturmführer Dr Josef Mengele studied medicine and philosophy at Munich University, where in 1935 he defended his dissertation based on the racial-morphological study of the mandible of four racial groups. In 1938 he completed his medical degree at Goethe University Frankfurt. He worked at the Institute for Hereditary Biology and Racial Hygiene of the Third Reich in Frankfurt, where his focus was on twinning, the physiology and pathology of dwarfism, genetic defects and other deformations. He was sent to Auschwitz in May 1943 directly from the Eastern Front, where he had been injured. He arrived at the camp with two Iron Crosses and ambitious research plans. Mengele carried out the first phase of his experiments personally, on living twin children. For the second phase he needed someone who could expertly perform dissections (the twins had to be put to death in order to obtain the anatomical specimens necessary for continued research), which determined the fate of Dr Miklós Nyiszli, a Jew educated at German universities in Kiel and Breslau, where in 1930 he earned his doctorate in medicine. He had performed autopsies for many years as a forensic examiner. In May 1944, he was deported along with his family from Hungary to KL Auschwitz. On the selection ramp, he heard a call go out for doctors who had completed studies in Germany, who knew how to perform postmortems, and who were well-versed in forensic medicine. Nyiszli stepped forward and immediately became Dr Mengele's assistant.

From the gloomy space of Crematorium I in Birkenau one stepped into the bright dissection room with modern equipment. A gray marble tabletop attached to a cement plinth was in the center, with drainage channels leading concentrically downward. Water tanks, three porcelain basins, nets on the windows to protect against flies and mosquitoes. The walls were painted light green. Next to that, Dr Mengele's office: a comfortable chair, a microscope on a long table, a glass case with chemicals, and - above all - a large book shelf containing expert literature: books, books and more books. "In short," Nyiszli wrote, "the exact replica of any large city's institute of pathology." ${ }^{32}$ We might add that such images do not depart too far from the classic representations of the theatrum anatomicum: dissection table in the center, accessories in service to the postmortem, books. On the other end of the building Nyiszli had his own room; he thus worked and lived on the site of the crematorium. By the time the camp was evacuated in January 1945, he had carried out a large number of dissections. In his memoirs on the camp (published in Hungarian in 1946), Nyiszli emphasized that:

632 Miklos Nyiszli, Auschwitz: A Doctor's Eyewitness Account, trans. Richard Sevear and Tibere Kremer (Penguin Modern Classics 2012), 20. 
The confines of the $\mathrm{KZ}$ offered vast possibilities for research, first in the field of forensic medicine [...]. The abundance - unequaled elsewhere in the world - of corpses, and the fact that one could dispose of them freely for purposes of research, opened up even wider horizons. I knew from experience that, whereas the clinics in most major cities of the world managed to furnish their institutes of forensic medicine with from 100 to 150 bodies for purposes of research, the Auschwitz KZ was capable of furnishing literally millions. ${ }^{633}$

We should point out the way in which Nyiszli talks about the postmortem performed on a certain pair of twins. These were children under ten years old who had been transferred from the so-called gypsy camp. The dry medical discourse that we saw in the dissection protocols of the Choroba głodowa is suddenly interrupted. Emotion breaks through the dispassionate report of a dissection professional. The voice of the pathologist cracks and someone entirely different begins to talk to us - a prisoner in KL Auschwitz-Birkenau with the number A 8450 tattooed on his left arm:

Together with the cerebellum I extracted the brain and examined them. Then followed the opening of the thorax and the removal of the sternum. Next I separated the tongue by means of an incision made beneath the chin. With the tongue came the esophagus, with the respiratory tracts came both lungs. I washed the organs in order to examine them more thoroughly. The tiniest spot or the slightest difference in color could furnish valuable information. I made a transverse incision across the pericardium and removed the fluid. Next I took out the heart and washed it. I turned it over and over in my hand to examine it. In the exterior coat of the left ventricle was a small pale red spot caused by a hypodermic injection, which scarcely differed from the color of the tissue around it. There could be no mistake. The injection had been given with a very small needle. Without a doubt a hypodermic needle. For what purpose had he received the injection? Injections into the heart can be administered in extremely serious cases, when the heart begins to fail. I would soon know. I opened the heart, starting with the ventricle. Normally the blood contained in the left ventricle is taken out and weighed. This method could not be employed in the present case, because the blood was coagulated into a compact mass. I extracted the coagulum with the forceps and brought it to my nose. I was struck by the characteristic odor of chloroform. The victim had received an injection of chloroform in the heart, so that the blood of the ventricle, in coagulating, would deposit on the valves and caused instantaneous death by heart failure. My discovery of the most monstrous secret of the Third Reich's medical science made my knees tremble. Not only did they kill with gas, but also with injections of chloroform into the heart. A cold sweat broke out on my forehead. Luckily I was alone. If others had been present it would have been difficult for me to conceal my excitement. I finished the dissection [...]. ${ }^{634}$

633 Ibid., 33.

634 Ibid., 37-38. 
Nyiszli mentioned nothing about his discovery in his protocol. He did not fill in the part involving the cause of death. He explained:

I was not timorous by nature and my nerves were good. [...] but now a shudder of fear ran through me. If Dr Mengele had any idea that I had discovered the secret of his injections he would send ten doctors, in the name of the political SS, to attest to my death. ${ }^{635}$

On territories ruled by the Third Reich, the art of the autopsy could be developed in a way that was not burdened by previous restrictions. There was no shortage of bodies, and though they originated from the same category as always "criminals" - that category grew to unprecedented proportions. Every representative of the "lower" races belonged there, above all Jews, Gypsies, and Slavs, but also all of the Reich's enemies, above all "Jewish Bolsheviks." Dr Johann Paul Kremer did not have to worry about "dissection material" for his research. And doctors in the Warsaw Ghetto were aware that they found themselves in a peculiar situation. As Dr Józef Stein wrote:

The abundance of human material from the 1939-1943 war years within the Warsaw ghetto, where chronic hunger was at the forefront of all matters tied to society and disease, was exceptionally suited to such research. [...] Dissection material was extremely abundant. ${ }^{636}$

The head of the Warsaw team, Dr Milejkowski, explained how work had been stopped as a result of the Grossaktion and the fact that 300,000 Jews had been sent to Treblinka; in his introduction to Choroba głodowa, he wrote:

[...] work on starvation stopped: the hospitals and laboratories were destroyed, as was most importantly - the raw material of our expert medical research, namely the human material. ${ }^{637}$

One thing that is shocking but also entirely understandable is the fact that perpetrators and victims spoke about their research in the same way: they were connected by their professional medical language (or rather jargon), with a special role played by the terms "human material" and "dissection material."

During the Nazis' twelve-year rule in Germany, dissections were performed by well trained and highly educated professionals, prominent clinicians with academic titles working at renowned research institutes, one of the most important of which - in this story - was the Kaiser Wilhelm Institute of Anthropology,

635 Ibid., 38.

636 Choroba głodowa, 22.

637 Ibid., 9. 
Human Heredity, and Eugenics in Berlin-Dahlem. As the head physician at Auschwitz, Dr Mengele cooperated with this institute; anatomical specimens from his laboratory at Crematorium I at Birkenau, including children's heads and prisoners' eyes, including those of children, were sent to the institute in Dahlem. Eyes, especially the matter of the inherited color of eyes, were of particular interest to Dr Karin Magnussen, an anthropologist at the institute and a member of the Nazi Office of Racial Policy. ${ }^{638}$

The expert nature of autopsies did not change, but their goals did. For centuries, the final conceptual horizon of research in anatomic pathology had been the discovery of the secrets behind the human being and life itself. For the Nazis, however, it was about confirming their ideological phantasms about race and racial hierarchy. It was about attaining the tools that would allow them to manipulate the human species. The goal of Nazi anthropologists was a kind of correction of nature. They had created a set of theories based on the policy of Blut und Boden (blood and soil), whose aim was to create a perfect race of people and to have those people settle in the so-called Altreich. Anthropologists were to "create a state in which the German gene pool became homogeneous and the racial and genetic qualities of the citizens matched their national identity as Germans." ${ }^{39}$ This goal could be achieved by two means: sterilization and extermination. The research on twins conducted by Dr Mengele was at the center of this great project to correct (not discover) the human being. Dr Eugen Fischer, a specialist at the Institute of Anthropology, Human Heredity, and Eugenics, claimed that research on twins was necessary to promote "positive racial hygiene," and that the results of such research would make it possible to "influence the biological basis of culture." 640

It is worth pointing out a change in the hierarchy of internal organs that appeared in the field of anatomical activity. While for Kremer, a dissection was performed in order to prepare the liver, spleen and pancreas, for Dr Mengele it was for the eyes. Mengele's assistants packed up various "specimens" acquired through dissections, including eye balls extracted from corpses which were then placed in special glass containers, and they sent them to Berlin. Anatomical

638 Gretchen E. Schafft, From Racism to Genocide: Anthropology in the Third Reich (University of Illinois Press, 2007), 172-173.

639 Ibid., 152.

640 Ibid., 156. 
specimens would then become the object of further research, but they were already treated in part as trophies. Along with his "specimens in $96 \%$ alcohol," Kremer meticulously packed bottles of vodka, razor blades, soap and shaving cream, thermometers, nail clippers, perfumes, needles, tooth powder, and darning wool, and he sent it all to his friends. ${ }^{641}$

And what happened to the heart? It is difficult to avoid the impression that it lost its privileged position; the heart was a matter usually taken care of by an orderly, who injected the appropriate dose of phenol into one of its chambers during routine treatment. The heart, the miraculous mechanism that so delighted Descartes, was turned into a mere container for poison.

\section{Between the Grotesque and the Sublime}

\section{In the Arms of Eudoxie's Corpse}

It is not only the case that the First World War devastated the world order in a political and moral sense. Mass killing on an unprecedented scale, the use of a modernized arsenal of weapons (including poisonous gases), the senseless death of hundreds of thousands of soldiers trapped in a position war, the horrible conditions in the trenches, the direct contact between the living and the dead - all of this transformed war into "slaughter" and "butchery," ${ }^{442}$ but also into a modern danse macabre. The war inspired the iconography of a new "death dance," as Michel Vovelle has claimed. These militarized danse macabres:

$[\ldots]$ even if they assume old forms, reveal the new face of brutality - a magma of corpses and mud from the trenches, the hell of artillery fire, the furious storms of bayonets, and often a new level of annihilation - poisonous gases, inconceivable and undeniable evidence that we have perfected death and stepped over a certain threshold. ${ }^{63}$

641 The package weighed $14 \mathrm{Kg}$. See entry in Kremer's journal dated 17 November 1942. Höss et al., KL Auschwitz Seen by the SS, 169.

642 On the concept of war as a machine and the method of rationalized and mechanized slaughter, see D. Pick, War Machine, The Rationalization of Slaughter in the Modern Age (New Haven; London 1993). The First World War has often been defined with the metaphor slaughter. See for example M. Janion, "Wojna i forma" (section "Ekspresjonizm: wojna jako rzeżnia") in Płacz generała. Eseje o wojnie (Warszawa 1998).

643 M. Vovelle, Śmierć w cywilizacji Zachodu. Od roku 1300 po współczesność, trans. T. Swoboda et al. (Gdańsk 2004), 688. 
The particular experience of the trenches abounded in macabre encounters with corpses. Historians and cultural anthropologists highlight this phenomenon of the "trench experience." ${ }^{44}$

From among the many sources illustrating the horror and terror (though also the trivialization) of such encounters, I have chosen an example that has a clearly different stylistic intonation. In this text, the reader will sense a certain dissonance, impropriety, an imbalance between the macabre subject matter and the way it is captured, the image's unsettling deformation, the unreconciled comic effect in collision with the broader atrocity. The result is a breakdown in the formulaic ways of perceiving macabre situations, the creation of some distance between us and those commonplace views, and as a consequence the possibility that horror can be appeased, disarmed. The source under discussion here thus has, I would say, the character of the grotesque.

I want to focus on a fragment of Henri Barbusse's Under Fire: The Story of a Squad. Eudoxie Dumail is a beautiful country girl who wanders here and there around the front. The fat and ugly private Lamuse is crazy about her. "I want her; but, you know, I shall marry her all right," Lamuse confided to his friend. "Ah, my boy, there are times when I've just got to hold myself back with a hook [...]. She's so beautiful." One evening Lamuse meets Eudoxie, "in the sunshine, this woman crowned with gold," alluring and intoxicating with "the moon-like purity of her skin $[\ldots]$ her teeth, too, glisten white in the living wound of her half-open mouth, red as her heart." The soldier tries to touch the girl, but she pulls back and cries: "Leave me alone - you disgust me!" ${ }^{445}$ Such is the exposition of an unfulfilled war romance, loaded with conflicting emotions, desires, and contempt. This love story comes to an unexpected end in a scene built on the principle of reversal: what is beautiful becomes disgusting, what arouses, causes disgust, and the dreamed-of hug turns into a horrifying kiss of death. Here is a fragment that might well be entitled "In the Arms of Eudoxie's Corpse":

"I have seen Eudoxie again," He gasps for breath, his chest wheezes, and with his eyeballs fast fixed upon a nightmare, he says, "She was putrid."

"It was the place we'd lost," Lamuse went on, "and that the Colonials took again with the bayonet ten days ago.

"First we made a hole for the sap, and I was in at it, since I was scooping more than the others I found myself in front. The others were widening and making solid behind. But

644 See "The Troglodyte World" in Paul Fussell, The Great War and Modern Memory; D. Winter, "Trench life" and "The strain of Trench Warfare," in op. cit.; Modris Eksteins, "Rites of War," in his Rites of Spring.

645 Henri Barbusse, Under Fire, 52, 54. 
behold I find a jumble of beams. I'd lit on an old trench, caved in, 'vidently; half caved in - there was some space and room. In the middle of those stumps of wood all mixed together that I was lifting away one by one from in front of me, there was something like a big sandbag in height, upright, and something on the top of it hanging down.

"And behold a plank gives way, and the queer sack falls on me, with its weight on top. I was pegged down, and the smell of a corpse filled my throat - on the top of the bundle there was a head, and it was the hair that I'd seen hanging down.

"You understand, one couldn't see very well; but I recognized the hair 'cause there isn't any other like it in the world, and then the rest of the face, all stove in and moldy, the neck pulped, and all the lot dead for a month perhaps. It was Eudoxie, I tell you.

"Yes, it was the woman I could never go near before, you know - that I only saw a long way off and couldn't ever touch, same as diamonds. She used to run about everywhere, you know. She used even to wander in the lines. One day she must have stopped a bullet, and stayed there, dead and lost, until the chance of this sap.

"You clinch the position? I was forced to hold her up with one arm as well as I could, and work with the other. She was trying to fall on me with all her weight. Old man, she wanted to kiss me, and I didn't want - it was terrible. She seemed to be saying to me: 'You want to kiss me, well then, come, come now!' She had on her - she had there, fastened on, the remains of a bunch of flowers, and they was rotten, too, and the posy stank in my nose like the corpse of some little beast.

"I had to take her in my arms, in both of them, and turn gently around so that I could put her down on the other side. The place was so narrow and pinched that as we turned, for a moment, I hugged her to my breast and couldn't help it. With all my strength, old chap, as I should have hugged her once on a time if she'd have let me.

"I've seen half an hour cleaning myself from the touch of her and the smell that she breathed on me in spite of me and in spite of herself. Ah, lucky for me that I'm as done up as a wretched cart-horse."

He turns over on his belly, clenches his fists, and slumbers, with his face buried in the ground and his dubious dream of passion and corruption. ${ }^{646}$

Barbusse presented war as a nightmare that exceeds the limits of human endurance: soldiers torn about by bullets and artillery shells, trenches and battlefields flowing with decaying bodies, congealed horror and cruelty. Under Fire is one of the classic depictions of this kind, full of bestial and monstrous behavior, highlighting - as Maria Janion wrote - the "frenetic effect of estrangement." 647 The macabre nature of war collides with the situation's clearly comical nature. At the same time, it seems that horror and comedy coexist, though after the work has been read, the impression remains that the comical element is dominant. ${ }^{648}$

646 Ibid., 128-129.

647 M. Janion, "Wojna i forma," in Janion, Płacz generała, 40.

648 Something new that the romantic theory of art brought to the history of the grotesque is the principle of the inseparable connection between beauty and ugliness, horror and 
The short scene cited above is one element of a greater whole; it is the finale to a certain plot thread. It had started within the convention of a harsh but passionate war romance. The long passage serves as a kind of punch line to this romance, and the effect of surprise, or even shock, is achieved thanks to a reversal in expectations, conventions, and tradition.

Though the reader is already used to books filled with images of brutality, in this case the author saturates his macabre scene with eroticism tied to baroque concepts of the "beautiful, alluring death." But this is a macabre eroticism $\dot{a}$ rebours that does not exude an ambiguous, dark beauty, an ecstatic union of love and death. It is trivial, disgusting, ridiculous. The necrophilic romance of the eighteenth-century tradition is turned on its head, parodied. ${ }^{649}$ Eudoxie is not the "beautiful dead woman" with a sensual and captivating charm, but rather a stinking carcass. The living lover does not want to be close to his dead beauty, he does not want to satisfy his perverse lust at her side. On the contrary - at all costs, he wants to free himself from her abominable embrace.

The passage I have entitled "In the Arms of Eudoxie's Corpse" is an example of yet another reversal. Barbusse performs a parodic inversion of the old topos of "death and the maiden."

This topos has its roots in Greek mythology (Hades abducted Persephone to his underworld kingdom), and it stems directly from the tradition of the danse macabre, though it modifies that tradition in a significant way. From the beginning, the dance of death contained an element of the erotic; death appeared alongside a young woman or a beautiful virgin. In German Renaissance art, this element underwent a particular intensification. The motif of the dance with death transformed itself into the separate subject of "death and the maiden," and along with that, there emerged the dark but exciting connection of sex with death, Eros and Thanatos. The characters in these representations no longer

comedy (V. Hugo). See W. Bolecki’s encyclopedia article “Groteska, groteskowość," in Słownik literatury polskiej XX wieku, zespoł redakcyjny: A. Brodzka et al. (Wrocław 1993), 348. Emphasizing that the essential feature of the grotesque is a balance between horror and amusement, the demonic and the ridiculous, horror and comedy, L. B. Jennings wrote: "A grotesque creation [...] always features a combination of frightening and comical features - or more strictly, [...] it causes the recipient to simultaneously react with fear and amusement. [...] Grotesque is the demonic transformed into triviality." See “Termin 'groteska”' trans. B. Fedewicz, Pamiętnik Literacki (1979), z. 4, 297, 307.

649 On seventeenth- and eighteenth-century representations of the topos of Eros and Thanatos, and on necrophilia in the eighteenth century, see P. Ariès, op. cit., 361-372. 
participate in a dance, but rather in an amorous convergence. In the Swiss painter Niklaus Manuel Deutsch's (1485-1530) Death as a Soldier Hugs a Girl (see VII), death takes on the character of a transi - a decaying corpse - lasciviously embracing a young woman, pulling her closer, lifting her dress, pushing his hand between her legs and into her groin. On a fresco in a church in Bern, the same painter represented death as a skeleton embracing a woman from behind which, with bony hands, is making his way toward her breasts. The German painter and printmaker Hans Baldung (1484-1545) (see VI), one of Albrecht Dürer's students, painted a series of works in the cycle "death and the maiden." We see, for example, death as a corpse passionately kissing the lips of a horrified woman. Her falling gown reveals her naked white body, and it is precisely this female nakedness that is at the forefront of Baldung's paintings in this cycle. But in his most famous work, entitled The Knight, the Young Girl, and Death, the girl is clothed. She is the object of a struggle between the knight, who is trying to keep the girl mounted on his galloping horse, and death, who is trying to pull her by the dress to the ground.

Franz Schubert (1797-1828) took up this classic subject in his music twice: in a song composed in 1817 entitled "Der Tod und das Mädchen," whose text is based on a poem by Matthias Claudius, and which Schubert included in his famous violin quartet from the year 1824. The song takes the form of a dialogue between a girl, who begs an approaching skeleton to go away and not touch her, and death, who promises the girl soft sleep in his arms. We find an unusual return to this motif of "death and the maiden" in a work by Edvard Munch (1863-1944), a painter of death and final matters who, since childhood, had lived in the shadow of sickness and dying. In a drawing from the year 1894 (see VIII) and a previous oil painting, we see a skeleton in an amorous embrace with a naked girl. Death is neither aggressive nor insolently lascivious, as in the paintings by Deutsch and Baldung. Here, the loving devotion is mutual; the girl is not ensnared by death, but rather succumbs to death's caresses. He hugs her around her bare waist and thrusts his bony leg between her knees. Here, love conquers death. In his Kiss of Death (1899), a girl has her hair entwined around the neck and shoulders of a skeleton, whose skull is delicately touching her cheek. Egon Schiele's canvas Death and the Maiden (1915) presents a couple embracing. On a white sheet covering stones that resemble the blurred features of human faces, a young woman in a patterned dress is kneeling and hugging death imagined as an old man in a coat. He is pressing the woman's head to his chest. This image represents a departure from the traditional motif; devoid of eroticism, it emanates melancholy tinged with a vague feeling of anxiety and the pain of separation. 
There remains only a distant echo of the twisted motif of "death and a maiden" in Barbusse and of that moralizing element which was always present in similar performances: life is short, a woman's beauty is fragile and passes quickly. But this moral seems muddied by the language through which Eudoxie's story is told. Colloquialisms, diminutives, and brutalism all serve to establish a distance between us and the monstrosity of the larger situation.

Barbusse's reversal of this topos creates an effect of grotesque degradation. It is not death, imagined traditionally as a skeleton or the decaying corpse of a man, who makes an advance on the beautiful girl, pawing at her, ensnaring her. It is exactly the opposite: the decaying corpse of a once beautiful - but now monstrous - woman advances toward the horrified soldier. And what we have here is a gender exchange and a role exchange. Lamuse's erotic dream comes true in a macabre scene of necrophilic contact that, in fact, does not happen. The thanatotic erotic is negated, stripped of the dark but fascinating aura of "unhealthy" lust. What remains is only the "dubious dream of passion and corruption." The realism of the front comes to the fore: an old trench and months of corpses, stench and disgust, because the essential "reversal" of convention has to do with the fact that the story - according to the documentary, autobiographical nature of this "story of a squad" - really happened, and that the reader is prepared for such a factual-graphic story. The dance with death is reality, and not just a representation; stinking corpses and living humans are entwined with one another in a literal sense, not just in images.

How, then, can we present the experience of the macabre of war, in order to capture its terrifying strangeness? According to Wolfgang Kayser, "the grotesque world is - and is not - our world," in which the human being has lost his bearings, where certainty turns out to be a guise. According to Lee Byron Jennings, the simultaneous excitement of horror and laughter is the manifestation of a "disarming mechanism" that serves as a source for the grotesque imagination, whose deepest intention is to tame demonic fear. ${ }^{650}$

Barbusse himself conceived the appearance of his friend's corpse in precisely these categories:

Death has bestowed a grotesque look and attitude on the man who was so comely and so tranquil. With his hair scattered over his eyes, his mustache trailing in his mouth, and his face swollen - he is laughing. One eye is widely open, the other shut, and the tongue

650 Wolfgang Johannes Kayser, The Grotesque in Art and Literature (Columbia University Press, 1981), 37; W. Kayser, "Próba określenia istoty groteskowości," trans. R. Handle, Pamiętnik Literacki 4 (1979), 276-277. 
lolls out. His arms are outstretched in the form of a cross: the hands open, the fingers separated. The right leg is straight. The left, whence flowed the hemorrhage that made him die, has been broken by a shell; it is twisted into a circle, dislocated, slack, invertebrate. A mournful irony has invested the last writhe of his agony with the appearance of a clown's antic. ${ }^{651}$

It is not the place here to cite and analyze the wide range of examples of the grotesque that serve as a means of expressing the macabre experience. We encounter them in the literature of the First World War, in memoirs, journals and letters from the front. And we encounter them in Holocaust testimonies. ${ }^{652}$

\section{The Earth Discloses Its Corpses}

Genocide in the twentieth century devoured tens of millions of victims. An unimaginable mass of human bodies: starved, tormented, battered, executed, gassed, and burned. As Paul Celan wrote in his poem "Todesfuge," victims of the Holocaust have their graves "in the clouds where it's roomy to lie." ${ }^{653}$ And what about the rest? Where are their corpses? Where are their graves? Mass crimes leave behind mass graves - pits of death dug often by the victims themselves just before their execution - and they leave behind old trenches, forts, excavations, quarries adapted to this purpose. Corpses are thrown into these pits, corpses that must be precisely and expertly arranged in order to pack in the greatest number. The pits are then filled up, and maybe a woods will grow over them. The corpses are to be covered by earth, and graves are to disappear in lush greenery. The buried cannot leave behind a single trace.

But the earth has ways of disclosing these corpses, and this real situation serves as a source for one of the fundamental metaphors describing the experience of the twentieth-century macabre. One can distinguish two variants of this "disclosure." First - when it is people who seek, find, and dig up a collective grave. And second - when it is earth itself that discloses its corpse-filled interior.

The history of mass graves and their disclosure is marked out by innocentsounding place-names which, only after their macabre contents have been discovered, take on an ominous feel: Katyń, Babi Yar, Kurapaty, Srebrenica.

651 Henri Barbusse, Under Fire, 172.

652 On the macabre grotesque in R. Auerbach's journal on the Warsaw Ghetto, see my Tekst wobec Zagłady, op. cit., 246-250. See also the section below entitled "Contemporary Antigone."

653 Paul Celan, Selections, ed. and intro. Pierre Joris (University of California Press, 2005), 47. 
Meticulously, layer by layer, the bodies are removed: stuck together with putrid dampness, or dried up and shriveled, or turned into skeletons covered in scraps of clothing. Personal articles found next to the corpses are collected. And then the arduous process of identifying the victims begins. Prosecutors, historians, and family members (if they are still alive) wait for the results. Secrets buried by the perpetrators are extracted from the earth's interior. That which was meant to fall into oblivion, into the abyss, and to disappear forever, is now discovered. The moral passion behind the search for evidence of crimes, transformed into a collective effort by groups of people acting in the name of international investigative institutions, makes it impossible for anything to remain hidden. The executioners tried to cover their tracks, the earth discloses its corpses, and their bones begin to talk. ${ }^{64}$

I will take a closer look at the second variant. The example I will use is drawn from the prose of Varlam Shalamov. I call this passage "The Earth of Kolyma Discloses its Corpses":

The logging area was just ahead, the slope of the mountain had been laid bare, and the shallow snow had been blown away by the wind. The stumps had all been rooted out; a charge of ammonal was placed under the larger ones, and the stump would fly into the air. Smaller stumps were uprooted with long bars. The smallest were simply pulled out by hand like the shrubs of dwarf cedar.

The mountain had been laid bare and transformed into a gigantic stage for a camp mystery play.

A grave, a mass prisoner grave, a stone pit stuffed full with undecaying corpses of 1938 was sliding down the side of the hill, revealing the secret of Kolyma.

In Kolyma, bodies are not given over to earth, but to stone. Stone keeps and reveals them. The permafrost keeps and reveals secrets. All of our loved ones who died in Kolyma, all those who were shot, beaten to death, sucked dry by starvation, can still be recognized even after tens of years. There were no gas furnaces in Kolyma. The corpses wait in stone, in the permafrost. [...]

In 1938 entire work gangs dug such graves, constantly drilling, exploding, deepening the enormous gray, hard, cold stone pits. [...]

654 For a guide through contemporary mass graves, see Clea Koff, The Bone Woman: A Forensic Anthropologist's Search for Truth in the Mass Graves of Rwanda, Bosnia, Croatia, and Kosovo (Random House Trade Paperbacks, 2005). Koff is a forensic anthropologist and osteologist. She was part of the team sent by the International Criminal Tribunal for Rwanda to investigate the 1994 genocide, and was part of the team in Bosnia, Croatia and Serbia and Kosovo sent by the International Criminal Tribunal for the former Yugoslavia. 
These graves, enormous stone pits, were filled to the brim with corpses. The bodies had not decayed; they were just bare skeletons over which stretched dirty, scratched skin bitten all over by lice.

The north resisted with all its strength this work of man, not accepting the corpses into its bowels. Defeated, humbled, retreating, stone promised to forget nothing, to wait and preserve its secret. The severe winters, the hot summers, the winds, the six years of rain had not wrenched the dead men from the stone. The earth opened, baring its subterranean storerooms, for they contained not only gold and lead, tungsten and uranium, but also undecaying human bodies.

These human bodies slid down the slope, perhaps attempting to arise. From a distance, from the other side of the creek, I had previously seen these moving objects that caught up against branches and stones; I had seen them through the few trees still left standing and I thought that they were logs that had not yet been hauled away.

Now the mountain was laid bare, and its secret was revealed. The grave 'opened', and the dead men slid down the stony slope. ${ }^{655}$

This entire scene contains within itself a certain majestic beauty, and in describing it one could no doubt make use of the category of grandeur, the sublime. Here, feelings and values reach a summit. The victims' pain and suffering, in an eternal deep freeze, do not vanish, but rather persist, sublimated and monumentalized. The corpses of the exterminated Gulag prisoners survived in the "white crematoria" of Kolyma and, once freed from their rocky grave, they testify to crimes committed. Which is why these corpses, having been brought to the surface, are surrounded not so much by a threat of the macabre as by an aura of the mystery of resurrection. The imagery is not so much terrifying as it is pathetic; it brings a kind of metaphysical consolation.

A key role in this imagery is played by nature. Nature is active; it reveals its terrible internal deposit and thus serves as the perpetrator in a certain act of justice. But nature faces resistance. The forces of nature are endowed with conflicting vectors, as if a struggle of sorts has taken place between supporters of evil (who work to cover the tracks of crimes) and the allies of good, who help to expose the truth, to disclose hidden bodies. Permafrost, the arctic winter freeze, serves as a protective cover, concealing mysteries. The summer sun, wind and rain scrape that cover away. One might say that they push aside the tombstone. The resurrection metaphor is absolutely appropriate here; in any case, Shalamov himself uses it. The earth breaks up and slides away; the rock is "defeated, humbled, retreating." The dead come out of their graves, human bodies slide "down the slope, perhaps attempting to arise."

655 Varlam Shalamov, Kolyma Tales, trans. John Glad (Penguin Classics, 1995), 280-282. 
Here, the topos of nature as a force that is indifferent to human suffering, the juxtaposition of beautiful nature and monstrous crimes, a topos that is repeated over and over again in accounts describing both wars and pogroms, in testimonies written by victims of both communism and Nazism, is placed in doubt. In his poem "In the City of Slaughter," which is based on events of the Kishinev pogrom of 1903 and serves as the poetic prototype of the pogrom discourse, Hayim Nahman Bialik makes use of a characteristic parallel: "The slayer slew, the blossom burst, and it was sunny weather!" 656

Forty years later, Itzhak Katzenelson cursed the heavens, which were deaf to the tragedies of Jews being deported to Treblinka from the Warsaw ghetto, and he accuses the sun of being complicit in the crime:
Wyście patrzyły tu z wysokości, a blask wasz dalej promieniał!
Wasz tani błękit się nie zachmurzył i błyszczał zły i nieszczery,
Słońce w czerwieni, jak kat okrutne, w wiecznej toczyło się ciszy. ${ }^{657}$
You were watching from above, with your continued radiance!
Your cheap azure was not clouded over and shined evil and insincere,
The sun in its redness, like a cruel executioner, moved on in eternal silence.

In poetic homage to the Gulag's "dokhodyagi" (those who were reaching the very end of their lives), Varlam Shalamov wrote: "I raise my glass to a road in the forest / To those who fall on their way / To those who can't drag themselves farther / But are forced to drag on." ${ }^{58}$ In Shalamov's prose cited above, nature is not indifferent to victims; on the contrary, it offers them justice, it reveals, it brings things into the light of day.

Here we have a scene that strikes at the heart of the traumatic experience of our times, which lend genocide an ideological motivation, which reshape murder into a product of state-run industrial death; times that reverse the poles of good and evil, that call truth lies, and lies truth. The spirit of history reveals the "pain of the twentieth century," ${ }^{59}$ the age of the "animal," the "adder," 660 in which "Everything is confused forever / And it's not clear to me / Who is beast

656 H. N. Bialik, “The City of Slaughter" in Complete Poetic Works of Hayyim Nahman Bialik, vol. 1, ed. Israel Efros (New York, 1948): 129-43.

657 Itzhak Katzenelson, Pieśń o zamordowanym zydowskim narodzie, trans., notes and intro. by Ficowski (Warszawa 1986), 52.

658 Anne Applebaum, Gulag: A History (Anchor Books, 2004), 336.

659 Czesław Miłosz, “Traktat poetycki,” in Miłosz, Wiersze wybrane (Warszawa 1980), 85.

660 "The Age" in Osip Mandelstam, The Selected Poems of Osip Mandelstam, trans. Clarence Brown, W. S. Merwin (NYRB Classics, 2004), 44. 
now, who is a man / And how long before the execution." ${ }^{661}$ In the face of totalitarian lies, the annihilation of people, and the annihilation of memory, calls that we often see in victims' testimonies for "the world to learn" about these crimes, that these crimes be "remembered," are particularly poignant. The authors of the manuscript hidden in Birkenau's human ash pits by members of the Sonderkommando, declared among other things: "We shall try to preserve all this for the world [...] show all this to the world," and requested:

Dear finder, search everywhere, in every inch of soil. Tens of documents are buried under it [...]. Great quantities of teeth are also buried here. It was we, the Kommando workers, who expressly have strewn them all over the terrain, as many as we could, so that the world should find material traces of the millions of murdered people. ${ }^{662}$

The student Dawid Graber, as he helped bury the Underground Archive of the Warsaw Ghetto in the basement of the building at Nowolipki 68 in Warsaw, placed a testament in the metal box, in which he wrote: "May this treasure [...] alarm the world that lost its way in the twentieth century. [...] [May] the world learn the entire truth." 663

But the portrait painted by Shalamov fits neither into the category of the sentimental landscape, in which nature works in harmony with characters' feelings and serves as a correlate of human emotions, nor into the category of the romantic landscape, where it is a separate, threatening, mysterious entity with a life of its own. ${ }^{664}$ Neither can one describe the earth of Kolyma, as it discloses its corpses, within the framework of the topos, deeply rooted in tradition, of the "language of nature," or the "parlance of nature." 665 Because, after all, what language does nature speak when it is part of the territory of the gulag archipelago? What hieroglyphics, signs or symbols are we to decipher? Nature speaks to us with corpses, for Kolyma's "subterranean storerooms [...] contained not only gold and lead, tungsten and uranium," but also a deposit of corpses. What message does this deathly script, extracted from the earth, carry? Is it legible at all? Does earth, as it discloses its corpses, speak? Or does it just babble? ${ }^{666}$ Or

661 Anna Akhmatova, The Complete Poems of Anna Akhmatova, ed. Roberta Reeder, trans. Judith Hemschemeyer (Zephyr Press, 2000), 388.

662 Jadwiga Bezwińska, Amidst a Nightmare of Crime, 176, 76.

663 See R. Sakowska's introduction to Archiwum Ringelbluma. Getto warszawskie lipiec 1942 - styczeń 1943, ed. R. Sakowska (Warszawa 1980), 17.

664 See A. Kowalczykowa, Pejzaż romantyczny (Kraków 1982), 25-40.

665 See M. Janion, Goraczka romantyczna (Warszawa 1975), 55-58, 254.

666 I am indebted to M. P. Markowski for suggestions regarding the reversal of the romantic topos of nature and the babble-like speech of Kolyma earth. 
maybe it allows the victims' frozen bodies to speak; maybe it allows them to give testimony that is silent and, at the same time, most meaningful.

\section{Contemporary Antigone}

In his Scienza Nuova (1723), Giambattista Vico pointed to three basic behaviors characterizing the human being:

We observe that the barbarous and civilized nations of the world, despite their great separation in space and time and their separate foundation, all share these three human customs: all have some religion, all contract solemn marriages, and all bury their dead. And in every nation, no matter how savage and crude, no rites are celebrated with more elaborate ceremonies or more sacred solemnities than those of religion, marriage and burial. Now, according to Axiom 13, whenever uniform ideas originate among peoples unknown to each other, they must have a common ground of truth. Hence, all the nations must have grasped that these three institutions are the origin of all civilizations, and hence that they must be guarded religiously. For otherwise, the world would return to a brutish state and again become wilderness. ${ }^{667}$

One can find in Vico's thinking a warning against violating the order on which the "human world" is based. In the context of contemporary discussions on human existence, on transhumanism and posthumanism, and on relations between human beings and non-humans, it is worth pondering one of the indicators - in Vico's view - of humanity and civilization, namely the burying of the dead. ${ }^{668}$ Differences in how dead bodies are treated and how burials take place are indications of differences in culture and in the way the human being is conceived. For the Italian thinker, to be a human meant above all to perform burials. As he emphasized, the word humanitas stems from the word humando burying. Thus, any departure from cultural rites regulating behavior towards the dead body and the funeral means entering into a non-human sphere, in effect savagery.

667 Giambattista Vico, New Science, trans. Dave Marsh (Penguin Classics, 2000), 120. See also S. Krzemień-Ojak, Vico (Warszawa 1971), 211, 220.

668 For the argument that the act of burying the dead is only a human custom, see following in Vico's footsteps - R. P. Harrison, The Dominion of the Death (Chicago 2003). For pointing this work out to me, I want to thank E. Domańska, who in her review emphasized the controversy surrounding Harrison's claim, pointing to research conducted on the behavior of elephants, who take care of the remains of the animals in their herd. See E. Domańska, "Nekrokracja," Konteksty 1-2 (2004), 105. 
What is of interest to me here is textual evidence describing situations involving the desecration of the human corpse and the violation of funeral rituals, and evidence describing attempts to reestablish the order of things thus disrupted. I wonder, what is a funeral in extreme situations (war, genocide)? Why did people sometimes, in great desperation, attempt to maintain ritual even when it endangered their own life? Burial practices are often interpreted as an attempt to mitigate fears of the dead, or as an act stemming from fear of the corpse's impurity. ${ }^{669}$ These explanations are well-known, which is why I skip them here. I will focus instead on the burial understood as an obligation imposed on the living and directed at those who did not survive. One cannot help but regard efforts to perform funeral rituals during the Holocaust as a final defense of humanity's foundation.

\section{Ancient Tradition}

From Greek tragedy we have the character of Antigone. Against the king's edict, but according to the will of the gods, Antigone attempts to bury the corpse of Polyneices, who had been killed in fratricidal battle at the gates of Thebes. The duty to care for her brother's body, out of obedience to the unwritten laws of the gods, led Antigone to break the law as represented by the monarch's will, which embodied the idea of the state. Antigone is able to only partially carry out the funeral ritual; she symbolically covers the body with a thin layer of earth, after which she "thrice on the dead [...] poured a lustral stream" ${ }^{670}$ consisting of wine, milk, olive oil, or honey. Such is how the chorus comments on her tragic guilt: "Your devotion and piety ring true, / But rites be paid when rites are due. / Yet is it ill to disobey / The powers who hold by might the sway."671

She, who did not agree that Polyneices ought to remain "a dishonored corpse" which "no man may bury [...] or make lament," ${ }^{672}$ was sent by Creon into the dungeon and condemned to a slow death. The prophet Tiresias revealed to the king that by prohibiting the burial of Polyneices and condemning Antigone to death, he was provoking the wrath of the gods and inflicting suffering on himself and the city. Creon assented, by freeing Antigone and by himself going "to

669 See, for example, L-V Thomas, Le Cadavre: De la biologie à l'anthropologie (Complexe, 1980); Antropologia śmierci. Myśl francuska, ed. and trans. S. Cichowicz and J. M. Godzimirski (Warszawa 1993); M. Vovelle, op. cit.

670 Sophocles, trans. F. Storr, vol. 1 (W. Heinemann, 1912), 347.

671 Ibid., 381.

672 Ibid., 317. 
a clear place, where the naked corpse lies." ${ }^{173}$ A proper burial ceremony was performed: the body was cleaned, and the remains were burned and placed in a grave. But catastrophe could not be avoided. Antigone, Creon's son Haemon, and Creon's wife Eurydice all commit suicide, and the devastated king flees the city.

The Creon of Sophocles' tragedy, by leaving Polyneices' body as "a feast / For vultures to scent and swoop upon," ${ }^{\prime 674}$ had a predecessor, namely Achilles. Having slain Hector at the gates of Troy, the "most valiant of Achaeans" declares he will take terrible revenge on Priam's dying son for the death of his beloved Patroclus: "But Hector! [...] / Thee the dogs shall rend / Dishonorably, and the fowls of the air, / But all Achaia's host shall him entomb. ${ }^{675}$

The desecration of Hector's corpse is juxtaposed to the great funeral celebrations that surrounded Patroclus' death. The Greek hero not only denies Hector a funeral, but he also torments the Trojan's corpse by promising several times that he would "give Hector dragg'd hither to be torn by dogs ${ }^{676}$ Apollo calls on the gods to end these disgraceful acts. In the end, the hero answered Priam's pleas, submitting himself to the law of a contrite heart ${ }^{677}$; he hands Hector' body over to the Trojan king, having ordered it to be cleaned and richly clothed. The Trojans would thus be able to give Hector a proper burial.

An emblematic image of the desecration of a corpse is the topos of "thrown to be eaten," according to which a dead person experiences the final humiliation: a body, which should be cared for and protected, becomes scavengers' prey or is left to decay in an open field. Such was the case in The Iliad and Antigone, and - to refer to Roman tradition - such was the case with Lucan's Pharsalia, the

673 Translator's note: Translations of Antigone vary wildly. The lines in question here are lines 1108-1109 of the play. In the Polish edition cited by Professor Leociak, they read: "Na miejsce widne, gdzie nagi trup leży," which I have translated above directly from the Polish because - with its clear reference to a corpse - it applies to the Professor's intentions. See Sofokles, Antygona, trans. K. Morawski (Wrocław 1984), 42. The Storr translation, at lines 1108-1109, reads: "Speed away / To the mountain. I too will go." See Sophocles, 399.

674 Ibid., 317.

675 Homer, The Iliad of Homer, trans. William Cowper (CreateSpace Independent Publishing Platform, 2018), 479.

676 Ibid., 486. According to Curtius, Homer reprimands Achilles for mistreating Hector's corpse and for denying it a proper burial. See Ernst Robert Curtius, European Literature and the Latin Middle Ages (Princeton University Press, 2013), 170.

677 For more on the law of a contrite heart and Homer's characters, see A. Krokiewicz, Moralność Homera i etyka Hezjoda (Warszawa 1959) (for material on The Iliad, see pp. 97-117). 
unfinished epic poem about the civil war between Caesar and Pompey. The Battle of Pharsalus in 48 BCE ended in Pompey's defeat. Victorious Caesar looked out over the battlefield - "He fixes his gaze on rivers racing with blood, bodies in piles high as the tops of the highest hills" 678 - and he denies Pompey's fallen soldiers a burial, leaving them instead as prey for wild animals. Lucan scrupulously lists the animals that descend upon the macabre feast: wolves, Iions, she-bears, dogs, vultures. He wrote: "Often, from the skies above, gouts of blood or rotten flesh rained down on the victor's upturned face and impious standards, as birds, their weary talons strengthless, let some limbs drop."679

Biblical tradition also regards denying the dead a proper burial as a terrible misfortune. In Psalms 79:2, we come upon the topos of "thrown to be eaten": "The dead bodies of thy servants have they given to be meat unto the fowls of the heaven, the flesh of thy saints unto the beasts of the earth." The prophet Ahijah the Shilonite, foretelling the destruction of Jeroboam's dynasty, prophesized (1 Kings 14:11): "Dogs will eat those belonging to Jeroboam who die in the city, and the birds will feed on those who die in the country. The Lord has spoken!" 680

The failure to carry out a proper funeral ceremony prevents the deceased from successfully completing the ritual of transition; it blocks the path to the land of the dead. Unburied, they wander along the fringes, with no chance of getting to the other side, without hope of peace. Patroclus, appearing to Achilles in a dream, begs him to hold his funeral, complaining that - unburied - he cannot enter the land of the dead. Which is why Hector pleaded with Achilles: "By thy own life [...] / Send home my body, grant me burial rites / Among the daughters and the sons of Troy".681

And which is why, in an encounter with Odysseus in Hades, the spirit of Elpenor begs: "[...] please my lord, remember me. / Do not go on and leave me here unburied, / abandoned, without tears and lamentation." ${ }^{682}$ We see the

678 Lucan, Pharsalia, trans. and intro. Jane Wilson Joyce (Cornell University Press, 1993), 193.

679 Ibid., 194.

680 As yet another example of this topos, one can refer to what is perhaps Shakespeare's most bloody tragedy. Titus' son, Lucius, engaged in a campaign of revenge against Tamora, Queen of the Goths, refuses to allow a funeral only for her: "As for that ravenous tiger, Tamora, / No funeral rite, nor man in mourning weed, / No mournful bell shall ring her burial, / But throw her forth to beasts and birds to prey." Shakespeare, Titus Andronicus, ed. Jonathan Bate (The Arden Shakespeare; 2 edition, 2018), 318.

681 Homer, The Iliad of Homer, 479.

682 Homer, The Odyssey, trans. Emily Wilson (Norton, 2017), 281. 
gloomy image of the spirits of unburied people, milling around in the Vestibulum of Hades and unable to cross over to the other bank of the river Styx, in Book VI of Virgil's Aeneid. The Sibyl, priestess and seeress, accompanying Aeneas on his journey to the underworld, explains:

And the great rout you see is helpless, still not buried. That ferryman there is Charon. Those borne by the stream have found their graves. And no spirits may be conveyed across the horrendous banks and hoarse, roaring flood until their bones are buried, and they rest in peace. ${ }^{683}$

\section{The Inhumanity of the Twentieth Century}

In his journal on the First World War, Paul Cazin referred to the Homeric tradition. The view of the corpses of anonymous soldiers scattered among the trenches brought to mind the wandering Ulysses. But this is a Ulysses of the twentieth century, who never finds the road home, does not return to his relatives, and does not rest in a grave. His rotting body sinks into the mud of the battlefield, and though he goes down as a legend, he disappears from living human memory. Here is a passage from Cazin's journal under the date 22 March 1915:

Ulysses is the great lost one. The gods turned him into the most lost of all people. Is he not also one of those unnamed dead who are scattered so close between the stumps and whose bones bleach in the rain? Is he not one of those who dry out on the wires, effigies in rags, hopping around in this macabre game? Is he not one of those unknown ones, tossed here and there, swept up by the waves of battle, whom artillery shells tear to bits such that not even one piece is left whole? Why did no devoted spirit place him into the hands of friends who would provide him with the sacred privilege of a funeral? Why was no one there to hear what he had to confess before death? Blessed Geniuses of the grave could not protect him under their wings. Harpies savaged him. And today, as in ancient times, the Lost One crossed over into fairy tale, into legend. At the same time, as his body rots, his image falls apart in old memories and imperfect imaginations. ${ }^{684}$

Two motifs are intertwined with one another in many of the testimonies describing First World War experiences: unburied corpses and rotting bodies left on the battlefield. Let me mention just three representative examples. Ernst Jünger: "All around were dozens more, rotted, dried, stiffened to mummies, frozen in an eerie dance of death. The French must have spent months in the proximity of their fallen comrades, without burying them.” ${ }^{685}$ Zofia Nałkowska:

683 Virgil, The Aeneid, trans. Robert Fagles (Penguin Classics, 2008), 193.

684 P. Cazin, Humanista na wojnie, trans. and afterword by K. Eberhardt (Warszawa 1957), 46.

685 Jünger, Storm of Steel, 25. 
Away from the road, in a grassy area, lay a corpse - not buried, long forgotten. [...] Its hands, spread out as if on a cross, were turned palms upward, the skin there dried and cracked. Large, white worms with black heads were crawling around in the cracks, eating rotten human flesh, diligently pulling it from the bones. ${ }^{686}$

Andrzej Strug: "A heavy, nauseous-sweet odor formed a wall around the silent homes (...), with every step one stumbled upon unburied corpses, where a large number of bodies, contained in choleric hovels, were decaying, crowded together." ${ }^{387}$

In a world that had been pulled into a vortex of war, people not only kill each other but also violate the majesty of death. Significantly, in the trenches and on the battlefields of the First World War, death itself was, in a certain sense, taken for granted, and thus suffered degradation. The senseless slaughter of hundreds of thousands of troops, corpses littering the earth carved up by bullets, the dead in the trenches alongside the living, the inability to assure victims a proper burial - all of this caused the world to begin slipping toward "inhumanity."

When the world betrays the eternal rituals of death, it returns - as Vico wrote "to a brutish state and again become[s] wilderness." The wilderness is a state of regression, and within its sphere basic human reactions are not in force. The final and most spectacular blow to the basic principles on which interpersonal communion has been founded since the dawn of time came with the Second World War, which opened the gates to modern, industrialized and bureaucratized genocide. But here, let us set aside the moral questions tied to the twentieth-century wars and the Holocaust, and to the paroxysm of genocide in the second half of the century, ${ }^{688}$ and focus instead just on the matter of the treatment of corpses. From this perspective, the "inhumanity" of the war experience manifests itself not only in aggression directed against the human being, but also in the fact that death is stripped of its majesty, and the corpse of its dignity. The norm became what had been the violation of norms: degradation, objectification, desecration, and finally the utilization of the human body.

686 Nałkowska, op. cit., 217.

687 A. Strug, "Klucz przepaści," in Strug, Klucz otchłani (Warszawa 1957), 28-29.

688 For moral reflections on the wars and genocide in the twentieth century, see J. Glover, Humanity. A Moral History of the Twentieth Century (London 2001). For a panoramic view of war and genocide in the twentieth century, see M. Shaw, War \& Genocide. Organized Killing in Modern Society (Cambridge; Malden 2003); and The Specter of Genocide. Mass Murder in Historical Perspective, ed. R. Gellately and B. Kiernan (New York 2003). 


\section{“A City Engulfed by Plague"}

Let us move from the battlefields to the Warsaw Ghetto - to the "dead city",689 to the city in which death walked "in broad daylight through the streets," ${ }^{\prime \prime 90}$ and on whose sidewalks and at whose gates lay corpses that were so numerous that "they have completely stopped causing any feeling of fear in the pedestrian, any horror or indeed any interest or sympathy." ${ }^{691}$ The ordinary nature of dying, the commingling of the living and the dead, the stumbling over human corpses in the streets, wagons moving through the streets loaded with corpses, and the mass graves into which bodies were thrown - all of this reminds us of the scenery, known from the old chronicles, of a city engulfed by plague. In such a city, death - in a sense - cuts itself loose, breaks away from its designated place. During a plague, the city could thus constitute an anthropological model for the ghetto. ${ }^{62}$

The death cart loaded with corpses is one of the emblems of the world engulfed by plague. For example, the chronicle of the plague in Geneva in 1530 describes carts loaded with dead bodies ${ }^{693}$; Daniel Defoe presented the image of such a cart drawn by horses through the plague-ridden streets of London in 1666; $;^{694}$ and in a chronicle of the plague raging in Kraków in 1707 we read about corpses being carried "out of the city on ladder-carts day and night." ${ }^{95}$ In a sense, death carts

689 A. Lewin used this description in "Dziennik z getta warszawskiego," trans. from the Yiddish by A. Rutkowski, Biuletyn ŻIH 23 (1957), 72.

690 These words are taken from the diary of R. Auerbach, op. cit.

691 Such is how S. Ernest described the ghetto from his position on the Aryan side of the wall, in O wojnie wielkich Niemiec z Żydami Warszawy 1939-1943, ed. M. Młodkowska (Warszawa 2003), 81.

692 In his sketch on L. Landau’s Kronika lat wojny i okupacji, G. Herling-Grudziński also situated the figure of the plague in this context, citing as a model Daniel Defoe's A Journal of the Plague Year, which (consciously or not) is referenced also in Ringelblum's Notes from the Warsaw Ghetto ("Kronikarz piekła," Kultura 11 (1962), 6). For more on comparisons between the ghetto and a city engulfed by plague, see my Tekst wobec Zagłady. op. cit., 217-226; see also B. Engelking, "Czas przestał dla mnie istnieć...": analiza doświadczenia czasu w sytuacji ostatecznej (Warszawa 1996), 160-177. On the anthropological and mythological meanings of the plague, see M. Sznajderman, Zaraza. Mitologia dżumy, cholery i AIDS (Warszawa 1994).

693 See J. Ruffié, J. Ch. Sournia, Historia epidemii. Od dżumy do AIDS, trans. B. A. Matusiak (Warszawa 1996), 97.

694 D. Defoe, op. cit., 60-62.

695 Quote from J. Kracik, Pokonać czarna śmierć. Staropolskie postawy wobec zarazy (Kraków 1991), 109. 
moved on the streets of the Warsaw ghetto in two dimensions. In a real one - as a material element of the ghetto's fabric, one of the hallmarks of the ghetto landscape; and in a mythologized one that co-creates the scenery of the "dead city," a city engulfed by plague.

Images of the macabre carts with corpses evoke an excess, an abundance, a rich harvest of death. Emanuel Ringelblum also described the carts loaded with corpses for transport: "The horse-carts are loaded with corpses, both inside and on top. Two or three boxes full of the dead are piled up." ${ }^{696}$ And Marian Berland: "The cart is fully loaded, the springs are bending, the horse can hardly pull." ${ }^{697}$ In another text we read about the macabre image of carts loaded to the brim, from which blood is dripping: "Black two-story carts moved through the streets carrying boxes with corpses, sometimes the corpses lay on top. Often blood trickled from the carts." ${ }^{\prime 698}$ The story of a thirteen-year-old boy illustrates the horror that came with this deadly harvest and continuous contact with an unimaginable mass of corpses. This accumulation exceeded all boundaries; it became unbearable, giving the ghetto an apocalyptic dimension:

He was a helper on a cart-caravan, who collected bodies of Jews on the streets and apartments and took them to the collective graves at the Jewish cemetery near Gęsia [...]. He tells horrifying stories. Always corpses, dead bodies, whole mountains of corpses. ${ }^{699}$

Pieter Bruegel the Elder's painting The Triumph of Death serves as a metaphorical illustration of the experiences of the little gravedigger from the Warsaw Ghetto. Borrowing from the tradition of the danse macabre, Bruegel intensifies the macabre imagery by showing the staggering exuberance of death and its uncurbed power. Bruegel's nightmarish vision is marked by chaos; the world and people are consumed by a deadly whirlpool. Like the little gravedigger's story, Bruegel's painting depicts "dead bodies, whole mountains of corpses." From among all the various ways to die, they both draw attention to "sudden" death, one that is not the product of war or execution; the corpses in Bruegel's painting are most likely victims of the plague, and the huge cart filled with human skulls (being pulled by a bony nag ridden by a corpse) resembles the carts used during

696 Emanuel Ringelblum, Polish-Jewish Relations During the Second World War, trans. Dafna Allon, Danuta Dabrowska, Dana Keren (Northwestern University Press, 1974), 88.

697 M. Berland, Dni dlugie jak wieki (Warszawa 1992), 24.

698 A. and B. Berman, "Zagłada getta w Warszawie. (Szkic kronikarski)," Biuletyn ŻIH 45-46 (1963), 153.

699 M. Berland, op. cit., 24, 348. 
a plague. Bruegel's The Triumph of Death is an excellent example of the iconographic imagery of the plague. ${ }^{700}$

Carts loaded with corpses are also a sign of how the mysteries of death, which have always been expressed through funeral rites, are laid bare, exposed, and violated. Bodies change into products, becoming an object of transport, like things. In the ghetto, the traditional attitudes of respect and fear of the corpse are turned on their heads, which is reflected in the very way the reality of the ghetto was talked about. Here are a chain of comparisons drawn from various sources: "a mountain of corpses, men and woman of various ages, lying like a pile of junk set aside for ZOM [Zarząd Oczyszczania Miasta, City Sanitation Board] vehicles"701; "next to the garbage bin, in a sea of blood, lie women, girls and children. An abandoned pile of old and useless rags"702; "children's corpses lie in a large stack, from one-day-olds to more or less three-year-olds. It looks like a large pile of broken dolls." 703

\section{The Cemetery That Is Not a Cemetery}

In order for us to fully realize the meaning of what happened at the Jewish cemetery on Okopowa Street in the Warsaw ghetto, we must take a close look at the foundations of the Jewish cemetery ritual, deeply rooted in Judaism, and at one of its main principles - faith in the resurrection. ${ }^{704}$ This principle is at the foundation of customs associated with the treatment of a body after death. The funeral is supposed to take place as soon as possible, preferably within 24 hours after the death; a delayed burial is forbidden. Bodies are carefully cleaned, anointed, and dressed in a shroud before they are placed directly in consecrated ground, where they are covered with a board in such a way that soil does not fall on the body, which would be a sign of neglect of the deceased. Burial in a casket

700 See J. Delumeau, op. cit., 146-147.

701 M. Berland, op. cit., 85.

702 L. Najberg, Ostatni powstańcy getta (Warszawa 1993), 91.

703 F. Blättler [in fact, F. Mawick], Warszawa 1942. Zapiski szofera szwajcarskiej misji lekarskiej, trans. K. Bartos, ed. T. Szarota (Warszawa 1982), 64.

704 The doctrine of the resurrection, which was an object of debate between the Pharisees, who recognized it, and the Sadducees, who rejected it, is treated as a dogma of faith. The Sanhedrin states that "since a person repudiated belief in the Resurrection of the dead, he will have no share in the Resurrection." See Abraham Cohen, Everyman's Talmud: The Major Teachings of the Rabbinic Sages (Schocken, 1995), 357. See the full chapter on "Resurrection of the Dead", pp. 357-363. 
is possible. Graves in the cemetery are to be arranged according to a strict hierarchy: according to biblical rules, "the just" ought not be laid in a "grave with the wicked" (see Isaiah 53:9); criminals, apostates, and suicide victims were thus to be buried far from other graves. In some cemeteries, women and men are buried in separate rows, except for married couples, as are little children and women who died in childbirth. This hierarchical order is supposed to be part of the preparations for the moment of resurrection. When the dead rise from the grave, their gathering will be marked by order. Descendants of the priestly families are not allowed to enter the cemetery out of a fear of defiling the dead through their proximity. Thus, priests stay close to the gates without going into the depths of the cemetery, as the family visits the graves. A group of volunteers, the chevra kadisha, effectively a burial society, prepares the body for burial. These volunteers care particularly for the corpses of those who were alone, poor, abandoned, and they treat their work as a manifestation of the highest degree of compassion. The dead are afforded respect, since they carry within themselves the image of God (Genesis 1:26), which is why they are subject to proper rituals and why cremation is prohibited. They are supposed to rest in peace and in an undisturbed state (hence, exhumation is prohibited) until the moment of resurrection, when the vision of the prophet Ezekiel would be fulfilled, when the valley of bones would come alive again with body and spirit (Ezekiel 37:1-14). For Jews, the cemetery is one of the most important of all religious sites, as evidenced by the Hebraic terms given to them, including "house of life," "house of eternity," "holy place," "good place."705

As early as the September siege of Warsaw, the Jewish cemetery on Okopowa became an object of desecration. Nachum Remba, an employee of the Gmina Wyznaniowa Żydowska (Jewish Religious Community) in Warsaw and later a Judenrat official, having made his way to the cemetery under German fire to attend the funerals of Jewish dead, came upon hundreds of bodies that had been plundered for their "valuables, gold and money" and then buried in "mass collective graves." It was not known who had robbed the corpses: City Sanitation Board employees, the funeral parlors, or gravediggers. Everyone was shifting

705 For religious, cultural and administrative-legal reflections on the Jewish cemetery, see L. Hordo, "Przestrzeń żydowskiego cmentarza" in Smierć, przestrzeń, czas, tożsamość w Europie Srodkowej okolo 1900, eds. K. Grodziska, J. Purchła (Kraków 2002), 195-208. On Jewish funeral customs, see A. Unterman, Żydzi. Wiara $i \dot{z} y c i e$, trans. J. Zabierowski (Łódź 1989), 199-201. 
the blame to "common robbers" or "international funeral hyenas." 1940, the trees in the cemetery were cut down, the benches were stolen, and marble slabs were broken up and taken away. Ringelblum noted: "The Jewish cemetery is a depressing sight $[\ldots]$ as if it were naked and poor." ${ }^{\prime 07}$ But under the date 11 August 1940, Adam Czerniaków made a significant entry in his diary: "Reflections on the cemetery. Will they give us peace here?" 088 Very quickly it turned out that even this "house of eternity" and "holy place" would not be a place of rest for Jews.

Near the gate there was the notorious graveyard shed, the sight of which caused shivers, and whose reputation reached not just Jews in the ghetto but also Germans who came to view the cemetery. Ringelblum called these people "excursionists," groups of both soldiers and civilians. While some limited themselves to making malignant comments about the cemetery, "others take various photographs. Particular interest is caused by the shed, in which dozens of dead people can be seen laying every day." ${ }^{709}$ The bodies filling this mortuary, lying around in their final disgrace, were viewed as a kind of exciting peculiarity, which represented yet another act of humiliation. "They lie in piles, waiting for their final rites, exposed to the camera lenses of German soldiers." 110 The result of one of these photographic excursions is a series of photos taken by the Wehrmacht Sergeant Wilhelm Jöst, who - on his birthday on 19 September 1941 - took a daytrip to the ghetto, during which he took along his Rolleiflex camera and a couple dozen rolls of film. He visited the cemetery and took several photos showing the inside of the shed filled with a disorganized arrangement of corpses, carts loaded with corpses, and a pit into which gravediggers were throwing naked bodies. ${ }^{711}$ In the spring of 1942, German officials prohibited Germans from entering the cemetery based, they said, on sanitation concerns, but Ringelblum had a different opinion. He claimed that the macabre sight of maltreated corpses had a terrible influence on German morale. But the prohibition did not stop visitors from coming:

706 "Wspomnienia pracownika Gminy i Judenratu w Warszawie (wrzesień-październik 1939)," Biuletyn ŻIH 93, no. 2 (1976), 99-101. This document is located in Part II of the Archiwum Ringelbluma. Nachum Remba's authorship is hypothetical.

707 Ringelblum, Kronika getta warszawskiego, 114.

708 Adama Czerniakowa dziennik getta warszawskiego 6 IX 1939 - 23 VII 1942, 139.

709 Ringelblum, Kronika getta warszawskiego, 288 (entry dated 20 May 1941).

710 S. Ernest, op. cit., 106.

711 G. Schwarberg, In the Ghetto of Warsaw. Heinrich Jöst's Photographs (Göttingen 2001). 
At the Jewish cemetery there are more and more German trips even though there is a big sign "The Germans not allowed to visit the cemetery." The reason is obvious: the infamous shed with the bodies [of those who died] of hunger is a terrible indictment against the Germans and their [politics of] starving of the Jewish people."712

Death carts and wagons moved from various corners of the ghetto toward the cemetery, where a huge pit was dug to be filled with a mass of bodies. In Rachel Auerbach's diary, the cemetery stretching along Okopowa Street, from its gate at Gęsia Street, was an ocean of corpses:

Wagons full of their deadly cargo are flooding in from everywhere. [...] Black wagons and carts move briskly along every road and alleyway toward Gęsia Street. [...] Like streams, flowing into a great river, which swallows everything. ${ }^{713}$

Marek Edelman also painted a picture of a cemetery flooded with corpses:

Hundreds were dying at a given instance. The grave-diggers were unable to dig fast enough. Although hundreds of corpses were being put into every grave, hundreds more had to lie around for several days, filling the graveyard with a sickening, sweetish odour. $^{714}$

The cemetery was no longer a cemetery. Funerals were not performed. The principles of how to handle the dead, sanctified by religion and custom, were being trampled on. The funeral ritual succumbed to its final degradation. In his description of ghetto "burials," Leyb Goldin got to the heart of the matter - here, death itself was demeaned, brutally deprived of the aura bestowed upon it by culture:

Like dung - that's how they drop the dead into the grave. Turned the box over and flipped them in. The bystanders get such a livid expression of disgust on their faces, as if death were taking revenge for the aura of secrecy. For the various irrelevant, unnecessary things that had been tied on to him, now, out of spite, he let down his pants and here! Look at me, kiss my ass. ${ }^{715}$

712 See the Warsaw Jewish Historical Institute web page: http://www.jhi.pl/en/blog/201305-25-emanuel-ringelblum-diary (accessed 9 April 2018). Entry dated 25 May 1942. See also the entry dated 8 May 1942.

713 R. Auerbach, Pamiętnik z getta, op. cit, k. 39.

714 Marek Edelman, The Ghetto Fights (American Representation of the General Jewish Workers' Union of Poland, 1946), 7.

715 Leyb Goldin, "Chronicle of a Single Day," in David G. Roskies, ed., The Literature of Destruction. Jewish Responses to Catastrophe (Philadelphia 1988), 424-434. See also: https://training.ehri-project.eu/c04-leyb-goldin-description-single-day-ghetto (accessed 9 April 2018) 


\section{Rescuing Funeral Rituals}

During the Ghetto's existence, "normal" funerals were sometimes performed in the Jewish cemetery on Okopowa. The Gazeta Żydowska $a^{716}$ published "traditional" obituaries, mourners walked behind caskets, words were spoken at gravesites. The funeral of the attorney Leon Berenson, the famous defender of members of the PPS after the Revolution of 1905 and defender of at least two of those accused in the Brest trials of $1931-1932,{ }^{717}$ had just a ceremonial aspect. The event took place - as Czerniaków noted - on 24 April 1941 at three in the afternoon. We do not know if the head of the Warsaw Judenrat spoke at the ceremony, but he certainly delivered eulogies on 23 November 1941 over the coffin of the educational activist Cecylia Oderfeldowa; on 22 February 1942 during the funeral of the attorney and member of the Jewish police Maksymilian Schoenbach; and on 17 June 1942 at the funeral of Michał Król, a PPS member, Siberia exile, and secretary general of the Judenrat. ${ }^{718}$ The cemetery remained within the borders of the ghetto until 21 December 1941, after which - along with the stadium "Skra," where a mass grave had been dug - it was definitively cut off from the area of the closed Jewish quarter. Thereafter, a special pass was required to enter the cemetery.

The pompa funebris was reserved for the elite, while common people - if they still had the means and power to oppose the advancing degradation - tried to save at least the appearance of a normal funeral. In passages from an anonymous diary we read that, based on requests by relatives "who are still able to pay a couple złoty for the body to be cleaned and placed in an individual grave," the gravediggers were able to find the bodies of particular dead people in the pile and bury them individually. ${ }^{719}$ Janina Bauman, who worked on the "Toporol" campaign to cultivate beets in a distant corner of the cemetery, noticed:

716 Gazeta Żydowska serves as an example of the "prasa gadzinowa" (often translated as "reptile press"), run in the interest of the German occupiers. It was one of the open Polish-language Jewish periodicals intended for readers in all ghettos in the Generalgouvernement, but above all in the Warsaw ghetto. It was published in Kraków twice a week (Tuesday and Friday), and for a period of time - from 23 July 1940 to July 1942 - three times a week.

717 Translator's note: "PPS" refers to the Polska Partia Socjalistyczna (Polish Socialist Party), of which Józef Piłsudski was the leader. The Brest trials were trials of the Polish government's political opponents in the "Centrolew" coalition. As a result of these trials, several prominent politicians spent up to 3 years in prison.

718 See Adama Czerniakowa dziennik getta warszawskiego 6 IX 1939 - 23 VII 1942, 172, 230, 255, 290.

719 See [author unknown], Wrażenia z pokoika śmierci, AŻIH, Ring 1,1030. 
[...] a nightmarish funeral procession [...]. Two people from Pinkert [burial society] were pulling a ladder cart, filled to the brim with corpses [...]. An old, bearded Jew, probably a rabbi, was walking after the cart much too quickly for his age, wailing and lamenting as if without great interest. ${ }^{720}$

In the spring of 1942 a group of social and religious activists set up an association called "Haławajat Hamet" - that is, Care for the Corpses of the Poor. They sent a memorial to the head of the Warsaw Judenrat, Adam Czerniaków, sounding the alarm about the increasing number of instances in which corpses were being profaned. In this text we find reference to one of the concepts that is key to my considerations here: what was happening to dead bodies in the ghetto "is dulling the sense of humanity in people." In the memorial we read that, within a short period of time, "the basic ethical principles and traditions in relation to the dead Jew have been broken [...]. With pain in their hearts, the broad Jewish masses [...] watch as corpses are treated shamelessly." The authors proposed that immediate action be taken, which was to be based above all on helping the poor arrange and pay for the formalities of a funeral, and on assuring that the dead were immediately removed from public spaces to the cemetery. ${ }^{721}$

In his diary under the date 25 June 1942, Jechiel Górny, writing in Yiddish, described the work being done by a certain porter and a woman junk peddler taking care of dead bodies that had been abandoned on the sidewalks and at building gates.

I had not been in Ostrowska Street for a few weeks, I had almost forgotten about it: at almost every gate - dead bodies, naked, barely covered with a newspaper. In Ostrowska there are so-called sztuby; for a small fee, beggars spend the night there [...]. In dirty, gloomy basements without windows, they lie in rows on moist, stone floors [...]. The owners wait for someone to die, and only then does the "hotel" business pay, they pull the rags off the dead body, for which you can still get a few złoty [...]. The naked body is taken to the street. Two people clean and prepare the dead body, a porter called "Blind Eli" and a junk peddler called "Fat Woman." Both collect small donations from people - the man on Smocza, and the woman on Lubecki. After an hour, a black cart takes the dead to the cemetery. I want to emphasize, these people are performing this sacred work only out of religious obligation. The porter and the fat peddler are basically honest people, and they often pitch in a few groszy from their own pockets for the funerals of strangers. $^{722}$

720 J. Bauman, Zima o poranku. Opowieść dziewczynki $z$ warszawskiego getta (Poznań 1999), 76.

721 See AŻIH, Ring II, 119.

722 Quote from R. Sakowska, Ludzie z dzielnicy zamkniętej. Z dziejów Żydów w Warszawie w latach okupacji hitlerowskiej: październik 1939 - marzec 1943, second, updated and expanded edition (Warszawa 1993), 136-137. 


\section{Rachel-Antigone}

Two documents were saved from the Warsaw ghetto in which the cemetery shed serves as the object of long and insightful description. Both of them are fragments of diaries preserved in Emanuel Ringelblum's Underground Archive of the Warsaw Ghetto, and both of them contain the motif of the search for corpses in the cemetery. We do not know the name of the author of one of them, which is made up of eight cards of hand-written Yiddish with entries dated 1 and 2 June $1941 .{ }^{723}$ The author reports on the funeral held for one Chmielnicki, who had died of hunger, and on the search for the body of his son, who had been brought out unconscious from a labor camp and who died a few days before the death of his father. The author's search in the shed, serving as a morgue, comes up with nothing. The second document is made up of fragments from Rachel Auerbach's diary, sixty-four cards with Polish handwriting, with entries dated from 4 August 1941 to 26 July 1942.724 Auerbach - a journalist, translator and writer who published in both Polish and Yiddish - was associated with the interwar Jewish press and the influential Polish-Jewish daily Chwila, published in Lwów. In the ghetto she ran a soup kitchen for literati at 40 Leszno Street while cooperating with the Ringelblum Archive. From that group surrounding the Archive, only she and Hersz Wasser survived. In 1950 Auerbach left for Israel, where she worked on the creation of Yad Vashem in 1953. The passage from her diary which is of greatest interest to me can be found in the long entry dated 20 September 1941, which involves the search for the body of one Braxmeier, a Czech Jew and athlete who had often frequented Auerbach's ghetto soup kitchen. Despite her personal attention, Braxmeier died of starvation. Her long diary entry is a kind of report on the search for Braxmeier's body in and around the cemetery shed. Auerbach's motivation was to save his corpse from an anonymous burial in a mass grave.

The authors of the above-mentioned diaries were witnesses to the extreme debasement and desecration of the human body. The scene at the cemetery exceeded the boundaries of what had previously been understood as the macabre; it broke the framework of the infernal nightmare; it outstripped all previous images of what was horrific. In that scene there was a collision of the living with the dead that had not been domesticated by any kind of cultural rites. The inexpressible borders of the death experience, their ambivalence, reveal

\section{See the above-cited Wrażenia z pokoika śmierci.}

724 See R. Auerbach, Dziennik [entries dated: 4 August 1941 - 26 July 1942], Ring I, 641, Ring I, 654. 
themselves with full force: simultaneous horror and fascination. The author of the anonymous account did not shy away from describing extreme situations, though this text fits - so to speak - into the category of a traditional discourse, with the conventions of a naturalistic description. Rachel Auerbach, on the other hand, went much further and in so doing created something quite new. She expressed the horror, strangeness, and ambivalence of that limit experience in the form of the macabre grotesque. ${ }^{725}$ Through her pen, terribly deformed and decomposing human corpses, scattered and tangled in repulsive poses, trigger a spasm of terror, though they are at the same time comical, the object of laughter. But this is not the liberating laughter of Mikhail Bakhtin's carnivalesque, or a "blasphemous devilish cackle," or the mocking, satanic laughter that "opens the abyss of hell." 726

Rachel Auerbach consciously accepted the role of a contemporary Antigone. ${ }^{727}$ News of Braxmeier's death, a lonely but quiet death ("as if he died in his sleep"), was for Auerbach a "real blow," even though she was already accustomed to so much death. She decided to distinguish this death from all the others, to rescue its individuality, its uniqueness. She wrote: "I took sad consolation in providing him a funeral, in arranging for him a luxurious thing: his own personal grave" (k. 25). Rachel-Antigone wanted to bury Braxmeier's body with dignity, contrary to the unwritten laws in the ghetto, during - as she put it herself - "death's busy season" (k. 33). But she did not break any state prohibition; she did not come out against the raison détat; she did not place herself in conflict with any kind of law maker. She opposed the "inhumanity" that was striking at the majesty of death; she tried to break down the barriers put up by apathy, bewilderment, and acquiescence to "inhumanity."

Rachel-Antigone began her search for the body in a stack of naked and anonymous corpses, and in the shed it is precisely that nakedness of the piled-up

725 For more on the image of corpses in records from the Warsaw Ghetto, see my book Tekst wobec Zaglady, op. cit., 215-250, where I develop the concept of the macabre grotesque applied by R. Auerbach in her cemetery description.

726 "Blasphemous devilish cackle" is a phrase used by Łotman and Uspienski, quoted in M. Sznajderman, Zaraza, op. cit., 58. W. Kayser wrote about grotesque laughter: "Laughter originates on the comic and caricatural fringe of the grotesque. $[\ldots]$ it takes on characteristics of the mocking, cynical, and ultimately satanic laughter [...]. [Is it] the kind of laugher that is an involuntary response to situations which cannot be handled in any other way? The laughter which [...] sounds more horrible than the most terrible curses?" (Kayser, op. cit., 187).

727 In a conversation with me, Ewa Domańska suggested this interpretive trope. 
bodies that strikes her: "[...] nakedness [...] shimmering with various pinkyellow tones, nakedness" (k. 33). The motif of nakedness returns often, not just in descriptions of the cemetery shed. The naked bodies of victims awaiting execution, standing in line to the death pit, or crossing the threshold of a gas chamber - nakedness is one of the most expressive emblems of the Holocaust, as evidenced by a wide range of source material, ${ }^{728}$ including accounts written by eye-witnesses and survivors, as well as photographs, among which are clandestine photos taken by members of the Sonderkommando at Birkenau. They show naked women moving toward the gas chamber, and they show naked, gassed corpses burning on a pile outside of the crematorium, which in the summer of 1944 was overflowing. Having victims undress to a point of nakedness was not just a matter of practicality, a desire to make use of the clothes taken from the murdered. In the hungry ghetto, still-alive paupers undressed the alreadydead paupers in order to sell the clothing off the dead body. But the Germans organizing mass murder had their victims completely undress not for practical reasons, but for metaphysical reasons. Crowds of naked Jews walking to their deaths resembled images of the Final Judgment, the iconographic representation of which had shaped the European imagination for centuries. Here, the condemned were receiving their just punishment and were being thrown into the Abyss. ${ }^{729}$ But in the end, piles of naked bodies were in fact testimony to extreme shamelessness and the desecration of the dead.

Beyond nakedness, the cemetery shed forced Rachel-Antigone to confront yet another traumatic reality, namely the animality of death. Ringelblum

728 See, for example, Bezwińska, Amidst a Nightmare of Crime.

729 On the refined scenario of the mass murder of Jews, which can be interpreted as a parody of the Final Judgment, and in the context of the nakedness of the victims, see S. Lem, according to whom the spectacle of naked bodies, arranged by the Nazis, can be interpreted in terms of the genocidal aesthetics of kitsch. See S. Lem, Prowokacja (Kraków, 1984), 27-28. Pawel Spiewak has pointed to the Third Reich's central project of self-redemption, whose mediator and perpetrator was Der Führer himself, "who regarded himself as the inalienable, earthly judge at the Final Judgment who would decide on the immortality and the destruction of each and every human being." See "Szoah, drugi upadek," Więź 7-8 (1986), 9-10. See also G. Steiner, "Sezon w piekle," in Steiner, W zamku Sinobrodego (Gdańsk 1993). It is also worth pointing out the observations of J. Mackiewicz, who - writing about the pits of Katyn - stated that nakedness destroys the pathos surrounding death: "Piles of naked corpses usually cause abhorrence. Piles of corpses in clothing tend to excite awe and dread. See J. Mackiewicz, "Dymy nad Katyniem," in Mackiewicz, Fakty, przyroda i ludzie. Dzieła vol. 12 (Londyn 1993), 65. 
wrote: "Terrible atrocities in the graveyard. The mass graves, the mean way of burying the poor, throwing them into graves like dogs [...]." ${ }^{330}$ In this mortuary on Okopowa, it was still possible to distinguish between the various kinds of deadly stench, but there was no way to talk about the dead bodies in any other way than with the word "carcass," regardless of whether the matter involved a human being or an animal. As Rachel-Antigone searched for Braxmeier's body, there was a "sweet, deadly smell. A distinctive smell of a human carcass, different than an animal carcass" (k. 32). The bodies gathered in the shed did not resemble dead humans. They looked like they "were 'dressed' in the skin of an animal and put on show, with all of their intimate posthumous alterations" (k. 32). To the author, a dead baby caught by one of the gravediggers with a smooth movement by the back of the neck is a "puppy" that the "mother cat" has taken hold of, in typical fashion, by the teeth. Since death had been stripped of dignity, it stopped being "human," and became "animal."

During her search, Rachel-Antigone faced a peculiar paradox. Contrary to the common opinion that death is the great equalizer, the cemetery shed revealed a fundamental inequality and recreated, in grotesque form, the social stratification that was determined, as in life, by one's financial circumstances. The corpse, as a product of the "death industry of the Jewish cemetery in September 1941" (k. 30), was subject to an extensive hierarchy. The shed space was divided into better and worse, and the number of "respectable" was low. In this regard, while a select few of the bodies were lying comfortably, most were lying "along the walls, abandoned one on top of the other, one this way, one the other way, one facing the ceiling, another one facing the floor, and some in a position unlike anything, acrobatic - in a pile. In piles" (k. 33-34). But this hierarchy of bodies ended at the shed's walls, beyond which bodies that could not fit into the shed were scattered around, disordered, mixed up with one another such that they formed an amorphous block, no longer having any similarity to people, and thus terrible and monstrous.

Rachel-Antigone stood before impassable barriers. How could Braxmeier be found, how could he be identified from among all the others, given the fact that, after death, the face - a sign of human identity - completely loses its singular and unique features and thus begins to resemble all other corpse faces? There was no way to recognize an individual body. "We did not find Braxmeier, we did not see him, but we did see dozens of other Braxmeiers" (k. 30). In the Holocaust's morgues, the faces of corpses were all the same. The anonymous author, who

730 Ringelblum, Notes from the Warsaw Ghetto, 211. 
like Rachel Auerbach also tried to find the body of a friend in the cemetery shed, wrote:

[...] all of them had their heads thrown far back, and their necks tightened forward, as if they were about to be slaughtered. [...] Had it not been for their hair and open eyes, they could be taken for skeletons dug up 20 years after death. [...] it is not possible that even a friend or relative could recognize such a face ${ }^{731}$

In distant Bergen-Belsen, the little Jewish boy Jona Oberski was looking for his father's body in the camp boiler house, which - like the cemetery shed on Okopowa - had been turned into a morgue. On the floor there were:

[...] naked human bodies. [...] They were all mixed up, thrown in helter-skelter. [...] I tried to find my father. I twisted my head in all directions, to the side, upside-down, so as to look straight at the faces which were tilted at every possible angle. But they all looked terribly alike." 732

During the death march westward from Auschwitz, little Michał was looking for his brother's body. At one of the stops along the way, "he went out into the night and looked among the dead, but all of them looked the same, all of them had his brother's face."733

Rachel-Antigone did not find Braxmeier's body, and she was thus not able to perform even the symbolic burial that Sophocles' heroine was able to perform for Polyneices' body. The starved-to-death Braxmeier did not receive a dignified funeral; no unfortunate Creon crumbled under the pressure of the gods' anger; and no Creon rushed "to a clear place, where the naked corpse lies"734 in order to bury it. Braxmeier's corpse blended in with the mass of other corpses, it rotted in an anonymous pile. The contemporary Antigone questioned the sense of her own efforts. Looking over the "death industry of the Jewish cemetery," she was aware that the entire venture to "give last rites to a lonely human being" was "childish in its unimportance." She was consumed by doubt about:

[...] whether he would really care if he had to lie like [a nomen nescio] in a fraternal grave with so many others, with whom he, in life, might have stood in a crowded line, for soup, for a bath, for a saccharide coffee with a three-decagram portion of bread. What difference does it make with whom and how one lies after death, when one is already a naked, gray-yellow corpse stripped of its last dirty shirt [...]" (k. 30-31).

731 [author unknown], Wrażenia z pokoika śmierci, op. cit.

732 J. Oberski, Childhood, trans. Ralph Manheim (Penguin 2014), 50.

733 H. Grynberg, Memorbuch (Warszawa 2000), 329.

734 Sofokles, Antygona, 42. 
Rachel-Antigone no longer felt a fear of death, of a dead body; she had cut loose those fears. "And I will never again feel horror toward a dead body. The cemetery shed cured me of the last rudiments of fear of the dead" (k. 34). She was not afraid because she herself was a living corpse.

The epilogue to the story about Antigone of the Warsaw Ghetto plays out after the war, at a time when Gęsia Street was being renamed Mordechaj Anielewicz Street (along which the Monument to the Ghetto Heroes - the first monument erected on Warsaw's left bank - had stood since 1948 at the ruins of the Artyleria Koronna - Crown Artillery - barracks), and as Władsław Gomułka was about to begin his fourteen year rule (1956-1970) of Poland. The Jewish cemetery in Okopowa Street became once again the object of barbaric aggression. Plans were being made to build an east-west transportation artery - through the cemetery - that would link Anielewicz Street with Młynarska and Obozowa Streets. Such a project would have destroyed around a hectare of the cemetery's land and eaten up 5,400 graves. As Janusz Sujecki has written, Warsaw's head architect, Adolf Ciborowski, began to push the plan in December 1956. Lying, he defined that part of the cemetery set for destruction as a "skrawek" (patch) of land, and he argued that the matzevot in the oldest part of the Jewish cemetery "have no value even as a memorial." He countered opposition from the Jewish community with an official complaint in the Urząd do Spraw Wyznan (Office of Religious Affairs) ${ }^{735}$ Plans for this transportation artery were never implemented, thank God, though the cemetery trees designated to be cut down had already been marked with red paint.

\section{Exiting the Grave}

In the eleventh chapter of the Gospel of John, Jesus, having received word of Lazarus' death, talks to Martha about "resurrection," but what he in fact performed was a "revival." As Jesus told Martha: "Thy brother shall rise again" (John 11:23). ${ }^{736}$ Lazarus was raised and thus returned to life on earth, but over the course of his life he was headed once again toward death. By contrast, the prospect of resurrection is an eschatological matter. For my purposes, I want to

735 See J. Sujecki, "Druga śmierć miasta. Przyczyny i konsekwence," in Historyczne centrum Warszawy. Urbanistyka, architektura, problemy konserwatorskie, ed. B. Wierzbicka (Warszawa 1998), 196.

736 In the Polish original, Professor Leociak cites the Biblia Tysiąclecia (the Millennium Bible), the main Polish Bible translation, used in the Roman Catholic Church in Poland. 
draw a clear distinction between resurrection and revival, and to emphasize that what is of interest to me here is that sphere of phenomena that - in an anthropological sense, not in a theological sense - one can define metaphorically as a "revival."

The Gospel story about the revival of Lazarus highlights his real death. Martha, sober and practical, warns Jesus, who had ordered the stone to be rolled away: "Lord, by this time he stinketh: for he hath been dead four days" (John 11:39). One must differentiate Lazarus' real death from a condition resembling death, from a situation in which the human being is nudged toward death, a death intended for him, but a death which - by some stroke of luck - he manages to avoid. Precisely such situations - in which a person stands face to face with death, in which a person "experiences" (in a metaphorical sense) his own death will continue to be my focus here.

Jesus wept at Lazarus' tomb. Exegetes point out that the Greek expressions used in the Gospel text indicate a powerful reaction of disapproval, and even anger, a state of being upset, of internal agitation. In his wide-ranging commentary included in the Latin-Polish edition of the Bible representing nineteenth-century exegesis, the Jesuit Menochiusz interpreted Jesus' condition as "outrage - against death and the devil, through whose envy death came into the world." ${ }^{\prime 37}$ Modern exegesis emphasizes a lack of faith on the part of those lamenting. The mourners' despair closes with a purely human reaction, as if they were ignoring Judaism's well-known maxim about resurrection. ${ }^{738}$ It also points to the fact that Jesus hides his agitation toward the grim harvest of death. The mystery of Jesus having wept at Lazarus' tomb thus directs us toward the unfathomable horror of death, in the face of which even God is shaken. The situations I consider here are precisely those that reveal this irreconcilable horror.

In the canonical Gospel of John, Lazarus exited the tomb still in grave clothes. He said nothing. Jesus instructed those gathered around to take off those clothes and to let Lazarus go. In the apocryphal gospel we also find no statement by Lazarus. The revived one remains silent.

For me, narratives of revival, understood as an anthropological metaphor, are a fundamental object of reflection. Stories of those who made their way to

737 Biblia Święta Łacińsko-Polska, vol. III (Wilno 1896), 312.

738 See the exegetical commentary in Ewangelia według sw. Jana. Wstęp - przekład z oryginału - komentarz, ed. Father L. Stachowiak (Poznań; Warszawa 1975), 276-278; A. Cohen, op. cit., 359-366; entry "Resurrection: Judaism" in The Encyclopedia of Religion, ed. M. Eliade, vol. XII (New York 1987), 345-347. 
the edge of the afterlife only to return, and stories about what they witnessed, fill the pages of mythology and literature. Orpheus traveled to the underworld to retrieve Eurydice, who had died of a snake bite. Odysseus went there to ask Tiresias for a prophesy about his return to Ithaca. Along with the bard Sybil, Aeneas visited Hades before moving on to Elysium. Gilgamesh, shaken by the death of his friend Enkidu, traveled to the underworld and crossed the Waters of Death in order to learn the secrets of immortality. The most famous wanderer through hell, purgatory, and heaven is Dante, guided by Virgil and Beatrice, but the Divine Comedy grew out of countless artistic images and stories of the other world that had shaped the mass imagination long before Dante. ${ }^{739}$ Medieval legends took up the motif of revival, which was present in the New Testament apocrypha, as proof of innocence. Here, the act of returning to life was treated instrumentally, with the person risen from the grave proclaiming the glory of the resurrector and testifying to his righteousness. ${ }^{740}$ Particularly eloquent are the contemporary Argonauts - that is, people who survived their own clinical death, having experienced what Raymond Moody (author of the world bestseller Life After Death) called a near-death experience. Their accounts fill the pages of many books and internet web sites.

Apocryphal literature provides us with information about Lazarus' words and actions after having been revived. In them we find two polar-opposite visions of the revived Lazarus. One, authored by Karel Čapek, depicts an experience that I would call the trauma of revival..$^{71}$ The second, authored by Eugene O'Neill, presents something that one might call the euphoria of revival.

In Čapek's Apocryphal Tales (1932), Lazarus is deeply concerned about his health and is panic-stricken about dying. He is no longer the same person; he is buckling under the pressure that came with his return to life, he feels strange and frightened by his existence after death. He complains about being ill:

"Well, you are healthy, Lazarus," Martha retorted. "You must be healthy, since $\mathrm{He}$ healed you!"

739 See A. Guriewicz "Boska Komedia przed Dantem," in Guriewicz, Problemy średniowiecznej kultury ludowej, trans. Z. Dobrzyniecki (Warszawa 1987), 170-232.

740 For example, the legend of St. Stanisław's resurrection of Piotr, who had been in his grave for four years. See L. Siemieński, Podania i legendy polskie, ruskie i litewskie (Poznań 1845).

741 Here, the word "trauma" is used more in a general sense (a psychological injury) than in a strict sense as indicated in works by Freud or D. LaCapra, though - I would argue - the two are not antithetical. 
"Healthy!" Lazarus said bitterly. "I'm the one to know if I'm healthy or not. I'm only telling you that, ever since that time things haven't been easy for me, even for a minute Not that I'm not extremely grateful to Him for - getting me back on my feet; don't think that, Martha. But once someone goes through what I did, that - that - ." Lazarus shuddered and covered his face. ${ }^{72}$

Having learned that Jesus had been arrested in Jerusalem, Mary decides to go there immediately. Lazarus at first wants to go with her, but he succumbs to fear and stays in Bethany: "Tears trickled slowly from Lazarus's eyes. 'I'd like so very much to go with you, Mary - if only I weren't so afraid of dying again. '”743

In O'Neill's Lazarus Laughed (1927), Lazarus does not remain silent, as does the Lazarus in the Gospel, but rather makes triumphant orations which are punctuated with euphoric laughter. In Bethany he sets up a new religion that radiates to Rome, where it attracts throngs of followers. He pronounces an ecstatic joy for life, in which there is no place for fear. He not only rejects the fear of death, but also questions its existence.

There is no death, really. There is only life. There is only God. There is only incredible joy [...]. Death is not the way it appears from his side. Death is not an abyss into which we go into chaos. It is, rather, a portal through which we move into everlasting growth and everlasting life. [...] The grave is as empty as a doorway is empty. It is a portal through which we move into a greater and finer life. Therefore there is nothing to fear. [...] There is only life. There is no death ${ }^{744}$

Let us first present a typology of situations in which someone condemned to death manages to escape that death. Those saved from execution can be divided into two fundamental categories. The first contains people who survived but were not allowed to live because they were put out of their misery. The second contains people who survived and were given a chance to continue living.

Those who survived but were then killed did not leave behind testimony. We know of their fates through the accounts of others. Leaders of the firing squad approached the pits filled with corpses or they walked among the prostrate victims to kill them off with pistol shots or with blows of a rifle butt. The injured who managed to crawl out from underneath the bodies were too weak to escape.

742 Karel Capek, "Lazarus," Apocryphal Tales, trans. Norma Comrada (Catbird Press, 1997), 73.

743 Ibid., 74.

744 Eugene O’Neill, Lazarus Laughed, in O’Neill, Plays, vol. 1 (New York 1951). For more on O'Neill's play, see the entry "Lazarus" in M. Bocian, Leksykon postaci biblijnych, trans. J. Zychowicz (Kraków 1995), 331. 
Such was the fate of the people who, during the massacre of Jews at Berdychiv on 15 September 1941, did not die on the spot.

They crawled out of the grave and over the field, instinctively trying to get as far from the pits as possible. Their strength failing them due to a loss of blood, most of them died there in the field, a few dozen meters from the execution site. [...] Later that morning the Germans and the police took the bodies away, killed those who were still breathing, and buried them again. ${ }^{75}$

There are many such accounts describing both the annihilation of the Jews and the extermination of the civilian population during the Warsaw Uprising. But for a change, let me refer to accounts from the communist terror in Poland. The author here is Father Jan Skiba, who in 1946-1947 served as a prison chaplain in Wrocław.

One of the most terrible visions involved the three attempts to execute an officer. [...] When the first volley went off, it turned out that only one rifle fired a shot, and the bullet missed the target. The officer [in charge of the execution] ordered that the guns be reloaded. But this time only two rifles fired a shot, and the bullets did not cause a fatal injury. This time the officer could not stand it. He walked up to the man lying on the ground in a puddle of his own blood, pulled out his pistol, and shot him right in the head. ${ }^{746}$

Stories about people who emerged from a gas chamber alive are entirely exceptional in nature. They had absolutely no chance of surviving further. At Chełmno nad Nerem, victims were killed in trucks using gas fumes. Szymon Srebrnik reported that, on one particular day, some people fell out of the trucks alive. "They were all moving, they were coming back to life, and when they were thrown into the ovens, they were all conscious. Alive. They could feel the fire burn them. ${ }^{747}$ Jankiel Wiernik escaped from Treblinka during the prisoner uprising of 2 August 1943. He had seen how half-live people would sometimes be pulled out of the gas chambers:

745 Ilya Ehrenburg, Vasily Grossman, The Complete Black Book of Russian Jewry, trans. and ed. David Patterson (Transaction Publishers, 2003), 17.

746 See T. Balbus, S. A. Bogaczewicz, “Człowiek z piętnem wyroku śmierci”, Nowe Życie. Dolnoślaskie Pismo Katolickie (February 2002).

747 Claude Lanzmann, Shoah: The Complete Text of the Acclaimed Holocaust Film, intro. Simone de Beauvoir (Da Capo Press, 1995), 91. Three prisoners survived the concentration camp at Chełmno - Podchlebnik, Żurawski, and Srebrnik. The latter, seriously injured in an execution, managed to escape a mass grave and hide. 
When the chambers were opened again, many of the victims were only half dead and had to be finished off with rifle butts, bullets or powerful kicks. [...] particularly the children showed a remarkable degree of resistance. They were still alive when they were dragged out of the chambers $[\ldots] .^{78}$

Szlama Dragon, a member of the Sonderkommando in Auschwitz, pulled bodies out of the gas chambers.

Once we found a baby whod been stuffed into a pillow and was still alive. [...] We took the bundle to Oberscharführer Moll and told him that he was alive. Moll took the kid to the edge of the pit, put him on the ground, stepped on his neck, and threw him into the fire. ${ }^{79}$

Doctor Miklós Nyiszli recalled that once, as the corpses were being removed from a gas chamber, a live sixteen-year-old girl was found. Along with the Sonderkommando prisoners, he immediately attempted to resuscitate her. The girl regained consciousness.

Perhaps she remembered that everyone had had to undress. [...] All of a sudden the lights had gone out, leaving her enveloped in total darkness. Something had stung her eyes, seized her throat, suffocated her. She had fainted. There her memories ceased.

They all wanted to help the girl, but they all understood that the girl was doomed. No one, not even those in the Sonderkommando, could come out alive from the crematoria. No one could betray the truth, no one could break the code of silence. No one could survive this execution. More importantly, no one could talk about it. Which is precisely what determined the girl's fate. SS-Oberscharführer Erich Muhsfeldt from Crematorium I handed down the sentence:

If she had been three or four years older that might have worked. A girl of twenty would have been able to understand clearly the miraculous circumstances of her survival, and have enough foresight not to tell anyone about them. She would wait for better times, like so many other thousands were waiting, to recount what she had lived through. But Mussfeld [Muhsfeldt] thought that a young girl of sixteen would in all naiveté tell the first person she had met where she had just come from, what she had seen and what she had lived through.

748 Jankiel Wiernik, A Year in Treblinka: An Inmate who Escaped Tells the Day-to-day Facts of One Year of His Torturous Experience (American Representation of the General Jewish Workers' Union of Poland, 1945), 20.

749 Gideon Greif, We Wept Without Tears: Testimonies of the Jewish Sonderkommando from Auschwitz (Yale Univ. Press, 2014), 141. 
The girl was killed with a bullet in the back of the neck. ${ }^{750}$ Another member of the Sonderkommando, Eliezer Eisenschmidt, recalled probably the same event. ${ }^{75}$

The group of execution survivors is quite large, and it includes those who were pardoned at the last minute. Though the executions were not carried out, these people had stood face-to-face with death. Literary characters are members of this group (the title character in Słowacki's play Kordian, and Pablo Ibbieta from Jean-Paul Sarte's story "The Wall”), as are real-life characters, such as Fyodor Dostoyevsky, whose death sentence - handed down on 22 December 1849 during the trial of the Petrashevsky Circle - was commuted at the last moment to four years of hard labor in Siberia.

And then there are mock executions. This particularly refined form of torture keeps the victim alive, but only after that person has been forced to experience the full fear of death, to experience every stage of being killed, except the last. Two examples. Just before the liquidation of the Białystok Ghetto in August 1943 the Germans gathered a group of Jews together and ordered them to dig a large grave. By this time, the victims were perfectly aware of the modus operandi of a mass execution. They knew what awaited them. As they stood over the prepared grave - one of those who survived reports - "one thinks only of taking a quick bullet, so as not to have to hear the laughter of the shooters and not to have to look at their faces." But the Germans ordered the Jews, who were prepared for death, to lug sacks of potatoes and dump their contents into the open graves, after which they set free the would-be condemned. ${ }^{752}$ Leib Rotsztajn told the story about a double mock execution in the Baranavichy ghetto. Jews were led into a square where a deep pit had been dug, around which machine guns had been set up. They were told to go down into the pit, turn around, and put their hands up.

We were waiting for a bullet, many of the Jews were mumbling under their breath, I understood that they were preparing for death with prayer. We knew we would die. No one wanted to die on such a beautiful, sunny day, knowing at the same time that we were innocent.

But a moment later the order came for them to leave the pit. The Jews crawling out of the grave were met by German laughter. Trucks took them to some other

750 Patricia Heberer, Children During the Holocaust (AltaMira Press, 2011), 160-162.

751 See Greif, We Wept Without Tears, 231.

752 See F. Landau, account submitted on 10 November 1945 at the Wojewódzka Komisja Historyczna in Białystok, AŻIH, Relacje 301/1267, trans. from the Yiddish by J. Jakubowska. 
place, where they were read the charges against them (they were to be executed in exchange for the fact that ten Germans had been murdered). They were told to walk down into a pit that they themselves had dug, from which they could see rifle barrels pointed down at them.

The officer raised his arm and the guns let loose. I fell, but I felt that I was still alive. No bullet had struck me. I think and find myself envying the others, since I will no doubt be buried alive. I look up and see that everyone is alive. Suddenly the order "turn around." Turning around, we see the Germans bent over laughing. ${ }^{753}$

What is of interest to me below are those on whom an execution had been carried out, but who survived.

We find in criminal records a surprising number of cases in which people survived the gallows. Historians of the British judiciary suggest that, in the seventeenth and eighteenth centuries, there were several dozen such cases. Let us take three of the most famous. On Christmas Eve 1705, John Smith - a soldier and sailor sentenced to death for burglary - was executed in Tyburn (where London's Marble Arch now stands). He hung by a rope for a good fifteen minutes, giving signs of life the entire time. The crowd began to call out for a reprieve. He was pulled down, taken to a nearby home, and revived. People immediately began to ask him questions about his impressions of the experience, and Smith was glad to share his views, which readers of Raymond Moody's book Life After Death would find strangely familiar. The conclusion of the story is not exactly inspiring. Smith did not give up his criminal ways, though he "slipped from the noose" two more times. Another example: Maggie Dickson, found guilty of infanticide, was hanged in Edinburgh in 1724. Her body was put into a coffin, which was placed on a wagon. The wagon took off, bouncing along the bumpy road. Having stopped at an inn, the driver returned to the wagon only to see Maggie alive, sitting up in her coffin. The court decided the accused could not be hanged twice and it pardoned her. Maggie Dickson took advantage of her life, miraculously returned, to bear a large brood of children. The third example: sixteen-year-old William Duell was hanged in Tyburn on 24 November 1740 for raping and murdering Sarah Griffin. According to practices common at the time, his body was to be quartered and offered for use by anatomy students. But the young murderer

753 See L. Rotsztajn, account submitted on 11 March 1945 at the Wojewódzka Komisja Historyczna in Białystok, AŻIH, Relacja 301/77, trans. from the Yiddish by A. Bielecki. 
woke up on the dissection table, and he was transported to Newgate prison. $\mathrm{He}$ was also pardoned. ${ }^{754}$

The most famous convict in Victorian England never had a chance to hang from a rope, even though all procedures for hanging had been followed carefully. The date was 23 February 1885. A crowd was already waiting in front of the prison at Exeter. John Henry George Lee, sentenced to death for the brutal murder of his employer, Emma Keyse, at Babbacombe Bay in Devon county, was strung up three times, each time unsuccessfully. According to reports filed by the prison warden, by the sheriff, and above all by the master of ceremonies and first-class professional executioner James Berry, the trap door under Lee's body stuck three times. The gallows had been carefully checked the day before, and no problem was found. After the trap door failed the first time, Lee was taken aside, where he waited for the mechanism to be tested. The tests were successful, and the convict stood once again on the gallows with a noose around his neck. Once again the trap door failed to open. Guards tried to loosen the door with axes and crowbars, but to no effect. The third attempt also failed. Lee returned to his cell. His death sentence was reduced to life in prison. After 23 years, he was released. He knew perfectly well how to make use of his unusual experience. His story about life in an English prison and, above all, about his experiences as "the man they could not hang" (which is what he was called in the tabloid press), turned into a source for fame and fortune. Lee sold the rights to his story to Lloyd's Weekly News, a penny-press newspaper that also wrote widely on Jack the Ripper. Lee emigrated to the United States, where he died in $1945 .{ }^{755}$

Michał Maksymilian Borwicz (Boruchowicz) - author of concentration camp memoirs, analyst of the Nazi language of hate, editor of works of poetry about Jews under the German occupation, a pioneer in sociological-literary scholarship on Holocaust testimony - survived his own execution at the Janowska concentration camp in Lwów. In his case, the noose literally broke. He had been working in the camp underground, teaching chosen prisoners how to use weapons. During one of those lessons he was caught by an SS-man. He stood on the gallows. Later, he remembered the final seconds before the sentence was to be carried out.

754 All of these examples are derived from The History of Judicial Hanging in Britain. See http://www.richard.clark32.btinternet.co.uk/hanging1.html (accessed 25 May 2008).

755 See M. Holgate, I. D. Waugh, The Man They Could Not Hang: The True Story of John Lee (Stroud, Gloucestershire 2005). 
I see the SS-man approaching me. Around me something of a vague commotion ensues, [...] a chaotic tussle, my view - not of the gallows but of the end of a rope being dragged along the ground. I am still aware that I am losing my footing. I get the feeling I am being strangled - terrible, yet grotesque, since it is so ridiculously expected. And the hazy awareness that it is really all over - the end. Was I really conscious of all this at the moment of my "resurrection"? Or did I reconstruct it all only later? [...] Even in such a reconstruction the entire scene is reduced to a few details. My sudden awakening on the ground. [...] A sensation of being in a deep haze. [...] My friends told me later that - at the very moment I was hanging in the air - the rope broke. I fell to the ground. ${ }^{756}$

After he had picked himself up off the ground and rejoined the other prisoners, the German overseeing the execution said: "An old Germanic custom demands [...] that a condemned man who breaks free of the gallows will be pardoned."757 As one who had "broken free of the rope," Borwicz was treated specially. He was respected even among the SS-men.

There is one more group of execution survivors, namely those who were executed but survived and then dug themselves out from under the corpses, crawled out of the death pits or mass graves, and escaped the perpetrators.

Mass executions have never been $100 \%$ effective. Somebody always survives. Thanks to those who managed to escape the grave and live to tell their stories, the world has learned about these crimes. There is a large number of such stories, and we could fill a large anthology with them. For me, the main source here will be the records from the Second World War involving Jews who survived extermination operations and Poles who survived executions during the pacification of the civilian population during the Warsaw Uprising.

On the basis of multiple testimonies, we can construct a model of the situation of interest to us here - its particular phases, and the kinds of behavior and types of experiences had by those who "exited the grave" (thus, the "revived") and by those who then encountered them.

Everything began with the firing squad. Mass executions of Jews were usually schematic in nature and followed procedures that were downright monotonous in their banal brutality. The victims were forced to dig their own graves or were herded toward pits prepared beforehand. They were ordered to undress. Then they had to stand on the edge of the pit or on a plank thrown across the pit, or to lay down directly on the bodies of those already murdered. The climax of this phase came with German gunshots and Jews falling into the pit immediately after (or a split second before) the shots went off. Sometimes an individual victim

756 M. Borwicz, Spod szubienicy $w$ teren (Paris 1980), 23-24.

757 Ibid., 25. 
would not be injured or even grazed by a bullet. Jonasz Stern told the story of how he was taken with other prisoners from the Janowska camp to a forest outside of Lwów: "And here they were supposed to shoot me. But I tricked them and fell earlier." 758 The sixteen-year-old Zvi Michałowski - the son of a melamed from Ejszyszki - "fell into the grave a split second before the volley of fire hit him."759 With other Jews from Słonim, Salomon Szlakman stood in front of an execution squad made up of Germans and Lithuanians. It was November 1941. Darkness had fallen. Guided by intuition, he was able to avoid the shots: "unbeknownst to them," Szlakman reported, "I fell into the grave, and a second later the machines guns let loose [...], a mass of human bodies fell on me with a moan, and after a minute had passed, there was complete silence." ${ }^{\prime 60}$ A certain boy from Tłuste "fell into the pit untouched by the bullet." ${ }^{761}$ Children protected in their mothers' arms as the shots went off found themselves in a peculiar situation when they fell into the pits, still alive. Sara Glejch talked of such scenes in the context of mass executions in Marianpol in October $1941 .{ }^{762}$ Poles murdered in the Wola district during the Warsaw Uprising had been lined up and shot against walls, in the courtyards of apartment buildings, in cellars. Mrs. Wacława Gałka, on Wolska Street, was shot at twice, and twice the bullets missed the target. ${ }^{763}$ Sometimes a person was shot but only wounded. Maria Cyrańska, who survived an execution carried out in August 1944 at Sowiński Park in Wola, testified to the Warsaw Commission for the Investigation of German Crimes that she "fell to the ground wounded. I had been shot in the left arm and some shrapnel had wounded me in the temple and cheek." 764

An inherent feature of the mass murder of Jews was the victims' nakedness. Men, women, and children entered the gas chambers naked. In forest ravines, gorges, fields, and cemeteries - wherever the death pits were dug - victims were forced to undress before the execution. Describing the scene during

758 Jonasz Stern, [Interview by M. A. Potocka], Odra 11 (1988), 37.

759 See Y. Eliach, Hasidic Tales of the Holocaust (New York 1988), 54.

760 S. Szlakman, manuscript put together by the author in September 1945. See AŻIH, "Pamiętniki," 302/155.

761 B. Milch, Testament (Warszawa 2001), 173.

762 See I. Ehrenburg, V. Grossman, op. cit.; quote from R. Rhodes, op. cit, 277-279.

763 See W. Gałka's account in Ludność cywilna w powstaniu warszawskim, vol. 1: Pamiętniki. Relacje. Zeznania, part 1, eds. M. M. Drozdowski, M. Maniakowna, T. Strzembosz (Warszawa 1974), 316-318.

764 See M. Cyrańska’s account in Ludność cywilna w powstaniu warszawskim, vol. 1, op. cit., 312-313. 
the liquidation of the Horodenka Ghetto in December 1941, little Mendel Rosenkranz stated: "They stripped naked and were shot just like that." 765 Women who survived an execution at Ponary in July 1941 said that "dozens of Jews had to undress at the pits where they were shot."766 Over and over again we read in reports by those who survived mass executions such words as: In the forest "we were ordered to go into the pavilion to undress ourselves fully, herded in groups of twenty into the forest, where pits had been dug" (Horodenka, Kolomyia powiat, December 1942) ${ }^{767}$; “we were ordered to undress and lay down in groups of ten, one next to the other" (during a liquidation operation in Łomazy, August 1942); ${ }^{768}$ "we were ordered to undress completely and walk down into the pits, and the Germans sent automatic fire after us" (mass execution in Wołyński Horyńgrad in October 1942). ${ }^{769}$ During her testimony at the Eichmann trial, Ryfka Joselewska reconstructed the final moments before the shooting began, when everybody was already undressed. Only her father had kept his clothes on: "They began to beat him. We prayed, we begged him to get undressed, but he would not do so. He wanted to stay in his underwear. He did not want to stand naked. So they tore the clothing of this old man and shot him."770

Those who managed to escape the grave after a shooting - and thus, in a certain sense, after death - were naked. Revived, Lazarus had the grave clothes removed from his body. Execution survivors returned to life with the stigma of nakedness, which hampered their escape and sowed terror among those they encountered. Estera Winderbaum survived the shootings during the liquidation of the Poniatowa concentration camp on 4 November 1943; she crawled out from under the corpses and roamed naked among the nearby peasant huts, begging the terrified peasants for clothing. ${ }^{771}$ After an execution in Horodenka in 1942 , once the Germans had "finished their work and left the graves," a butcher's daughter "pulled herself out of the pit, naked, [and] made her way to the village of Siemakowce."772 In a story entitled "Krajobraz, który przeżył śmierć" (The

765 M. Rosenkranz's account in Dzieci żydowskie oskarżaja (Warszawa 1993), 104.

766 M. Fejgenberg’s account in Życie i zagłada Żydów polskich 1939-1945. Relacje świadków, eds. M. Grynberg and M. Kotowska (Warszawa 2003), 533.

767 H. Steinkohl, Relacja ŻIH 301/1396.

768 B. Goldszer, AŻIH, relacje 301/663, trans. from the Yiddish by A. Bielecki.

769 A. Rubin Winicer, AŻIH, relacje 301/663, trans. from the Yiddish by J. Jakubowska.

770 R. Joselewska - testimony at the Eichmann trial, 8 May 1961, in M. Gilbert, op. cit., 421.

771 See E. Winderbaum, Likwidacja Poniatowej, relacja 2209/118-1, Archive Yad Vashem.

772 B. Glik talked about this in his account in Życie i zagłada Żydów polskich, op. cit., 372. 
Landscape That Survived Death), Kornel Filipowicz depicted nakedness as the execution survivor's burden. In a purely practical sense, nakedness can expose a person's real identity, since the body glows in the dark:

How can you cover your nakedness so that - when one breaks away from the shiny background of human bodies and finds himself on the rough, light-absorbing surface of the earth - one does not suddenly become an isolated shape visible from a distance? [...] The night still shielded his nakedness well enough. But with the coming day, he would face a cruel reality - how to once again put on that skin that forms the most human of shells clothing. A dressed person has no idea what a problem nakedness is ${ }^{173}$

On the metaphorical plane, nakedness represents the stigmatized "otherness" of the person who has managed to crawl out of the grave. It sets those trying to return to life (and to people) apart from life (and people).

After the shots rang out, and as the victim lay among the corpses, the time came to try and comprehend this state of suspension between life and death, one which evaded consciousness while still being recorded by it. In many accounts, this moment of unawareness is key: am I still alive or am I already dead? A boy from Wyszków expressed this question with childish simplicity and naiveté: "I didn't know whether I was dead or alive [...]. It was completely dark when I felt a kick in the side. I was terrified that the dead were rising up."774

Ryfka Joselewska, from Zagrodzko near Pinsk, was shot in August 1942 only to come back to life when the mass of bodies falling into the ditch began to smother her:

I thought that maybe I was no longer alive, that it was just that I was feeling something after dying. I thought that I am dead, that this was precisely the feeling that comes after death. Then I felt that I was suffocating, people were pressing down on me. I tried to move and then I felt that I am alive and that I could get up. ${ }^{775}$

Henryk Bryskier, who was shot on 24 April 1943 in the Warsaw Ghetto at the Brauer szop on Nalewki Street, reflected broadly ("philosophized") on this subject:

I could not assume that I was alive, and yet, [though I was in fact] still alive, I believed that I was dead. It seemed to me that life and death did not follow one another, but rather existed alongside one another other at every moment. I fell into a dark chasm. Then it was as if my astral body was floating through space with clouds sometimes below and

773 K. Filipowicz, "Krajobraz, który przeżył śmierć," in Filipowicz, Krajobraz niewzruszony (Warszawa 1956), 95-96.

774 H. Grynberg, Dzieci Syjonu (Warszawa 1994), 22.

775 R. Joselewska, op. cit., 422. 
sometimes above. I do not know whether I subconsciously opened my eyes a bit or whether the rays of the sun broke through my eyelashes to the narrow slit of my lowered eyelids, but I do know that a kind of vague consciousness came into play, thanks to which I understood that I was not being cradled by the clouds, but lying on the earth and peering up - as if through a fog - at the sky, where I could see white clouds guided by a light breath of wind. I was afraid to open my eyes wider, onto which that wind had carried a layer of dust, because if I was in a state of nirvana, then it seemed a pity to return to reality. This philosophizing took place in a moment of physical paralysis, but also as my cerebral lobes were beginning to function again. ${ }^{776}$

The experiences described here seem to make up a scenario that repeats itself in hundreds of accounts from people who have returned to life after clinical death. But it is telling that Bryskier rationalized the mystical aura of his near-death experience and even added a certain dose of irony.

On 3 August 1944, the Germans pulled Antoni Czarkowski from a burning building on Oleandrów Street in Warsaw and shot him. His thinking, freed by the bullet, wavered between "hallucination and reality," between "body and soul":

I heard behind me only a slight pop. Then humming in my head. A sweet taste in my mouth. Peace - quiet. After an insane level of tension, total relaxation. Finally, the end. I have everything behind me. When I regained consciousness in the street, it was already dark. In the glow of the burning buildings, I saw next to me men's corpses. I was convinced that despite the death of the body, the human soul must know what is happening with his body. Hallucination and reality were so mixed with each other that it was difficult for me to distinguish between them.

Czarkowski pulled himself away from a własowiec ${ }^{777}$ who was trying to pull off his boots, and he jumped toward an open cellar window. He just managed to hear the surprised voice of the perpetrator: "The boy is alive." 778

Sooner or later survivors became conscious of their paradoxical situation. What they had taken for symptoms of death turned out to be evidence of life. The main character of Kornel Filipowicz's story, lying among the dead in a deep pit,

776 H. Bryskier, Żydzi pod Swastyką, czyli getto w Warszawie w XX wieku (Warszawa 2006), 255.

777 Translator's note: The word własowiec refers to a soldier serving under the command of General Andrey Vlasov, a Soviet military leader who defected to Nazi Germany and led the so-called Russian Liberation Army (or Vlasov Army).

778 See A. Czarkowski's memoirs (in manuscript form, May 1977). Quote from Exodus Warszawy. Ludzie i miasto po powstaniu 1944, vol. 2: Pamiętniki. Relacje, eds. M. Berezowska, E. Borecka, K. Dunin-Wąsowicz, J. Korpetta, H. Szwankowska (Warszawa 1993), 397-398. 
believed that "death is some dazzling liberation of consciousness from the weight of the body. But then he quickly understood that thinking itself meant life."779

Life's return to full consciousness was tied to the imperative to save that life. An obvious survival strategy in this kind of situation was to pretend to be a corpse. The perpetrators always tried to finish off the wounded after an execution, so the only chance was to look like a corpse. Children were perfectly well aware of this fact. During the Warsaw Ghetto Uprising, Germans shot at tenyear-old Irka Rubinsztajn and other Jews hiding in a bunker at 38 Świętojerska Street. Irka and her friend Halinka survived. They crawled out from under the pile of bodies: "Then I heard footsteps. Halinka and I lay back down among the corpses, pretending to be corpses." ${ }^{780}$ In order to survive among the bodies, a living person had to look like a dead person. Above all, one could not move. Maria Cyrańska was lying in a group of executed people during the Warsaw Uprising when "a German soldier stood on her back," shooting at anyone who moved. She managed to endure it. ${ }^{781}$

But simply pretending to be a corpse might not suffice. An additional form of camouflage was often necessary. Here, the dead might be of assistance. Their bodies could cover a person and protect him from the perpetrators' sight. The dead's blood could splatter the living, giving them the appearance of a corpse. During the liquidation of the camp at Poniatowa, an SS-man led a woman and child to a ditch filled with bodies, where Estera Winderbaum already lay: "There was a shot and her blood spurted onto my head, covering my neck and hair. From behind I probably looked like a corpse." ${ }^{782}$ Situations in which this solidarity between the dead and the living involved the survivor's closest family members were particularly powerful, for example when mothers' corpses concealed their living children. Irka Rubinsztajn described one such situation:

I lay there a little longer and pushed a corpse off me. It was then that I noticed that the corpse which had been covering me was ... my mom. Her blood was trickling onto me. Mommy was already dead. [...] Halinka was only wounded and was lying there in a faint. I pushed aside the body that was covering her, which turned out to be Halinka's mother. $[\ldots]^{783}$

779 K. Filipowicz, op. cit., 95.

780 L. Najberg wrote about this in Ostatni powstańcy getta (Warszawa 1993), 92.

781 See Cyrańska’s account in Ludność cywilna w powstaniu warszawskim, vol. 1, op. cit., 312-313.

782 E. Winderbaum, op. cit.

783 I. Rubinsztajn quoted in L. Najberg, op. cit., 92. 
A son's corpse could also save a mother. Before the Warsaw Commission for the Investigation of German Crimes, Wacława Gałka, who was shot on Wolska Street during the Warsaw Uprising, gave the following testimony:

My son Leszek began to cry, saying that his knees were stiff. Then a gendarme shot him. My little son was lying on top of my cousin Damian Pasterski, who was next to me and had been shot during the first volley. After the gendarme shot my son, his blood trickled onto me and no doubt that's why they thought I was dead. ${ }^{784}$

The next link in the chain of events was to dig one's way out from under the heap of bodies and to the surface. Some accounts present this as a long process, difficult and laborious. Those who managed to make their way out had to watch their every movement. The smallest mistake could destroy their cover and squander their chance of surviving. So they moved very slowly, waiting for all danger to pass, looking for the right moment. Tima Kac, a Vilnius school teacher, lay in the pits at Ponary after an execution of 10 September 1941:

Despite the late hour, somebody was still stepping among the corpses, pouring out lime, digging through the grave. I lay there, holding my breath, listening for every murmur and rustle [...]. Suddenly, nearby, I heard a soft cry. I realized it was a child crying. I began to crawl toward the sound. [...] A three-year-old little girl was crying. She was not only alive, she was not even wounded. I decided to save her and myself. Whenever I stopped crawling through the corpses to rest a while, I hugged the little girl.785

Those who had been shot but were still alive formed a pile with the corpses of their fellow victims in order to escape the deep grave. Mina Gurewicz had only to use a girl's corpse next to her in order to crawl out of a two-meter pit in Ponary. ${ }^{786}$ Białobroda Fiszel, from the Lida ghetto, was buried deeper. So when he woke up he began to "stack bodies. In building this hill, I woke up a young boy and, together with him, I jumped out of the pit." 787 Salomon Szlakman, after being shot in Słonim, climbed out of the grave with Joel Cymerman. They worked together. First they pushed aside the corpses crushing them, and then Solomon tried to estimate the situation: "at the [grave's] wall we built a kind of platform with human bodies and furtively looked out." 788

784 W. Gałki’s account in Ludność cywilna w powstaniu warszawskim, vol. 1, op. cit., 317.

785 T. Kac's account in Życie i zagłada Żydów polskich, op. cit., 543.

786 See M. Gurewicz, Relacje ŻIH 301/2398.

787 B. Fiszel, account dated 1945, AŻIH, Relacje 301/665, trans. from the Yiddish by J. Jakubowska.

788 S. Szlakman, AŻIH, “Pamiętniki,” 302/155. 
Survivors escaped the grave with great difficulty and great effort. Not only did they have to avoid being seen by their watchful executioners and fight their own exhaustion (after all, they were injured and in shock), they also had to overcome the resistance of the grave itself, along with the bodies filling it. It seems that in order to get out, they had to wage a kind of battle with the corpses. Roles were unexpectedly reversed; the corpses that had saved them, by providing cover, were now in the way, blocking their path, as if they wanted no living person to escape. Ryfka Joselewska provided a poignant account of this battle:

I felt that I was suffocating, choking, but I tried to save myself, tried to find some air to breathe. And then I realized I was climbing over bodies toward the edge of the grave. I lifted myself up and the hands of the corpses began to pull at me, clinging to my legs, dragging me back down. But with a final effort I managed to pull myself out of the grave, and when I had done that, I could not recognize the place. Bodies were lying everywhere, a huge number of dead people. I wanted to see where this field of bodies ended, but I could not. ${ }^{789}$

Anna Szaret, a character in Kazimierz Traciewicz's novel Yom Kippur, was shot with a group of labor camp prisoners. She survived and managed to get out of the mass grave. But first she had to wage a real battle for her life:

She detested the corpse lying on top of her, which seemed almost by design, intentionally, to be getting heavier and heavier. Anna was convinced that he was grinning maliciously, that he was baring his teeth through lips parted with pain, that he was smiling with half-open eyes. With a great and desperate effort, she finally managed to free herself from this despicable burden. She turned him over on his side and knelt on his chest. Then there was a leg, but no, it was not his leg, then a hand, which seemed to be trying to hold her down in the pit. They wanted her to stay with them. Never, never ever [...] with violent movements she began to crawl out of the grave. Something snapped under her foot, something shifted. Air, finally air. She drew it in with open mouth. [...] She pushed off with one leg [...] probably off the head of that corpse, and at last she found herself on the surface. ${ }^{790}$

Those who had managed to escape from the death pits and now took their regained lives into a dark and hostile world had a choice: they could either speak or be silent. It is significant that this dilemma does not appear in the Polish accounts I have examined. The problem of whether to speak or be silent, along with related questions tied to the reactions of those who listened to stories from beyond the grave, are not thematized within them. But the accounts of Jews who

789 R. Joselewska, op. cit., 422

790 K. Traciewicz, Jom Kipur (Warszawa 1992), 140. 
survived executions reveal two extreme models of behavior. Members of the first group talk about what they experienced; indeed, they feel compelled to talk. This imperative stems both from a desire to shed the burden of an experience that exceeds all human measure, and from a sense of mission that commands them to bear witness to the Holocaust and to convey a message of warning. This group has a clear majority. Members of the second group retreat within themselves and are silent. They remain separate, isolated, divided from other people by an insurmountable barrier. They do not want to cross this line. In this regard, the response of two girls who survived the extermination operation at Tłuste is illustrative: "They dug themselves out from under the corpses and returned to town. But they were behaving as if they had gone mad, and they did not want to speak." ${ }^{\prime 91}$ We might call this attitude of silence the canonical model of behavior, particularly if we recall Lazarus from the Gospel of John, who - having exited the grave - said nothing and simply walked away. Accordingly, one could define the opposing attitude (of speaking) as the apocryphal model.

Under the conditions of occupation, in a situation in which the hunt was on for Jews, excessive talk by survivors - if they were able to talk - was usually severely punished. The compulsion to speak, which - being still in a state of shock - they could not control, led inevitably to ruin. A hospital, which - to a fugitive from the grave - would seem like a safe haven, usually turned out to be a deadly trap. Mendel Rosenkranz reported: "One of those women who survived was pregnant, and two weeks later she gave birth to a child in the hospital, where she talked her head off about this bottom in the forest. The Gestapo came to the hospital, took her and her child away, and shot them at Kolomyia."792 One Miss Kugelmanówna, saved from the massacre at Horodenka, also went to a hospital, "but she talked about everything and the Germans shot her." ${ }^{393}$ Eight of those who survived the Słonim execution found themselves in the local hospital. "The Germans learned about this fact, it turned out that 'good people' had informed them and this group of eight was immediately taken out and shot."794

Every story must have listeners. Otherwise, story-telling becomes an idle effort. Baruch Milch learned of the massacre at Horodenka from "those who managed to escape the grave after the executioners had left [...]. I spoke to one of

791 S. Eisen's account, Dzieci żydowskie oskarżaja (Warszawa 1993), 16.

792 M. Rosenkranz, ibid., 103-104.

793 H. Steinkohl, Relacja ŻIH 301-1396.

794 Jachwidowicz, Los Żydow w Słonimiu w czasie niemieckiej okupacji. Account submitted on 30 October 1946 in front of the Żydowska Wojewódzka Komisja Historyczna (Jewish Regional Historic Committee) in Białystok, AŻIH, Relacje 301/1972. 
them myself; practically naked, he had fled to our town. He told me terrible things." ${ }^{795}$ Milch wanted to listen, but he was one of the exceptions; it was usually very difficult for survivors to find listeners. People did not believe those who had exited the grave. They turned away from them, regarded them as lunatics. Six women who had escaped from the Ponary death pits "told what happened. Nobody wanted to believe their terrifying stories." 796 The survivors' despair stemmed in part from the fact that they were unable to convey their testimony. It is the despair of a person who has been crushed by the burden of terrible knowledge, paid for in suffering and extracted from death, which is really of no use at all. It is the despair of a messenger from beyond the grave, whose rescue mission is ridiculed and rejected. Moishe the Beadle, from Elie Wiesel's Night, is precisely this kind of tragic narrator. Having been deported from Sighet and survived execution, he returned to his little town:

Day after day, night after night, he went from one Jewish house to the next, telling his story and that of Malka, the young girl who lay dying for three days, and that of Tobie, the tailor who begged to die before his sons were killed.

[...] But people not only refused to believe his tales, they refused to listen. Some even insinuated that he only wanted their pity, that he was imagining things. Others flatly said that he had gone mad.

As for Moishe, he wept and pleaded:

"Jews listen to me! That's all I ask of you. No money. No pity. Just listen to me! [...] I was saved miraculously. I succeeded in coming back. Where did I get my strength? I wanted to return to Sighet to describe to you my death so that you might ready yourselves while there is still time." 797

People who had been shot but survived, though their wounds were still oozing blood; who had been thrown into a pit filled with corpses, and yet somehow escaped - they were wounded once again on their road back from the grave. The people they encountered did not want to listen; they did not want to believe; they did not want to understand, and often did not want to help. They reacted with fear, aggression, or evasion. They refused contact with these survivors. Salomon Günsberg told the story of the survivors of an extermination action in Stanisławów on 12 November 1941:

795 B. Milch, op. cit., 121.

796 M. Fejgenberg's account, in Życie i zagłada Żydów polskich, op. cit., 533.

797 Elie Wiesel, Night, trans. Marion Wiesel (Hill \& Wang, 2006), 7. 
They were victims who, only wounded, had escaped from the mass graves at night, trying to save their own lives. Only a handful managed, through their own efforts, to save themselves. The people of the neighboring farmsteads refused to take in those who had already been "put to death." 798

Tima Kac hid for two days in the woods along with five other women who, like her, had escaped from the grave after the Ponary executions: She reported: "We crossed paths with a peasant who took fright at the sight of us and ran away screaming. Later, we met him again and he told us that he had taken us for ghosts, terrible sinful ghosts." 799 The superstitious fear of the "dead" often served as a reason for their rejection. The peasants whom survivors approached for help often treated them like specters, apparitions, or foul spirits. They warded them off with the sign of the cross or a curse, as they did to Zvi Michałowski from Ejszyszki: "Jew, go back to the grave, your place is there!" 800 They threw stones at them, as they did at Ryfka Joselewska, who remained in one place for three days after exiting the grave. They threw stones at her so long that she was eventually forced to leave. ${ }^{801}$

But sometimes people extended a helping hand despite their fears - some of them reluctantly, as if compelled. Estera Winderbaum told the story of an elderly couple she encountered as she was seeking assistance after the liquidation of the camp at Poniatowa:

The old people were terrified of us, they crossed themselves at the sight of these three naked women. The old woman threw us some tattered trousers and a tattered dress. She began to drive us away, frightened that we would attract the Ukrainians. I ran into the kitchen, hoping to warm myself up a bit, but the old woman would not allow it. We had to leave the house. [...] We ran into another hut, where we asked for warm water to wash ourselves a little. We were completely soaked in blood. They gave us water, a blouse for me, since I was still naked, and a piece of bread for each of us. Then, once again, we had to move on. ${ }^{802}$

Others treated the act of helping survivors as simply the Christian thing to do: to feed and clothe. I. Kogan, who survived the Ponary executions, reported:

Covered in blood, I made it to the nearest village and entered a run-down peasant house. A poor farm hand working for a rich Lithuanian lived there. I told him who I was and

798 See S. Günsberg's account in Życie i zagłada Żydów polskich, op. cit, 349.

799 T. Kac's account in ibid., 543.

800 J. Eliach, op. cit., 54.

801 See R. Joselewska, op. cit., 423-424.

802 E. Winderbaum, op. cit. 
what had happened to me. He gave me hot water, so I could wash off the blood, and something to drink. [...] The farm hand gave up his bed for me and the next day he took me back to the ghetto. ${ }^{803}$

Let us continue the theme of Christian behavior. In the case below, the sight of unfortunate fugitives from the mass grave not only caused tears of emotion. The host also gave them protection under his roof, shared his food, watched over their safety:

[...] we knocked on the door of the first hut, I remember well the owner who let us in and who cried terribly: 'What'd they do?' Above all, he gave us water to wash off the blood, and then bread with pork fat, he put us in the home, not in the barn, he stood on watch all night, and in the morning he led us along the winding road to Słonim." ${ }^{\text {"804 }}$

Bullet wounds could be washed and would heal. But those who exited the grave carried with them an indelible stigma - the "trauma of revival." For the people around them, they were now different, irretrievably altered. One could not cross the border between life and death with impunity. One had to pay for it with bitterness that comes with useless knowledge, with alienation, and with the stigma of madness. Folk imagination classified these survivors as specters and lunatics - as dangerous beings, since they had dwelled at the border of two worlds, in between. In one of his short stories, Bogdan Wojdowski drew the following scene:

Franek swears that he saw a naked specter again today at dawn. A specter, just that.

"A specter, my foot. A Jewess escaped from a pit and people saw her at Babice"

"I'm telling you it was a specter."

"A Jewess!"

"A specter!"

"She escaped from under their shovels and fled naked through the fields." 805

Stealing through the fields, the bloody and naked escapees from the grave were treated like lunatics, though there was no way to determine where their madness began or ended. Artur Schneider told a story about one of those who survived the liquidation of the Dubno Ghetto in October 1942:

The woman had lost her mind. She was walking across the field half-naked, shaking her fist at the bright moon, as if to blame it for what had happened. She wandered around

803 I. Kogan's account, cited by R. Korczak, in Życie i zagłada Żydów polskich, op. cit., 544. 804 S. Szlakman, op. cit., 524. In the published version the host's words "Czto oni zdielali" ("What'd they do?") are left out. See AŻIM 302/155, p. 12 of the manuscript.

805 B. Wojdowski, Mały człowiek, nieme ptasze, klatka i świat. Opowiadania (Warszawa 1975), 68. 
like this for two days until somebody from the village, probably the village administrator, finally notified the police. ${ }^{806}$

We find an excellent study of the trauma of revival in Saul Bellow's novel Mr. Sammler's Planet. The eccentric New York intellectual, Artur Sammler, had once been "marked for death" in German-occupied Poland. He passed through all of the above-described stages in the experience of revival. Together with his wife and a few dozen other people, he stood naked on the edge of a ditch that they had dug themselves. Shots were fired and he tumbled down into a pit. The weight of the falling bodies bore down upon him and his dead wife lying beside him. Somehow he escaped: "Struggling out much later from the weight of corpses, crawling out of the loose soil." ${ }^{807}$ Having dug himself out from under the corpses, he later became a partisan in the woods around Zamość. He carried a gun and began to shoot people himself. Once, he captured a German, disarmed him, ordered him to undress, and then shot him at close range:

$[\ldots]$ that man to Sammler was already underground. He was no longer dressed for life. He was marked, lost. Had to go. Was gone. [...] Sammler pulled the trigger. [...] A second shot went through the head and shattered it. Bone burst. Matter flew out. [...] When he fired his gun, Sammler, himself nearly a corpse, burst into life. ${ }^{808}$

Later he had to flee bullets fired by Polish partisans, who had turned against the Jewish fighters. He found refuge in a tomb. The prewar caretaker of the cemetery hid him inside a family mausoleum and brought him food. Years later, Sammler reflected: "By opening the tomb to me, he let me live." 809

For Sammler, his existence in the tomb is both a wartime memory and a symbol of fate. "Humankind marks certain people for death," against whom "there shuts a door." Sammler belongs to this "written-off category." He is still alive, despite everything, but certain "idiosyncrasies" - as he puts it - remain in him. ${ }^{810}$ Sammler finds it difficult to define his attitude towards himself. What is a person who "has come back from the grave," and who "for quite a long time [...] felt that he was not necessarily human?" 111 What is a person who has been "inside death?" 12 Is he filled with indifference towards the world or with joy

806 A. Schneider, Jak ścigane zwierzę (Lublin 2003), 152-153.

807 Saul Bellow, Mr Sammler's Planet (Penguin Books, 2004), 75.

808 Ibid., 113-115.

809 Ibid., 190.

810 Ibid.

811 Ibid., 95-96.

812 Ibid., 226. 
over the most trivial manifestations of existence? Does he become a pure spirit, completely isolated and liberated from the bonds of Nature, or rather somebody who is particularly sensitive to the material substance of reality and the biological conditions of human life? Sammler is unable to answer these questions. He is a mystery to himself. As an American newspaper correspondent during the Suez Crisis in 1956, he waded through hundreds of corpses in the hot desert sands:

The clothes of the dead [...] were strained by the swelling, the gases, the fluids. [...] In the sun the faces softened, blackened, melted, and flowed away. The flesh sank to the skull, the cartilage of the nose warping, the lips shrinking, eyes dissolving [...]." ${ }^{\text {13 }}$

He looks at the decaying bodies of the Egyptian soldiers as if at his own macabre self-portrait.

Conscious of his otherness, conscious of his deformity ("I am of course deformed. And obsessed" ${ }^{814}$ ), he constructs two metaphors with which he tries to capture the reality of his life after death. One of them is - so to speak telecommunicational in nature. It places emphasis on the contact that never happened - on the bullet missing his temple and death missing life. Once he had stood naked before an open grave:

But somehow he had failed, unlike the others, to be connected. Comparing the event, as mentally he sometimes did, to a telephone circuit: death had not picked up the receiver to answer his ring. Sometimes, when he walked on Broadway today, and heard a phone ringing in a shop when doors were open, he tried to find, to intuit, the syllable one would hear from death. "Hello? Ah, you at last." "Hello."\$15

The second metaphor is built on the trivial experience of an ordinary day:

And had the war lasted a few months more, he would have died like the rest. Not a Jew would have avoided death. As it was, he still had his consciousness, earthliness, human actuality - got up, breathed his earth gases in and out, drank his coffee, consumed his share of goods [...]. In short, a living man. Or one who had been sent back again to the end of the line. Waiting for something. ${ }^{816}$

At the end of the novel, this man who has failed to connect, and who has been sent back to the end of the line, meets a dead friend. The meeting scene takes place in a hospital dissection room, just before the autopsy, and comes in the form of an epiphany. Sammler had never been able to precisely describe his own

813 Ibid., 207.

814 Ibid., 190.

815 Ibid., 112-113.

816 Ibid., 226-227. 
status. To the obsessive question: "They say that you were in the grave once. [...] How was it?" - he always replied: "Let us change the subject." ${ }^{17}$ Now he stands before the body of his friend. He pulls back the sheet covering the man's face, on which "bitterness and an expression of obedience were combined." Sammler understands that his friend has kept "the terms of his contract. The terms which, in his inmost heart, each man knows." For the first time, Sammler discovers the truth he has carried throughout his entire life, snatched from the death pit: "For that is the truth of it - that we all know, God, that we know, that we know, we know, we know." 818 But this knowledge does not belong to the sphere of episteme. It is inexpressible; it comes with the removal of the grave cloth from the face of a revived man, one who cannot, or will not, say anything.

It was no victory to escape a mass grave of the Second World War; rather it was a deferred sentence. It allowed the intended victim to feel in his temples the joyful pulsing of blood for years to come, but it left him with a permanent stigma of dread and humiliation. It was not a liberation, but rather the bondage of a person trapped between the black pit of death and the blue expanse of life, between apathy and action, between the courage that comes with having passed an impassable border and the fear aroused by the same event. Between dignity, madness and buffoonery. It was an escape to nowhere, one which led a person along the back roads of existence into a sphere of otherness, into a dimension where the order is reversed, into a crevice of existence, into a state of persistent dilemma.

It seems that the experience of surviving one's own execution - that is, surviving one's own death - resembles the experience of torture, and that it creates a similar state of "stigmatization." The alienation felt by those who exited the grave and the alienation felt by those who were tortured have a great deal in common.

Torture is more than physical torment; above all, it destroys the will and the spirit, it strikes at the very core of humanity, because it leads to the destruction of identity, it turns the victim against himself. The deadly enemy is no longer the perpetrator but one's own body; it is one's own body that suffers intolerable pain, and it is one's own body that sends forth the scream that erupts from the tortured one's lips. The victim's scream, which turns into gibberish - it humiliates and degrades the victim; it leads to a place beyond articulated speech, descends into an abyss of animal howling and yelping. The experience of torture, understood

817 Ibid., 155-156.

818 Ibid., 260. 
by me here as a limit experience, leads to the destruction of language. ${ }^{819}$ The victory of pain is based on the separation of the person experiencing pain from everyone else, on rendering him lonely. Pain can be shared with no one; it cannot be talked about, only screamed. Pain resists lingual expression, and in the final analysis it destroys language; it demotes language to the ranks of unarticulated sounds, and it prevents understanding. ${ }^{820}$

In his reflections on torture, Jean Améry also draws our attention to the indescribable nature of pain; it eludes communication. Pain is corporeality itself. Améry wonders:

But maybe it is even more, that is: death: No road that can be travelled by logic leads us to death, but perhaps the thought is permissible that through pain a path of feeling and premonition can be paved to it for us. ${ }^{821}$

The experience of death thus lifts the victim beyond the border of life and death and makes an indelible mark. Améry put forward the hypothesis that:

[...] torture, through which we are turned into body by the other, blots out the contradiction of death and allows us to experience it personally. But this is an evasion of the question. We have for it only the excuse of our own experience and must add in explanation that torture has an indelible character. Whoever was tortured, stays tortured. Torture is ineradicably burned into him, even when no clinically objective trace can be detected..$^{822}$

It is worth citing one more of Améry's thoughts in the context of our reflections on those who exited the grave and remain forever separated from people and the world:

Whoever has succumbed to torture can no longer feel at home in the world. The shame of destruction cannot be erased. Trust in the world, which already collapsed in part at the first blow, but in the end, under torture, fully, will not be regained. That one's fellow man was experienced as the antiman remains in the tortured person as accumulated horror. It blocks the view into a world in which the principle of hope rules. One who was martyred is a defenseless prisoner of fear that henceforth reigns over him. Fear - and

819 See W. Sofsky, “Tortury," in Sofsky, Traktat o przemocy, trans. M. Adamski (Wrocław 1999), 92-96.

820 See Elaine Scarry, The Body in Pain. The Making and Unmaking of the World (New York; Oxford 1985), 4-6.

821 Jean Améry, At the Mind's Limits: Contemplations by a Survivor on Auschwitz and Its Realities, trans. Sidney Rosenfeld and Stella P. Rosenfeld (Indiana University Press, 1980), 33-34.

822 Ibid., 34. 
what is called resentments. They remain, and have scarcely a chance to concentrate into a seething, purifying thirst for revenge." 823

Jolanta Brach-Czaina has written about a kind of elevation of those who became the victim of what she calls negative tragedy. An attack of annihilating and unrelenting evil, of brutality that causes paroxysms of fear, sets in motion within us an irreversible process of destruction, one against which we cannot defend ourselves. This destruction "has no justification in either actions or choices; it is beyond the reach of the persecuted one's will." 824 In such situations there emerge what Brach-Czaina calls the "limit properties of existence." ${ }^{25}$ Following the trail blazed by Brach-Czaina, not only am I able to get at the heart of my reflections on how those who had survived their execution were marked, but I also enter that sphere of limit experiences that form the subject of my entire book.

We are powerless in the face of such evil aggression, so understood. We know that there is no way out, no return, no hope at all. There is only failure. There are only pits dug with the victims' own hands and rifles aimed at heads. Such evil aggression divides an individual's fate "into two incommensurable parts: before and after the event. If a person survives the event." 826 The fates of those who survived gun shots fired by execution squads, and who managed to exit the grave, were similarly divided.

A condition for true tragedy, Brach-Czaina argues, is absurdity and randomness. Which is why we are not able to reconcile ourselves with it, we cannot accept it. It is a tragedy without catharsis. It is negative tragedy, in which evil is triumphant, and this triumph, though unnecessary, is irreversible. It is accompanied by desperation and a sense of guilt on the part of the victims. By the victims' loneliness and stigmatization. "Tragedy cuts off and sets apart the person who has experienced it; it places the victim in a space to which no one else has access." $\$ 27$ Negative tragedy catches the victims in a trap, it imposes itself completely, it renders defense impossible. The victims put up no resistance, since resistance is impossible. They can only gaze at the destruction of themselves, of their relatives, of their world. But destruction of this kind reveals a particular axiological situation - the author argues - since "the ones affected by the brutality of criminal

823 Ibid., 40.

824 J. Brach-Czaina, "Nietykalność," in Brach-Czaina, Szczeliny istnienia [Cracks in Existence] (Warszawa 1992), 153.

825 Ibid., 140.

826 Ibid.

827 Ibid., 146. 
murder not as a result of their own guilt, against their own will, and having nothing to do with their own actions and attitudes, become part of an event that opens a view onto a fundamental value of existence." 828 Brach-Czaina's philosophical argument leads us to the conclusion that "absurd cruelty is an existential shock that brings about awareness," 829 that reveals the value of existence as "a tragic value, because it binds the invaluable with the promise of annihilation." 830 Paradoxically, the negative experience of cruelty, which crushes the victims and ends their existence, affirms their existence. "In the face of the cruel event, our existence grapples with itself, becomes stronger, grows. [...] With every blow, the tormentor singles out the tormented, lifts them beyond their selves, while he himself becomes smaller. [...] Meanwhile, those subjected to cruelty become inviolable, untouchable." ${ }^{831}$ They are stigmatized, marked, exalted, cut off from others, doomed to remain in existential loneliness, from which there is no way out. Around them is an "empty circle" - a sign of "the presence of fate's anointed one." 832

The experience described in the accounts cited above is a traumatic one. But Elias Canetti seems to think otherwise. Referring to the "stories of people who come back to life in the midst of a heap of the dead," he claims that "such people tend to think of themselves as invulnerable." 833 It is difficult to agree with this claim. Survivors who have told us their stories gained no sense of triumph over death, or ecstatic affirmation of life, from their having exited the grave. Quite the contrary. Some of them, like Tima Kac, envied the dead for the fact that they were already liberated from horror. Others, like Ryfka Joselewska, prayed for death, begging God to open the grave once again so it would devour her. Perhaps we can understand Canetti's thinking based on the two different visions of Lazarus from the apocryphal literature presented above. While Eugene O’Neill depicted

828 Ibid., 158.

829 Ibid., 162.

830 Ibid., 163.

831 Ibid., 164-165.

832 Ibid., 167. This analysis of the victims of negative tragedy and their condition is remarkably similar to the descriptions of survivor syndrome from the Holocaust. Henryk Grynberg pointed this out in his essay "Nowoczesne wielkie zło," which broadly examines the chapters in Brach-Czaina’s book "Święte zło" and "Nietykalność," and which states that she had offered "the most intelligent answer to the agonizing question - what was the Holocaust? Despite the fact that she never mentions Jews." H.Grynberg, "Nowoczesne wielkie zło," Res Publika Nowa 5 (1994), 10.

833 Canetti, Crowds and Power, 247. 
the euphoria of revival, Karel Čapek presented the trauma of revival. The author of Crowds and Power seems to have followed in the footsteps of O'Neill. But I find myself closer to the Lazarus of Čapek's apocryphal account - torn, uncertain, and so very fearful of dying a second time.

One final set of comments. Mass killing has not come to an end; execution squads had not gone silent; and machine guns, machetes, knives, crowbars and common sticks have not stopped their work. Rwanda, 1994. "When you 'clear the bush', a few weeds always escape the blade." These are words told to the author of a book on the Rwandan genocide by someone whose niece had been "macheted, then stoned, then dumped in a latrine, only to get up each time and stagger away [...]." 834 Srebrenica, 1995. Evidence of the massacre of 2,000 men was provided by five survivors of a death pit. A young man told of another, less well-known execution in the town of Nova Kasaba in Bosnia-Herzegovina. When the Bosnian Serbs opened fire, he fell - injured only in the leg - and rolled down into the ditch with the others who had been shot. ${ }^{835}$ Kosovo, the village of Izbica, where a massacre of 120 Albanians took place in 1999. Those who survived the execution described the entry of Serb units into the village, the division of men and boys from women, the herding of the condemned into already-dug pits, shots fired from automatic weapons. The injured - still alive and crushed by corpses - waited for the soldiers to leave before they crawled out of the grave." 836

The world's slaughterhouse remains in good working order. And there are still those whose execution was not completed, who escape the death that had been assigned to them, and who crawl up from under the pile of bodies, in order to give testimony. And the tragic stigmatization and elevation of those who have exited the grave continues.

834 Philip Gourevitch, We Wish to Inform You That Tomorrow We Will be Killed With Our Families: Stories from Rwanda (Picador, 1999), 123.

835 http://www.csmonitor.com/atcsmonitor/specials/bosnia/p-1024.html (accessed 25 May 2008).

836 See http://web.amnesty.org/library/Index/ENGEUR700791999?open\&of = ENG-2EU (accessed 25 May 2008). 


\section{Epilogue}

I am aware that, having conducted research into limit experiences for so long, I have grown used to visions of horror and the macabre. But this does not mean that I have become indifferent and insensitive to them. I remain constantly in search of a language with which I can talk about this subject: without pathos, but also without analytical coldness; without an excess of emotion, but also without cynicism, perversity, or unhealthy fascination. I try not to succumb to such fascination, even though we know how attractive and alluring evil can be. I try not to succumb to the temptation to aestheticize evil, horror, and the macabre. Such, at least, have been my intentions. It is for the reader to decide the extent to which I have succeeded in resisting these temptations. I realize that I move between the poles of appropriateness and inappropriateness, but this is a risk I have taken upon myself consciously.

Writing this book has been a risky venture. Research into limit experiences, for the scholar himself, is a kind of limit experience. It runs up not only against cognitive boundaries, but also against barriers of expression and articulation. It also encounters a great ethical challenge.

Trauma is not the past; rather, it continuously "happens" here and now. It plays itself out again and again, which is why it does not entirely submit to the rigor of academic discourse. To some extent, the same holds true for the act of writing about trauma. It penetrates the scholar's world, and he must defend himself against it. For me, writing this book has been an extremely important cognitive experience. It has served as a path to the acquisition of self-knowledge, just as it has been - simply put - a challenge: to take the risk of understanding human limit experiences, and the risk of understanding oneself. 



\section{Bibliography}

\section{Bibliographic Abbreviations}

Archiwum Ringelbluma - Archiwum Ringelbluma. Getto warszawskie lipiec 1942 - styczeń 1943. Ed. R. Sakowska. Warszawa 1980.

Cywilna obrona Warszawy - Cywilna obrona Warszawy we wrześniu 1939

r. Dokumenty, materiały prasowe, wspomnienia i relacje. Collected and ed. by

L. Dobroszycki, M. Drozdowski, M. Getter, A. Słomczyński. Warszawa 1964.

Exodus Warszawy - Exodus Warszawy. Ludzie i miasto po powstaniu 1944. Vol.

2: Pamiętniki. Relacje. Collected and ed. by M. Berezowska, E. Borecka, K.

Dunin-Wąsowicz, J. Korpetta, H. Szwankowska. Warszawa 1993.

Ludność cywilna - Ludność cywilna w powstaniu warszawskim. Vol.

1: Pamiętniki. Relacje. Zeznania. Część 1. Collected and ed. By M. M.

Drozdowski, M. Maniakówna, T. Strzembosz. Warszawa 1974.

Obrona Warszawy - Obrona Warszawy 1939 we wspomnieniach. Collected and ed. by M. Cieplewicz, E. Kozłowski. Warszawa 1984.

"Pamiętniki" - Archiwum Żydowskiego Instytutu Historycznego; zespół "Pamiętniki".

Pamiętniki z getta warszawskiego - Pamiętniki z getta warszawskiego. Fragmenty i regesty. Updated second edition. Ed. M. Grynberg. Warszawa 1993.

Petnić stużbę - Petnić służbę... Z pamiętników i wspomnień harcerek Warszawy 1939-1945. Ed. A. Zawadzka, Z. Zawadzka. Warszawa 1983.

Polacy - Żydzi 1939-1945 - Polacy - Żydzi 1939-1945. Wybór źródeł. Ed. A. K. Kunert. Warszawa 2001.

"Relacje" - Archiwum Żydowskiego Instytutu Historycznego; zespół "Relacje z czasów Zagłady".

Ring I - Archiwum Żydowskiego Instytutu Historycznego; Archiwum Ringelbluma częśś I.

Ring II - Archiwum Żydowskiego Instytutu Historycznego; Archiwum Ringelbluma częśś II.

Wśród koszmarnej zbrodni - Wśród koszmarnej zbrodni: notatki więźniów Sonderkommando, trans. from the Yiddish and French. Manuscripts selected and ed. by J. Bezwińska, D. Czech. Second expanded edition. Oświęcim 1975.

Życie i zagłada Żydów - Życie i zagłada Żydów polskich 1939-1945. Relacje świadków. Ed. M. Grynberg, M. Kotowska. Warszawa 2003. 


\section{Sources}

[author unknown]. Wrażenia z pokoika śmierci. Ring 1/1030.

[author unknown]. "Wspomnienia pracownika Gminy i Judenratu w Warszawie (wrzesień-październik 1939).” Biuletyn ŻIH 93, no. 2 (1976).

Adelson, A. and R. Lapides, eds. Łódź Ghetto. Inside a Community under Siege. New York, 1989.

Aksamitowski, A. "Działalność władz cywilnych Warszawy." In Warszawa we wrześniu 1939 roku. Obrona i życie codzienne. Ed. Cz. Grzelak. Warszawa 2004.

Améry, Jean. At the Mind's Limits: Contemplations by a Survivor on Auschwitz and Its Realities. Trans. Sidney Rosenfeld and Stella P. Rosenfeld. Indiana University Press 1980.

Archiwum Prezydenta Warszawy Stefana Starzyńskiego. Ed. and intro. by M. M. Drozdowski. Warszawa 2004.

Auerbach, R. Dziennik getta (entries: 6 III 1942 - 6 VI 1942). Ring I/641.

Auerbach, R. "Lament rzeczy martwych," Przełom 2 (1946).

Auerbach, R. Pamiętnik z getta (entries: 4 VIII 1941 - 13 II 1942). Ring I/654.

Bambus, T. and S. Bogaczewicz. "Człowiek z piętnem wyroku śmierci." Nowe Życie. Dolnoślaskie Pismo Katolickie, February 2002.

Barbusse, Henri. Under Fire: The Story of a Squad. BBBZ Books 2010.

“Barykada Wolności. 30 November 1941.” In Polacy - Żydzi 1939-1945.

Bauman, J. Zima o poranku. Opowieść dziewczynki z warszawskiego getta. Poznań 1999.

Bellow, Saul. Mr Sammler's Planet. Penguin Books 2004.

Berland, M. Dni długie jak wieki. Warszawa 1992.

Berman, A. and B Berman. "Zagłada getta w Warszawie. (Szkic kronikarski)." Biuletyn ŻIH. 45-46 (1963).

Bezwińska, Jadwiga. Amidst a Nightmare of Crime: Manuscripts of Prisoners in Crematorium Squads Found at Auschwitz. H. Fertig, 1973.

Bialik, H. N. “The City of Slaughter." In Complete Poetic Works of Hayyim Nahman Bialik. vol. 1. Ed. Israel Efros. New York, 1948, 129-143.

Biuletyn Informacyjny. Część III, przedruk rocznika 1944, konspiracja. "Przegląd Historyczno-Wojskowy.” Rok IV (LV) nr specjalny 3 (2000). Warszawa 2003.

Biuletyn Informacyjny. Część IV, przedruk roczników 1944-1945. Powstanie warszawskie i konspiracja. "Przegląd Historyczno-Wojskowy." Nr specjalny 4 (205), Warszawa 2004. 
Blady-Szwajger, Adina. I Remember Nothing More: the Warsaw Children's Hospital and the Jewish Resistance. Trans. Tasja Darowska and Danusia Stok. Simon \& Schuster 1992.

Blättler, F. [in fact, F. Mawick]. Warszawa 1942. Zapiski szofera szwajcarskiej misji lekarskiej. Trans. K. Bartos. Ed. T. Szarota. Warszawa 1982.

Bobkowski, A. Szkice piórkiem. Warszawa 1995.

Borwicz, M. Spod szubienicy w teren. Paryż 1980.

Brandys, K, Miasto niepokonane (first edition, 1946). Quote from edition IX. Warszawa 1962.

Bryskier, H. Żydzi pod Swastyka, czyli getto w Warszawie w XX wieku. Warszawa 2006.

Buczkowski, L. "Powstanie na Żoliborzu” [dziennik powstańczy]. Regiony 3/4 (1992).

Buzy, T. "Relacje" 301/6001.

Čapek, Karel. "Lazarus.” In Apocryphal Tales. Trans. Norma Comrada. Catbird Press 1997.

Cazin, P. Humanista na wojnie. Trans. and afterword by K. Eberhardt. Warszawa 1957.

Choroba głodowa. Badania kliniczne nad głodem wykonane w getcie warszawskim z roku 1942. Warszawa 1946.

Cohen, Abraham. Everyman's Talmud: The Major Teachings of the Rabbinic Sages. Schocken 1995.

Cyrańska, M. Accounts in Ludność cywilna.

Czarkowski, A. Accounts in Exodus Warszawy.

Czerniaków, A. Adama Czerniakowa dziennik getta warszawskiego 6 IX 1939-23 VII 1942. Ed. M. Fuks. Warszawa 1983.

Cyprys, Ruth Altbeker. A Jump for Life: A Survivor's Journal from Nazi-Occupied Poland. New York: Continuum, 1997.

Dąbrowska, M. Dzienniki 1933-1945. Vol. 2. Ed. and intro. by T. Drewnowski. Warszawa 1988.

Delacroix, E. Dziennik, część pierwsza (1822-1853), część druga (1854-1863).

Ed. A. Joubin. Trans. J. Guze and J. Hartwig. Wrocław 1968.

Disasters of War: Callot, Goya, Dix. Published on the occasion of "Disaster of

War: Callot, Goya, Dix, a National Touring Exhibition" organized by the Hayward Gallery. London 1998.

Dłużniewska, S. Pamiętnik warszawski. Warszawa 1965. 
Documents on the Holocaust. Selected Sources on the Destruction of the Jews of Germany and Austria, Poland and the Soviet Union. Ed. Y. Arad, I. Gutman, A. Margolit. London; Jerusalem 1999.

Dzieci żydowskie oskarżaja. Warszawa 1993.

Edelman, Marek. The Ghetto Fights. American Representation of the General Jewish Workers' Union of Poland 1946.

Ehrenburg, Ilya and Vasily Grossman. The Complete Black Book of Russian Jewry. Trans. and ed. David Patterson. Transaction Publishers 2003.

Eliach, J. Hasidic Tales of the Holocaust. New York 1988.

Ernest, S. O wojnie wielkich Niemiec z Żydami Warszawy 1939-1943. Ed. M. Młodkowska. Warszawa 2003.

Filipowicz, K. “Krajobraz, który przeżył śmierć." In Krajobraz niewzruszony. Filipowicz. Warszawa 1956.

Fiszel, B. "Relacje" 301/665. Trans. from the Yiddish by J. Jakubowska.

Galka, W. Relacje in Ludność cywilna.

Glowinski, Michal. The Black Seasons. Trans. Marci Shore. Northwestern University Press 2005.

Goetel, F. Czasy wojny [first edition: London 1955]. Gdańsk 1990.

Goldin, Leyb. "Chronicle of a Single Day," In, ed. The Literature of Destruction. Jewish Responses to Catastrophe. Ed. David G. Roskies. Philadelphia 1988.

Goldman. "Relacje” 301/1419.

Goldszer, B. "Relacje” 301/167. Trans from the Yiddish by A. Bielecki.

Greif, Gideon. We Wept without Tears: Testimonies of the Jewish Sonderkommando from Auschwitz. Yale Univ. Press 2014.

Grossman, M. My Secret Camera. Life in the Lodz Ghetto. Photographs by Mendel Grossman. San Diego 2000.

Grossman, M. With the Camera in the Ghetto. Ed. Z. Szner and A. Sened. New York 1977.

Grünberg, F. [no title]. "Pamiętniki," 302/97, fragments in Pamiętniki z getta warszawskiego.

Grynberg, H. Dzieci Syjonu. Warszawa 1994.

Grynberg, H. Memorbuch. Warszawa 2000.

Grynberg, Michał, ed. Words to Outlive Us: Eyewitness Accounts from the Warsaw Ghetto. Trans. Philip Boehm. Picador 2002.

Guillain, R. I Saw Tokyo Burning. An Eyewitness Narrative from Pearl Harbor to Hiroshima. Garden City 1981.

Gurewicz, M. “Relacje” 301/2398. 
Hachiya, Michihiko. Hiroshima Diary: The Journal of a Japanese Physician. The University of North Carolina Press 1995.

Heberer, Patricia. Children during the Holocaust. AltaMira Press 2011.

Hirszfeld, L. The Story of One Life. Trans. Marta A. Balińska. University of Rochester Press 2010.

Höss, Rudolf, Pery Broad, Johann Paul Kremer. KL Auschwitz Seen by the SS. Interpress Publishers 1972.

Irving, David. The Secret Diaries of Hitler's Doctor. Focal Point 2009. Irzykowski, K. Dziennik tom 2: 1916-1944. Ed. A. Lama Kraków 1998. Iwańska A. and J. Gralewski. Wojenne odcinki (Warszawa 1940-1943). Warszawa 1990.

Iwaszkiewicz, J. Dzienniki 1911 - 1955. Ed. A. Papieska, R. Papieski. Warszawa 2007.

Jachwidowicz, Los Żydów w Słonimiu w czasie niemieckiej okupacji. "Relacje" 301/1972.

Janowski, J. “Dziennik zastępcy dowódcy obrony Warszawy w 1939 roku.” In Obrona Warszawy.

Joselewska, R. “Testimony at the Eichmann trial, 8 May 1961.” In The Holocaust. The Jewish Tragedy. M. Gilbert. London 1990.

Jünger, Ernst. Sämtliche Werke - Band 3: Tagebücher III: Strahlungen II. Klett-Cotta 1978.

Jünger, Ernst. Storm of Steel. Trans. Michael Hofmann. Penguin 2004.

Katzenelson, Itzhak. Pieśń o zamordowanym żydowskim narodzie. Trans., notes and intro. by Ficowski. Warszawa 1986.

Kamper, W. ("Sławka"). Quote from Petnić stużbę.

Kaplan, Chaim. Scroll of Agony. The Warsaw Diary of Chaim A. Kaplan. Trans. A. I. Katsh. Bloomington 1999.

Kilpatrick, M. Car Crashes and Other Sad Stories. Taschen 2000.

Kirkor-Kiedroniowa, Z. Wspomnienia. Vol. III. Kraków 1989. Quote from KARTA 45 (2005).

Kisch, Egon Erwin. "Schreib das auf, Kisch!": Das Tagebuch von Egon Erwin Kisch. Berlin: Erich Reiss Verlag 1930.

Klemperer, Victor. I Will Bear Witness 1942-1945: A Diary of the Nazi Years. Trans. Martin Chalmers. Modern Library 2001.

Klemperer, Victor. Language of the Third Reich: LTI: Lingua Tertii Imperii. Bloomsbury Academic 2006.

Klukowski, Z. Zamojszczyzna. Vol. 1: 1918-1943. Warszawa 2007. 
Korczak, J. “Pamiętnik.” In Pisma wybrane. Vol. 4, [selected by A. Lewin, ed. and notes by M. Falkowska, M. Kopczyńska-Ciesielska, I. Olecka]. Warszawa 1986.

Kragen, W. “Kronika dni wrześniowych.” Odrodzenie. 1946, nr 36.

Krall, Hanna. Shielding the Flame: an Intimate Conversation with Dr. Marek Edelman, the Last Surviving Leader of the Warsaw Ghetto Uprising. Trans. Joanna Stasinska and Lawrence Weschler. Henry Holt and Co. 1986.

Krawczyńska, J. Zapiski dziennikarki warszawskiej 1939-1947. Warszawa 1971.

Kutrzeba, T. Ze wspomnień dowódcy armii "Poznañ". In Obrona Warszawy Laffin, John, ed. Letters from the Front 1914-1918. London 1973.

Landau, F. "Relacje” 301/1267. Trans. from the Yiddish by J. Jakubowska. Landau, L. Kronika lat wojny i okupacji. Text prepared for publication by Z. Landau and J. Tomaszewski. Vols. I-III. Warszawa 1962-1963.

Lanzmann, Claude. Shoah: The Complete Text of the Acclaimed Holocaust Film. Intro. Simone de Beauvoir. Da Capo Press 1995.

Letters from a Lost Generation. First World War Letters of Vera Brittain and Four Friends: Roland Leighton, Edward Brittain, Victor Richardson, Geoffrey Thurlow. Ed. A. Bishop and M. Bostridge. Abacus 1999.

Lewicki, F. “Różne bywają dachy nad głową.” In Niepiękne dzielnice. Reportaże o międzywojennej Warszawie. Ed. J. Dąbrowski, J. Koskowski. Warszawa 1964.

Lewin, Abraham. "Dziennik z getta warszawskiego." Biuletyn ŻIH. Trans. A. Rutkowski. 1956, nr 19-20; 1957, nr 21-24; 1958, nr 25.

Lewin, Abraham. A Cup of Tears: A Diary of the Warsaw Ghetto. Fontana 1988.

Lipiński, W. Dziennik: wrześniowa obrona Warszawy 1939 r. Warszawa 1989.

Lorentz, S. Accounts in Cywilna obrona Warszawy.

Lukrec, H. Piszcie kroniki w ogniu. In Cywilna obrona Warszawy.

Mackiewicz, J. "Dymy nad Katyniem." In Mackiewicz, Fakty, przyroda i ludzie. London 1993.

Mackiewicz, J. Sprawa pułkownika Miasojedowa. London 1989.

Makower, H. Pamiętnik z getta warszawskiego. Październik 1940 - styczeń 1943. Ed. N. Makowerowa. Wrocław 1987.

Małgorzewski, J. “Polskie Radio podczas obrony Warszawy,” In Cywilna obrona Warszawy.

Mawult, J. Wszyscy równi.... Biuletyn ŻIH. No. 62 (1967).

Márai, Sándor. Dziennik (fragmenty). Trans. T. Wornowska. Warszawa 2004. 
Memoriał dated 31 March 1942. Patronat Opieki nad Zwłokami Ubogich Żydów "Haławajat Hamet," Ring II 119.

Merenholc, H. "Nie żaluję ani jednego dnia spędzonego w getcie" Conversation with Helena Merenholc in Engelking. Na łace popiołów. Ocaleni $z$ Holocaustu. Warszawa 1993.

Miedzyrzecki, Feigele Peltel [Meed]. On Both Sides of the Wall: Memoirs from the Warsaw Ghetto. Holocaust Library, Jan. 1, 1979.

Milch, B. Testament. Warszawa 2001.

Najberg, L. Ostatni powstańcy getta. Warszawa 1993.

Nałkowska, Z. Dzienniki. V. 1939-1945. Ed, intro., and commentary by H. Kirchner. Warszawa 1996.

Nałkowska, Z. Hrabia Emil. Warszawa 1977.

Nocuj, M. and W. Pięciak. Musiałem myśleć jak maszyna. Tygodnik Powszechny, 13 lutego 2005.

O’Neill, Eugene. Lazarus Laughed. In O’Neill, Plays. Vol. 1. New York 1951.

Oberski, J. Childhood. Trans. Ralph Manheim. Penguin 2014.

Obrona Warszawy. Lud polski w obronie stolicy (wrzesień, 1939 roku). New York 1942.

Passenstein, M. “Szmugiel w getcie warszawskim,” Biuletyn ŻIH 26 (1958).

Petersowa, Z. Wrzesień Warszawy 1939. Reportaż. Warszawa 1946.

Pragłowski, A. “Ze wspomnień szefa sztabu armii 'Warszawa.” In Obrona Warszawy. "Prawda," periodical of the Front Odrodzenia Polski. Ed. Z. Kossak, issue for October-November 1943.

Prorok, L. "Notatnik powstańczy." In Prorok. Kepi wojska francuskiego. Warszawa 1973.

"Raport zjednoczonych organizacji podziemnych getta dla Rządu Polskiego w Londynie i Rządów Sprzymierzonych 'Likwidacja żydowskiej Warszawy"' In Archiwum Ringelbluma.

Regulska, H. Dziennik z oblężonej Warszawy. Wrzesień - październik - listopad 1939 r. Warszawa 1978.

Regulski, J. Straż Obywatelska. Wrzesień 1939 r. In Cywilna obrona Warszawy. Remarque, Erich Maria. All Quiet on the Western Front. Trans. A W. Wheen. Ballantine Books 1987.

Rembek, S. Dziennik okupacyjny. Warszawa 2000.

Ringelblum, Emanuel. Kronika getta warszawskiego: wrzesień 1939 - styczeń 1943. Intro. and ed. A. Eisenbach. Trans. from the Yiddish A. Rutkowski. Warszawa 1983. 
Ringelblum, Emanuel. Notes from the Warsaw Ghetto: The Journal of Emanuel Ringelblum. Ed. and trans. Jacob Sloan. McGraw-Hill 1958.

Ringelblum, Emanuel. Polish-Jewish Relations during the Second World War. Trans. Dafna Allon, Danuta Dąbrowska, Dana Keren. Northwestern University Press 1974.

Rola-Arciszewski, S. Wrzesień 1939. In Obrona Warszawy.

Ross, H. Łódź Ghetto Album. Photographs by Henryk Ross. London 2004.

Rotgeber, K. Pamiętnik. In "Pamiętniki”, 302/48.

Rotsztejn, L. "Relacje" 301/77. Trans. from the Yiddish A. Bielecki.

Rotszyld, P. Account from the Yad Vashem Archive, 033/438.

Rubin, Winicer A. "Relacje" 301/663. Trans. from the Yiddish J. Jakubowska.

Schmidt, L. Cudem przeżyliśmy czas zagłady. Kraków 1983.

Schneider, A. Jak ścigane zwierzę. Lublin 2003.

Sierakowiak, Dawid. The Diary of Dawid Sierakowiak: Five Notebooks from the Lodz Ghetto. Ed. Alan Adelson. Trans. Kamil Turowski. Oxford University Press; Reprint edition 1998.

Sieroszewski, W. Dziennik (29.11.1938-31.12.1939). Selected and prepared for publication by A. Lam. In Sieroszewski. Dzieła. vol. XX, part 2. Kraków: Varia 1966.

Singer, O. Przemierzając szybkim krokiem getto... Reportaże i eseje z getta łódzkiego. Trans. K. Radziszewska. Łódź 2002.

Speer, Albert. Inside the Third Reich: Memoirs. Trans. Richard and Clara Winston. Simon \& Schuster 1970.

Srokowski, S. Zapiski - dziennik 1 IX 1939 - 29 VIII 1944. Archiwum PAN, sygn. III, 22.

Steinkohl, H. "Relacje” ŻIH 301/1396.

Stempowski, J. Od Berdyczowa do Lafitów. Ed., selected and preface by A. S. Kowalczyk. Wołowiec 2001.

Stern, J. [interview conducted by M. A. Potocka]. Odra 11 (1988).

Strug, A. “Klucz przepaści.” In Klucz otchłani.Strug. Warszawa 1957.

Szac-Wajnkranc, N. Przeminęło z ogniem. Pamiętnik. Warszawa 1947.

Shalamov, Varlam. Kolyma Tales. Trans. John Glad. Penguin Classics 1995.

Szlakman, S. "Pamiętniki," 302/155.

Szpilman, Wladyslaw. The Pianist: The Extraordinary True Story of One Man's Survival in Warsaw, 1939-1945. Trans. Anthea Bell. Picador 2000.

Święcka-Skoczkowa, H. Account recorded in 1958 r. In Cywilna obrona Warszawy 
Tomaszewski, T. “Byłem szefem Sztabu Obrony Warszawy w 1939 roku.” In Obrona Warszawy 1939.

Traciewicz, K. Jom Kipur. Warszawa 1992.

Vonnegut, Kurt. Slaughterhouse-Five: A Novel. Dial Press Trade Paperback; Reissue edition 1999.

Wiernik, Jankiel. A Year in Treblinka: An Inmate Who Escaped Tells the Day-today Facts of One Year of His Torturous Experience. American Representation of the General Jewish Workers' Union of Poland 1945.

Wiesel, Elie. Night. Trans. Marion Wiesel. Hill \& Wang 2006.

Winderbaum, E. Likwidacja Poniatowej. Relacja 2209/118-1, Yad Vashem Archive.

Wojdowski, B. Chleb rzucony umartym. Warszawa 1981.

Wojdowski, B. Mały człowiek, nieme ptaszę, klatka i świat. Opowiadania. Warszawa 1975.

Wojdysławski, Refleksje z okresu okupacji (1939-1942). Archiwum ŻIH, Ring/I, $489,28$.

Wyka, K. Życie na niby. Pamiętnik po klęsce. Kraków 1984.

Wyszyński, F. Dziennik z lat 1941-1944. Ed. J. Grabowski and Z. R. Grabowski. Warszawa 2007.

Zawadzki, A. W. Account recorded in 1946, quote from: Cywilna obrona Warszawy

Zeremba, Z. Wojna i konspiracja [first edition, London 1957]. Kraków 1991.

Żeromski, S. Charitas. Warszawa 1974.

Żywulska, K. Pusta woda. Warszawa 1963.

\section{Secondary Sources}

Addison, P. and J. A. Crang, eds. Firestorm. The Bombing of Dresden 1945. London 2006.

Akhmatova, Anna. The Complete Poems of Anna Akhmatova. Ed. Roberta Reeder. Trans. Judith Hemschemeyer. Zephyr Press 2000.

Andrzejewski, M. "Bombardowanie niemieckich miast w latach II wojny światowej przez brytyjskie i amerykańskie lotnictwo. Zarys problematyki," Dzieje Najnowsze 4 (2007).

Ankersmit, F. R. “The Linguistic Turn: Literary Theory and Historical Theory." In Historical Representation. Stanford: Stanford University Press 2001.

Ankersmit, F. R. Narracja, reprezentacja, doświadczenie. Studio z teorii historiografii. Ed. and intro. E. Domańska. Kraków 2004. 
Ankersmit, F. R. “The Postmodernist 'Privatization' of the Past” [chapter 5]. In. Historical Representation. F. R. Ankersmit. Stanford: Stanford University Press 2001.

Ankersmit, F. R. "In Praise of Subjectivity." In Historical Representation, 80.

Ankersmit, F. R. "Remembering the Holocaust: Mourning and Melancholia." In Historical Representation. Stanford: Stanford University Press 2001.

Ankersmit, F. R. Sublime Historical Experience. Stanford: Stanford University Press 2005.

Antropologia śmierci. Myśl francuska. Selected and trans. by S. Cichowicz and J. M. Godzimirski. Warszawa 1993.

Applebaum, Anne. Gulag: A History. Anchor Books 2004.

Arendt, Hannah. Eichmann in Jerusalem: A Report on the Banality of Evil. Viking 1963.

Aries, Philippe. The Hour of Our Death: The Classic History of Western Attitudes toward Death over the Last One Thousand Years. Trans. Helen Weaver. Vintage 2008.

Arnheim, R. The Genesis of a Painting. Picasso's Guernica. Berkeley 1973.

Augustine of Hippo, St. The City of God. Trans. Marcus Dods. Hendrickson Pub. 2009.

Bachelard, Gaston. The Psychoanalysis of Fire. Trans. Alan C. M. Ross. Beacon Press 1987.

Bachórz, J. "Karta z dziejów zdrowego rozsądku, czyli o fizjonomice w literaturze." Teksty 2 (1976).

Bailey, R.H. and the editorial team of Time-Life Books. Wojna nad Europa. Trans. S. Kędzierski. Warszawa 2000.

Bakke, M. Ciało otwarte. Filozoficzne reinterpretacje kulturowych wizji cielesności. Poznań 2000.

Bakula, B. [review of Klemperer's Language of the Third Reich: LTI]. Pamiętnik Literacki 4 (1985).

Baraniewski W. "Ideologia w architekturze Warszawy okresu realizmu socjalistycznego." Rocznik Historii Sztuki 22 (1996).

Barthes, Roland. Camera Lucida: Reflections on Photography. Trans. Richard Howard. Hill \& Wang 1980.

Bartoszewski, W. 1859 dni Warszawy. Kraków 1974.

Bataille, Georges. Inner Experience. Trans. Stuart Kendall. Albany: State University of New York Press 2014.

Bataille, Georges. Erotism: Death \& Sensuality. Trans. Mary Dalwood. San Francisco: City Lights Books 1986. 
Baudrillard, Jean. Symbolic Exchange and Death. Trans. Iain Hamilton Grant. Sage 1993.

Baudrillard, Jean. Modernity and the Holocaust. Cornell University Press 1989.

Bauman, Zygmunt. Mortality, Immortality and Other Life Strategies.

Stanford: Stanford University Press.

Bazin, André. "The Ontology of the Photographic Image." Trans. Hugh Gray,

Film Quarterly 13, no.4 (Summer 1960), 4-9.

Benedyktowicz, Z. Portrety “obcego". Od stereotypu do symbolu, Kraków 2000.

Benn, Gottfried. “Negerbraut.” Gedichte. Reclam 1988.

Benn, Gottfried. "Little Aster." Trans. Michael Hofmann. Poetry. March 2011.

Benn, Gottfried. "Beautiful Youth.” Trans. Michael Hofmann. Poetry. March 2011.

Bergander, Götz. Dresden im Luftkrieg: Vorgeschichte, Zerstörung, Folgen. 2nd updated edition. Weimar 1994 (1st edition, 1977).

Berger, John. About Looking. Vintage 1992.

Bernstein T. and A. Rutkowski. "Liczba ludności żydowskiej i obszar przez nią zamieszkiwany w Warszawie w latach okupacji hitlerowskiej." Biuletyn ŻIH 26 (1958).

Bettelheim, Bruno. “The Ultimate Limit." In Surviving and other Essays. New York 1979.

Blanchot, M. The Writing of the Disaster. Trans. A. Smock. New Edition. Lincoln; London 1995.

Bocian, M. Leksykon postaci biblijnych. Trans. from the German J. Zychowicz. Kraków 1995.

Bolecki, W. "Groteska, groteskowość." In Słownik literatury polskiej XX wieku, zespół redakcyjny: A. Brodzka et al. Wrocław 1993.

Bolecki, W., E. Nawrocka, eds. Literackie reprezentacje doświadczenia. Warszawa 2007.

Bolecki, W., R. Nycz, eds. Narracja i tożsamość. Vol. I: Narracje w kulturze; Vol. II: Antropologiczne problemy literatury. Warszawa 2004.

Bourke, J. An Intimate History of Killing. Face-to-Face Killing in Twentieth-Century Warfare. London 2000.

Brach-Czaina, J. Szczeliny istnienia. Warszawa 1992.

Braudel, Fernand. Civilization and Capitalism, 15th-18th Century. Vol. 1: The Structures of Everyday Life. William Collins Sons \& Company Limited 1981).

Braudel, Fernand. The Mediterranean and the Mediterranean World in the Age of Philip II. Vol. 2. Trans. Siân Reynolds. Berkeley: University of California Press 1996. 
Bruner, E. M. "Experience and its Expressions." In The Anthropology of Experience. Eds. V. W. Turner, E. M. Bruner, Urbana 1986.

Buras, P., ed. Spór o niemiecka pamięć. Debata Walser-Bubis. Intro. K. Wóycicki. Wrocław 1999.

Buruma, I. [review of Der Brand]. The Guardian. 22 November 2002.

Canetti, Elias. The Human Province. Seabury Press 1978.

Canetti, Elias. Crowds and Power. Farrar, Straus and Giroux 1984.

Celan, Paul. Selections. Ed. and intro. Pierre Joris. University of California Press 2005.

Cirlot, J. E. Słownik symboli. Trans. I. Kania. Kraków 2000.

Cohen, A. Talmud. Syntetyczny wykład na temat Talmudu i nauk rabinów dotyczących religii, etyki i prawodawstwa. Trans. R. Gromadzka. Warszawa 2002.

Collier, C. The Body as Teacher: From Source of Knowledge to Object of Knowledge. http://www.bu.edu/wcp/Papers/Anth/AnthColl.htm (accessed 23 March 2018).

Curtius, Ernst Robert. European Literature and the Latin Middle Ages. Princeton University Press 2013.

Czermińska, M. Autobiograficzny trójkąt. Świadectwo, wyznanie, wyzwanie. Kraków 2000.

Dąbrowska, D. "Struktura i funkcje administracji żydowskiej w getcie łódzkim.” Biuletyn ŻIH 51 (1966), 46-50.

Delacroix, Eugène. The Journal of Eugène Delacroix. Trans. Walter Pach. New York: Crown Publishers 1948.

Delacroix, Eugène . Dziennik, czesść pierwsza (1822-1853). Wrocław 1968.

Delumeau, Jean. Sin and Fear: The Emergence of the Western Guilt Culture, 13th - 18th Centuries. Trans. Eric Nicholson. Palgrave Macmillan 1990.

Descartes, René. Discourse on Method and Meditations on First Philosophy. Trans. Donald A. Cress. Fourth Edition. Hackett Publishing 1998.

Didi-Huberman, Georges. Images in Spite of All: Four Photographs from Auschwitz. Trans. Shane B. Lillis. University of Chicago Press 2012.

Dobrzyńska, T. Tekst. Próba syntezy. Warszawa 1993.

Domańska E. "Doświadczenie jako kategoria badawcza i polityczna we współczesnej anglo-amerykańskiej refleksji o przeszłości." In Nowoczesność jako doświadczenie: dyscypliny - paradygmaty - dyskursy. Eds. A. ZeidlerJaniszewska, R. Nycz. Warszawa 2008.

Domańska E. "Miejsce Franka Ankersmita w narratywistycznej filozofii historii." In Narracja, reprezentacja, doświadczenie. Studia z teorii historiografii. Ed. E. Domańska. Kraków 2004. 
Domańska E. Mikrohistorie. Spotkania w międzyświatach. 2nd edition, expanded and updated. Poznań 2005.

Domańska E. "Nekrokracja." Konteksty 1-2 (2004).

Drozdowski, M. M. Starzyński: legionista, polityk gospodarczy, prezydent Warszawy. Warszawa 2006.

Dyer, G. War. Toronto 2004.

Dzieje Miejskich Zakładów Komunikacyjnych podczas wojny i okupacji w latach 1939 - 1945, Archiwum Państwowe m. st. Warszawy, Zbiór Rękopisów, sygn. 76.

Easthope, A. “Holokaust i niemożność przedstawienia.” Trans. M. PietrzakMerta. Res Publica Nowa 11 (1997).

Eksteins, Modris. "Rites of War." In Eksteins. Rites of Spring: The Great War and the Birth of the Modern Age. Boston, New York: Houghton Mifflin 1989.

Eliade, M., ed. The Encyclopedia of Religion. Vol. XII. New York 1987.

Engelking, B. “Czas przestał dla mnie istnieć...”. Analiza doświadczenia czasu sytuacji ostatecznej. Warszawa 1996.

Engelking, B. and J. Leociak. Getto warszawskie. Przewodnik po nieistniejacym mieście. Warszawa 2001.

Estreicher, K. Historia sztuki w zarysie, Warszawa; Kraków 1977.

Ewangelia według św. Jana. Wstęp - przekład z oryginału - komentarz. Ed. Father L. Stachowiak. Poznań; Warszawa 1975.

Felman, S. "The Return of the Voice: Claude Lanzmann's 'Shoah"' In Testimonies: Crisis of Witnessing in Literature, Psychoanalysis, and History. Eds. S. Felman and D. Laub. New York 1992.

Film i audiowizualność w kulturze. Zagadnienia i wybór tekstów. Część I: Audiowizualność w kulturze: wprowadzenie. Część II: Film w kulturze. Ed. S. Kuśmierczyk Warszawa 2002.

Fleming, M. "Genocide and the Body Politic in the Time of Modernity." In The Specter of Genocide. Mass Murder in Historical Perspective. Eds. R. Gellately and B. Kieman. New York 2003, 98-99.

Forstner, D. Świat symboliki chrześcijańskiej. Trans. W. Zarzewska et al. Warszawa 1990.

Foucault, Michel. The Birth of the Clinic: An Archaeology of Medical Perception. Vintage 1994.

Friedlander, S. "The 'Final Solution': On the Unease in Historical Interpretation." In Friedlander, Memory, History, and the Extermination of the Jews of Europe. Bloomington 1993.

Friedrich, J. The Fire. The Bombing of Germany 1940-1945. Trans. A. Brown. New York 2008. 
Fujimoto M. “The Great Tokyo Raid: 'Scorched and Boiled and Baked to Death"' The Japan Times, 13 March 2005.

Fussell, Paul. The Great War and Modern Memory. Oxford University Press 2000.

Gadamer, Hans-Georg. Truth and Method. Second, Revised Edition. Trans. revised by Joel Weinsheimer and Donald G. Marshall. New York: Continuum 1993.

Garrett S.A. Ethics and Airpower in World War II. The British Bombing of German Cities. New York 1997.

Gellately, R. and B. Kiernan, eds. The Specter of Genocide. Mass Murder in Historical Perspective. New York 2003.

Gennep, Arnold van. The Rites of Passage: A Classic Study of Cultural Celebrations. Trans. Monika B. Vizedon and Gabrielle L. Caffee. University of Chicago Press 1961.

Gigliotti S. "Unspeakable Pasts as Limit Events: The Holocaust, Genocide, and the Stolen Generations." Australian Journal of Politics \& History 49 no. 2 (June 2003).

Gillies, Sir Harold D. Plastic Surgery of the Face, based on selected cases of war injures of the face, including burns, with original illustrations. London 1920.

Glover, J. Humanity. A Moral History of the Twentieth Century. London 2001.

Głowacka, D. “'Jak echo bez źródła. Podmiotowość jako dawanie świadectwa a literatura Holokaustu." Teksty Drugie 6 (2003).

Głowiński, M. and T. Kostkiewiczowa, A. Okopień-Sławińska, J. Sławiński, Słownik terminów literackich. Ed. J. Sławiński. Wrocław 1998, entry "Metonimia," 308.

Głowiński, M. “Labirynt, przestrzeń obcości." In Mity przebrane. Dionizos. Narcyz. Prometeusz. Marcholt. Labirynt. Kraków 1990.

Goldberg, V. The Power of Photography. How Photographs Changed Our Lives. New York 1991.

Gourevitch, Philip. We Wish to Inform You That Tomorrow We Will be Killed with Our Families: Stories from Rwanda. Picador 1999.

Graves, Robert. Good-Bye to All That: An Autobiography. Vintage 1958.

Grayling, A. C. Among the Dead Cities. The History and Moral Legacy of the WWII Bombing of Civilians in Germany and Japan. New York 2006.

Greimas, A. J. “Ku semiotyce topologicznej.” In E. Leach, A. J. Greimas. Rytuat i narracja. Trans. M. Buchowski, A. Grzegorczyk, E. Umińska-Plisenko. Warszawa 1989.

Grynberg, H. "Nowoczesne wielkie zło." Res Publika Nowa 5 (1994). 
Grzelak, Cz., ed. Warszawa we wrześniu 1939 roku. Obrona i życie codzienne. Warszawa 2004.

Guriewicz, A. "Boska Komedia przed Dantem." In Guriewicz. Problemy średniowiecznej kultury ludowej. Trans. Z. Dobrzyniecki. Warszawa 1987.

Gutschow, N. and B. Klain. Zagłada i utopia. Urbanistyka Warszawy w latach 1939-1945. Warszawa 1995.

Harding, L. “Germany's Forgotten Victims." The Guardian. 22 October 2003.

Harris, W. B. France, Spain and the Rif. London 1927.

Harrison, R.P. The Dominion of the Death. Chicago 2003.

Haska, A. "Jestem Żydem, chcę wejśćc". Hotel Polski w Warszawie, 1943. Warszawa 2006.

Hazard, Paul. European Thought in the Eighteenth Century: From Montesquieu to Lessing. Peter Smith 1973.

Herbert, Zbigniew. "Apollo and Marsyas." Trans. Czesław Miłosz and Peter Dale Scott. Selected Poems. Ecco 1986.

Herbert, Zbigniew. "Labyrinth on the Sea/Acropolis." In The Collected Prose, 1948-1998. Ed. and intro. Alissa Valles. Preface by Charles Simic. Ecco 2010.

Herling-Grudziński, G. "Kronikarz piekła." Kultura 11 (1962).

Hilberg, Raul. The Destruction of the European Jews. Holmes \& Meier 1985.

The History of Judicial Hanging in Britain, http://www.richard.clark32. btintemet.co.uk/hangingl.html (accessed 25 May 2008).

Holden W. Shell Shock. London 1998.

Holgate, M. and I. D. Waugh. The Man They Could Not Hang: The True Story of John Lee. Stroud, Gloucestershire 2005.

Homer. The Iliad of Homer. Trans. William Cowper. CreateSpace Independent Publishing Platform 2018.

Homer. The Odyssey. Trans. Emily Wilson. Norton 2017.

Hordo, L. "Przestrzeń żydowskiego cmentarza." In Śmierć, przestrzeń, czas, tożsamość w Europie Środkowej około 1900. Eds. K. Grodziska, J. Purchła. Kraków 2002.

Huet, M. H. Monstrous Imagination. Cambridge, MA; London 1993.

Hutter, Mark. Experiencing Cities. Routledge 2016.

Innes, B. Granice śmierci. Trans. M. Bernacki, E. Krzak-Ćwiertnia. Warszawa 1999.

Irving, David. Apocalypse 1945: The Destruction of Dresden. Focal Point Publications 2007. 
Jałowiecki, B. "Proces waloryzacji przestrzeni miejskiej." In Przestrzeń $i$ społeczeństwo. Z badań ekologii społecznej. Ed. Z. Pióro. Warszawa 1982. Janion, M. Czas formy otwartej. Tematy i media romantyczne, Warszawa 1984. Janion, M. Gorączka romantyczna. Warszawa 1975. Janion, M, S. Rosiek, eds. Maski. Vol. II. Gdańsk 1986. Janion, M. Płacz generała. Eseje o wojnie. Warszawa 1998. Janion, M. Reduta. Romantyczna poezja niepodległościowa. Kraków 1979. Janion, M. Żmigrodzka, Romantyzm i historia. Warszawa 1978. Janion, M. Życie pośmiertne Konrada Wallenroda. Warszawa 1990. Janz, Rolf-Peter. "Zum Tabu des Antisemitismus: Die Kontroversen um Martin Walser und Günther Grass." Zeitschrift für interkulturelle Germanistik: 7, nr. 1. (Jahrgang, 2016).

Jaspers, K. “Sytuacje graniczne," in Rudziński, Jaspers. Warszawa 1978. Jay, Martin. "The Limits of Limit-Experience: Bataille and Foucault." Constellations: An International Journal of Critical and Democratic Theory 2 (1995).

Jay, Martin. Songs of Experience: Modern American and European Variations on a Universal Theme. Berkeley; Los Angeles; London: University of California Press 2005.

Jennings, L. B. “Termin 'groteska.” Trans. B. Fedewicz. Pamiętnik Literacki (1979), z. 4.

Kamiński, L. "Romantyzm i polityka dwudziestolecia." In Problemy polskiego romantyzmu. Seria trzecia. Ed. M. Żmigrodzka. Wroclaw 1981.

Kayser, Wolfgang Johannes. The Grotesque in Art and Literature. Columbia University Press, 1981.

Kayser, Wolfgang Johannes. "Próba określenia istoty groteskowości.” Trans. R. Handle. Pamiętnik Literacki 4 (1979), 276-277.

Kemp, Martin and Marina Wallace, eds. Spectacular Bodies. The Art and Science of the Human Body from Leonardo to Now. London 2000.

Kershaw, Ian. Hitler: 1889-1936 Hubris. W. W. Norton \& Company 2000.

Kershaw, Ian. Hitler: 1936-1945. Norton \& Company 2001.

Kępiński, A. “Twarz i ręka”, Teksty 2 (1977).

Koff, Clea. The Bone Woman: A Forensic Anthropologist's Search for Truth in the Mass Graves of Rwanda, Bosnia, Croatia, and Kosovo. Random House Trade Paperbacks 2005.

Konecki, T. Stalingrad 1942-43. Warszawa 2007. 
"Konteksty. Polska sztuka ludowa. Antropologia kultury - etnografia- sztuka" (1992) nr 3-4; (1997) nr 3-4 [devoted to visual anthropology].

Kopka, B. Konzentrationslager Warschau. Historia i następstwa. Warszawa 2007.

Kortko, D. and M. Nycz. "Spacer po bastionie Auschwitz." In "Magazyn," a weekly supplement to Gazeta Wyborcza 19 (13 May 1999), 6-10.

Kossoy, E. "Chybiona parada. Dzieje pewnej fotografii." Zeszyty Historyczne, nr. 149.

Kowalczykowa, A. Pejzaż romantyczny. Kraków 1982.

Kracik, J. Pokonać czarna śmierć. Staropolskie postawy wobec zarazy. Kraków 1991.

Kragen, W. "Kronika dni wrześniowych.” Odrodzenie 36 (1946).

Kristeva, Julia. Powers of Horror: An Essay on Abjection. Trans. Leon Roudiez. Columbia University Press 1982.

Krokiewicz, A. Moralność Homera i etyka Hezjoda. Warszawa 1959.

Krzemień-Ojak, S. Vico. Warszawa 1971.

Kunert, A. K. “Obrońca honoru stolicy.” Kierunki. 8 September 1985 (R. 30), no. 30 .

Kwiatkowski, M. J. Wrzesień 1939 w warszawskiej rozgłośni Polskiego Radia. Warszawa 1984.

LaCapra, D. "Approaching Limit Events. Siting Agamben." In Giorgio Agamben. Sovereignty and Life. Eds. M. Calarco, S. DeCardi. Stanford 2007.

LaCapra, D. History and Memory After Auschwitz. Ithaca, New York 1998.

LaCapra, D. Representing the Holocaust. History, Theory, Trauma. Ithaca; London 1996.

LaCapra, D. Writing History, Writing Trauma. Baltimore; London 2001.

Lang, B., ed. Writing and the Holocaust. New York 1988.

Laub, D. “Zdarzenie bez świadka: prawda, świadectwo oraz ocalenie.” Teksty Drugie 5 (2007).

Le Goff, J. The Medieval Imagination. Trans. Arthur Goldhammer. Chicago; London: University of Chicago Press, 1988.

Leeuw, Gerardus Van der. Religion in Essence and Manifestation. Trans. Ninian Smart and John Evan Turner. Princeton University Press 2014.

Lem, S. Prowokacja. Kraków 1984.

Leociak, Jacek. "Literatura dokumentu osobistego jako źródło do badań nad zagładą Żydów. (Rekonesans metodologiczny)," Zagłada Żydów. Studia i materiały 1 (2005). 
Leociak, Jacek. Tekst wobec Zagłady. (O relacjach z getta warszawskiego). Wrocław 1997.

Leon-Dufour, X., ed. Słownik teologii biblijnej. Trans. K. Romaniuk. Poznań; Warszawa 1985.

Leszczyński, D. “Foucault, Kartezjusz, szaleństwo." Nowa Krytyka 14 (2004).

Levi, Primo. The Drowned and the Saved. Trans. Raymond Rosenthal. Simon \& Schuster 1986.

Levin, J. and D. Uziel. “Ordinary Men, Extraordinary Photos." Yad Vashem Studies XXVI (1998)

Lewis, T. Moonlight Sonata. The Coventry Blitz, 14/15 November 1940 (Coventry 1990).

Ligęza, W. Jerozolima i Babilon. Miasta poetów emigracyjnych. Kraków 1998. Lindqvist, Sven. A History of Bombing. Trans. Linda Haverty Rugg. The New Press 2001.

Lis-Turlejska, M. Stres traumatyczny. Występowanie, następstwa, terapia. Warszawa 2002.

Lucan. Pharsalia. Trans. and intro. Jane Wilson Joyce. Cornell University Press 1993.

Lurker, M. Słownik obrazów i symboli biblijnych. Trans. K. Romaniuk. Poznań 1989.

Lyotard, Jean-Francois. "Answering the Question: What Is Postmodernism?" The Postmodern Condition: A Report on Knowledge. Trans. Regis Durand. Minneapolis: University of Minnesota Press, 1984, 71-82.

Lyotard, Jean-Francois. The Differend; Phrases in Dispute. Trans. G. Van Den Abbeele. Minneapolis 1996, 32-33, 56-58.

Mack J. and S. Humphries. London at War. The Making of Modern London 1939-1945. London 1985.

Mandelstam, Osip. “The Age." The Selected Poems of Osip Mandelstam. Trans. Clarence Brown and W. S. Merwin. NYRB Classics, 2004.

Manvell, Roger and Heinrich Fraenkel. Doctor Goebbels: His Life and Death. Skyhorse Publishing 2010.

Mark B. [introduction to]: The Report of Jürgen Stroop Concerning the Uprising in the Ghetto of Warsaw and the Liquidation of the Jewish Residential Area. Warsaw 1958.

Markowski, M. P. and R. Nycz, eds. Kulturowa teoria literatury. Główne pojęcia i problemy. Kraków 2006.

Markowski, M. P. and R. Nycz. Pragnienie obecności. Filozofie reprezentacji od Platona do Kartezjusza, Gdańsk 1999. 
Marrus, Michael Robert. The Holocaust in History. University Press of New England, 1987.

Matuszewski, K. "Wstęp" in Bataille, G. Doświadczenie wewnętrzne. Trans. O. Hedemann. Warszawa 1998.

McKee, Alexander. Dresden 1945: The Devil's Tinderbox. London: Souvenir Press.

Micale, M. S. and P. Lerner, eds. Traumatic Pasts: History, Psychiatry, and Trauma in the Modern Age, 1870-1930 (Cambridge Studies in the History of Medicine). New York 2001.

Michalski, K. Heidegger i filozofia wspótczesna. Warszawa 1978.

Middlebrook, M. The Battle of Hamburg. Allied Bomber Forces against a German City in 1943. London 1984.

Mikulski, J. Medycyna hitlerowska w stużbie III Rzeszy. Warszawa 1981.

Milchman, Alan and Alan Rosenberg, eds. Postmodernism and the Holocaust. Amsterdam, Atlanta: Rodopi, 1998. 2006. . Experiments in Thinking the Holocaust. Palgrave Macmillan Limited

Miłosz, Czesław. “Traktat poetycki.” In Wiersze wybrane. Warszawa 1980.

Morris, L., ed. Henry Tonks and the Art of Pure Drawing. Norwich 1985.

Mumford, L. The City in History. New York 1961.

Musgrove, G. Operation Gomorrah. The Hamburg Firestorm Raids. London; New York; Sydney 1981.

Nancy, Jean-Luc. The Ground of the Image. Fordham Univ. Press 2005.

Nancy, Jean-Luc. “Zakazana reprezentacja." Trans. A. Dziadek. Teksty Drugie 5 (2004).

Neillands, R. The Bomber War. The Allied Air Offensive Against Nazi Germany. New York 2005.

Nola, A. M. di, Tryumf śmierci. Antropologia żałoby. Ed. M. Woźniak. Trans. J. Korecka et al. Kraków 2006.

Nycz, R. and A. Zeidler-Janiszewska, eds. Nowoczesność jako doświadczenie. Kraków 2006.

Nycz, R. "Kulturowa natura. Kilka uwag o przedmiocie poznania literackiego," Teksty Drugie 5 (2001).

Nycz, R. "Literatura nowoczesna wobec doświadczenia." In Literackie reprezentacje doświadczenia. Eds. W. Bolecki, E. Nawrocka. Warszawa 2007.

Nycz, R. “O nowoczesności jako doświadczeniu. Uwagi na wstępie.” In Nowoczesność jako doświadczenie. Ed. R. Nycz, A. Zeidler-Janiszewska. Kraków 2006. 
Nycz, R. O przedmiocie studiów literackich dziś. Teksty Drugie, no. 1-2 (2005).

Nycz, R. Tekstowy świat. Poststrukturalizm i wiedza o literaturze. Warszawa 1993.

Nyiszli, Miklos. Auschwitz: A Doctor's Eyewitness Account. Trans. Richard Sevear and Tibere Kremer. Penguin Modern Classics 2012.

Oakeshott, Michael. Experience and Its Modes. Cambridge: The University Press 1978.

Olechnicki, K. Antropologia obrazu. Fotografia jako metoda, przedmiot $i$ medium nauk spolecznych. Warszawa 2003.

Olivier, K. "Witnessing and Testimony." Parallax 11 (2004).

Otto, Rudolf. The Idea of the Holy. Trans. John W. Harvey. Oxford University Press 1936.

Owen, Wilfred. The Collected Poems of Wilfred Owen. Ed. C. Day Lewis. New Directions Book 1965.

Patkaniowska, D. "Legenda literacka Stefana Starzyńskiego." Pamięć września. Ed. A. Brodzka. Biuletyn Polonistyczny 1990, z. 3-4.

Pawełczyńska, A. Wartości a przemoc. Zarys socjologicznej problematyki Oświęcimia Warszawa 1995.

Pick, D. War Machine, The Rationalization of Slaughter in the Modern Age. New Haven, London 1993.

Piekałkiewicz, J. Kalendarium wydarzeń II wojny światowej. Trans. P. Seydak et al. 2nd edition. Janki k. Warszawy 1999.

Pięciak, W. “Drezno, akt oskarżenia.” „Rzeczpospolita” 22-23 lutego 2003.

Pięciak, W. “Naród ofiar." Rzeczpospolita. 2 August 2003.

Pięciak, W. Niemiecka pamięć. Współczesne spory w Niemczech o miejsce III Rzeszy w historii, polityce i tożsamości (1989-2001). Kraków 2002.

Pięciak, W. "Requiem dla miasta Drezna." In Pięciak, Jak obalano mur. Niemcy 1988-96. Kraków 1996.

Plato. Republic. Ed. C. D. C. Reeve. Trans. G. M. A. Grube. Hackett Publishing Company, Inc., 2nd edition 1992.

Płuciennik, J. Retoryka wzniosłości w dziele literackim. Kraków 2000.

Pope, A. [compiled by]. Memories of the Blitz. The People's Story of the Bombing of Canterbury, 1st June 1942. Canterbury 1992.

Radomski, A. "Pojęcie doświadczenia we współczesnej refleksji humanistycznej i w historiografii - jego zmiana jako rezultat przeobrażeń kulturowych w świecie współczesnym." Historyka 29 (1999).

Rhodes, R. Mistrzowie śmierci. Einsatzgruppen. Trans. M. Urbański. Warszawa 2007. 
Robin, M.-M. 100 Historic Photos of the 20th Century. Köln 1999.

Rodak, P. “Dziennik osobisty: praktyka, materialność, tekst." Przeglad Kulturoznawczy 1 (2006).

Rodak, P. "Wojna i zapis (o dziennikach wojennych).” Teksty Drugie 6 (2005).

Rouillé, A. Fotografia. Między dokumentem a sztuką współczesną. Trans. O. Hedemann. Kraków 2007.

Ruby, J. Secure the Shadow. Death and Photography in America. London 1995.

Rudziński, P. Jaspers. Warszawa 1978.

Ruffié, J. and J. Ch. Sournia. Historia epidemii. Od dżumy do AIDS. Trans. B. A. Matusiak. Warszawa 1996.

Sakowska, R. Ludzie z dzielnicy zamkniętej. Z dziejów Żydów w Warszawie w latach okupacji hitlerowskiej: październik 1939 - marzec 1943, second, updated and expanded edition. Warszawa 1993.

Scarry, Elaine. The Body in Pain. The Making and Unmaking of the World. New York: Oxford 1985.

Schafft, Gretchen E. From Racism to Genocide: Anthropology in the Third Reich. University of Illinois Press 2007.

Schwarberg, G. In the Ghetto of Warsaw. Heinrich Jöst's Photographs. Göttingen 2001.

Sebald W. G. On the Natural History of Destruction. Trans. A. Bell. New York 2003.

Sennett, Richard. Flesh and Stone: The Body and the City in Western Civilization. New York; London 1994.

Shakespeare, William. Titus Andronicus. Ed. Jonathan Bate. The Arden Shakespeare. 2nd edition, 2018.

Shaw, M. War \& Genocide. Organized Killing in Modern Society. Cambridge; Malden 2003.

Siemieński, L. Podania i legendy polskie, ruskie i litewskie. Poznań 1845.

Sikora, S. Fotografia. Między dokumentem a symbolem. Izabelin 2004.

Skarga, B. “Doświadczenie.” In Skarga, Kwintet metafizyczny. Kraków 2005.

Sofsky, Wolfgang. Traktat o przemocy. Trans. M. Adamski. Wrocław 1999.

Sofsky, Wolfgang. Violence: Terrorism, Genocide, War. Granta, 2003.

Sontag, Susan. Illness as Metaphor and AIDS and its Metaphors. Picador 2001.

Sontag, Susan. On Photography. Picador 2001.

Sophocles. Trans. F. Storr. Vol. 1. W. Heinemann 1912.

Soulages, F. Estetyka fotografii. Strata i zysk. Trans. B. Mytych-Forajter, W.

Forajter. Kraków 2007 (for the original, see Soulages, Esthétique de la photographie [Nathan Université, 1999]). 
Steiner, G. W zamku Sinobrodego. Trans. O. Kubińska. Gdańsk 1993.

Stone, D. “Genocide as Transgression." European Journal of Social Theory 1, no. 7 (2004), 48-49.

Stroop, Jürgen. The Report of Jürgen Stroop Concerning the Uprising in the Ghetto of Warsaw and the Liquidation of the Jewish Residential Area. Warsaw 1958.

Struk, Janina. Photographing the Holocaust: Interpretations of the Evidence. I. B. Tauris, 2004.

Strzelecki, J. “Próby świadectwa.” In Kontynuacje (2). Warszawa 1974.

Sujecki, J. “Druga śmierć miasta. Przyczyny i konsekwencje." In Historyczne centrum Warszawy. Urbanistyka, architektura, problemy konserwatorskie. Ed. B. Wierzbicka. Warszawa 1998.

Szarota, T. Karuzela na placu Krasińskich. Studia i szkice z lat wojny i okupacji. Warszawa 2007.

Szarota, T. "Naloty na Warszawę podczas II wojny światowej," Kronika Warszawy 3/4 (1993).

Szarota, T. Okupowanej Warszawy dzień powszedni. Studium historyczne. Third Edition. Warszawa 1988.

Szczepański, M. S. “Z historii socjologii miasta i procesów urbanizacji. Ekologia klasyczna i konwencjonalne teorie urbanizacji." In Problemy socjologii miasta. Ed. J. Wódz. Katowice 1984.

Sznajderman,M. Zaraza. Mitologia dżumy, cholery i AIDS. Warszawa 1994.

Sztompka, P. Socjologia wizualna. Fotografia jako metoda badawcza. Warszawa 2006.

Szuchta, R. and P. Trojański. Holocaust Zrozumieć dlaczego. Warszawa 2003.

Święch, J. Pieśń niepodległa. Model poezji konspiracyjnej 1939-1945. Warszawa 1982.

Taylor, Frederick. Dresden: Tuesday 13 February 1945. Harper Perennial 2005.

Taylor, Frederick. The Berlin Wall. 13 August 1961-9 November 1989.London: Bloomsbury 2007.

Taylor R. R. The Word in Stone. The Role of Architecture in the National Socialist Ideology. Berkeley 1974.

Terraine J. The Great War. London 1999.

Thomas, Gordon and Max Morgan-Witts. The Day Guernica Died. London: Hodder and Stoughton 1975.

Thomas L.-V. Trup. Od biologii do antropologii. Trans. K. Kocjan. Łódź 1991.

Tomaszczuk, Z. Świadomość kadru. Szkice z estetyki fotografii. Września 2003.

Topolski, J. Jak się pisze i rozumie historię. Tajemnice narracji historycznej. Warszawa 1996. 
Trenkner, J. “Wieluń, czwarta czterdzieści.” Tygodnik Powszechny. 29 August 2008. Trudi, T. Modernism, History and the First World War. Manchester; New York 1998.

Tuchman, Barbara W. The Guns of August. Presidio Press, 1962.

Ubertowska A. "Popioły i dyskursy. Zagłada i etyczny wymiar reprezentacji (od Adorna do Lyotarda).” In Ubertowska. Świadectwo - trauma - głos. Literackie reprezentacje Holokaustu. Kraków 2007.

Unterman A. Żydzi. Wiara i życie. Trans. J. Zabierowski. Łódź 1989.

Uziel D. "Wehrmacht Propaganda Troops and the Jews." Yad Vashem Studies XXIX (2001).

Vernant J.-P. “Śmierć grecka - śmierć o dwóch obliczach.” In Wymiary śmierci. Ed. and intro. S. Rosiek. Gdańsk 2002.

Vico, Giambattista. New Science. Trans. Dave Marsh. Penguin Classics 2000.

Virgil. The Aeneid. Trans. Robert Fagles. Penguin Classics 2008.

Vovelle, M. Śmierć w cywilizacji Zachodu. Od roku 1300 po wspótczesność. Trans. T. Swoboda et al. Gdańsk 2004.

Walser, M. "Przemyślenia przy pisaniu mowy na niedzielę." In Spór o niemiecką pamięć. P. Buras, ed.

Walter, V. From Body Snatching to Bequeathing. http://www.quotesandsayings. com/findquoteframes.htm (accessed 25 May 2008).

Walton, K. L. "Transparent Pictures: On the Nature of Photographic Realism.” Critical Inquiry 11, no. 2 (1984).

Weber, John. Shearer's Manual of Human Dissection. 8th Edition. McGraw-Hill Education/Medical, 1999.

Werner, A. Zwyczajna apokalipsa. Tadeusz Borowski i jego wizja świata obozów. Warszawa 1971.

Westwell, I. World War I Day by Day. Osceola 2001.

Wieczorkiewicz, A. Muzeum Ludzkich ciał. Anatomia spojrzenia. Gdańsk 2000.

Winter, Denis. Death's Men: Soldiers of the Great War. Penguin 2014.

Włodarczyk, W. Socrealizm. Sztuka polska w latach 1950-1954. Paryż 1986.

Wójcik, W. Legenda Piłsudskiego w polskiej literaturze międzywojennej. Katowice 1986.

[Ysabean, A.] Zasady fizyognomiki i frenologii. Wykład popularny o poznawaniu charakteru z rysów twarzy i kształtu głowy. Przez A. Ysabeau, profesor nauk przyrodniczych. Trans. W. Noskowski. Warszawa 1883.

Zeidler-Janiszewska, A. ed. Pisanie miasta - czytanie miasta. Poznań 1997. 
Zelizer, B. Remembering to Forget: Holocaust Memory through the Camera's Eyes. Chicago 1998.

Zimand, R. Diarysta Stefan Ż. Wrocław 1990.

Żółkiewski, S. Teksty kultury: studia. Warszawa 1988.

Żelazko, J. and A. Ossowski, eds. Wieluń 1 IX 1939. Łódź 2009. 


\section{Index}

A

Abbeele, Georges Van Den 10, 348

Adamski, Marek 325, 351

Addison, Paul 135, 136, 179, 339

Adelson, Alan 240, 242, 332, 338

Aksamitowski, Andrzej 44, 332

Alertz, Hipolit 102, 104

Altbeker, Ruth 96, 333

Améry, Jean 325, 332

Andrzejewski, Jerzy 50

Andrzejewski, Marek 130, 339

Ankersmit, Frank 14, 15, 17, 21 ,

224, 225, 339, 340, 342

Apollinaire, Guillaume 130

Applebaum, Anne 280, 340

Appelfeld, Aharon 118

Arad, Yitzhak 232, 334

Aragon, Luigi d' 248

Arazamagni, Antonio 147

Arendt, Hannah 25, 340

Ariès, Philippe 340

Arnheim, Rudolf 124, 340

Aristotle 10

Ash, Timothy Garton 137, 174

Auerbach, Rachela 97, 98, 224,

233, 234, 277, 288, 293, 296, 297 . 300, 332

Augustine, St. 253, 255, 340

Avicenna 247

B

Bachelard, Gaston 152, 340

Bachórz, Józef 193, 340

Backer, Adriaen 192, 255

Bailey, Ronald H. 131, 340

Bakke, Monika 259, 340

Bakula, Bogusław 340

Balbus, Tomasz 305
Baldung, Hans 275

Baraniewski, Waldemar 79, 340

Barbero, Giuseppe 160

Barbusse, Henry 199, 203, 272-274, 276, 277, 332

Barthes, Roland 184-186, 188, 189, 210, 241, 340

Bartos, Krzysztof 290, 333

Bartoszewski, Władysław 73, 166,340

Bataille, Georges 22, 245, 258, 340, 346, 349

Baudelaire, Charles 246

Baudrillard, Jean 99, 341

Bauman, Janina 294, 295, 332

Bauman Zygmunt 25, 99, 341

Bazin, André 184, 341

Beatis, Don Antonio de 248

Bell, Anthea 41, 176, 338, 351

Bellow, Saul 322, 332

Benedetti, Alessandro 248, 249, 256, 257

Benedyktowicz, Zbigniew 156, 341

Benivieni, Antonio 248

Benn, Gottfried 260, 341

Berek, Putersznyt 218, 221

Berezowska, Małgorzata 314, 331

Bergander, Götz 179, 341

Berger, John 213, 216, 341

Berland, Marian 289, 290, 332

Berman, Adolf 289, 332

Berman, Barbara 289, 332

Bernacki, Marek 250, 345

Bernini, Gianlorenzo 192

Bernstein, Richard 177

Bernstein, Tatiana 113, 341

Berry, James 309

Bettelheim, Bruno 17-19, 341 
Bezwińska, Jadwiga 11, 281, 298, 331, 332

Bialik, Hayyim Nahman 280, 332

Bichat, Marie François 256

Biebl, Konstantin 262

Biebow, Hans 236, 237

Bielecki, Adam 308, 312, 334, 338

Bishop, Alan 167, 209, 336

Blady-Szwajger, Adina 86, 333

Blanchot, Maurice 9, 10, 341

Blaskowitz, Johannes 68

Blättler, Franz 290, 333

Blösche, Josef 227, 228

Blumenfeld, Stanisława 88

Bobkowski, Andrzej 166, 333

Bocian, Martin 304, 341

Bogaczewicz, Stanisław

Antoni 305, 332

Bolecki, Włodzimierz 12, 30, 274, 341, 349

Böll, Heinrich 176

Boltański, Chrystian 222

Boniface VIII, Pope 258

Borecka, Emilia 314, 331

Borkowska, S. 44

Borowski, Andrzej 252

Borowski, Tadeusz 10, 80, 353

Borwicz (Boruchowicz), Michał

Maksymilian 309, 310, 333

Bose, Hans-Jürgen von 174

Bostridge, Mark 209, 336

Bourke, Joanna 145, 341

Brach-Czaina, Jolanta 326, 327, 341

Brandys, Kazimierz 88, 89, 333

Braudel, Fernand 84, 85, 341

Brittain, Vera 167, 209, 336

Brodzka-Wald, Alina 30, 38, 274, 341,350

Broniewski, Władysław 165

Brooke, Rupert Chawner 205

Brown, Allison 128, 176, 343

Bruegel, Pieter Starszy 202, 289, 290
Bruner, Edward M. 14, 342

Brunier, Charles 201, 202

Bruno, Antonio 248

Bryskier, Henryk 91, 102, 313, 314, 333

Buchowski, Michał 35, 344

Buczkowski, Leopold 154, 333

Buras, Piotr 158, 342, 353

Burke, Edmund 21

Buruma, I. 177, 342

Buze, Tadeusz 103

C

Calarco, Matthew 19, 347

Calderón de la Barca, Pedro 56, 57

Callot, Goya 203, 333

Canetti, Elias 152, 157, 327, 342

Čapek, Karel 303, 328, 333

Carr, Ian 248

Cary, Robert 139

Cazin, Paul 286, 333

Celan, Paul 277, 342

Churchill, Winston 126, 132, 133, $134,136,138,139,142,175$, 177,178

Ciborowski, Adolf 301

Cichowicz, Stanisław 283, 340

Cieplewicz, Mieczysław 38, 41, 331

Cirlot, Juan Eduardo 252, 342

Claudius, Matthias 275

Cloete, Stuart 199

Cohen, Abraham 290, 302, 333, 342

Collier, Carol 256, 342

Courbet, Gustave 192

Cox, Sebastian 135, 137

Crang, Jeremy A. 135, 179, 339

Crooke, Helkiah 256

Crozier, Frank Percy 198, 201

Curtius, Ernest Robert 252, 284, 342

Cymerman, Joel 316

Cyprys, Ruth 96, 333

Cyrańska, Maria 311, 315, 333 
Czarkowski, Antoni 314, 333

Czech, Danuta 331

Czermińska, Małgorzata 29, 342

Czerniaków, Adam 93, 292, 294, 295, 333

Czuma, Walerian 48, 69, 72-74, 76

D

Dahrendorf, Ralf 26

Dalewski, Zbigniew 215

Dali, Salvador 161

Dante, Alighieri 303

Dąbrowska, Danuta 231, 338, 342

Dąbrowska, Maria 86-88, 108, 110, $112,113,333$

Dąbrowski, Jan 53, 120, 336

Debussy, Claude 37

DeCardi, Steven 19, 347

Defoe, Daniel 288

Delacroix, Eugéne 189, 190, 191, 195, 196, 202, 204, 333, 342

Delavigne, Casimir 53, 54

Delbo, Charlotte 10

Delumeau, Jean 23, 247, 290, 342

Descartes, René 247, 249, 253, 261, 271, 342

Deutsch, Niklaus Manuel 275

Dickson, Maggie 308

Dicksteinówna, Julia 44

Didi-Huberman, Georges 221, 342

Dilthey, Wilhelm 13, 22

Dix, Otto 202

Dłużniewska, Sabina 148, 151, 33

Dobroszycki, Lucjan 44, 150, 331

Dobrzyniecki, Zdzisław 303, 345

Dobrzyńska, Teresa 28, 342

Domańska, Ewa 12, 14, 15, 21, 30 , 282, 297, 339, 342

Dostoyevsky, Fyodor 307

Douhet, Giulio 128

Dragon, Szlama 306

Drewnowski, Tadeusz 88, 333
Drozdowski, Marian Marek 37, 38, 44, 59, 63, 150, 311, 331, 332, 343

Dubisz, Stanisław 23

Duell, William 308

Dunin-Wąsowicz, Krzysztof 314, 331

Dürer, Albrecht 275

Dyer, Gwynne 140, 141, 343

Dziadek, Adam 349

E

Easthope, Antony 16, 343

Eberhardt, Konrad 286, 333

Edelman, Marek 60, 293, 334, 336

Ehrenburg, Ilya 305, 311, 334

Eichmann, Adolf 25, 231, 265, 312, 335,340

Eisen, Samuel 318

Eisenbach, Artur 93, 337

Eisenschmidt, Eliezer 307

Eksteins, Modris 24, 130, 204-207, 272, 343

Eliach, Jafa 311, 320, 334

Eliade, Mircea 302, 343

Engelking, Barbara 96, 97, 113, 288, 337, 343

Ernest, Stefan 234, 288, 292, 334

Estienne, Charles 251

Estreicher, Karol 211, 343

Euripides 212

F

Falkowska, Maria 234, 336

Fedewicz, Bożena 274, 346

Fehrenthei, Claus von 169

Fejgenberg, Mozes 312, 319

Felman, Shoshana 13, 343

Ficowski, Jerzy 280, 335

Phidias 70

Filipowicz, Kornel 313, 314, 315, 334

Fischer, Eugen 270 
Fischer, Ludwig 83

Fiszel, Bialobroda 316, 334

Fleming, Marie 26, 343

Forsdike, A. 155

Forstner, Dorothea 252, 343

Foucault, Michel 22, 248, 253, 256, 343, 346, 348

Fraenkel, Heinrich 169, 348

Franz Ferdinand, Archduke 204

Freud, Sigmund 19-21, 24, 303

Frezer, Margaret 162

Friedlander, Saul 26, 343

Friedrich, Jörg 175, 176-178, 343

Frisius, Gemm 183

Frederick II 258

Fudakowski, Jerzy 104

Fujimoto, Masaru 180, 344

Fuks, Marian 93, 333

Fussell, Paul 24, 207, 272, 344

G

Gadamer, Hans-Georg 12, 14, 22, 30,344

Gajcy, Tadeusz 148

Galen, Claudius 247

Gałka, Wacława 311, 316

Gancwajch, Abraham 112

Garczyński, Stefan 56

Gardner, Alexander 186, 190, 191

Garret, Stephen A. 125, 126, 131, $138,144,344$

Gellately, Robert 26, 287, 343, 344

Geller, Stephen 173

Genewein, Walter 236, 237, 238, 242

Gennep, Arnold van 35, 344

Getter, Marek 44, 150, 331

Gigliotti, Simone 19, 344

Gilbert, Martin 215, 312, 335

Gillies, Harold D. 192-198, 202, 344

Glejch, Sara 311

Glik, Berel 312

Glover, Jonathan 133-135, 144, 287, 344
Głowacka, Dorota 11, 13, 344

Głowiński, Michał 92, 225, 236, 344

Godzimirski, Jakub M. 283, 340

Goebbels, Joseph 132, 137, 138, 140, 142-144, 168-170, 179, 348

Goetel, Ferdynand 46, 114, 115, 148,334

Goff, Jacques Le 85, 347

Goldberg, Vicki 191, 344

Goldhagen, Daniel 158, 177

Goldin, Leyb 113, 293, 334

Goldszer, Baruch 312, 334

Gomulicki, Juliusz Wiktor 50, 213

Göring, Herman 124, 132, 169

Gourevitch, Philips 328, 344

Goya, Francisco 203, 333

Górny, Jechiel 295

Grabowski, Jan 87, 339

Grabowski, Zbigniew R. 87, 339

Graham, Spencer 199

Gralewski, Jan 90, 335

Grass, Günther 158, 159, 219, 287, 346

Graves, Robert 197, 200, 291, 344

Grayling, Anthony C. 128, 144, 167,344

Greif, Gideon 306, 307, 334

Greimas, Algirdas Julien 35, 344

Grenfell, Bernard 212

Griffin, Sara 308

Grinker, Roy R. 144

Grochowiak, Stanisław 259

Grodziska, Karolina 291, 345

Gromadzka, Regina 342

Grossman, Mendel 215, 231, 238-242

Grossman, Vasily 305, 311, 334

Grosz, George 123, 124, 173

Grünberg, Franciszka 96, 334

Grynberg, Henryk 300, 313, 327, 334,344

Grynberg, Michał 93, 312, 331

Grzelak, Czesław 44, 67, 332, 345 
Guderian, Heinz 170

Guillain, Robert 155, 180, 334

Günsberg, Salomon 319, 320

Gurewicz, Mina 316, 334

Guriewicz, Aron 303, 345

Gutman, Israel 229, 232, 334

Gutschów, Niell 79, 345

Guze, Joanna 333

$\mathbf{H}$

Habermas, Jürgen 26

Hachiya, Michihiko 157, 335

Handle, Ryszard 276, 346

Harding, Luke 177, 345

Harriman, Averell 134

Harris, Artur 128, 129, 131, 133, $134,135,145$

Harris, Walter B. 345

Harrison, Robert Pogue 282, 345

Hartung, Albert 154

Hartwig, Julia 333

Hashimoto 157

Haska, Agnieszka 229, 345

Hay, Ian 207

Hazard, Paul 261, 345

Hedemann, Oskar 184, 349, 351

Hegel, Georg Wilhelm Friedrich 10

Heidegger, Martin 12, 15, 349

Henryk VIII, King 257

Herbert, Zbigniew 213, 254, 255,345

Herling-Grudziński

Gustaw 288, 345

Hilberg, Raul 83, 118, 345

Hill, George Roy 173

Himmler, Heinrich 227, 265

Hirszfeld, Ludwik 38, 46, 93, 95, 148,335

Hirszowicz, Maria 31

Hirt, August 265

Hitler, Adolf $37,67,68,72,74$, $76,83,104,113,132,137,138$, 142-144, 158, 159, 167-170, 177,
206, 235, 265, 295, 335, 341, 346, 349,351

Hoffmann, Heinrich 206

Holden, Wendy 25, 123, 145, 345

Holgate, Mike 309, 345

Homer 145, 284-286, 345, 347

Hordo, Leszek 291, 345

Horoszowski, Paweł 227

Huberband, Szymon 112

Huet, Marie Hélène 190, 195, 345

Hugo, Victor 274

Humphries, Steve 133, 348

Hunt, Arthur 212

\section{I}

Ibbieta, Pablo 307

Innes, Brian 250, 345

Irving, David 137, 155, 161, 162, $164,169,179,335,345$

Irzykowski, Karol 37, 38, 63-65, 68-72, 74, 75, 77, 78, 335

Iwańska, Alicja 90, 91, 335

Iwaszkiewicz, Jarosław 36, 37, 107, 110-113, 119, 335

\section{J}

Jabłonkówna, Leonia 166

Jabłoński, Dariusz 237, 238

Jachwidowicz 318, 335

Jäckel, Günter 168

Jakobson, Roman 224

Jakubowska, Julia 307, 312, 316, 334, 336, 338

Jałowiecki, Bohdan 35, 346

Janiczek, Jan 55

Janion, Maria 52-54, 56, 57, 59, 60,

$78,196,271,273,281,346$

Janowski, Julian 74, 335

Jaspers, Karl 17, 346, 351

Jay, Martin 12, 16, 22, 24, 346

Jennings, Lee Byron 274, 276, 346

Joselewska, Ryfka 312, 313, 317,

$320,327,335$ 
Jöst, Heinrich 351

Joubin, André 333

Jünger, Ernst 169, 198, 200, 201, 286, 335

Jurandot, Jerzy 73

K

Kac, Tima 316, 320, 327

Kadish, George 215

Kamiński, Aleksander 42, 47

Kamiński, Leszek 58, 346

Kammler, Heinz 79

Kamper, Wiesława 154, 335

Kania, Ireneusz 252, 342

Kant, Immanuel 10

Kaplan, Chaim A. 72, 91, 92, 105, 148, 335

Kartuziński, Leo 228

Katsh, Abraham Isaac 72, 335

Kayser, Wolfgang 276, 297, 346

Kemp, Martin 187, 192, 250, 252, 346

Kershaw, Ian 142, 144, 170, 206, 346

Keyse, Emma 309

Kędzierski, Sławomir 131, 340

Kępiński, Antoni 193, 346

Kiernan, Ben 287, 344

Kiersnowski, Ryszard 38

Kilpatrick, Mell 246, 335

Kirchner, Hanna 89, 337

Kirkor-Kiedroniowa Zofia 119 , 120, 335

Kisch, Egon Erwin 196, 197, 335

Kitchener, Horatio 206, 207

Klain, Barbara 79, 345

Klemperer, Eva 170

Klemperer, Victor 137, 138, 168, 170-172, 179, 335

Klukowski, Zbigniew 108, 110, 112,335

Kłodziński, Stanisław 221

Koch, Trute 160
Kocjan, Krzysztof 245, 352

Koff, Clea 278, 346

Kogan, Josifowicz 320, 321

Konecki, Tadeusz 346

Kopczyńska-Ciesielska, Marta 234, 336

Kopka, Bogusław 79, 347

Korczak, Janusz 234, 336

Korczak, Róża 321

Korecka, Jolanta 246, 349

Korpetta, Jacek 314, 331

Kortko, Dariusz 80, 347

Koskowski, Józef 120, 336

Kossak, Zofia 166, 337

Kossoy, Edward 227-229, 347

Kostkiewiczowa, Teresa 225, 344

Kotowska, Maria 312, 331

Kowalczyk, Andrzej Stanisław 168, 338

Kowalczykowa, Alina 281, 347

Kozłowski, Eugeniusz 38, 41, 331

Krabbe, Fredrich 177

Krabbe, Hanna 177

Kracik, Jan 288, 347

Kragen, Wanda 43, 46, 336, 347

Krall, Hanna 60, 336

Kraskowska- Nitschowa, Ludwika 39

Krawczyńska, Jadwiga 45, 46, 336

Kremer, Josef

Kremer, Johann Paul 266, 269-271, 335

Kristeva, Julia 259, 347

Kröger, Hermann 150

Krokiewicz, Adam 284, 347

Król, Michał 294

Krzak-Ćwiertnia, Elżbieta 250, 345

Krzemień-Ojak, Sław 282, 347

Kühnemund, Gerhard 159

Kunert, Andrzej Krzysztof 39, 41, $42,49,58,70,108,331,347$

Kuśmierczyk, Seweryn 30, 189, 343 
Kutrzeba, Tadeusz 66-68, 77, 336

Kwiatkowski, Jerzy 130

Kwiatkowski, Maciej Józef 44, 48, $50,53,66,74,76,347$

L

La Mettrie, Julien Offray de 261

LaCapra, Dominick 17, 19, 20, 303, 347

Laffin, John 196, 197, 336

Lam, Andrzej 37, 76, 338

Lamet, Matylda 228

Lamet, Hanka 228

Landau, Ludwik 36, 46, 75, 76, 85, $151,164,165,288,307,336$

Landau, Zbigniew 36, 336

Lang, Berel 118, 347

Lanzmann, Claude 13, 305, 336, 343

Lapides, R. 332

Laub, Dori 13, 343, 347

Lavater, Johann Kaspar 193

Le Brun, Charles 192

Leach, Edmund 35, 344

Lebrun, François 248

Lechoń, Jan 38, 43, 51, 52

Lee, John Henry Georg 23, 309, 345

Leeuw, Gerard van der 156, 347

Leighton, Roland 209, 336

Leist, Ludwik 84

Lem, Stanisław 298, 347

Leociak, Jacek 97, 113, 284, 301, $343,347,348$

Leonardo, da Vinci 192, 248

Leon-Dufour, Xavier 253, 348

Lerner, Paul 25, 349

Lesman, Stanisław 63

Leszczyński, Damian 253, 348

Levi, Primo 10, 80, 235, 348

Levin, Judith 214, 348

Levinas, Emmanuel 10

Lewczyński, Jerzy 221, 222

Lewicki, Franciszek 120, 336
Lewin, Abraham 97, 98, 288, 336

Lewin, Dorka 218

Lewis, Tim 132, 150, 348

Ley, Robert 170

Ligęza, Wojciech 58, 71, 348

Lindbergh, Charles 130

Lindqvist, Sven 125-127, 348

Lipiński, Wacław 36, 48, 66, 336

Lis-Turlejska, Maria 24, 348

Lorentz, Stanisław 45, 46, 336

Łotman Jurij 297

Ludendorff, Erich 140, 141, 142

Lukrec, Henryk 60, 336

Lurker, Manfred 348

Luzzi, Mondino de' 248

Lyotard, Jean-François 10, 16, 20 , 348,353

\section{M}

Macioszczyk, Bolesław 104

Mack, Joanna 133, 348

Mackiewicz, Józef 150, 170, 172, 173, 179, 298, 336

Magnussen, Karin 270

Makower, Henryk 93, 94, 99, 336

Makowerowa, Noemi 94, 336

Małachowski, Stanisław 39

Małgorzewski, Jerzy 47, 49, 336

Małgorzewski Józef 50, 53, 61

Mandelstam, Osip 280, 348

Maniakówna, Maria 331

Mann, Thomas 205

Mantegna, Andrea 256

Manvell, Roger 169, 348

Márai, Sándor 146, 147, 336

Margolit, Abraham 232, 334

Mark, Ber 227, 348

Markowski, Michał Paweł 15, 30, 281, 348

Marrus, Michael R. 178, 349

Matusiak, Bożena Anna 288, 351

Matuszewski, Krzysztof 349 
Matywiecki, Piotr 118

Mawult, Jan 111, 336

Mącznik, Jadzia 218

Mącznik, Szlamek 218

McKee, Alexander 147, 155, 159, $160,162-164,169,349$

Meed, Władka 95, 337

Mengele, Josef 267, 269, 270

Menochiusz, Jesuit 302

Merenholc, Helena 92, 337

Myers, Charles 123

Miasojedow Grigorij 150, 172, 173, 179,336

Micale, Mark S. 25, 349

Michalski, Krzysztof 12, 349

Michelangelo 52, 248

Michałowski, Zvi 311, 320

Mickiewicz, Adam 43, 57, 58, 61

Middlebrook, Martin 125-127, 131, $133,134,144,150,154,155,160$, 167,349

Mikulski, Jan 265, 349

Milch, Baruch 311, 318, 319, 337

Milchman, Alan 10, 25, 349

Milejkowski, Izrael 263, 269

Miłaszewski, Stanisław 55

Miłosz, Czesław 254, 255, 280, 345, 349

Młodkowska, Marta 288, 334

Moeltgen, Gisela-Alexandra 155

Moll, Otto 306

Moody, Raymond 303, 308

Morawski, Kazimierz 284

Morell, Teodor Gilbert 169

Morgan-Witts, Max 147, 352

Morris, Lynda 202, 349

Mortkowicz-Olczakowa, Hanna 51

Moscicki, Ignacy 63

Muhsfeldt, Erich 306

Mumford, Lewis 85, 349

Munch, Edvard 275

Musgrove, Gordon 160, 349
Mussolini, Benito 142

Mytych-Forajter, Beata 184, 351

$\mathbf{N}$

Nebuchadnezzar II 145

Najberg, Leon 290, 315, 337

Nałkowska, Zofia 89, 90, 107, 109, 110-112, 200, 286, 287, 337

Nancy, Jean-Luca 16,349

Nawrocka, Ewa 12, 341, 349

Neck, Albert van 192, 255, 261

Neillands, Robin 128, 135, 349

Newton, Isaak 246, 261

Niklaus, Matthius Manuel 275

Nocuj, Małgorzata 163, 337

Nola, Alfonso M. Di 246, 349

Norwid, Cyprian 50, 58, 78, 153, 212, 213

Noskowski, Władysław 193, 353

Nussbaum, Tsvi 228, 229

Nycz, Marek 80, 347

Nycz, Ryszard 12, 13, 15, 16, 29, 30, $341,342,348,349,350$

Nyiszli, Miklós 267, 268, 269, 306, 350

O

O’Neill, Eugene 303, 304, 327, 328, 337

Oakeshott, Michael 12, 350

Oberski, Jona 300, 337

Okopień-Sławińska, Aleksandra 225, 344

Olechnicki, Krzysztof 30, 189, 350

Olecka, Irena 234, 336

Olivier, Kelly 13, 350

Oppman, Artur 44

Orwell, George 167

Ossowski, Artur 131, 354

Otto, Rudolf 23, 156, 350

Owen, Wilfred 209, 210, 350

Ozick, Cynthia 118 
$\mathbf{P}$

Pabst, Friedrich 79

Papieska, Agnieszka 37, 335

Papieski, Robert 37, 335

Park, Robert E. 35

Passenstein, Mojżesz 103, 337

Pasterski, Damian 316

Patkaniowska, Danuta 38, 51, 53-55, 350

Paulus, Friedrich 142

Paul IV, Pope 82

Pawełczyńska, Anna 80, 350

Payne, Lewis 186

Petelewicz, Jakub 227

Petersowa, Zofia 46, 337

Piasecki, Bolesław 114

Picasso, Pablo 124, 173, 340

Pick, Daniel 271, 350

Piekałkiewicz, Janusz 126, 131, 133, 151, 350

Pierce, Charles 184

Pietersz, Aert 255

Pietroń, Agata 216

Pietrzak-Merta, M. 16, 343

Pięciak, Wojciech 158, 159, 162, $163,174,337,350$

Piłsudski, Józef $38,39,44,58,66$, $119,294,353$

Pindar 212

Pióro, Zygmunt 35, 346

Platon 15,348

Płuciennik, Jarosław 21, 350

Podchlebnik, Michał 305

Polesiński, Władysław 76

Pompey (Cnaeus Pompeius Magnus) 285

Poniatowski, Józef 78

Pope, Anne 153, 350

Portal, Charles 136

Potocka, Maria Anna 311, 338

Pragłowski, Aleksander 67, 337

Prażmowski, Wojciech 222
Prędki, Artur 44

Printz, Artur 215

Prorok, Leszek 154, 337

Putersznyt, Berko 218, 221

$\mathbf{R}$

Radomski, Andrzej 13, 350

Radziszewska, Krystyna 233, 338

Ranke, Leopold von 29

Regulska, Halina 36, 45, 46, 47, 61, 337

Regulski, Janusz 60, 337

Remarque, Erich Maria 196, 197, 337

Remba, Nachum 291, 292

Rembek, Stanisław 105-111, 337

Rembrandt, van Rijn 192, 255, 256, 259, 261

Renes, Andrzej 39

Rhodes, Richard 311, 350

Ribera, José de 254

Riecker, Wilhelm 160

Ringelblum, Emanuel 91, 93, 101, $105,109,112,215,234,235,281$, 288, 289, 292, 293, 298, 299, 331, 337, 338

Robin, Marie-Monique 229, 351

Rodak, Paweł 223, 351

Rodenberg, Axel 179

Rola-Arciszewski, Stanisław 38, 41, 42, 55, 151, 338

Romaniuk, Kazimierz 253, 348

Romanowski, Andrzej 199

Roosevelt, Franklin Delano 134, $142,175,177,178$

Rosenberg, Alan 10, 25, 349

Rosenberg, Maria 147

Rosenkranz, Mendel 312, 318

Rosiek, Stanisław 52, 196, 346, 353

Ross, Henryk 215, 216, 219, 220, 231-233, 235, 238-240, 338

Ross, Stefania 219, 231 
Rotgeber, Karol 47, 338

Rotsztejn, Lejb 338

Rotszyld, Pola 45, 47, 116, 338

Rouillé, André 184, 185, 210, 351

Rowecki, Stanisław 78

Rowecki, Stefan Grot

Rosenkranz, Mendel 312, 318

Rómmel, Juliusz 38, 65, 67, 68, 69, 72

Rubin, Abraham 312

Rubinsztajn, Irka 315

Ruby, Jay 191, 351

Rudnicki, Adolf 47

Rudziński, Roman 17, 18, 346, 351

Ruffié, Jacques 288, 351

Rugg, Linda Haverty 125, 348

Remba, Nachum 291, 292

Rumkowski, Chaim 232, 233, 239, 240

Rutkowski, Adam 93, 113, 288, 336, 337, 341

Rydz-Śmigły, Edward 67

Rygier, Leon 44

Rymkiewicz, Jarosław Marek 262

S

Sappho 212, 214

Sakowska, Ruta 83, 109, 281, 295, 331,351

Sennacherib, Assyrian King 145

Sargent, John Singer 202

Sarte, Jean-Paul 307

Scarry, Elanie 325, 351

Schafft, Gretchen E. 270, 351

Schiele, Egon 275

Schliemann, Heinrich 145

Schmidt, Leokadia 95, 97

Schmidt, Ludwik 96, 338

Schmitz, Marii 151

Schneider, Artur 321, 322, 338

Schoenbach, Maksymilian 294

Schopenhauer, Artur 69
Schubert, Franz 275

Schwarberg, Günther 292, 351

Scipio Aemilianus 140, 146

Sebald, Winfried

Georg 175-177, 351

Sedlis, Aleksander 217

Sedlis Anna 217

Sedlis, Elian 217

Semmler, Rudolf 169

Sennett, Richard 81, 82, 351

Seydak, Pawel 126, 350

Seydewitz, Max 179

Shakespeare, William 285, 351

Shaw, Martin 287, 351

Shearer, John Weber 262, 353

Siegel, Walter 130

Siemieński, Lucjan 303, 351

Siemiontek 228

Sierakowiak, Dawid 240, 242, 338

Sieroszewski, Wacław 76, 92, 338

Sikora, Sławomir 30, 184, 185, 189, 351

Silliaco, Juan 149

Simonson, Eric 173

Sinclair, Archibald 136

Singer, Oskar 232, 233, 338

Skarga, Barbara 13, 24, 351

Skiba, Jan 305

Skwarczyński, Adam 58, 59

Sławek, Walery 39

Sławiński, Janusz 225, 344

Słomczyński, Adam 44, 150, 331

Słonimski, Antoni 38, 42, 52

Słowacki, Juliusz 49, 56, 57, 58, 60, 307

Smith, John 308

Smock, Ann 9, 341

Sofokles 284, 300

Sofsky, Wolfgang 26, 325, 351

Sontag, Susan 82, 183, 184, 351

Soulages, François 184-186, 210, 211,351 
Sournia, Jean Charles 288, 351

Speer, Albert 132, 138, 338

Spiegel, John P. 144

Spielberg, Steven Allan 227

Spiewak, Paweł 298

Srebrnik, Szymon 305

Średnicka, E. 44

Srokowski, Stanisław 92, 93, 106, 107, 110-112, 338

Stachowiak, Lech 302, 343

Stalin, Józef 134, 136, 178

Starzyński, Stefan 37-63, 65, 66, 69-75, 78, 343, 350

Stein, Józef 263-265, 269

Steiner, George 298, 352

Steinkohl, Herman 312, 318, 338

Stempowski, Jerzy 167, 168, 338

Stern, Jonasz 311, 338

Stiller, Robert 262

Stone, Dan 26, 352

Strachan, Hew 142

Strasser, Peter 141

Strom, Kelvin Alfred 174, 175, 177

Stroop, Jürgen 79, 227, 230, 235, 348,352

Strosberg, Hans 79

Strug, Andrzej 287, 338

Struk, Janina 184, 214, 215, 352

Strzelecki, Jan 22, 352

Strzembosz, Tomasz 311, 331

Sujecki, Janusz 301, 352

Susini, Clemente 187

Święch, Jerzy 148, 352

Święcka-Skoczkowa, Halina 60, 338

Swoboda, Tomasz 271, 353

Szac-Wajnkranc, Noemi 91, 95, 97, 338

Szaret, Anna 317

Szarota, Tomasz 63, 81, 84, 131, 290, 333,352

Szatkowski, Marian 172, 173
Szlakman, Salomon 311, 316, 321, 338

Śliwiński, Artur 56

Sznajderman, Monika 288, 297, 352

Szpilman, Władysław 41, 94, 338

Sztompka, Piotr 30, 352

Szuchta, Robert 229, 352

Szwankowska, Hanna 314, 331

Szymczak, Mieczysław 23

$\mathrm{T}$

Tabaczyńska, Gina 218

Taylor, Frederick 84, 131, 137, 146, $175,179,352$

Taylor, Robert R. 79, 352

Terraine, John 206, 352

Thomas, Gordon 147, 352

Thomas, Louis-Vincent 245, 283, 352

Tołwiński, Stanisław 41

Tomaszczuk, Zbigniew 222, 352

Tomaszewski, Jerzy 36, 336

Tomaszewski, Tadeusz 41, 51, 68, 69, 339

Tonks, Henry 202, 349

Topolski, Jerzy 28, 29, 352

Traciewicz, Kazimierz 317, 339

Trenchard, Hugo 128, 129

Trojański, Piotr 229, 352

Troost, Cornelis 192, 255

Trudi, Tate 24, 353

Truman, Harry 178

Tuchman, Barbara W. 205, 353

Turner, Victor W. 14, 342

Titian 254

U

Ubertowska, Aleksandra 16, 353

Ubisz, Mieczysław 54

Umiastowski, Roman 47, 48, 66, 74, 76

Umińska-Plisenko, Ewa 35, 344 
Unterman, Alan 291, 353

Urbański, Maciej 350

Uspienski, Borys 297

Uziel, Daniel 214, 348, 353

V

Vernant, Jean-Pierre 52, 353

Vesalius, Andreas 192, 248, 255, 261

Vico, Giambattista 282, 287, 353

Virgil 286, 303, 353

Vonnegut, Kurt 150, 170, 173, 174,339

Vovelle, Michel 271, 283, 353

W

Waehmann, Annemarie 148

Wallace, Marina 187, 192, 250, 252, 346

Waller, Jack 153

Walser, Martin 158, 342, 346, 353

Walter, V. 257, 258, 353

Walton, Kendall L. 185, 353

Wasser, Hersz 296

Waugh, Ian David 309, 345

Weber, John C. 262, 353

Werner, Andrzej 80, 353

Wesselow, Peter de 163

Westwell, Ian 205, 353

Wieczorkiewicz, Anna 248, 250, 251, 253, 257, 258, 353

Wiernik, Jankiel 305, 306, 339

Wierzbicka, Bożena 301, 352

Wierzyński, Kazimierz 41, 199

Wiesel, Elie 10, 319, 339

Willett, John 203

Winderbaum, Estera 312, 315, 320,339

Winter, Denis 24, 199, 201, 272, 353

Wirz, Henry 191

Witos, Wincenty 39

Włodarczyk, Wojciech 79, 353
Wojdowski, Bogdan 103, 104, 234, 321, 339

Wojdysławski, Jakób 99, 100, 339

Wołowski, Jacek 53, 54

Wornowska, Teresa 147, 336

Woźniak, Monika 246, 349

Wódz, Jacek 35, 352

Wójcik, Włodzimierz 44, 353

Wóycicki, Kazimierz 342

Wyka, Kazimierz 71, 75, 339

Wyszyński, Franciszek 86, 87, 109, 339

Wyszyński, Stefan 39

Z

Zabierowski, Janusz 291, 353

Zaleszczyc, Naftali 215

Zaremba, Zygmunt 39, 40, 44-46, 55, 114-116, 148

Zarzewska, Wanda 253, 343

Zawadzka, Anna 154, 331

Zawadzka, Zofia 154, 331

Zawadzki, Aleksander Władysław 51, 339

Zeidler-Janiszewska, Anna 13, 35, 342, 349, 353

Zeilinwarger, Chana 228

Żelazko, Joanna 131, 354

Zeldowicz, Emilia 217

Zeldowicz, Henrietta 217

Zelizer, Barbie 183, 354

Żeromski, Stefan 198, 339

Zimand, Roman 29, 354

Żmigrodzka, Maria 57, 58, 346

Znaniecki, Florian 28

Żółkiewski, Stefan 28, 354

Zubrzycki, Józef 163

Żukrowski, Wojciech 43

Żurawski, Israel 305

Zychowicz, Juliusz 304, 341

Żywulska, Krystyna 235, 339 


\section{Eastern European Culture, Politics and Societies}

Edited by Irena Grudzińska-Gross and Andrzej W. Tymowski

Vol. 1 Lidia Jurek: Polish Risorgimento - Visions of the Modern Polish Nation and their Italian Foundations. 2012.

Vol. 2 Irena Grudzińska-Gross: Czesław Miłosz und Joseph Brodsky - Die Freundschaft zweier Dichter. 2012.

Vol. 3 Irena Grudzińska-Gross / Andrzej Tymowski (eds.): Eastern Europe: Women in Transition. 2013.

Vol. 4 Agata Araszkiewicz: La révolution oubliée. L'émergence d'une écriture féminine polonaise dans l'entre-deux-guerres. 2013.

Vol. 5 Irena Grudzińska-Gross / Andrzej W. Tymowski (eds.): Eastern Europe: Continuity and Change (1987-1995). Editorial assistance by Elisabeta Pop. 2014.

Vol. 6 Jan Tomasz Gross: Collected Essays on War, Holocaust and the Crisis of Communism. 2014.

Vol. 7 Andrzej Walicki: The Flow of Ideas. Russian Thought from the Enlightenment to the Religious-Philosophical Renaissance. Translated by Jolanta Kozak and Hilda Andrews-Rusiecka. Editorial Work by Cain Elliott. 2015.

Vol. 8 Robert Traba: The Past in the Present. The Construction of Polish History. Translated by Alex Shannon. 2015.

Vol. 9 Milica Antić Gaber (ed.): Gender Structuring of Contemporary Slovenia. 2015.

Vol. 10 Irena Grudzińska-Gross / Iwa Nawrocki (eds.): Poland and Polin. New Interpretations in Polish-Jewish Studies. 2016.

Vol. 11 Aleksandra Sulikowska: The Icon Debate. Religious Images in Russia in the $15^{\text {th }}$ and $16^{\text {th }}$ Centuries. Translated by Krzysztof Kościuczuk. 2016.

Vol. 12 Joanna Tokarska-Bakir: Pogrom Cries - Essays on Polish-Jewish History, 1939-1946. 2017.

Vol. 13 Jacek Leociak: Text und Holocaust. Die Erfahrung des Ghettos in Zeugnissen und literarischen Entwürfen. 2018.

Vol. 14 Jacek Leociak: Limit Experiences. A Study of Twentieth-Century Forms of Representation. 2019.

www.peterlang.com 